\title{
GEOQUÍMICA, GEOL_OGIA ISOTÓPICA E ASPECTOS PETROLÓGICOS DOS DIQUES MÁFICOS PRÉ-CAMBR..ANOS DA REGIÃO DE LAVRAS (MG), PORÇÃO SUL DO CRÁTON DO SÃO FRANCISCO
}

\author{
JOSÉ PAULO PECCININI PINESE
}

Orientador: Prof. Dr. Wilson Teixeira

TESE DE DOLITORAN: NTO

COMISÃO WULGADGRAA

Nome

Presidente: Prof. Dr. Wilson Teixeira

Examinadores: Prof. Dr. Asit Choudhuri
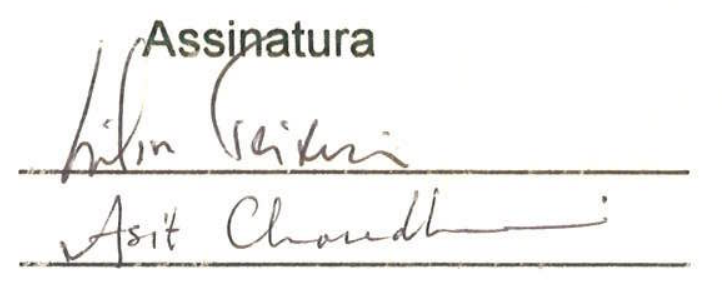

Prof ${ }^{\text {a. }}$ Dr. $^{\text {a. }}$ Marly Babinski

Prof. Dr. Maurício Antônio Carrieiro

Prof. Dr. Vicente Antonio V. Girardi

$$
\begin{gathered}
\text { S.AO : AULO } \\
\text { IS.97 }
\end{gathered}
$$

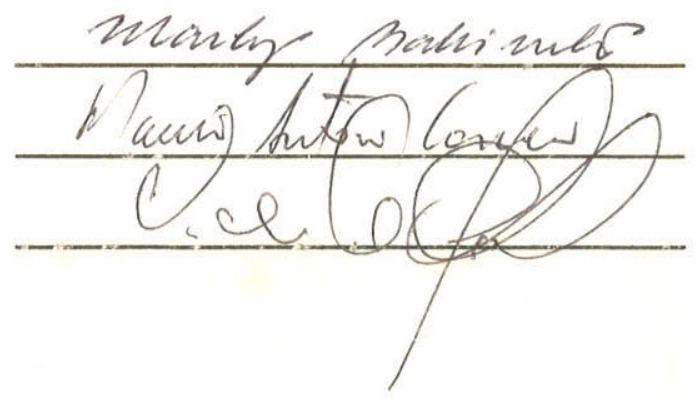




\section{UNIVERSIDADE DE SĀO PAULO \\ INSTITUTO DE GEOCIENCIAS}

\section{GEOQUÍMICA, GEOLOGIA ISOTÓPICA E ASPECTOS PETROLÓGICOS DOS DIQUES MÁFICOS PRÉ-CAMBRIANOS DA REGIĀO DE LAVRAS (MG), PORÇÃO SUL DO CRÁTON DO SÃO FRANCISCO}

José Paulo Peccinini Pinese

Orientador: Prof. Dr. Wilson Teixeira

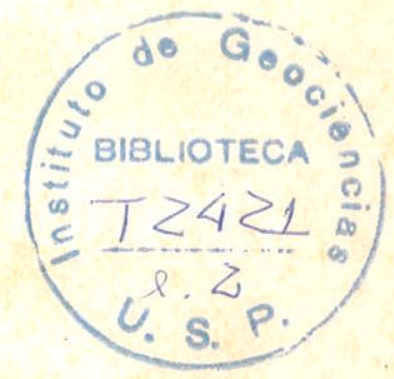

TESE DE DOUTORAMENTO

Programa de Pós-Graduação em Geoquímica e Geotectônica

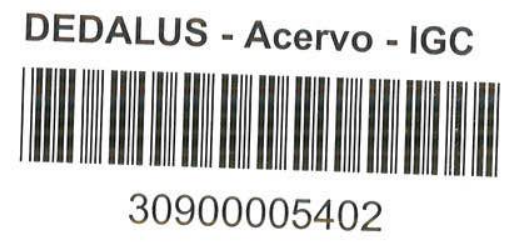


À minha filha Beatriz,

pelo amor incondicional.

À minha esposa Rosely,

pelo carinho, compreensão e paciência.

À minha mãe Sylvia e à memória do meu pai Agenor,

pelo dom da vida e os ensinamentos sobre ela. 


\section{AGRADECIMENTOS}

Em primeiro lugar a Deus, criador do Cráton do São Francisco e seus inúmeros enigmas. Quem sabe um dia ele nos contará sua verdadeira história evolutiva.

Agradeço ao Prof. Dr. Wilson Teixeira pela orientação, apoio, paciência e os constantes ensinamentos prestados na realização deste trabalho. Sobretudo, pelo incentivo diário na busca das melhores soluções para o aprimoramento constante da pesquisa. Minha eterna gratidão.

Com a mesma gratidão, dirijo meus agradecimentos ao Prof. Dr. Enzo Michele Piccirillo pelas inúmeras discussões criticas e valiosas sugestões que, sem dúvida, em muito contribuíram na elaboração deste trabalho. Pela oportunidade concedida para o nosso treinamento, pela orientação e apoio na realização das análises químicas em rocha total e de parte das análises isotópicas, realizadas nos laboratórios do Departamento de Ciências da Terra da Universidade de Trieste, Itália.

A Profa Dra. Leila Marques do Instituto Astronômico e Geofísico (USP) pelas discussões e conselhos sempre altamente pertinentes e importantes no desenvolvimento desta tese.

Aos Profs. Drs. Joel J. G. Quéméneur (UFMG), Maurício Carneiro (UFOP) e Issamu Endo (UFOP) pelo companheirismo e as diversas discussões geológicas muitas vezes "in loco". Em particular, ao Prof. Quéméneur pela cessão de algumas amostras dos diques da região de Bom Sucesso (MG) e empréstimo da imagem de satélite.

Ao grupo de paleomagnetismo do Instituto Astronômico e Geofísico (USP) nas pessoas da Profa. Dra. Marcia Ernesto, Prof. Dr. Igor I. G. Pacca, Dr. Manoel D'Agrella Filho e o Msc. Cosme Ferreira, por incentivarem a integração dos trabalhos geoquimicos/paleomagnéticos e que na fase inicial do projeto propiciaram apoio logístico para diversas etapas de campo.

Ao Prof. Dr. Giuliano Bellieni do Departamento de Mineralogia e Petrologia da Universidade de Pádua (Itália), por permitir a utilizaçăo da microssonda eletrônica daquele departamento, bem como auxiliar na confecção das análises quimicas das fases minerais.

Ao Prof. Dr. Riccardo Petrini pelos ensinamentos e acompanhamento metodologico das analises isotopicas $\mathrm{Sm}-\mathrm{Nd}$, quando do nosso estágio no Laboratório de Geoquimica Isotópica da Universidade de Trieste, Itália. 
Ao Prof. Dr. Francesco Princivalle, Dr. Angelo De Min, Dr. Paolo Antonini, e ao pessoal técnico-administrativo (Romano, Silvana e Lorenzo) do conjunto de laboratórios da Universidade de Trieste, pelo incondicional suporte técnico e logístico durante minha estadia na Itália. Particularmente, ao colega e amigo Dr. Angelo De Min pelos ensinamentos quanto ao procedimento e realização em fluorescência de raios- $X$ das análises químicas em rocha total.

Aos Profs. Drs. Gilberto Lage e Hélcio Andrade da Escola Superior de Agricultura de Lavras (ESAL-MEC), pelo auxilio na obtenção da infraestrutura para os trabalhos de campo como veiculo e alojamento.

Ao Dr. Paul Renne do "Berkeley Geochronology Center" (EUA) pela cooperação prestada por meio das análises ${ }^{40} \mathrm{Ar}-{ }^{39} \mathrm{Ar}$.

Aos amigos e colegas do Instituto de Geociências da USP, em especial Prof. Dr. Gergely Szabó, Dra. Silvia Vieira, Prof. Dr. Marcos Egydio Silva, Vera Lucia Pereira, Ossama Arara, Diana Ragatky, Miguel Tupinambá e Roseli Imbernon, entre tantos outros, pela amizade, incentivo e compreensão no decurso das diversas etapas deste trabalho. Particularmente, ao grande colega e amigo Prof. Dr. Joel Sígolo (Dr. JB) um agradecimento adicional pelo convívio, amizade e apoio logístico na cidade de São Paulo.

Ao corpo técnico do Centro de Pesquisas Geocronológicas (CPGeo-USP), Liliane Petronilho, Margarida Martins, Ivone Sonoki, Helen Sonoki, Valéria Cristina Reis Santos, Solange Souza, Décio Rosas, João Antunes, José Gouveia (In memorian), Artur Takashi, Walter Sproesser, Claudio Comerlatti e o incansável Key Sato, pelo apoio laboratorial na execução das análises isotópicas.

Ao Instituto de Geociências da USP, ao corpo docente nele lotado e ao pessoal técnico-administrativo que forneceram sem restrições toda a infraestrutura disponivel para o bom desenvolvimento deste trabalho.

Ao Departamento de Geociências da Universidade Estadual de Londrina e aos colegas deste departamento, muitíssimo obrigado pelo período de licença concedida e apoio irrestrito no desenvolvimento deste trabalho.

Finalmente, agradeço as instituições que financiaram esta tese, a saber: FAPESP (Proc. 92/0591-0), CNPq (Proc. 201.385/94-5, bolsa no exterior), CAPES-PICD e CNR (Itália). 


\section{RESUMO}

Na região de Lavras - Bom Sucesso (Minas Gerais), localizada na porção extremo sul do Cráton do São Francisco, alojam-se corpos de diques máficos pré-cambrianos diagnósticos da existência de no mínimo dois enxames. Tais diques, são intrusivos principalmente em crosta arqueana $(2790$ - $2660 \mathrm{Ma})$ que foi parcialmente retrabalhada no Paleoproterozóico (2140 - $1980 \mathrm{Ma}$ ) sendo que parte deles secciona as supracrustais do Supergrupo Minas na Serra de Bom Sucesso. Orientam-se preferencialmente a $N 40^{\circ}-60^{\circ} \mathrm{W}$, $\mathrm{N} 20^{\circ}-40^{\circ} \mathrm{E}, \mathrm{N}-\mathrm{S}$ e subordinadamente a $\mathrm{N} 10^{\circ}-30^{\circ} \mathrm{W}, \mathrm{N} 50^{\circ}-70^{\circ} \mathrm{E}$ e E-W. Em geral, os diques com direções $\mathrm{N} 40^{\circ}-60^{\circ} \mathrm{W}$ são os mais espessos (até $100 \mathrm{~m}$ ) e os mais longos (até $30 \mathrm{Km}$ ).

Estudos petrográficos e dados de campo permitem subdividir os diques máficos nos seguintes grupos: 1) diques básicos noríticos $(\mathrm{DBN}) ; 2)$ diques básicos - $1\left(\mathrm{DB}_{1}\right)$; 3) diques básicos - $2\left(\mathrm{DB}_{2}\right)$; 4) diques metabásicos (DMB); 5) diques anfibolíticos (DA).

Similaridades mineralógicas (e.g. presença de biotita como acessório e bronzita) são assinaladas entre os $\mathrm{DB}_{1}$ e DBN. Dados geoquímicos revelam que os $\mathrm{DB}_{1}$ se constituem no prosseguimento evolutivo dos DBN, sendo o conjunto denominado de suite básico norítica. Por outro lado, os tipos não metamórficos $\mathrm{DB}_{2}$ se constituem em um grupo composicionalmente diferente denominado de suite básica. Os diques desta suíte são predominantemente basaltos toleíticos, enquanto aqueles da suite básico noritica são representados por basaltos e andesi-basaltos toléticos. Quimicamente, a evolução dos piroxênios reafirma a afinidade toleítica destas suítes. As similaridades quimicas e os dados Rb-Sr sugerem que os diques metamórficos (DMB e DA) estejam relacionados à evolução da suíte básica.

Elementos maiores e traços assinalam diferenças composicionais significativas entre os diques máficos da suite básica e aqueles da suíte básico noritica. Para o mesmo indice evolutivo $[\mathrm{mg}(0,15) \# 0,50]$ os diques da suite básico noritica apresentam maiores concentrações em: $\mathrm{SiO}_{2}(55$ vs $51 \%) ; \mathrm{K}_{2} \mathrm{O}(1,2$ vs $0,5 \%)$; Rb (40 vs 10 ppm); $\mathrm{Sr}$ (225 vs $140 \mathrm{ppm}$ ); $\mathrm{Ba}(300$ vs $90 \mathrm{ppm})$ e menores concentrações em: FeOt (10 vs 13\%); CaO (9 vs $10 \%$ ) e Y (23 vs 35 ppm), quando comparados aos diques da suite básica. As variaçoes nos valores das razões $\mathrm{Zr} / \mathrm{Ba}(0,23$ a 0,73 vs 0,61 a 3,10$), \mathrm{Zr} / \mathrm{Ce}(2,8$ a 4,0 vs 3,7 a 5,9$)$ e $\mathrm{Zr} / \mathrm{Rb}$ (1,9 a 5,7 vs 4,0 a 24,6), são sempre menores para os exemplares básico noríicos, ratificando as diferenças quimicas entre as suites. Adicionalmente, os padrões dos elementos terras raras (ETR) também são significativamente diferentes. Em geral, os diques da suite básico norítica 
apresentam valores mais elevados nas razões $\mathrm{La}_{N} / \mathrm{Yb}_{\mathrm{N}}(6,1$ a 5,8 vs 2,0 a 1,6$), \mathrm{La}_{\mathrm{N}} / \mathrm{Sm}_{\mathrm{N}}(3,5$ a 3,0 vs 1,6 a 1,4) e $\mathrm{Sm}_{\mathrm{N}} / \mathrm{Yb}_{\mathrm{N}}(2,0$ a 1,9 vs 1,3 a 1,1) do que os diques da suíte básica. Estes dados sugerem a presença de duas suites geoquímicas distintas, que possivelmente sofreram processos de enriquecimento em ETR leves comparativamente aos basaltos da cadeia mesooceânica ("MORB").

Análises Rb-Sr, Sm-Nd, K-Ar e ${ }^{40} \mathrm{Ar}-{ }^{39} \mathrm{Ar}$ indicam a ocorrência de duas gerações pré-cambrianas de magmatismo físsural na região. A geração mais antiga é representada pelos diques da suite básico norítica, cujos dados $\mathrm{Sm}-\mathrm{Nd}$ em concentrados minerais e rocha total proporcionaram uma isócrona de $2.658 \pm 44 \mathrm{Ma}(1 \sigma)$, razão inicial ${ }^{143} \mathrm{Nd} /{ }^{144} \mathrm{Nd}\left(\mathrm{Nd}_{\mathrm{i}}\right)$ de $0,50916 \pm 0,00005(12$ pontos e MSWD $\cong 3)$. Esta idade é interpretada como a idade de intrusão. Dados $\mathrm{Rb}-\mathrm{Sr}$ produziram uma errócrona com idade aparente de $2.788 \pm 79(1 \sigma)$, razão ${ }^{87} \mathrm{Sr} /{ }^{86} \mathrm{Sr}$ inicial $\left(\mathrm{Sr}_{i}\right)$ de $0,70110 \pm 0,00048$ (MSWD $\cong 31$ ). O alto MSWD pode estar relacionado a distúrbios isotópicos ou a características originais da fonte ou ambos. A segunda geração de diques é representada pela suite básica, cuja idade de intrusão é inferida com base em uma errócrona $\mathrm{Rb}-\mathrm{Sr}\left[1.875 \pm 101 \mathrm{Ma}(\mathrm{l} \sigma), \mathrm{Sr}_{1}\right.$ igual a $0,70255 \pm 0,00028$ e MSWD $\cong 24]$ e relações de contemporaneidade com o Granito Tabuões, este anteriormente datado pelo método $\mathrm{Rb}-\mathrm{Sr}$ em $1.932 \pm 21 \mathrm{Ma}$

A evolução isotópica do $\mathrm{Sr}$ e Nd indica que os diques da suite básico noritica $[\varepsilon(\mathrm{Nd})=-2,5 \mathrm{a}+6 ; \varepsilon(\mathrm{Sr})=-18 \mathrm{a}+37]$ e os diques da suite básica $[\varepsilon(\mathrm{Nd})=-5,3$ a $-0,6 ; \varepsilon(\mathrm{Sr})=$ $-7 \mathrm{a}+40]$ predominantemente derivaram de uma fonte enriquecida comparativamente a "Terra Global". Contudo, duas amostras da suite básico noritica plotam no quadrante $\varepsilon(\mathrm{Nd})$ vs $\varepsilon(\mathrm{Sr})$ empobrecido, indicando heterogeneidade que é típica de fonte litosférica. O conjunto de dados geoquímicos (e.g. $\mathrm{SiO}_{2}, \mathrm{~K}_{2} \mathrm{O}, \mathrm{Ba}$ ) aliados aos dados isotópicos de $\mathrm{Sr}$ e $\mathrm{Nd}$, não demonstram evidências de contaminação crustal durante o processo intrusivo

As suites básico noritica $(2,65 \mathrm{Ga})$ e básica $(1,9 \mathrm{Ga})$, evoluiram a partir de magmas quantitativamente compativeis com processos de cristalização fracionada e caracterizados pela heterogeneidade em pequena escala. Tais magmas se originaram, no entanto, a partir de duas fontes geoquimicamente distintas. Uma propiciou a suite básico noritica e é caracterizada por anomalias negativas de Nb, P, Sm e Ti. A outra propiciou a suíte básica e e caracterizada pelas anomalias negativas de $\mathrm{Ba}, \mathrm{K}, \mathrm{Sr}$ e Eu e pela anomalia positiva de Th. Estes dados, demonstram um comportamento diferenciado entre o manto litosférico do 
Neoarqueano e aquele do Paleoproterozóico. Adicionalmente, a anomalia negativa de $\mathrm{Nb}$ da suite básico norítica $(2,65 \mathrm{Ga})$, sugere que o manto litosférico no Neoarqueano possa ter sido fertilizado através de um processo de subducção envolvendo crosta oceânica e/ou sedimentos terrigenos continentais.

Comparações isotópicas e geoquímicas dos diques de Lavras com outros enxames de diques no âmbito do Cráton do São Francisco revelam que a suite básica (1,9 Ga) apresenta similaridades composicionais com o enxame de Uauá (Bahia), entre outros, sugerindo um possivel manto subcontinental geoquimicamente similar em diferentes porções do segmento cratônico.

Tectonicamente, os diques da suite básico noritica $(2.658 \mathrm{Ma})$ intrudiram a crosta continental sob regime extensional após o Evento Rio das Velhas (2.780-2.700 Ma), ilustrando os processos finais de estabilização do Complexo Campo Belo. Os diques da suíte básica (1.875 Ma), teriam se colocado durante a tectônica extensional associada aos estágios finais da orogenia transamazônica, responsável pelo desenvolvimento do Arco Magmático Mineiro. 


\begin{abstract}
At least two Precambrian mafic dyke swarms are located in Lavras - Bom Sucesso region in the southern part of São Francisco Craton (Minas Gerais State, Brazil). Such dykes are intrusive into Archean rocks of the Campo Belo Complex (2790 - 2660 Ma) that were reworked in the Paleoproterozoic (2140 - $1980 \mathrm{Ma}$ ) and some of them intruded the supracrustals of the Minas Supergroup. The dykes trend preferably $N 40^{\circ}-60^{\circ} \mathrm{W}, \mathrm{N} 20^{\circ}-40^{\circ} \mathrm{E}$, $\mathrm{N}-\mathrm{S}$ and subordinantly $\mathrm{N} 10^{\circ}-30^{\circ} \mathrm{W}, \mathrm{N} 50^{\circ}-70^{\circ} \mathrm{E}, \mathrm{E}-\mathrm{W}$ orientations, and those oriented $\mathrm{N} 40^{\circ}$ $60^{\circ} \mathrm{W}$ are the tickest (until $100 \mathrm{~m}$ ) and the longest dykes (until $30 \mathrm{Km}$ ).

Petrographic studies and field data support the subdivision of the dykes in the following groups: 1) basic-noritic dykes (BND); 2) basic dykes 1 (BD, $)$; 3) basic dykes 2 $\left(\mathrm{BD}_{2}\right)$; 4) metabasic dykes (MBD); 5) amphibolitic dykes (AD). The $\mathrm{BD}_{1}$ has similar mineralogical composition (e.g. biotite accessory and bronzite) when compared to the BND.

Geochemical data show that the $\mathrm{BD}_{1}$ and $\mathrm{BND}$ belong to a same group named basic-noritic suite, the former being the more evolved member in the suite. On the other hand, $\mathrm{BD}_{2}$ is compositionally different from this suite and is named basic suite. The basic suite dykes are predominantly tholeiitic basalts while the basic-noritic suite comprises tholeiitic basalts and tholeitic andesi-basalts. The chemical similarities and $\mathrm{Rb}-\mathrm{Sr}$ isotope data suggest that the metamorphic dykes (MBD and $A D)$ are related to the basic suite evolution.
\end{abstract}

Major and trace elements reveal significant compositional variations between these two dyke suites. The basic-noritic suite displays higher contents of $\mathrm{SiO}_{2}(55$ vs $51 \%), \mathrm{K}_{2} \mathrm{O}(1.2$ vs $0.5 \%), \mathrm{Rb}(40$ vs $10 \mathrm{ppm})$, Sr (225 vs $\left.140 \mathrm{ppm}\right)$, Ba (300 vs $90 \mathrm{ppm}$ ) than those from the basic suite, based on similar mg\# values $\left[\left(\mathrm{Mg}^{2} / \mathrm{Mg}^{\cdot 2}+\mathrm{Fe}^{\cdot 2}\right)\right.$ to $\mathrm{Fe}_{2} \mathrm{O}_{3} / \mathrm{FeO}=$ $0.15]$. Basic-noritic and basic suites are distinct in terms of $\mathrm{Zr} / \mathrm{Ba}, \mathrm{Zr} / \mathrm{Ce}$ and $\mathrm{Zr} / \mathrm{Rb}$ ratios. The basic-noritic suite has $\mathrm{Zr} / \mathrm{Ba}(0.23$ to 0.73$), \mathrm{Zr} / \mathrm{Ce}(2.8$ to 4.0$)$ and $\mathrm{Zr} / \mathrm{Rb}(1.9$ to 5.7$)$ ratios usually lower than those of the basic suite (higher than $0.61,3.7$ and 4.0 , respectively). The REE patterns also indicate significant differences: basic-noritic suite rocks have higher normalized $\mathrm{La}_{N} / \mathrm{Yb}_{\mathrm{N}}$ (6.1 to 5.8), $\mathrm{LaN}_{N} / \mathrm{Sm}_{\mathrm{N}}$ (3.5 to 3.0) and $\mathrm{Sm}_{N} / \mathrm{Yb}_{\mathrm{N}}$ (2.0 to 1.9) values compared to those of the basic suite rocks $(2.0$ to $1.6 ; 1.6$ to $1.4 ; 1.3$ to 1.1 , respectively). These data indicate that the Lavras dykes derived from two different geochemical suites both enriched in LREE when compared to MORB. 
$\mathrm{Rb}-\mathrm{Sr}, \mathrm{Sm}-\mathrm{Nd}, \mathrm{K}-\mathrm{Ar}$ and ${ }^{40} \mathrm{Ar}-{ }^{39} \mathrm{Ar}$ dates, reveal the existence of two generations of the Precambrian mafic dykes in the study area. The oldest generation, the basic-noritic suite, presents a $\mathrm{Sm}-\mathrm{Nd}$ mineral and whole rock isochron that yielded a ${ }^{143} \mathrm{Nd} /{ }^{144} \mathrm{Nd}$ initial ratio of the $0.50916 \pm 0.00005(12$ points; MSWD $\cong 3)$ and age of $2,658 \pm$ 44. $\mathrm{Ma}(\mathrm{I} \sigma)$, interpreted as the intrusion age. The Rb-Sr whole rock systematics of the basicnoritic suite was probably either disturbed by Paleoproterozoic events that overprinted the country rocks or they reflect the nature of the source or both. A nine points errorchron yields an apparent age of $2,788 \pm 79 \mathrm{Ma}(1 \sigma)$ and ${ }^{87} \mathrm{Sr} /{ }^{86} \mathrm{Sr}$ initial $\left(\mathrm{Sr}_{i}\right)$ of $0.70110 \pm 0.00048$ $(M S W D \equiv 31)$. The second generation of dykes comprises a basic suite and has a $\mathrm{Rb}-\mathrm{Sr}$ errorchron age of $1,875 \pm 101 \mathrm{Ma}(1 \sigma), \mathrm{Sr}_{i}$ of $0.70255 \pm 0.00028$ and MSWD of 24 (7 points). In addition, according to field relations these dykes are contemporaneous to the Tabuões granite $(\mathrm{Rb}-\mathrm{Sr}$ age of $1,932+21 \mathrm{Ma})$.

The variation in the $\varepsilon(\mathrm{Nd})$ and $\varepsilon(\mathrm{Sr})$ values on the basic-noritic $[\varepsilon(\mathrm{Nd})=-2.5$ to $+6 ; \varepsilon(\mathrm{Sr})=-18$ to +37 , for $\left.\mathrm{T}_{0}=2.65 \mathrm{Ga}\right]$ and basic suites $[\varepsilon(\mathrm{Nd})=-5.3$ to $-0.6 ; \varepsilon(\mathrm{Sr})=-7$ to +40 , for $\mathrm{T}_{0}=1.9 \mathrm{Ga}$ ] indicates that these suites are derived predominantly from an enriched source comparing to the Bulk Earth. However two samples of the basic-noritic suite plot on the depleted quadrant of the $\varepsilon(\mathrm{Nd})$ vs $\varepsilon(\mathrm{Sr})$ diagram and this indicates a heterogeneity of the lithospheric mantle source. Furthermore, the plot all of these data in an $\varepsilon(\mathrm{Nd})$ vs $\varepsilon(\mathrm{Sr})$ diagram might suggest a radiogenic $\mathrm{Sr}$ and $\mathrm{Nd}$ contamination of the basic-noritic suite from the Archean crust during the intrusion. Nevertheless, this assessment is not supported neither by the negative correlation between $\mathrm{SiO}_{2}, \mathrm{~K}_{2} \mathrm{O}, \mathrm{Rb}, \mathrm{Sr}$ and ${ }^{87} \mathrm{Sr} /{ }^{86} \mathrm{Sr}$ initial ratios nor the positive correlation with the ${ }^{143} \mathrm{Nd} /{ }^{1 / 4} \mathrm{Nd}$ initial ratios.

The basic-noritic and basic suites are consistent with magmas which evolved from fractional crystallization processes, derived from two different sources. One of them provided a basic-noritic suite and it is characterized by negative anomalies of $\mathrm{Nb}, \mathrm{P}, \mathrm{Sm}$ and Ti. The other one provided the basic suite and it is characterized by negative anomalies of Ba, K, Sr, Eu and positive anomaly of Th. These data suggest a lithospheric mantle with compositional differences from the Neoarchean to Paleoproterozoic times. In addition, the $\mathrm{Nb}$ negative anomaly indicates a lithospheric mantle in the Archean, probably metassomatized, by crustal components related to dehydration of a subducting slab processes. 
Isotope and geochemical data reveal that the basic suite dykes of Lavras are similar to the Paleoproterozoic dyke swarm of Uauá (Bahia), in the São Francisco Craton.

Tectonically, the basic-noritic suite $(2,658 \mathrm{Ma})$ probably originated during extensional conditions in the continental crust after Rio das Velhas event (2,780-2,700 Ma), and it represents the cratonization stage of the Campo Belo Complex evolution. The basic suite $(1,875 \mathrm{Ma})$ formed within the margin of this Archean continent during the late-stage extensional phase of the Transamazonian orogeny that formed the Mineiro Belt magmatic arc. 
ÍNDICE

I - INTRODUÇÃO

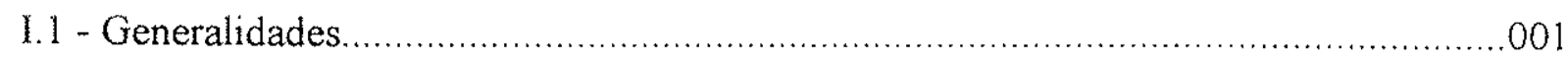

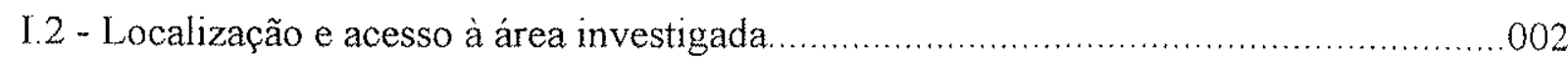

I.3 - Principais características dos enxames de diques máficos .....................................002

II - METODOLOGIA

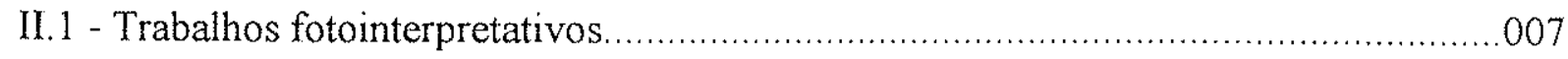

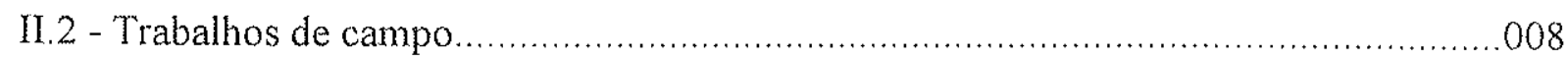

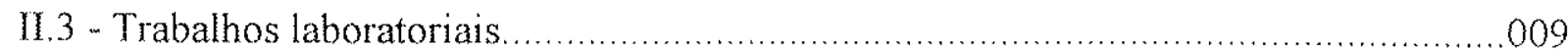

III - O SEGMENTO SUL DO CRÁTON DO SÃO FRANCISCO

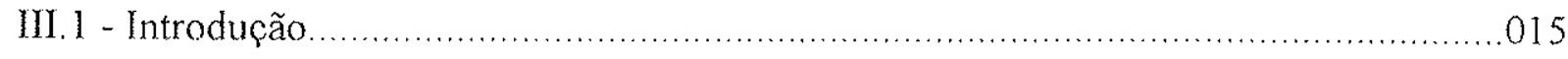

III.2 - Quadro Geológico-Geocronológico Regional................................................. 015

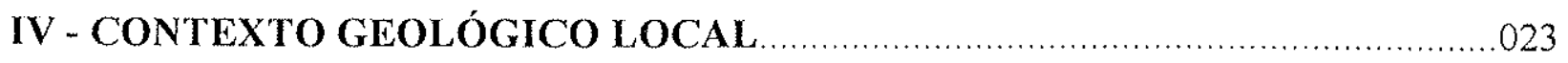

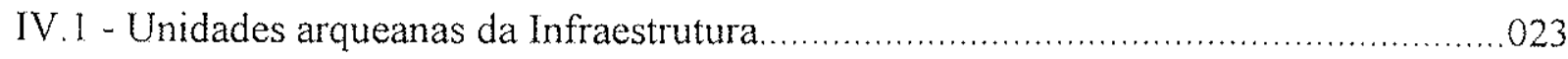

IV.2 - Unidades paleoproterozóicas do Cinturão Mineiro e mais jovens...........................030

IV.3 - O Enxame de Diques Máficos de Lavras.............................................................

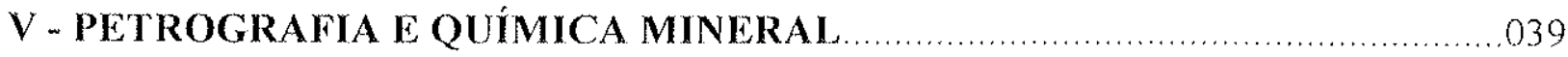

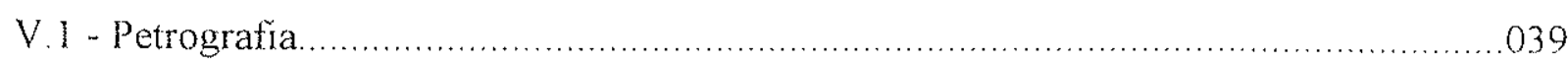

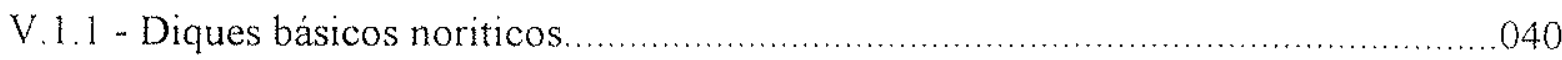

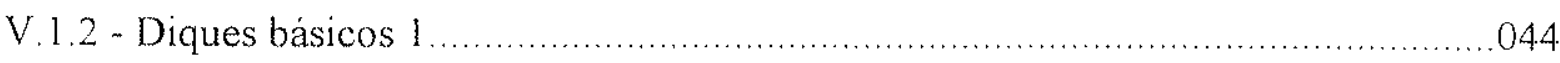

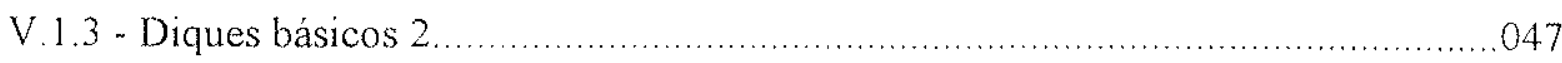

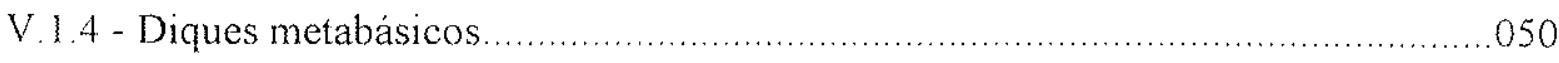

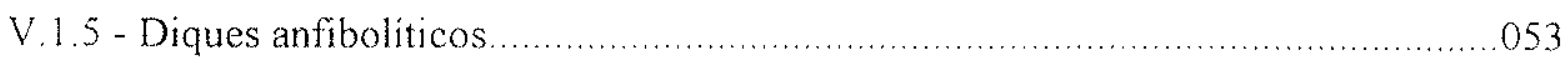

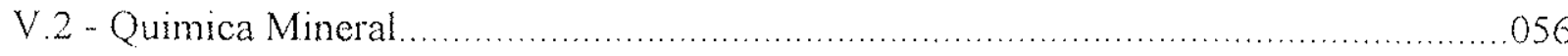

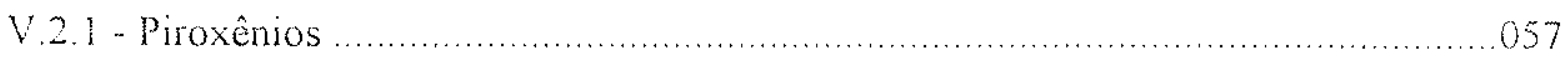

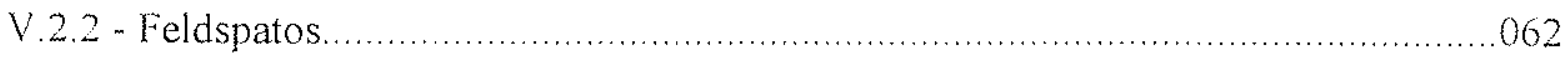




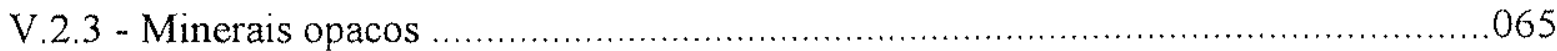

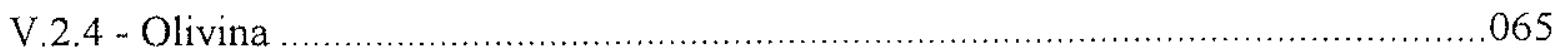

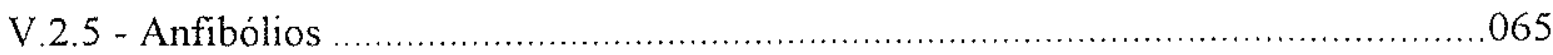

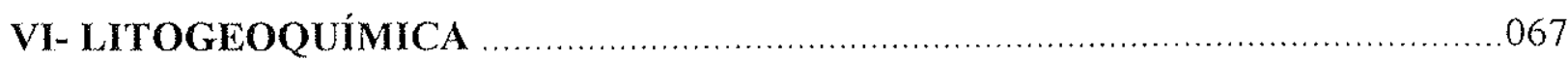

VI.1 - Mobilidade de elementos em processos metamórficos, hidrotermal ou

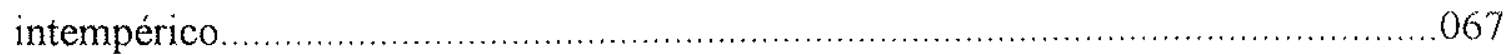

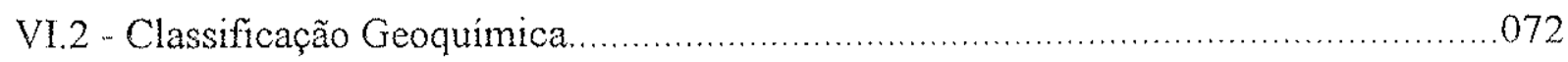

VI.2.1 - Classificação com base no conteúdo em sílica e álcalis................................073

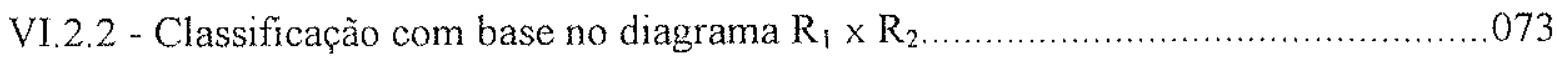

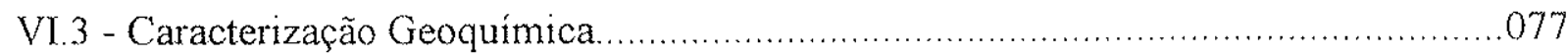

VI.3.1 - Elementos maiores e traços ............................................................... 077

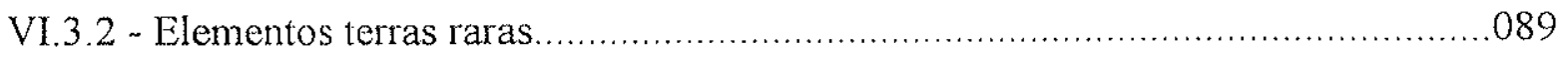

VII - GEOCRONOLOGIA E GEOQUIMICA ISOTÓPICA ...............................098

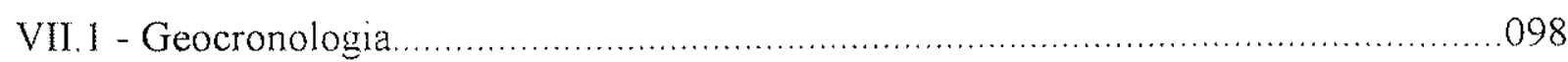

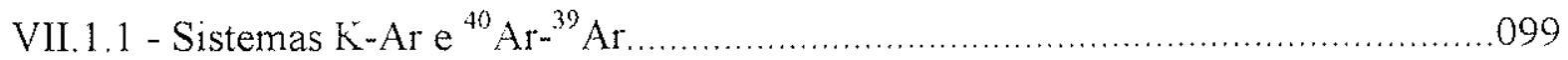

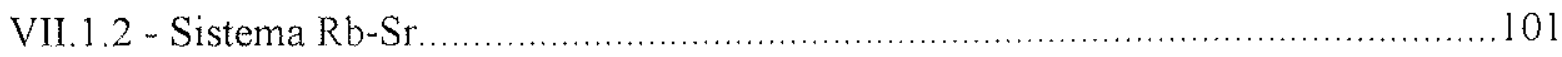

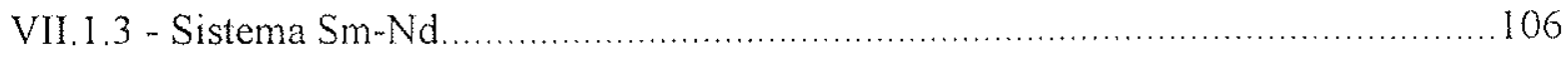

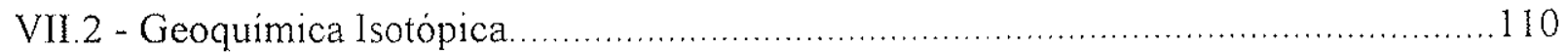

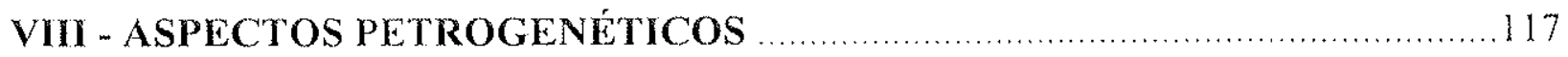

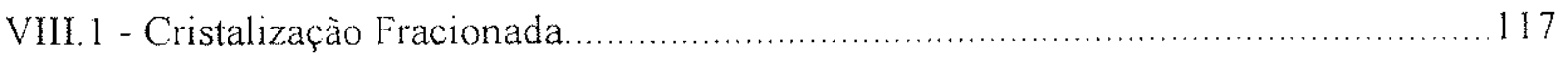

VIII.2 - Inferências sobre a natureza da fonte............................................. 124

IX - COMPARAÇÃO COM OUTROS ENXAMES DE DIQUES MÁFICOS ..........128

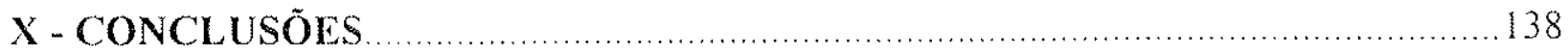

XI-BUBLIOGRARIA 
Apêndice 1: Análises químicas em rocha total (elementos maiores e traços) 155

Apêndice 2: Análises químicas das principais fases minerais. 170

Apêndice 3: Descrições petrográficas simplificadas das amostras estudadas...... 176 


\section{I - INTRODUCÃ̃}

\section{I.1 - Generalidades}

$\mathrm{Na}$ última década o estudo do magmatismo básico sob forma de enxame de diques, tem assumido papel relevante na elucidação dos processos mantélicos e tectônicos envolvidos (e.g. Halls, 1987; Condie et al, 1987; Oliveira et al, 1990; Choudhuri et al, 1990; Teixeira, 1990; Hall \& Hughes, 1990; Piccirillo et al, 1990; Bellieni et al, 1991; Summers et al, 1995; Vuollo et al, 1995; Heimann et al, 1995; Wirth \& Vervoort, 1995). Com relação a este tema, a geocronologia associada a geoquímica isotópica, bem como as investigações geoquímicas são ferramentas imprescindiveis na complementação de estudos de evolução de segmentos crustais de diferentes idades.

No leste brasileiro, o Cráton do São Francisco representa um segmento crustal de evolução policíclica tectonicamente estável relativamente ao desenvolvimento dos cinturões móveis do Ciclo Brasiliano que o circundam. Os eventos distensivos que ocorreram no Cráton, no pré-Cambriano, propiciaram a intrusão de vários enxames de diques máficos, parte dos quais já foram objeto de estudos diversos (e.g. Parenti Couto et al, 1983; Sial et al, 1987; Teixeira et al, 1988; D’Agrella Filho et al, 1990; Bellieni et al, 1991; Quéméneur, 1991; Correa Gomes et al, 1991; D'Agrella Filho, 1992; Menezes, 1992; Moraes Brito, 1992; Bastos Leal, 1992; Oliveira, 1993; Bastos Leal et al, 1994; Oliveira \& Tarney, 1995; Menezes Leal et al, 1995; Chaves, 1996; Pinese et al, 1995).

O fato de existir uma densidade elevada de diques máficos pré-cambrianos na porção extremo sul do Cráton do São Francisco e a inexistência, até o momento, de estudos sistemáticos sobre os mesmos, justificaram o interesse pelo desenvolvimento do presente trabalho, sem contudo ter a pretensão de esgotar um assunto tão amplo.

A presente pesquisa tem como objetivos contribuir no melhor entendimento do magmatismo básico prémcambriano fissural da porção meridional do Cráton do São Francisco, por meio de investigações isotópicas e geoquímicas fundamentadas em estudos petrográficos e de química mineral, para fins de investigar os processos magmáticos e tectônicos envolvidos na sua colocaçào. 


\section{2 - Localização e Acesso à Área Investigada}

A área investigada neste trabalho localiza-se a sudoeste da cidade de Belo Horizonte e é parte integrante da região sudeste do Estado de Minas Gerais (Fig. 1.1 e I.2) É balizada pelos meridianos $44^{\circ} 00^{\prime}$ e $45^{\circ} 30^{\prime}$ de longitude oeste de Greenwich e os paralelos $20^{\circ} 45^{\prime}$ e $21^{\circ} 20^{\prime}$ de latitude sul. A extensão territorial é da ordem de $9.000 \mathrm{Km}^{2}$ e está compreendida pelas seguintes folhas topográficas (IBGE) na escala 1:50.000: Santana do Jacaré, Nepomuceno, Santo Antônio do Amparo, Lavras, São Tiago, Nazareno, Jacarandira e São João Del Rei.

O acesso à área investigada é facilitado pelas Rodovias Federais "Fernão Dias" (BR-381) e "Lavras-Barbacena" (BR-265). Para viagens com saídas da cidade de São Paulo, o percurso é um pouco mais longo (cerca de $350 \mathrm{Km}$ de Lavras) do que aquele com origem em Belo Horizonte (cerca de $200 \mathrm{Km}$ de Lavras). As principais drenagens que cortam a região são representadas pelos rios Grande e das Mortes.

\section{3 - Principais características dos enxames de diques máficos}

Diques de composição básica se distribuem por todos os continentes do Globo Terrestre na forma de enxames (Halls, 1982 e 1987). Recentemente, estas feições também tem sido assinaladas e interpretadas (Ernst et al, 1995) na superficie do planeta Vênus. Em geral, os enxames de diques máficos apresentam ampla distribuição geográfica, preferencialmente são quartzo-toleitos ricos em ferro, ocorrem individualizados na forma de corpos tabulares, bi-dimensionais, favorecendo modelagens geológicas, geoquímicas e geofisicas. Por esta razão, são importantíssimos na elucidação evolutiva de blocos continentais pré-cambrianos, nas análises de deformaçăo crustal e na compreensão de processos mantélicos e tectônicos.

Enxames de diques máficos encontram-se associados a um número diversificado de ambientes tectônicos tais como: margens de placas divergentes (LeCheminant \& Heaman, 1989); edifícios vulcânicos em zonas de subducção (Walker, 1987); ambiente de retro-arco (Hooper, 1988); zonas de colisão continental (Féraud et al, 1987), entre outros. 


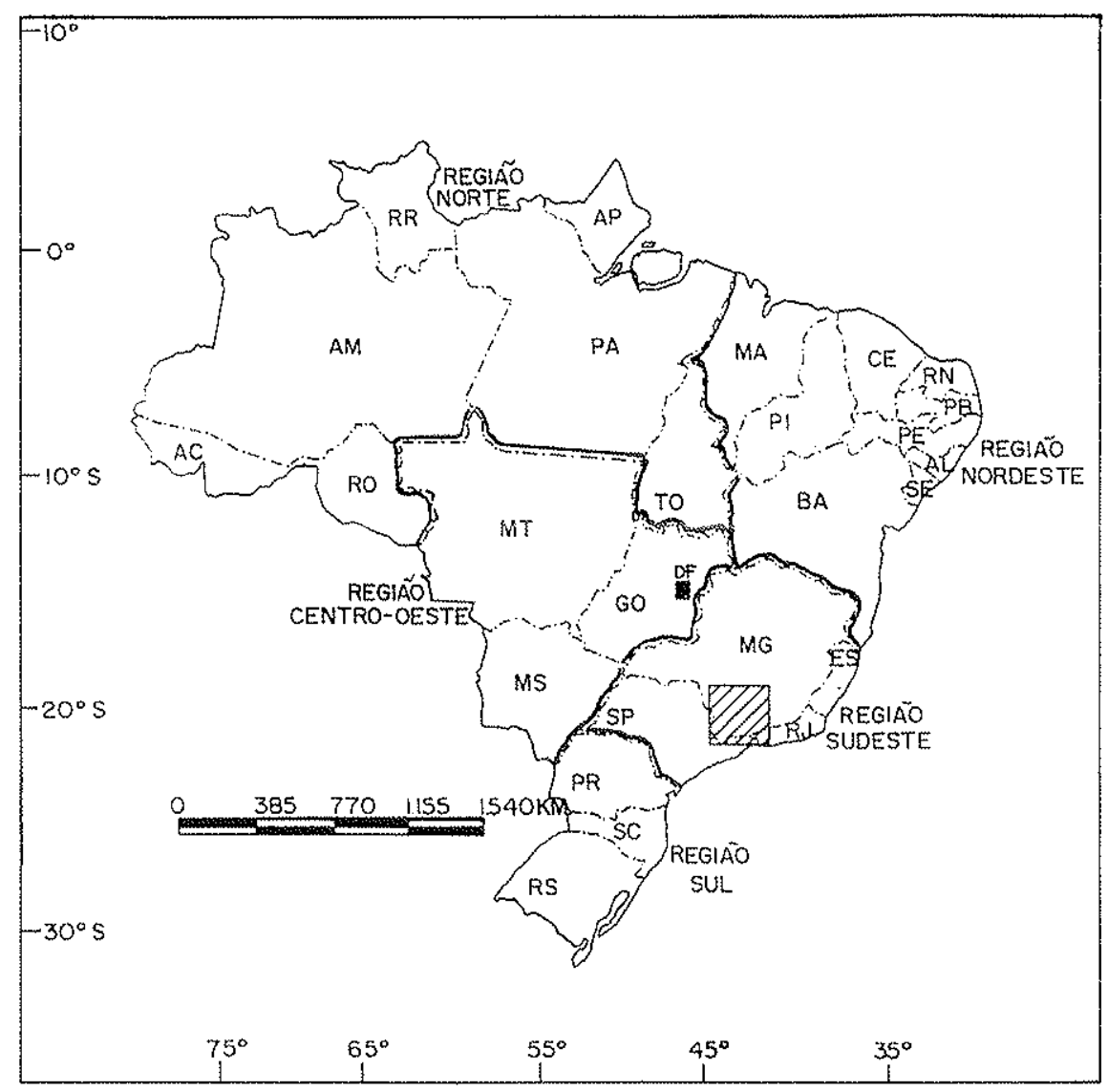

FIGURA 1.1: Localização geográfica.

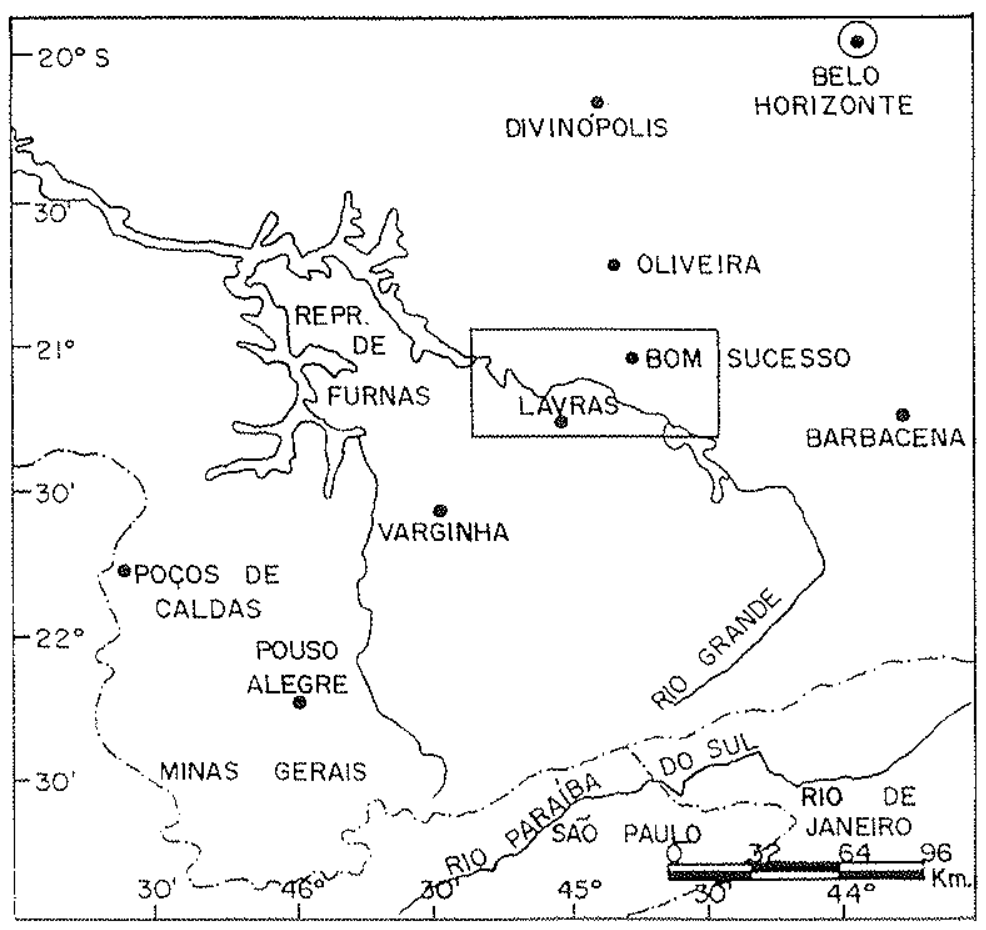

FIGURA 1.2: Localização da área investigada na região sudeste de Minas Gerais. 
Tais intrusões apresentam registros desde os primórdios de uma litosfera rígida (3,0 Ga). No entanto, segundo Halls (1987) alguns períodos no tempo se destacam como de maior ocorrência dessa atividade magmática intrusiva $(\sim 2,9 \mathrm{Ga} ; \sim 2,5 \mathrm{Ga} ; 2,2-1,9$ $\mathrm{Ga} ; 1,3-1,1 \mathrm{Ga} ; 0,9-0,6 \mathrm{Ga}$ e $0,2-0,1 \mathrm{Ga})$.

Em geral, enxames de diques de idade pré-cambriana sâo mais significativos do que aqueles do Fanerozóico, indicando condições especiais de tensão crustal propiciadas por gradientes geotermais elevados, rápida convecção, ou por uma litosfera delgada.

As dimensões de um enxame de diques chega a alcançar milhões de quilômetros quadrados, como é o caso do enxame de Mackenzie no Canadá que recobre uma área de 2,7 milhões de $\mathrm{km}^{2}$ (Fahrig, 1987), podendo incluir em seu domínio centenas ou milhares de diques. Em geral, as dimensões podem auxiliar na elucidação da profundidade e tamanho da fonte magmática. Individualmente os diques podem atingir $700 \mathrm{~km} \mathrm{de}$ comprimento como o grande dique Abitibi (Ernst et al, 1995). Destaca-se também, o dique básico do centro oeste da Groenlândia $(400 \mathrm{~km}$ ) descrito por Kalsbeek \& Taylor (1986).

Em relação a espessuras, o Grande Dique do Zimbabwe apresenta cerca de $11 \mathrm{~km}$ e se destaca daqueles tidos como muito espessos, como o dique Jimberlana da Austrália $(\sim 2,5 \mathrm{Km})$ e o dique de Muskox ( 500 metros).

Enxames de diques máficos com idades neoarqueanas e da transição Arqueano/Proterozóico, tem sido relatados na: Escócia [ 2,42 Ga] (Heaman \& Tarney, 1989); Antártica [2,42 Ga] (Sheraton et al, 1987; Kuehner, 1989); Zimbabwe [2,5 Ga] (Wilson et al, 1987); Canadá/Matachewan [2,45 Ga] (Heaman, 1995); Canadá/Minto Block [2,72 Ga] (Stern et al, 1994) e Finlândia [2,45 Ga] (Vuollo et al, 1995), entre outras regiões. Vale ressaltar, que estes enxames são predominantemente caracterizados por uma composição enriquecida em magnesio $(\mathrm{MgO}), \mathrm{SiO}_{2}$ e forte afinidade noritica e/ou boninitica.

De outra parte enxames do Paleoproterozóico posicionados entre 1,9-2,2 Ga são assinalados, na Groenlândia [ 2,13 Ga] (Kalsbeek et al, 1978; Kalsbeek \& Taylor, 1985; Hall \& Hughes, 1987); no Uruguai [1,9-1,7 Ga] (Bossi et al, 1993; Mazzucchelli et al, 1995), Antártica $\sim 1.8$ Ga] (Collerson \& Sheraton, 1986; Lanyon et al, 1993), Canadá/Provincia Superior $[\sim 2,07 \mathrm{Ga}]$ (Wirth \& Vervoort, 1995), Finlândia [2,1 1,9 Ga] (Vuollo et al, 1995), e em outros escudos pré-cambrianos. Via de regra, tratam-se de Toleitos 
ricos em ferro, embora aqueles da Groenlândia também apresentem composição similar aos pertencentes ao grupo da transição Arqueano/Proterozóico.

De maneira geral, acredita-se que a intrusão de diques é restrita a fraturas pré-existentes nos diferentes níveis crustais. Entretanto, Emerman \& Marret (1990) sustentam que a pressão exercida pelo magma por si só é capaz de gerar fraturamentos, os quais são posteriormente preenchidas pelo fluxo magmático.

Este fluxo se propaga tanto na vertical como na horizontal e tem sido motivo de amplas discussões sobre sua irradiação a partir de um centro (foco). Em particular, quanto a sua capacidade de percorrer grandes distâncias, como observado para o enxame Mackenzie no Canadá (LeCheminant \& Heaman, 1989). Técnicas como anisotropia de susceptibilidade magnética (AMS) tem complementado as investigações acerca da orientação do fluxo magmático, auxiliando também na definição das fontes magmáticas, conforme relatado por Raposo \& Ernesto (1995).

Em geral, a ocorrência de um enxame está relacionada a esforços de tração como fruto de amplos sistemas tectônicos extensionais desenvolvidos na litosfera. Por outro lado, um ou outro enxame tem sido relacionado a zonas de cisalhamento transcorrente (e.g. Tarney \& Weaver, 1987; Cadman et al, 1990; Tarney, 1992).

Destacam-se entre os extensionais aqueles associados a rifteamento, como proposto por Fahrig (1987), cujo desenvolvimento ocorre em 3 etapas, a saber: rifteamento com intrusão de diques e vulcanismo; início da formação do oceano com um grupo de diques paralelo e outro perpendicular as margens continentais; fechamento do oceano anteriormente aberto, provocando a deformação ou destruição dos diques paralelos à costa, no decorrer da colisão continente-continente.

Diversos autores (e.g. Tarney \& Weaver, 1987; Cadman et al, 1990; Correa Gomes et al, 1991; Tarney, 1992 e Chaves, 1996) tem relacionado enxames de diques máficos com zonas de cisalhamento transcorrentes, as quais indicam terem participado da origem dos diques através de marcas de cisalhamentos assinaladas nas bordas da intrusão e na encaixante adjacente. Enxames de diques situados a noroeste da Escócia, no oeste da Groenlândia e no sudeste do Cráton do Săo Francisco, colocaram-se sob a influência de zonas de cisalhamentos, as quais foram ativas durante e depois do periodo intrusivo (e.g. Tanney \& Weaver, 1987 e Chaves, 1996). 
Segundo Cadman et al (1990), a colocação de diferentes enxames no Proterozóico, deve ter ocorrido sob a influência direta de regimes de cisalhamentos transtensivos e transpressivos concomitantes e sequêenciais. Desse modo, baseado no fato de que as zonas de cisalhamento transcorrentes não são homogêneas em termos de condições de esforços, os segmentos transtensionais destas zonas facilitariam a intrusão magmática em um primeiro momento, para posteriormente tornarem-se segmentos transpressionais ocasionando o cisalhamento do material intrudido.

Um ponto interessante no desenvolvimento das zonas de cisalhamento, é sua forte associação com o ingresso e migração de fluídos antes durante e após a intrusão. Estes fluídos são responsáveis pelo extensivo metamorfismo registrado nos diques e encaixantes das proximidades, conforme relatado por Tarney \& Weaver (1987) e Tarney (1992).

As principais características petrológicas e composicionais dos enxames de diques máficos são extremamente diversificadas. Entretanto, Tarney (1992), Tarney \& Weaver (1987) e Condie et al (1987), entre outros, sintetizaram 4 tipos volumetricamente mais importantes: a) noritos; constituidos por ortopiroxênios, clinopiroxênios, biotitas, opacos e olivinas; b) bronzita-picritos ricos em olivina (20-40\%); com orto e clinopiroxênio mais plagioclásio, flogopita e cromita. c) quartzo toleitos ricos em ferro; constituidos por plagioclásio, clinopiroxênio e titanomagnetita como minerais fundamentais, e quartzo, hormblenda e biotita como minerais acessórios; d) olivina-gabros; com cerca de $15 \%$ de olivina, mais plagioclásio e clinopiroxênio como principais, e como minerais acessórios ortopiroxênio, biotita e opacos.

Os tipos noriticos e picríticos representam um importante tipo de magma da transição Neoarqueano/Paleoproterozóico e, segundo diversos pesquisadores (e.g. Hall \& Hughes, 1987; Kuehner, 1989; Vuollo et al, 1995), eles apresentam fortes afinidades com os boninitos atuais de arco de ilha. Designados também como basaltos enriquecidos em silicio e magnésio, são composicionalmente caracterizados por altas concentrações em: $\mathrm{SiO}_{2}, \mathrm{MgO}_{\text {, }}$ $\mathrm{Cr}$ e Ni e por baixas concentrações em elementos de alta densidade de carga I(e.g. Ti, Nb, Ta) "HFSE"]. Adicionalmente, mostram-se tipicamente enriquecidos em elementos terras raras leves (ETRL) e elementos com ions de grande tamanho [(eg. Rb, Ba, K) "LILE"]

Em geral. os diques quartzo-toleiticos e de olivina-gabro são caracterizados pelo forte enriquecimento em ferro, atas concentrações em "LILE", "HFSE" e ETRL. 
O comportamento dos elementos traços, normalizados ao manto primitivo, comprova as fortes semelhanças assinaladas entre os diques de olivina-gabro e os quartzotoléíticos. No tocante aos noritos e picritos assinalam-se também semelhanças composicionais, em particular se destacam as fortes anomalias negativas de $\mathrm{Nb}$, $\mathrm{P}$ e Ti (Tarney \& Weaver, 1987).

Entretanto, o comportamento dos elementos traços mostra que os diques noríticos e picríticos são relativamente mais enriquecidos em "LILE" e ETRL do que os diques quartzo-toleiticos e de olivina-gabro.

As semelhanças e as discrepâncias entre estes tipos, conduziram Tarney \& Weaver (1987) e Tarney (1992) a sugerir duas fontes mantélicas para a geração dos 4 tipos. Uma rica em ferro para o conjunto do diques quartzo-toleíticos e de olivina-gabro e outra, rica em magnésio para o conjunto dos noritos e picritos.

\section{II - Metodologia}

Com a finalidade de alcançar os objetivos propostos foram realizadas as seguintes etapas de trabalho:

\section{II.1 - Trabalhos Fotointerpretativos}

Concomitante a revisão pormenorizada da bibliografia existente realizaramse os estudos fotointerpretativos da região investigada. Nesta etapa, foram analisadas cerca de 109 fotos aéreas do vôo da PROSPEC de 1985, pertencentes a CEMIG e em escala aproximada de 1:30.000.

Inicialmente as fotografias foram preparadas para estereoscopia e delimitação da área, para logo após, proceder-se a aplicação de técnicas de fotoleitura. Neste sentido, o primeiro passo foi o reconhecimento das drenagens e dos principais lineamentos fornecidos tanto pelo relevo quanto pela drenagem. Estes lineamentos foram um dos principais critérios utilizados com vistas à identificaçào preliminar de diques, os quais foram confirmados ou não em trabalhos de campo. Todavia, outros criterios como padrão de drenagem, densidade de drenagem, textura, estrutura, formas de relevo e declividade tambem foram utilizados com a finalidade de situar as diferentes litologias envolvidas no contexto 
geológico local. A vegetação e o tipo de erosão não foram levados em consideração, haja visto. a grande intervenção humana na região.

$\mathrm{Na}$ confecção do esboço geológico local, a fotointerpretação contribuiu principalmente na delimitação das unidades geológicas e somente em alguns casos os resultados não foram satisfatórios, isto provavelmente em função da similaridade petrográfica e maturidade geomorfológica das unidades. Um típico exemplo na região, é dado pela similaridade entre gnaisses graníticos migmatizados e granitos tipo Bom Sucesso (Fig.IV.1).

Os dados da fotointerpretação permitiram também a construção de um mapa de diques (Fig.IV.2), os quais estiveram sempre monitorados pelos dados de campo. Entretanto, alguns diques não foram identificados nos estudos fotogeológicos por apresentarem comprimentos e espessuras não compatíveis com a escala disponível, ou mesmo estarem recobertos por reativações mais jovens como escorregamento de solo. Estes diques foram inseridos no mapa com base exclusivamente nas observações de campo.

Adicionalmente foi utilizada nas interpretações uma imagem do satélite Francês SPOT na escala 1:250.000 (gentilmente cedida pelo Prof. Dr. J.Quéméneur da UFMG) da qual se extrairam os grandes lineamentos NW (noroeste) que cortam a região e, que na verdade, correspondem a diques de extensão quilométrica do tipo $\mathrm{DB}_{1}$ (veja petrografia). Este tipo de rocha, embora de fácil visualização em imagem de satélite, raramente possibilita seu monitoramento em fotos aéreas no exemplo estudado.

\section{II.2 - Trabalhos de Campo}

Após a confeç̧ão de um mapa aerofotogeológico preliminar, aprimorado no decorrer das atividades de campo, procurou-se coletar um número cada vez crescente de informações sobre os diques máficos e suas encaixantes. Cumpre ressaltar, que o esboço geológico confeccionado nesta tese (veja cap. IV), apoiou-se fundamentalmente na cartografia geológica proposta por Quéméneur (1996), e que o mesmo não reflete um mapeamento sistemático da regiăo, mas sim uma investigação acerca dos diques máficos locais.

As bases geologicas utilizadas no inicio dos trabalhos foram: Carta Geológica do Brasil ao Milionésimo, Folha Rio de Janeiro/Vitória/Iguape, (DNPM, 1978); Carta Geológica do Projeto Sapucai, na escala 1:250.000 (Cavalcante et al, 1979) e mapa 
geológico da região de Bom Sucesso - São João Del Rei (MG), que enfatiza a geologia da porção leste da Serra de Bom Sucesso, conforme Quéméneur (1991).

Desse modo, um total de 8 campanhas de campo foram realizadas, totalizando 73 dias de atividades, as quais permitiram a amostragem sistemática de aproximadamente 110 diques máficos (121 amostras) bem como, estudos de detalhe de alguns corpos específicos, caracterização da forma, dimensões, contatos, espessuras, estrutura e geometria.

Com a finalidade de controlar e checar as rochas encaixantes destes corpos intrusivos, foram coletadas 62 amostras do embasamento cristalino que, adicionadas as descriçôes dos afloramentos no campo permitiram a elaboração do esboço geológico da região (Fig. IV.1). Para tanto, foram utilizadas como base cartográfica as folhas Varginha, Barbacena, Furnas e Divinópolis, na escala 1:250.000 e editadas pelo IBGE (1979).

\section{II.3 - Trabalhos Laboratoriais}

Todas as amostras coletadas foram analisadas petrograficamente através do microscópio de luz polarizada: As seções delgadas permitiram a caracterização mineralógica, granulométrica e textural das rochas investigadas. Adicionalmente, foram avaliados os percentuais em volume das principais fases minerais.

Do conjunto de diques máficos, 121 amostras foram analisadas quimicamente nos laboratórios do Departamento de Ciências da Terra da Universidade de Trieste, Itália, sendo que 15 entre estas foram cedidas pelo Prof. Joel Quéméneur. Análises químicas também foram efetuadas em 45 amostras de rochas do embasamento metamórfico.

No caso das intrusivas máficas, objeto maior deste trabalho, as interpretações geoquimicas foram favorecidas pela observação em 90 exemplares virtualmente isentos de saussuritização e epidotização.

As determinações quimicas de oito elementos maiores $\left(\mathrm{SiO}_{2}, \mathrm{TiO}_{2}, \mathrm{Al}_{2} \mathrm{O}_{3}\right.$, $\mathrm{Fe}_{2} \mathrm{O}_{3}, \mathrm{MgO}, \mathrm{CaO}, \mathrm{Na}_{2} \mathrm{O}$ e $\mathrm{K}_{2} \mathrm{O}$ ) dois elementos menores ( $\mathrm{MnO}$ e $\mathrm{P}_{2} \mathrm{O}_{5}$ ) e onze elementos traços $(\mathrm{Nd}, \mathrm{Nb}, \mathrm{Cr}, \mathrm{Ni}, \mathrm{Ba}, \mathrm{Rb}, \mathrm{Sr}, \mathrm{La}, \mathrm{Ce}, \mathrm{Zr}$ e $\mathrm{Y}$ ), foram obtidas pela técnica da fluorescência de raios-X (FRX), através de um aparelho PHILIPS PW 1404. Os elementos maiores e os traços $\mathrm{Rb}, \mathrm{Sr}, \mathrm{Zr}, \mathrm{Y}, \mathrm{Nb}, \mathrm{Cr}$ e $\mathrm{Ni}$ foram analisados com tubo de $\mathrm{Rh}$ (Ródio) enquanto que os elementos $\mathrm{Ba}, \mathrm{La}, \mathrm{Ce}$ e $\mathrm{Nd}$ foram analisados com tubo de $\mathrm{W}$ (Tungstênio). 
Utilizaram-se curvas de calibração de 40 padrões geológicos internacionais (Bellieni et al, 1983). O Fe ${ }^{42}$ foi determinado através de titulação volumétrica, enquanto que a perda ao fogo (LOI) por aquecimento à $1.000^{\circ} \mathrm{C}$ por 12 horas e corrigida para oxidação do ferro. $\mathrm{O}$ erro estimado para elementos maiores e menores não ultrapassa $5 \%$ enquanto que para os traços é inferior a $10 \%$.

As microanálises químicas das principais fases minerais dos diques máficos (piroxênios, plagioclásios, minerais opacos e anfibólios) foram realizadas pelo autor no Departamento de Mineralogia e Petrologia da Universidade de Pádua, Itália. Para tal utilizou se uma microssonda eletrônica da marca ETEC AUTOSCAN, nas condições de potência de aceleração igual a $15 \mathrm{Kv}$, com corrente de $5 \mu \mathrm{A}$ e com espectrômetro de raios - X EDS ORTEC. Para a análise dos elementos empregaram-se os seguintes padrões : quartzo para o $\mathrm{Si}$; augita natural de Kahauni (Nova Zelândia) para o $\mathrm{Na}$; wollastonita para o $\mathrm{Ca}$; diopsidio para o $\mathrm{Mg}$; coríndon para o $\mathrm{Al} \mathrm{e}$, os elementos puros para o $\mathrm{Cr}, \mathrm{Ti}, \mathrm{Mn}$ e $\mathrm{Fe}$. O erro estimado está em torno de 2 a $6 \%$ para os elementos maiores e não ultrapassa $9 \%$ para os elementos menores.

Os elementos terras raras (ETR) foram determinados pela metodologia da ativação neutrônica (INAA), cujos detalhes técnicos podem ser observados em Marques (1988). As amostras selecionadas para estas análises foram pulverizadas pelo autor em moinho de bolas de ágata do Departamento de Mineralogia e Petrologia (IGc-USP), na tentativa de evitar qualquer possibilidade de contaminação de elementos como o Ta. Os nove ETR a saber: La, Ce, Nd, Sm, Eu, Tb, Yb e Lu, mais os elementos Hf, Th, Ta e U foram processados pelo Activation Labs. em Ontario, Canadá. De um conjunto de 29 amostras de diques máficos analisados para os ETR e outros elementos traços incompativeis, cerca de $90 \%$ apresentaram concentrações abaixo do limite de detecção para os elementos Ta $(0,5$ ppm) e U $(0,2 \mathrm{ppm})$, inviabilizando qualquer tipo de interpretação para tais elementos. Destaca-se ainda, o caso de um grupo de diques que apresentaram o mesmo problema em relação ao Tb (concentrações abaixo de 0,5 ppm).

Antes de iniciar os estudos isotópicos (Rb-Sr, Sm-Nd e K-Ar), os exemplares selecionados para analises em rocha total foram britados (britador de mandibulas), quarteados e logo após pulverizados pelo autor em moinho de bolas (carbeto de tungstênio) marca Mixer/Mill 8000, no Centro de Pesquisas Geocronológicas (CPGeo) da Universidade 
de São Paulo. O material pulverizado de cada amostra foi testado com HCl para verificar a existência ou não de carbonatos. Os concentrados minerais foram obtidos após britagem e quarteação seguidas por peneiramento com vistas a separação mineral nas frações 80-100 e 100-150 mesh. O primeiro concentrado mineral foi obtido através do imã de mão e é composto por minerais magnéticos (magnetitas e titano-magnetitas). Para obter outros concentrados minerais de interesse (biotita, anfibólio, plagioclásio e apatita) utilizou-se o separador magnético Frantz. Adicionalmente, para obter apatita, empregou-se o bromofórmio e posterior separação manual em lupa binocular (catação), com a finalidade de evitar possiveis agregados. Os plagioclásios também foram separados manualmente em lupa binocular, após terem passado no separador magnético.

\section{Metodologia $K-A r$}

As análises pelo método potássio-argônio foram efetuadas de acordo com as técnicas descritas por Amaral et al (1966). Algumas pequenas modificações foram introduzidas no CPGeo-USP desde então, dentre as quais, se destaca o aprimoramento do sistema de introdução do ${ }^{38} \mathrm{Ar}$ (spike) na amostra. As amostras selecionadas representam um dique anfibolítico (veja Petrografia) e um dique da suite básica (veja Litogeoquímica). Este último foi analisado em rocha total, enquanto que no dique anfibolítico as análises foram realizadas nos concentrados minerais (biotita, plagioclásio e anfibólio).

As dosagens dos teores de potássio, foram realizadas através de ataque químico em duplicata e leitura por fotometria de chama, em aparelho Micronal B-262 com padrão interno de litio.

As extrações de argônio foram processadas em unidade de uitra-vácuo, com pressões geralmente inferiores a $6 \times 10^{-8} \mathrm{mmHg}$. Aos gases liberados na fusão é introduzido uma aliquota mensurável do traçador ${ }^{38} \mathrm{Ar}$ e em seguida a amostra é purificada em fornos de $\mathrm{Cu}-\mathrm{CuO}$ e titânio. As análises de argônio foram obtidas em espectrômetro de massa de fonte gasosa Nuclide tipo Reynolds MS-1. A leitura dos espectrogramas é executada de modo digital em micro-computador "on-line".

As constantes utilizadas nos cálculos das idades, são aquelas propostas por Steiger \& Jäger (1977), a saber: $\lambda_{\mathrm{kB}}^{40}=4,962 \times 10^{-10} \operatorname{anos}^{-1} ; \lambda_{\text {kital }}^{40}=0,581 \times 10^{-10}$ anos $^{-1}$; $\left({ }^{40} \mathrm{Ar}{ }^{36} \mathrm{Ar}\right)_{\mathrm{atm}}=295,5 \mathrm{e}{ }^{40} \mathrm{Ka}=0.01167 \% \mathrm{~K}$ tolal .

Uma amostra dos diques metabásicos (DMB, veja Petrografia), foi analisada pelo sistema ${ }^{40} \mathrm{Ar}^{39} \mathrm{Ar}$ (anfíbólio) no "Berkeley Geochronology Center" (EUA) pelo Dr. Paul 
Renne. A metodologia utilizada é por laser em fusão seqüencial conforme descrito em Renne et al (1996).

\section{Metodologia $\mathrm{Rb}-\mathrm{Sr}$}

Para as análises $\mathrm{Rb}-\mathrm{Sr}$ em rocha total, realizadas pelo autor no Centro de Pesquisas Geocronológicas (CPGeo - USP), foram selecionadas 22 amostras de diques máficos, sendo que deste conjunto 9 pertencem ao grupo de diques da suite básica (veja Litogeoquímica), 9 pertencem ao grupo de diques da suite básico norítica (veja Litogeoquímica) e 4 aos diques metabásicos (veja Petrografia).

As razões ${ }^{87} \mathrm{Sr} /{ }^{86} \mathrm{Sr}$ e os valores de $\mathrm{Rb}$ e $\mathrm{Sr}$ foram obtidos pela técnica de diluição isotópica. Este processo consiste na mistura da amostra com traçadores ("spikes") dos elementos que se deseja dosar, propiciando dados mais precisos. Adicionalmente, foram selecionadas 5 amostras do embasamento metamórfico e 2 dos diques máficos para efetuar apenas análises em suas razões ${ }^{87} \mathrm{Sr} /{ }^{86} \mathrm{Sr}$ pelo método "natural" ( $\mathrm{Sr}$ natural ), cujos teores de $\mathrm{Rb}$ e $\mathrm{Sr}$ são previamente determinados por análises quantitativas através da fluorescência de raios- $X$.

O procedimento químico para o sistema $\mathrm{Rb}-\mathrm{Sr}$, inicia-se com a abertura da amostra atacada pela açào do ácido nítrico $\left(\mathrm{HNO}_{3}\right)$ e ácido fluorídrico $(\mathrm{HF})$ na proporção $1: 2$. Após o ataque, a amostra é dissolvida em $\mathrm{HCl} 2,62 \mathrm{~N}$ e delas são extraidas 3 aliquotas, a saber: estrôncio natural, estrôncio mais "spike" e rubidio mais "spike". No caso da técnica denominada "natural", apenas a aliquota de estrôncio natural é analisada espectrometricamente. Por outro lado, na técnica de diluição isotópica todas as três aliquotas são analisadas no espectrômetro. Nas aliquotas pertinentes são adicionadas quantidades pré calculadas de "spike", em geral, utilizando-se valores já obtidos pela fluorescência de raios- $X$. No prosseguimento as amostras são depositadas em colunas de troca iônica (resina cationica AG-50WX8, 200-400 mesh) seguida pela coleta do $\mathrm{Rb}$ ou $\mathrm{Sr}$ através de $\mathrm{HCl} 2,62 \mathrm{~N}$. O material coletado, apos secagem, tem seu residuo resultante analisado por espectrometria de massa.

As medidas das razões isotópicas de $\mathrm{Sr}$ (estrôncio) foram executadas em espectrômetro de massa VG-354 MICROMASS do CPGeo, principalmente no monocoletor e subordinadamente no coletor multiplo opcional com amplificador Daly e sistema automático. O erro destas medidas è de $2 \sigma$. 
A reprodutibilidade analítica para o método geocronológico $\mathrm{Rb}-\mathrm{Sr}$ no CPGeo é controlada pela repetição de análises do padrão internacional NBS-987 (carbonato de Estrôncio), cujo valor médio foi de $0,71028 \pm 0,00003(1 \sigma)$ no periodo da realização das análises. O valor médio se refere a médias distintas de vários grupos em diferentes dias, sendo que cada grupo teve no minimo 100 valores de razões isotópicas. O valor do "branco" de $\mathrm{Sr}$ do laboratório de química do CPGeo, na época da execução das análises, é da ordem de 6,4 ng/g (nanograma/grama). No Laboratório de Geoquímica Isotópica de Trieste o valor é da ordem de $5,3 \mathrm{ng} / \mathrm{g}$.

Os valores de ${ }^{87} \mathrm{Sr} /{ }^{86} \mathrm{Sr}$ foram normalizados de acordo com a razão ${ }^{86} \mathrm{Sr} /{ }^{88} \mathrm{Sr}$ $=0,1194$, sendo utilizadas nos cálculos as constantes propostas por Steiger \& Jäger (1977), a saber: $\lambda_{\mathrm{Rb}}=1,42 \times 10^{-11}$ anos ${ }^{-1},{ }^{84} \mathrm{Sr} /{ }^{86} \mathrm{Sr}=0,056584 \mathrm{e}^{85} \mathrm{Rb} /{ }^{87} \mathrm{Rb}=2,59265$. As demais razões utilizadas são: $\left({ }^{87} \mathrm{Sr} /{ }^{86} \mathrm{Sr}\right)$ prIMORDIAL [BABI] $=0,69898 ;\left({ }^{87} \mathrm{Rb} /{ }^{86} \mathrm{Sr}\right)_{\mathrm{DM} \text { atua! }}=0,0494$; $\left({ }^{87} \mathrm{Rb} /{ }^{86} \mathrm{Sr}\right)_{\text {UR atual }}=0,0816 ;\left({ }^{87} \mathrm{Sr} /{ }^{86} \mathrm{Sr}\right)_{\mathrm{DM} \text { atual }}=0,7023 ;\left({ }^{87} \mathrm{Sr} /{ }^{86} \mathrm{Sr}\right)_{\text {UR atual }}=0,7045$. Para se obter a razão ${ }^{87} \mathrm{Rb} /{ }^{86} \mathrm{Sr}$ utilizou-se a seguinte equação: ${ }^{87} \mathrm{Rb} /{ }^{86} \mathrm{Sr}=2,8934 \times[\mathrm{Rb}(\mathrm{ppm}) / \mathrm{Sr}(\mathrm{ppm})]$.

Diagramas e cálculos isocrônicos foram obtidos conforme Williamson (1968), utilizando-se o programa ISOJOB de Vlach (1990). O erro fornecido é de $1 \sigma$.

\section{Metodologia Sm-Nd}

As análises Sm-Nd foram realizadas pelo autor no CPGeo (USP) e no Laboratório de Geoquimica Isotópica da Universidade de Trieste, Itália. Ambos empregam a técnica de diluição isotópica, seguindo o mesmo procedimento de separação dos elementos que se realiza em duas etapas. Antes porém, a amostra sofre um ataque químico inicial com os ácidos nitrico e fluoridrico na proporção $1: 2$. Após a evaporação da solução o material é redissolvido em $\mathrm{HCl} 2,5 \mathrm{~N}$.

A primeira etapa realiza-se em coluna de troca ionica (resina AG50WX8/200-400 mesh) ou coluna primária, com o objetivo de coletar o conjunto das terras raras utilizando-se $\mathrm{HCl} 6,2 \mathrm{~N}$. As terras raras coletadas são dissolvidas em $\mathrm{HCl} 0,26 \mathrm{~N}$ após o processo de secagem. A segunda etapa, realiza-se em coluna preenchida com pó de teflon ou coluna secundária (200 mesh) tratada com HDEHP (ácido di-2 etilexil fosfórico), com o objetivo de separar o samário e o neodimio do conjunto das terras raras. Nesta última etapa, utiliza-se $\mathrm{HCl}$ 0,26 $\mathrm{N}$ para a coleta do $\mathrm{Nd}$ e $\mathrm{ICl}$ 0,55 $\mathrm{N}$ para a coleta de $\mathrm{Sm}$. O residuo seco é encaminhado para a espectrometria de massa. No Laboratório de Geoquimica Isotópica 
da Universidade de Trieste, o valor do "branco" de Nd para o período de análises é de 0,025 nanogramas. No CPGeo-USP o "branco" de Nd é da ordem de 0,031 nanogramas.

As leituras espectrométricas foram efetuadas em espectrômetro de massa multicoletor tipo VG-354 do CPGeo. Os valores ${ }^{143} \mathrm{Nd} /{ }^{144} \mathrm{Nd}$ foram normalizados pela razão ${ }^{146} \mathrm{Nd} /{ }^{144} \mathrm{Nd}=0,7219$ (Hawkesworth \& Van Calsteren, 1984; Ben Othman et al, $1984 \mathrm{e}$ Michard et al, 1985). Para obter a razão ${ }^{147} \mathrm{Sm} /{ }^{144} \mathrm{Nd}$ utilizou-se a equação ${ }^{147} \mathrm{Sm} /{ }^{144} \mathrm{Nd}=$ $0,60847 \times[\mathrm{Sm}(\mathrm{ppm}) / \mathrm{Nd}(\mathrm{ppm})]$. As constantes adicionalmente utilizadas foram: $\lambda_{\mathrm{Nd}}=6,54 \times$ $10^{-12}$ anos $^{-1} ;\left({ }^{147} \mathrm{Sm} /{ }^{144} \mathrm{Nd}\right)_{\text {CHUR atual }}=0,1967 ;\left({ }^{147} \mathrm{Sm} /{ }^{144} \mathrm{Nd}\right)_{\text {DM atual }}=0,222 ;\left({ }^{143} \mathrm{Nd} /{ }^{144} \mathrm{Nd}\right)_{\text {CHUR }}$ atual $=0,512638 \mathrm{e}\left({ }^{143} \mathrm{Nd} / /^{144} \mathrm{Nd}\right)_{\mathrm{DM} \text { atual }}=0,513114$.

A média de 4 análises do padrão La Jolla no CPGeo é de 0,511857 t

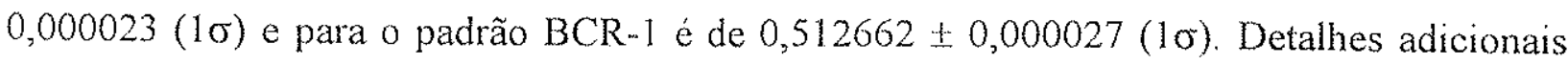
dos demais procedimentos analíticos adotados encontram-se descritos em Sato et al (1995).

Os cálculos das idades modelo $\left[\mathrm{T}^{\mathrm{DM}}\right]$ e os cálculos dos $\varepsilon$ de $\mathrm{Sr}$ e $\mathrm{Nd}$, utilizaram-se das constantes e parâmetros de Ben Othman et al (1984) e Michard et al (1985), e foram efetuados por programas específicos do CPGeo (USP). As constantes utilizadas para o tempo atual são aquelas anteriormente mencionadas. Os diagramas e cálculos isocrônicos para o sistema Sm-Nd (cf. Williamson, 1968) bem como os resultados concernentes aos mesmos (MSWD, idade, desvio padrão e razões iniciais), foram obtidos através do mesmo programa utilizado para o $\mathrm{Rb}-\mathrm{Sr}$.

Das 19 amostras selecionadas para o sistema Sm-Nd, 15 pertencem aos diques máficos e 4 pertencem ao embasamento metamórfico. Dentre as 15 amostras dos diques, 8 são da suite básico norítica (veja Litogeoquimica) e 7 são da suite básica (veja Litogeoquimica)

No primeiro conjunto, foram obtidas 11 análises em rocha total e $3 \mathrm{em}$ concentrados minerais, sendo um concentrado de plagioclásio e dois de apatita. No segundo conjunto e nas rochas do embasamento, foram realizadas análises $\mathrm{Sm}-\mathrm{Nd}$ em rocha total, em número de 7 e 4 respectivamente. 


\section{III - O SEGMENTO SUL DO CRÁTON DO SÃO FRANCISCO}

\section{III.1 - Introdução}

A evolução tectônica da Plataforma Sul-Americana é, entre outros aspectos, marcada por extensas regiões tectonicamente estabilizadas ao término do Paleoproterozóico. A etapa final do Paleoproterozóico é caracterizada pelo Ciclo Transamazônico $(2,2-1,8 \mathrm{Ga})$, que foi um dos principais periodos de crescimento continental (e.g. Cordani et al, 1988). A presença desses cinturões vestigiais bordejando núcleos cratônicos arqueanos é típica desse período da história geológica (Brito Neves, 1990; Brito Neves \& Cordani, 1991). O Cráton do São Francisco constitui-se numa dessas regiões (Almeida, 1977; Almeida et al, 1977 e Almeida et al, 1981), que atuou como antepaís das faixas móveis do Ciclo Brasiliano (Alkmin et al, 1993; Brito Neves \& Alkmin, 1993) a saber: Riacho do Pontal, a norte; Sergipana, a nordeste; Araçuai, a leste; Alto Rio Grande, a sul; Brasília, a oeste e Rio Prêto, a noroeste (Fig. III. 1).

A evolução tectônica do Cráton do São Francisco está intimamente ligada à do Congo, na África, do qual é sua extensão (Trompette, 1994). As similaridades entre as feições encontradas nos dois segmentos cratônicos são bastante evidentes. Ambos exibem embasamento cristalino de idade arqueana e paleoproterozóica, bacias e rifts do Mesoproterozóico, com supracrustais associadas e vulcanismo subordinado, além de extensivas coberturas sedimentares pertencentes ao Neoproterozóico (Teixeira \& Figueiredo, 1991; Trompette, 1994).

\section{III.2 - Quadro Geológico-Geocronológico Regional}

Na região meridional do Cráton do São Francisco, o embasamento polimetamórfico de idade arqueana e paleoproterozóica se expõe de Belo Horizonte para sudoeste, no Estado de Minas Gerais, sendo recoberto em discordância erosiva pelos sedimentos do Bambui. Em geral, três tipos de terrenos podem ser individualizados: 1) terrenos granito-greenstone arqueanos e granitóides intrusivos, a exemplo dos Complexos Bonfim, Belo Horizonte e Campo Belo (Fig. III.2); 2) cinturões supracrustais do Paleoproterozóico, que incluem os representantes do Supergrupo Minas e 3) terrenos de 


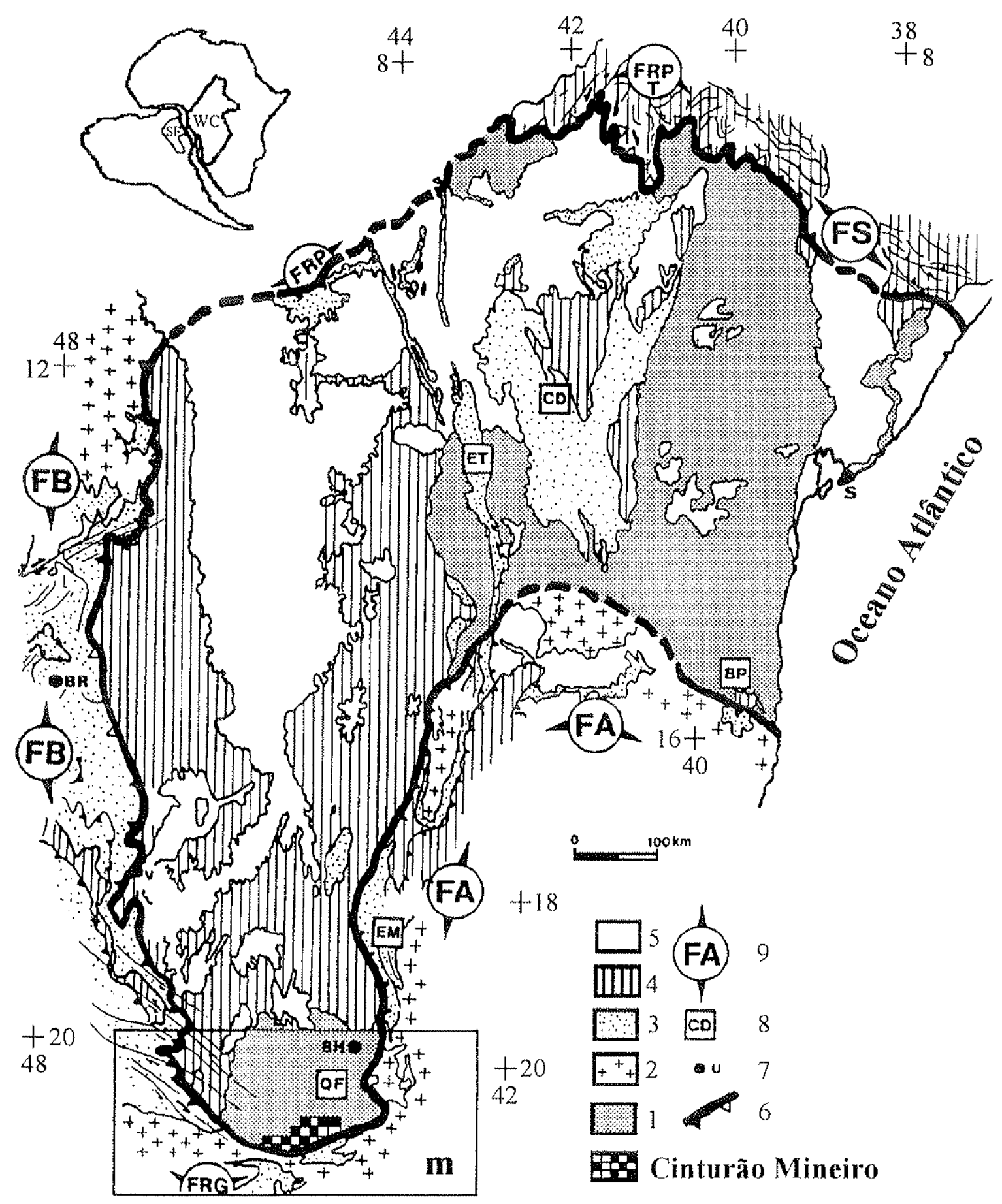

FIGURA III. 1: O Cráton do São Francisco, suas faixas marginais e as grandes unidades geológicas (modificado de Alkmim et al, 1993). 1) Embasamento do cráton (Arqueano), incluindo supracrustais mais velhas que $1.8 \mathrm{Ga}$ e rochas igneas. 2) Embasamento cnvolvido nos processos do deformação e metamorfismo do Evento Brasiliano. 3) Unidades mesoproterozóicas. 4) Unidades neoproterozóicas. 5) Coberturas fanerozóicas. 6) limites do cráton. 7) Cidades: S. Salvador; BR, Brasília: BH. Belo Horizonte. 8) Provincias físiográficas c geológicas: CD. Chapada Diamantina: ET, Espinhaço setentrional: BP. Bacia do Rio Pardo: EM, Espinhaço meridional; QF, Quadrilátero Ferrífero. 9) Faixas do dobramentos marginais brasilianas. FA: Faixa Araçai: FRG: Faixa Alto Rio Grande: FB: Faixa Brasilia: FRP: Faixa Rio Prêto: FRPT: Faixa Riacho do Pontal FS: Faixa Sergipana. Cinturão Mineiro: desenvolvimento da orogenia transamazônica $(2,25 \mathrm{~m}, 85 \mathrm{Ga}) \mathrm{m}=$ porçăo meridional do cráton. SF= Cráton do São Francisco: $W \mathrm{~W}=$ Cráton do Congo-Oeste. 
médio e alto grau metamórfico, granitizados intensamente no Ciclo Transamazônico com preservação de fragmentos mais antigos (e.g. Cordani \& Brito Neves, 1982; Teixeira \& Figueiredo, 1991; Schorscher, 1992; Noce, 1995; Carneiro et al, 1995; Teixeira et al, 1996 a e b).

\section{Arqueano}

Os terrenos arqueanos, no setor meridional do Cráton, constituem um núcleo com cerca de $10.000 \mathrm{Km}^{2}$, exposto ao sul da cobertura Bambuí, circundado por uma província geocronológica deformada no Paleoproterozóico, a qual foi denominada de Cinturão Mineiro (Teixeira, 1985) [Fig. III.1], e intrudido por plutonismo de natureza granitica e básica de diferentes idades. A região mais estudada é o Quadrilátero Ferrifero, onde devido aos enormes depósitos minerais, tem-se um alto grau de conhecimento geológico. Nessa região, o embasamento gnáissico-migmatítico arqueano encontra-se exposto em domos como os complexos de Bação e Caeté (Schorscher, 1992). Além destes, assinalamse inúmeros outros com denominações locais: Lavras (Cavalcante et al, 1979); Barbacena (Machado Filho et al, 1983); Bonfim (Carneiro, 1992; Carneiro et al, 1995); Belo Horizonte (Noce, 1995); Campo Belo (Teixeira et al, $1996 \mathrm{a}$ e b) e Passa Tempo (Fiumari et al, 1985).

De um modo geral, o embasamento arqueano na região pode ser dividido em dominios, os quais recebem as seguintes denominações (Fig.III.2): Complexo Belo Horizonte (porção norte), Complexo Bonfim (porção central) e Complexo Campo Belo (porção centrooeste). O embasamento é composto predominantemente por rochas que apresentam idades entre 2,60 a 3,20 Ga, obtidas pelos métodos Rb-Sr, Pb-Pb, U-Pb e Sm-Nd. Estes dados geocronológicos destacam o Neoarqueano como principal fase de formação de crosta continental (Teixeira \& Figueiredo, 1991; Cameiro et al, 1995; Teixeira et al, 1996 a e b; Noce \& Teixeira, 1996).

O Complexo Campo Belo, é o que preserva idades radiométricas das mais antigas do setor cratônico, este dominio encontra-se adjacente ao enxame de diques investigados (Fig.III.2). Os migmatitos deste complexo apresentam zircões que fornecem idade U-Pb (SHRIMP) de $3204 \pm 12 \mathrm{Ma}$ (Teixeira et al, 1996 b). Assinalam-se também idades Pb-Pb de $3076+182 / 470$ Ma e U-Pb de $3068+19$ Ma obtidas em ortognaisses regionais (Teixeira et al 1996 b). Uma idade U Pb (SHRIMP) de $2839 \pm 17$ Ma, obtida em zircões prismaticos, é interpretada como referente a época de cristalizaçăo do material 


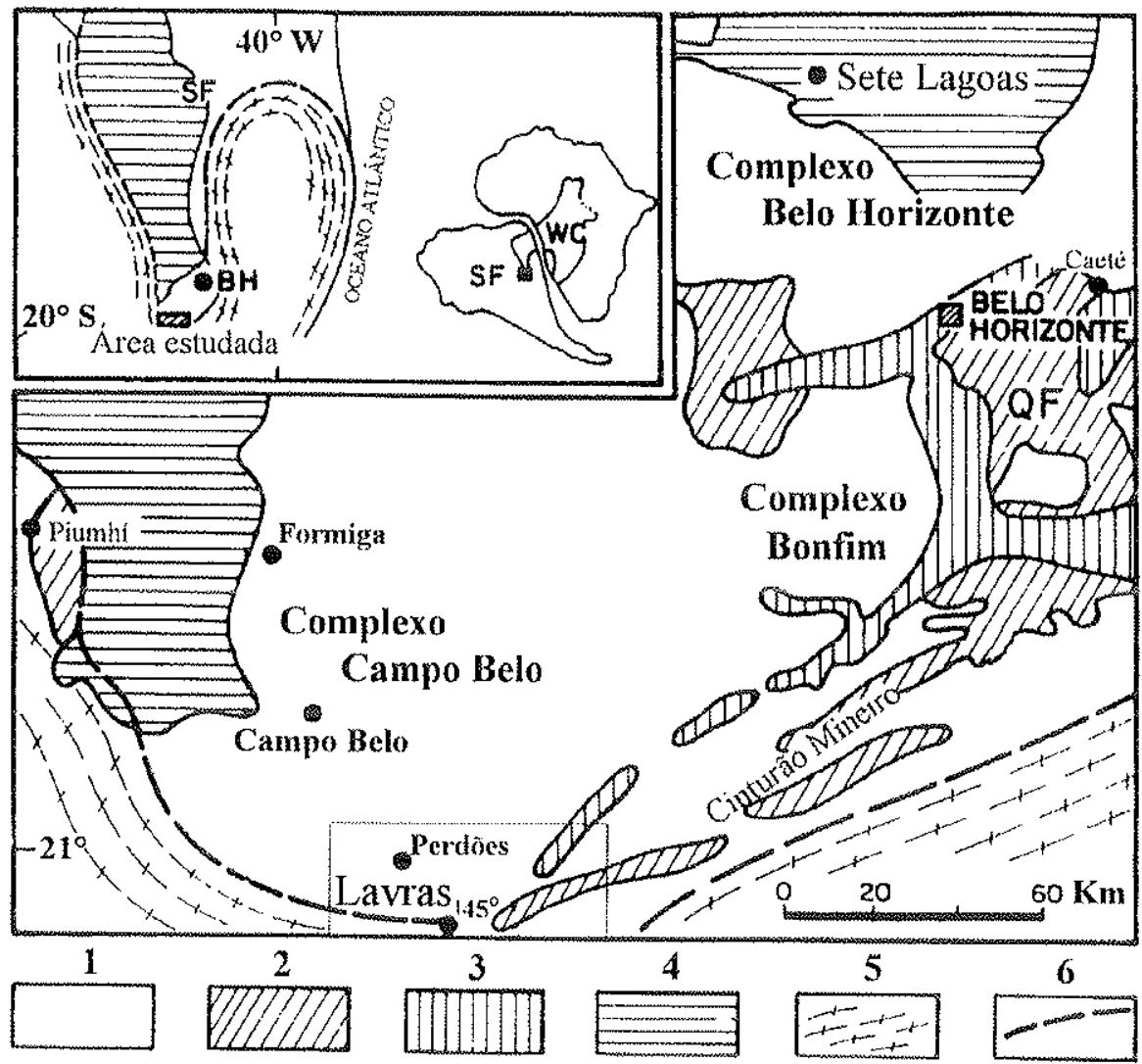

FIGURA III.2: Esboço geológico do segmento meridional do Cráton do São Francisco, mostrando a localização dos 3 complexos metamórficos arqueanos (Campo Belo, Belo Horizonte e Bonfim), seqüências supracrustais e o Cinturão Mineiro de idade paleoproterozóica (modificado de Teixeira et al, 1996b). 1 = Terrenos de alto a médio grau (Arqueano); 2 = "Greenstone belts" arqueanos; 3 = Supergrupo Minas (Paleoproterozóico); 4 = Grupo Bambuí (Neoproterozóico); 5 $=$ cinturões móveis neoproterozóicos; $6=$ limites do Cráton do São Francisco.

leucossomático do migmatito (Teixeira et al, 1996 b). Há que se destacar, no entanto, evidências de crosta continental ainda mais primitiva, que ocorre na região do Quadrilatero Ferrifero, onde se verifica idades da ordem de $3539 \pm 34$ Ma obtida através da datação de zircões detríticos das seqüências do Supergrupo Rio das Velhas (Machado et al, 1996).

Adicionalmente, Teixeira et al (1996 b) obtiveram em granitóides rosados da região de Campo Belo uma isócrona $\mathrm{Pb}-\mathrm{Pb}$ com idade de $2650 \pm 54 \mathrm{Ma}$, atribuida a distúrbios isotópicos no sistema $\mathrm{Pb}-\mathrm{Pb}$. Resultados semelhantes foram obtidos em isócronas Rb-Sr em granitóides a leste do Complexo Campo Belo, sugerindo que este processo de rehomogenização isotópica seja de escala regional. Em geral, as rochas do Neoarqueano possuem baixas razões ${ }^{87} \mathrm{Sr} /{ }^{86} \mathrm{Sr}(0.7001)$ e valores de $\mu_{1}\left({ }^{238} \mathrm{U} /{ }^{204} \mathrm{~Pb}\right)$ próximos de 8,18 , o que evidencia um crescimento crustal por diferenciação mantélica nessa época (Teixeira et al, 1996a). 
Os complexos Belo Horizonte (Noce, 1995) e Bonfim (Carneiro, 1992) mostram indicios da existência de uma crosta mesoarqueana $(>3,0 \mathrm{Ga}$ ), onde os registros (U. $\mathrm{Pb}, \mathrm{Pb}-\mathrm{Pb}$ ) mais antigos, obtidos nos núcleos de zircões, pertencentes aos gnaisses dos referidos complexos, fornecem idades ${ }^{207} \mathrm{~Pb} /{ }^{206} \mathrm{~Pb}$ de $2920 \mathrm{Ma}$ (Carneiro et al, 1995).

No Neoarqueano, assinalam-se nestes complexos duas fases de eventos tectonomagmáticos, desenvolvidos no intervalo de 2,8 a 2,6 Ga. Este conjunto de eventos é denominado como Evento Rio das Velhas por Carneiro (1992). A primeira fase do evento (2778 - $2773 \mathrm{Ma}$ ), caracterizada no Complexo Bonfim, envolveu retrabalhamento crustal e magmatismo em margem continental ativa com fechamento oceânico seguido por colisão continental (Cameiro et al, 1995 e Noce, 1995). Nesse ambiente teriam sido gerados os Tonalitos Samambaia com idades U-Pb de 2778 + 3/-2 Ma (Carneiro, 1992), o Granito Caeté de idade U-Pb de $2776+7 /-6$ Ma (Machado et al, 1992) e os Anfibolitos Paraopeba com idade modelo $\mathrm{Sm}-\mathrm{Nd}\left(\mathrm{T}^{\mathrm{DM}}\right)$ de $2,80 \mathrm{Ga}$. Este último corresponde a diques boudinados segundo Cameiro et al, (1995). A segunda fase $(2712$ - $2703 \mathrm{Ma})$ encerra o processo colisional e inicia uma granitogênese pósutectônica representada pelas intrusốes dos granitos Santa Luzia com idade U-Pb de $2712+5 /-4$ Ma (Noce, 1995), e Brumadinho com idade U$\mathrm{Pb}$ de $2703+24 /-20 \mathrm{Ma}$ (Machado \& Carneiro, 1992).

O Evento Rio das Velhas corresponde a aglutinação e cratonização dos vários complexos metamórficos (e.g. Campo Belo, Bonfim e Belo Horizonte) do segmento meridional do Cráton do São Francisco (Carneiro et al, 1995). Os estágios finais da cratonização encontram-se representado pelo Granito Salto do Paraopeba com idade U-Pb de $2612 \pm 5 \mathrm{Ma}($ Noce, 1995$)$

No dominio do Complexo Belo Horizonte (Noce, 1995), intrusivas granodioriticas e tonalíticas estão presentes, por vezes circundadas por supracrustais, a exemplo dos domos de Bação e Caeté.

As dimensões desse continente arqueano são incertas, devido a cobertura Bambui e por conta das superimposições metamórficas envolvendo retrabalhamentos, decorrentes da evolução do Cinturão Mineiro (Teixeira, 1985).

Associadas a esses complexos, encontram-se as rochas supracrustais do Supergrupo Rio Das Velhas, um "greenstone bell" tipico, que constitui extensa faixa metavulcanowsedimentar na regiào do Quadrilatero Ferrifero (Dorr, 1969; Inda et al, 1984; 
Schorscher, 1988 e 1992), porém com seus restos ainda preservados mais a oeste e sul, a exemplo do observado em Lavras e Conselheiro Lafaiete.

Admite-se para este Supergrupo uma divisão em três unidades litoestratigráficas: Grupo Quebra-Osso (basal), de caráter ultrabásico (Schorscher, 1978); Grupo Nova Lima (intermediário), de caráter vulcano-clástico (Noce et al, 1992); e Grupo Maquiné (topo), de natureza epiclástica. As supracrustais do Supergrupo Rio das Velhas também se formaram no Neoarqueano, a julgar pela idade U-Pb de $2776 \pm 6 \mathrm{Ma}$ (Machado et al, 1992) obtida em metafelsitos posicionados imediatamente acima da seqüencia toleíticakomatiítica de base.

\section{Paleoproterozóico}

O Paleoproterozóico encontramse representado essencialmente por seqüências metavulcano-sedimentares do Supergrupo Minas, além de terrenos gnáissicosmigmatíticos e granitoides intrusivos. Em geral, esta seqüência apresenta metamorfísmo predominantemente na fácies xisto-verde e contatos tectônicos com o embasamento arqueano e Supergrupo Rio das Velhas (Pedrosa Soares et al, 1994; Noce, 1995). A estratigrafia do Supergrupo Minas, atualmente em uso, foi elaborada por Dorr (1969), e tem as seguintes unidades: Grupo Caraça (unidade basal) epiclástico; Grupo Itabira (unidade intermediária) químico e Grupo Piracicaba (unidade do topo) epiclástico. Mais recentemente, Noce (1995) considerou a Formação Sabará (unidade superior do Grupo Piracicaba; Dorr, 1969) como um conjunto litológico distinto das demais formações do Grupo Piracicaba, elevando-a à categoria de Grupo Sabará.

O Ciclo Transamazônico coincide com a deformação principal do Supergrupo Minas (Cordani et al, 1980; Teixeira, 1985) e está caracterizado por um conjunto de processos sedimentares, tectônicos e magmáticos que ocorreram no âmbito do Cráton do São Francisco. A sedimentação do Supergrupo Minas iniciou-se por volta de $2575 \pm 15 \mathrm{Ma}$, segundo Renger et al (1994) e Noce (1995), em bacias formadas sob regimes extensionais (riftes) a partir de blocos crustais estabilizados no Arqueano. Neste periodo, depositam-se os sedimentos da Formaçào Moeda. Na sequência, inicia-se um longo período de estabilidade tectônica com a deposiçào em ambiente plataformal das Formaçòes Batatal, Cauê e Gandarela. Rochas carbonáticas da Fomação Gandarela fomeceram idade Pb-Pb de $2420=$ $19 \mathrm{Ma}$ (Babinski et al, 1995). 
Uma nova etapa de instabilidade tectônica retorna à bacia Minas ao redor de $2400 \mathrm{Ma}$ e inicia-se a sedimentação do Grupo Piracicaba em possível ambiente de abertura oceânica (Noce, 1995). Ao se encerrar a deposição do Grupo Piracicaba o ambiente torna-se compressivo e inicia-se a subducção de crosta oceânica, cujo reflexo, segundo Noce (1995), é a intrusão de diversos corpos graníticos. O Grupo Sabará também é atribuido a este periodo, a julgar pela idade $\mathrm{U}-\mathrm{Pb}$ de $2125 \pm 4 \mathrm{Ma}$ (Machado et al, 1992) obtida em metagrauvaca com contribuição vulcânica.

Os corpos graniticos encontram-se intimamente associados à evolução do Supergrupo Minas e do Cinturão Mineiro (e.g. Quéméneur et al, 1994), como o Batólito Alto Maranhão com idade de $2124 \pm 2 \mathrm{Ma}$, os corpos de Ritápolis e Tabuões de idade Rb-Sr igual a 1932 \21 Ma (Quéméneur \& Vidal, 1989), além do Maciço de Porto Mendes com idade $\mathrm{Pb}-\mathrm{Pb}$ de $1821+179 /-204$ e $\mu_{1}=8,24$ (Teixeira et al, 1987), este situado no sudoeste da área investigada, onde também ocorrem seqüências correlatas ao Supergrupo Minas (Quéméneur et al, 1994; Noce, 1995; Teixeira \& Figueiredo, 1991).

No âmbito do Cinturão Transamazônico, os principais eventos de deformação e metamorfísmo de natureza colisional (Noce, 1995; Carneiro et al, 1995) ocorreram entre 2,1 a 2,0 Ga. O pico dos eventos apresenta idade U-Pb de $2041 \pm 5 \mathrm{Ma}$ em titanita do Complexo Bação e idade $\mathrm{Pb}-\mathrm{Pb}$ de $2050 \pm 230 \mathrm{Ma}$ (Noce, 1995). Já as atividades plutônicas mais tardias do Cinturão Mineiro ocorrem mais a sudoeste, representada pelo Maciço Porto Mendes.

\section{Mesoproterozóico}

O Mesoproterozóico encontra-se na porção meridional do Cráton representado pela extremidade sul das seqüencias metassedimentares do Supergrupo Espinhaço, cuja sedimentação e granitogênese de natureza alcalina associada, desenvolveurse na abertura de um rifte intracontinental. O Supergrupo Espinhaço é constituido pelos Grupos Diamantina (base) e Conselheiro Mata (topo) [Dussin, 1994]. A seqüência de base é representada por quartzitos e metaconglomerados com intercalaçòes metavulcânicas, as quais se desenvolveram em um contexto de rifte. Os sedimentos continentais do Grupo Diamantina passam para uma sequência de topo amplamente monotona e constituida por quartzitos e mica-xistos intercalados. Esta seqüencia representa os depósitos marmhos transgressivos do Grupo Conselheiro Mata, os quais se desenvolveram no periodo pós-rifte. 
Idades $\mathrm{Pb}-\mathrm{Pb}$ de vulcânicas ácidas da base do Supergrupo Espinhaço indicam uma deposição ao redor de $1,71 \mathrm{Ga}$, contemporânea a intrusão do Granito Borrachudos de idade Pb-Pb igual a $1729 \pm 12 \mathrm{Ma}$ (Dussin, 1994). Estas idades são semelhantes a outras mencionadas para a Cordilheira do Espinhaço (1,79 a 1,75 Ga) obtidas por Brito Neves et al (1979) e Machado et al (1989), respectivamente.

\section{Neoproterozóico}

O Neoproterozóico é representado principalmente pelo Grupo Bambuí (Supergrupo São Francisco), que se distribui segundo um grande arco desde a região norte até a oeste, exibindo contatos erosivos com as rochas do embasamento (e.g. Machado Filho et al, 1983). O Grupo Bambui é constituido da base para o topo por cinco formações (Dardenne, 1978; Pedrosa Soares et al, 1994; Trompette, 1994): Sete Lagoas, Serra de Santa Helena, Lagoa do Jacaré, Serra da Saudade e Três Marias. A exceção da Formação Três Marias, todas as demais são agrupadas no Subgrupo Paraopeba, o qual representa uma seqüencia pelitocarbonatada depositada em plataforma isolada. A Formação Três Marias, composta principalmente por arcósios, arenitos, siltitos e conglomerados, representaria um ambiente marinho plataformal com tempestades.

Dados isotópicos $\mathrm{Rb}$ - $\mathrm{Sr}$ indicam que o evento Bambuí ocorreu entre 570 $640 \mathrm{Ma}$, enquanto que uma isócrona $\mathrm{Pb}-\mathrm{Pb}(690 \pm 70 \mathrm{Ma})$ sugere que o seu início deve ter sido um pouco anterior (Kawashita, 1996). Adicionalmente, a quimio-estratigrafia com base em razões isotópicas de ${ }^{87} \mathrm{Sr} /{ }^{86} \mathrm{Sr}$ de seqüências calcárias apresenta um valor da ordem de 595 $\pm 5 \mathrm{Ma}$ (Kawashita, 1996). Contudo, Babinski (1993) sugere idades mais antigas que $690 \mathrm{Ma}$ para o início da deposição do Bambui (cerca de $900 \mathrm{Ma}$ ), com base na evolução isotópica de $\mathrm{Pb}$ e dados $\mathrm{Pb}-\mathrm{Pb}$.

Em sintese, dados geológicos e geocronológicos disponiveis sugerem que a região meridional do Cráton do São Francisco foi afetada por uma evolução policiclica durante o Arqueano e Paleoproterozóico. Essa evolução é baseada em interpretação integrada de dados geocronológicos U-Pb, Rb-Sr, Pb-Pb, K-Ar, ${ }^{40} \mathrm{Ar}-{ }^{39} \mathrm{Ar}$ e Sm-Nd. A maioria desses dados radiometricos e suportado por isócronas $\mathrm{Rb}-\mathrm{Sr}$ e $\mathrm{Pb}-\mathrm{Pb}$ em rocha total e, subordinadamente por idades modelo Sm-Nd, K-Ar e ${ }^{16} \mathrm{Ar}-{ }^{39} \mathrm{Ar}$ em minerais e U-Pb principalmente em zircöes e titanitas (Machado et al, 1992; Carneiro, 1992; Noce, 1995; Teixeira, 1982, 1985, 1992; Teixeira \& Figueiredo, 1991; Teixeira et al, 1990 e 1996 a e b). 


\section{IV - CONTEXTO GEOLÓGICO LOCAL}

Na região investigada, foi possivel reconhecer 12 unidades litológicas do embasamento metamórfico, definidas a partir de dados de campo e petrográficos. Todavia cabe destacar, que as rochas metamórficas encaixantes do enxame de diques foram. investigadas neste trabalho, por constituirem tema complementar ao mesmo. Desse modo, as informações aqui apresentadas são referentes a perfis de reconhecimento das unidades geológicas regionais, compilação da literatura (e.g. Quéméneur, 1991) e trabalho em preparação de Quéméneur (1996), pesquisador que tem-se dedicado nos últimos anos à cartografia geológica da região de Lavras - Bom Sucesso.

Por outro lado, a opção por uma descrição em termos de unidades litológicas, se deve a dificuldade em estabelecer uma estratigrafia precisa, tanto no Arqueano como no Proterozóico, em função da complexidade geológica e escassa disponibilidade de dados geocronológicos. Estes fatos por si só, justificam futuros trabalhos de detalhamento do embasamento local.

Com o intuíto de facilitar a visualização dos diques máficos, optoumse pela sua cartografia isoladamente conforme a figura IV.2, onde também aparecem os principais lineamentos regionais. Em função da cartografia realizada a área é maior que o esboço geológico da figura IV.1. Os números de cada ponto amostrado se refere ao número da amostra coletada.

As unidades litológicas descritas a seguir encontram-se nas figuras IV.l e IV. 2 .

\section{IV.1 - Unidades arqueanas da in fraestrutura}

A semelhança com as unidades geológicas das áreas adjacentes já estudadas e os dados geocronológicos disponiveis (Teixeira, 1985; Teixeira \& Figueiredo, 1991; Teixeira et al, 1996 a e b; Quéméneur, 1996), confirmam uma geração predominantemente arqueana para a maioria das unidades geológicas aqui descritas.

\section{Cranulitos}

Trata se da unidade litológica mais extensa da regiào, por estender-se além dos perfís de caminhamento executados nos setores norte e oeste da área. 


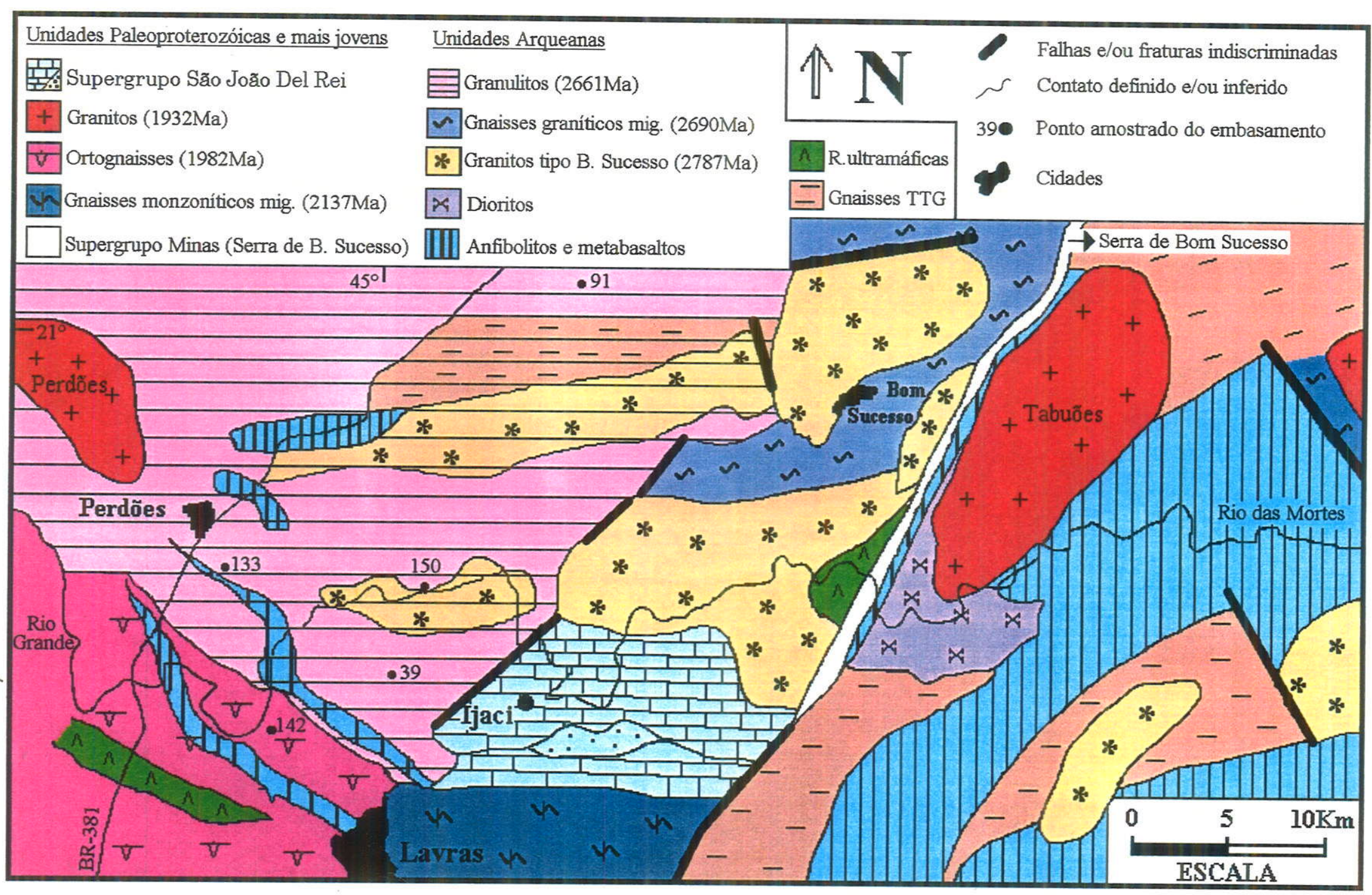

FIGURA IV.1: Esboço geológico do embasamento metamórfico e pontos amostrados para geoquímica e isótopos de $\mathrm{Sr}$ e Nd da região de Lavras (MG), porção extremo sul do Cráton do São Francisco. Base geológica adaptada e modificada de Quéméneur (1996). 
Constituida predominantemente por granulitos de filiação ácida, intercalados com enderbitos e gnaisses bandados, apresenta via de regra, foliação com direção preferencial $\mathrm{N} 60^{\circ} \mathrm{W}$ e E-W.

As descrições destes granulitos são escassas e restringem-se a dados do Projeto Sapucaí (Cavalcante et al, 1979) e trabalho em preparação de Quéméneur (1996). Alguns corpos granuliticos, com fácies granitóide, parecem estar delimitados por zonas de falhas. Para leste a unidade encontra-se em contato com o granito arqueano de Bom Sucesso e para sul está em contato com ortognaisses, havendo ainda a ocorrência de anfibolitos e rochas ultramáficas.

Os granulitos podem ser divididos em 3 grupos com base na petrografia e geoquímica: granulitos trondhjemitico-tonalíticos, granulitos cálcio-alcalinos potássicos e granulitos máfico-ultramáficos (Quéméneur, 1996). Na parte norte da unidade granulítica predominam as suites trondhjemitica-tonalítica e cálcio-alcalina potássica com charnockitos e enderbitos. Na parte sul predominam niveis máficos e ultramáficos com piroxênio-anfibolitos

A suite granulitica cálcio-alcalina potássica é assim interpretada por Quéméneur (1996) em função das semelhanças quimicas com o granito arqueano de Bom Sucesso. Em geral, a suite pode ser definida por charnockitos e gnaisses charnockíticos. Os charnockitos são rochas de cor cinza clara esverdeada com granulação média a grossa, e a mineralogia fundamental é fornecida por ortoclásio, oligoclásio e quartzo. Os minerais acessórios são biotita e piroxênios. O pouco piroxênio encontramse parcialmente alterado para anfibólio fibroso e sericita. Os gnaisses charnockíticos são fortemente orientados e caracterizam-se pela cor cinza clara moderadamente a fortemente esverdeadas. Sua mineralogia fundamental é dada por: feldspato potássico na forma sigmoidal predominando sobre plagioclásio, quartzo na forma de lentes recristalizadas e homblendas com restos de piroxênios no núcleo.

Na suite trondhjemitica-tonalítica, destacam-se granulitos fortemente bandados com cor cinza clara quando predomina plagioclásios, cor cinza esverdeado claro as vezes amarronzada propiciada por muita biotita e cor cinza esverdeada escuro quando anfibólios e piroxênios dominam. Os granulitos de composição trondhjemitica-tonalítica sào denominados de enderbitos, em função das classificaçòes existentes não contemplarem este tipo de rocha (Quemeneur, 1996). Tais enderbitos, se caracterizam mineralogicamente por volumes abundantes de plagioclásios poligonizados (até 70\%), moderados volumes de 
quartzo e feldspatos de potássio e baixa quantidade de biotita, orto e clinopiroxênios. Os termos mais básicos mostram maiores volumes de clinopiroxênios.

A suíte máfica-ultramáfica apresenta metabasaltos (Quéméneur, 1996), cuja mineralogia é predominantemente constituída por plagioclásios cálcicos e associações de orto-clinopiroxênios com anfibólios. O representante das faixas ultramáficas, em geral, é o piroxenito constituido por orto e clinopiroxênios, porções de tremolita e serpentina.

Os gnaisses bandados, de ocorrência abundante na ponte do Funil $( \pm 10 \mathrm{Km}$ ao norte da cidade de Lavras), se caracterizam pelas bandas centimétricas quartzo-feldspáticas intercaladas a bandas biotita/anfibólio e pela estrutura "flaser" nos minerais de quartzo.

Recentes investigaçôes geocronológicas no dominio granulítico (Quéméneur, 1996) indicam idades arqueanas para este dominio [isócrona $\mathrm{Rb}$-Sr com valor de $2661 \pm 36 \mathrm{Ma}$, razão inicial ${ }^{87} \mathrm{Sr} /{ }^{86} \mathrm{Sr}$ de 0,70148 e MSWD $\left.=1,14\right]$. Todavia, dados Sm-Nd e Rb-Sr obtidos nesta tese referentes a 4 amostras da área granulitica (Tabelas IV.1 e IV.2), apresentaram diagramas isocrônicos com arranjos lineares que não possuem significado geológico. Este fato possivelmente esteja relacionado à distúrbios isotópicos em ambos os sistemas. Por outro lado, as idades modelo $\mathrm{Sm}-\mathrm{Nd}\left(\mathrm{T}^{\mathrm{DM}}\right)$, indicam a existência de crosta arqueana para este dominio, a julgar pelos valores situados entre 2,92 e 3,46 Ga, com média de $3,14 \pm 0,28 \mathrm{Ga}(\mathrm{n}=3)$.

\begin{tabular}{|c|c|c|c|c|c|c|}
\hline Amostra & $\mathrm{Rb}\left({ }^{*}\right)$ & $\mathrm{Sr}$ & ${ }^{87} \mathrm{Rb} /{ }^{86} \mathrm{Sr}$ & Erro & ${ }^{87} \mathrm{Sr} /{ }^{86} \mathrm{Sr}$ & Erro $(2 \sigma)$ \\
\hline 150 gramulito & 16,5 & 672 & 0.0716 & 0,0020 & 0,705255 & 0.000012 \\
\hline 142 ortognaisse & 134,5 & 137 & 2.8354 & 0,0860 & 0,815790 & 0,000010 \\
\hline 39 granulito & 179.5 & 136 & 3,8239 & 0,1160 & 0.790857 & 0,000013 \\
\hline 91 granulito & 18.5 & 456 & 0.1182 & 0.0040 & 0.705062 & 0,000015 \\
\hline 133 gramulito & 4,0 & 267 & 0,0423 & 0.0001 & 0.702113 & 0,000008 \\
\hline
\end{tabular}

Tabela IV.1: Dados analiticos $\mathrm{Rb}-\mathrm{Sr}$ do embasamento metamórfico da região de Lavras. $\mathrm{Rb}$ e $\mathrm{Sr}$ obtidos por fluorescência de raios-X $(F R X) .\left({ }^{*}\right)=O s$ valores de Rb foram calculados pelo confronto entre $\mathrm{Rb}(\mathrm{DI})$ is $\mathrm{Rb}(\mathrm{FRX})$, com desvio máximo de $2,5 \mathrm{ppm}$.

\section{Gnaisses TTG}

A unidade predominantemente se distribui a leste da Serra de Bom Sucesso (Quéméneur, 1996). Subordinadamente, sua presença é assinalada na área granulítica a oeste da Serra de Bom Sucesso. O corpo a leste da serra se constituí em uma extensa faixa orientada E-W. Tais gnaisses, denominados por Quéméneur (1996) de gnaisses "Pau da Bandeira", apresentam granulaçăo média e são constituidos essencialmente por: oligoclásio, 
quartzo, feldspato potássico e biotita. Os minerais acessórios mais comuns são: titanita, apatita e opacos.

Segundo Quéméneur (1996), os dados geoquimicos evidenciam uma grande variedade composicional para os gnaisses que variam de trondhjemito a tonalito $\mathrm{e}$ granodiorito (TTG).

\begin{tabular}{|c|c|c|c|c|c|c|c|}
\hline Amostra & $\mathrm{Sm}$ & $\mathrm{Nd}$ & ${ }^{147} \mathrm{Sm} / /^{144} \mathrm{Nd}$ & Erro & ${ }^{143} \mathrm{Nd}^{144} \mathrm{Nd}$ & Erro (2o) & $\mathrm{T}^{\mathrm{DAM}}(\mathrm{Nd})[\mathrm{Ga}]$ \\
\hline 150 granulito & 4,968 & 28,727 & 0,1052 & 0,0001 & 0,510802 & 0,000036 & 3,04 \\
\hline 142 ortognaisse & $\overline{9,826}$ & 55,657 & 0,1074 & 0,0001 & 0,510870 & 0,000037 & 3,00 \\
\hline 39 granulito & 8,073 & 50,503 & 0,0973 & 0,0007 & 0,510724 & 0,000045 & 2,92 \\
\hline 91 granulito & 6,456 & 29,409 & 0,1336 & 0,0001 & 0,511195 & 0,000026 & 3,46 \\
\hline 1074 anfíbolito* & 3,06 & 10,13 & 0,1825 & 0,0001 & 0,512457 & 0,000010 & 2,63 \\
\hline 1080 anfibolito* & 9,38 & 35,74 & 0,1587 & 0,0001 & 0,511953 & 0,000011 & 2,83 \\
\hline 1082 anfibolito* & 4,87 & 15,82 & 0,1860 & 0,0001 & 0,512541 & 0,000030 & 2,53 \\
\hline 1147 anfibolito* & 5,41 & 18,41 & 0,1777 & 0,0001 & 0,512271 & 0,000014 & 3,14 \\
\hline
\end{tabular}

Tabela IV.2: Dados analíticos Sm-Nd do embasamento metamórfico da região de Lavras, obtidos pela técnica de diluição isotópica (DI). ${ }^{*}=$ amostras de anfibolitos cujos dados $\mathrm{Sm}-\mathrm{Nd}$ foram extraidos de Quéméneur (1996).

\section{Anfibolitos e metabasaltos}

Com maior expressão na porção leste do mapa, a unidade é representada por anfibolitos e metabasaltos pertencentes ao "Greenstone Belt" Rio das Mortes (Quéméneur \& Garcia, 1993). Na porção oeste da Serra de Bom Sucesso também se assinalam alguns corpos associados com ultramáficas, cujo conjunto é denominado por Quéméneur (1996) de "Greenstone Belt" Lavras. Em geral, os anfibolitos intercalam-se com rochas ultramáficas e com grande expressão no domínio dos gnaisses do tipo TTG.

No caso do "Greenstone" Rio das Mortes verifica-se duas raixas de anfibolitos, separadas por gnaisses e Granitos tipo Bom Sucesso, uma à norte e outra à sul. A faixa norte é constituida por metabasaltos toleíticos e rochas ultramáficas de composição komatiitica, enquanto à sul se constitue em metabasaltos toléticos, komatiticos e corpos ultramáficos komatiiticos. Alguns pontos mais próximos do Maciço Transamazônico Tabuões, mostram niveis de injeções quartzo-feldspática introduzindo-se nos anfibolitos, demonstrando o seu caráter intrusivo.

A composiçăo do "Greenstone" Lavras apresenta fortes semelhanças com aquela do "Greenstone" Rio das Mortes (Quéméneur, 1996). Ambas seqüências apresentam 
intercalações sedimentares inter derrame no empacotamento basáltico. Trata-se de formações ferriferas bandadas, quartzitos ricos em grafita e gonditos.

Dados recentes obtidos por Quéméneur (1996), demonstram que os metabasaltos toléticos são do tipo "MORB" e apresentam idades T" $\mathrm{TM}$ "Nd entre 2,53 e 3,14 Ga (Tabela IV.2), com média de 2,78 $\pm 0,27 \mathrm{Ga}(\mathrm{n}=4)$.

\section{Dioritos}

Situada a sul do Granito Transamazônico Tabuões, esta unidade é representada por rochas dioríticas. Os dioritos apresentam coloração cinzamescura e granulação média. A mineralogia é dominada por plagioclásios epidotizados, hornblenda e quartzo em cristais intergranulares. Segundo Quéméneur (1996) o diorito deve estar associado a evolução do "Greenstone" Rio das Mortes.

\section{Rochas ultramáficas}

A unidade é constituida por rochas ultramáficas distribuidas em 2 corpos de formato diferentes. O primeiro localizado a noroeste de Lavras se apresenta como uma faixa NW intercalada na unidade dos ortognaisses, dispondo-se segundo a orientação preferencial na região. O segundo situa-se no sopé sudoeste da Serra de Bom Sucesso com formato ovalado. Ambos estão representados por rochas de granulação fina e mineralogia essencialmente composta por talco e serpentina.

Alguns corpos ultramáficos adicionais foram observados, porém ainda carecem de melhor delimitação, sendo constituidos por piroxenitos. Estes se apresentam em rochas de granulação fina a média compostos por bronzita, pargasita, clorita, talco, serpentina e opacos

\section{Gnaisse granitico migmatizado}

Localizamse nas imediações da cidade de Bom Sucesso e está representada por gnaisses graniticos migmatizados de coloração cinza-clara, granulação fina a média e isenta de porfiroblastos. A mineralogia essencial do paleossoma é fornecida por quartzo, biotita, anfibólio e feldspato. Em escala microscópica, verifica-se que os feldspatos são a microclina e o plagioclásio, enquanto o anfibólio é a hornblenda. Assinalam-se ainda: titanitas, apatita, zircão e opacos

Interessante notar, que está unidade praticamente circunda o Granito Bom Sucesso, demonstrando estar associado ao mesmo. 
Uma isócrona $\mathrm{Rb}-\mathrm{Sr}$ estabelecida para migmatitos (4 pontos do paleossoma) situados a nordeste do municipio de Bom Sucesso (IGA/CPGeo, inédito), forneceu um valor de $2690 \pm 56 \mathrm{Ma}$ com razão ${ }^{87} \mathrm{Sr} /{ }^{86} \mathrm{Sr}$ inicial de 0,7001 e MSWD $=4,8$. Resultados semelhantes também são obtidos de migmatitos (paleossoma) e gnaisses graníticos de alto grau, posicionados mais à noroeste de Bom Sucesso (IGA/CPGeo, inédito) e com idade isocrônica da ordem de $2.688 \pm 50 \mathrm{Ma}$, razão ${ }^{87} \mathrm{Sr} /{ }^{86} \mathrm{Sr}$ inicial de 0,70213 e MSWD $=1,6(12$ pontos).

\section{Granitos tipo Bom Sucesso}

Diversos corpos intrusivos de granitos com coloração cinza-escura as vezes azulada, granulação média a grossa e mineralogia fundamental dada por: quartzo, biotita e feldspatos. Uma das maiores intrusões e a melhor estudada é aquela situada a norte da cidade de Bom Sucesso. Os demais corpos ocorrem tanto a oeste quanto a leste da Serra de Bom Sucesso.

Em particular, o corpo de maior dimensão ocorre na parte central da região investigada. Em geral, sua granulação é um pouco mais fina e a coloração é mais clara do que - Granito Bom Sucesso, posicionado à norte. Em alguns locais o bandamento é incipiente mas, em outros o corpo mostra-se orientado predominantemente E-W, tectônica está possivelmente representativa da Faixa Alto Rio Grande, marginal ao Cráton do São Francisco. Áreas restritas deste corpo apresentam concentrações anômalas de titanita.

O Maciço de Bom Sucesso se apresenta envolvido por gnaisses graniticos migmatizados e com formato quase ovalado. Segundo Quéméneur (1996) é constituido por duas fácies distintas. A primeira correspondente ao núcleo do maciço, é composta por um granito cinza azulado cuja mineralogia principal é fornecida por feldspato potássico, oligoclásio, quartzo e biotita verde, enquanto os acessórios principais são: apatita, ilmenita e zircão. A segunda restringe-se a porçăo nordeste do maciço e é constituída por um granito de cor bege com textura porfiritica onde os fenocristais são de mesopertita e oligoclásio. Destacam-se ainda: quartzo, biotita verde e minerais acessórios como epídoto, apatita, ilmenita e zircão.

Adicionalmente, os facies apresentam diferenças composicionais, as quais conduziram Quéméneur (1996) a propor uma origem a partir da mistura de magmas com fusào parcial na base da crosta seguida por diferenciaçào. 
Cumpre ressaltar, que a composição cálcio-alcalina potássica de algumas faixas da área granulitica, em muito se assemelham a obtida para o Maciço Bom Sucesso, sugerindo uma possivel continuidade deste tipo de intrusão mais para à oeste do referido maciço.

Quéméneur \& Vidal (1989) e Quéméneur (1996), definiram uma idade arqueana para estas intrusões com base em uma isócrona $\mathrm{Rb}-\mathrm{Sr}$ de $2.787 \pm 143 \mathrm{Ma}$, razão inicial ${ }^{87} \mathrm{Sr} /{ }^{86} \mathrm{Sr}$ de $0,70806 \pm 0,0059$ e MSWD de 0,72 . As rochas utilizadas para a obtenção desta isócrona se referem a parte central do maciço.

\section{IV.2 - Unidades paleoproterozóicas do Cinturão Mineiro e mais jovens}

\section{Gnaisses monzoniticos porfiroblásticos migmatizados}

Localizada a sudeste da cidade de Lavras é constituida essencialmente por gnaisses monzoniticos porfiroblásticos de coloração cinza-clara e granulação média a grossa. A mineralogia principal é fornecida por: plagioclásios $(\sim 50 \%)$, quartzo $(\sim 18 \%)$, feldspato de potássio $(\sim 10 \%)$, biotitas $(\sim 5 \%)$ e opacos. Assinalam-se porfiroblastos de feldspatos.

Freqüentemente, a unidade é recortada por injeções quartzo-feldspáticas com espessuras variando de 20 a 50 centimetros, e seu limite a sul deve se estender até os quartzitos da Serra da Bocaina (Itumirim-MG). A leste os migmatitos estão em contato (por falhamento) com os gnaisses tipo TTG dos quais apresentam algumas semelhanças mineralógicas e petrográficas, afora a forte migmatização dos primeiros.

Uma isocrona Rb-Sr obtida por Teixeira (1985) para este domínio forneceu

idade de $2.137 \pm 123 \mathrm{Ma}$ com razão ${ }^{87} \mathrm{Sr} /{ }^{86} \mathrm{Sr}$ inicial de $0,70260 \pm 0,0020$ e MSWD $=3,8$. Este valor atesta que uma parcela do embasamento arqueano local sofreu retrabalhamento significativo no Paleoproterozóico por conta da evolução do Cinturão Mineiro.

\section{Ortognaisses}

Situada a sudoeste da cidade de Lavras e da região investigada (Fig. IV. 1), a unidade é constituida exclusivamente por ortognaisses de composição granodioritica levemente superimpostos por uma deformação tectônica cisalhante, possivelmente ligada a Faixa Alto Rio Grande. Vão raro os diversos afloramentos descritos nesta unidade apresentam enclaves de rochas melanocráticas e mesocráticas e a foliação medida invariavelmente situa- 
se entre $N 70^{\circ} \mathrm{W}$ a E-W, muito semelhante a unidade dos granulitos. Assinalam-se também corpos máficos e ultramáficos no interior desta unidade, conforme já caracterizado.

Em geral, as rochas apresentam cor cinza-clara as vezes esverdeadas, com granulação variando de média a grossa. A mineralogia fundamental é dada por: biotita, quartzo e porfiroblastos milimétricos de feldspatos geralmente na forma sigmoidal. Os feldspatos encontram-se representados por plagioclásios saussuritizados e microclinas. Assinala-se ainda: muscovita, epidoto-zoisita, titanita e zircão.

Os limites sul e oeste desta unidade não foram alcançados pelos perfís executados nas etapas de campo, e a norte os ortognaisses parecem gradar para granulitos.

Uma isócrona Rb-Sr obtida a partir destes ortognaisses por Heilbron et al (1989), produziu idade de $1982 \pm 134 \mathrm{Ma}$ com razão ${ }^{87} \mathrm{Sr} /{ }^{86} \mathrm{Sr}$ inicial de 0,70410 $\pm 0,0017 \mathrm{e}$ MSWD igual a 4. Este resultado, demonstra que os ortognaisses associam-se com a evolução do Cinturão Mineiro. A amostra 142 representativa dos ortognaisses forneceu uma idade modelo Sm-Nd $\left(\mathrm{T}^{\mathrm{DM}}\right)$ da ordem de 3,0 Ga.

\section{Granitos}

É constituida predominantemente por dois maciços intrusivos de granitos, a saber: Tabuões e Perdões.

O primeiro situado a nordeste da Serra de Bom Sucesso apresenta composição trondhjemitica, forma ovalada e exceto sua porção norte as demais mostram se fortemente intemperizadas. Em geral, o Maciço Tabuões apresenta coloração cinza clara, granulação média e textura microporfirítica. A mineralogia essencial é dada por oligoclásio, quartzo, microclina e biotita verde. A mineralogia acessória é fornecida por apatita, titanita e zircão.

A intrusão do Tabuões desenvolveu uma importante aureóla de metamorfismo (Quéméneur, 1996), a qual encontra-se amplamente registrada em diversas formações metassedimentares da Serra de Bom Sucesso (Supergrupo Minas), por exemplo, nos quartzo-biotita-xistos o metamorfismo propiciou o desenvolvimento de granadas e sillimanitas. Dados geocronológicos do Granito Tabuões (Quéméneur \& Vidal, 1989) indicam que tal corpo foi gerado no Ciclo Transamazônico (isócrona Rb-Sr de $1932 \pm 21 \mathrm{Ma}$, e razão inicial ${ }^{87} \mathrm{Sr} r^{86} \mathrm{Sr}=0,70251$ ). 
O segundo corpo, posicionado a noroeste da cidade de Perdões, também tem forma ovalada. Via de regra apresenta granulação fina, cor cinza clara e a mineralogia fundamental é constituida por feldspatos potássicos, plagioclásios parcialmente saussuritizados, quartzo e biotita.

Os Maciços Tabuões e Perdões se inserem nas duas suítes (trondhjemíticatonalítica e granítica) que constituem o arco magmático transamazônico do sul da área cratônica, proposto por Quéméneur et al (1994).

Cumpre ressaltar, que uma das familias de diques máficos (suite básica, veja Litogeoquímica) apresentam no campo relações de concomitância com o Granito Tabuões.

\section{Supracrustais do Supergrupo Minas}

Metassedimentos do Supergrupo Minas sấo os responsáveis pela feição geomorfológica conhecida como Serra de Bom Sucesso. Esta correlação entre estes metassedimentos é antiga e de ampla aceitação no âmbito cratônico.

Segundo Quéméneur (1987), a sequência da Serra de Bom Sucesso se constitui em: a) xistos inferiores, caracterizados por quartzo-muscovita-biotita xistos miloníticos com espessuras variáveis entre 50 a 100 metros; b) quartzitos principais, caracterizados por quartzitos brancos com muscovita e espessura entre 5 a 250 metros; c) xistos intermediários, caracterizados por xistos ferruginosos com espessura entre 5 e 20 metros; d) itabiritos, caracterizados por formações ferriferas bandadas com espessura de 1 a 250 metros; e) xistos superiores, caracterizados por quartzo-biotita-muscovita xistos intercalados de quartzitos micáceos e ferríferos com espessura de cerca de 100 metros.

Recentemente Quéméneur (1996), correlaciona as unidades dos quartzitos principais, xistos intermediários e itabiritos, com as Formações Moeda, Batatal e Cauê do Quadrilátero Ferrifero e, os xistos superiores a Formação Cercadinho. Ao equipará-las, e com base no acervo geocronológico existente para os metassedimentos do Supergrupo Minas (e.g. Noce, 1995; Babinski et al, 1995), o referido autor sugere uma idade entre 2500 a $2600 \mathrm{Ma}$ para o início da sedimentação da Serra de Bom Sucesso, mesmo com a ausência dos metassedimentos equivalentes a Formação Gandarela. Os diques máficos dos tipos $\mathrm{DB}_{2}$ (suite básica), DMB e DA (veja Petrografia) segmentam estas unidades.

\section{Supracrustais do Supergrupo Săo João Del Rei}

Distribui-se a nordeste da cidade de Lavras sendo constituida por metacalcários e xistos quartzosos. 
Os metacalcários pertencem a Formação Barroso e mantém os estratos remanescentes da fase sedimentar que se orientam sub a horizontalmente. No pacote superior encontram-se os xistos quartzosos pertencentes a Formação Macaia (Ebert, 1984) ou Formação Carandai (Machado Fitho et al, 1983). O pacote superior acompanha a estratificação do metacalcário e juntos repousam em discordância angular sobre rochas do embasamento, propiciando a feição geomorfológica conhecida como Serra de ljaci. Machado Filho et al (1983) e DNPM (1978) relacionam o pacote às supracrustais do Supergrupo São João Del Rei.

Vale ressaltar, que não foram assinalados diques máficos segmentando os pacotes sedimentares desta unidade.

\section{IV.3 - O Enxame de Diques Máficos de Lavras}

A região investigada tem sido relativamente pouco estudada, em particular os diques máficos, cujas primeiras descrições incluindo mineralogia e petrografia foram realizadas apenas a partir dos estudos desenvolvidos pelo Projeto Sapucaí (Cavalcante et al, 1979). Posteriormente, se destacam os primeiros dados geocronológicos (K-Ar) obtidos por Teixeira (1985) e os trabalhos de mapeamento geológico do embasamento metamórfico e enxame de diques desenvolvidos por Quéméneur (1989 e 1991). Recentemente, estudos acerca da evolução paleomagnética dos diques tem sido elaborados na região por Ponte Neto (1996).

Os diques máficos distribuem-se por toda região investigada (Fig.IV.2) e apresentam maior densidade de intrusão entre as cidades de Lavras e Bom Sucesso, seccionando indistintamente as diferentes unidades litológicas descritas (Fig.IV.1) a exceção dos metacalcários e xistos quartzosos do Supergrupo São João Del Rei.

De maneira geral, as rochas dos diques apresentam coloração preta, estrutura maciça e são faneríticas, holocristalinas com a granulação variando de fina a média. Rochas com textura porfiritica e granulação média-grossa são assinaladas mas, restritas aos pontos 22 , 24, 52, 62 e 63 (Fig. IV.2). Aquelas dos pontos 62 e 63 nordeste e norte de Bom Sucesso respectivamente, se destacam das demais por apresentarem megafenocristais de plagioclásios que atingem $8 \mathrm{~cm}$ de comprimento, conferindo-lhes um aspecto de "cumulatus" (Quéméneur, 1989). 


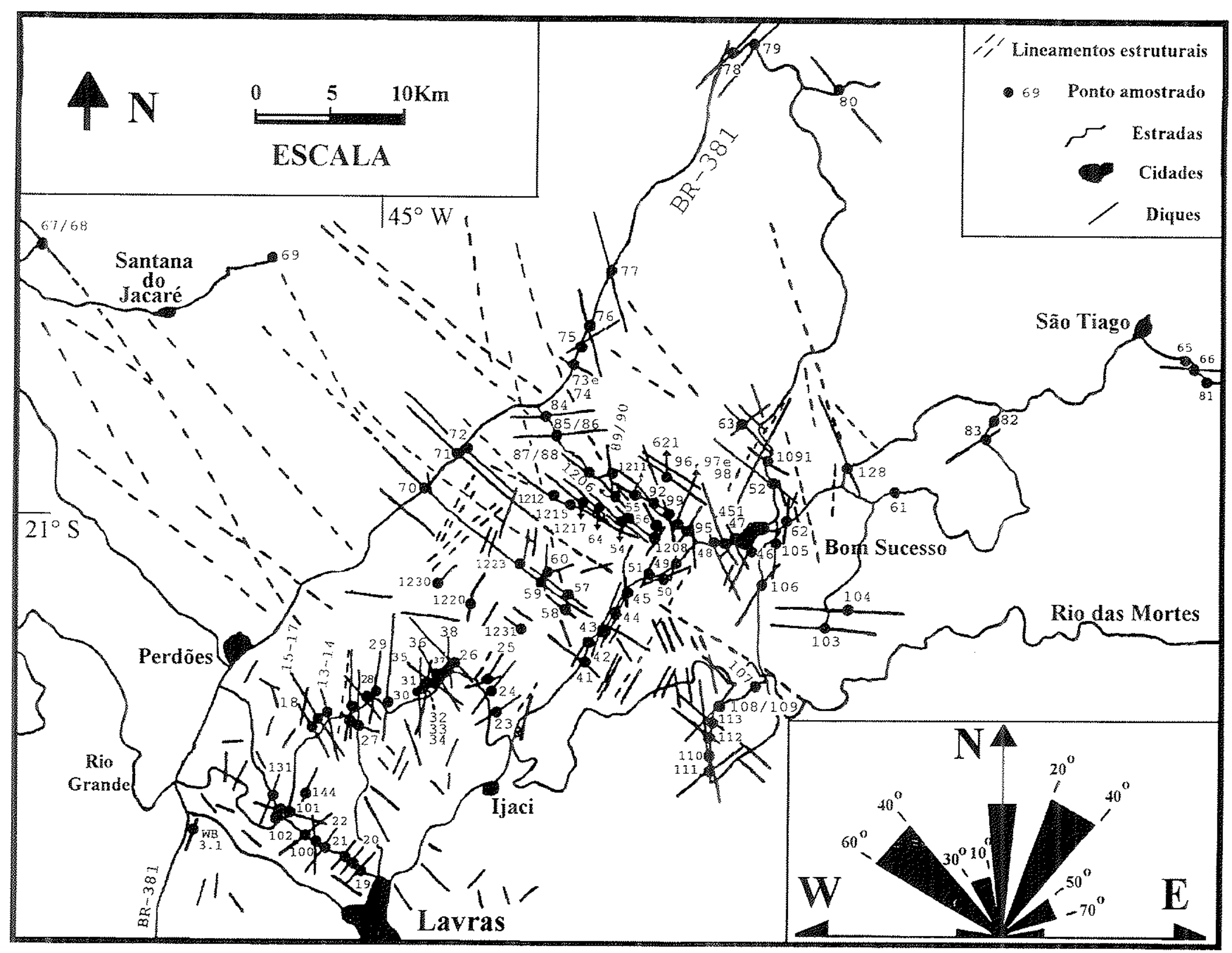

FIGURA IV.2: Mapa dos diques máficos da região de Lavras (MG) que inclue a rosácea de direções preferenciais bem como os pontos amostrados. Os números dos pontos se referem ao número de campo das amostras coletadas. 
Os diques apresentam-se discordantes da direção geral da foliação e/ou bandamento metamórfico das rochas do embasamento $\left(\mathrm{N} 70^{\circ} \mathrm{W}\right.$ a $\mathrm{E}-\mathrm{W}$ ). O conjunto dos diques máficos demonstra 6 direções preferenciais de colocação, a saber: $\mathrm{N}_{2} 0^{\circ}-40^{\circ} \mathrm{E} ; \mathrm{N} 50^{\circ}$ $70^{\circ} \mathrm{E} ; \mathrm{N} 40^{\circ}-60^{\circ} \mathrm{W} ; \mathrm{N} 10^{\circ}-30^{\circ} \mathrm{W} ; \mathrm{N}-\mathrm{S}$ e E-W (cf. rosácea na Fig. IV.2). As direções N40 ${ }^{\circ}$ $60^{\circ} \mathrm{W}, \mathrm{N}-\mathrm{S}$ e $\mathrm{N} 20^{\circ}{ }^{\circ} 40^{\circ} \mathrm{E}$ são as predominantes.

Os diques são subverticais e apresentam espessuras que variam de poucos centimetros até 100 metros. A soma das estimativas de espessuras do conjunto dos diques máficos para a região, indica uma expansão crustal mínima de aproximadamente $1 \mathrm{Km}$.

Em geral, os diques da suite básica (veja Litogeoquímica) e aqueles metamórficos (DMB e DA, veja petrografia), apresentam espessuras entre 1 a 50 metros, sendo que as mais freqüentes estão no intervalo de 1 a 10 metros (Foto IV.1). Por outro lado, assinala-se um outro grupo de diques que representam uma suíte básico norítica (veja Litogeoquímica). Suas espessuras variam de 10 a 100 metros, sendo que as mais freqüentes se posicionam entre 10 a 20 metros (Foto IV.2).

O grupo de diques mais espesso, também se caracteriza como o de maior extensão (até $30 \mathrm{~km}$ de comprimento) e um exemplo é representado pelas amostras 59, 70 e 1223 (Fig. IV.2). Interessante notar, que estes diques de maior extensão e espessura orientamse predominantemente no quadrante $\mathrm{NW}$, preferencialmente $\mathrm{N} 40^{\circ}-60^{\circ} \mathrm{W}$. Embora este grupo seja de fácil observação em imagens de satélites, raramente possibilita sua observação no campo e em fotos aéreas, por conta dos processos intempéricos.

Por outro lado, alguns diques de menor extensão (suite básica) não apresentam correlação alguma entre composição e atitude. Um exemplo deste fato pode ser visualizado na figura IV.2, onde os diques 19 (NE), 26 (NW) e 60 (N-S), pertencentes a mesma suíte (suíte básica), orientam-se em diferentes quadrantes. Isto sugere um preenchimento ao longo de fraturas pré-existentes. Entretanto, outros diques do grupo com menor extensão (e.g. DMB e DA) indicam uma predominância de orientações NE, seguidas pelas N-S, com raríssimas orientações NW e E-W. O "trend" NE na região é aquele relacionado a evolução da Serra de Bom Sucesso.

Via de regra, os contatos com as encaixantes, quando visíveis, são nítidos e discordantes e, em geral, os afloramentos se apresentam frescos, de tal modo que amostras de boa qualidade puderam ser obtidas para os experimentos do trabalho. 


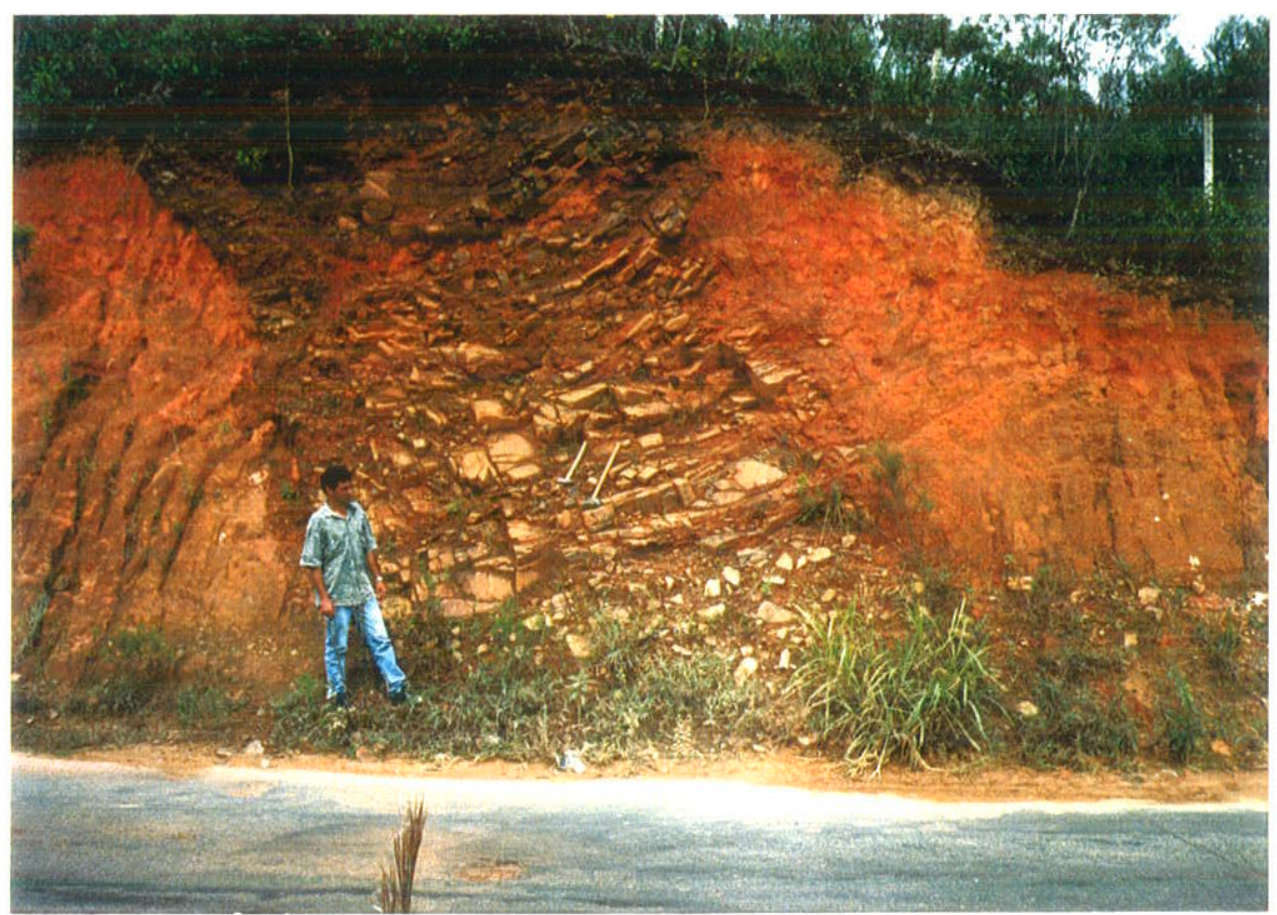

FOTO IV.1: Dique não metamórfico da suíte básica com espessura entre 3 a 4 metros, típica deste grupo (DB-100).

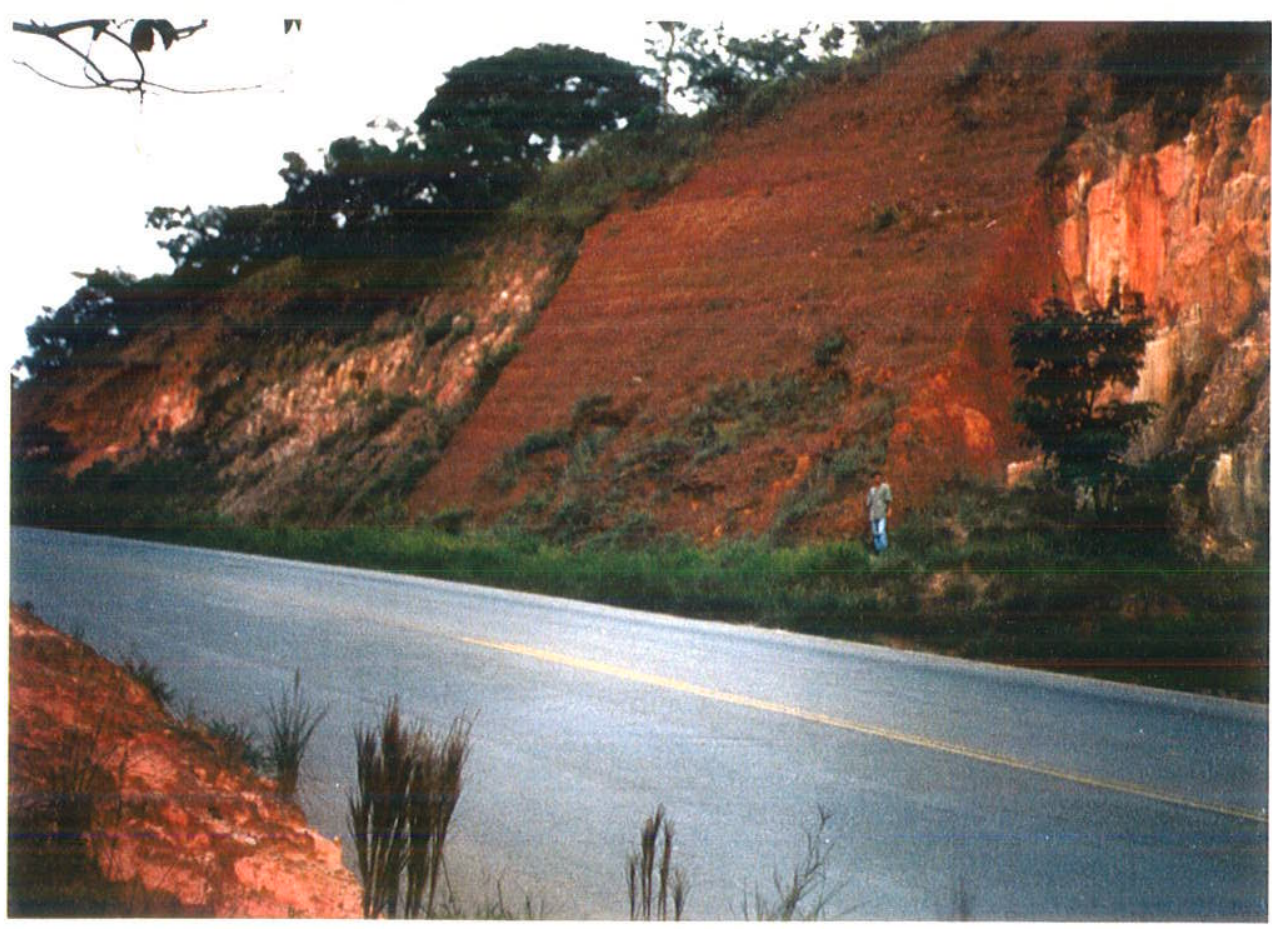

FOTO IV.2: Dique não metamórfico da suíte básico norítica com éspessura entre 15 a 20 metros, típica deste conjunto (DBN-72). 
Conforme anteriormente antecipado, um dique do grupo dos menos extensos e espessos da suíte básica (veja Litogeoquimica), segmenta o Granito Tabuões e é cortado por veios aplíticos e pegmatíticos associados as fases finais da cristalização deste granito. Outro dique posicionado mais a noroeste também mostra-se cortado por vênulas graníticas. Tais feições de campo, já haviam sido mencionadas por Quéméneur (1991) e são assinaladas em outros locais além daqueles descritos acima.

Isto permite antecipar que a intrusão do dique ocorreu na última fase de cristalização do Granito Tabuões, cuja idade é de $1932 \pm 21 \mathrm{Ma}$, sugerindo uma fase intrusiva de diques máficos no Transamazônico e por conseqüência uma associação tectônica com o Cinturão Mineiro. Aspectos cronológicos e químicos dos diferentes grupos de diques na região, serão detalhados nos capítulos posteriores.

Adicionalmente cabe destacar, que um evento de cisalhamento atingiu alguns diques investigados (diques anfibolíticos, veja petrografia), os quais desenvolveram uma foliação paralela $\left(\mathrm{N}-\mathrm{S}\right.$ a $N 10^{\circ} \mathrm{E}$ e $\left.\mathrm{N} 20^{\circ}-40^{\circ} \mathrm{E}\right)$ a direção do próprio corpo. Tal deformação, sugere que estes diques tiveram origem a partir de corpos ígneos que foram submetidos a processos de cisalhamentos desenvolvidos longitudinalmente aos corpos tabulares durante ou após sua colocação (Foto IV.3). Este fato é apoiado pela foliação restrita às bordas dos diques e nos contatos das rochas encaixantes. Como as zonas de cisalhamento mostram-se fortemente associadas com a migração de fluidos, é de se supor que a geração dos diques classificados como metabásicos (DMB, veja Petrografia) também se relacione a este evento.

O evento cisalhante descrito, pode ser similar ao encontrado em outras zonas de cisalhamento transcorrente, onde a intrusão de diques é controlada por regimes de cisalhamentos transtensivos e transpressivos concomitantes (e.g. Cadman et al, 1990; Chaves, 1996). Outra possibilidade, reside na atuação de regimes transcorrentes após o periodo intrusivo, aproveitando-se das zonas de fraqueza originais (e.g. Tarney \& Weaver, 1987; Tarney, 1992).

Em sintese, é de se esperar o seguinte quadro evolutivo, com base nos dados disponiveis da tabela IV.3 e ao se correlacionar a região com complexos adjacentes (e.g. Complexo Campo Belo): a) geração no Mesoarqueano ( $>3,0 \mathrm{Ga})$ dos gnaisses TTG e anfibolitos/ultrabásicas associadas; b) intrusão dos Granitos tipo Bom Sucesso no 
Neoarqueano, entre 2,78 - 2,77 Ga, os quais podem ser os correspondentes da primeira fase do Evento Rio das Velhas (Carneiro et al, 1995); c) granulitização também no Neoarqueano de parte das unidades litológicas à oeste da Serra do Bom Sucesso entre 2,70 - 2,66 Ga; d) início da sedimentação dos metassedimentos da Serra de Bom Sucesso na interface Arqueano/Proterozóico ( 2,5 Ga); e) granitização e migmatização ao redor de 2140 Ma; f) intrusão dos granitos do tipo Tabuões e fase final da evolução do Cinturão Mineiro ao se encerrar o Paleoproterozóico. O referido cinturão afetou as unidades dos ortognaisses e dos gnaisses monzoníticos porfiroblásticos entre 2,1 a 1,9 Ga.

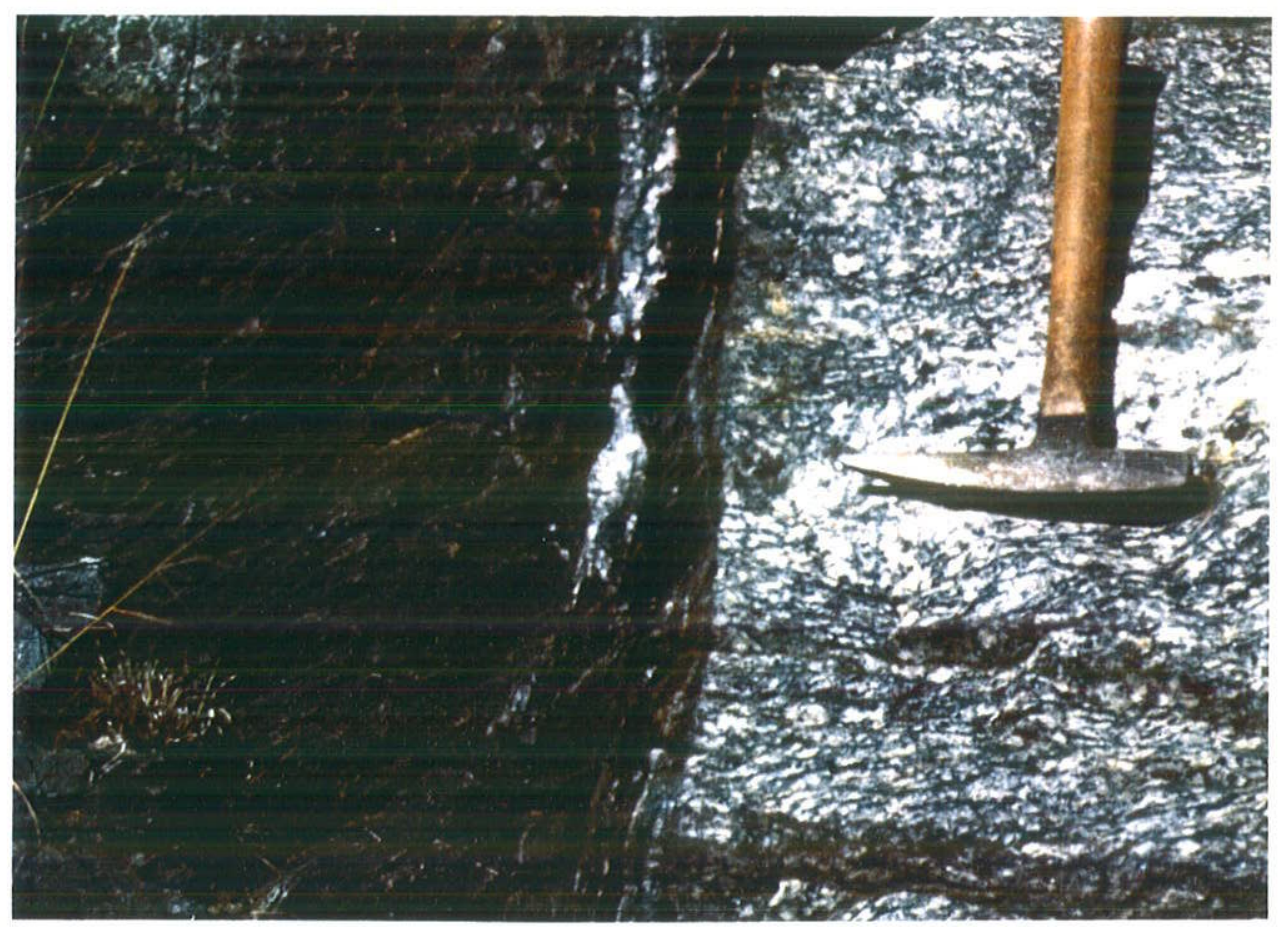

FOTO IV.3: Dique metamórfico anfibolítico (DA) em contato tectônico com o ortognaisse Lavras. O contato se destaca pela foliação restrita à borda do dique e pela presença de quartzo estirado.

\begin{tabular}{|c|c|c|c|}
\hline Unidades Litológicas & Idade & Método & Referências \\
\hline Granulitos & $\begin{array}{l}2661 \pm 36 \mathrm{Ma} * * \\
{[2,92-3,46 \mathrm{Ga}] 3,14 \mathrm{Ga}(\mathrm{n}=3)}\end{array}$ & $\begin{array}{l}\mathrm{Rb}-\mathrm{Sr}\left({ }^{87} \mathrm{Sr} /{ }^{86} \mathrm{Sr}\right) \mathrm{i}=0,7015 \\
\mathrm{Sm}-\mathrm{Nd}\left(\mathrm{T}^{\mathrm{DM}}\right) \text { Média }\end{array}$ & $\begin{array}{l}\text { Quéméneur (1996) } \\
\text { Presente trabalho }\end{array}$ \\
\hline $\begin{array}{l}\text { Gnaisses graníticos } \\
\text { migmatizados } *\end{array}$ & $\begin{array}{l}2688 \pm 50 \mathrm{Ma} * * \\
2690 \pm 56 \mathrm{Ma} * *\end{array}$ & $\begin{array}{l}\mathrm{Rb}-\mathrm{Sr}\left({ }^{87} \mathrm{Sr} /{ }^{86} \mathrm{Sr}\right) \mathrm{i}=0,7021 \\
\mathrm{Rb}-\mathrm{Sr}\left({ }^{87} \mathrm{Sr} /{ }^{86} \mathrm{Sr}\right) \mathrm{i}=0,7000\end{array}$ & $\begin{array}{l}\text { IGA/CPGeo } \\
\text { IGA/CPGeo }\end{array}$ \\
\hline Granitos Bom Sucesso & $2787 \pm 143 \mathrm{Ma}$ & $\mathrm{Rb}-\mathrm{Sr}\left({ }^{87} \mathrm{Sr} /{ }^{86} \mathrm{Sr}\right) \mathrm{i}=0,7081$ & Quéméneur (1996) \\
\hline $\begin{array}{l}\text { Anfibolitos } \\
\text { metabasaltos }\end{array}$ & $\begin{array}{l}{[2,53-3,14 \quad \mathrm{Ga}] \quad 2,78 \pm} \\
0,27 \mathrm{Ma}(\mathrm{n}=4) * *\end{array}$ & Sm-Nd $\left(T^{D M}\right)$ Média & Quéméneur (1996) \\
\hline Ortognaisses & $\begin{array}{l}1982 \pm 134 \mathrm{Ma} \\
3,0 \mathrm{Ga}\end{array}$ & $\begin{array}{l}\mathrm{Rb}-\mathrm{Sr}\left({ }^{87} \mathrm{Sr} /{ }^{86} \mathrm{Sr}\right) \mathrm{i}=0,7041 \\
\mathrm{Sm}-\mathrm{Nd}\left(\mathrm{T}^{\mathrm{DM}}\right)\end{array}$ & $\begin{array}{l}\text { Heilbron et al (1989) } \\
\text { Presente trabalho }\end{array}$ \\
\hline $\begin{array}{l}\text { Gnaisses monzoníticos } \\
\text { porf. migmatizados }\end{array}$ & $2137 \pm 123 \mathrm{Ma}$ & $\mathrm{Rb}-\mathrm{Sr}\left({ }^{87} \mathrm{Sr} /{ }^{86} \mathrm{Sr}\right) \mathrm{i}=0,7026$ & Teixeira (1985) \\
\hline Granito Tabuões & $1932 \pm 21 \mathrm{Ma}$ & $\mathrm{Rb}-\mathrm{Sr}\left({ }^{87} \mathrm{Sr} /{ }^{86} \mathrm{Sr}\right) \mathrm{i}=0,7025$ & Quéméneur \& Vidal (1989) \\
\hline
\end{tabular}

Tabela IV.3: Idades Rb-Sr e Sm-Nd no âmbito da região investigada e áreas adjacentes. (*)= Amostras com posição fora da região em apreço. $(* *)=$ Dados inéditos. Porf.=porfiroblásticos. 


\section{V- PETROGRAFIA E QUIMICA MINERAL}

\section{V.1 - Petrografia}

Os dados petrográficos obtidos de 121 lâminas delgadas permitem subdividir os diques máficos da região investigada em 5 grupos distintos, os quais de maneira geral serão descritos a seguir (descrições simplificadas de cada amostra estudada encontram-se resumidamente no apêndice 3). Cumpre ressaltar, que cerca de 30 exemplares deste conjunto mostram-se fortemente epidotizados e/ou saussuritizados e por esta razão foram excluídos dos estudos previstos.

$\mathrm{Na}$ análise petrográfica foram adotados os seguintes critérios: 1) Quanto a granulação (mm): a) muito fina $(\varnothing \leq 0,1)$; b) fina $(0,1<\varnothing \leq 1,0)$; c) média $(1,0<\varnothing \leq 5,0)$; d) grossa $(5,0<\varnothing \leq 20,0)$; e) muito grossa $(\varnothing>20,0)$. 2) Quanto ao tamanho dos cristais (mm): a) matriz $(\varnothing \leq 0,1)$; b) microfenocristais $(0,1<\varnothing \leq 0,5)$; c) fenocristais $(0,5<\varnothing \leq$ $2,0)$; d) macrofenocristais $(2,0<\varnothing \leq 10,0)$; e) megafenocristais $(\varnothing>10,0)$.

As rochas analisadas são holocristalinas, mas alguns casos de rochas hipocristalinas foram assinalados, como por exemplo a amostra $\mathrm{DB}_{2}-15$. Amostras com granulação média e fina predominam sobre as de granulação muito fina e, via de regra, as médias-finas representam as partes mais centrais dos diques enquanto as muito finas representam as margens. Na realidade as amostras de granulação muito fina mostram-se intensamente intemperizadas. Por outro lado, todo o conjunto de diques máficos apresenta amostras com ligeiro predomínio de granulação fina.

As texturas mais comuns observadas nas amostras estudadas são:

A - Subofítica: as ripas de plagioclásios encontram-se parcialmente englobadas por cristais oticamente contínuos de piroxênios, cujo tamanho médio é inferior ao dos plagioclásios.

B - Intergranular: os intersticios dos plagioclásios são ocupados por cristais de piroxênios.

C - Porfiritica: caracterizada por apresentar megafenocristais, macrofenocristais, fenocristais e raramente microfenocristais de plagioclásios e/ou piroxênios imersos em matriz de granulação fina, muito fina a vitrea. 
D - Granoblástica: caracterizada por apresentar plagioclásios e anfibólios preferencialmente subpoligonizados com contatos justapostos em típica trama grão mais crescimento. Em diques com indicação de estágios deformativos (cisalhamento), como deve ter ocorrido nos diques anfibolíticos, além deste tipo de textura são observados também a textura granonematoblástica com forte orientação dos grãos minerais.

Destaca-se, que em um dos grupos atingidos pelo metamorfismo (DMB), as feições ígneas originais não foram obliteradas e adotou-se o termo blasto para designação textural (e.g. blasto-subofítica).

\section{V.1.1 - Diques Básicos Noríticos}

Este grupo encontra-se posicionado geograficamente entre as cidades de Lavras e Bom Sucesso, mas mostra tendência em se distribuir para noroeste a partir da porção central do enxame. Conforme relatado no item geologia eles se orientam preferencialmente no quadrante NW.

Os diques básicos noríticos (DBN) representam cerca de $13 \%$ das rochas investigadas e a granulação de suas rochas varia de fina (tmédio $=0,8 \mathrm{~mm}$ ) a média (tmédio $=$ $2,0 \mathrm{~mm}$ ) com ligeiro predominio daquelas com granulação média. Os contatos entre os cristais são em grande maioria do tipo reto seguidos por escassos contatos reentrantes ou irregulares.

As texturas iniciam-se pelas cumuláticas (amostras 1212 e 72) que passam gradativamente a intergranulares e subofiticas (amostras 64 e 54). O tipo de textura cumulática identificada é a heteradcumulática (Wager \& Brown, 1968), onde o plagioclásio ocorre como fase "intercumulus", enquanto olivina, orto e clinopiroxênios ocorrem como fase "cumulus" (Fotomicrografia V.1).

Os minerais fundamentais dos DBN são: plagioclásio (precoce $\mathrm{An}=74-$ $59 \% ;$ tardio $\mathrm{An}_{\mathrm{n}}=71-52 \%$ ); augita (precoce $\mathrm{W}_{\mathrm{O}}=39-27 \% ;$ tardia $\mathrm{W}_{\mathrm{O}}=36-27 \%$ ); ortopiroxênio (precoce $W_{0}=4,3-1,2 \%$; tardio $W_{0}=4,9-3,2 \%$ ); minerais opacos e pouca biotita. A olivina é escassa e ocorre predominantemente em rochas com textura cumulática e subordinadamente em rochas com textura intergranular ou subofitica. Intercrescimentos micropegmatíticos mais a pigeonita (tardia $W_{0}=15 \%$ ) são raros ou totalmente ausentes. 
Com representação volumétrica variando de cerca de 30 a $40 \%$, os plagioclásios ocorrem na forma de ripas euédricas a subédricas e prismas alongados. Quando em rochas de textura heteradcumulática encontram-se em macrofenocristais (tmédio $=5,0$ $\mathrm{mm}$ ) incluindo os demais minerais e quando em rochas de textura intergranular mostram-se em feno (tmédio $=1,8 \mathrm{~mm}$ ) e microfenocristais (tamanho médio $=0,4 \mathrm{~mm}$ ), cujos interstícios são preenchidos por outros minerais. Nas rochas com textura cumulática, os plagioclásios apresentam volumes sempre inferiores $(\sim 30 \%)$ quando relacionados à aqueles com texturas intergranular e subofitica $(\sim 40 \%)$. Geralmente, os plagioclásios encontram-se maclados polissinteticamente segundo a lei da albita, albita-carlsbad-periclina e a aplicação do método Michel-Levy nos geminados, proporcionaram conteúdos da molécula de anortita correspondentes predominantemente aos termos da labradorita. Em algumas amostras pode se observar cristais de plagioclásios recobertos por uma fina nuvem acastanhada e de aspecto difuso. Zhang \& Halls (1995) atribuem as nuvens a exsolução de impurezas (Fe por exemplo) no decorrer da cristalização dos plagioclásios. Manchas de saussuritização e epidotização também são assinaladas nos núcleos de alguns poucos cristais. Nestas manchas de aspecto difuso pode se verificar sericita, calcita e epidoto.

Os piroxênios ocupam 35 a $45 \%$ do volume total da rocha. São representados predominantemente por augitas e subordinadamente por ortopiroxênios e rara pigeonita. Em geral, encontram-se em prismas isolados, as vezes geminados ou de maneira composta (Fotomicrografia V.2). Os piroxênios compostos apresentam-se de duas formas: uma predominantemente com ortopiroxênio no núcleo e clinopiroxênio na borda e outra mais escassa com pigeonita no núcleo e clinopiroxênio na borda. Este tipo complexo de piroxênio é semelhante à aqueles de rochas lunares e dos diques da região sudoeste da Groenlândia, relatados por Hall et al (1985) e Hall \& Hughes (1987). Os cristais compostos de piroxênios somente não são observados nas rochas com textura cumulática.

A augita representa volumetricamente valores entre 20 a $30 \%$, e ocorre frequentemente como fenocristais (tmédio $\cong 1,5 \mathrm{~mm}$ ), microfenocristais (tmédio $\cong 0,3 \mathrm{~mm}$ ) e matriz (tmédio $\cong 0,08 \mathrm{~mm}$ ), tanto para rochas com textura cumulática como para intergranular. Apresenta-se incolor a verde-claro, exclusivamente em prismas euedrais nas rochas de textura cumulática e em grãos euedrais, subedrais a anedrais nas demais texturas. 


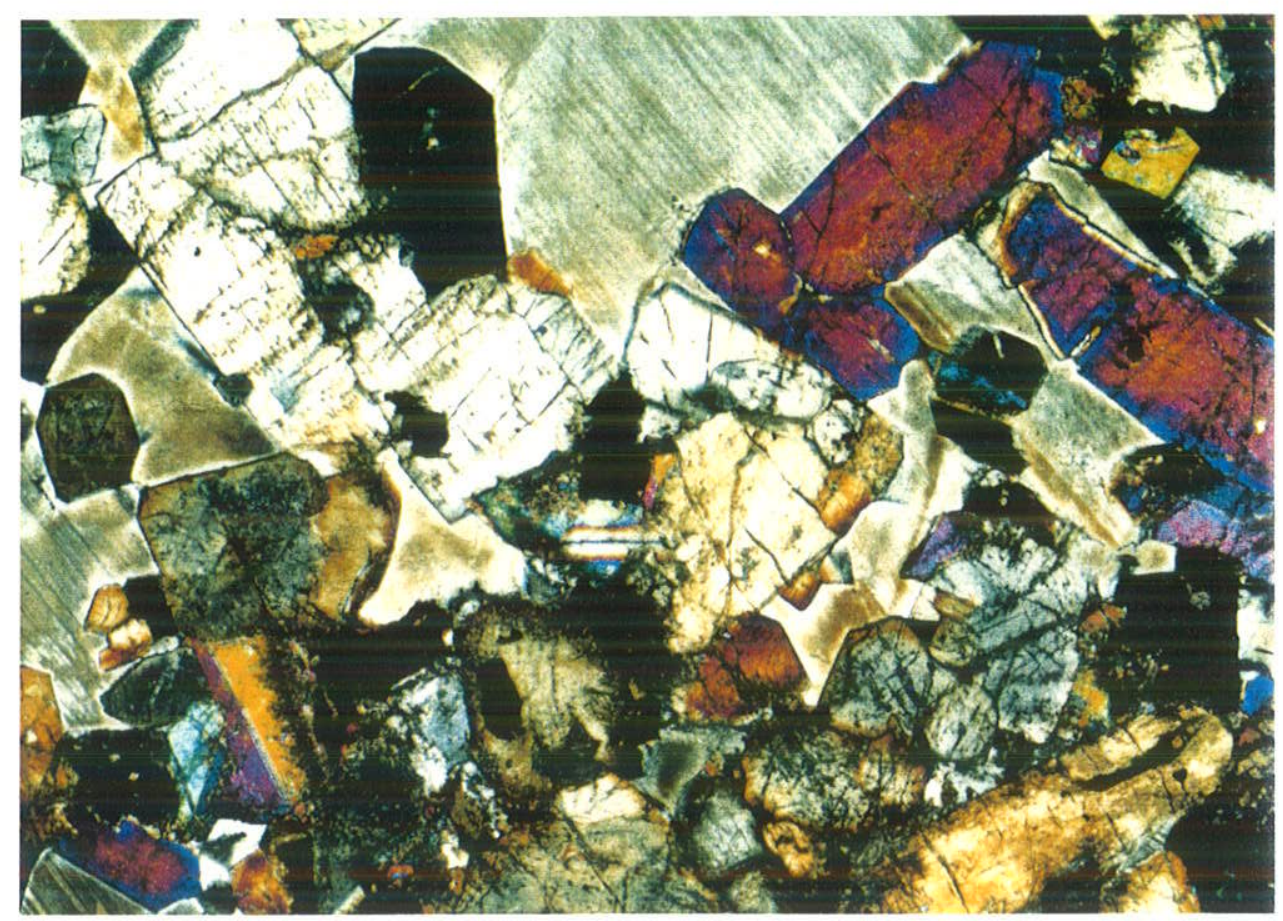

FOTOMICROGRAFIA V.1: Amostra DBN-1212 - Aspecto geral da textura cumulática (heteradcumulática) assinalada nos diques básicos noríticos, com plagioclásios "intercumulus" e orto e clinopiroxênios "cumulus". Nicóis cruzados (objetiva 2,5x), lado maior da foto $\cong 5,0 \mathrm{~mm}$.

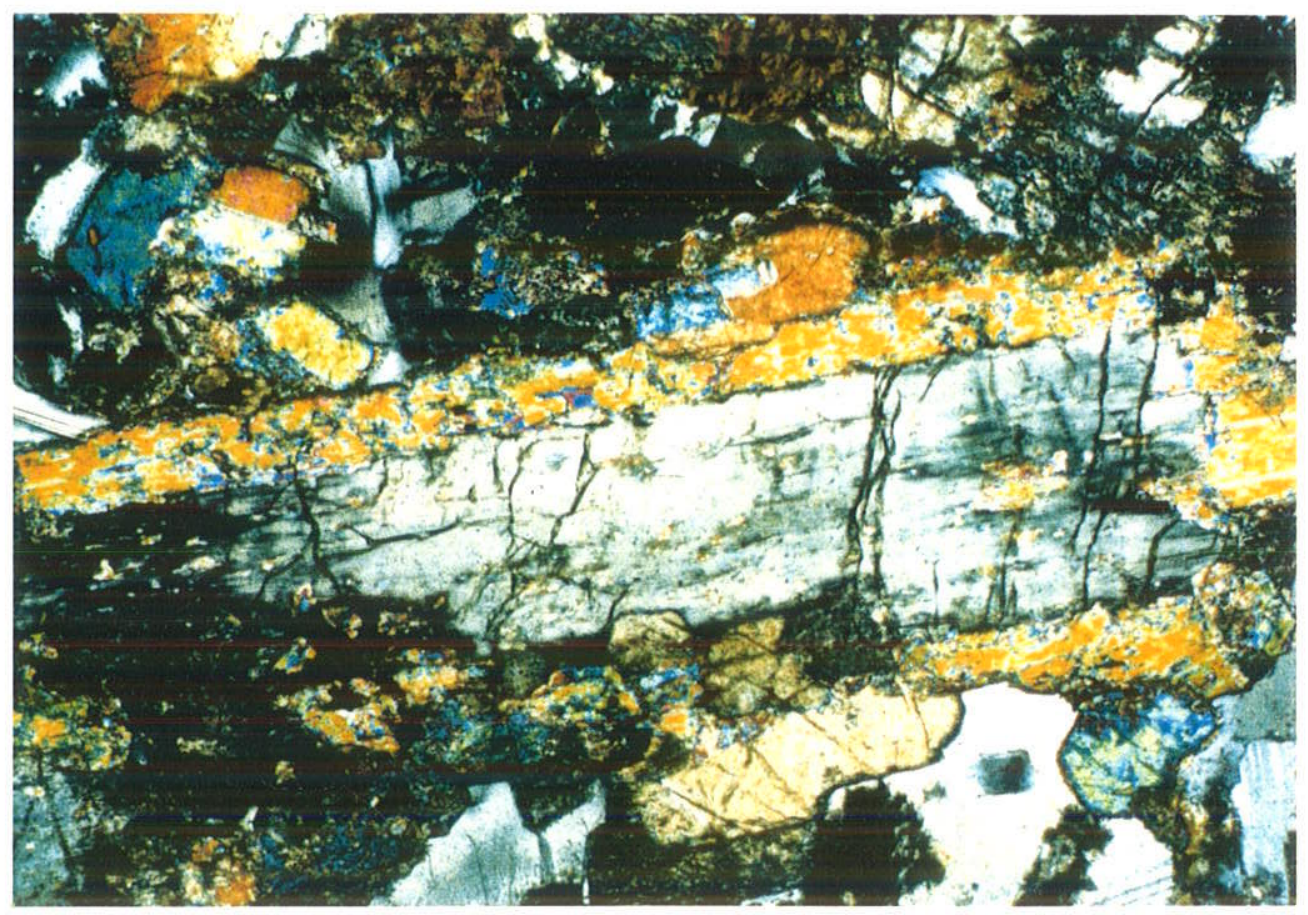

FOTOMICROGRAFIA V.2: Amostra DBN-28 - Detalhe de um cristal composto de piroxênios, onde ortopiroxênio (bronzita) ocorre no núcleo e clinopiroxênio (augita) ocorre na borda, diagnosticado nos diques básicos noríticos. Nicóis cruzados (objetiva 5,0x), lado maior da foto 2,3 $\mathrm{mm}$. 
Quando não inclusa poiquiliticamente encontra-se preenchendo intersticios entre plagioclásios ou englobando-os parcialmente. Distribui-se em cristais isolados e quando em cristais conjugados ocupa sempre suas bordas laterais.

Os ortopiroxênios (bronzita) ocupam volumes na rocha que variam de 10 a $18 \%$, sendo que os exemplares de textura cumulática apresentam os maiores volumes, enquanto as demais texturas os menores volumes. Caracterizam-se pelas cores rosadas a verde pálida e extinção reta. Geralmente, apresentam-se em fenocristais (tmédio $\cong 1,5 \mathrm{~mm}$ ) e microfenocristais (tmédio $\cong 0,3 \mathrm{~mm}$ ) euedrais a subedrais. Ocorrem isoladamente preenchendo interstícios dos plagioclásios mas se destacam por constituirem os núcleos dos piroxênios compostos. Em geral, a proporção em fenocristais dos ortopiroxênios é semelhante a proporção dos fenocristais de plagioclásio.

A pigeonita não ultrapassa os $3 \%$ em volume da rocha e quando em cristais isolados se apresentam em prismas subedrais à anedrais. Nos tipos conjugados, ocorre sempre no núcleo em prismas euedrais a subedrais sendo bordejada pela augita. Em geral se constituem em fenocristais (tmédio $\cong 1,0 \mathrm{~mm}$ ) e microfenocristais (tmédio $\cong 0,2 \mathrm{~mm}$ ). Os fenocristais predominam nos tipos conjugados e os microfenocristais no tipo isolado. Exemplares com textura cumulática são volumetricamente ricos em piroxênios, contudo, as pigeonitas são restritas a poucas amostras com textura intergranular ou subofitica.

Exclusividade dos DBN, a olivina (Fo $=76-78 \%$ ) não ultrapassa $5 \%$ do volume da rocha e ocorre freqüentemente em microfenocristais (tmédio $\cong 0,2 \mathrm{~mm}$ ) e como matriz (tmédio $\cong 0,08 \mathrm{~mm}$ ). Apresentam-se anedrais com contornos arredondados, bordejados por minerais opacos e inclusas nos cristais de piroxênios. Em geral, encontram-se em cristais não alterados.

Os minerais opacos estão representados por magnetitas e ilmenitas, as quais no conjunto chegaram a comprometer até $5 \%$ do volume de rocha total. Em geral, as magnetitas ocorrem em microfenocristais (tmédio $\cong 0,2 \mathrm{~mm}$ ) subédricos nas formas cúbicas ou octaédricas, enquanto as ilmenitas ocorrem comumente em microfenocristais (tmédio $\cong 0,2$ $\mathrm{mm}$ ) na forma acicular.

Quando presente, o intercrescimento micropegmatítico apresenta volume não superior a $5 \%$ e é caracterizado por intercrescimentos micrográficos ou granofiricos de composição quartzo-K feldspática. Estes intercrescimentos têm sido encontrados em 
diferentes tipos de "diques noriticos" na Groenlândia (Hall \& Hughes, 1987), mas ocorre também em outros tipos de diques toleiticos, como por exemplo nos diques do Uruguai.

Neste grupo, a biotita pode alcançar $3 \%$ do volume da rocha e ocorre em microfenocristais (tmédio $\cong 0,2 \mathrm{~mm}$ ) e como matriz na forma de palhetas anédricas de coloração marrom avermelhada.

A apatita, raramente ultrapassa $1 \%$ em volume na rocha, mostra-se acicular ou em cristais hexagonais.

Assinalam-se ainda: clorita, sericita, calcita, epidoto e raro anfibólio. Os quatro primeiros são fruto da desestabilização dos plagioclásios e piroxênios.

\section{V.1.2 - Diques Básicos - 1}

$O$ conjunto também encontra-se posicionado geograficamente entre as cidades de Lavras e Bom Sucesso. Todavia, estão sempre localizados na parte central do enxame. Orientam-se preferencialmente no quadrante NW seguindo a tendência já assinalada para os DBN.

Os diques básicos $1\left(\mathrm{DB}_{1}\right)$ representam cerca de $11 \%$ das rochas investigadas e a granulação predominante é a do tipo fina (tmédio $=0,8 \mathrm{~mm}$ ). Em geral, os contatos entre os cristais são retos, as vezes reentrantes ou irregulares. São caracterizados pela textura intergranular e pela textura subofitica (Fotomicrografia V.3).

Os minerais essenciais dos $\mathrm{DB}_{1}$ são: plagioclásio (precoce $\mathrm{An}=67-55 \%$; tardio An $=54-42 \%$ ); augita (precoce $W_{0}=34-32 \%$; tardia $W_{0}=33-27 \%$ ); pigeonita (precoce $W_{0}=10-13 \% ;$ tardia $\left.W_{0}=11-15 \%\right)$; ortopiroxênio; minerais opacos e escassa biotita.

Os plagioclásios representam cerca de $40-45 \%$ do volume da rocha e ocorrem na forma de ripas euédricas a subédricas e prismas alongados. Mostram-se em feno (tmédio $=0,8 \mathrm{~mm}$ ) e microfenocristais ( tmédio $=0,2 \mathrm{~mm}$ ), cujos interstícios são preenchidos por outros minerais. Em geral, encontram-se geminados segundo a lei da albita, albitacarlsbad-periclina e a aplicação do método Michel-Levy proporcionaram conteúdos da molécula de anortita correspondentes predominantemente aos termos da labradorita. Alguns cristais de plagioclásios apresentam-se recobertos por uma nuvem acastanhada clara, 
semelhante a aquelas observadas nos plagioclásios do grupo anterior. Saussuritização e epidotização são fenômenos assinalados nos núcleos de alguns poucos cristais, via de regra posicionados nas microfaturas destes cristais.

Os piroxênios ocupam 35 a $45 \%$ do volume total da rocha. São representados predominantemente por augitas e subordinadamente por pigeonitas e escasso ortopiroxênio. Geralmente, encontram-se em prismas individualizados, as vezes geminados. Cristais compostos são raros, restritos a alguns exemplares e se apresentam da mesma maneira que aqueles identificados nos DBN.

A augita representa volumes da ordem de 25 a $30 \%$ da rocha, e ocorre freqüentemente como fenocristais (tmédio $\cong 0,8 \mathrm{~mm}$ ), microfenocristais (tmédio $\cong 0,2 \mathrm{~mm}$ ) e matriz (tmédio $\cong 0,08 \mathrm{~mm}$ ). Apresenta-se incolor a verde-clara em prismas subedrais a anedrais. Via de regra, encontra-se preenchendo intersticios entre plagioclásios ou englobando-os parcialmente. Distribui-se em cristais individualizados e quando em raros cristais compostos ocupa sempre suas bordas laterais.

Com representação volumétrica entre 8 a $10 \%$ do volume da rocha, a pigeonita se apresenta em prismas subedrais a anedrais. Em geral, constituem fenocristais (tmédio $\cong 0,6 \mathrm{~mm}$ ) e microfenocristais (tmédio $\cong 0,2 \mathrm{~mm}$ ), os quais se distribuem preenchendo interstícios entre os plagioclásios.

A bronzita representa os ortopiroxênios, os quais se distribuem ocupando volumes na rocha que variam de 5 a $8 \%$. Caracterizam-se pelas cores rosadas a verde pálida e extinção reta. Freqüentemente, apresentam-se em fenocristais (tmédio $\cong 0,7 \mathrm{~mm}$ ) e microfenocristais (tmédio $\equiv 0,2 \mathrm{~mm}$ ) subedrais a anedrais, que ocorrem individualizados preenchendo interstícios dos plagioclásios. Nos raros cristais conjugados de piroxênios, tanto a bronzita como a pigeonita restringem-se ao núcleo.

Também neste grupo, assinalamse o micropegmatito cujos volumes variam entre 5 a $10 \%$ da rocha total e são caracterizados por intercrescimentos micrográficos ou granofiricos de composição quartzo-K feldspática (Fotomicrografia V.4).

A biotita não ultrapassa $5 \%$ do volume da rocha e ocorre como microfenocristais (tmédio $\cong 0,1 \mathrm{~mm}$ ) e como matriz na forma de palhetas anédricas de coloração marrom avermelhada. 


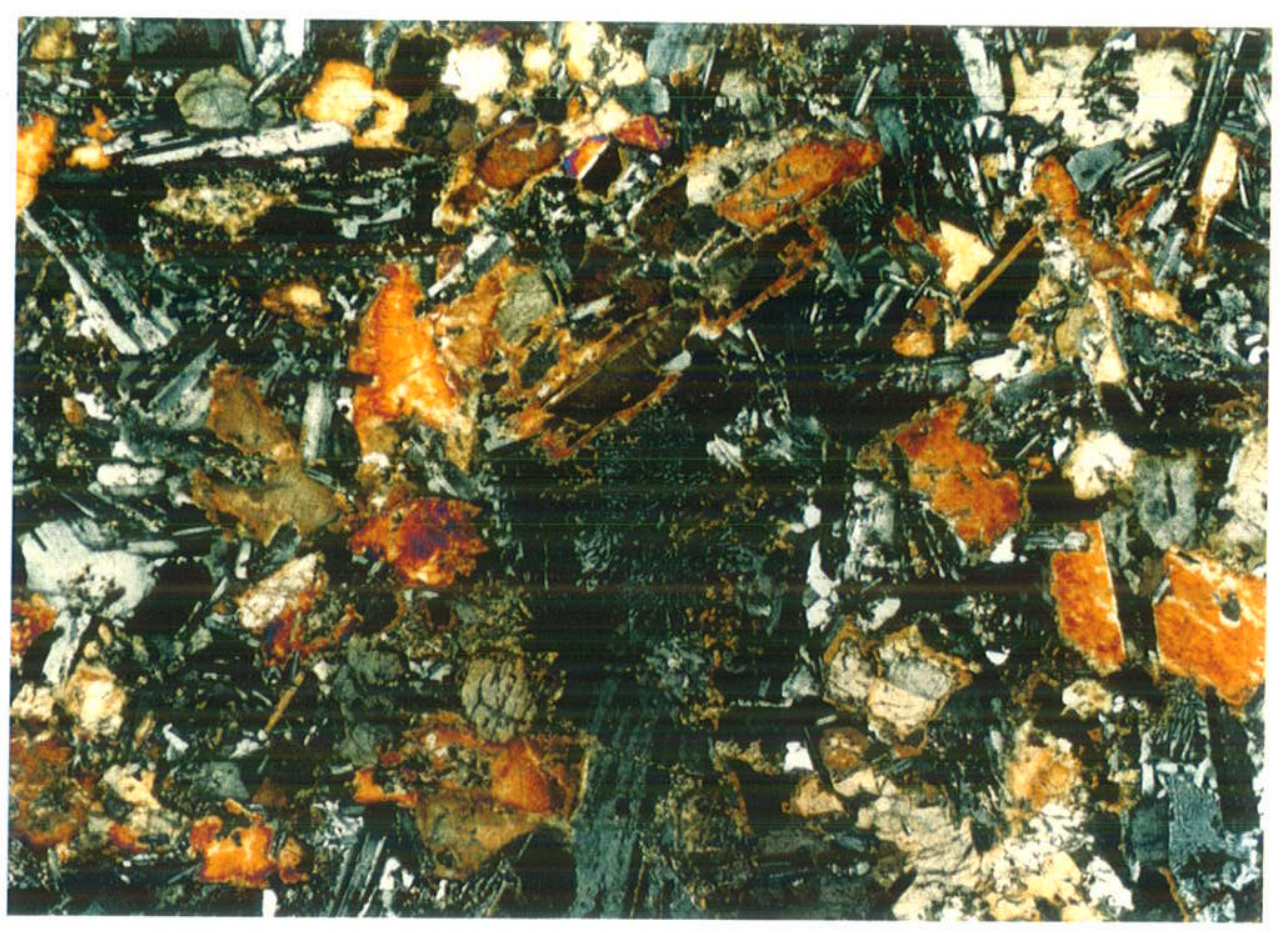

FOTOMICROGRAFIA V.3: Amostra $\mathrm{DB}_{1}-112$ - Aspecto geral da textura subofítica, localmente intergranular, típica nos diques básicos 1, onde se observa fundamentalmente plagioclásios ripiformes, intercrescimentos micropegmatíticos e cristais subedrais de augita. Nicóis cruzados (objetiva 2,5x), lado maior da foto $\cong 5,0 \mathrm{~mm}$.

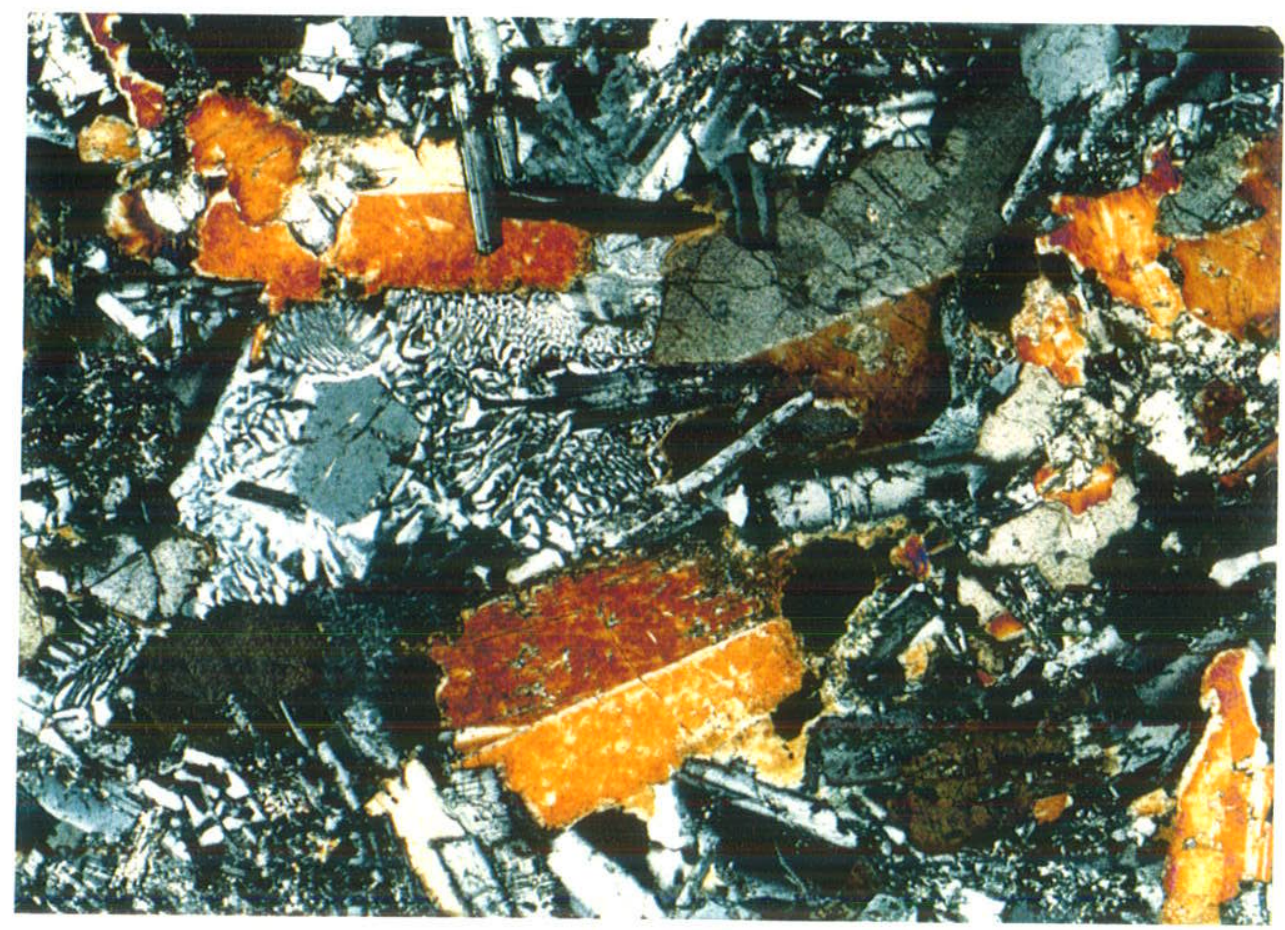

FOTOMICROGRAFIA V.4: Amostra DB $1-70$ - Detalhe do intercrescimento quartzo-feldspático (micropegmatito) e da textura subofítica, de ocorrência comum nos diques básicos 1, onde se destacam ripas de plagioclásios e cristais subedrais de augita. Nicóis cruzados (objetiva 5,0x), lado maior da foto $\cong 2,5 \mathrm{~mm}$. 
Os minerais opacos estão representados por magnetitas e ilmenitas, as quais não ultrapassam $5 \%$ do volume de rocha total. Em geral, as magnetitas ocorrem em microfenocristais (tmédio $\cong 0,1 \mathrm{~mm}$ ) subédricos nas formas cúbicas ou octaédricas, enquanto as ilmenitas freqüentemente ocorrem em microfenocristais aciculares (tmédio $\equiv 0,1 \mathrm{~mm}$ ).

A apatita se distribui por até $1 \%$ do volume da rocha e mostra-se com hábitos aciculares ou em cristais hexagonais.

Assinalam-se ainda: clorita, sericita, calcita, epídoto e raro anfibólio.

Cabe notar, as similaridades assinaladas entre os DBN e os $\mathrm{DB}_{1}$, tais como: presença de micropegmatito, pequena distribuição de biotita primária e ocorrência de ortopiroxênios magnesianos, as vezes, na forma de cristais conjugados.

\section{V.1.3 - Diques Básicos - 2}

Os diques básicos $2\left(\mathbf{D B}_{2}\right)$ são os de maior freqüência na região representando cerca de $42 \%$ das amostras descritas. Predominam aquelas de granulação média (tmédio dos grãos $\cong 1,0 \mathrm{~mm}$ ). O grupo se distribui por toda a região investigada e seu posicionamento direcional é aleatório.

Geralmente os exemplares apresentam textura subofitica a intergranular (Fotomicrografia V.5 e V.6), as vezes porfiritica como nas amostras 15, 74, 24 e 37. Na textura subofitica os minerais comumente ocorrem como fenocristais (tmédio $=1,1 \mathrm{~mm}$ ), microfenocristais (tmédio $=0,4 \mathrm{~mm}$ ) e raramente como matriz. Na textura intergranular predominam minerais como microfenocristais (tmédio $=0,4 \mathrm{~mm}$ ) e matriz. As rochas com textura porfiritica mostram fenocristais de plagioclásios e piroxênios (tmáx $=2,6 \mathrm{~mm}$ e tmin $=$ $1,2 \mathrm{~mm}$ ) dispersos em matriz vitrea ou constituída por microfenocristais (tmédio $=0,2 \mathrm{~mm}$ ), também de plagioclásios e piroxênios. Na grande maioria das amostras os contatos entre os grãos é reto mas, contatos reentrantes e/ou irregulares também são assinalados.

Os constituintes mineralógicos fundamentais são: plagioclásios (precoce An $=72-50 \%$; tardio $A_{n}=39-62 \%$ ); augitas (precoce $W_{0}=35-47 \%$; tardio $W_{0}=23-49 \%$ ); escassa pigeonita $\left(W_{0}=9 \%\right)$ e hiperstênio $\left(W_{0}=1 \%\right)$.

Subordinadamente assinalam-se anfibólios, minerais opacos, apatita, clorita, epídoto e sericita. 


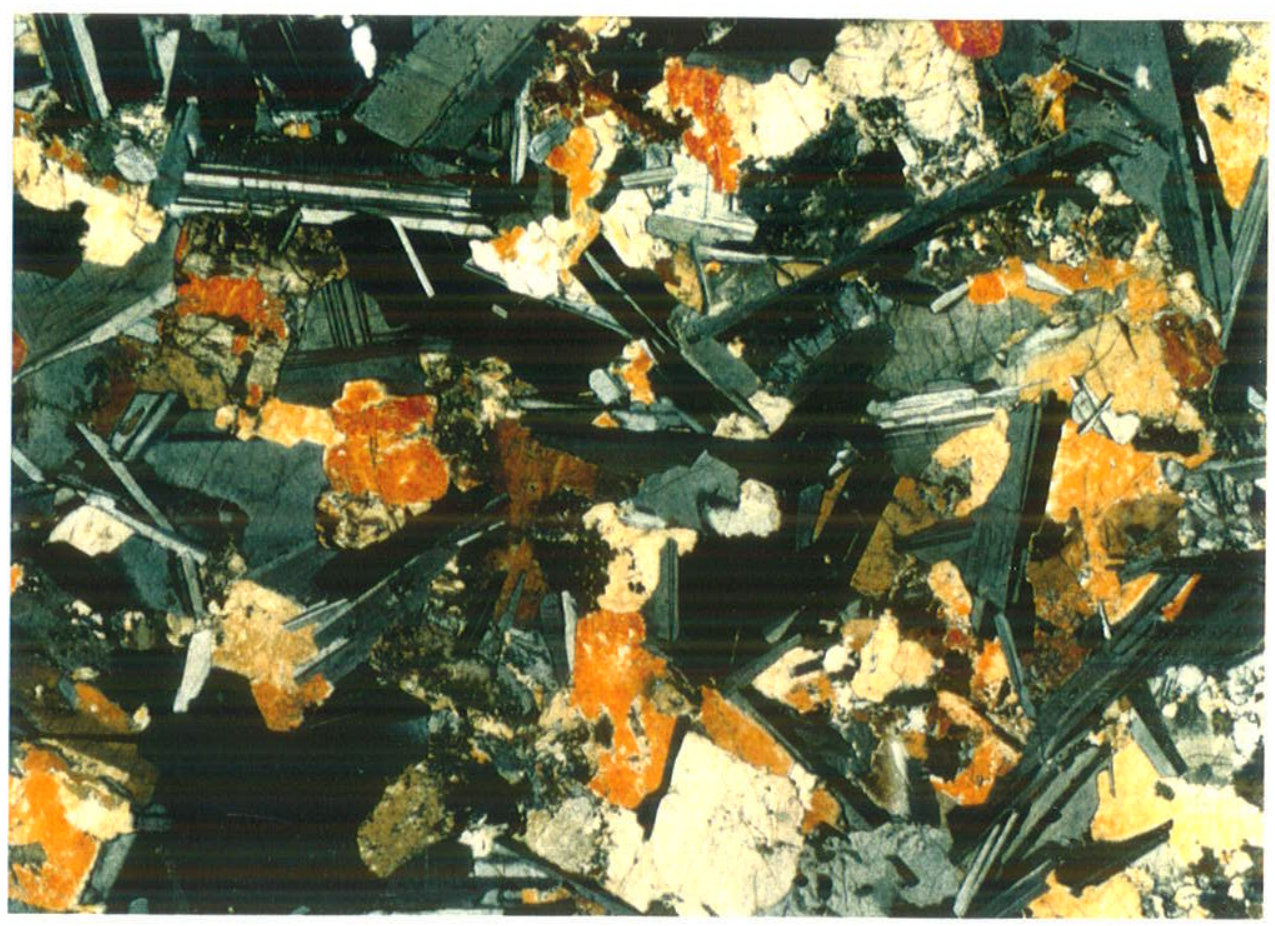

FOTOMICROGRAFIA V.5: Amostra $\mathrm{DB}_{2}-60$ - Aspecto geral da textura subofítica dos diques básicos 2, mostrando a disposição das ripas de plagioclásios e dos cristais de augita. Nicóis cruzados (objetiva $2,5 \mathrm{x}$ ), lado maior da foto $\cong 5,0 \mathrm{~mm}$.

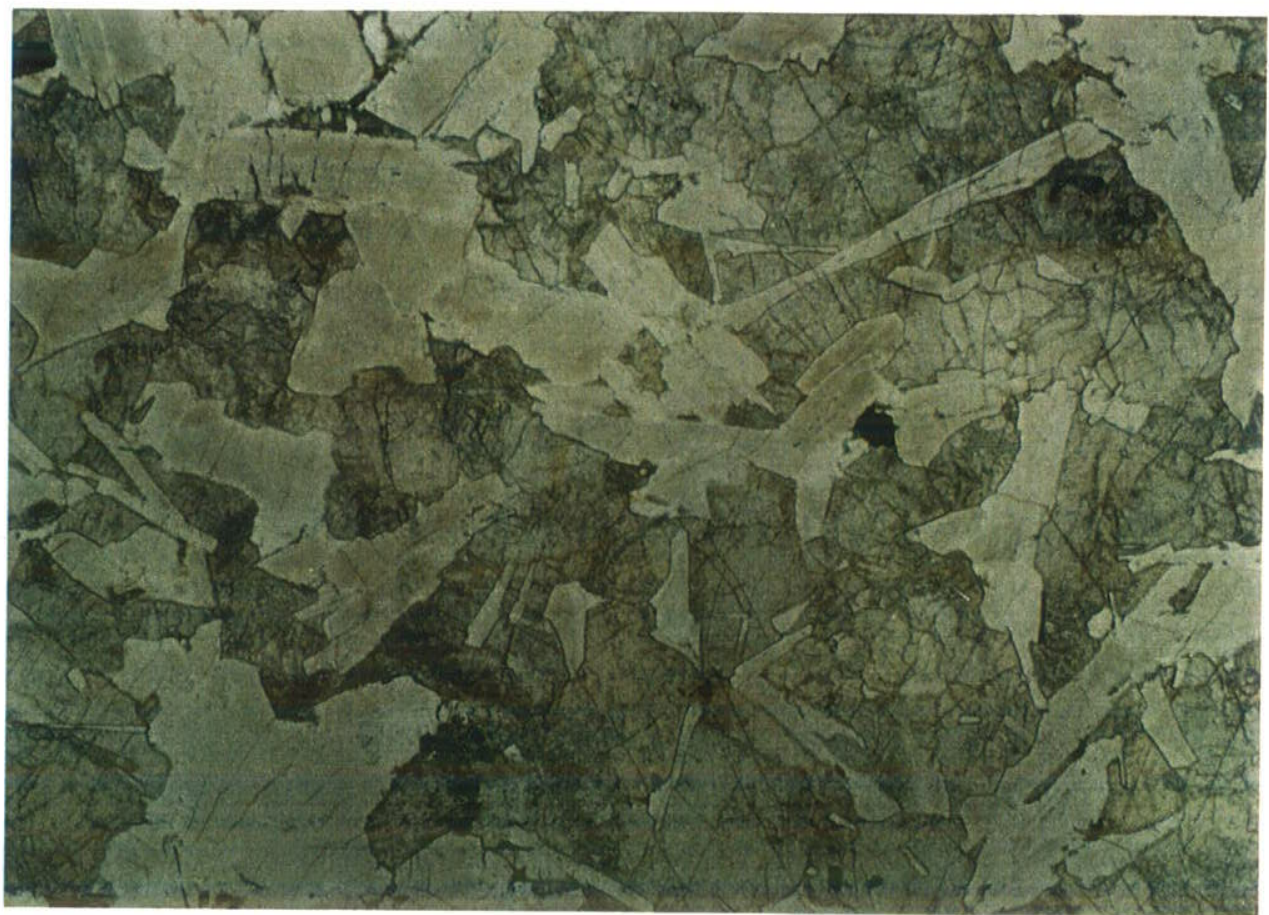

FOTOMICROGRAFIA V.6: Amostra $\mathrm{DB}_{2}-60$ - idem anterior, com nicóis paralelos (objetiva $2,5 \mathrm{x}$ ), lado maior da foto $\cong 5,0 \mathrm{~mm}$. 
Com representação volumétrica oscilando entre 40 e $45 \%$ da rocha, os plagioclásios predominantemente ocorrem em fenocristars (tmedio $\cong 1,2 \mathrm{~mm}$ ) e subordinadamente em microfenocristais (tmédio $=0,5 \mathrm{~mm}$ ). De maneira geral, apresentam-se ripiformes, euedrais a subedrais e estão geminados segundo a lei da albita ou albita Carlsbad. Utilizando-se o método de Michel-Levy obtiveram-se termos composicionais no intervalo andesina-labradorita. Manchas de saussuritização ou epidotização, quando observadas, são de baixa freqüência e restrita a microfraturas nos cristais. Algumas amostras exibem cristais de plagioclásios recobertos por uma fina nuvem de coloração acastanhada e de aspecto difuso.

Os piroxênios ocupam cerca de $25-30 \%$ do volume da rocha, podendo chegar a $40 \%$ se a amostra não apresentar anfibólios. São representados predominantemente por fenocristais, microfenocristais e matriz de augita, sendo pequena a quantidade assinalada de pigeonita e hiperstênio.

A augita apresenta-se incolor em cristais anedrais a subedrais com dimensões que variam de 0,01 a $2,0 \mathrm{~mm}$, freqüentemente com dimensões médias ao redor de $1,2 \mathrm{~mm}$. Os cristais mostram formas granulares à prismáticas, às vezes geminadas, e invariavelmente englobam parcialmente os plagiociásios ou preenchem seus intersticios.

Individualmente, hiperstênio e pigeonita raramente ultrapassam $5 \% \mathrm{em}$ volume da rocha. Via de regra, encontram-se como matriz ou microfenocristais (tmédio $=0,2$ $\mathrm{mm}$ ), e estão na forma de agregados policristalinos ou associados a augita. As pigeonitas encontram-se dominantemente em cristais anedrais e também são incolores como augita. $O$ hiperstênio é de coloraçẫo rósea e ocorre em cristais subedrais a anedrais. Em geral, todos os tipos de piroxênios encontram-se mais ou menos alterados, em suas bordas e fraturas, para anfibólios e cloritas.

Os minerais opacos (tmédio $=0,5 \mathrm{~mm}$ ) ocupam 5 a $10 \%$ do volume da rocha e são representados por magnetitas e ilmenitas. Preferencialmente distribuem-se como microfenocristais e matriz. Em geral, as ilmenitas são aciculares enquanto as magnetitas podem ser cúbicas e octaédricas. São escassas as magnetitas esqueletais, as quais envolvem piroxênios e plagioclásios.

Os anfibólios, quando presentes, chegam a atingir até 15\% (comumente entre 5 a $10 \%$ ) do volume da rocha e podem ser visualizados nas bordas dos piroxênios ou mais raramente em cristais isolados. Quando isolados apresentam-se preferencialmente em 
cristais anédricos e subordinadamente subédricos. São fortemente pleocróicos (verde claro [Z] a acastanhado $[\mathrm{X}]$ ) e exibem as vezes planos de clivagem. Dados óticos adicionais sugerem que esses minerais sejam do grupo das hornblendas.

A apatita é rara $(<1 \%$ em volume) e encontramse em cristais aciculares e hexagonais. Também rara, a biotita encontra-se sempre interdigitada em cristais de anfibólio a partir do qual parece ter se originado.

Clorita, epídoto, calcita e sericita constituem um grupo que está sempre relacionado a instabilidade deutérica de plagioclásios e piroxênios.

Vale ressaltar, as diferenças observadas entre os $\mathrm{DB}_{1}$ e $\mathrm{DB}_{2}$ como a moda e a composição dos ortopiroxênios envolvidos, a ausência nos $\mathrm{DB}_{2}$ do micropegmatito, a presença dos cristais compostos de piroxênios e da biotita nos $\mathrm{DB}_{\mathrm{I}}$, e a presença de anfíbólio nos $\mathrm{DB}_{2}$.

\section{V.1.4-Diques Metabásicos}

Geograficamente mostram-se posicionados entre ljaci e Bom Sucesso, na parte mais central do enxame, e orientam-se preferencialmente a NE e N-S.

Os diques metabásicos (DMB) representam 10\% das amostras estudadas. Estes diques assemelham-se aos $\mathbf{D B}_{2}$ e são caracterizados por uma textura variável do tipo blasto-subofitica a blasto-intergranular (Fotomicrografias V.7 e V.8). Geralmente na lâmina se reconhece a estrutura magmática original, por este motivo será adotada a mesma nomenclatura. Adiciona-se, que encontram-se presentes reliquias dos minerais magmáticos originais (e.g. plagioclásio, piroxênio).

O grupo é petrograficamente semelhante àquele descrito em Uauá „Bahia, norte do Cráton do São Francisco (Menezes Leal et al, 1995), onde os diques estão associados a zonas de cisalhamentos. Suas rochas apresentam granulação fina (tmédio $\cong 0,7 \mathrm{~mm}$ ) a granulação média (tmédio $\equiv 1,2 \mathrm{~mm}$ ). Em geral, os minerais distribuem-se em fenocristais (tmédio $\cong 1,0 \mathrm{~mm})$ microfenocristais (tmédio $=0,3 \mathrm{~mm}$ ) e mais raramente como matriz. Os contatos entre os cristais são retos, irregulares ou com aparência de corroídos pelos cristais adjacentes. 


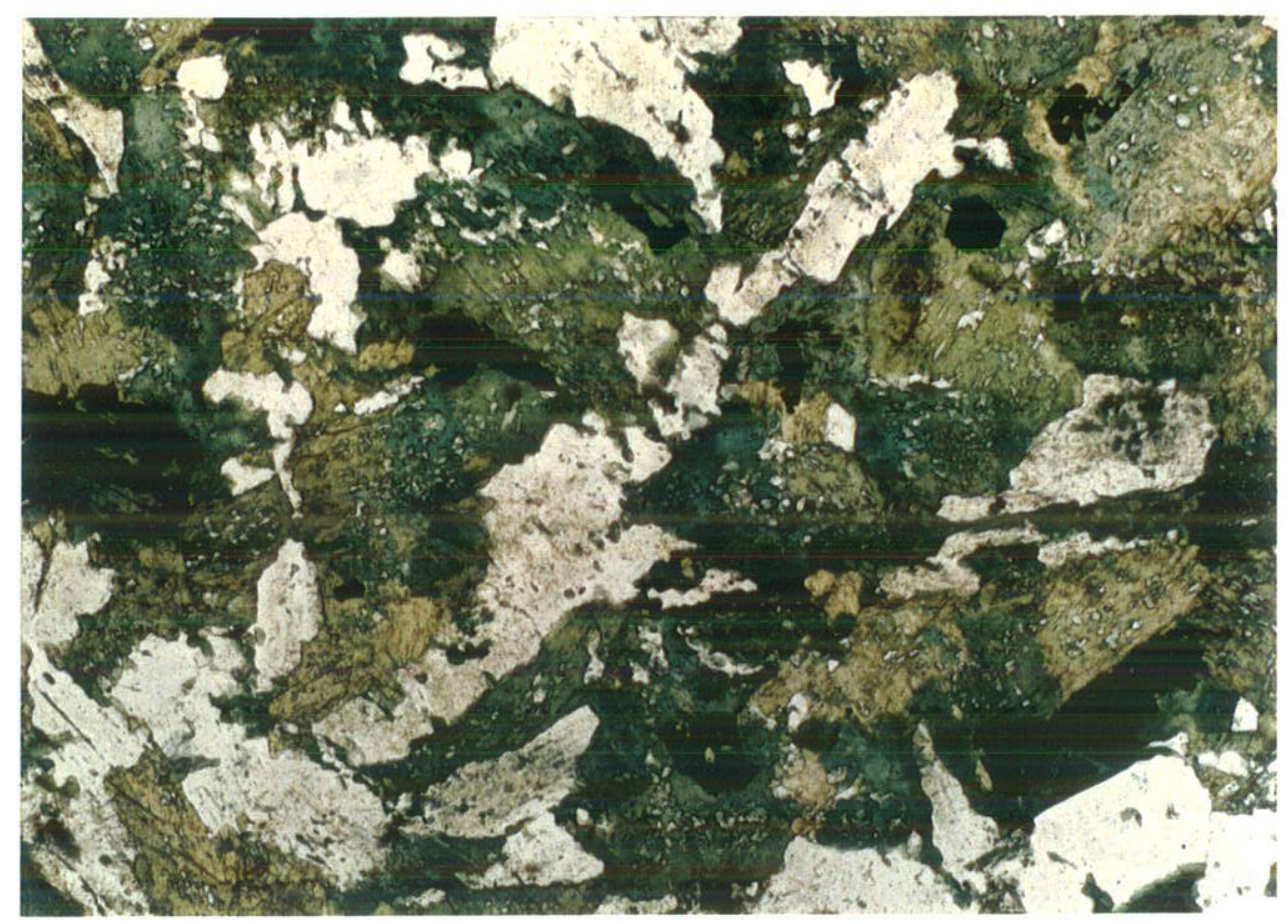

FOTOMICROGRAFIA V.7: Amostra DMB-97 - Aspecto geral da textura blasto-subofítica dos diques metabásicos, mostrando ripas de plagioclásios com bordas reentrantes e cristais de hornblenda com inclusões gotiformes de quartzo. Nicóis paralelos (objetiva 5,0x), lado maior da foto $\cong 2,5 \mathrm{~mm}$.

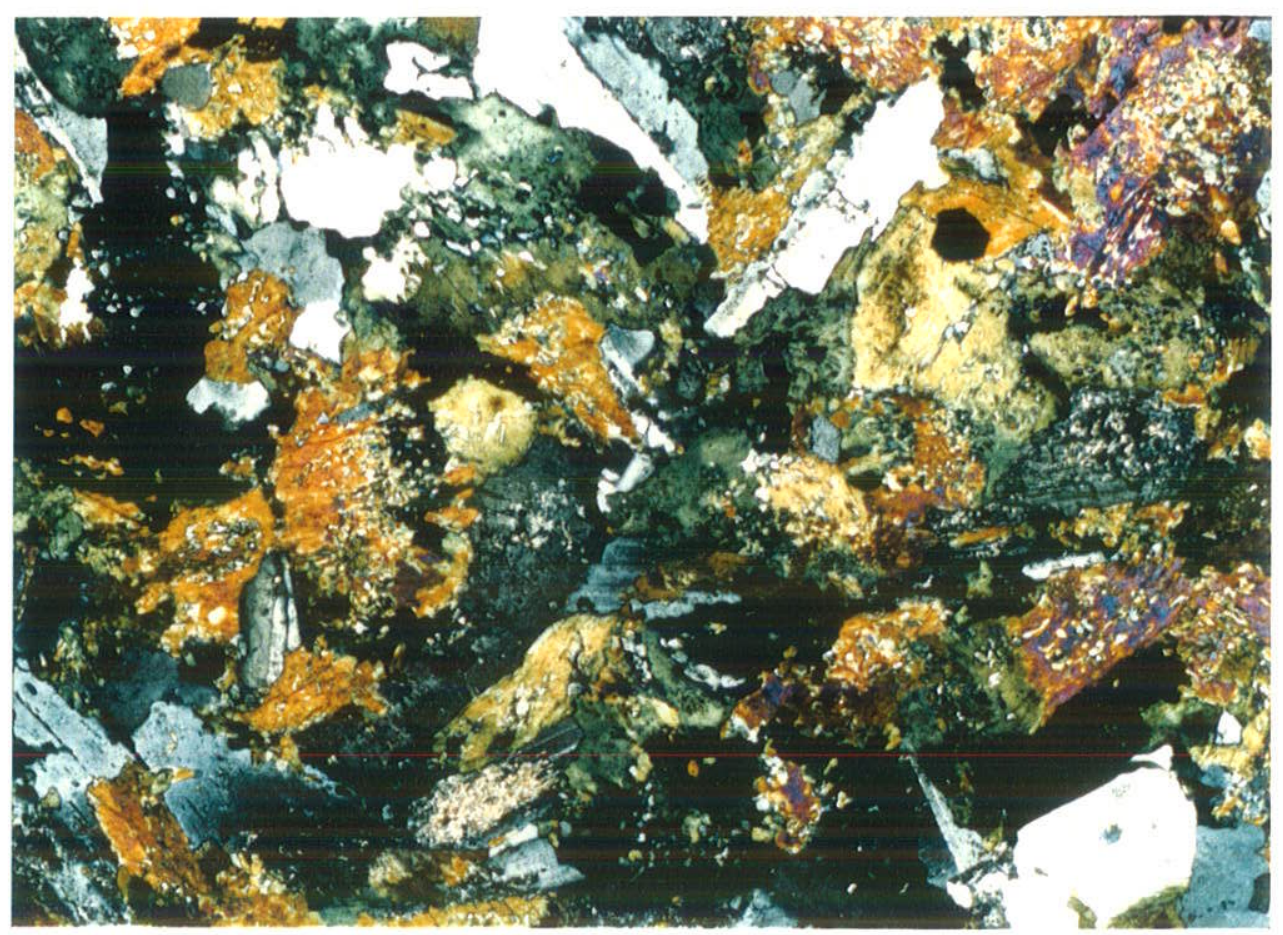

FOTOMICROGRAFIA V.8: Amostra DMB-97 - idem anterior, com nicóis cruzados (objetiva $5,0 \mathrm{x}$ ), lado maior da foto $\cong 2,5 \mathrm{~mm}$. 
Por outro lado, as amostras 62 e 63 apresentam textura blasto-porfiritica com macrofenocristais (tmédio $\cong 8 \mathrm{~mm}$ ) e megafenocristais (tmédio $\cong 23 \mathrm{~mm}$ ) de plagioclásios dispersos em matriz dominada por anfibólios e plagioclásios.

A mineralogia essencial é representada por anfibólios e plagioclásios (reliquia $A_{n} \equiv 72 \%$; matriz $\mathrm{An} \cong 39 \%$ ), os quais alcançam cerca de $80 \%$ a $90 \%$ do volume da rocha. Subordinadamente assinalam-se minerais opacos, epidoto, clinopiroxênios (relíquia $W_{0} \cong 31 \%$ ), quartzo, titanita, calcita e biotita.

Os anfibólios (tmáximo $\cong 1,5 \mathrm{~mm} ;$ tmínimo $\cong 0,05 \mathrm{~mm}$ ) predominam ocupando cerca de $50 \%$ do volume da rocha e apresentam características óticas das hornblendas. Ocorrem com maior freqüência como micro (tmédio $=0,3 \mathrm{~mm}$ ) e fenocristais $($ tmédio $=0,8 \mathrm{~mm})$ isolados ou agregados, exibindo formas subédricas a anédricas. São de coloração verde, fortemente pleocróicos [variam de verde claro (Z) a acastanhado (X)], e às vezes encontram-se subpoligonizados.

São assinalados casos onde se observam reliquias de piroxênios augíticos nos núcleos dos anfibólios sugerindo uma origem para os anfibólios a partir de transformações em piroxênios. Tais piroxênios restringem-se ao núcleo e apesar de suas dimensões, podem ser discernidos pelas cores de interferência e relevo mais elevado que o anfibólio. Além dos piroxênios, os anfibólios incluem quartzo, plagioclásio, apatita e biotita.

Os plagioclásios ocupam cerca de 30 a $40 \%$ do volume da rocha e invariavelmente ocorrem em ripas subédricas com bordas corroidas e reentrantes que sugerem pequeno consumo de plagioclásios para a produção de anfibólios. Comumente distribuem-se como feno e microfenocristais com tamanhos médios de $0,8 \mathrm{~mm}$ e $0,3 \mathrm{~mm}$ respectivamente. As ripas que encontram-se geminadas segundo a lei da albita e albitamcarlsbad possibilitaram, através do método Michel-Levy, obter composições nos termos da andesina e subordinadamente labradorita. Os macrofenocristais das amostras 62 e 63 apresentaram composições do intervalo da bitonita $(\mathrm{An}>70 \%)$. Algumas amostras apresentam ripas de plagioclásio parcialmente saussuritizadas e as vezes epidotizadas, enquanto que os megafenocristais das amostras blasto-porfiriticas encontram-se totalmente epidotizados. Os plagioclásios parcialmente saussuritizados, via de regra, mostram manchas de aspecto difuso, onde é possivel distinguir essencialmente calcitas e sericitas. 
Magnetitas representam fundamentalmente o conjunto dos minerais opacos e distribuem-se entre 5 a $10 \%$ do volume da rocha. Em geral, apresentam-se em cristais subédricos a anédricos na forma cúbica ou octaédrica e não raro na feição esqueletal. Os microfenocristais (tmédio $=0,3 \mathrm{~mm}$ ) predominam sobre os fenocristais (tmédio $=0,8 \mathrm{~mm}$ ) e ambos comumente encontram-se inclusos nas hornblendas. As ilmenitas são raras.

$\mathrm{Na}$ forma de pequenos cristais anédricos inclusos na hornblenda, o guartzo ocupa até $5 \%$ do volume da rocha e também ocorre nos interstícios entre plagioclásio e hornblenda. O quartzo posicionado na hornblenda pode indicar excesso de sílica que não foi incorporado ao anfibólio.

A biotita e a titanita são raras no conjunto ( $\sim 1 \%$ do volume) e ocorrem como matriz e microfenocristais (tmédio $=0,1 \mathrm{~mm}$ ). A primeira distribui-se em lamelas sempre interdigita na homblenda, enquanto a titanita apresenta-se microgranular.

Epidoto, calcita e sericita representam minerais cuja origem se relaciona a alteração das fases minerais principais.

Interessante assinalar a presença de diminutos cristais possivelmente de escapolita em uma das lâminas pertencentes a este grupo.

As feições reliquiares de minerais, a associação mineralógica e texturas observadas sugerem a atuação de uma fácies do tipo epidoto-anfibolito

\section{V.1.5 - Diques Anfibolíticos}

Também como os DMB, este grupo se orienta preferencialmente no quadrante NE e a N-S. Contudo sua distribuição geográfica é mais abrangente que os DMB e podem ser encontrados desde Lavras até a região norte de Bom Sucesso.

Os diques anfiboliticos (DA) representam 24\% das amostras estudadas e, de maneira geral, destacam-se preferencialmente pela textura granonematoblástica a granoblástica (Fotomicrografias V.9 e V.10). Entretanto, uma amostra que representa a borda de um dique, cuja foliação no campo já havia sido destacada, apresenta textura nematoblástica propiciada pela forte orientação planar dos minerais. 


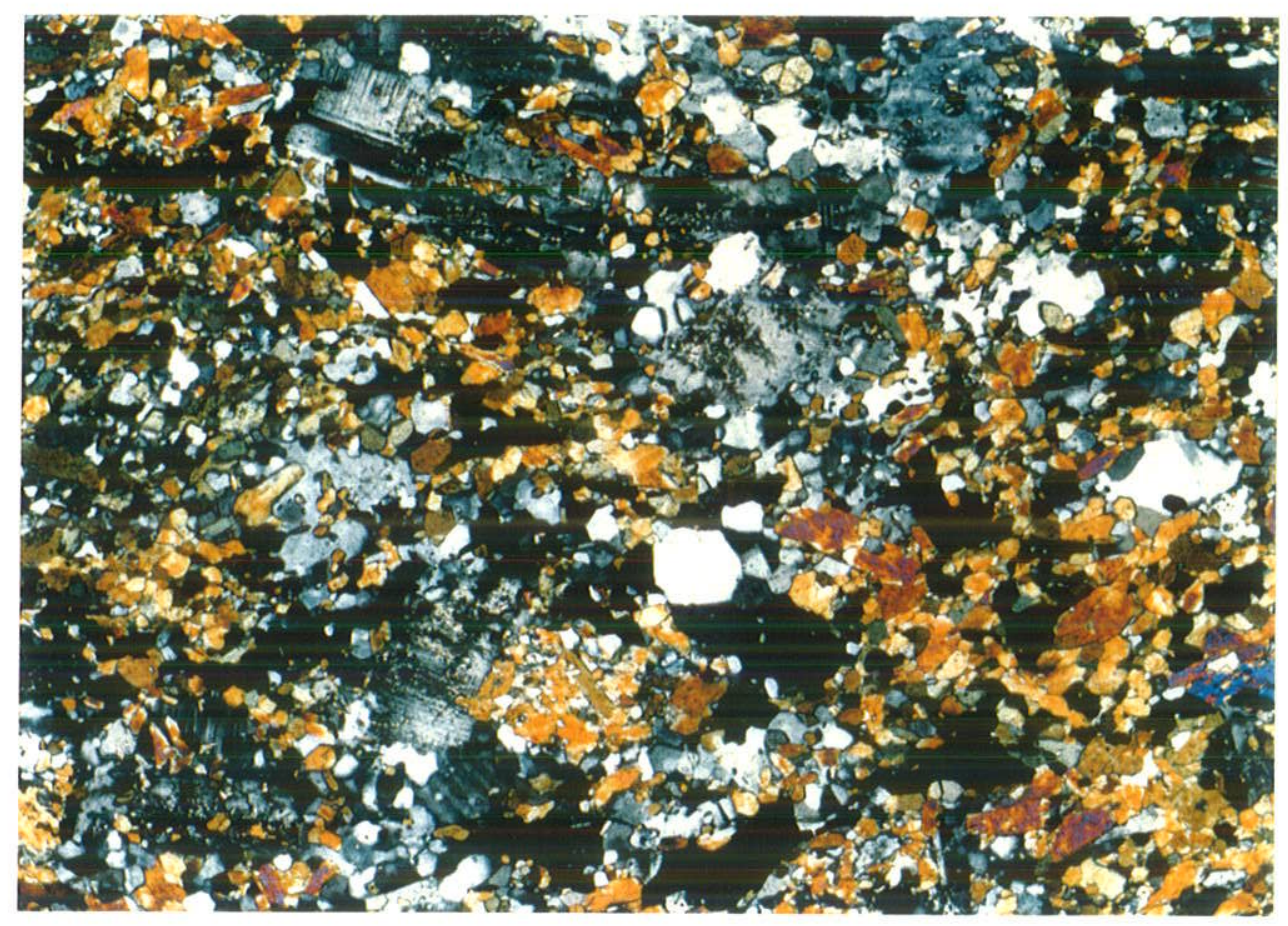

FOTOMICROGRAFIA V.9: Amostra DA-48 - Aspecto geral da textura granoblástica dos diques anfibolíticos, mostrando anfibólios e plagioclásios subpoligonizados e raras relíquias de plagioclásios ripiformes ígneos. Nicóis cruzados (objetiva 5,0x), lado maior da foto $\cong 2,5 \mathrm{~mm}$.

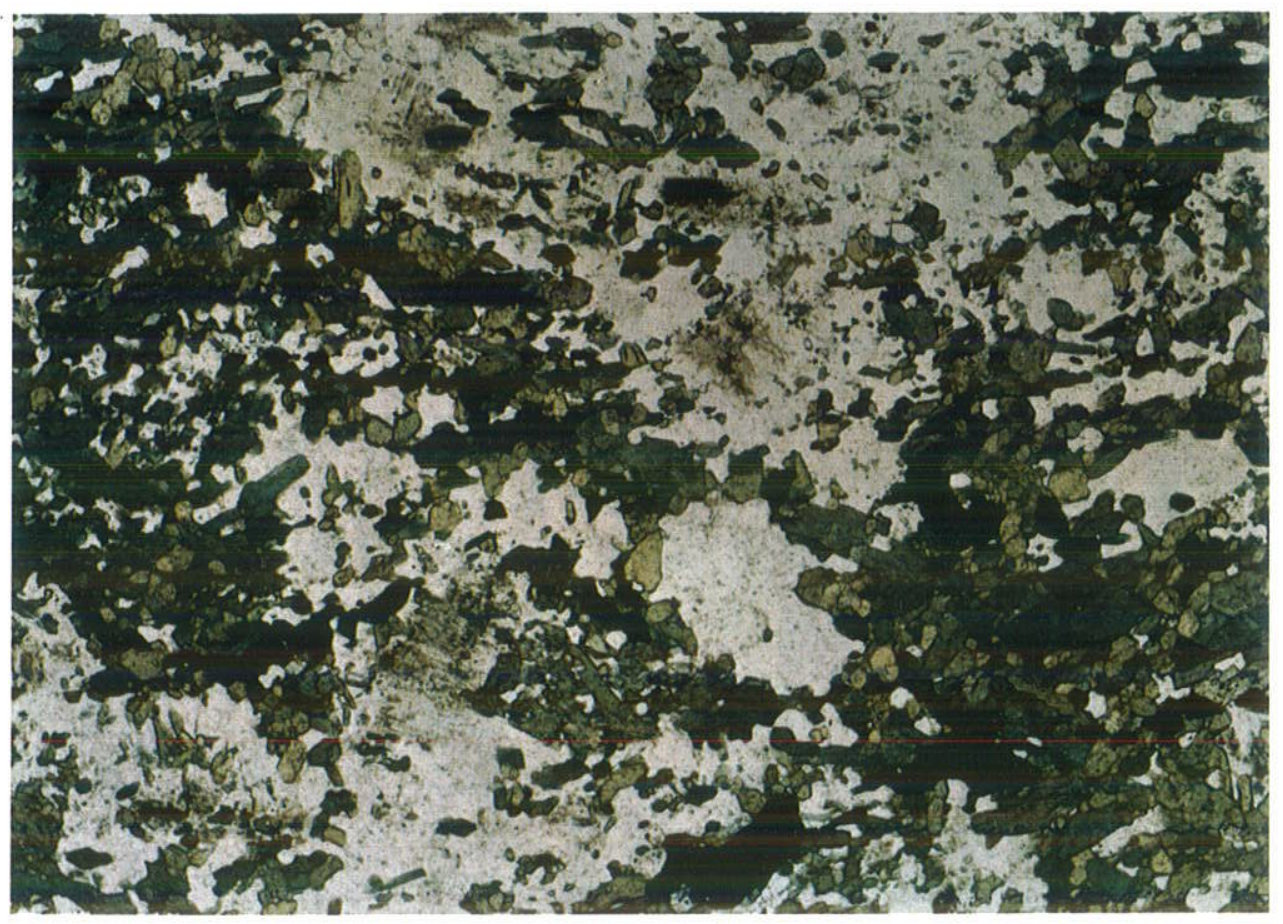

FOTOMICROGRAFIA V.10: Amostra DA-48 - idem anterior, com nicóis paralelos (objetiva $5,0 \mathrm{x}$ ), lado maior da foto $\cong 2,5 \mathrm{~mm}$. 
Em geral, as rochas deste grupo possuem granulação fina (tmédio dos grãos $=0,3 \mathrm{~mm}$ ) e os contatos entre os cristais são predominantemente retos, as vezes lobulados e curvos.

Os constituintes mineralógicos de maior destaque são: anfibólios e plagioclásios que somados ocupam até $90 \%$ do volume da rocha. Subordinadamente encontram-se quartzo, minerais opacos, titanita, epidoto, apatita e sericita.

Os anfibólios ocorrem em cristais subédricos subpoligonizados a poligonizados, clivagem proeminente e atingem até $60 \%$ do volume total da rocha com freqüência maior entre $45-50 \%$. São caracterizados pela cor verde com forte pleocroismo que geralmente varia do castanho-claro a verde escuro. Outras características óticas indicam que estes anfibólios pertencem ao grupo das hornblendas. Em geral, encontram-se em cristais cujo tamanho médio varia entre $0,3 \mathrm{~mm}$ a $0,1 \mathrm{~mm}$, os quais ocorrem isoladamente ou em agregados cristalinos semelhantes a um mosaico (concentrações granoblásticas). Algumas inclusões de quartzo são observadas nas hornblendas, bem como cristais de plagioclásio, titanita e epidoto. Indicativos de uma origem tardia a partir de piroxênios são as vezes assinaladas em algumas amostras. Contudo, não se observa como nos metabásicos cristais de clinopiroxênios nos núcleos de anfibólios.

De maneira geral, os plagioclásios representam $40 \%$ do volume total da rocha e encontram-se em cristais subpoligonizados isentos de geminação. Estes são predominantemente anédricos e com tamanho médio de $0,3 \mathrm{~mm}$. Por outro lado, alguns poucos espécimes euedrais maclados polissinteticamente segundo a lei da albita, permitiram a obtenção de composições que correspondem a andesina. O grupo de plagioclásios isentos de geminação, na realidade chegam a mostrar algumas lamelas interrompidas parcial ou totalmente. Geralmente neste grupo a extinção é ondulante e não se verificam cristais zonados. É verificada uma epidotização e saussuritização incipiente de amostra para amostra. Entretanto, uma ou outra ripa pode apresentar em seu interior, manchas de saussuritização constituída por minerais secundários.

Com representação entre 5 a $10 \%$ do volume da rocha as magnetitas representam os opacos. Também pouca ilmenita é assinalada. Encontram-se em cristais anédricos as subédricos e sua dimensão média é de $0,1 \mathrm{~mm}$. 
O quartzo distribui-se em cristais anédricos e nunca ultrapassa $5 \% \mathrm{em}$ volume da rocha. Caracterizam-se pela extinção ondulante e por dimensões médias de 0,1 $\mathrm{mm}$.

A titanita ocorre em cristais subedrais (tmédio $=0,08 \mathrm{~mm}$ ) freqüentemente em concentraçôes granoblásticas inclusas em hornblendas e plagioclásios.

As apatitas são raras ( $1 \%$ do volume da rocha) e assinalam-se em cristais (tmédio $=0,02 \mathrm{~mm}$ ) aciculares e hexagonais.

Epidoto, sericita e calcita são os minerais secundários sempre oriundos da alteração de plagioclásios.

Em sintese, além dos diques metabásicos e anfibolíticos, 3 grupos não metamórficos de diques básicos predominam na região $\left(\mathrm{DB}_{1}, \mathrm{DB}_{2}\right.$ e $\left.\mathrm{DBN}\right)$. Os $\mathrm{DB}_{1}$ apresentam algumas diferenças em relação aos $\mathrm{DB}_{2}$ (e.g. presença de biotita primária nos $\mathrm{DB}_{1}$ ) e algumas similaridades em relação aos DBN (e.g. presença de piroxênios compostos e micropegmatito). Estas similaridades e diferenças sầo também assinaladas na geoquímica (veja cap. Litogeoquímica).

Adicionalmente, a análise petrográfica sugere que a sequêencia de cristalização dos DBN deve ter sido, olivina - bronzita - augita - plagioclásio - opacos, enquanto a sequência dos $\mathrm{DB}_{2}$ deve ter sido, plagioclásio - augita - hiperstênio - pigeonita opacos. Os $D B_{1}$ parecem indicar uma seqüência similar ao dos $D B N$, com a pigeonita se posicionando um pouco antes ou um pouco depois dos plagioclásios.

\section{V.2 - Química mineral}

Para avaliar e reafirmar as principais fases minerais envolvidas, bem como determinar suas principais variações químicas, foram realizadas microanálises químicas em um conjunto de amostras representativas dos grupos petrográficos assinalados (DBN, $\mathrm{DB}_{1}$, $\mathrm{DB}_{2}$, DMB e DA). Todavia, em função das prioridades do trabalho e das condições metamórficas de alguns grupos petrográficos, procurou-se investigar um maior número de exemplares igneos (DBN, $\mathrm{DB}_{1}$ e $\mathrm{DB}_{2}$ ) em detrimento daqueles metamórficos (DMB e DA). 
Desse modo, foram efetivamente analisadas nove amostras dos $\mathrm{DB}_{2}$, seis dos DBN, três dos $\mathrm{DB}_{1}$ e apenas uma dos DMB. Os dados encontram-se nas tabelas V.1 a V.5 do apêndice 2 .

Conforme já evidenciado no item anterior, as principais fases minerais independentemente dos típos de diques são: piroxênios, feldspatos, minerais opacos, anfibólios e olivina.

\section{V.2.1 - Piroxênios}

Para a classificação dos piroxênios, adota-se na presente pesquisa a nomenclatura segundo Poldervaart \& Hess (1951). No quadrilátero dos piroxênios (Figura $\mathrm{V}$.1) pode-se observar que a maioria dos piroxênios analisados tratam-se de augitas, seguidas por ortopiroxênios e pigeonitas. As salitas só ocorrem nos exemplares estudados dos diques básicos $2\left(\mathrm{DB}_{2}\right)$ enquanto os ortopiroxênios magnesianos ocorrem apenas nos diques básicos noríticos (DBN) e nos $\mathrm{DB}_{1}$.

Alguns piroxênios, que na análise petrográfica demonstraram-se oticamente homogêneos e com características óticas intermediárias entre aquelas da augita e da pigeonita, posicionam-se nos campos da augita e ferroaugita subcálcicas (Figura V.1). Tais cristais, são caracterizados em escala submicroscópica pelo fenômeno de exsolução augita/pigeonita do tipo lamelar e espinoidal, a semelhança dos estudados por Mellini et al (1988) e Secco et al (1988)

Os dados químicos dos piroxênios ricos (augita, salita) e pobres (ortopiroxênio, pigeonita) em cálcio para os estágios de cristalização precoce $(\mathrm{P})$ e tardia $(\mathrm{T})$ encontram-se na tabela V.l do apêndice 2. Os estágios de cristalização precoce (P) correspondem aos núcleos de macro, feno e/ou microfenocristais, enquanto os estágios tardios (T) referem-se as bordas de feno e/ou microfenocristais e cristais isolados como matriz.

A coexistência de piroxênios ricos e pobres em cálcio e a evolução do estágio de cristalização precoce para o tardio, sempre acompanhada de um enriquecimento regular em ferro e decréscimo em $\mathrm{Ca}$, é típica da evolução de suítes toleíticas (Wager \& Brown, 1968). Este padrăo é assinalado para todos os tipos de piroxênios dos diques básicos l e $2\left(D_{1}\right.$ e $\left.D B_{2}\right)$ e diques básicos noríticos (DBN) como pode se observar nas figuras V.2 a e b. 


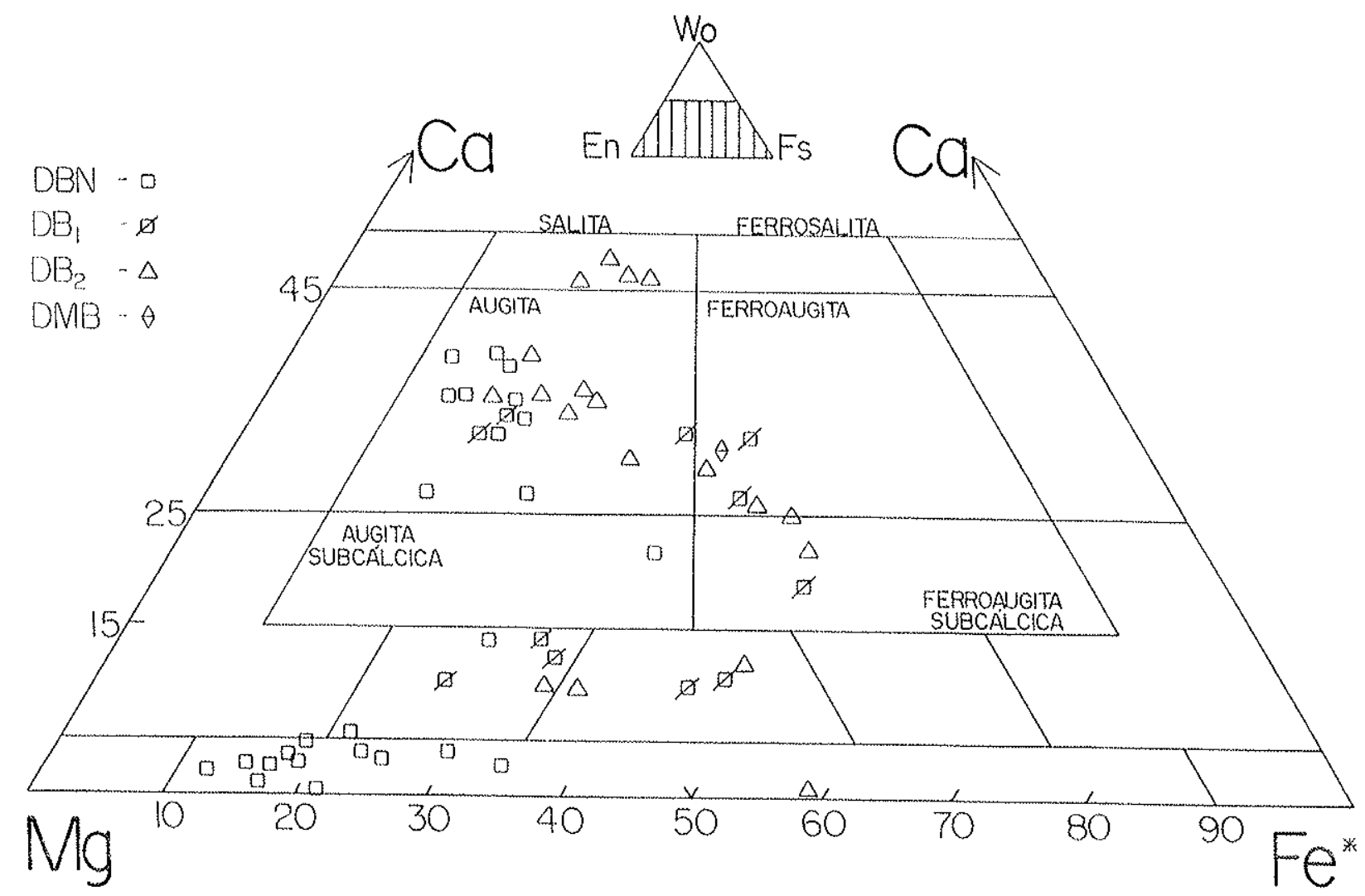

FIGURA V.1: Variações nas composições em termos de $\mathrm{Ca}-\mathrm{Mg}-\mathrm{Fe}$ * (\% atômica) no diagrama dos piroxênios (cf. Poldervaart \& Hess, 1951) dos diques máficos da região de Lavras (MG). $\mathrm{DBN}=$ diques básicos noriticos; $\mathrm{DB}_{1}=$ diques básicos $1 ; \mathrm{DB}_{2}=$ diques básicos $2 ; \mathrm{DMB}=$ diques metabásicos. $\mathrm{Fe}^{*}=\mathrm{Fe}^{+2}+\mathrm{Fe}^{+3}+\mathrm{Mn}$.

Adicionalmente, nos diagramas convencionais $\mathrm{Ca}-\mathrm{Mg}-\mathrm{Fe}^{*}\left(\mathrm{Fe}^{*}=\mathrm{Fe}^{+2}+\right.$ $\left.\mathrm{Fe}^{+3}+\mathrm{Mn}\right)$ verifica-se que o destacado enriquecimento em $\mathrm{Fe}^{*}$ se desenvolve paralelamente a um regular empobrecimento em Ca nos piroxênios do tipo cálcico. (Figura V.2 a e b). Nos tipos pigeoníticos, verifica-se um débil incremento de Ca no âmbito do grupo dos $\mathrm{DB}_{2}$ (Fig. V.2 a) e um fraco empobrecimento em Ca naqueles pertencentes aos DB 1 (Fig. V.2 b).

Nos DB2 (Fig. V.2 a) os clinopiroxênios (augita e salita) se posicionam normalmente no "trend" evolutivo dos piroxênios da intrusão de Skaergaard (Brown, 1957; Brown \& Vincent, 1963) com exceção de quatro análises das amostras 22, 27, 34 e 100. Em geral, os feno e microfenocristais de augita mostram anfibólios nas bordas, como já antecipado no item anterior. Entretanto, alguns cristais isentos desta feição permitiram verificar uma fraca zonação onde os núcleos são constituídos de augita e as bordas de ferroaugita. Esta última, ocorre preferencialmente como matriz e mais raramente como microfenocristais (Fig. V.2 a). 


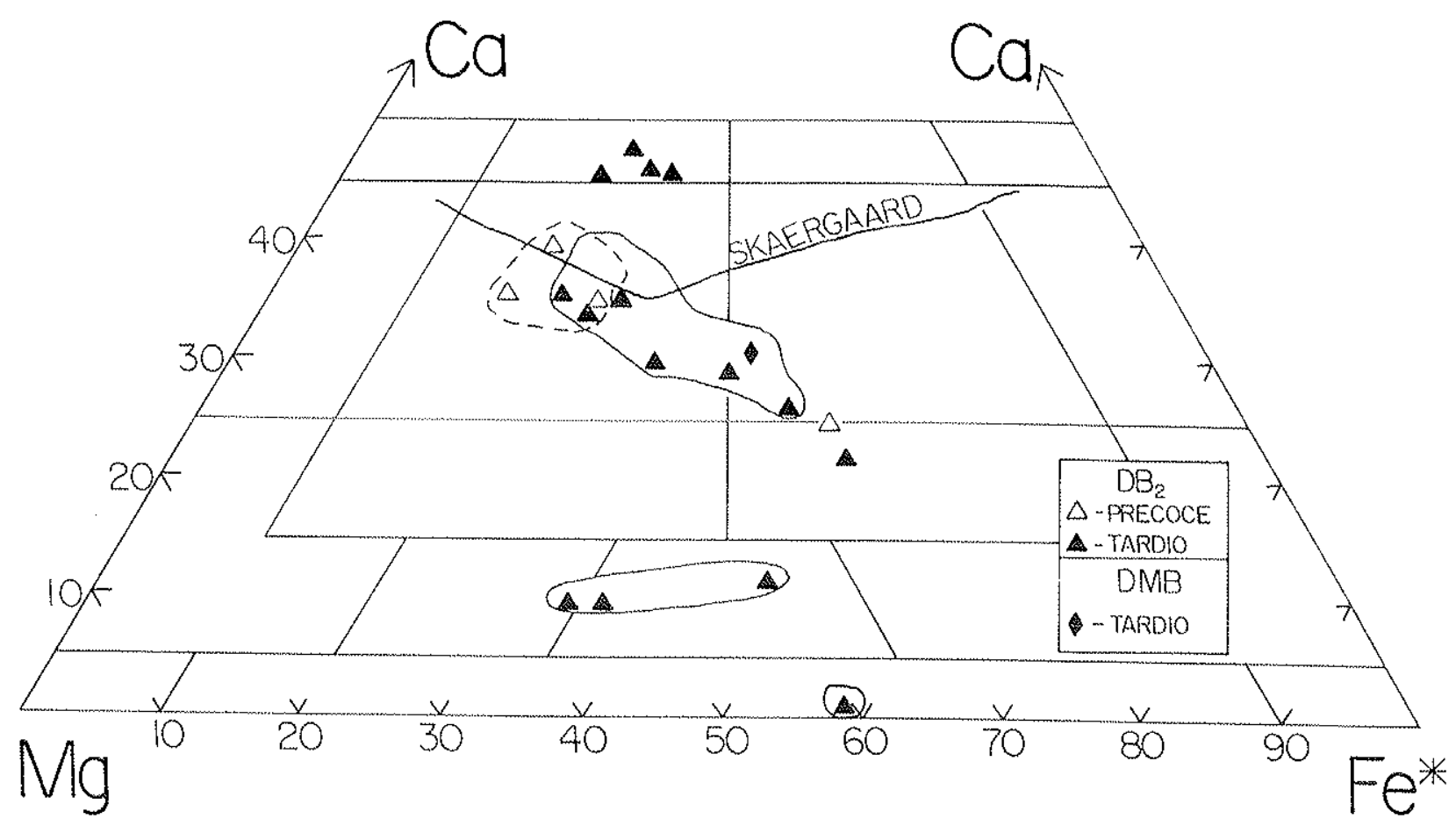

FIGURA V.2 a: Variações nas composições em termos de Ca-Mg-Fe* (\% atômica) dos piroxênios de cristalização precoce e tardia pertencentes aos diques básicos $2\left(\mathrm{DB}_{2}\right)$ e diques metabásicos (DMB). $\mathrm{Fe}^{*}=\mathrm{Fe}^{+2}+\mathrm{Fe}^{+3}+\mathrm{Mn}$.

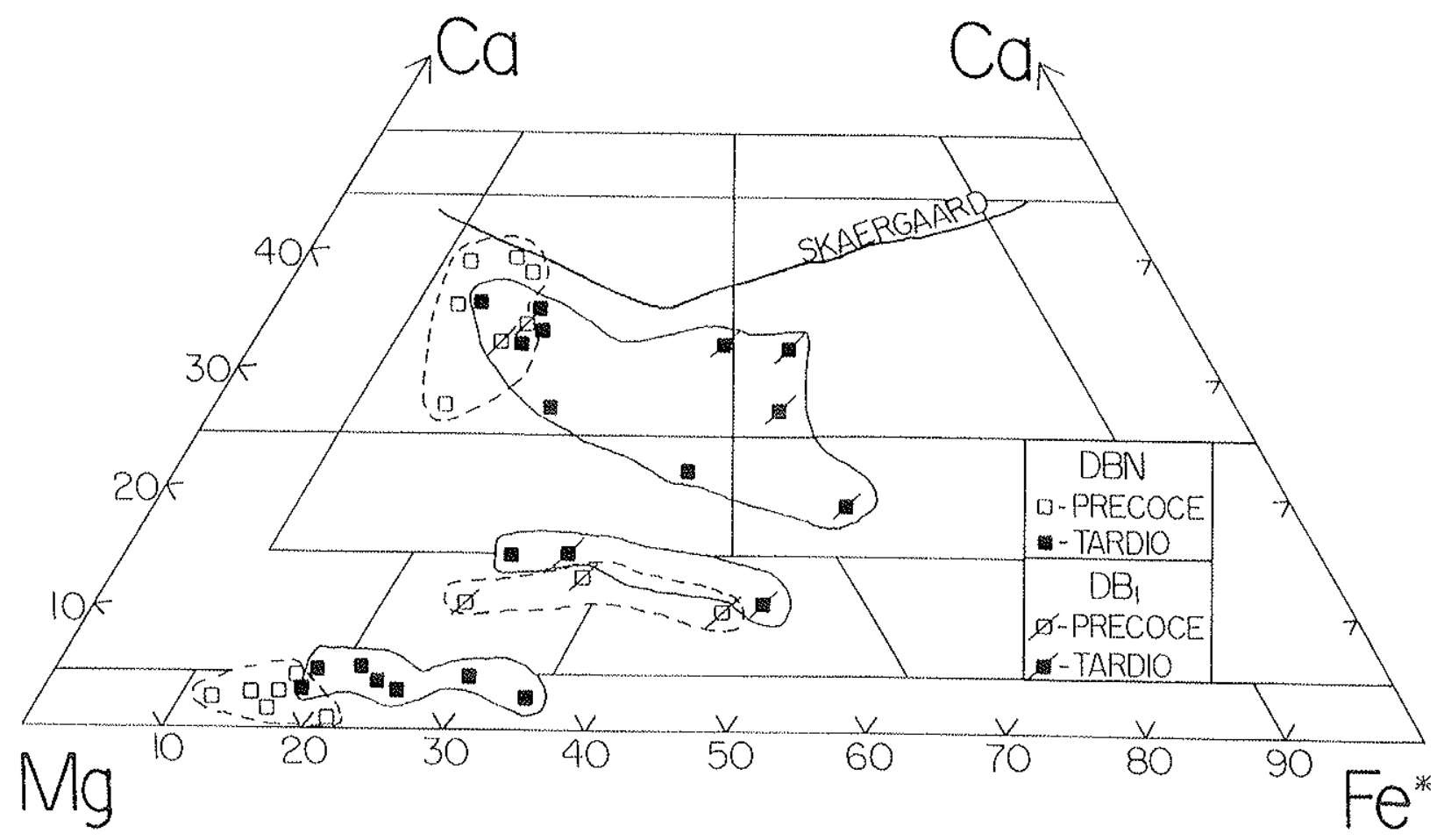

FIGURA V.2 b: Variações nas composições em termos de Ca-Mg-Fe* (\% atômica) dos piroxênios de cristalização precoce e tardia pertencentes aos diques básicos noríticos (DBN) e diques básicos $1\left(\mathrm{DB}_{1}\right) . \mathrm{Fe}^{*}=\mathrm{Fe}^{+2}+\mathrm{Fe}^{+3}+\mathrm{Mn}$. 
A pigeonita do tipo intermediária e o ortopiroxênio do tipo ferro-hiperstenio distribuem-se predominantemente como matriz e subordinadamente como microfenocristais individualizados no âmbito dos $\mathrm{DB}_{2}$ (Fig. V.2 a).

Por outro lado, os clinopiroxênios dos DBN e DB, (Fig. V.2 b) situam-se pouco abaixo da linha evolutiva de Skaergaard (Brown, 1957). Nestes grupos as relações entre os piroxênios são um pouco mais complexas do que as do grupo anterior. Em geral, os piroxênios ocorrem em cristais individualizados, contudo, cristais conjugados chegam a ser freqüentes como aqueles observados nos DBN com textura intergranular a subofitica .

Os macro, feno e mais raramente microfenocristais individuais de augita, as vezes apresentam-se ligeiramente zonados quimicamente com ferro-augita nas bordas, as quais por sua vez são predominantes como matriz. Também alguns ortopiroxênios que são do tipo bronzita mostram-se levemente zonados com hiperstênio na borda. A pigeonita preferencialmente do tipo magnesiana, quando isolada, restringe-se a matriz e não mostra evidências de zoneamento químico. Aquela do tipo intermediária é restrita aos $\mathrm{DB}_{1}$.

Nos cristais compostos, o núcleo é constituído predominantemente por bronzitas e subordinadamente por pigeonitas. As bordas laterais são de augitas e as vezes assinalam-se bordas de ferro-augita.

Piroxênios compostos similares e até com maior complexidade do que os assinalados nos $\mathrm{DBN}$ e $\mathrm{DB}$, são relatados em diferentes enxames de composição noritica, boninítica e básica. Entre eles se destacam aqueles do oeste da Groenlândia (Hall et al, 1985; Hall \& Hughes, 1987), noroeste da Escócia (Tarney \& Weaver, 1987) e na Antártica (Kuehner, 1989). Segundo Hall \& Hughes (1990) tais tipos de piroxênios devem estar intimamente associados a processos de cristalização que ocorrem concomitantes a fortes regimes de turbulência. Tais regimes, seriam controlados por enérgicas perturbações de ocorrência seqüencial, intercaladas por períodos de tranquilidade de tal forma a permitir a cristalização de frações do líquido magmático.

Diversos autores, entre eles Bellieni et al (1988), têm demonstrado uma correlação positiva entre as concentrações de $\mathrm{TiO}_{2}$ dos piroxênios ricos em cálcio (augita) precocemente cristalizados e as concentrações de $\mathrm{TiO}_{2}$ de suas respectivas rochas hospedeiras. Esta correlação é fraca para augitas dos $\mathrm{DB}_{1}, \mathrm{DB}_{2}$ e $\mathrm{DBN}$ com suas respectivas rochas hospedeiras e a amostra $\mathrm{DB}_{2}-19$ se distancia das demais (Fig. V.3). 


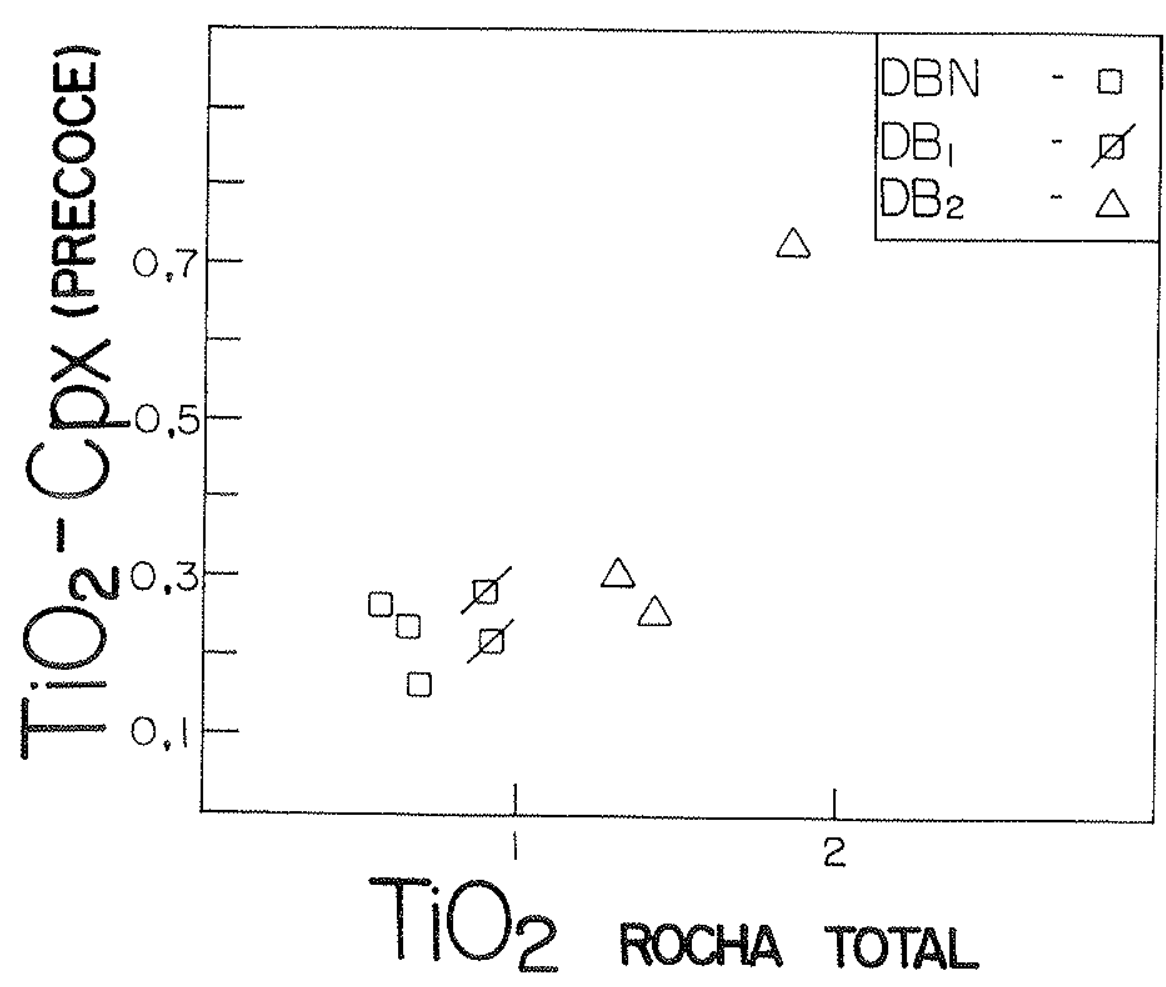

FIGURA V.3: Correlação entre as concentrações de $\mathrm{TiO}_{2}$ das rochas totais e os piroxênios ricos em cálcio $(\mathrm{Cpx})$ de cristalização precoce nela contidos, para os diques máficos da região de Lavras $(\mathrm{MG}) . \mathrm{DBN}=$ diques básicos noríticos; $\mathrm{DB}_{1}=$ diques básicos 1 e $\mathrm{DB}_{2}=$ diques básicos 2 .

Os piroxênios dos DBN apresentam-se enriquecidos em $\mathrm{Cr}_{2} \mathrm{O}_{3}$ relativamente à aqueles pertencentes aos $\mathrm{DB}_{2}$ e $\mathrm{DB}_{1}$. Em geral, as concentrações de $\mathrm{Cr}$ nos ortopiroxênios dos DBN varia entre 0,5 a $0,8 \%$ com um máximo de $1,0 \%$, enquanto os clinopiroxênios chegam a atingir 1,2\%. Ressalta-se que os clinopiroxênios dos $\mathrm{DB}_{2}$ apresentam $0,29 \%$ de concentração máxima em $\mathrm{Cr}_{2} \mathrm{O}_{3}$ e dos $\mathrm{DB}_{1} 0,23 \%$. A alta concentração em cromo dos $\mathrm{DBN}$ é semelhante a obtida em piroxênios dos diques noríticos da Antártica, onde ortopiroxênios e pigeonitas apresentam cerca de $0,5 \%$ de $\mathrm{Cr}_{2} \mathrm{O}_{3}$, enquanto os clinopiroxênios cálcicos alcançam concentrações da ordem de 1\% (Kuehner, 1989).

$\mathrm{Na}$ determinação das temperaturas de cristalização dos piroxênios, utilizaram-se as equações dos geotermômetros de Kretz (1982) para o par augita coexistente com pigeonita e/ou bronzita e o de Ishii (1975) aplicado exclusivamente em pigeonitas.

Apesar da certa complexidade de cristalização dos piroxênios pertencentes aos DBN e DB, foram efetuados os cálculos de temperaturas através dos geotermômetros mencionados. Em geral, os resultados são consistentes com as observações petrográficas. 
Os valores médios de temperaturas obtidos pelo geotermômetro de Kretz (1982) para os DBN são (em $\left.{ }^{\circ} \mathrm{C}\right): 1250 \pm 48(\mathrm{n}=2)$ para estágios de cristalização precoce e $1181 \pm 42(n=3)$ para estágios tardios. Quando se avalia o conjunto dos $D B_{1}$, obtém-se os seguintes valores em ${ }^{\circ} \mathrm{C}: 1224 \pm 31(n=2)$ e $1110 \pm 18(n=2)$ para os estágios de cristalização precoce e tardio respectivamente. Como era de se esperar os valores precoces são sempre mais elevados que os tardios.

Em geral, as pigeonitas apresentam valores de temperatura sempre mais baixos (cerca de 50 a $80^{\circ} \mathrm{C}$ ) do que aqueles da augita. Nos $\mathrm{DB}_{1}$, o valor médio para o estágio de cristalização precoce é de $1086 \pm 46^{\circ} \mathrm{C}(\mathrm{n}=3)$ e para o estágio tardio é de $1064 \pm 52^{\circ} \mathrm{C}(\mathrm{n}$ $=2)$. Nos DBN o valor de $1123^{\circ} \mathrm{C}(\mathrm{n}=1)$ representa o estágio de cristalização tardia da pigeonita.

Nos diques básicos $2\left(\mathrm{DB}_{2}\right)$ o número reduzido de análises não permitiram definir as temperaturas do estágio de cristalização precoce dos piroxênios envolvidos. Entretanto, para o estágio tardio obtiveram-se para as augitas valores médios de $1171 \pm 20^{\circ} \mathrm{C}$ $(n=2)$ e para as pigeonitas valores de $1063 \pm 42^{\circ}$.

\section{V.2.2 - Feldspatos}

Os feldspatos são representados por plagioclásios levemente zonados e por feldspatos alcalinos. Os plagioclásios ocorrem como feno, microfenocristais e mais raramente como matriz, enquanto que o feldspato alcalino é restrito a matriz.

As microanálises quimicas destes feldspatos tanto para estágios de cristalização precoce (núcleos de feno e microfenocristais) como para estágios de cristalização tardia (bordas de feno, microfenocristais e cristais na matriz) encontram-se reportadas na tabela V.2 do apêndice 2 .

Nos diagramas albita-anortita-ortoclásio (\% em peso) da figura V.4, verificase uma variação composicional dos plagioclásios que se inicia em $\mathrm{An}_{74}$ (bitonita) e finaliza em $\mathrm{An}_{27}$ (oligoclásio). Entretanto, os termos predominantes referem-se ao intervalo da labradorita seguido pelo da andesina (Fig. V.4). Em geral, os plagioclásios cristalizam-se precocemente como labradoritas e tardiamente como andesinas. Todavia, esta feição é mais pronunciada nos plagioclásios pertencentes aos diques básicos $2\left(\mathrm{DB}_{2}\right)$ e metabásicos (DMB). 


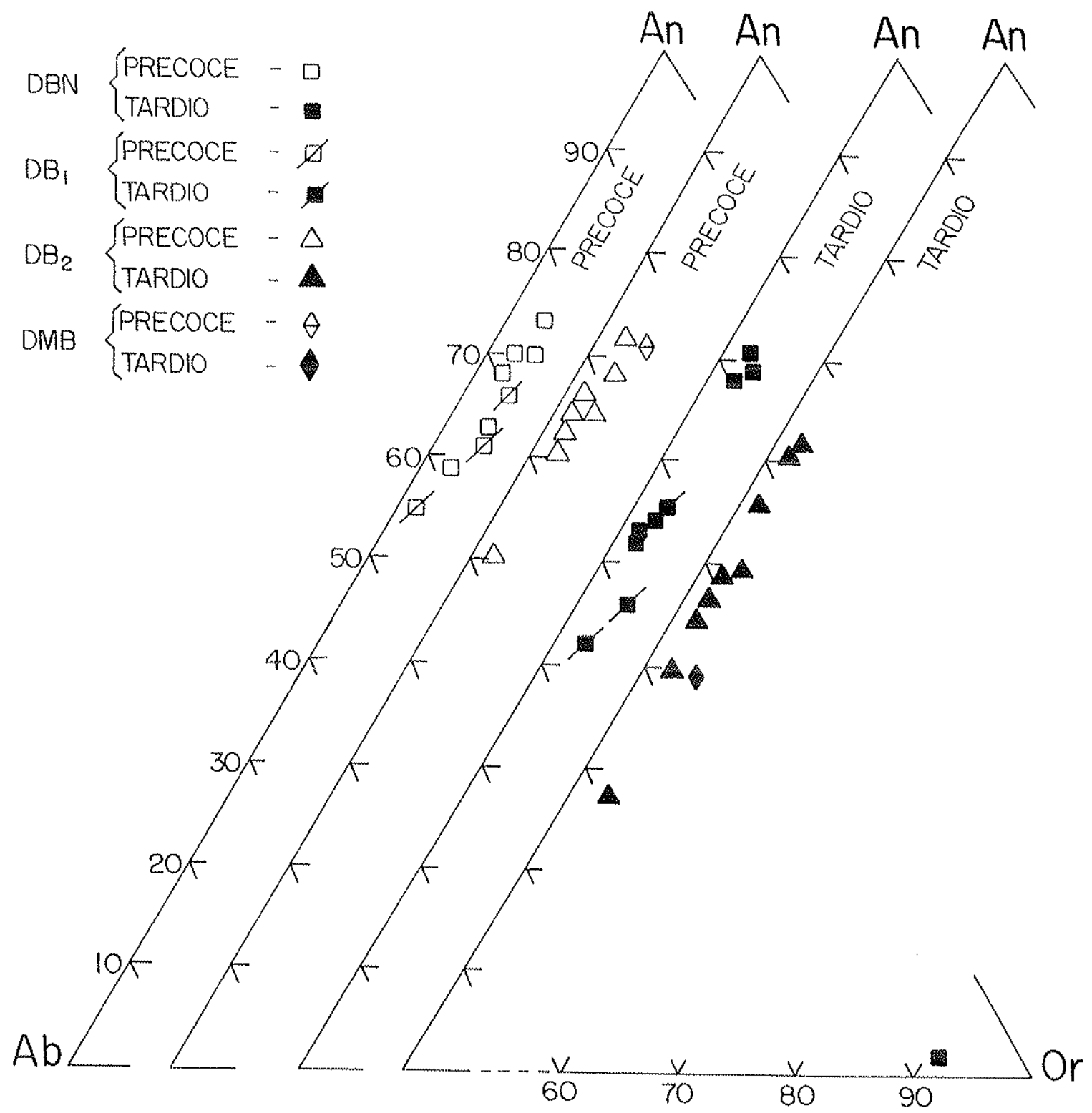

FIGURA V.4: Variações das composições em termos de Ab-An-Or (\% em peso) dos feldspatos de cristalização precoce e tardia, pertencentes aos diques máficos de Lavras (MG). DBN = diques básicos noriticos; $\mathrm{DB}_{1}=$ diques básicos $1 ; \mathrm{DB}_{2}=$ diques básicos 2 e $\mathrm{DMB}=$ diques metabásicos. 
Vale ressaltar, os extremos fornecidos pela amostra $\mathrm{DB}_{2}-15$ (oligoclásio) e pela amostra DBN - 1212 (bitonita). Esta última, que representa os DBN com textura heteradcumulática, demonstra que as variações composicionais entre o núcleo $\left(\mathrm{An}_{n}=73,5 \%\right) \mathrm{e}$ a borda $(\mathrm{An}=71,2 \%)$ dos cristais são insignificantes. Outra amostra com textura intergranular pertencente ao grupo dos DBN (DBN - 54), também demonstra uma variação insignificante (Fig. V.4 e tabela V.2 [apêndice 2]), quando se confronta os valores precoce $(A n=70,5 \%)$ com o tardio $(\mathrm{An}=69,2 \%)$.

Conforme antecipado na petrografia, os grupos dos DBN e dos $\mathrm{DB}_{1}$ assinalam, entre outras características, a presença de intercrescimento quartzo-feldspático (micropegmatito). No entanto, os $\mathrm{DB}_{1}$ apresentam maior frequência destes em relação aos DBN. Uma análise do feldspato alcalino do micropegmatito da amostra DBN-54 (tabela V.2 do apêndice 2) forneceu um valor percentual da molécula de ortoclásio igual a 91 (Fig. V.4).

Para obter as temperaturas de cristalização dos plagioclásios foram utilizados os geotermômetros de Kudo \& Weill (1970) e Mathez (1973), assumindo condições anidras para ambos.

Desse modo, os valores médios obtidos para os plagioclásios dos DBN são $\left(\mathrm{em}{ }^{\circ} \mathrm{C}\right)$ : (a) Por Kudo \& Weill: $1153 \pm 35(\mathrm{n}=6)$ para o estágio de cristalização precoce e $1118 \pm 53(n=6)$ para o estágio de cristalização tardio; $(b)$ Por Mathez: $1125 \pm 30(n=6)$ para o estágio precoce e $1096 \pm 46(n=6)$ para o estágio tardio.

Para os $\mathrm{DB}_{1}$ os valores por Kudo \& Weill são: $1166 \pm 40^{\circ} \mathrm{C}(\mathrm{n}=3) \mathrm{em}$ estágios de cristalização precoce e $1097 \pm 24{ }^{\circ} \mathrm{C}(\mathrm{n}=3)$ em estágios de cristalização tardia. Por Mathez, os estágios precoces apresentam valor de $1138 \pm 34(n=3)$ e nos tardios é de $1078 \pm 20^{\circ} \mathrm{C}(\mathrm{n}=3)$.

Os plagioclásios pertencentes ao grupo dos $\mathrm{DB}_{2}$ apresentam sistematicamente valores médios mais elevados do que aqueles pertencentes ao grupo dos DBN e DB. Estes valores são: (a) Por Kudo \& Weill: $1211 \pm 35(\mathrm{n}=7$ ) para o estágio precoce e $1127 \pm 71(n=9)$ para o estágio tardio; (b) Por Mathez: $1177 \pm 36(n=7)$ para o estágio precoce e $1103 \pm 60(n=9)$ para o estágio tardio.

As temperaturas obtidas para os plagioclásios são coerentes com as sequêencias de cristalização assinaladas na análise petrográfica. 


\section{V.2.3 - Minerais Opacos}

Os minerais opacos são assinalados em todos os grupos petrográficos de diques e encontram-se representados por magnetitas e ilmenitas. Contudo, as análises químicas desta fase restringem-se a amostras dos grupos não metamórficos.

Os dados químicos referentes a magnetitas e ilmenitas encontram-se na tabela V.3 do apêndice 2.

Em geral, as magnetitas e ilmenitas ocorrem em microfenocristais e como matriz, não se evidenciando variações químicas significativas entre estes minerais distribuídos tanto nos $\mathrm{DB}_{1} \mathrm{eDB}_{2}$ como nos DBN (tabela V.3 [apêndice 2]).

\section{V.2.4 - Olivina}

As olivinas, conforme indicação de dados petrográficos, ocorrem como microfenocristais e matriz e é uma fase mineral exclusiva dos DBN (textura cumulática).

As composições químicas de dois cristais de olivina obtidos na amostra DBN-1212 encontram-se na tabela V.4 (apêndice 2), onde se verifica que a variação no conteúdo em forsterita situa-se entre 76,1 e $77,9 \%$.

A olivina analisada provavelmente se cristalizou de um líquido, cujos valores de $m g$ \# $(0,15)$ estariam entre 0,489 e 0,515 (Roeder \& Emslie, 1970).

\section{V.2.5 - Anfibólios}

$\mathrm{O}$ anfibólio analisado se refere exclusivamente a amostras dos $\mathrm{DB}_{2}$ e são, como já assinalado, originários da transformação tardia de piroxênios.

Os dados quimicos encontram-se na tabela V.5 (apêndice 2), onde se verifica que se tratam, segundo a classificação de Leake (1978), de ferro-pargasita hornblenda e ferroedenita, posicionadas nas bordas dos cristais de piroxênios, enquanto as magnésio hornblendas e ferro-edenita hornblendas ocorrem em cristais individualizados.

Em suma, os dados da química mineral também revelam algumas diferenças entre os minerais dos $\mathrm{DBN}$ e dos $\mathrm{DB}_{1}$ e $\mathrm{DB}_{2}$. As diferenças composicionais residem 
preferencialmente no âmbito dos piroxênios, que em geral, são um pouco mais magnesianos e menos cálcicos nos DBN. Subordinadamente no âmbito dos plagioclásios, verifica-se que aqueles dos $\mathrm{DB}_{2}$ são um pouco mais sódicos. Algumas diferenças de temperaturas são assinaladas, destacando-se a dos plagioclásios dos $\mathrm{DB}_{2}$ que são ligeiramente mais elevadas do que aquelas dos $D B N$ e $D B_{1}$. Adicionalmente, as temperaturas de cristalização reafirmam as seqüências de cristalização sugeridas pela análise petrográfica.

A química mineral revela que os piroxênios investigados sofrem um empobrecimento em cálcio e magnésio e um enriquecimento em ferro, enquanto os plagioclásios sofrem um enriquecimento em sódio. Nos piroxênios a feição descrita é compativel com uma suite toleítica. 


\section{VI - LITOGEOQUIMICA}

Neste item, discutem-se em linhas gerais, aspectos relativos ao comportamento geoquímico dos grupos de diques máficos assinalados na região investigada. Para tal, utilizam-se dados constantes no apêndice 1, referentes a elementos maiores, menores e traços que incluem terras raras. Desse modo, os conjuntos de diques são classificados quimicamente e suas principais características geoquímicas delineadas, com vistas a uma avaliação individual de cada grupo.

\section{VI.1 - Mobilidade de elementos em processos metamórficos, hidrotermal ou intempérico}

Com base nas observações petrográficas dos 5 grupos investigados na área assinalam-se dois grupos de diques máficos os quais, mostram-se afetados em menor ou maior grau pelo metamorfismo. No primeiro grupo dos diques metamórficos verificam-se a textura ígnea preservada e raros cristais de augita no núcleo dos anfibólios (DMB), enquanto que no segundo observa-se a completa recristalização da rocha (DA).

Embora seja desnecessária uma investigação nas rochas estudadas no que se refere a natureza do protólito (ortoderivadas), pelo simples fato de representarem corpos tabulares bi-dimensionais, na forma de diques claramente posicionados e que não apresentam evidências de deformações plásticas, deve ser considerada contudo, a possibilidade de mobilização de certos elementos químicos como fruto da atuação de processos pósmagmáticos. Tais processos, denominados também de secundários, são de natureza metamórfica, hidrotermal ou intempérica.

O comportamento dos elementos químicos em processos que incluem uma fase fluída, depende das suas propriedades químicas, em particular, dos potenciais iônicos dos elementos (potencial iônico = carga/raio) que culminam por controlar suas mobilidades em fluídos. Quanto ao potencial iônico os elementos podem ser divididos em: a) elementos de baixo potencial $(<3)$; b) elementos de potencial intermediário $(3-10)$ e c) elementos de alto potencial $(>10)$.

Em geral, nos processos intempéricos os elementos de potenciais intermediários [e.g. Al, Sc, Ti, V, Cr, Co, Ga, Y, $\mathrm{Zr}, \mathrm{Nb}$, terras raras (exceto La), Hf, Ta e Th] 
se comportam como imóveis, enquanto aqueles de altos (e.g. B, C, N, Si e S) e baixos (e.g. $\mathrm{Na}, \mathrm{Mg}, \mathrm{K}, \mathrm{Ca}, \mathrm{Ni}, \mathrm{Cu}, \mathrm{Zn}, \mathrm{Rb}, \mathrm{Sr}, \mathrm{Cs}, \mathrm{Ba}$ e La) potenciais podem ser facilmente mobilizados por meio de soluções aquecidas.

Nos processos metamórficos a mobilidade tende a ser mais intensa em função da atuação de temperaturas sempre mais elevadas. A rápida e vigorosa formação e solubilização de íons pode atingir condições críticas de mobilização, como ocorre na fácies de alta temperatura (e.g. granulítica).

Contudo, sob condições metamórficas pertencentes as fácies anfibolito a xisto verde os elementos de baixo e de alto potencial são sistematicamente mobilizados, em particular nas zonas de cisalhamentos (Winchester, 1984; Gelinas et al, 1982; Winchester \& Max, 1984; Brewer \& Atkin, 1989).

Para os elementos de potencial iônico intermediário sob condições metamórficas relativamente brandas, alguns deles (e.g. $\mathrm{Zr}, \mathrm{Nb}, \mathrm{Ti}$ ) são considerados como relativamente imóveis (e.g. Cann, 1970; Field \& Elliot, 1974; Winchester \& Floyd, 1976; 1977). Todavia, algumas posições ambiguas tem sido assinaladas para elementos como $\mathrm{Al}, \mathrm{Ti}$, $\mathrm{Cr}, \mathrm{Zr}$ e $\mathrm{Y}$, a exemplo do ocorrido com basaltos em zonas de cisalhamentos (Winchester \& Max, 1984), que apresentam mobilização de elementos consagradamente considerados imóveis (e.g. Ti, $\mathrm{Zr}, \mathrm{Nb}, \mathrm{Y}$ ).

Diante do exposto, tornamse interessante se avaliar a possibilidade de mobilização de elementos químicos nos diques afetados pelo metamorfismo (e.g. DMB e DA).

Para investigar a mobilidade de elementos químicos, uma série de métodos e testes tem sido propostos (e.g. Pearce, 1968; 1970; Pearce \& Cann, 1973; Winchester \& Floyd, 1976; Beswick \& Soucie, 1978; Beswick, 1982; Rollinson \& Roberts, 1986; Russel \& Nichols, 1988). O método mais difundido (Pearce, 1968) consiste em verificar se um determinado elemento segue os "trends" de processos magmáticos, em caso positivo é dito "imóvel", caso contrário trata-se de um mobilizado. Outra alternativa é eleger rochas e/ou litotipos com mineralogia e texturas preservadas de tal forma a utilizá-las para comparações com as rochas menos preservadas.

No caso de se investigar elementos maiores um método que pode fornecer resultados satisfatórios é aquele que se utiliza das razões de proporções moleculares ou MPR (Molecular Proportion Ratios). Originalmente desenvolvido por Pearce (1968) para interpretar 
tendências de fracionamento em suites igneas inalteradas, foi posteriormente adaptado (Beswick \& Soucie, 1978 e Beswick, 1982) para avaliar os efeitos de alteração ou metamorfismo em amostras de komatiitos e basaltos.

O método propõe a avaliação de elementos maiores predominantemente, através da correlação entre suas razões dos seus óxidos do tipo $A / Z(x)$ e $B / Z(y)$, onde as proporções moleculares dos elementos A e B (normalizados) participam das fases fracionadas, enquanto o elemento $Z$ (normalizador) seria constante do decurso do fracionamento comportando-se como incompativel. Se não ocorrer tendência de correlação linear, mas sim um espalhamento dos pontos segundo um arranjo em leque a partir da origem dos eixos $x$ e $y$, pode-se considerar a mobilidade do óxido utilizado na normalização, pressupondo-se sempre como relativamente imóveis os dois óxidos normalizados. É óbvio que o primeiro problema é o de identificar os óxidos que não participaram do fracionamento e que não tenham sido mobilizados em litotipos que foram submetidos a processos secundários.

Cumpre ressaltar, que alguns autores (e.g. Rollinson \& Roberts, 1986; Rollinson, 1993) discordam do MPR enquanto método de investigação nos processos de mobilização de elementos. Contudo, nos diques máficos de Uauá (e.g. Menezes Leal et al, 1995; Menezes, 1992) bons resultados têm sido obtidos na avaliação de elementos mobilizados nos tipos metabásicos e anfibolíticos.

$\mathrm{Na}$ tentativa de investigar até que ponto os DMB e DA tiveram suas composições obliteradas, construiram-se os diagramas MPR da figura VI.1, utilizando-se $\mathrm{SiO}_{2}, \mathrm{TiO}_{2}, \mathrm{Al}_{2} \mathrm{O}_{3}, \mathrm{CaO}, \mathrm{Na}_{2} \mathrm{O}, \mathrm{K}_{2} \mathrm{O}$ e $\mathrm{FM}(\mathrm{FeO}+\mathrm{MgO})$.

Em geral, observa-se que $\mathrm{SiO}_{2}, \quad \mathrm{TiO}_{2}, \mathrm{CaO}$ e $\mathrm{FM}$ não foram significativamente mobilizados, apesar do $\mathrm{CaO}$ no diagrama $\mathrm{SiO}_{2} / \mathrm{CaO}$ vs $\mathrm{FM} / \mathrm{CaO}$ apresentar um alinhamento um tanto incomum. Observa-se também, que os dois óxidos volumetricamente mais importantes envolvidos no processo de fracionamento da suite são $\mathrm{SiO}_{2}$ e FM. O diagrama $\mathrm{SiO}_{2} / \mathrm{TiO}_{2}$ vs $\mathrm{FM} / \mathrm{TiO}_{2}$ sugere uma inflexão na tendência de fracionamento, devido a modificações na constituição das fases fracionadas (possivelmente olivina e/ou piroxênios). Por outro lado, $\mathrm{O} \mathrm{Na}_{2} \mathrm{O}, \mathrm{K}_{2} \mathrm{O}$ e $\mathrm{Al}_{2} \mathrm{O}_{3}$ devem ter sido mobilizados no metamorfismo, a julgar pelo típico arranjo em leque observado principalmente para $\mathrm{Na}_{2} \mathrm{O}$ e $\mathrm{K}_{2} \mathrm{O}$. No $\mathrm{Al}_{2} \mathrm{O}_{3}$ o arranjo mostra-se disperso e năo chega a definir uma distribuição em leque, mas pode se diagnosticar um padrão heterogêneo de modificações químicas (Figura VI.1). 

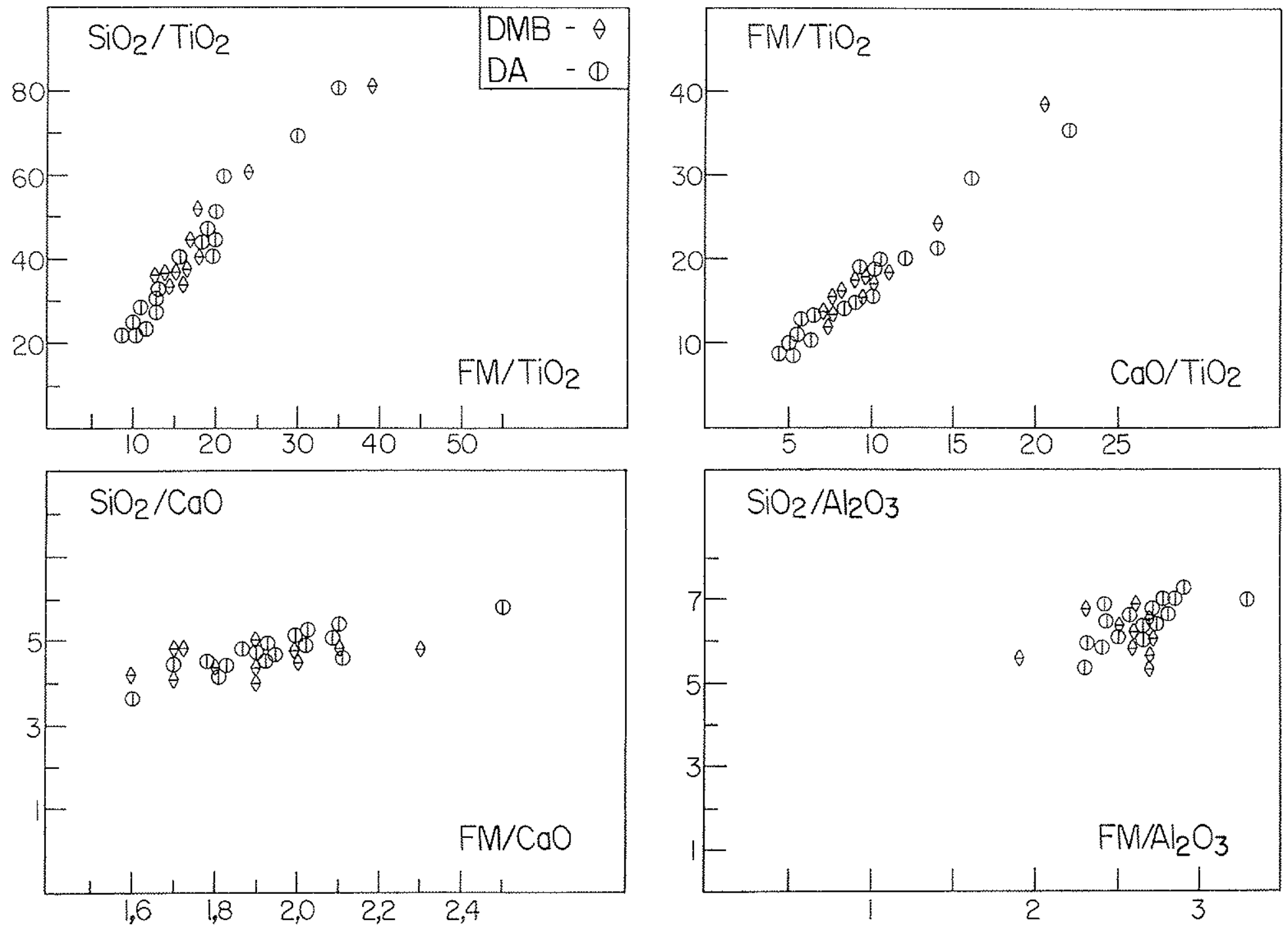

FIGURA VI.1: Diagramas de razões de proporções moleculares (MPR) entre $\mathrm{SiO}_{2} / \mathrm{TiO}_{2}$ vs $\mathrm{FM} / \mathrm{TiO}_{2} ; \mathrm{FM} / \mathrm{TiO}_{2} \mathrm{vs} \mathrm{CaO} / \mathrm{TiO}$; $\mathrm{SiO}_{2} / \mathrm{CaO}$ vs FM/CaO; $\mathrm{SiO}_{2} / \mathrm{Al}_{2} \mathrm{O}_{3}$ vs $\mathrm{FM} / \mathrm{Al}_{2} \mathrm{O}_{3}$, para os diques metamórficos da região de Lavras. DMB=diques metabásicos; $\mathrm{DA}=$ diques anfiboliticos. $\mathrm{FM}=\mathrm{MgO}+\mathrm{FeO}$. 

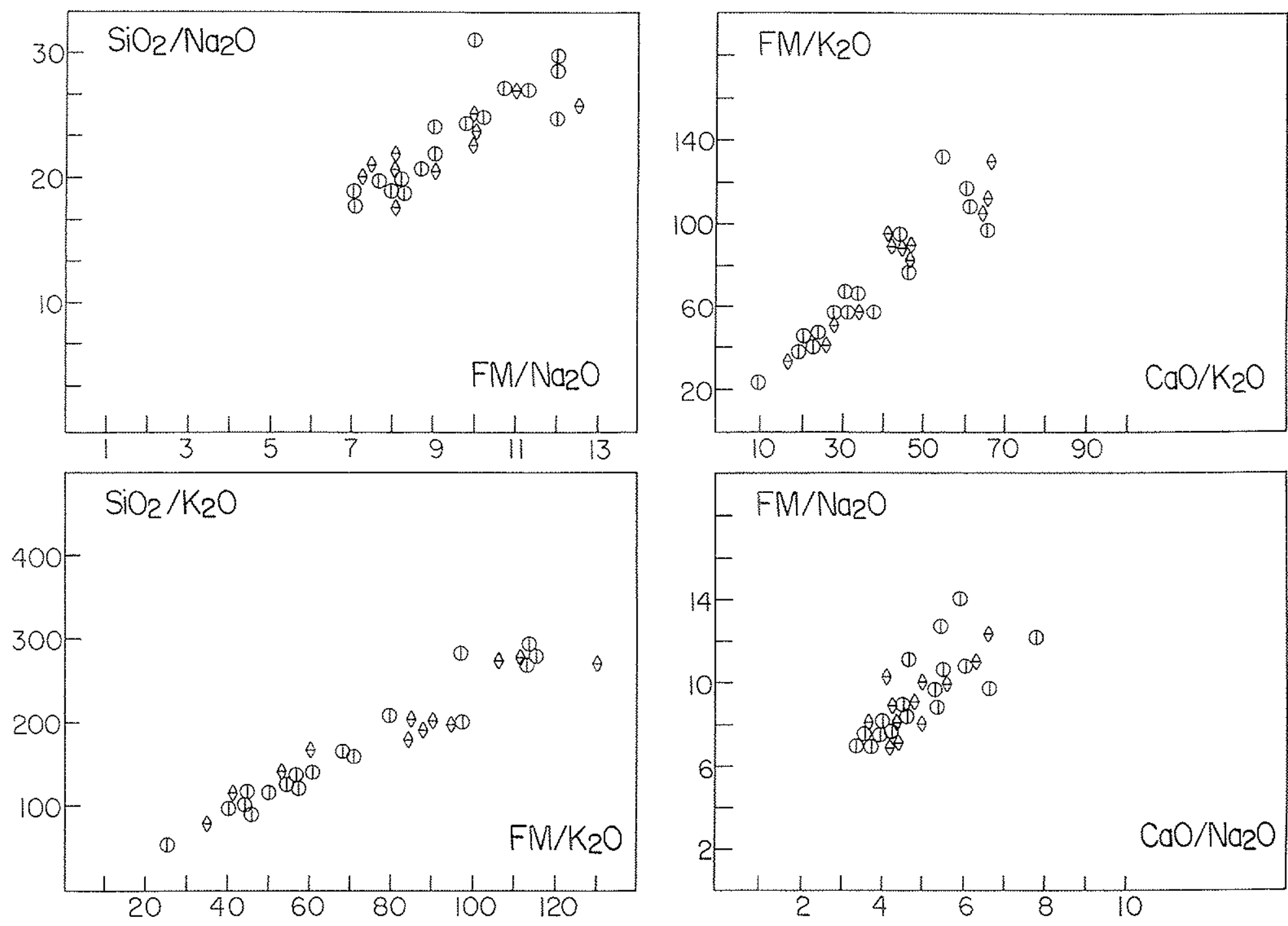

FIGURA VI. I (continuação): Diagramas MPR (\% molecular) entre $\mathrm{SiO}_{2} / \mathrm{Na}_{2} \mathrm{O}$ vs $\mathrm{FM} / \mathrm{Na}_{2} \mathrm{O} ; \mathrm{FM} / \mathrm{K}_{2} \mathrm{O}$ vs $\mathrm{CaO} / \mathrm{K}_{2} \mathrm{O} ; \mathrm{SiO} / \mathrm{K}_{2} \mathrm{O}$ vs $\mathrm{FM} / \mathrm{K}_{2} \mathrm{O} ; \mathrm{FM} / \mathrm{Na}_{2} \mathrm{O}$ vs $\mathrm{CaO} / \mathrm{Na}_{2} \mathrm{O} . \mathrm{FM}=\mathrm{MgO}+\mathrm{FeOt}$. 
No tocante a elementos traços, utilizou-se o critério empirico na avaliação dos possiveis elementos mobilizados. Para tanto, as amostras dos DMB e DA foram comparadas, através de diagramas de variação, com a evolução das amostras do grupo $\mathrm{DB}_{2}$ que são isentas de processos metamórficos.

Nesta comparação verificou-se que a maioria dos elementos traços dos DMB e DA mostra tendências compativeis com os processos magmáticos, sugerindo que não foram significativamente afetados pelo metamorfismo. Entretanto, alguns elementos representados predominantemente por $\mathrm{Rb}, \mathrm{Sr}$ e $\mathrm{Ba}$ (mais raramente $\mathrm{La}$ ) mostram-se dispersos da tendência geral indicando que o seu comportamento original foi obliterado e devem ter sofrido remobilizações.

Em suma, os diques metabásicos (DMB) e anfibolíticos (DA) apresentam claras evidências de metamorfismo, distorcendo consequentemente o comportamento de alguns de seus constituintes químicos, a saber: $\mathrm{Na}_{2} \mathrm{O}, \mathrm{K}_{2} \mathrm{O}, \mathrm{Al}_{2} \mathrm{O}_{3}$ (Fig. VI.1), $\mathrm{Rb}, \mathrm{Sr}, \mathrm{Ba}$ e raro La, não demonstrados na figura VI.1. Desse modo, qualquer consideração geoquímica e/ou isotópica que envolva tais grupos, deverá levar em conta esta situação. Isto favoreceu a realização de uma seleção de amostras como base de controle geoquímico e geocronológico.

\section{VI.2 - Classificação Geoquímica}

Embora a análise petrográfica tenha alcançado bons resultados na separação dos grupos de diques máficos investigados, utilizar-se-à também na presente pesquisa, algumas classificações geoquímicas com vistas à caracterização química dos grupos envolvidos, bem como para fornecer subsidios a inferências evolutivas posteriormente.

Entre as propostas para classificação geoquimica das rochas igneas se destacam aquelas que levam em consideração elementos maiores como $\mathrm{Si}, \mathrm{Na}, \mathrm{K}$ e $\mathrm{Mg}$. Todavia, aquela que considera maior número de elementos na discriminação dos tipos é a proposta por De La Roche et al (1980), modificada para o campo dos basaltos por Bellieni et al (1981). 


\section{VI .2.1 - Classificação com Base no Conteúdo em Sílica e Álcalis}

A classificação sílica versus álcalis mais recente e sugerida pela subcomissão de Sistemática das Rochas Ígneas da IUGS, é aquela proposta por Le Bas et al (1986). Denominada Silica-Álcalis-Total (TAS) ela não possui caráter genético.

Na figura VI.2 observa-se o diagrama TAS onde se verifica que os diques básicos noríticos (DBN) e os $\mathrm{DB}_{1}$ plotam-se predominantemente nos campos do andesito-. basalto e andesito. Por outro lado, os diques básicos $2\left(\mathrm{DB}_{2}\right)$ encontram-se agrupados no campo dos basaltos e posicionados abaixo da linha de Zanettin (1984), sendo assim classificados como basaltos subalcalinos. Os diques metabásicos (DMB) e anfíbolíticos (DA) também se posicionam no campo dos basaltos subalcalinos, resguardando-se as ressalvas mencionadas no item anterior (cf. detalhe da figura VI.2).

No diagrama AFM (Figura VI.3) observa-se que o conjunto dos diques básicos noríticos, básicos 1 e básicos 2 , se posicionam no campo tolético (cf. Irvine \& Baragar, 1971), e que algumas amostras dos $\mathrm{DB}_{1}$ situam-se na linha que divide os campos toleitico e cálcio-alcalino. Em geral, os $\mathrm{DB}_{2}$ demonstram um enriquecimento em $\mathrm{F}$ relativamente a $M$ típico de suites evoluídas a baixa fugacidade de oxigênio (e.g. tampão NNO-QFM) [Fig. VI.3]. Os diques básicos noríticos (DBN) e os DB 1 apresentam um moderado enriquecimento em $\mathrm{F}$, menos acentuado do que os $\mathrm{DB}_{2}$. Este enriquecimento, pode ser atribuído ao fracionamento de olivinas, piroxênios, e \pm magnetitas (cf. petrografia), indicando uma fugacidade de oxigênio um pouco mais elevada (e.g. tampão NNO-QFM) em relação aquela dos diques $\mathrm{DB}_{2}$. No detalhe da figura VI.3, se observa que os DMB e DA posiocionam-se no campo toleítico.

Pode-se visualizar ainda nos diagramas TAS (detalhe da figura VI.2) e AFM (detalhe da figura VI.3), que um grupo de amostras dos $\mathrm{DB}_{2}$ (e.g. 15, 61, 73, 74, 79, 80 e 451 ) encontra-se fora dos "trends" assinalados.

\section{Vl.2.2 - Classificação com Base no Diagrama $R_{1} \times R_{2}$}

Como anteriormente mencionado, esta classificação é a que considera maior número de elementos químicos na discriminação dos tipos envolvidos. 


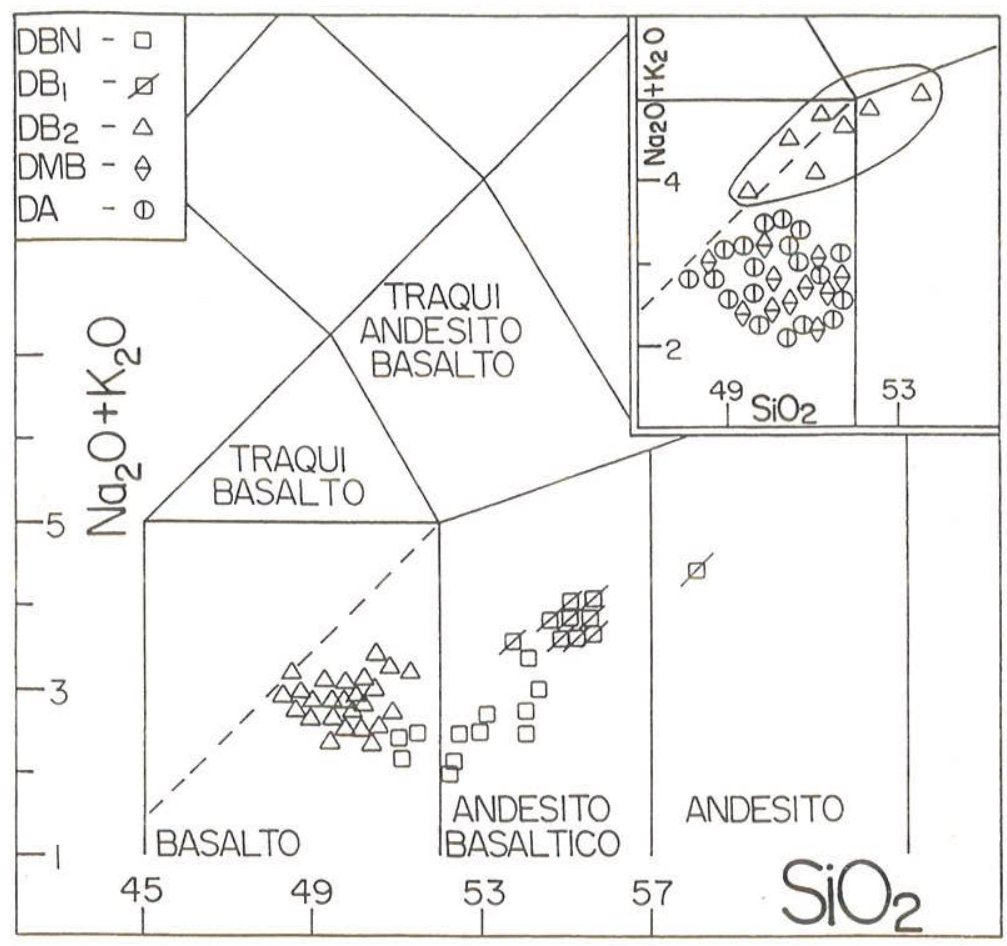

FIGURA VI.2: Diagrama sílica-álcalis-total (TAS) segundo Le Bas et al (1986) dos diques máficos da região de Lavras (MG). Linha tracejada divide o campo dos basaltos conforme Zanettin (1984). No detalhe da figura, o círculo com linha continua agrupa amostras inferidas como Mesozóicas e as demais pertencem a diques do grupo metamórfico. $\mathrm{DBN}=$ diques básicos noríticos; $\mathrm{DB}_{1}$ e $\mathrm{DB}_{2}=$ diques básicos 1 e 2; $\mathrm{DMB}=$ diques metabásicos; $\mathrm{DA}=$ diques anfiboliticos.

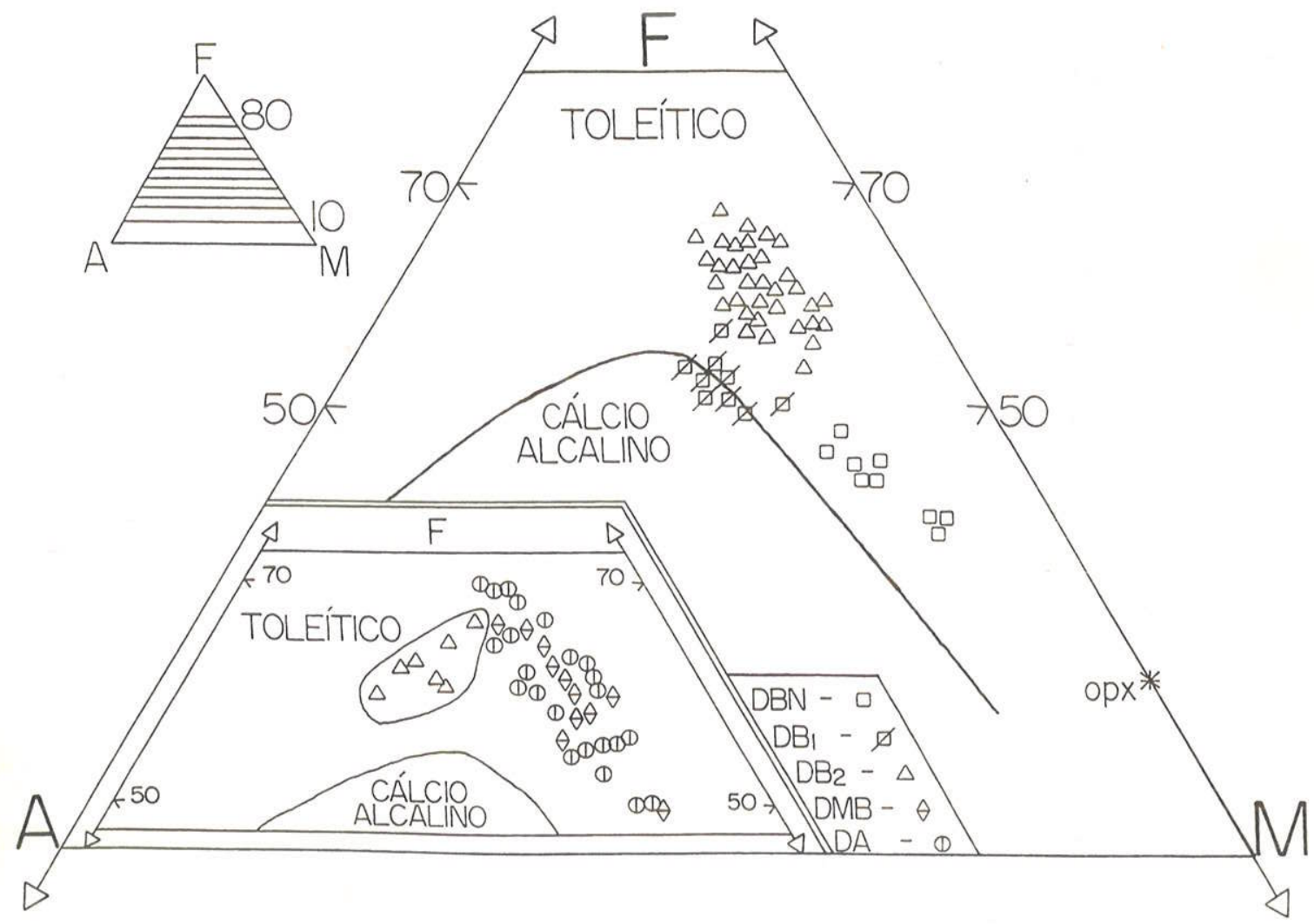

FIGURA VI.3: Diagrama A $\left(\mathrm{Na}_{2} \mathrm{O}+\mathrm{K}_{2} \mathrm{O}\right), \mathrm{F}(\mathrm{FeOt}), \mathrm{M}(\mathrm{MgO})$ dos diques máficos da região de Lavras (MG). Suítes toleítica e cálcio-alcalina conforme Irvine \& Baragar (1971). No detalhe da figura, o círculo com linha continua agrupa amostras inferidas como Mesozóicas e as demais pertencem a diques do grupo metamórfico. Simbolos e legenda como na figura VI.2. 
Ela se utiliza dos valores de $R_{1}=\left[4 \mathrm{Si}-11(\mathrm{Na}+\mathrm{K})-2\left(\mathrm{Fe}^{-2}+\mathrm{Fe}^{4 \cdot 3}+\mathrm{Ti}\right)\right]$ e $\mathrm{R}_{2}=$ $(6 \mathrm{Ca}+2 \mathrm{Mg}+\mathrm{Al})$, obtidos através das proporções milicatiônicas dos elementos maiores de cada amostra analisada.

No diagrama da figura VI.4a verifica-se que os diques básicos noriticos (DBN) plotam -se predominantemente no campo dos basaltos toleíticos e subordinadamente no campo dos andesi-basaltos toléticos. $\mathrm{OS}_{\mathrm{S}} \mathrm{DB}$, plotam-se exclusivamente no campo dos andesi-basaltos toleiticos.

Os diques básicos $2\left(\mathrm{DB}_{2}\right)$ posicionam-se preferencialmente no campo dos basaltos toleíticos e, subordinadamente são observados nos campos dos basaltos transicionais e andesi-basaltos toleíticos (Fig.VI.4a). Interessante notar, que este conjunto mostra uma tendência em se deslocar ao campo transicional.

Destacam-se ainda, os altos valores de $R_{1}$ dos diques básicos noríticos (DBN) e DB! quando confrontados aos valores de $\mathrm{R}_{1}$ dos $\mathrm{DB}_{2}$ (Fig. VI.4a).

Os diques metabásicos (DMB) e anfiboliticos (DA), se posicionam de maneira similar aos $\mathrm{DB}_{2}$, preferencialmente no campo dos basaltos toleíticos (Fig. VI.4b).

Em todos os esquemas classificatórios utilizados até o momento, observa-se a existência de um pequeno grupo de amostras representativas dos $\mathrm{DB}_{2}$ (marcadas com círculo de linha continua nos detalhes das figuras VI.2, VI.3 e figura VI.4b), as quais encontram-se sempre deslocadas da tendência geral do conjunto. Tais amostras apresentam concentrações de $\mathrm{TiO}_{2}$, em geral, maiores que $2,5 \%$ e se assemelham quimicamente a diques mesozóicos representativos do magmatismo básico que afetou a porção norte da Bacia do Paraná (Piccirillo et al, 1988; Pinese, 1989; Piccirillo et al, 1990).

Também em todas as classificações, verificamse que os grupos metamórficos (DMB e DA) possuem posicionamento semelhante aos $\mathrm{DB}_{2}$. Já os $\mathrm{DBN}$ e $\mathrm{DB}_{1}$ mostram significativas diferenças em relação aos $\mathrm{DB}_{2}$.

Cabe notar, que os $\mathrm{DB}_{1}$ se constituem no prosseguimento evolutivo dos diques básicos noriticos no campo dos andesi-basaltos (Figura VI.4a). Tal prosseguimento é observado também nos diagramas TAS (Fig. V1.2) e AFM (Fig. VI.3), indicando para ambos uma única sequêencia evolutiva. 


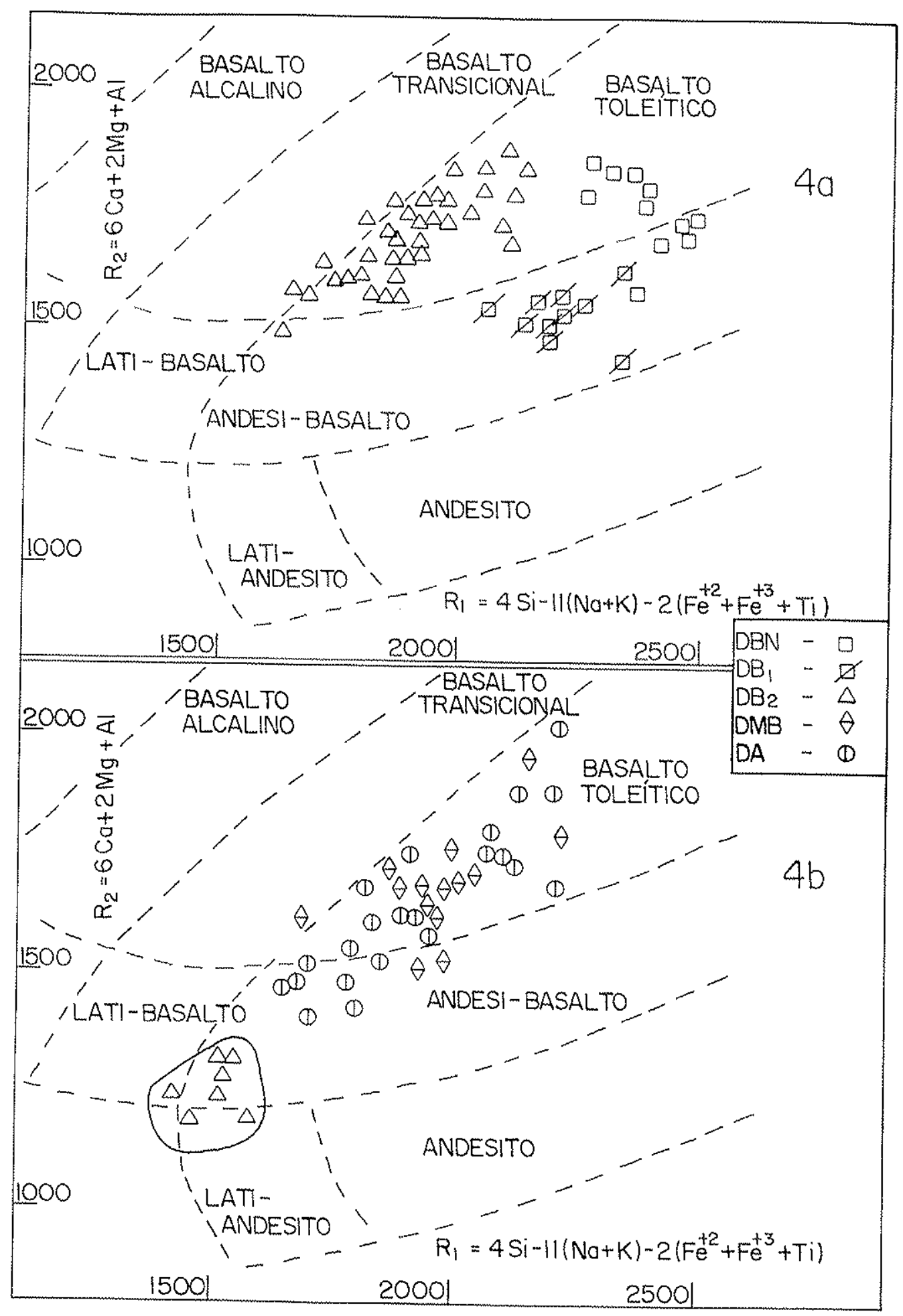

FIGURA VI.4: Diagrama $R_{1}$ vs $R_{2}$ (De La Roche et al, 1980; Bellieni et al, 1981) com as amostras dos diques máficos da região de Lavras (MG). (4 a) com diques não metamórficos dos tipos $\mathrm{DBN}_{1} \mathrm{DB}_{1}$ e $\mathrm{DB}_{2}$. (4 b) com diques metamórficos dos tipos DA e DMB, bem como aqueles não metamórficos do tipo $\mathrm{DB}_{2}$ inferidos como Mesozóicos e que se encontram agrupados por circulo de linha contínua. Simbolos e legenda como na figura VI.2. 


\section{VI.3 - Caracterização Geoquímica}

O estudo geoquímico de diferentes suítes igneas, através dos elementos maiores, traços e terras raras, em muito tem contribuido na elucidação da natureza dos processos petrogenéticos, da composição magmática e processos tectônicos envolvidos. $\mathrm{O}$ fornecimento deste tipo de informação é obtido via comparação entre diversos elementos dispostos em diagramas de variação, como os Harker e assemelhados.

Desse modo, discute-se neste item as principais feições geoquimicas apresentadas pelos diferentes grupos de diques máficos investigados com base em suas análises químicas (Apêndice 1).

Não foram consideradas as amostras com significativos graus de epidotização e/ou saussuritização e cuja perda ao fogo ultrapasse $2,5 \%$. As rochas dos DBN com textura cumulática, quando assinaladas nos diagramas encontram-se com simbologia especifica.

$\dot{E}$ importante salientar, que os diques não exibem bandamento e/ou acamamento e, que dentro de cada grupo específico os exemplares de índice evolutivo semelhantes, não apresentam variação química significativa entre termos com granulação média e fina. As amostras de granulação muito fina ("chilled margin") encontram-se totalmente alteradas, conforme anteriormente comentado.

\section{VI.3.1 - Elementos Maiores e Traços}

A exemplo do observado na classificação geoquímica, os $\mathrm{DB}_{1}$ se constituem, tanto para elementos maiores como para os traços, no prosseguimento da sequêencia evolutiva dos DBN. Conseqüentemente, trata-se dos termos mais evoluidos de uma suite aqui denominada de básico norítica. $\mathrm{Os}_{\mathrm{DB}}$ não apresentam características de continuidade em relação aos anteriores $\left(\mathrm{DB}_{1}\right.$ e $\left.\mathrm{DBN}\right)$ e constituem portanto, outro conjunto aqui denominado de suite básica.

Os diques máficos da área em estudo, caracterizam-se por ocuparem um intervalo em mg\# valores $\left[\mathrm{Mg}^{42} / \mathrm{Mg}^{+2}+\mathrm{Fe}^{+2}\left(\mathrm{Fe}_{2} \mathrm{O}_{3} / \mathrm{FeO}=0,15\right)\right]$ entre 0,325 e 0,725 . Todavia, os diques da suíte básico norítica ocupam predominantemente o intervalo entre 0,47 a 0,73 , enquanto os diques da suite básica e aqueles metamórficos encontram-se no intervalo 
entre 0,33 a 0,61 (Fig. VI.5). Os primeiros são relativamente menos evoluidos que os demais grupos.

De maneira geral, todos os grupos de diques mostram variações composicionais com a diminuição dos valores de mg\#, os quais são utilizados como índice de evolução na construção dos diagramas de variação. (Figuras VI.5).

\section{Suite básico norítica}

$\mathrm{Na}$ suíte básico noritica, a medida que o mg\# diminui verifica-se uma diminuição em $\mathrm{Cr}$, $\mathrm{Ni}$, e um leve decréscimo em $\mathrm{FeO}_{t}$, acompanhado de um aumento em $\mathrm{SiO}_{2}, \mathrm{TiO}_{2}, \mathrm{Al}_{2} \mathrm{O}_{3}, \mathrm{CaO}, \mathrm{Na}_{2} \mathrm{O}, \mathrm{K}_{2} \mathrm{O}, \mathrm{P}_{2} \mathrm{O}_{5}, \mathrm{Nd}, \mathrm{Ba}, \mathrm{Rb}, \mathrm{Sr}$, La, Ce e Zr (Figura VI.5). Destacam-se o modesto incremento das concentraçồes de $\mathrm{Y}$ e os valores mais ou menos constantes de $\mathrm{Nb}$ no decorrer do processo evolutivo (Figura VI.5). O aumento das concentrações de $\mathrm{Al}_{2} \mathrm{O}_{3}(\sim 10$ a $17 \%)$ e $\mathrm{CaO}(\sim 7 \mathrm{a} \sim 10 \%)$ nos diques da suíte básico norítica, pode ser explicado pelo fracionamento de ortopiroxênios e olivina. A elevação dos conteúdos de $\mathrm{SiO}_{2}(\sim 51$ a $\sim 57 \%), \mathrm{K}_{2} \mathrm{O}(\sim 0,5 \mathrm{a} \sim 1,75 \%)$ e Ba $(80$ a $300 \mathrm{ppm})$, é coerente com a presença significativa de intercrescimento quartzo feldspático.

Outros aspectos distintivos dos diques da suite básico noritica, são o amplo intervalo das concentrações em $\operatorname{MgO}(4,4$ a 17,5\%), as altas concentrações em $\mathrm{Cr}(\sim 2520$ a $160 \mathrm{ppm}), \mathrm{Ni}(\sim 550$ a $100 \mathrm{ppm})$ e em particular, dos elementos litófilos com íon de grande tamanho (e.g. K, Ba, Rb e Sr).

Os diques da suite básico norítica são caracterizados também, pelas baixas concentrações em elementos de alta densidade de carga (e.g. $\mathrm{Ti}, \mathrm{Zr}, \mathrm{Nb}, \mathrm{P}$ ). $\mathrm{O} \mathrm{TiO}_{2}$ encontrase sistematicamente no intervalo de 0,5 a $1,0 \%$ enquanto que o $\mathrm{Nb}$ parece se restringir entre 5 a $10 \mathrm{ppm}$. O $\mathrm{Zr}$ varia de 50 a 150 ppm e o $\mathrm{P}_{2} \mathrm{O}_{5}$ não ultrapassa $0,15 \%$ (preferencialmente entre 0,05 a $0,15 \%)$

Uma investigação mais detalhada ao longo da extensão de um dique da suite básico noritica, constituído pelas amostras, 59,70 e 1223, demonstra que as composições químicas praticamente não se modificaram em um percurso de aproximadamente $10 \mathrm{Km}$. Assim, ao se confrontar tais amostras (apêndice 1) verificamse a identidade composicional entre elas, por exemplo: $\mathrm{SiO}_{2}:(55,03 \rightarrow 55,20 \rightarrow 55,29 \%), \mathrm{TiO}_{2}:(0,82 \rightarrow 0,82 \rightarrow 0,87 \%)$; $\mathrm{MgO}:(4,44 \rightarrow 4,83 \rightarrow 4,87 \%) ; \mathrm{K}_{2} \mathrm{O}:(1,22 \rightarrow 1,20 \rightarrow 1,28 \%) ; \mathrm{Ba}:(281 \rightarrow 297 \rightarrow 305$ ppm $)$ 

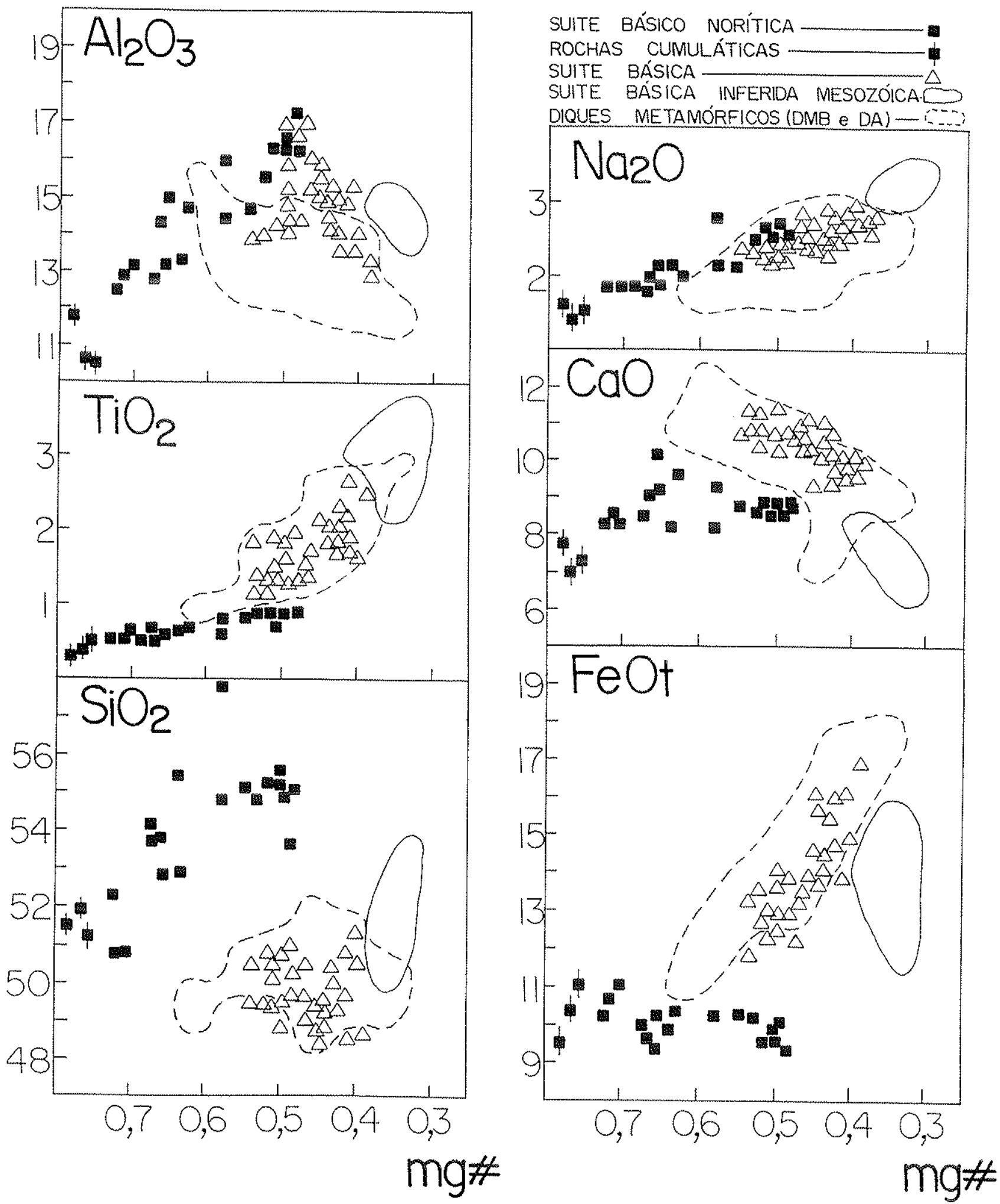

FIGURA VI.5: Diagramas de variação mgł valores $\left[\mathrm{Mg}^{42} / \mathrm{Mg}^{2}+\mathrm{Fe}^{* 2}\left(\mathrm{Fe}_{2} \mathrm{O}_{3} / \mathrm{FeO}=0,15\right)\right]$ versus elementos maiores (\% em peso), menores (\% em peso) e traços (ppm) dos diques máficos da região de Lavras $(\mathrm{MG})$. ( = suite básico norítica $\left(\mathrm{DBN}+\mathrm{DB}_{1}\right) ;(\Delta)=$ suite básica $\left(\mathrm{DB}_{2}\right)$. Linha tracejada forma o campo das amostras dos diques metamórficos (DMB+DA), enquanto que a linha contínua forma o campo das amostras dos diques inferidos como Mesozóicos. 


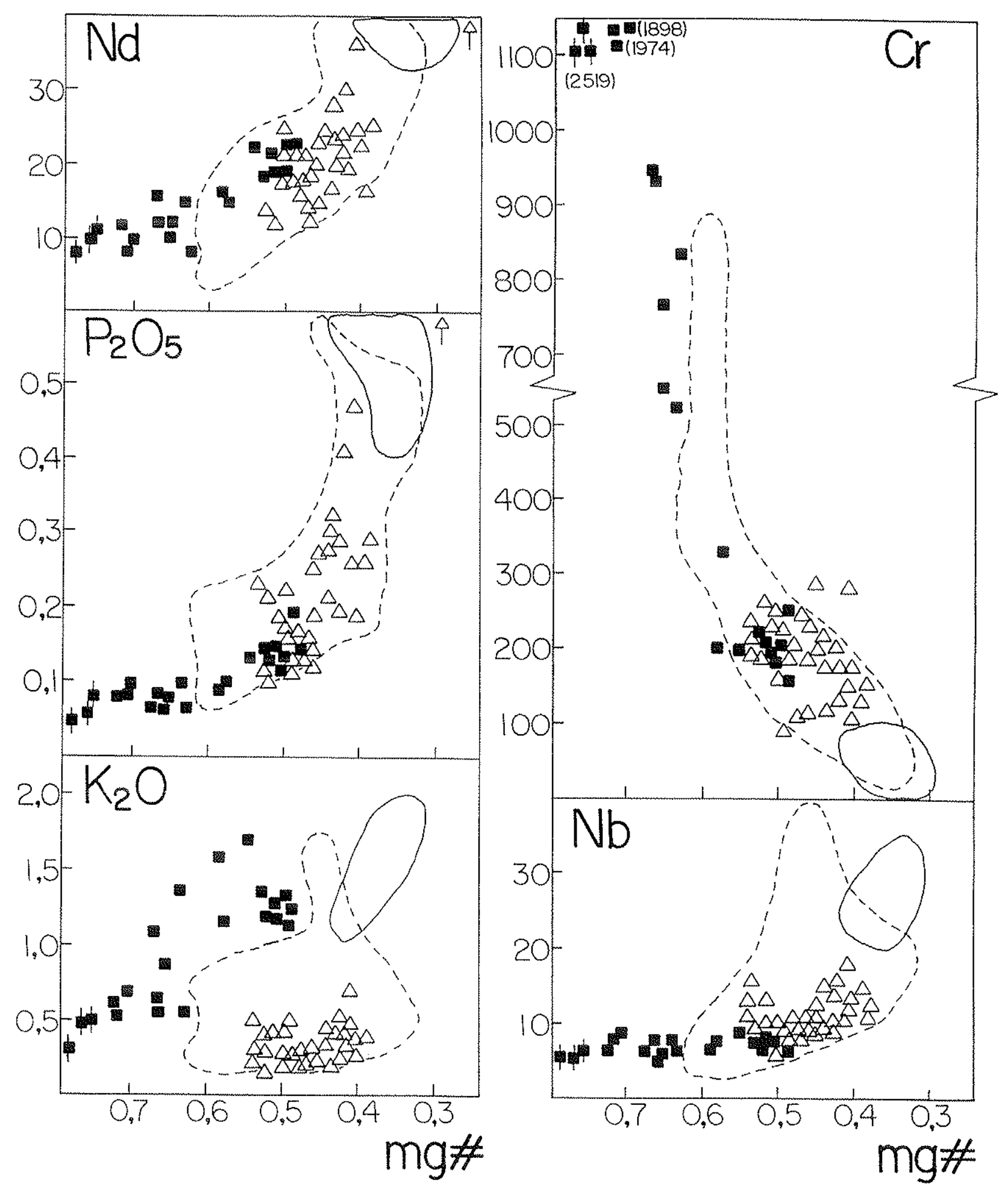

FIGURA VI.5: continuação. 


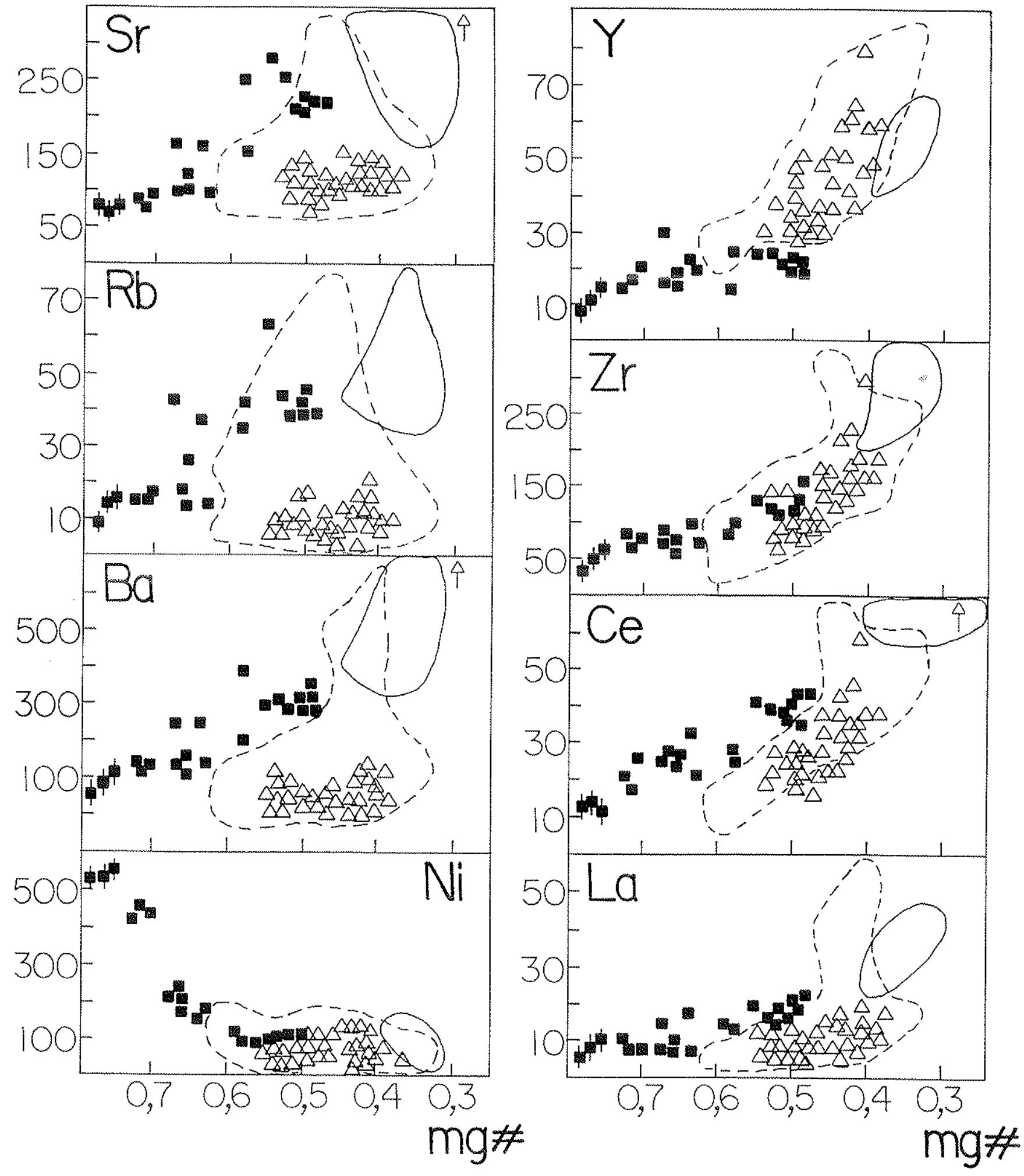

FIGURA VI.5: continuação. 
$\mathrm{Rb}:(38 \rightarrow 43 \rightarrow 42 \mathrm{ppm})$ e $\mathrm{Y}:(21 \rightarrow 21 \rightarrow 23 \mathrm{ppm})$. Esta identidade também é verificada do ponto de vista isotópico (veja Geoquímica Isotópica).

\section{Suite básica}

Os diques da suite básica evoluem diminuindo suas concentrações em $\mathrm{Al}_{2} \mathrm{O}_{3}$, $\mathrm{CaO}, \mathrm{Cr}$ e $\mathrm{Ni}$, e aumentando suas concentrações em $\mathrm{SiO}_{2}, \mathrm{TiO}_{2}, \mathrm{FeO}_{\imath}, \mathrm{Na}_{2} \mathrm{O}, \mathrm{K}_{2} \mathrm{O}, \mathrm{P}_{2} \mathrm{O}_{5}, \mathrm{Nd}$, $\mathrm{Nb}, \mathrm{La}, \mathrm{Ce}, \mathrm{Zr}$ e Y. O modesto aumento das concentrações de $\mathrm{K}_{2} \mathrm{O}$ não se apresenta em outros elementos litófilos como $\mathrm{Rb}$ e $\mathrm{Ba}$, que, via de regra, mostram-se mais ou menos constantes (Figura VI.5). Tais diques, mostram um decréscimo dos conteúdos em $\mathrm{CaO}(\sim 12$ a $9 \%)$ e $\mathrm{Al}_{2} \mathrm{O}_{3}(\sim 17$ a $13 \%)$, refletindo a importância do plagioclásio e clinopiroxênio no processo evolutivo, indicando desse modo um fracionamento do tipo gabro para o conjunto. $\mathrm{O} \mathrm{FeO}_{\mathrm{t}}$ nestes tipos aumenta consideravelmente $(\sim 12$ a $17 \%)$, sugerindo também um forte controle do fracionamento dos minerais anteriormente mencionados e baixa fugacidade de oxigênio

Apesar da escassa disponibilidade de bons afloramentos totalmente preservados, foi possível coletar para um dique da suíte básica, duas amostras representativas do centro e das proximidades da borda de um corpo com 10 metros de espessura. Trata-se dos exemplares 32 e 34 (suite básica $-\mathrm{DB}_{2}$ ), respectivamente a $80 \mathrm{~cm}$ e a 5 metros da margem. Como pode-se observar na figura VI.6, a variação composicional entre borda e o centro não é expressiva e indica, como era de se esperar, uma pequena diferenciação com um suave aumento em $\mathrm{TiO}_{2}$ e em elementos incompatíveis.

Em geral, merecem destaque algumas diferenças no comportamento geoquímico das concentrações de $\mathrm{Al}_{2} \mathrm{O}_{3}, \mathrm{CaO}$ e $\mathrm{FeOt}$, que são assinaladas entre os diques da suíte básico norítica e aqueles da suíte básica. Os primeiros evoluem aumentando suas concentrações em $\mathrm{Al}_{2} \mathrm{O}_{3}$ e $\mathrm{CaO}$, e diminuindo suas concentrações em $\mathrm{FeOt}$, enquanto aqueles da suite básica, evoluem diminuindo suas concentrações em $\mathrm{Al}_{2} \mathrm{O}_{3}$ e $\mathrm{CaO}$, e aumentando suas concentrações em FeOt (Fig. VI.5).

Adicionalmente, os diagramas de variação (Figura VI.5), revelam diferenças composicionais significativas quando se confronta os diques da suite noritica com os diques da suite básica. Desse modo, para um mesmo valor de mg \# (e.g. 0,5), os diques da suite básico norítica quando comparados aos da suíte básica, invariavelmente apresentam-se enriquecidos em: $\mathrm{SiO}_{2}(\sim 55$ vs $\sim 51 \%), \quad \mathrm{K}_{2} \mathrm{O}(\sim 1,2$ vs $\sim 0,5 \%), \mathrm{Sr}(\sim 225$ vs $\sim 140 \mathrm{ppm})$, 


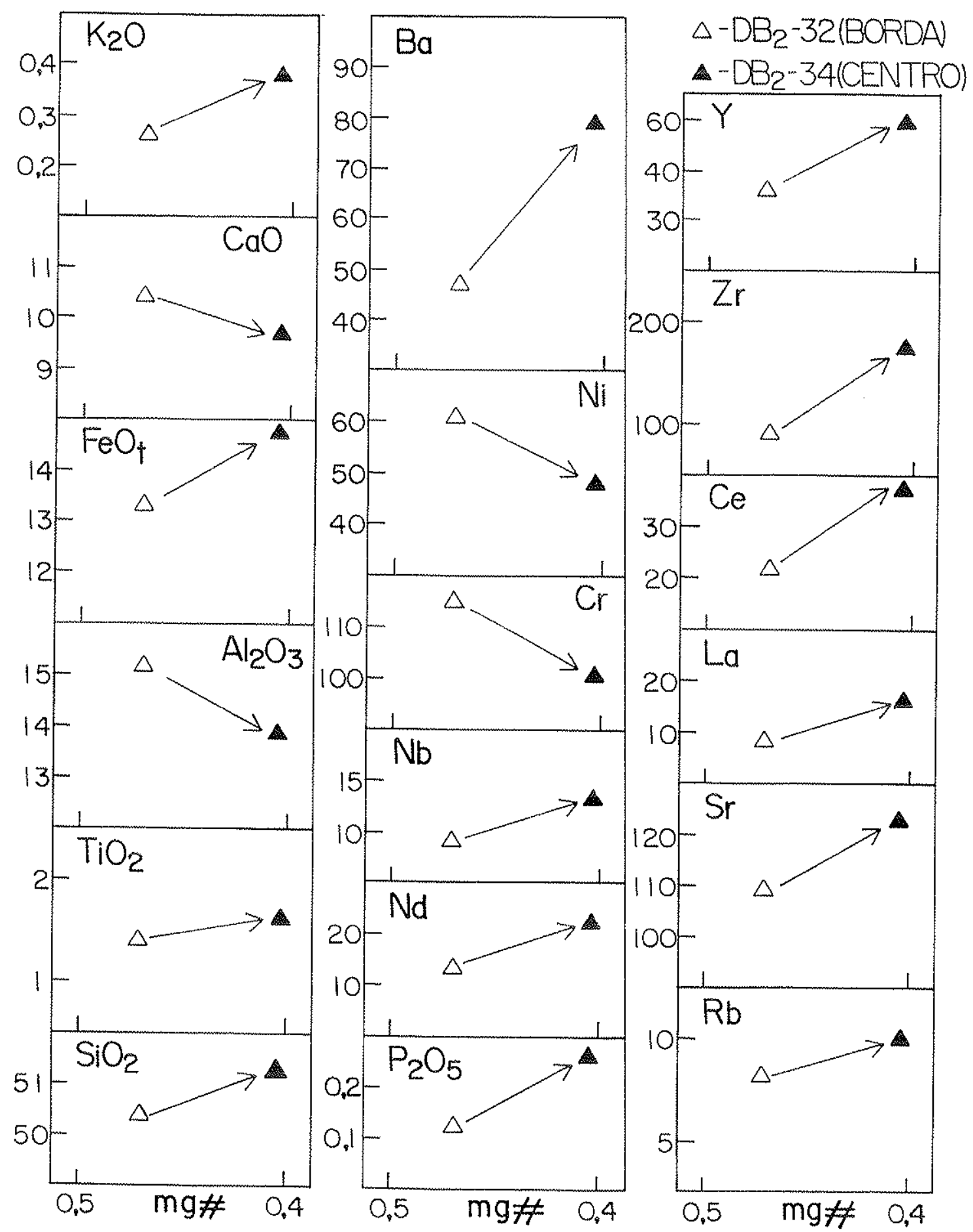

FIGURA V1.6: Diagramas de variação mg\# valores $\left[\mathrm{Mg}^{+2} / \mathrm{Mg}^{+2}+\mathrm{Fe}^{+2}\left(\mathrm{Fe}_{2} \mathrm{O}_{3} / \mathrm{FeO}=0,15\right)\right]$ versus elementos maiores (\% em peso) e traços (ppm) das amostras 32 e 34 representativas da migração borda/centro de um dique da suite básica do enxame de Lavras. $(\Delta)=$ centro do dique e $(\Delta)=$ borda do referido dique. 
$\mathrm{Rb}(\sim 40$ vs $\sim 10 \mathrm{ppm}), \mathrm{Ba}(\sim 300$ vs $90 \mathrm{ppm})$ e, empobrecidos em: FeOt $(\sim 10$ vs $\sim 13 \%)$; $\mathrm{CaO}$ $(\sim 9$ vs $\sim 10 \%)$ e $Y(\sim 23$ vs $\sim 35 \mathrm{ppm})$.

Os diagramas $\mathrm{Zr}$ versus outros elementos traços (e.g. Ba, Rb, La, Ce e Y) também mostram expressivas diferenças composicionais entre os diques da suíte básico noritica e os pertencentes a suite básica (Figura VI.7). Em geral, se observa uma correlação positiva entre $\mathrm{Zr}$ e os elementos $\mathrm{Ba}, \mathrm{Rb}, \mathrm{La}, \mathrm{Ce} \mathrm{e} \mathrm{Y}$, contudo nos diques da suíte básica a correlação é menos acentuada para os elementos $\mathrm{Ba}$ e Rb. Nos exemplares básicos noríticos as razôes $\mathrm{Zr} / \mathrm{Ba}(0,23$ a 0,73$), \mathrm{Zr} / \mathrm{Rb}(1,9$ a 5,7$), \mathrm{Zr} / \mathrm{La}(5,3$ a 8,9$)$ e $\mathrm{Zr} / \mathrm{Ce}(2,8$ a 4,0) são sempre menores que aquelas dos exemplares básicos, a saber: $\mathrm{Zr} / \mathrm{Ba}(0,61$ a 3,1$), \mathrm{Zr} / \mathrm{Rb}(4,0$ a 24,6), $\mathrm{Zr} / \mathrm{La}(8,8$ a 17,7$)$ e $\mathrm{Zr} / \mathrm{Ce}(3,7$ a 5,9). Por outro lado, as razões $\mathrm{Zr} / \mathrm{Y}$ dos diques da suíte noritica $(3,3$ a 7,3$)$ apresentam-se mais elevadas do que aquelas dos diques básicos $(2,5$ a 3,7$)$.

Entretanto, as diferenças composicionais são menores e pouco significantes quando se confrontam os diques metabásicos (DMB) com os anfiboliticos (DA), para o mesmo intervalo de mg\# (Figura VI.5), muito embora se reconheça que as interpretações geoquímicas sejam limitadas, por conta dos processos de mobilidade química anteriormente antecipados.

Em geral, tais conjuntos metamórficos apresentam-se em intervalos de concentração semelhantes, a saber (Fig. VI.5): $\mathrm{SiO}_{2}\left(48\right.$ a 52\%), $\mathrm{TiO}_{2}$ (I a $\left.3 \%\right), \mathrm{Al}_{2} \mathrm{O}_{3}(13$ a $15 \%), \mathrm{K}_{2} \mathrm{O}(0,25$ a $1,7 \%), \mathrm{Ba}(30$ a $1000 \mathrm{ppm}), \mathrm{Rb}(5$ a $80 \mathrm{ppm}), \mathrm{Sr}(100$ a $350 \mathrm{ppm}), \mathrm{La}(5$ a $70 \mathrm{ppm}), \mathrm{Ce}(15$ a $70 \mathrm{ppm})$, e Y (30 a $90 \mathrm{ppm})$. Embora, suas amostras se encontrem posicionadas predominantemente nos intervalos dos diques da suíte básica, parte do conjunto apresenta pequenas diferenças composicionais nas concentrações de $\mathrm{Al}_{2} \mathrm{O}_{3}, \mathrm{Na}_{2} \mathrm{O}, \mathrm{K} 2 \mathrm{O}, \mathrm{Sr}$, $\mathrm{Rb}$ e $\mathrm{Ba}$, fornecidas predominantemente pelos diques anfibolíticos (cf. item sobre mobilidade). Adicionalmente, o campo das amostras dos diques anfiboliticos e metabásicos (Fig. VI.5) mostra um deslocamento no âmbito dos elementos $\mathrm{Nd}, \mathrm{Nb}, \mathrm{La}, \mathrm{Ce}$ e $\mathrm{Zr}$, possivelmente como reflexo da mobilidade química em processos metamórficos.

O mesmo tipo de feição é observada nos diagramas $\mathrm{Zr}$ vs traços com o grupo dos DMB e DA se distribuindo muito além do campo de amostras da suite básica (Fig. VI.7). 


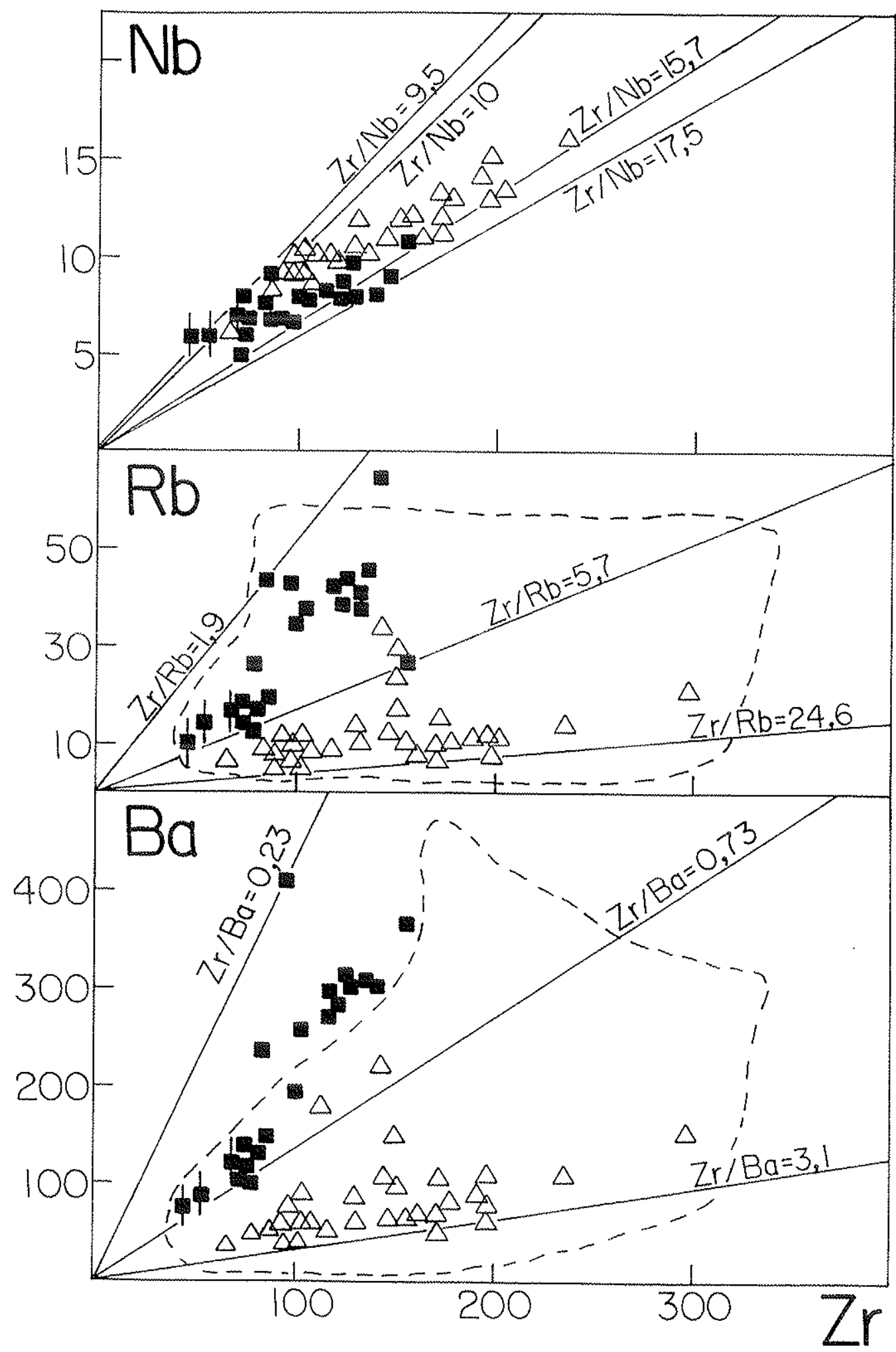

FIGURA VI.7: Diagramas Zr (ppm) versus Nb, Rb, Ba, La, Ce, Zr e Y (ppm), dos diques das suítes básico noritica e básica $(\Delta)$ da região de Lavras (MG). Linha tracejada forma o campo das amostras representativas dos diques metamórficos (DMB e DA). Simbolos e legenda como na figura VI.5. 


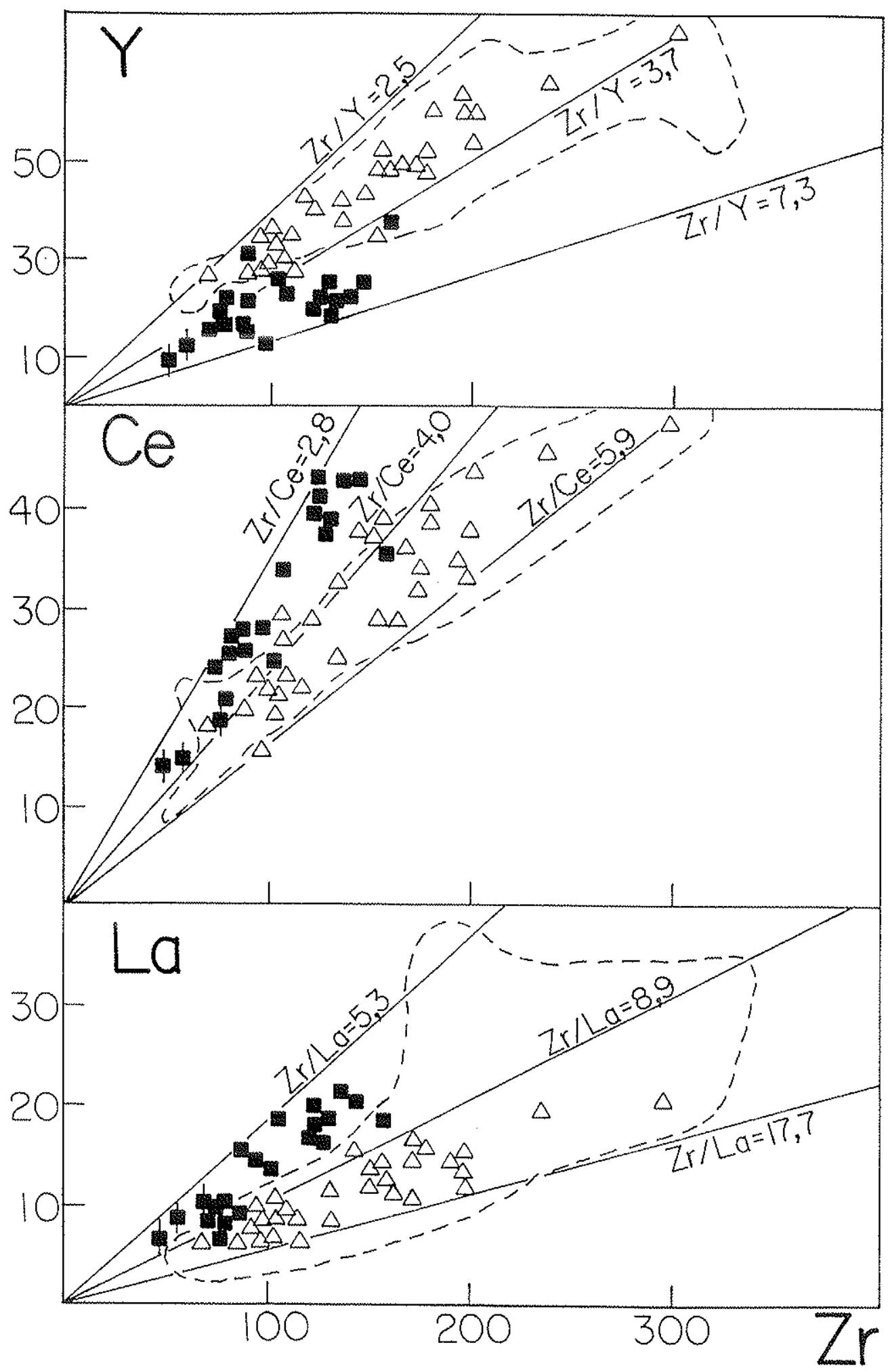

FIGURA VI.7: continuação. 
De qualquer forma, o comportamento geoquímico dos DMB e DA não são divergentes, indicando que ambos os grupos metamórficos são composicionalmente semelhantes entre si. Pode se considerar também que eles apresentam certa similaridade química com os diques da suíte básica.

Finalmente, alguns exemplares dos diques da suite básica com $\mathrm{TiO}_{2}$ elevado $(\sim 2,5$ a $4 \%)$ e mg抹 valores entre 0,45 a 0,30 , mostram um enriquecimento anormal em $\mathrm{K}_{2} \mathrm{O}$, $\mathrm{P}_{2} \mathrm{O}_{5}, \mathrm{Nd}, \pm \mathrm{Nb}, \mathrm{Sr}, \mathrm{Rb}, \mathrm{Ba}, \mathrm{La}$ e $\mathrm{Ce}$ (Fig. VI.5). Como anteriormente antecipado, eles indicam caracteristicas quimicas similares aos dos diques mesozóicos do Arco de Ponta Grossa (Pinese, 1989; Piccirillo et al, 1990). Por exemplo: $\mathrm{TiO}_{2}(\mathrm{APG})=3,31 \%$ versus (DB $74)=3,05 \% ; \mathrm{MgO}:(\mathrm{APG})=4,23 \%$ versus $(\mathrm{DB}-74)=4,34 ; \mathrm{K}_{2} \mathrm{O}:(\mathrm{APG})=1,44 \%$ versus $(\mathrm{DB}-74)=1,78 \% ; \mathrm{Ba}:(\mathrm{APG})=684$ ppm versus $(\mathrm{DB}-74)=707 ; \mathrm{La}(\mathrm{APG})=41$ versus $(\mathrm{DB}$ $-74)=37$ e Ce: $(A P G)=87$ versus $(D B-74)=79$ ppm. Também no Quadrilátero Ferrífero e Espinhaço Meridional são encontrados diques semelhantes a estes (e.g. Silva et al, 1996; Dussin, 1994). A comparação de uma amostra da região do Quadrilátero (IBI 01 ) com a DB ${ }_{2}$ 74 fornece os seguintes resultados: $\mathrm{TiO}_{2}: 3,44$ vs $3,05 \%, \mathrm{MgO}: 4,13$ vs 4,34\%; $\mathrm{Zr}: 270$ vs 341; Ba: 796 vs 707 ppm; Sr: 250 vs 274 ppm; Y: 50 vs 53 ppm e La: 36 vs 37 ppm.

Por outro lado, vale ressaltar, que a suite básico norítica apresenta comportamento geoquímico semelhante ao de outros enxames de diques enriquecidos em $\mathrm{MgO}$, os quais se distribuem por diferentes escudos pré-cambrianos, como aqueles da Groenlândia, Antártica, Escócia, Zimbabwe, Finlândia e Austrália. Diversos autores entre os quais, Hall \& Hughes (1987 e 1990), Vuollo et al (1995), relacionam estes diques com boninitos modernos, enquanto outros (e.g. Cawthorn \& Davies, 1982) o fazem com suites do tipo komatiiticas.

No diagrama $\mathrm{CaO}-\mathrm{Al}_{2} \mathrm{O}_{3}-\mathrm{MgO}$ (Viljoen et al, 1982) e no diagrama de porcentagens cationicas (Al, Mg e Fe, + Ti) de Jensen (Rollinson, 1993) das figuras VI.8a e 8b respectivamente, se observa que a maior parte das amostras estudadas da suite básico noritica encontra-se no campo tolético. Em que pese o fato, de que 3 amostras poderiam também representar os termos mais evoluidos de uma suíte komatiitica (basaltos komatíticos), tal interpretação é descartada, pelo simples motivo destes diques não apresentarem características texturais típicas de komatitos, bem como năo se encontrarem associados a rochas deste tipo na região. 


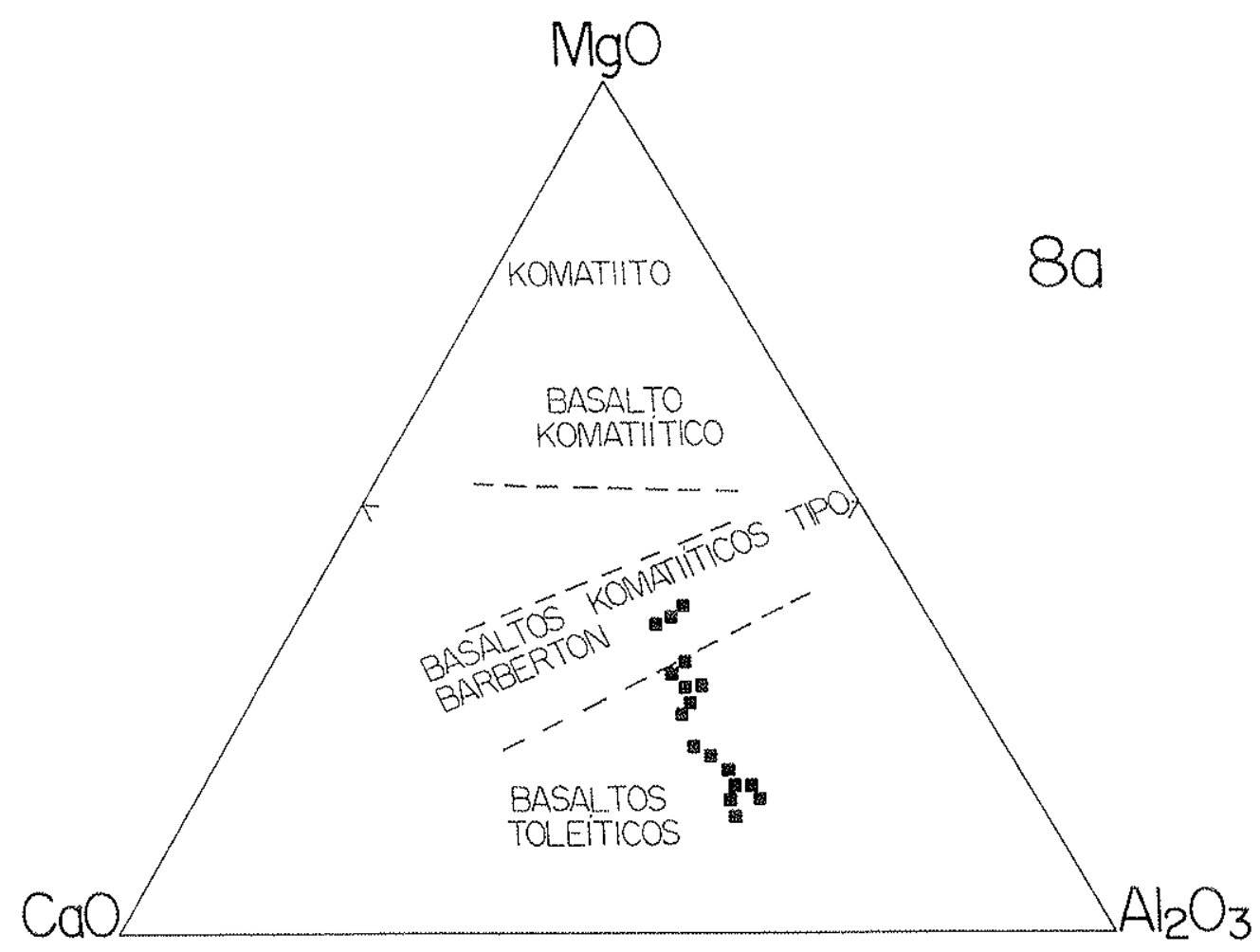

FIGURA VI.8 a: Diagrama $\mathrm{CaO}-\mathrm{Al}_{2} \mathrm{O}_{3}-\mathrm{MgO}$ (cf. Viljoen et al, 1982) para os diques da suíte básico norítica de Lavras (1). Linha tracejada separa campos dos komatiitos, basaltos komatiiticos e basaltos toleíticos.

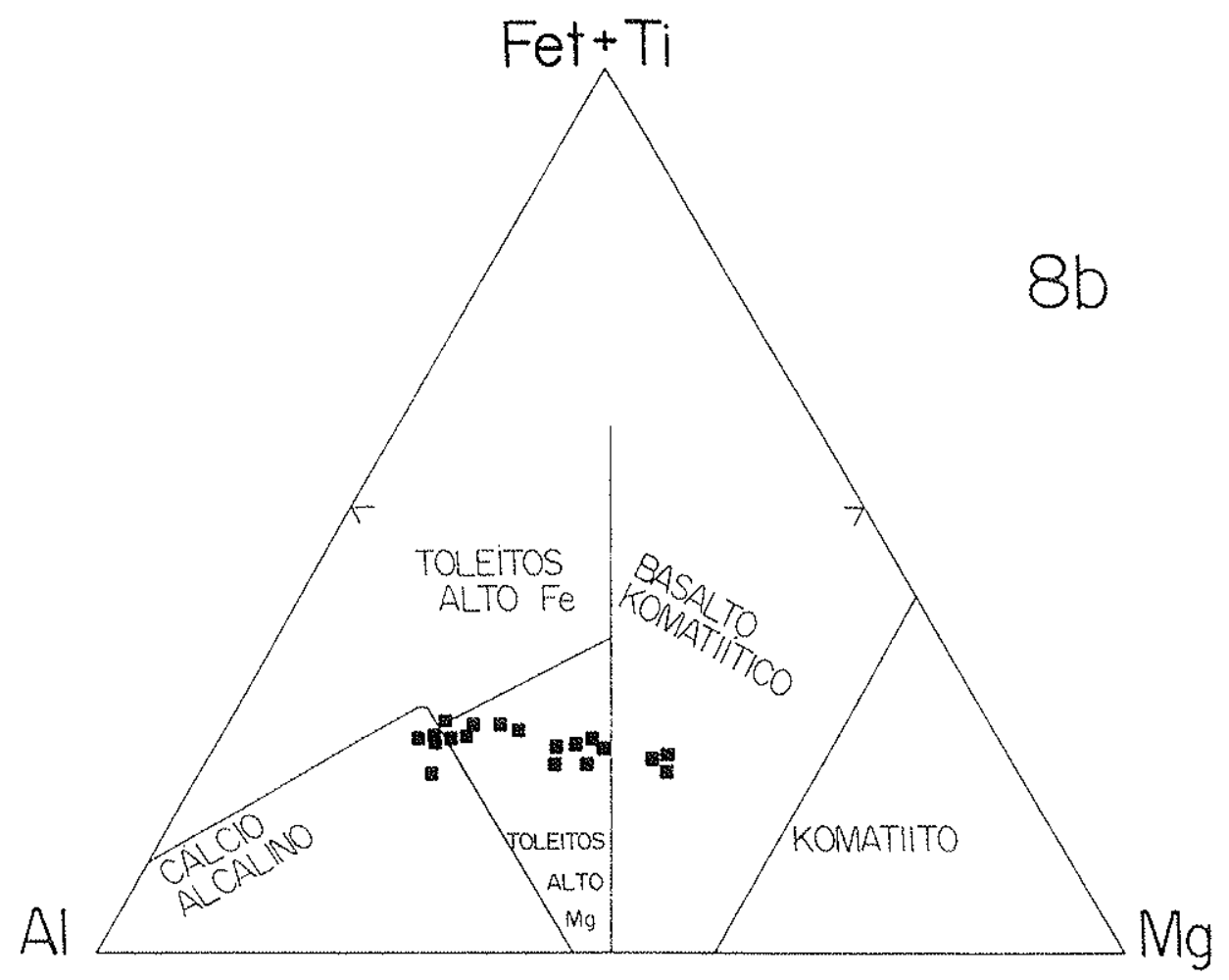

FIGURA VI.8 b: Diagrama Al-Mg Fet+Ti de porcentagens cationicas (diagrama de Jensen), conforme Rollinson (1993), dos diques da suíte básico norítica de Lavras (1). Linha continua separa os campos dos komatiitos, basaitos komatíticos e toleitos alto em Fe e alto em $\mathrm{Mg}$. 
Nos diagramas de variação da figura VI.9 encontram-se reportadas as composições representativas dos diferentes tipos de boninitos (cf. Crawford et al, 1989). Verifica-se que os diques da suite básico noritica, apresentam alguma semelhança com os boninitos no que diz respeito a álcalis, $\mathrm{Al}_{2} \mathrm{O}_{3}$ e razão $\mathrm{CaO} / \mathrm{Al}_{2} \mathrm{O}_{3}$. Diferenças importantes, no entanto, são assinaladas para $\mathrm{SiO}_{2}, \mathrm{TiO}_{2}, \mathrm{FeOt} e \pm \mathrm{CaO}$, as quais não apoiam o enquadramento dos diques estudados no conjunto dos boninitos clássicos. Tal fato, também pode ser verificado no diagrama $\mathrm{Ba}$ versus K/Ba (E.P. Oliveira, 1996, comunicação escrita) que contém dados mundiais de noritos proterozóicos (Hall \& Hughes, 1990) e boninitos modernos (Crawford, 1989), bem como inclue dados inéditos dos noritos de Uauá, Bahia (Fig. VI.10). Adicionalmente, na classificação TAS (in: Le Maitre, 1989) os boninitos devem apresentar concentrações em $\mathrm{TiO}_{2}$ sempre menores que $0,5 \%$, contrastando com aquelas obtidas para a suite básico norítica que são predominantemente maiores que $0,5 \%$.

Em síntese, os estudos empreendidos nos diques da região de Lavras indicam fortes diferenças composicionais entre a suite básico norítica e a básica, o que pode sugerir a existência de duas distintas familias geoquimicas de diques, as quais devem ter seguido diferentes processos petrogenéticos. A suíte básico norítica também pode ser considerada como composicionalmente diferente de outras rochas com altas concentrações em $\mathrm{MgO}$, haja visto os seus conteúdos elevados em $\mathrm{SiO}_{2}, \mathrm{~K}_{2} \mathrm{O}, \mathrm{Ba}, \mathrm{Rb}, \mathrm{Sr}$ e os baixos conteúdos em elementos de alta densidade de carga (e.g. Ti, Nb, Zr). Este quimismo, aliado a diferentes razões $\mathrm{Zr} / \mathrm{Rb}, \mathrm{Zr} / \mathrm{La}, \mathrm{Zr} / \mathrm{Ba}, \mathrm{Zr} / \mathrm{Y}$ e $\mathrm{Zr} / \mathrm{Ce}$, dificulta uma explicação que contemple uma origem para a suíte básica (baixíssimos conteúdos em elementos litófilos com ion de grande tamanho) a partir da suíte básico noritica.

\section{VI.3.2 - Elementos Terras Raras}

De um conjunto de 29 amostras de diques máficos analisados para os elementos Terras Raras (ETR) mais Hf e Th, 11 pertencem a suite básico noritica, 13 a suíte básica e 5 representam os diques metabásicos. Os valores referentes a estas análises encontram-se na tabela VI.1 e permitiram a construção de padrões de abundância observados nas figuras VI. II e VI.12. 


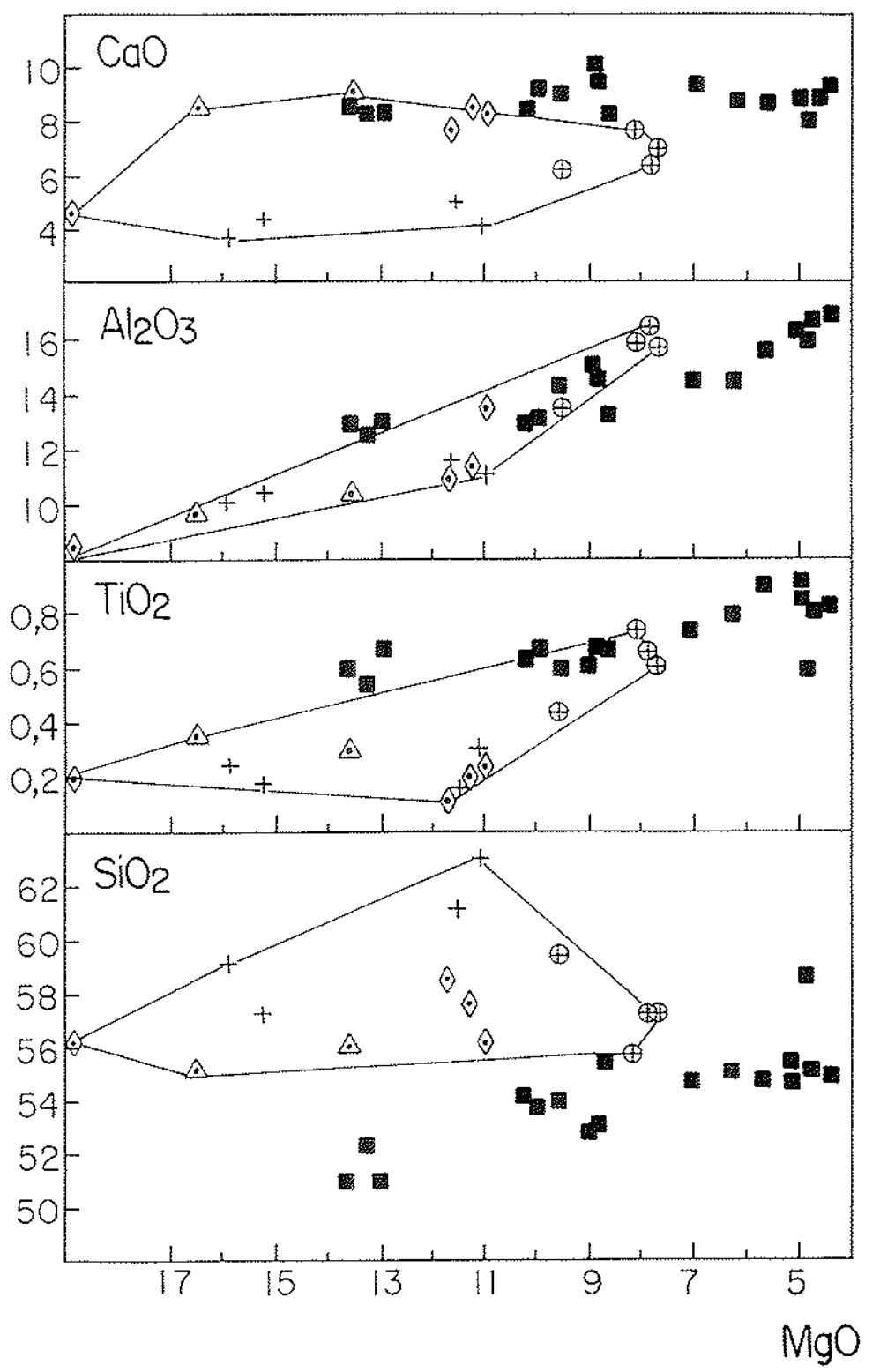

SUITE BÁSICO NORITICA

BONINITO BAIXO CÁLCIO TIPO $1-+$

BONINITO BAIXO CÁLCIO TIPO $2-\oplus$

BONNITO BAIXO CÁLCIO TIPO $3-\odot$

BONNTTO ALTO CÁLCIO

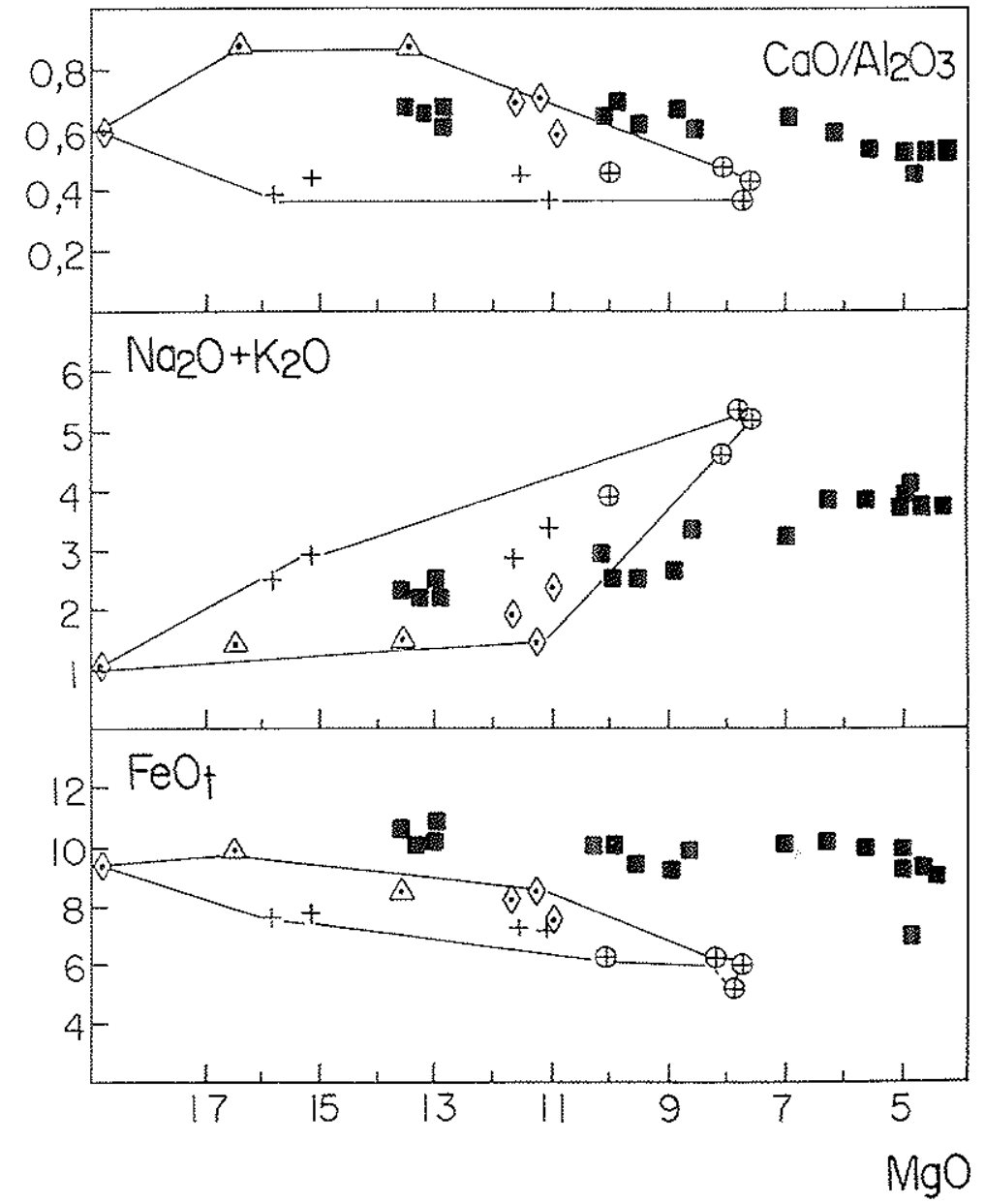

FIGURA VI.9: Diagramas de variação $\mathrm{MgO}$ (\% em peso) versus $\mathrm{SiO}_{2}, \mathrm{TiO}_{2}, \mathrm{Al}_{2} \mathrm{O}_{3}, \mathrm{CaO}$, FeOt, álcalis e razão $\mathrm{CaO} / \mathrm{Al}_{2} \mathrm{O}_{3}$, dos diques da suite básico norítica de Lavras (灌) e dos diferentes tipos de boninitos. Fonte de dados: presente trabalho e Crawford et al (1989). 


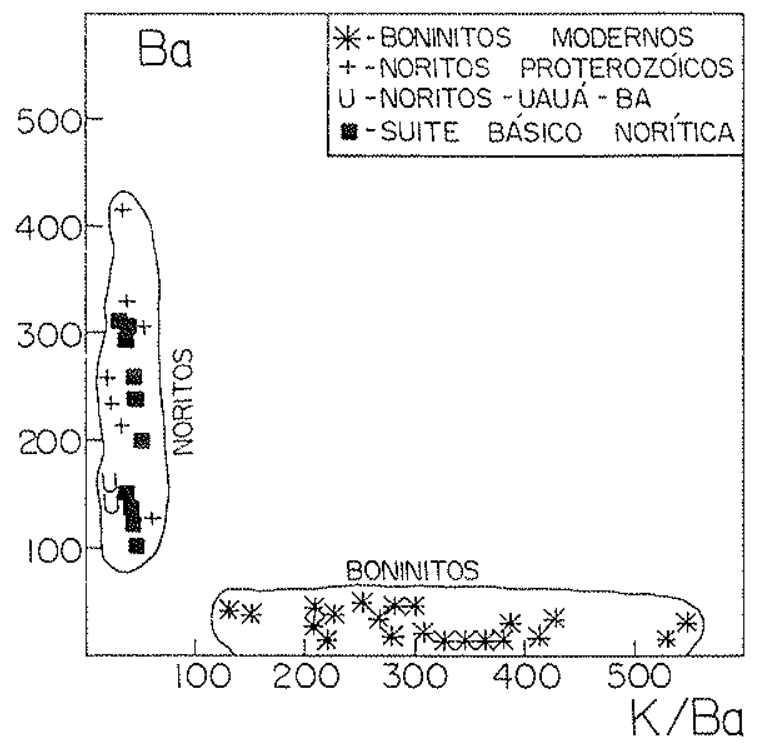

FIGURA VI. 10: Diagrama Ba vs K/Ba dos diques da suite básico norítica de Lavras (1), noritos proterozóicos, boninitos modernos e noritos de Uauá, Bahia. Fonte de dados: presente trabalho, Hall \& Hughes (1990); Crawford (1989) e E.P. Oliveira (comunicação escrita), respectivamente.

\begin{tabular}{|c|c|c|c|c|c|c|c|c|c|c|c|c|}
\hline AMOSTRAS & $\mathrm{HF}$ & $\mathrm{Th}$ & $\mathrm{La}$ & $\mathrm{Ce}$ & $\mathrm{Nd}$ & $\mathrm{Sm}$ & $\mathbf{E u}$ & $\mathbf{T b}$ & $\mathbf{Y b}$ & $\mathbf{L u}$ & $\mathrm{mg}(0,15)$ & $\mathrm{MgO}$ \\
\hline $\mathrm{DBN}-25$ & 1,9 & 3,5 & 11,7 & 22 & 9 & 2,13 & 0,63 & $<0,5$ & 1,51 & 0,21 & 0,640 & 8,72 \\
\hline DBN - 28 & 1,2 & 1,4 & 6,7 & 15 & 7 & 1,70 & 0,53 & $<0,5$ & 1,32 & 0,18 & 0,658 & 8,95 \\
\hline DBN - 54 & 1,6 & 2,0 & 8,4 & 18 & 5 & 1,84 & 0,65 & $<0,5$ & 1,42 & 0,21 & 0,706 & 13,06 \\
\hline DBN -55 & 1,5 & 1,5 & 7,4 & 15 & 7 & 1,66 & 0,60 & $<0,5$ & 1,57 & 0,22 & 0,632 & 8,86 \\
\hline DBN-64 & 1,3 & 2,2 & 9,5 & 18 & 8 & 1,77 & 0,58 & $<0,5$ & 1,25 & 0,20 & 0,724 & 13,28 \\
\hline DBN $-72^{*}$ & 1,1 & 1,1 & 5,1 & 10 & 6 & 1,11 & 0,35 & $<0,5$ & 0,93 & 0,15 & 0,772 & 17,49 \\
\hline DBN $-1212^{*}$ & 1,3 & 1,8 & 6,9 & 15 & 7 & 1,49 & 0,49 & $<0,5$ & 1,34 & 0,17 & 0,756 & 16,93 \\
\hline$D B N-1211$ & 1,2 & 1,8 & 7,1 & 15 & 4 & 1,56 & 0,45 & $<0,5$ & 1,34 & 0,19 & 0,718 & 13,58 \\
\hline $\mathrm{DB}_{1}-59$ & 2,2 & 2,3 & 14,2 & 31 & 14 & 2,91 & 0,92 & $<0,5$ & 1,57 & 0,23 & 0,506 & 4,83 \\
\hline$D B_{1}-70$ & 2,5 & 2,9 & 16,3 & 33 & 16 & 3,37 & 0,96 & 0,6 & 1,88 & 0,27 & 0,507 & 4.87 \\
\hline $\mathrm{DB}_{1}-112$ & 2,4 & 2,3 & 15 & 32 & 15 & 3,13 & 0,85 & 0,5 & 1,70 & 0,25 & 0,500 & 4.89 \\
\hline $\mathrm{DB}_{2}-1230$ & 1,6 & 0,8 & 5,8 & 14 & 9 & 2,29 & 0,74 & 0.6 & 2,15 & 0,33 & 0,539 & 6,76 \\
\hline $\mathrm{DB}_{2}-89$ & 1,6 & 1,0 & 6,0 & 14 & 7 & 2,50 & 0,75 & 0,6 & 2,07 & 0,31 & 0.516 & 6,46 \\
\hline $\mathrm{DB}_{2}-45$ & 1,6 & 0,9 & 5,4 & 14 & 8 & $2,3,3$ & 0,73 & $<0.5$ & 2,24 & 0,34 & 0,473 & 5,35 \\
\hline $\mathrm{DB}_{2}-60$ & 2,3 & 1,4 & 7,1 & 19 & 11 & 3,11 & 1,00 & 0,8 & 2.87 & 0,43 & 0,489 & 6,33 \\
\hline $\mathrm{DB}_{2}-34$ & 3,5 & 2,4 & 12,1 & 26 & 17 & 4,59 & 1,40 & 1,1 & 3,91 & 0,60 & 0,405 & 4,97 \\
\hline $\mathrm{DB}_{2}-18$ & 3,0 & 2,5 & 10,8 & 25 & 15 & 3,86 & 1,21 & 1,0 & 3,50 & 0,52 & 0,464 & 5,76 \\
\hline $\mathrm{Dl}_{2}-19$ & 3,3 & 2,3 & 11,5 & 26 & 11 & 4,47 & 1,30 & 0,9 & 3,60 & 0,58 & 0.457 & 5,75 \\
\hline $\mathrm{DB}_{2}-100$ & 3,3 & 2,3 & 11.7 & 28 & 20 & 4,45 & 1,22 & 0,9 & 3,79 & 0,52 & 0,439 & 5,48 \\
\hline $\mathrm{DB}_{2}-30$ & 3,6 & 2,6 & 12,7 & 28 & 19 & 4,55 & 1,31 & 0,9 & 3,83 & 0,55 & 0,446 & 5,84 \\
\hline $\mathrm{DB}_{2}-27$ & 4,3 & 3,3 & 15.5 & 34 & 19 & 5,55 & 1,42 & 1,2 & 4,48 & 0,67 & 0,425 & 5,36 \\
\hline $\mathrm{DB}_{2}-451^{* *}$ & 5,3 & 3,8 & 33,1 & 66 & 33 & 7,16 & 1,97 & 1,1 & 3,57 & 0,52 & 0,383 & 4,41 \\
\hline $\mathrm{DB}_{2}-79^{* *}$ & 3,2 & 1,8 & 18,2 & 40 & 22 & 5,97 & 2,34 & $<0,5$ & 2,11 & 0,30 & 0,437 & 5,56 \\
\hline $\mathrm{DB}_{2}-61^{* *}$ & 6,2 & 3,6 & 39,5 & 80 & 45 & 9,75 & 3,02 & 1,5 & 2,92 & 0,45 & 0,335 & 3,02 \\
\hline DMB -50 & 3,0 & 2,2 & 11,0 & 27 & 17 & 3,98 & 1,20 & 0,9 & 3,43 & 0,49 & 0,504 & 6,95 \\
\hline$D M B-96$ & 2,6 & 2,0 & 10,6 & 26 & 13 & 4,05 & 1,20 & 0,9 & 3,47 & 0,51 & 0,449 & 6,01 \\
\hline $\mathrm{DMB}-47$ & 3,4 & 2,8 & 12,2 & 27 & 16 & 4,53 & 1,32 & 1,0 & 3,63 & 0,58 & 0,477 & 6,68 \\
\hline DMB-56 & 2,4 & 0,7 & 6.8 & 16 & 10 & 3,27 & 1,03 & 0,6 & 2,74 & 0,39 & 0,460 & 6,60 \\
\hline DMB - 97 & 3,0 & 2,0 & 11.8 & 27 & 19 & 4,61 & 1,26 & 1,0 & 4,03 & 0,57 & 0,404 & 5,40 \\
\hline
\end{tabular}

Tabela VI.1: Elementos terras raras (ppm) mais Hf (ppm), Th (ppm), MgO (\% em peso) e mg\# $(0,15)$ valores, representativos dos diques máficos da região de Lavras $(\mathrm{MG})$. $\mathrm{DB}_{1 \mathrm{e} 2}=$ diques básicos 1 e $2 ; \mathrm{DMB}=$ diques metabásicos e DBN $=$ diques básicos noriticos. Suite básica $=\mathrm{DB}_{2}$; Suíte básico noritica $=\mathrm{DBN}+\mathrm{DB} \mathrm{B}_{1} .(*)$ = rochas com textura cumulática; $\left(^{* *}\right)$ amostras da súte básica de idade inferida mesozóica e ausentes das figuras deste item. 
Os padrões de abundância dos elementos terras raras (ETR) foram obtidos utilizando-se valores de Boynton (1984) para a normalização em relação aos condritos. As razões normalizadas $\mathrm{La} / \mathrm{Yb}, \mathrm{La} / \mathrm{Sm}, \mathrm{Sm} / \mathrm{Yb}$ e Eu/Eu* para cada amostra analisada, foram obtidas utilizando procedimento e margens de erros conforme Marques (1988).

De maneira geral, os padrões de ETR normalizados para condritos dos diques das suites básica e básico noritica, mostram um enriquecimento a medida que se tornam mais evoluídos (Figuras VI.11 e VI.12). Verifica-se também um enriquecimento dos elementos terras raras leves (ETRL) em relaçào aos elementos terras raras pesadas (ETRP). Todavia, o enriquecimento é mais expressivo entre os diques da suíte básico norítica (Figuras VI.11, VI.12). Desde que disponivel e para melhor visualização, as rochas foram agrupadas em função dos seus mgł valores.

\section{Suite Básico Noritica}

Os padrões dos diques da suite básico norítica (Figura VI.11) mostram-se fortemente fracionados em ETR. Os termos menos evoluídos desta suíte (mg\# 0,73-0,70) apresentam razões $\mathrm{La}_{\mathrm{N}} / \mathrm{Yb}_{\mathrm{N}}$ entre 5,1 e 3,6, La $/ \mathrm{Sm}_{\mathrm{N}}$ entre 3,4 e 2,9 e $\mathrm{Sm}_{\mathrm{N}} / \mathrm{Yb}_{\mathrm{N}}$ entre 1,5 e 1,2. As razões $\mathrm{Eu} / \mathrm{Eu}^{*}$ não foram calculadas pela falta do elemento $\mathrm{Tb}$, que conforme antecipado apresenta valores abaixo do limite de detecção $(0,5 \mathrm{ppm})$. Nos termos mais evoluídos (mg\# 0,51-0,50) as razões $\mathrm{La}_{\mathrm{N}} / \mathrm{Yb}_{\mathrm{N}}(6,1$ a 5,8$)$ e $\operatorname{Sm}_{\mathrm{N}} / \mathrm{Yb}_{\mathrm{N}}(2,0$ a 1,9$)$, são mais elevadas do que aquelas pertencentes as amostras menos evoluidas. Por outro lado, as razões $\mathrm{La}_{\mathrm{N}} / \mathrm{Sm}_{\mathrm{N}}$ são similares $(3,4-2,9$ vs $3,5-3,0)$.

Os termos evoluídos (mg\# 0,51-0,50) da suíte básico norítica apresentam anomalias de $\mathrm{Eu}$, as quais se caracterizam por serem fracamente negativas com razões Eu/Eu* entre 0,93 e 0,81 (Fig. VI.11).

Em comparação com os basaltos da cadeia meso-oceânica ("MORB"), se observa que os diques da suite básico noritica devem ter sido originados de uma fonte mantélica empobrecida, a qual sofreu sucessivos processos de enriquecimento particularmente em ETRL (Fig. VI.13)

\section{Suíte Básica}

Os diques da suite básica são caracterizados por apresentarem um padrão menos fracionado relativamente a suite anterior e pelas anomalias negativas de Eu (Fig. VI.12). Tais anomalias indicam que o plagioclásio deve ter sido uma fase importante na 

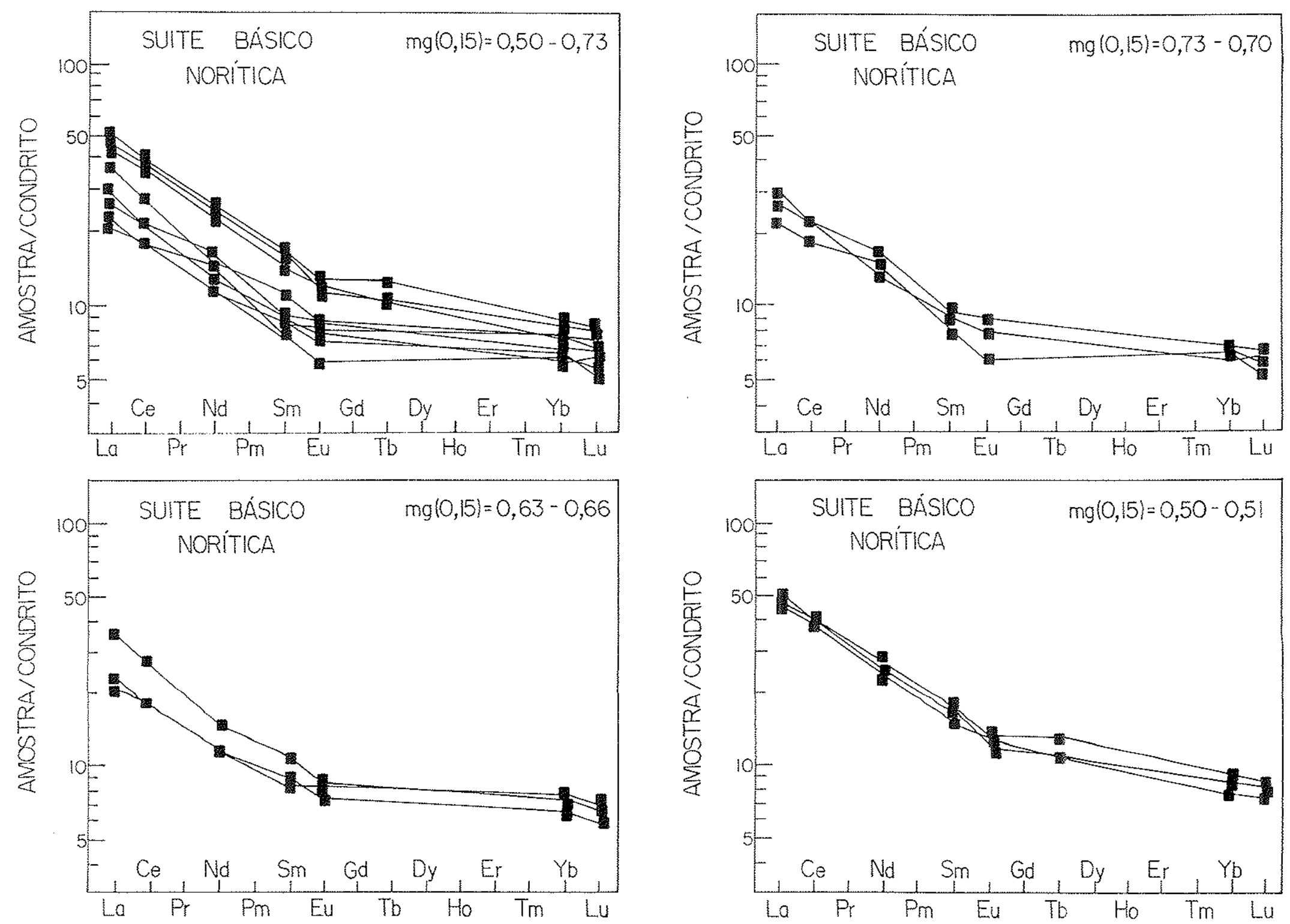

FIGURA VI.11: Padrões de abundância dos elementos terras raras (ETR) normalizados por condritos (Boynton, 1984), representativos dos diques da súte básico noritica (1) da região de Lavras (MG). 

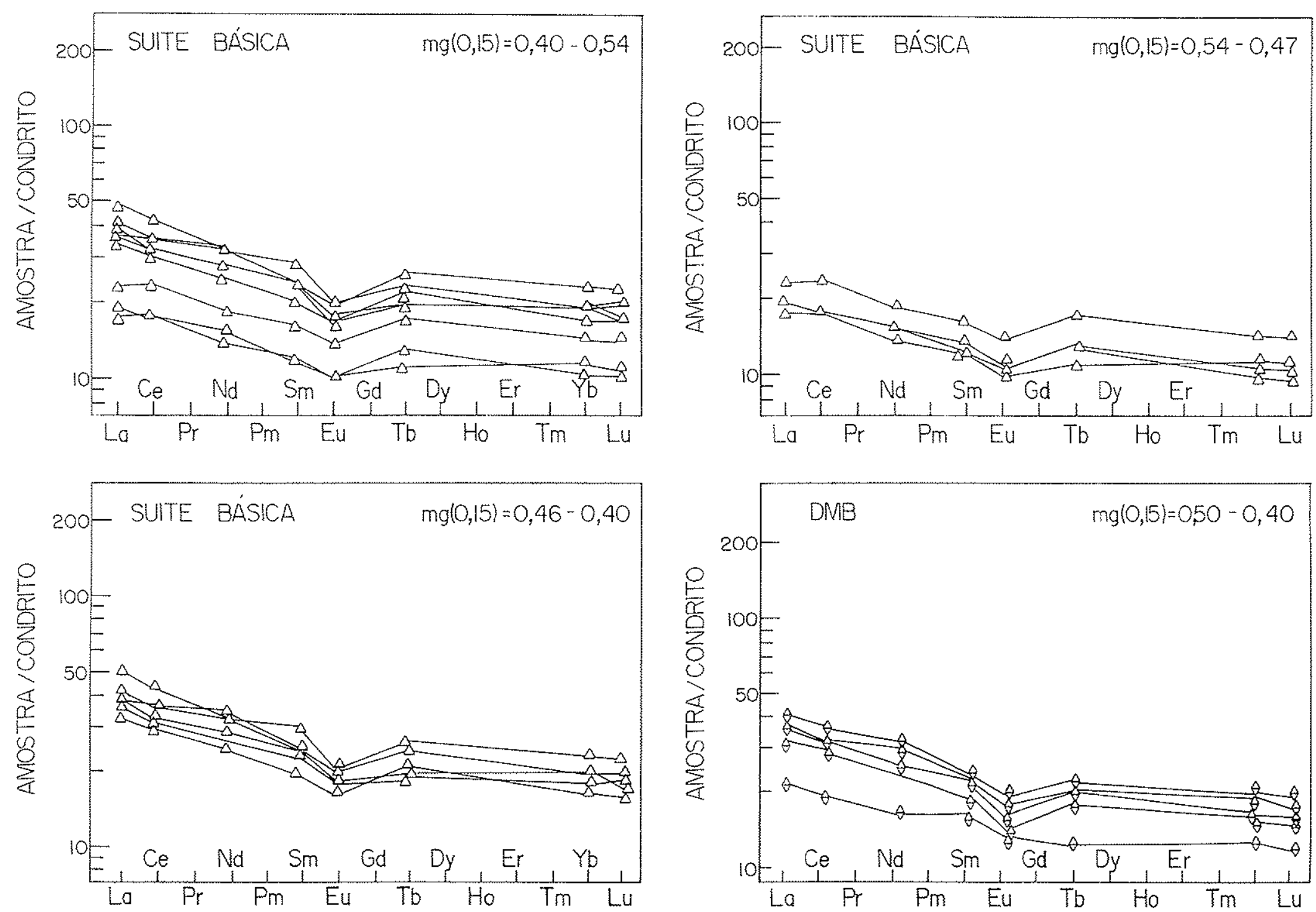

FIGURA VI.12: Padrões de abundância dos elementos terras raras (ETR) normalizados por condrivos (Boynton, 1984), representativos dos diques da suite básica $(\Delta)$ da região de Lavras (MG). 


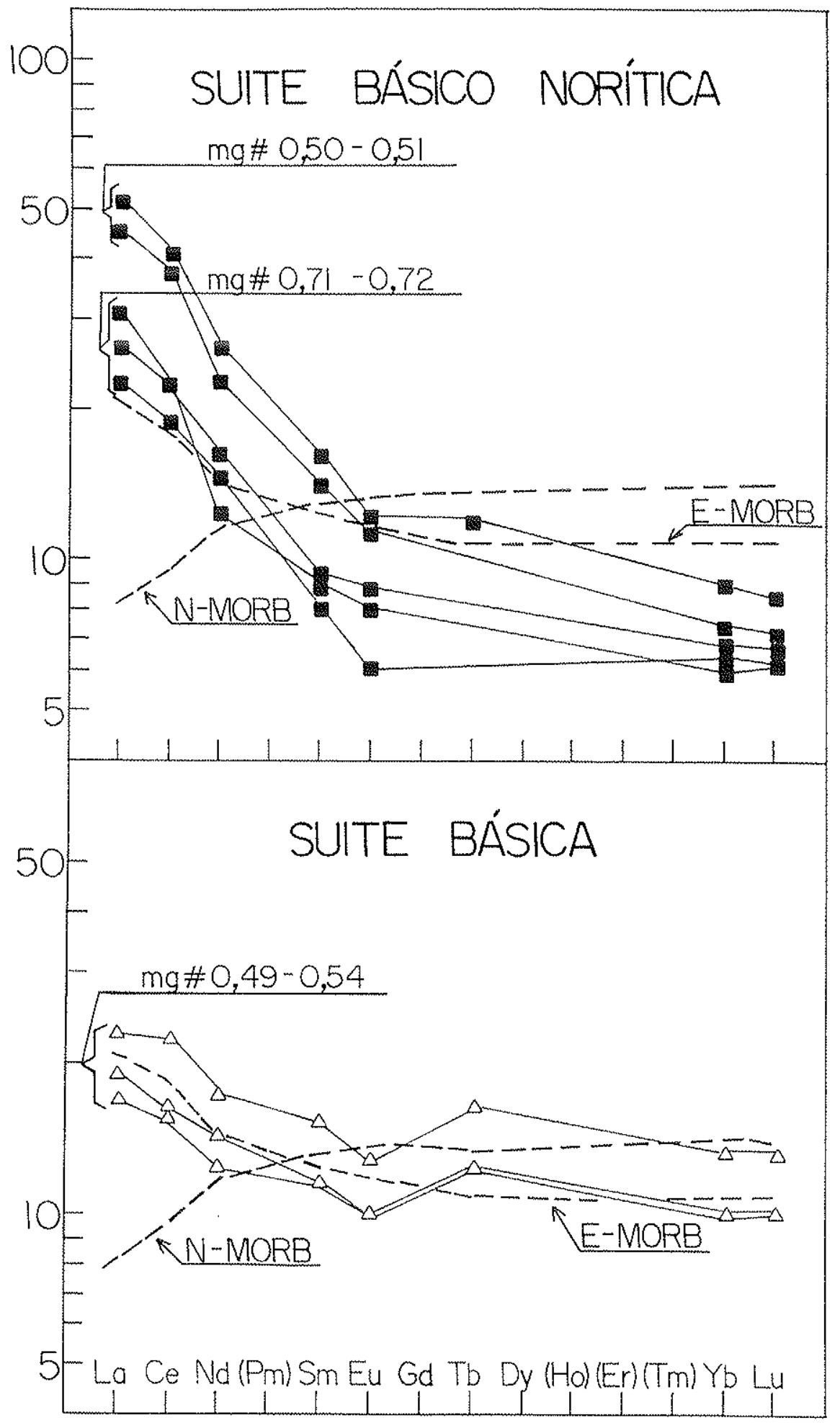

FIGURA VI.13: Padrões de abundância dos elementos terras raras (ETR), normalizados por condritos (Boynton, 1984), representativos dos diques das suítes básico norítica (1) e básica $(\triangle)$ da região de Lavras (MG), bem como dos Basaltos da Cadeia Meso Oceânica ("MORB") dos tipos normal ("N-MORB") e enriquecido ("E-MORB"). Linha tracejada representa a evolução dos "N" e "E-MORB". Fonte de dados: presente trabalho e Sun \& McDonough (1989). 
diferenciação. Os termos menos evoluidos (mgł 0,54-0,47) apresentam razões $L a_{N} / Y b_{N}$ entre 2,0 e 1,6, La $/ \mathrm{Sm}_{\mathrm{N}}$ entre 1,6 e 1,4 e $\mathrm{Sm}_{\mathrm{N}} / \mathrm{Yb}_{\mathrm{N}}$ entre 1,3 e 1,1. Todas estas razões, exceto $\mathrm{Sm}_{\mathrm{N}} / \mathrm{Yb}_{\mathrm{N}}$, aumentam nos termos mais evoluídos (mg\# 0,46-0,40), a saber: LaN $/ \mathrm{Yb}_{\mathrm{N}}(2,3-2,1)$ e $L a_{N} / S m_{N}(1,8-1,6)$. As razões $S m_{N} / Y b_{N}$ praticamente não apresentam variações entre os termos mais e menos evoluidos (valores entre 1,3 e 1,1). Uma importante característica da suite básica, são as anomalias de Eu, as quais também apresentam certa variabilidade entre amostras com graus de evolução diferentes. Os tipos mais evoluidos mostram anomalias negativas de Eu mais pronunciadas do que aquelas dos tipos menos evoluidos (Fig. VI.12). Os últimos apresentam razões $\mathrm{Eu} / \mathrm{Eu}^{*}$ no intervalo de 0,87 a 0,80 e os primeiros entre 0,82 0,70 .

Como anteriormente evidenciado na figura VI.13, os diques da suíte básica devem ter se originado de uma fonte mantélica "empobrecida", semelhante a dos basaltos da cadeia meso-oceânica ("MORB"), afetada por eventos de enriquecimento em ETRL.

Diante do exposto, verificamse também que no âmbito do comportamento dos ETR, as diferenças composicionais entre as suítes básica e básico norítica são significativas, ao se utilizar amostras com grau evolutivo similar (mg\# 0,5). Observa-se que os diques da suite básico norítica apresentam valores nas razões $\mathrm{La}_{N} / \mathrm{Yb}_{N} \quad(6,1-5,8$ versus 2,0-1,6), $\mathrm{La}_{\mathrm{N}} / \mathrm{Sm}_{\mathrm{N}}(3,5-3,0$ versus $1,6-1,4)$ e $\mathrm{Sm}_{\mathrm{N}} / \mathrm{Yb}_{\mathrm{N}}(2,0-1,9$ versus 1,3-1,1) sempre mais elevados do que aqueles da suíte básica.

Comportamento com padrões idênticos aos diques da suite básica são apresentados pelos diques metabásicos (DMB), os quais podem ser melhor visualizados na figura VI.12. Tais diques, apresentam razões $\mathrm{La}_{N} / \mathrm{Yb}_{\mathrm{N}}, \mathrm{La}_{\mathrm{N}} / \mathrm{Sm}_{\mathrm{N}}$ e $\mathrm{Sm}_{\mathrm{N}} / \mathrm{Yb}_{\mathrm{N}}$ nos intervalos de 2,3 a $1,7,1,7$ a 1,3 e 1,3 a 1,2 , respectivamente. A amostra com valor $L_{\mathrm{N}}$ de aproximadamente 20 se encaixa perfeitamente na sequência evolutiva dos diques menos evoluidos da suite básica (mg\# 0,54-0,47), enquanto as demais amostras com La $a_{N}$ acima de 30 são enquadradas na seqüencia dos mais evoluídos (mg\# 0,46-0,40). Cabe ainda notar, que as anomalias negativas de Eu dos DMB seguem o padrão anteriormente descrito, ou seja, a amostra menos evoluida apresenta razão Eu/Eu* $(0,93)$ maior do que aquelas das amostras mais evoluídas $(0,82-0,75)$. Esta identidade, indica que apesar do metamorfismo que deve ter atingido os DMB, os ETR não devem ter sofrido um importante fracionamento. 
Em sintese, os padrões dos ETR reafirmam a presença de duas suites geoquímicas distintas de diques pré-cambrianos. Em adição, o comportamento e a abundância relativa dos ETR sugerem que estas suites evoluiram de maneira diferente.

As amostras 451, 79 e 61 pertencentes aos diques da suite básica, reafirmam suas diferenças composicionats dentro do grupo e, mais uma vez, demonstram que são um conjunto a parte. Como anteriormente relatado, trata-se de amostras composicionalmente semelhantes aos diques mesozóicos. Este conjunto apresenta padrões altamente fracionados, com razões $\mathrm{La}_{N} / \mathrm{Yb}_{\mathrm{N}}(9,1$ a 5,8$)$ e $\mathrm{Sm}_{\mathrm{N}} / \mathrm{Yb}_{\mathrm{N}}(3,6$ a 2,1$)$ muito maiores do que aquelas verificadas para os diques da suite básica e básico norítica. Contudo, as razões $L a_{N} / S m_{N}(2,9$ a 1,9) mostram-se inferiores àquelas da suite norítica e superiores a da suíte básica. As anomalias de Eu, nesse grupo anômalo ao conjunto, são levemente negativas com razões $\mathrm{Eu} / \mathrm{Eu}^{*}$ entre 0,94 e 0,83 mas, uma das amostras apresenta anomalia positiva com razão $\mathrm{Eu} / \mathrm{Eu}{ }^{*}$ igual a 1,56 . 


\section{VII - GEOCRONOLOGIA E GEOQUIMICA ISOTÓPICA}

\section{VII.1 - Geocronologia}

O acervo geocronológico dos diferentes enxames de diques máficos précambrianos da porção sul do Cráton do São Francisco (Pará de Minas, Quadrilátero Ferrifero, Espinhaço Meridional, Bonfim) é constituido essencialmente por dados K-Ar (e.g. Teixeira et al, 1988; Carneiro, 1992; Teixeira et al, 1996c) e mais raramente por dados $\mathrm{Rb}-\mathrm{Sr}$ e Sm-Nd, além de datações U-Pb (e.g. Abreu, 1991; Silva et al, 1996).

De maneira geral, têm sido identificados pelo menos 3 conjuntos radiométricos representativos dos enxames de diques na porção sul do Cráton do São Francisco. O primeiro e mais antigo $(2,1-1,9 \mathrm{Ga})$, foi determinado por idades $\mathrm{K}$ - $\mathrm{Ar}$ em anfibólios (Teixeira et al, 1988; Carneiro, 1992). Estudos recentes (Chaves, 1996) em um dos ramos deste conjunto (região de Ribeirão das Neves - Pará de Minas), indicam que os diques estão geneticamente associados à evolução das zonas de cisalhamento regionais do Ciclo Transamazônico. Representantes deste conjunto aparecem no Quadrilátero Ferrifero e no Complexo Bonfim. O segundo conjunto, posicionado tentativamente entre 1,7 e 1,5 Ga, achase sinalizado através de análises K-Ar em anfibólios pertencentes aos enxames de Pará de Minas e Bonfim (Teixeira et al, 1988; Carneiro, 1992). Estas idades passaram a ter maior significado geológico, em função da recente idade U $\mathrm{Pb}$ de $1714 \pm 5 \mathrm{Ma}$ obtida em badeleita e zircão do gabro de Ibirité, localizado a sul de Belo Horizonte (Silva et al, 1996). O terceiro conjunto de dados $(1,0$ - 0,5 Ga), identificado por idades aparentes $\mathrm{K}$-Ar em anfibólios, plagioclásios e rocha total em enxames como Pará de Minas e Bonfim (e.g. Carneiro, 1992), pode ter um representante na região sul do Espinhaço, onde um dique apresenta idade U-Pb de $906 \pm 2$ Ma obtida através de zircões (Abreu, 1991). Por outro lado, as idades K-Ar entre 0,7 e 0,5 Ga (Teixeira et al, 1988) parecem, juntamente com idades U-Pb da ordem de $618 \pm$ 3 Ma (Silva et al, 1996) e Pb-Pb de 655 Ma (Silva, 1992), apontar para a presença de episodios tectono-termais superimpostos nos diques.

$\mathrm{Na}$ Tabela VII.1, pode-se observar o quadro atual de conhecimento geocronológico, em que são destacados os intervalos de idades assinalados para os principais 
enxames de diques máficos pré-cambrianos, da porção meridional do Cráton do São Francisco.

\begin{tabular}{|c|c|c|c|c|}
\hline Mćtodo & Material & Idade & $n^{\circ}$ de dados & Referência \\
\hline \multirow[t]{6}{*}{$\mathrm{K}-\mathrm{Ar}$} & \multirow[t]{2}{*}{ plagioclásio } & $1,5-1,8 \mathrm{Ga}$ & 2 & \multirow[t]{6}{*}{$\begin{array}{l}\text { Teixeira et al (1988) } \\
\text { e Carneiro (1992). }\end{array}$} \\
\hline & & $0.5-0,7 \mathrm{Ga}$ & 12 & \\
\hline & \multirow[t]{3}{*}{ anfibólio } & $1,9-2,1 \mathrm{Ga}$ & 4 & \\
\hline & & $1,5-1,8 \mathrm{Ga}$ & 3 & \\
\hline & & $0.5-0,7 \mathrm{Ga}$ & 1 & \\
\hline & rocha toial & $0,5-0,7 \mathrm{Ga}$ & 1 & \\
\hline $\mathrm{U}-\mathrm{Pb}$ & zircão/badeleita & $\begin{array}{l}1714 \pm 5 \mathrm{Ma} \mathrm{c} 618 \pm 3 \\
\mathrm{Ma}\end{array}$ & 1 & Silva et al (1996) \\
\hline $\mathrm{U}-\mathrm{Pb}$ & zircão/badeleita & $906 \pm 2 \mathrm{Ma}$ & 1 & Abreu (1991) \\
\hline
\end{tabular}

Tabela VII.1: Sumário geocronológico com os intervalos de idades em diques máficos précambrianos (Pará de Minas, Bonfim, Quadrilátero Ferrifero e Espinhaço meridional) da porção sul do Cráton do São Francisco.

Adicionalmente, a ocorrência de diques mesozóicos na área meridional do Supergrupo Espinhaço encontra-se relatada em Dussin (1994) e Silva et al (1996).

Apesar dos avanços obtidos, os dados geocronológicos disponiveis são ainda insuficientes para embasarem uma comparação cronológica entre os enxames de diques máficos da porção sul do Cráton do São Francisco. Desse modo, os resultados obtidos para o presente trabalho e apresentados a seguir, constituem uma contribuição para o melhor entendimento da época dos processos de fraturamento continental que atuaram no segmento meridional do Cráton do São Francisco, tendo em vista a multiplicidade de metodologias empregadas e sua interpretação integrada com dados geoquímicos.

\section{VII.1.1 - Sistemas K-Ar e ${ }^{40} \mathrm{Ar}-{ }^{39} \mathrm{Ar}$}

Embora para os diques básicos pré-cambrianos da porção sul do Cráton do São Francisco, a determinação da idade de intrusão pelo método K-Ar possa ser problemática, principalmente pela difusão e/ou excesso de argônio registrado seja nos minerais, seja na rocha total, inúmeras datações por este método são reportadas na literatura envolvendo a área de trabalho (e.g. Parenti Couto et al, 1983; Teixeira, 1985 e 1989; Teixeira et al, 1988; Carneiro, 1992). 
Segundo Teixeira (1992) os estudos K-Ar nos diques pré-cambrianos podem, apesar das limitações interpretativas, auxiliar no entendimento da evolução tectônica, com base na definição da maior frequência das idades aparentes obtidas para um enxame específico.

Os dados $\mathrm{K}$-Ar disponiveis na literatura dos diques pré-cambrianos adjacentes ou da região investigada (e.g. Teixeira, 1985), correspondem em grande parte a diques que sofreram a atuação de processos metamórficos (cr. petrografia revisada pelo presente autor nas amostras cedidas por $W$. Teixeira). Trata-se, segundo a classificação do presente trabalho de tipos metabásicos (DMB) e anfiboliticos (DA). Amostras petrograficamente selecionadas (isentas de alteração deutérica) dos DA apresentam idades KAr em rocha total de $1900 \pm 57$ Ma e em anfibólio de $2049 \pm 61$ Ma (amostras STG-MS 213 e 252 respectivamente; Teixeira, 1985). Uma amostra dos DMB apresenta idade K-Ar em plagioclásio de $2290 \pm 65 \mathrm{Ma}$ (amostra STG-240). Idade em plagioclásio semelhante a anterior (2299 $\pm 67 \mathrm{Ma}$ ) é assinalada em uma amostra representativa de um dique não metamórfico da suite básico norítica (amostra STG-MS-247.2). Tais idades em plagioclásios, devem ser consideradas com reservas em vista da possibilidade da existência de incorporação de argônio em excesso nesse mineral, problema este comun em diques pré-cambrianos.

$\mathrm{Na}$ Tabela VII.2 encontram-se as idades K-Ar processadas no CPGeo em plagioclásio, anfibólio e biotita de um dos diques anfibolíticos estudados (DA) do enxame, representado pela amostra WB-3.1 (veja figura IV.2), coletada nas imediações da cidade de Lavras (MG). Uma possivel interpretação para estes resultados, é a da existência de um evento tectono-metamórfico ocorrido há 1,2 Ga, ilustrado pela idade aparente da biotita coletada na borda cisalhada do dique. Tal hipótese é corroborada por registros K-Ar similares em granitóides na região de Boa Esperança, pouco à oeste da área investigada (Teixeira \& Canzian, 1994). Este episódio teria afetado os plagioclásios dos diques proporcionando valores de idades mais jovens (908 Ma), revelando a complexidade do plagioclásio em termos de retentividade de argônio em diques pré-cambrianos, conforme já antecipado. Contudo, o anfibólio da amostra WB-3.1, devido a sua alta retentividade de Ar não sofreu significativo distúrbio pelo episódio, e representaria, como tal, uma idade estimada da paragênese anfibolitica, sendo comparável com valores publicados anteriormente por Teixeira (1985) para os DA, bem como para os diques anfibolíticos de Pará de Minas (Teixeira et al, 1988). 


\begin{tabular}{|c|c|c|c|c|c|}
\hline Amostra/N ${ }^{0}$ CPGeo & Material & $\% \mathrm{~K}$ & $\mathrm{Ar}^{40} \mathrm{rad}$ & Ar atm & Idade (Ma) \\
\hline WB-3.1/5803 & Plagioclásio & 1,5768 & 72,35 & 9,06 & $908 \pm 14$ \\
\hline WB-3.1/5804 & Anfibólio & 0,5943 & 96.46 & 1,42 & $2163 \pm 43$ \\
\hline WB-3.1/6819 & Biotita & 7,3377 & 484,53 & 1,46 & $1198 \pm 19$ \\
\hline
\end{tabular}

Tabela VII.2: Dados analiticos K-Ar do dique anfibolítico WB-3. 1 da região de Lavras.

Esta interpretação acerca das idades K-Ar dos diques metamórficos entre 1,9 - 2,0 Ga é reforçada pelo valor obtido em análises ${ }^{40} \mathrm{Ar}^{39}{ }^{39} \mathrm{Ar}$ em anfibólios concentrados por catação de uma amostra dos DMB (DMB-63), recentemente processada no "Berkeley Geochronology Center" (EUA) [Paul Renne, comunicação escrita]. No diagrama da Figura VII.l, observa-se um espectro com definição de um "plateau" para $50 \%$ do gás liberado, com idade de $1975 \pm 7 \mathrm{Ma}$. A idade integrada de $1910 \pm 7 \mathrm{Ma}$ aproxima-se das idades aparentes $\mathrm{K}$-Ar convencionais reportadas por Teixeira (1985). Observa-se também que a razão $\mathrm{Ca} / \mathrm{K}$, acompanha o comportamento do espectro de argônio liberado o que reforça a qualidade interpretativa da idade obtida.

Cabe acrescentar finalmente, que uma minoria do conjunto ígneo dos diques investigados seja possivelmente de idade mesozóica, com base em uma idade aparente $\mathrm{K}-\mathrm{Ar}$ inédita da amostra $\mathrm{DB}_{2}-61(127 \pm 3 \mathrm{Ma})$. Esta inferência decorre também da composição química (veja geoquímica), de alguns diques da suíte básica a qual é semelhante a diques do Quadrilátero Ferrifero (Silva et al, 1996) e do Espinhaço Meridional (Dussin, 1994), para os quais idades $\mathrm{K}$ - $\mathrm{Ar}$ em rocha total forneceram valores de $120 \mathrm{Ma}$ e de 170 a $220 \mathrm{Ma}$, respectivamente.

\section{VII.1.2 - Sistema Rb - Sr}

Para o sistema $\mathrm{Rb}-\mathrm{Sr}$ a disponibilidade de dados é menor quando comparado ao sistema K-Ar. No segmento meridional do Cráton do São Francisco verifica-se apenas uma errócrona de $1030 \pm 256 \mathrm{Ma}$ obtida para os diques de Pará de Minas (Teixeira et al, 1996c e W. Teixeira comunicação verbal, 1997). Contudo, a elevada razão ${ }^{87} \mathrm{Sr} /{ }^{86} \mathrm{Sr}$ inicial de 0,71551 e a distribuição dos pontos no diagrama sugere um forte distúrbio no sistema $\mathrm{Rb}-\mathrm{Sr}$, conduzindo os referidos autores a considerar esta idade como de pouco significado geológico. 


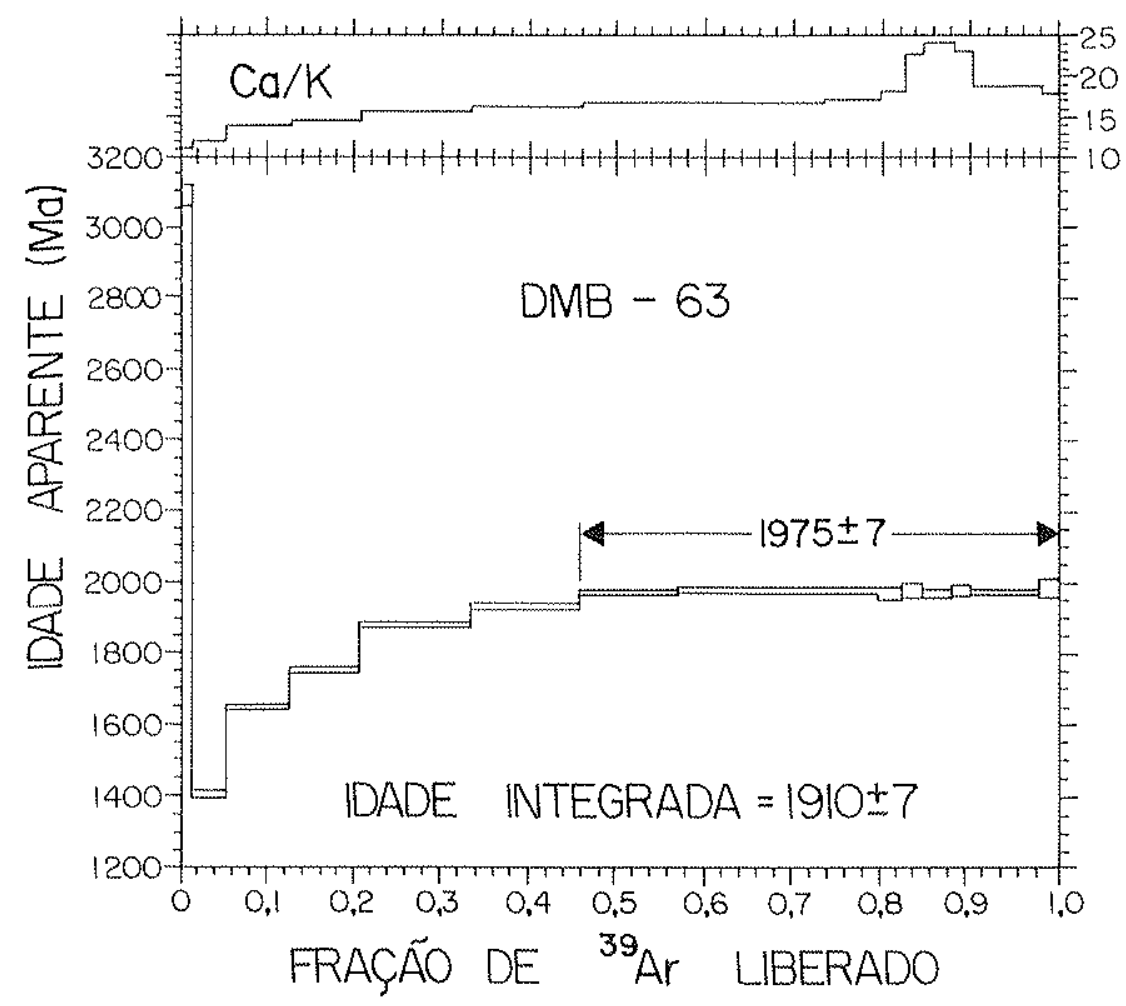

FIGURA VII.1: Diagrama de idade ${ }^{40} \mathrm{Ar}-{ }^{39} \mathrm{Ar}$ aparente versus fração de ${ }^{39} \mathrm{Ar}$ liberado para a amostra 63 dos diques metabásicos (DMB).

Com base em dados petrográficos, geoquímicos e de campo, foram selecionadas 22 amostras de diques máficos e 5 do embasamento metamórfico para a execução das análises do sistema isotópico $\mathrm{Rb}-\mathrm{Sr}$, conforme procedimento descrito no item metodologia. Os resultados encontram-se reportados na Tabela VII.3, que inclue dados obtidos pela técnica de diluição isotópica e por fluorescência de raios- $X$.

A seleção das amostras teve por base as caracteristicas petrográficas anteriormente observadas, tais como: grupos com a mesma composição mineralógica e textural $e$, ausência na amostra de indícios significativos da atuação de fenômenos metamórficos, intempéricos e deutéricos, conforme estudos petrográficos. Em seguida, as amostras foram agrupadas de acordo com suas características geoquímicas, levando-se em conta suas concentrações em elementos maiores, menores e traços, sempre se evitando aquelas que sugerissem a possibilidade de contaminação crustal. Foram excluídas todas as amostras, cujo comportamento em elementos como $\mathrm{Rb}, \mathrm{Sr}, \mathrm{Ba}, \mathrm{SiO}_{2}, \mathrm{~K}_{2} \mathrm{O}$, por exemplo, demonstrou significativas diferenças em relação ao padrão geral do grupo que pertenciam. Desse modo, os conjuntos de amostras como os diques de idade mesozóica não foram selecionados para o processo analítico. 
SUITE BÁSICO NORITICA

\begin{tabular}{|c|c|c|c|c|c|c|}
\hline $\begin{array}{l}\text { Amostra/Núme } \\
\text { ro do CPGeo }\end{array}$ & $\mathrm{Rb}$ & $\mathrm{Sr}$ & ${ }^{87} \mathrm{Rb} /{ }^{86} \mathrm{Sr}$ & Erro & ${ }^{87} \mathrm{Sr} /{ }^{86} \mathrm{Sr}$ & Erro $(2 \sigma)$ \\
\hline $54 / 12450$ & $16,0 \mathrm{I}$ & 102,12 & 0.4542 & 0,0064 & 0,720730 & 0,000090 \\
\hline $55 / 12452$ & 11,94 & 107,68 & 0,3212 & 0,0045 & 0,714790 & 0,000100 \\
\hline $64 / 12454$ & 13,95 & 102,01 & 0,3962 & 0,0057 & 0,719170 & 0,000070 \\
\hline $25 / 12624$ & 36,71 & 162,90 & 0,6534 & 0,0092 & 0,726800 & 0,000050 \\
\hline $28 / 12625$ & 14,16 & 127,04 & 0,3228 & 0,0049 & 0,713880 & 0,000090 \\
\hline $72 / \ldots$ & 13,81 & 88,01 & 0,4546 & 0,0082 & 0,719270 & 0,000110 \\
\hline $59 / \ldots$ & 35,80 & 227,05 & 0,4568 & 0,0070 & 0,717820 & 0,000090 \\
\hline $70 / \ldots \ldots$ & 37,47 & 233,16 & 0,4656 & 0,0074 & 0,717940 & 0,000070 \\
\hline $112 / \ldots$ & 38,46 & 240,74 & 0,4628 & 0,0079 & 0,717920 & 0,000080 \\
\hline \multicolumn{7}{|c|}{ SUITYE BÁSICA } \\
\hline $19 / 12448$ & 6,39 & 114,95 & 0,1608 & 0,0022 & 0,706930 & 0,000080 \\
\hline $27 / 12449$ & 11,16 & 114,27 & 0,2827 & 0,0040 & 0,710280 & 0,000090 \\
\hline $60 / 12451$ & 6,84 & 114.02 & 0,1736 & 0,0024 & 0,707930 & 0,000100 \\
\hline $18 / 12630$ & 8,21 & 117,40 & 0,2025 & 0,0029 & 0,707350 & 0,000090 \\
\hline $45 / 12632$ & 7,49 & 120,88 & 0,1794 & 0,0025 & 0,707360 & 0,000080 \\
\hline $34 / 12631$ & 8,33 & 120,22 & 0,2005 & 0,0028 & 0,707340 & 0,000080 \\
\hline $30 / 12636$ & 7,19 & 112,33 & 0,1853 & 0,0026 & 0,708060 & 0,000090 \\
\hline \multicolumn{7}{|c|}{ DIQUES METABÁSICOS } \\
\hline $97 / 12456$ & 17,58 & 117,12 & 0,4350 & 0,0060 & 0,714600 & 0,000100 \\
\hline $56 / 12453$ & 8,95 & 145,41 & 0,1782 & 0,0025 & 0,707750 & 0,000080 \\
\hline $42 / 12637$ & 8,85 & 103,27 & 0,2480 & 0,0034 & 0,707920 & 0,000100 \\
\hline $47 / 12638$ & 11,88 & 124,34 & 0,2766 & 0,0038 & 0,708830 & 0,000060 \\
\hline \multicolumn{7}{|c|}{ SUITE BÁSICA (FRX) } \\
\hline Amostra & $\mathrm{Rb}\left({ }^{* *}\right)$ & $\mathrm{Sr}$ & ${ }^{87} \mathrm{Rb} /{ }^{86} \mathrm{Sr}$ & Erro & ${ }^{87} \mathrm{Sr} /{ }^{86} \mathrm{Sr}$ & Erro $(2 \sigma)$ \\
\hline $22 * / \ldots$ & 13,5 & 133 & 0,2941 & 0,0050 & 0,713140 & 0,000070 \\
\hline $100^{*} / \ldots$ & 8,5 & 110 & 0,2239 & 0,0070 & 0,707900 & 0,000090 \\
\hline
\end{tabular}

Tabela VII.3: Dados analíticos $\mathrm{Rb}-\mathrm{Sr}$ dos diques da suíte básico noritica, suíte básica e diques metabásicos da região de Lavras. Dados obtidos por diluição isotópica (DI) e por fluorescência de raios-X (FRX). $\left({ }^{*}\right)=$ amostras obtidas por FRX; $\left({ }^{* *}\right)$ Os valores de $\mathrm{Rb}$ foram calculados pelo confronto entre $\mathrm{Rb}(\mathrm{DI})$ vs $\mathrm{Rb}$ (FRX) com desvio máximo de 2,5 ppm.

As amostras escolhidas para a datação representam as suítes básica e básico noritica, conforme anteriormente definidas.

\section{Suíte básico norítica}

A suite básico noritica representa a geração de diques mais antiga assinalada na região. O conjunto de 9 diques selecionados desta suite produziu no diagrama isocrônico em rocha total (errócrona calculada conforme Williamson, 1968) da Figura VII.2 uma idade de $2788 \pm 79 \mathrm{Ma}(1 \sigma)$, com razão ${ }^{87} \mathrm{Sr} /{ }^{86} \mathrm{Sr}$ inicial de $0,70110 \pm 0,00048$ e MSWD igual a 31,5. O alto MSWD ("mean square of weighted deviates") se deve a grande dispersão dos pontos em relação a reta, sugerindo um forte distúrbio isotópico de $\mathrm{Rb}$ e/ou Sr e re-equilíbrio parcial do sistema, ou ainda uma heterogeneidade da fonte, conforme verificada nos estudos petrogenéticos (cap. VIII). Os diques desta suite não foram observados seccionando os metassedimentos do Supergrupo Minas (localmente designados como Serra de Bom Sucesso), 
e portanto, são anteriores a $2,5 \mathrm{Ga}$ limite máximo considerado para o inicio da deposição destes sedimentos (cf. Noce, 1995 e Babinski et al, 1995).

\section{Suíte básica}

A suíte básica representa uma geração de diques mais nova, cujo diagrama Rb-Sr em rocha total (Figura VII.3) apresenta uma idade (errócrona de 7 pontos, conforme Williamson, 1968) de $1875 \pm 101 \mathrm{Ma}(1 \sigma)$, com razão ${ }^{87} \mathrm{Sr}{ }^{86} \mathrm{Sr}$ inicial igual a $0,70255 \pm$ 0,00028 e MSWD de 23,5. Também aqui o espalhamento dos pontos sugere um distúrbio de $\mathrm{Rb}$ e/ou Sr no sistema. É possível que estes distúrbios estejam associados a episódios tectonotermais que ocorreram no Proterozóico, como aqueles identificados pelos dados $\mathrm{K}$-Ar, por exemplo. Outra possibilidade, pode estar relacionada a já mencionada pequena heterogeneidade da fonte (cf. cap. VIII), uma vez que os processos de interação crustal durante a intrusão (cf. geoquímica isotópica) podem ser considerados insignificantes a ponto de afetar o sistema. Apesar do alto valor do MSWD, é sempre bom lembrar que esta idade de colocação para a suíte básica é corroborada pelas relações de contemporaneidade destes corpos no campo com os granitos transamazônicos datados em 1.932 21 Ma (Quéméneur \& Vidal, 1989).

Em adição, quatro amostras selecionadas dos diques metabásicos (DMB), foram analisadas e os dados encontram-se na Tabela VII.3. O conjunto apresenta uma errócrona (modelo Williamson, 1968) com idade de $1887 \pm 57 \mathrm{Ma}(1 \sigma)$, com razão ${ }^{87} \mathrm{Sr} /{ }^{86} \mathrm{Sr}$ inicial de 0,70205 $\pm 0,00021$ e MSWD de 80 (Figura VII.4). Este valor, semelhante ao da suite básica, deve ser tomado com cautela em função da mobilidade do Rb em processos metamórficos, conforme anteriormente evidenciado. De qualquer modo, estes dados vem sugerir que este grupo possui idade semelhante aos diques da suite básica, o que aliás é reforçado pelas datações $\mathrm{K}$-Ar e Ar-Ar predominantemente no intervalo 1,9 - 2,0 Ga (ver item anterior).

As similaridades químicas e cronológicas entre diques metabásicos e aqueles da suite básica permitem supor que os primeiros, na realidade são diques que se colocaram em regime transtensivos, os quais pouco tempo após foram submetidos a eventos tectônicos associados a regimes térmicos de baixo a médio grau que imprimiram as feições metamórficas observadas, durante a evolução do Cinturão Mineiro. Os diques anfibolíticos (DA) podem representar uma fase intrusiva precoce que antecedeu os DMB, conforme sugere 


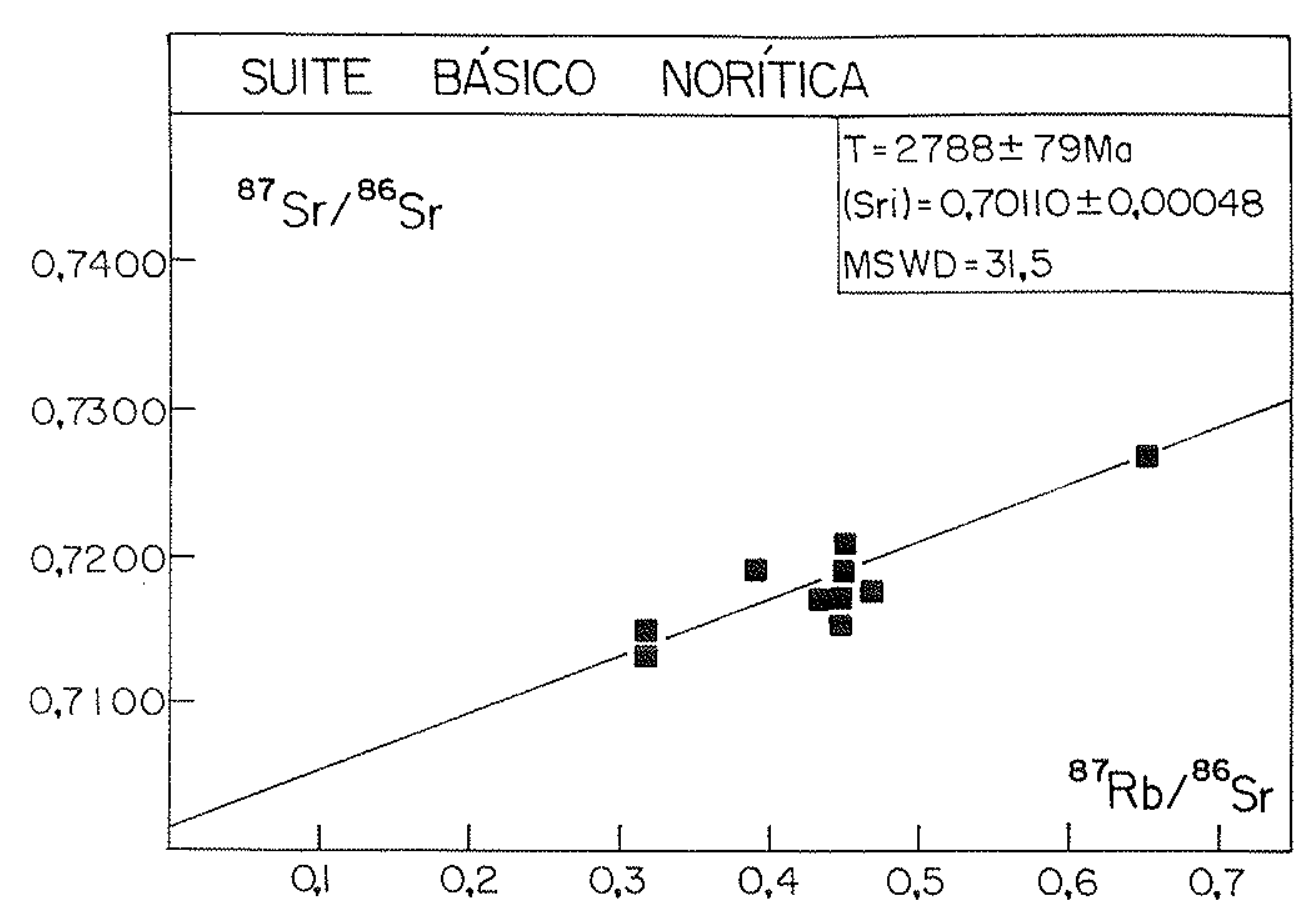

FIGURA VII.2: Diagrama isocrônico $\mathrm{Rb}$-Sr representativo dos diques da suite básico norítica de Lavras (MG).

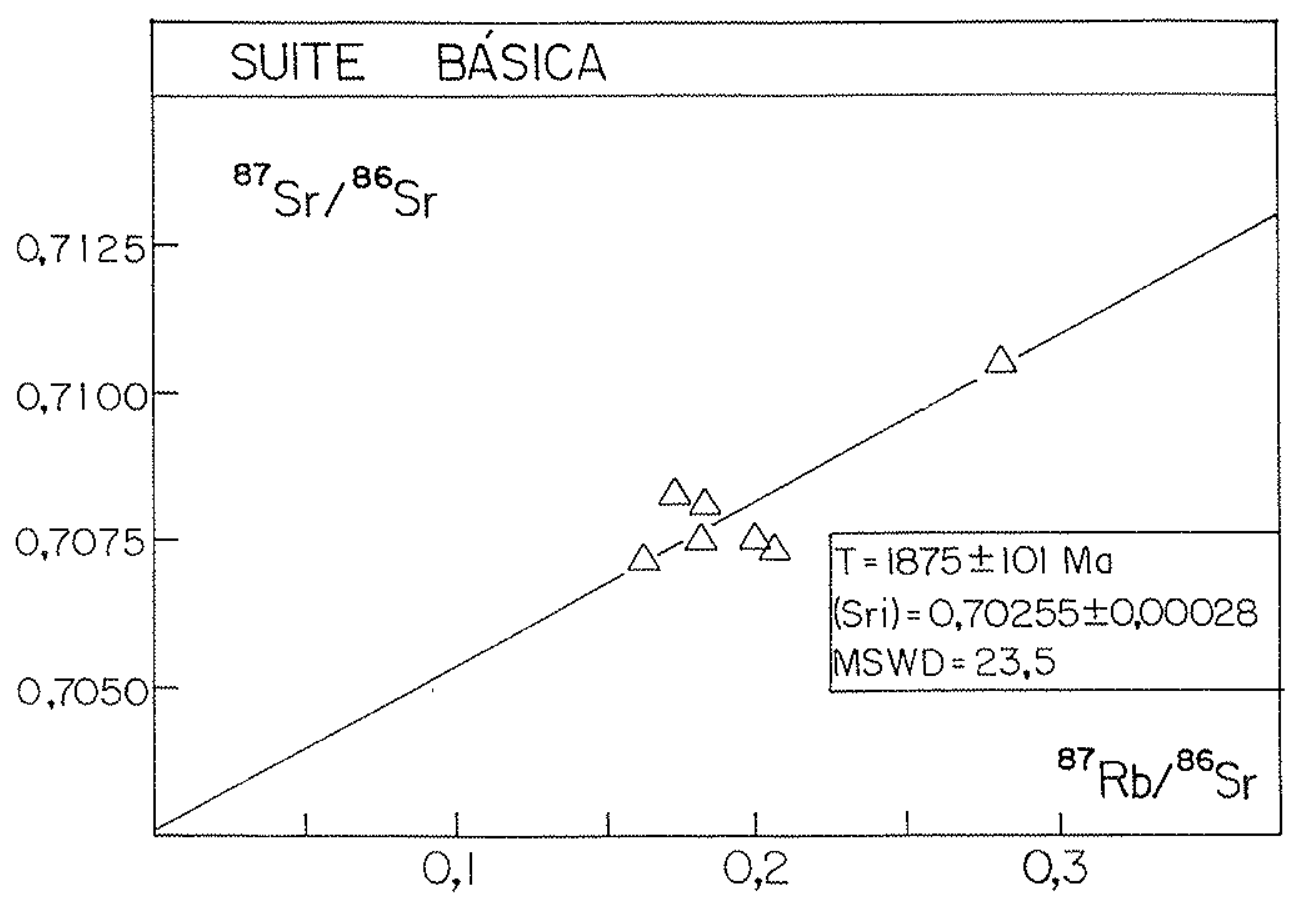

FIGURA VII.3: Diagrama isocrônico $\mathrm{Rb}$ - $\mathrm{Sr}$ representativo dos diques da suíte básica $(\Delta)$ de Lavras (MG). 
as idades $\mathrm{K}$ - Ar em anfibólio. Alternativamente, tanto os DMB como os DA podem representar uma geração anterior aos diques das suítes básica e básico noritica. Neste caso, as feições metamórficas teriam sido impressas durante as fases finais da evolução do Cinturão Mineiro, como atestam os dados K-Ar e Ar-Ar em anfibólios.

Contudo, cumpre ressaltar, que as idades $\mathrm{K}-\mathrm{Ar},{ }^{40} \mathrm{Ar}-{ }^{39} \mathrm{Ar}$ e $\mathrm{Rb}-\mathrm{Sr}$ dos $\mathrm{DMB}$ e DA, independentemente das limitações de cada método, são coerentes com a idade $\mathrm{Rb}$-Sr da suíte básica, sugerindo a possibilidade de contemporaneidade entre eles. Ressalta-se também, que o conjunto de diques da suite básica está intimamente associado à evolução transamazônica da porção sul do Cráton do São Francisco.

\section{VII.1.3 - Sistema Sm-Nd}

No âmbito do Cráton do São Francisco, nenhuma isócrona pelo sistema Sm$\mathrm{Nd}$ é assinalada na literatura concernente a diques máficos.

Nos diques investigados, foram realizadas 19 análises em rocha total e $3 \mathrm{em}$ concentrados minerais (Tabela VII.4), sendo um concentrado de plagioclásios e dois de apatitas, para fins de permitir a obtenção de razões isotópicas suficientemente distintas na confeç̧ão do gráfico isocrônico. Conforme anteriormente relatado (Tabela IV.2, cap. IV), foram efetuadas quatro análises em rochas do embasamento metamórfico, sendo 3 em granulitos (amostras 39,91 e 150), e 1 em ortognaisse (142).

\section{Suite básico norítica}

Do conjunto de amostras selecionadas da suíte básico norítica para o sistema Sm-Nd (Tabela VII.4), três representam rochas totais que foram analisadas em duplicata (542; 55-2 e 64-2). Uma das amostras do dique 54 (54b) representa um ponto cuja distância é cerca de 400 metros do local da primeira coleta. As amostras 70 e 112 não foram utilizadas na confeç̧ão do diagrama, por representarem um conjunto isotópico diferente da maioria das amostras estudadas (cf. geoquímica isotópica, veja a seguir)

Para os diques da suite básico norítica, os 12 dados $\mathrm{Sm}-\mathrm{Nd}$ proporcionaram uma isócrona interna com idade de $2658 \pm 44 \mathrm{Ma}(\mathrm{lo})$, razão ${ }^{143} \mathrm{Nd} /{ }^{144} \mathrm{Nd}$ inicial igual a 0,50916 0,00005 e MSWD de aproximadamente 3 (Fig. VII.5). Destacamse no diagrama isocrônico, os altos valores nas razões ${ }^{147} \mathrm{Sm} /{ }^{144} \mathrm{Nd}$ dos 2 concentrados de apatita, os quais em 


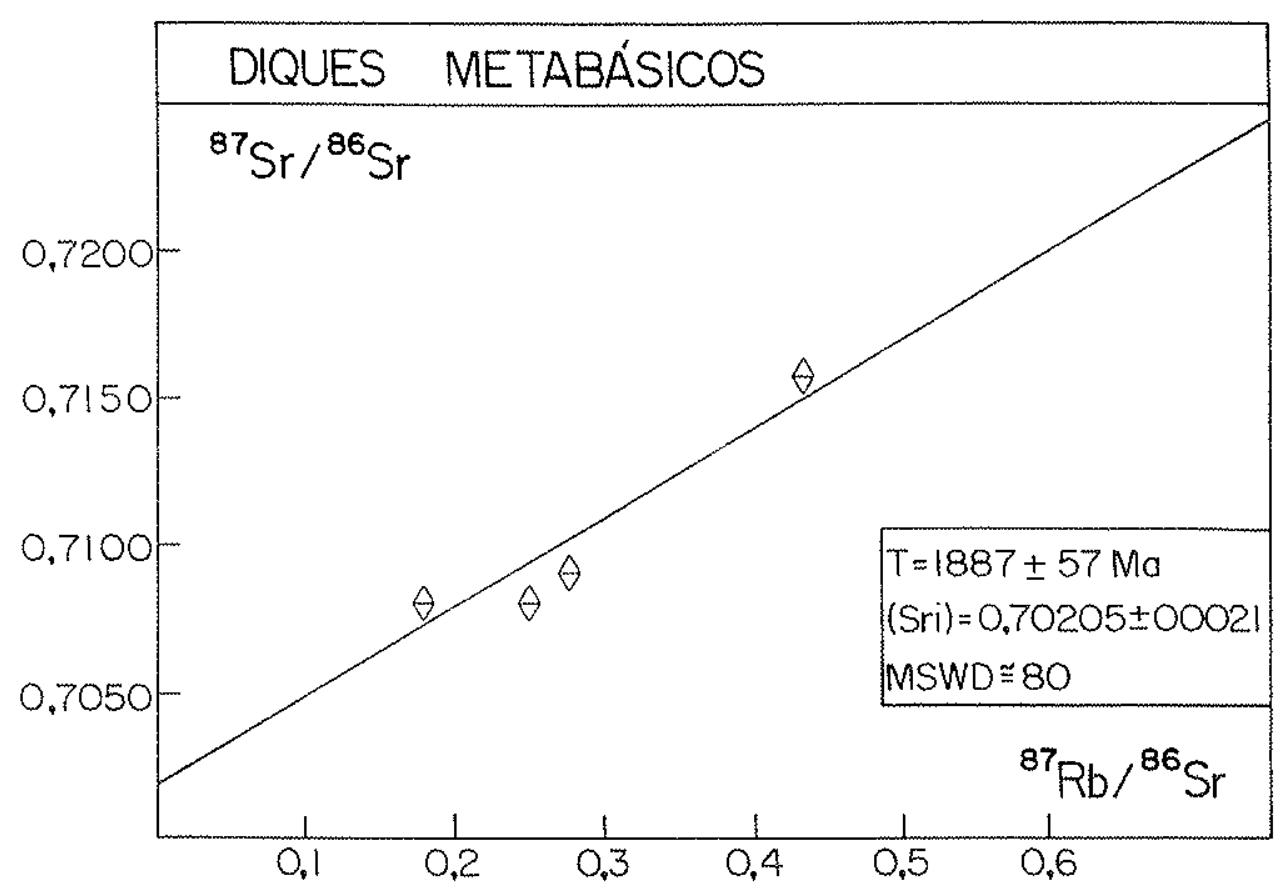

FIGURA VII.4: Diagrama isocrônico $\mathrm{Rb}$-Sr representativo dos diques metabásicos (DMB) pertencentes ao conjunto metamórfico da região de Lavras (MG).

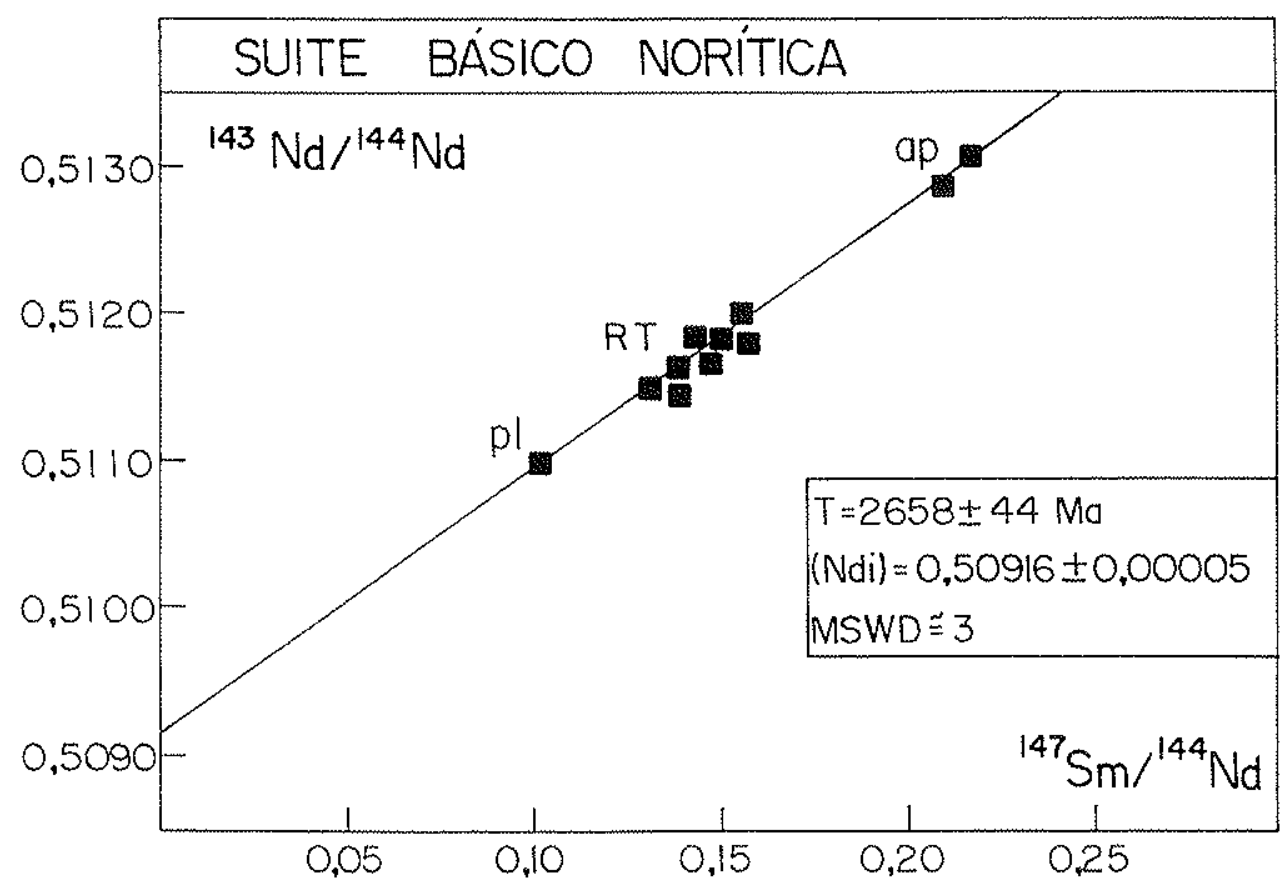

FIGURA VII.5: Diagrama isocrônico Sm-Nd representativo dos diques da suite básico norítica (iiㅁ) de Lavras (MG). Pl=plagioclásio; ap=apatita e RT=rocha total. 
conjunto com o baixo valor nesta razão apresentado pelo concentrado de plagioclásio, permitiram a boa colinearidade dos pontos e favoreceram a definição da isócrona. $\mathrm{A}$ isócrona $\mathrm{Sm}-\mathrm{Nd}$ obtida reafirma as inferências dos dados $\mathrm{Rb}-\mathrm{Sr}$, acerca da existência de um grupo de diques arqueanos na região, conforme inicialmente antecipado por Pinese et al (1995), com base em dados preliminares.

\begin{tabular}{|c|c|c|c|c|c|c|c|}
\hline \multicolumn{8}{|c|}{ SUITE BÁSICO NORÍTICA } \\
\hline $\begin{array}{l}\text { Amostra/Núme } \\
\text { ro do CPGeo }\end{array}$ & Sm & $\mathrm{Nd}$ & ${ }^{147} \mathrm{Sm} /{ }^{144} \mathrm{Nd}$ & Erro & ${ }^{143} \mathrm{Nd} /{ }^{144} \mathrm{Nd}$ & Erro $(2 \sigma)$ & $\mathrm{T}^{\mathrm{DM}}(\mathrm{Nd})[\mathrm{Ga}]$ \\
\hline $54 / 178$ & 2,080 & 8,570 & 0,1479 & 0,0001 & 0,511731 & 0,000023 & 2,81 \\
\hline $54-2 / \ldots$ & 2,021 & 8,075 & 0,1523 & 0,0001 & 0,511811 & 0,000015 & 2,82 \\
\hline $54 \mathrm{~b} / 428$ & 1,991 & 8,170 & 0,1483 & 0,0001 & 0,511792 & 0,0000021 & 2,72 \\
\hline $55 / 179$ & 1,930 & 7,640 & 0,1539 & 0,0001 & 0,511789 & 0,000042 & 3,00 \\
\hline $55 \cdot 2 /=-$ & 1,990 & 7,638 & 0,1585 & 0,0001 & 0,511802 & 0,000038 & 3,31 \\
\hline $64 / 180$ & 2,040 & 9,220 & 0,1349 & 0,0001 & 0,511527 & 0,000023 & 2,76 \\
\hline $64-2 / \ldots$ & 2,080 & 8,939 & 0,1416 & 0,0001 & 0,511621 & 0,000036 & 2,80 \\
\hline $25 / \ldots$ & 2,803 & 12,102 & 0,1410 & 0,0071 & 0,511586 & 0,000044 & 2,86 \\
\hline $28 / 282$ & 1,898 & 7,696 & 0,1501 & 0,0001 & 0,511778 & 0,000025 & 2,80 \\
\hline $70 / \ldots$ & 3,815 & 17,450 & 0,1330 & 0,0001 & 0,511842 & 0,000034 & 2,17 \\
\hline $112 / \ldots$ & 3,868 & 17,751 & 0,1326 & $0,000]$ & 0,511793 & 0,000033 & 2,24 \\
\hline 54 apatita / 284 & 0,522 & 1,453 & 0,2188 & 0,0006 & 0,513081 & 0,000028 & - nwm \\
\hline 64 plag. / 427 & 10,473 & 62,730 & 0,1016 & 0,0001 & 0,511052 & 0,000035 & $\ldots$ \\
\hline 64 apatita / 498 & 0,562 & 1,628 & 0,2100 & 0,0002 & 0,512812 & 0,000029 & - \\
\hline \multicolumn{8}{|l|}{ SUİTE BÁSICA } \\
\hline $19 / \ldots$ & 5,456 & 18,851 & 0,1761 & 0,0001 & 0,512311 & 0,000028 & 2,65 \\
\hline $27 / \ldots$ & 6,841 & 23,794 & 0,1749 & 0,0002 & 0,512109 & 0,000159 & 3,67 \\
\hline $60 / \cdots$ & 3,457 & 11,364 & 0,1851 & 0,0001 & 0,512444 & 0,000053 & 2,75 \\
\hline $45 / \ldots$ & 2,906 & 9,643 & 0,1833 & 0,0001 & 0,512523 & 0,000033 & 2,32 \\
\hline $34 /-\cdots$ & 5,761 & 19,509 & 0,1797 & 0,0002 & 0,512235 & 0,000099 & 3,56 \\
\hline $22 / \ldots$ & 5,140 & 18,239 & 0,1715 & 0,0001 & 0,512198 & 0,000028 & 2,75 \\
\hline $100 / \ldots$ & 5,866 & 20,328 & 0,1756 & 0,0001 & 0,512287 & 0,000036 & 2,70 \\
\hline
\end{tabular}

Tabela VII.4: Dados analíticos Sm-Nd obtidos por diluição isotópica, para o conjunto de diques das suites básico norítica e básica da região de Lavras. Plag.= plagioclásio. A tabela inclue idades modelo $\mathrm{T}^{\mathrm{l} \mathrm{M}}(\mathrm{Nd})$ das amostras analisadas em rocha total.

Desse modo, as rochas representativas da suite básico noritica são um dos primeiros registros de diques arqueanos, os quais em conjunto com o sill do "greenstone" de Piumhi (Machado \& Schrank, 1989) e Anfibolitos Paraopeba do Complexo Bonfim (Teixeira et al, 1996a), confirmam, por extrapolação, a antiguidade da crosta continental da porção sul do Cráton do São Francisco. Em regiões como Groenlândia (Hall \& Hughes, 1990), Antártica (Sheraton et al, 1987), Zimbabwe (Wilson et al, 1987) e Finlândia (Vuollo et al, 1995) suites 
noriticas se posicionam preferencialmente entre 2,1 a $2,5 \mathrm{Ga}$, em geral representando um fenômeno de cratonização.

\section{Suite básica}

Os diques da suite básica, não produziram uma variação suficiente nas razões (e.g. ${ }^{147} \mathrm{Sm} /{ }^{144} \mathrm{Nd}$ ) para fins de se obter um diagrama isocrônico. Contudo, as idades modelo $\mathrm{T}^{\mathrm{DM}}(\mathrm{Nd})$ calculadas para a suite básica variam entre 2,32 e 3,67 Ga (média de 2,91 \pm $0,50 \mathrm{Ga}$ ) [Tabela VII.4], sugerindo a natureza muito antiga do protólito.

Em geral, estas idades modelo $\mathrm{T}^{\mathrm{DM}}(\mathrm{Nd})$ [Tabela VII.4] são como as da suite básico norítica que se situa entre 2,17 e 3,31 Ga (média de 2,75 $\pm 0,32 \mathrm{Ga}$ ). As idades modelo $\mathrm{T}^{\mathrm{DM}}(\mathrm{Nd})$ do embasamento metamórfico local são um pouco mais elevadas do que aquelas dos diques, distribuindo-se no intervalo de 2,92 a 3,46 Ga (média de 3,11 $\pm 0,24 \mathrm{Ga}$ ) e coerentes com o contexto de uma derivação mantélica mais antiga. Uma possivel interpretação para este fato, é a de que o material mantélico se estabilizou na litosfera continental entre 200 a $400 \mathrm{Ma}$ depois da formação de grande parte da crosta.

Em sintese, os dados $\mathrm{K}-\mathrm{Ar}, \mathrm{Rb}-\mathrm{Sr}$ e $\mathrm{Sm}-\mathrm{Nd}$ disponiveis até o momento, mostram que o embasamento metamórfico arqueano da porção extremo sul do Cráton do São Francisco, é seccionado por duas gerações de diques máficos pré-cambrianos, afora os diques metabásicos e anfíbolíticos. A geração arqueana $(2.658 \mathrm{Ma})$ encontramse representada pelos diques da suite básico norítica, os quais podem estar associados as fases finais do Evento Rio das Velhas (Cameiro et al, 1995 e Carneiro, 1992) e devem ter se colocado depois de encerrado o processo colisional. A geração paleoproterozóica (1.875 Ma), constituída por diques da suite básica (dados $\mathrm{Rb}-\mathrm{Sr}$ ) e possivelmente pelos $\mathrm{DMB}$, haja visto os dados $\mathrm{K}$ - Ar e ${ }^{40} \mathrm{Ar}-{ }^{39} \mathrm{Ar}$ disponíveis para os últimos, relaciona-se ao desenvolvimento do Arco Magmático Mineiro (Teixeira, 1985 e Teixeira et al, 1996a) e seu processo intrusivo pelo menos para aqueles diques da suíte básica deve ter sido concomitante e pouco tempo após aos estágios finais da orogenia transamazônica, responsável pela evolução do referido arco magmático. É possivel especular-se que os DA sejam um pouco anteriores aos DMB e aqueles da suite básica, face aos dados radiométricos e uma vez que os primeiros podern ter se colocado na crosta em condições ainda compressivas ao passo que os últimos podem se relacionar a sistemas tracionais tipicos de final de orogenia. 


\section{VII.2 - Geoquímica Isotópica}

Com os valores de idades obtidos no item anterior, foram calculadas as razões iniciais de ${ }^{87} \mathrm{Sr} /{ }^{86} \mathrm{Sr}\left(\mathrm{Sr}_{\mathrm{i}}\right)$ e ${ }^{143} \mathrm{Nd} /{ }^{144} \mathrm{Nd}\left(\mathrm{Nd}_{\mathrm{i}}\right)$, e valores de $\varepsilon(\mathrm{Sr})$ e $\varepsilon(\mathrm{Nd})$ de cada amostra estudada. Estes valores encontram-se na Tabela VI1.5 e representam as suites básico norítica e básica, bem como rochas do embasamento metamórfico.

\section{Suíte Básico Noritica}

No diagrama que representa a evolução do Sr de acordo com o modelo do Reservatório Uniforme (UR) ou "Terra Global" (Fig.VII.6), se observa que os diques da suite básico norítica apresentam um amplo intervalo de $\mathrm{Sr}_{\mathrm{i}}\left(0,70009-0,70398\right.$ para $\left.\mathrm{t}_{0}=2,65 \mathrm{Ga}\right)$. Em geral, a maioria das amostras se posiciona acima da linha evolutiva da "Terra Global", com os valores de $\varepsilon(\mathrm{Sr})$ entre $+2,0$ e $+37,4\left(\mathrm{Sr}_{i}\right.$ entre 0,70150 e 0,70398, para $\left.\mathrm{t}_{0}=2,65 \mathrm{Ga}\right)$ [Tabela VII.5], o que sugere uma fonte enriquecida nas razões $\mathrm{Rb} / \mathrm{Sr}$. Nesse intervalo, encontram-se os tipos menos evoluidos da suíte, bem como a rocha com textura cumulática (amostra 72). Contudo, três amostras dos termos mais evoluídos da suite $(59,70$ e 112) indicam uma fonte empobrecida ( $\mathrm{Rb} / \mathrm{Sr}$ ) em relação à "Terra Global" [ $[\varepsilon(\mathrm{Sr})$ entre -15 e -18 , Tabela VII.5]. No detalhe da Figura VII.6, observa-se que estas amostras apresentam razões $\mathrm{Rb} / \mathrm{Sr}$ maiores $(0,16)$ do que a "Terra Global", com valores opostos a àqueles esperados.

No âmbito dos isótopos de Nd (Fig. VII.7), verificamse que os diques da suite básico noritica apresentam um intervalo nas razões $\mathrm{Nd}_{i}$ predominantemente entre 0,50903 e 0,50920 (para $t_{0}=2,65 \mathrm{Ga}$ ), cujos valores de $\varepsilon(\mathrm{Nd})$ encontram-se entre $-0,6$ a $-3,9$ (Tabela VII.5). Verifica-se também, que a maioria das amostras estudadas posiciona-se um pouco abaixo ou na linha evolutiva da "Terra Global" (CHUR), sugerindo uma fonte empobrecida nas razões $\mathrm{Sm} / \mathrm{Nd}$. Duas amostras $[70$ e 112: $\varepsilon(\mathrm{Nd})=+5,6$ e $+4,8$ respectivamente, Tabela VII.5], representativas dos termos mais evoluidos da suíte, sugerem uma fonte enriquecida nas razões $\mathrm{Sm} / \mathrm{Nd}$ em relação à "Terra Global". Tais amostras, contrariando o esperado, apresentam razões Sm/Nd $(0,22)$ menores do que a "Terra Global" (detalhe da Figura VII.6).

Os valores dos $\varepsilon(\mathrm{Nd})$ vs $\varepsilon(\mathrm{Sr})$ [Fig.VII.8], indicam que os diques da suite básico norítica predominantemente derivaram de uma fonte enriquecida em comparacão à "Terra Global". Duas amostras plotam-se no quadrante empobrecido. Adicionalmente, o diagrama sugere a possibilidade de interação dos magmas por parte de crosta siálica arqueana 


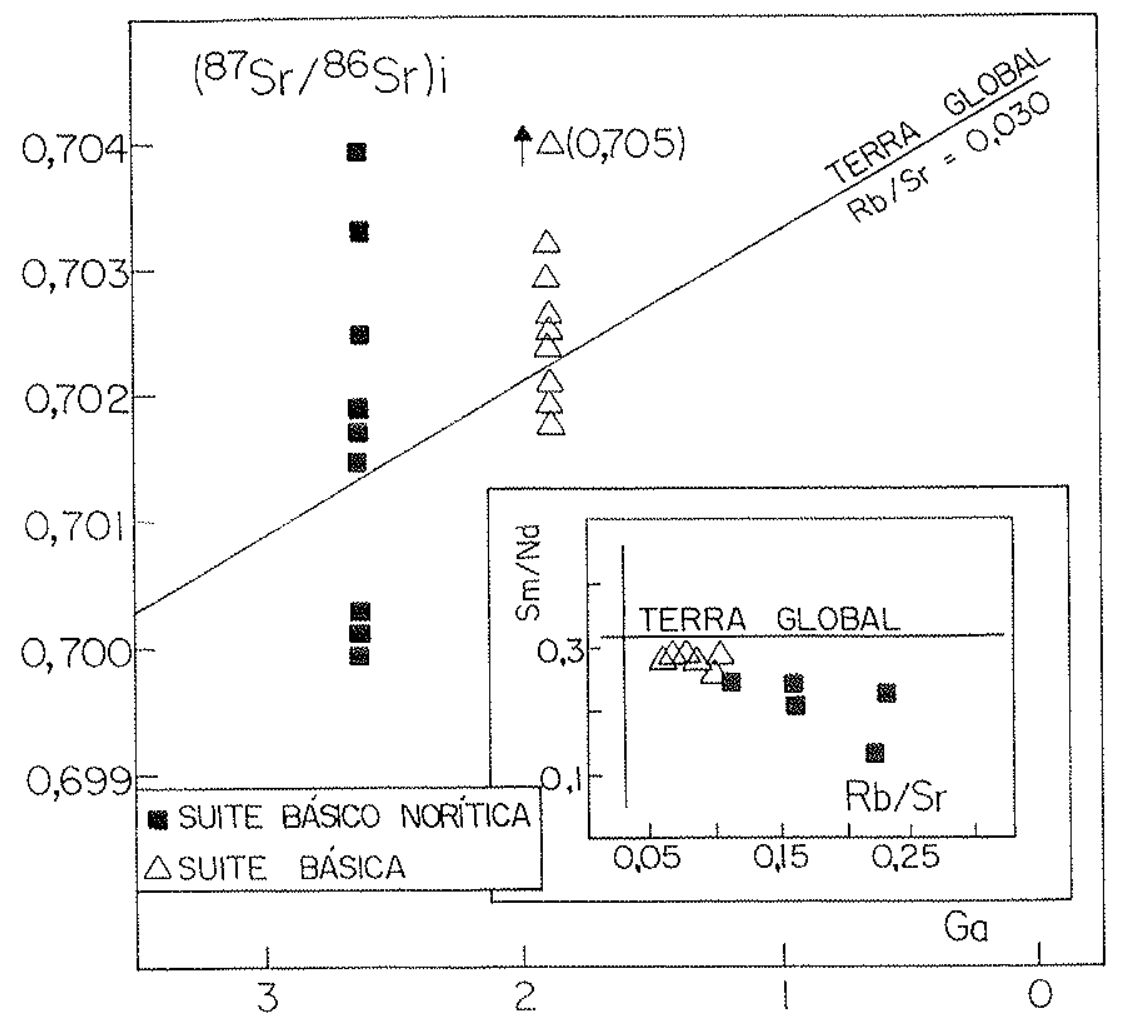

FIGURA VII.6: Diagrama da evolução isotópica do $\mathrm{Sr}\left({ }^{87} \mathrm{Sr} /{ }^{86} \mathrm{Sr}\right.$ inicial) no tempo geológico para os diques das suítes básico noritica (露) e básica $(\Delta)$ da região de Lavras. Razão $\mathrm{Sm} / \mathrm{Nd} \cong 0,308$; ${ }^{87} \mathrm{Sr} /{ }^{86} \mathrm{Sr}$ primordial $=0,69898 ;{ }^{87} \mathrm{Sr} /{ }^{86} \mathrm{Sr}$ atual $=0,7045$ (Faure, 1986).

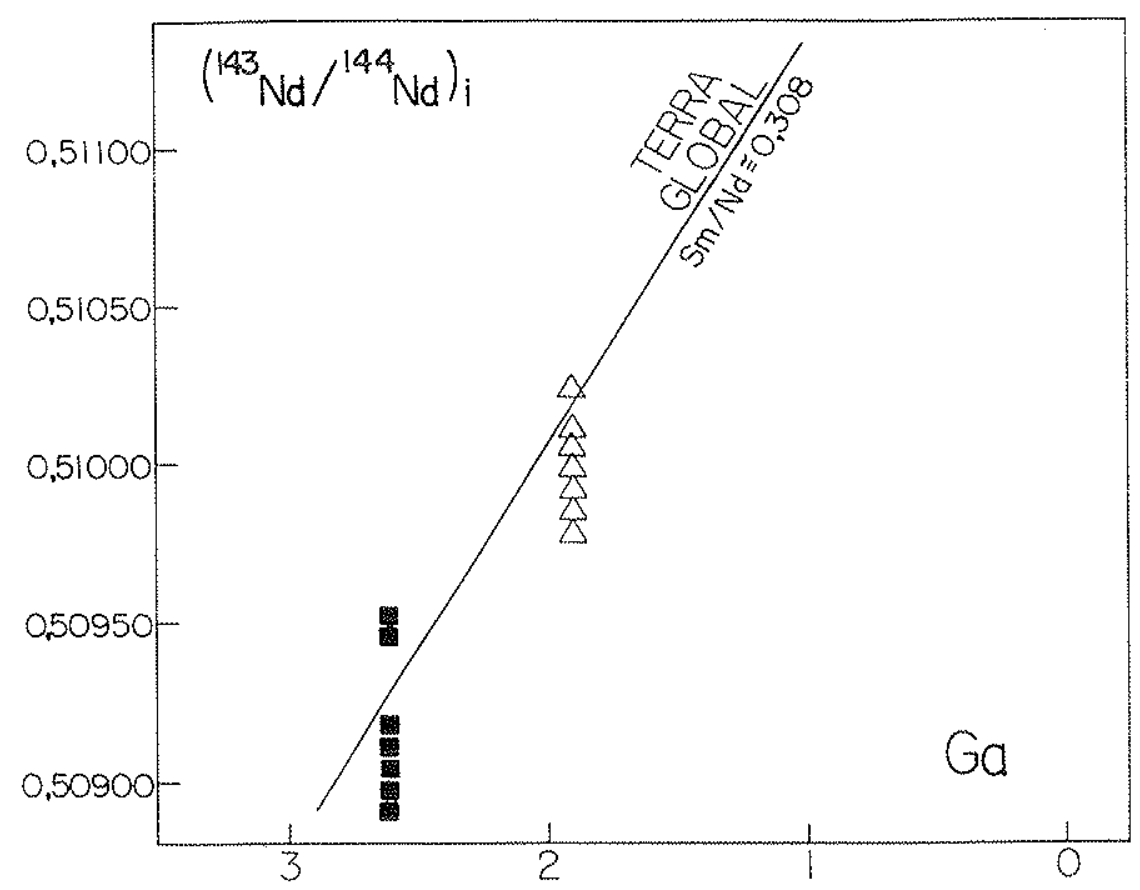

FIGURA VII.7: Diagrama da evolução isotópica do $\mathrm{Nd}\left({ }^{143} \mathrm{Nd} /{ }^{144} \mathrm{Nd}\right.$ inicial) no tempo geológico, para os diques das suites básico norítica e básica da região de Lavras. ${ }^{143} \mathrm{Nd} /{ }^{144} \mathrm{Nd}$ primordial = 0,$50677 ;{ }^{143} \mathrm{Nd} /{ }^{144} \mathrm{Nd}$ atual $=0,512638($ Faure, 1986). Simbolos e legenda como na figura VII. 6. 


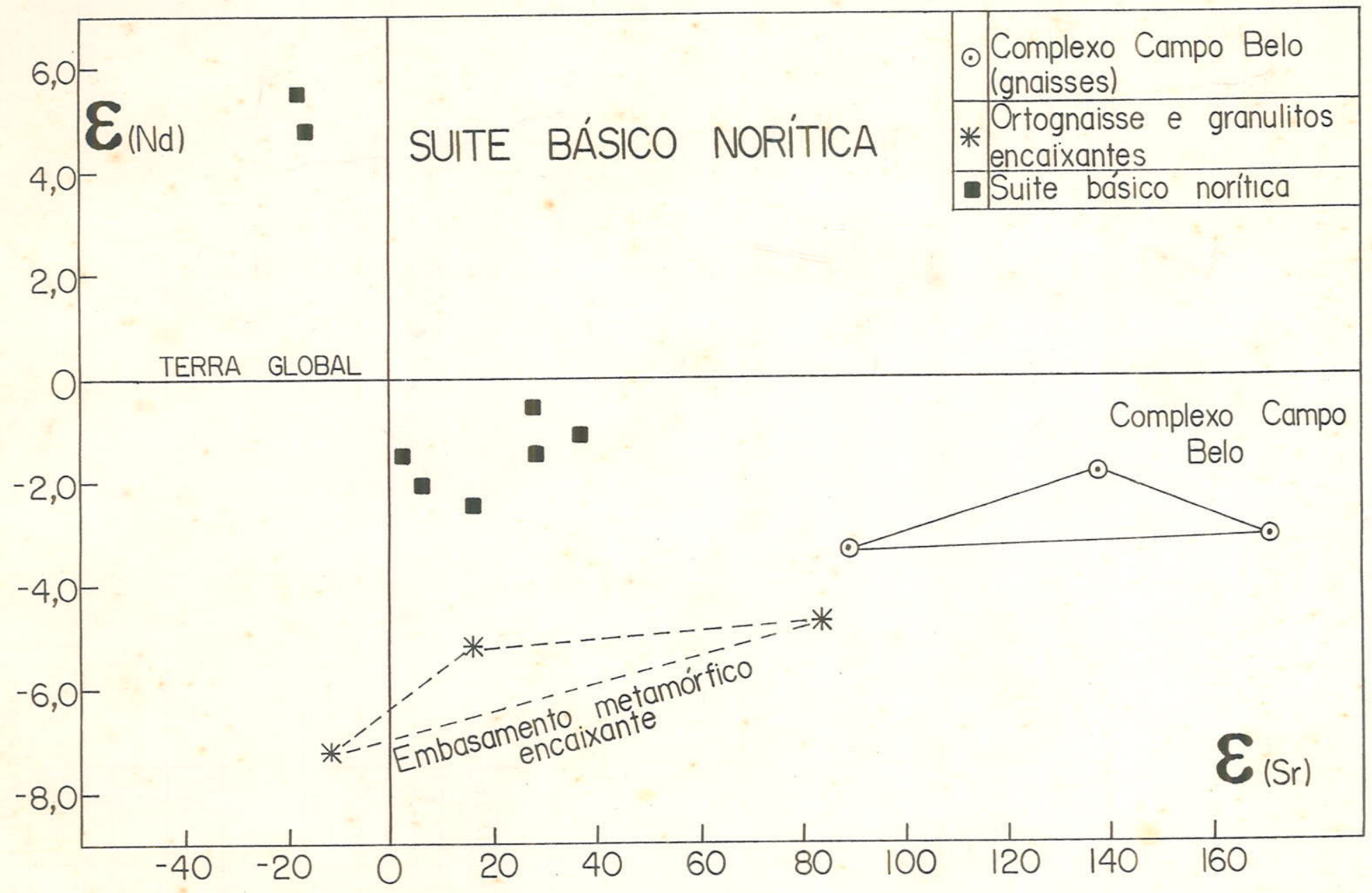

FIGURA VII.8: Diagrama $\varepsilon(\mathrm{Nd})$ vs $\varepsilon(\mathrm{Sr})$ com valores recalculados para idade de 2,65 Ga representativos dos diques da suíte básico norítica de Lavras ( Belo. Os valores atuais da "Terra Global": ${ }^{87} \mathrm{Sr} /{ }^{86} \mathrm{Sr}=0,7045$ e ${ }^{143} \mathrm{Nd} /{ }^{144} \mathrm{Nd}=0,512638$ (Faure, 1986). Fonte de dados: presente trabalho e Teixeira et al (1996 a e b). 
durante o processo intrusivo. Esta interação, poderia estar relacionada com os materiais de composição isotópica semelhantes ao ortognaisse e granulitos encaixantes e/ou em parte do gnaisse do Complexo Campo Belo (Teixeira et al, 1996 a e b) adjacente a àrea investigada $[\varepsilon(\mathrm{Nd})=-7,3$ a $-3,4 ; \varepsilon(\mathrm{Sr})=-11,9$ a $+91,2]$. Entretanto, esta interação no sentido de assimilação crustal tipo AFC (DePaolo, 1981), não é respaldada pelas correlações entre as razões de $\mathrm{Sr}_{i}$ e $\mathrm{Nd}_{i}$ vs $\mathrm{SiO}_{2}, \mathrm{~K}_{2} \mathrm{O}, \mathrm{Ba}, \mathrm{Rb}$ e $\mathrm{Sr}$ (Figura VII.9).

SUITTE BÁSICO NORÍTICA (2,65 Ga)

\begin{tabular}{|c|c|c|c|c|c|c|c|}
\hline Amostra & $\mathrm{Rb} / \mathrm{Sr}$ & $\mathrm{Sm} / \mathrm{Nd}$ & $\left({ }^{87} \mathrm{Sr} /{ }^{86} \mathrm{Sr}\right) \mathrm{i}$ & $\left({ }^{143} \mathrm{Nd} /{ }^{144} \mathrm{Nd}\right) \mathrm{i}$ & $\varepsilon(\mathrm{Sr})$ & $\varepsilon(\mathrm{Nd})$ & $\mathrm{T}^{\mathrm{DM}}(\mathrm{Nd})[\mathrm{Ga}]$ \\
\hline 54 & 0,16 & 0,24 & 0,70331 & 0,50915 & 28,0 & $-1,6$ & 2,81 \\
\hline $54-2$ & ----- & 0,25 & $\begin{array}{ll}-\cdots \\
-\cdots\end{array}$ & 0,50915 & $-\cdots$ & $-1,5$ & 2,82 \\
\hline $54 \mathrm{~b}$ & $-\cdots$ & 0,24 & $-\cdots$ & 0,50920 & $-\cdots$ & $-0,6$ & 2,72 \\
\hline 55 & 0,11 & 0,25 & \begin{tabular}{|l|}
0,70247 \\
\end{tabular} & 0,50910 & 16,0 & $-2,5$ & 3,00 \\
\hline $55-2$ & \begin{tabular}{|l|}
$-\cdots-$ \\
\end{tabular} & 0,26 & ---- & 0,50903 & ---- & $-3,9$ & 3,31 \\
\hline 64 & 0,14 & 0,22 & \begin{tabular}{|l|}
0,70398 \\
\end{tabular} & 0,50917 & 37,4 & $-1,1$ & 2,76 \\
\hline $64-2$ & \begin{tabular}{|l|}
--- \\
\end{tabular} & 0,23 & $\begin{array}{ll}--- \\
\end{array}$ & 0,50915 & $-\cdots$ & $-1,6$ & 2,80 \\
\hline 72 & 0,16 & $-\cdots$ & 0,70184 & $\ldots$ & 7,0 & ----- & $-\cdots$ \\
\hline 25 & 0,23 & 0,23 & 0,70174 & 0,50912 & 6,1 & $-2,1$ & 2,86 \\
\hline 28 & 0.11 & 0,25 & 0,70150 & 0,50915 & 2,0 & $-1,5$ & 2,80 \\
\hline 59 & 0,16 & --- & 0,70030 & $\ldots$ & $-15,0$ & $-\cdots$ & $\ldots$ \\
\hline 112 & 0,16 & 0,22 & 0,70017 & 0,50948 & $-16,8$ & 4,8 & 2,24 \\
\hline 70 & 0,16 & 0,22 & 0,70009 & 0,50952 & $-18,0$ & 5,6 & 2,17 \\
\hline 54 apatita & ----- & 0,36 & $-\ldots$ & 0,50926 & ---- & 0,7 & $\cdots$ \\
\hline $\begin{array}{l}64 \\
\text { plagioclásio }\end{array}$ & ----- & 0,17 & --- & 0,50928 & -- & 0,9 & $-\cdots$ \\
\hline 64 apatita & ---- & 0,34 & $-\cdots$ & 0,50914 & $-\ldots$ & $-1,6$ & $\ldots$ \\
\hline
\end{tabular}

\section{SUÍTE BÁSICA (1,9 Ga)}

\begin{tabular}{|l|l|l|l|l|l|l|l|}
\hline 19 & 0,06 & 0,29 & 0,70253 & 0,51011 & 3,7 & $-1,7$ & 2,65 \\
\hline 27 & 0,10 & 0,29 & 0,70255 & 0,50992 & 4,0 & $-5,3$ & 3,67 \\
\hline 60 & 0,06 & 0,30 & 0,70318 & 0,51013 & 13,0 & $-1,3$ & 2,75 \\
\hline 18 & 0,07 & ---- & 0,70181 & ---- & $-6,4$ & ---- & --- \\
\hline 45 & 0,06 & 0,30 & 0,70245 & 0,51023 & 2,7 & $-0,6$ & 2,32 \\
\hline 34 & 0,07 & 0,30 & 0,70186 & 0,50999 & $-5,9$ & $-4,0$ & 3,56 \\
\hline 30 & 0,06 & ---- & 0,70299 & ---- & 10,4 & --- & $-\cdots$ \\
\hline 100 & 0,08 & 0,29 & 0,70179 & 0,51009 & $-6,9$ & $-2,0$ & 2,70 \\
\hline 22 & 0,10 & 0,28 & 0,70511 & 0,51005 & 40,4 & $-2,7$ & 2,75 \\
\hline
\end{tabular}

\section{EMBASAMENTO METAMÓRFICO (2,65 Ga)}

\begin{tabular}{|l|l|l|l|l|l|l|l|}
\hline 150 & 0,03 & 0,17 & 0,70251 & 0,50896 & 16,3 & $-5,3$ & 3,04 \\
\hline 142 & 0,98 & 0,18 & 0,70720 & 0,50899 & 83,1 & $-4,7$ & 3,00 \\
\hline 39 & 1,32 & 0,16 & 0,64442 & 0,50902 & -812 & $-4,0$ & 2,92 \\
\hline 91 & 0,04 & 0,22 & 0,70054 & 0,50886 & $-11,9$ & $-7,3$ & 3,46 \\
\hline 133 & 0,02 & ---- & 0,70049 & ---- & $-12,2$ & ---- & ---- \\
\hline wt 12 1b $\left(^{*}\right)$ & 0,31 & 0,16 & 0,71353 & 0,50907 & 173,3 & $-3,2$ & 2,88 \\
\hline wt 4 $\left(^{*}\right)$ & 0,16 & 0,15 & 0,71092 & 0,50914 & 136,2 & $-1,8$ & 2,78 \\
\hline wt 6 a $\left(^{*}\right)$ & 0,24 & 0,18 & 0,70781 & 0,50906 & 91,2 & $-3,4$ & 2,92 \\
\hline
\end{tabular}

Tabela VII.5: Razões iniciais ${ }^{87} \mathrm{Sr} /{ }^{86} \mathrm{Sr}$ e ${ }^{143} \mathrm{Nd} /{ }^{144} \mathrm{Nd}$, $\varepsilon$ de $(\mathrm{Sr})$ e $(\mathrm{Nd})$, razões $\mathrm{Rb} / \mathrm{Sr}$ e $\mathrm{Sm} / \mathrm{Nd}$ e idades modelo $\mathrm{T}^{\mathrm{DM}}(\mathrm{Nd})$ dos diques máficos das suites básico norítica e básica da região de Lavras, bem como das rochas do embasamento metamórfico local e adjacente. $\left(^{*}\right)=$ Amostras do Complexo Campo Belo adjacente, com valores extraídos de Teixeira et al (1996a e b). 


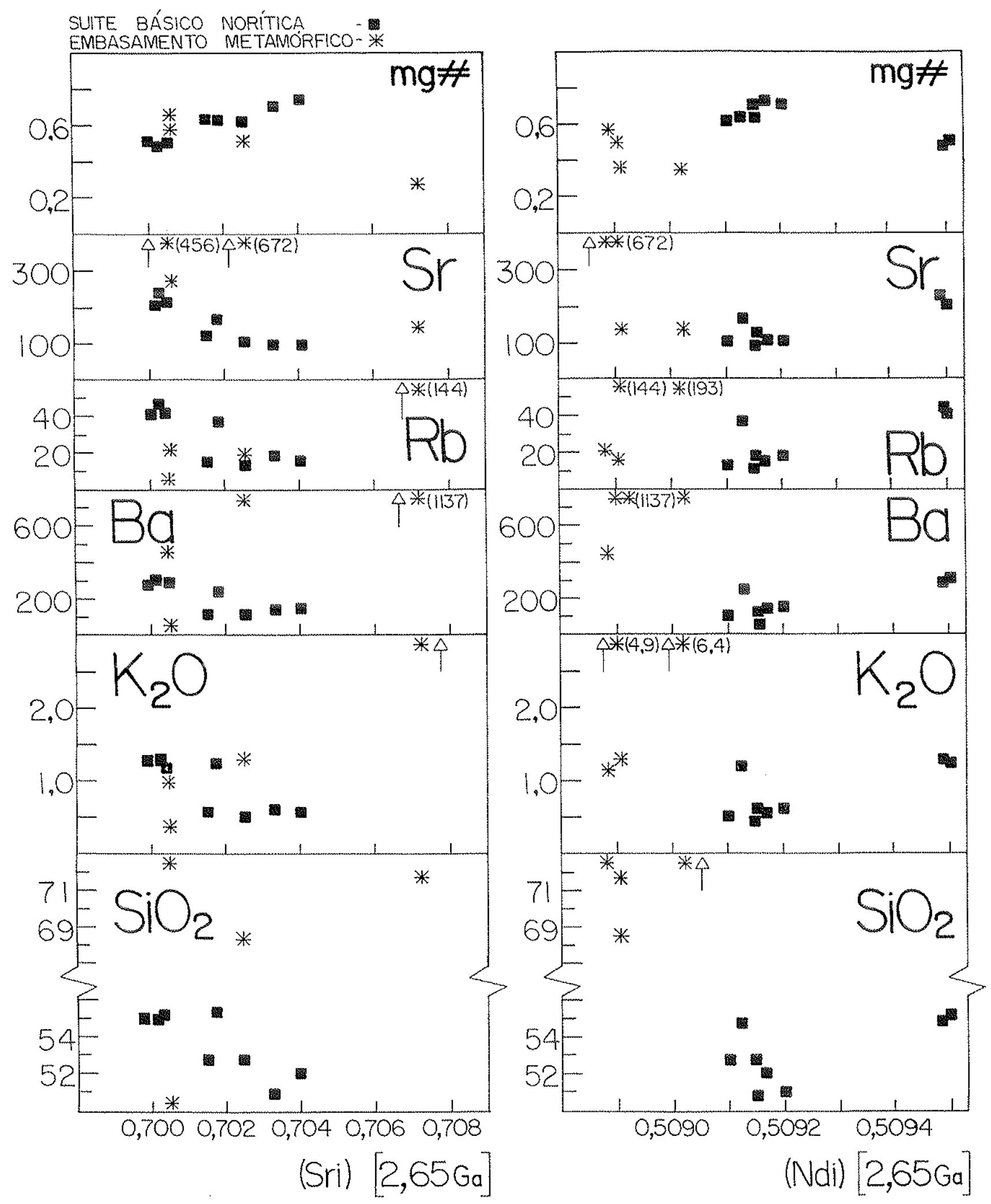

FIGURA VII.9: Razões iniciais ${ }^{87} \mathrm{Sr} /{ }^{86} \mathrm{Sr}$ (Sri) e ${ }^{143} \mathrm{Nd} /{ }^{144} \mathrm{Nd}$ (Ndi) versus $\mathrm{SiO}_{2}, \mathrm{~K}_{2} \mathrm{O}, \mathrm{Ba}$, Rb, Sr e mg\# dos diques da suite básico norítica ( e do embasamento metamórfico encaixante (*) da região de Lavras. Valores recalculados para $t_{0}=2,65 \mathrm{Ga}$. 
Em suma, os dados isotópicos e geoquimicos sugerem para a suite básico norítica, a existência de dois grupos distintos de magmas, que não foram afetados de maneira significativa por processos de interação crustal siálica durante o processo intrusivo.

Vale ressaltar neste contexto, a possibilidade da atuação de "processos metassomáticos" subcontemporaneamente ao processo de fusão da suíte básico norítica, os quais teriam provocado um enriquecimento de $\mathrm{Rb}$ em relação ao $\mathrm{Sr}$ e de $\mathrm{Nd}$ em relação ao $\mathrm{Sm}$ nas amostras que do ponto de vista isotópico plotam-se no quadrante empobrecido (cf. Tabela VII.5). Casos que envolvam "processos metassomáticos" subcontemporaneamente ao processo de fusão, também tem sido relatados para enxames de diques como aqueles do Uruguai (Bossi et al, 1993; Mazzucchelli et al, 1995) e da região llhéus-Olivença na Bahia, este último, situado na porção setentrional do Cráton do São Francisco (Bellieni et al, 1991).

\section{Suíte Básica}

Os diques da suíte básica apresentam intervalo de variação nas razões $\mathrm{Sr}_{\mathrm{i}}$ entre 0,70181 e 0,70318, com valores de $\varepsilon(\mathrm{Sr})$ entre $-6,4$ a +13 (para $t_{0}=1,9 \mathrm{Ga}$ ) [Tabela VII.5]. Além disso, há uma amostra (22) cujo $\mathrm{Sr}_{\text {; }}$ é de 0,70511 e $\varepsilon(\mathrm{Sr})$ igual a 40 . No diagrama de evolução do Sr com o tempo (Fig.VII.6), verifica-se que a maioria das amostras plota-se acima da linha evolutiva da "Terra Global", indicativo de uma fonte enriquecida nas razões $\mathrm{Rb} / \mathrm{Sr}$. Três amostras $(18,34$ e 100) se posicionam um pouco abaixo da referida linha, com valores de $\varepsilon(\mathrm{Sr})$ negativos $(-6,4 ;-5,9$ e $-6,9)$ [Tabela VII.5].

No diagrama de evolução do Nd com o tempo (Fig. VII.7), observamse que os diques da suite básica posicionam-se abaixo do padrão evolutivo da "Terra Global", no intervalo de razões $\mathrm{Nd}_{\text {; }}$ entre 0,50992 e $0,51013\left[\mathrm{\varepsilon}(\mathrm{Nd})=-5,3 \mathrm{a}-1,3\right.$, para $\left.\mathrm{t}_{0}=1,9 \mathrm{Ga}\right]$. Apenas a amostra 45 encontra-se posicionada um pouco acima do referido padrão evolutivo $\left[\mathrm{Nd}_{\mathrm{i}}=\right.$ $0,51023 ; \varepsilon(\mathrm{Nd})=0,6]$. Em geral, as características isotópicas indicam para a suite básica uma fonte com valores relativamente baixos nas razões $\mathrm{Sm} / \mathrm{Nd}$.

A evolução conjunta Nd vs Sr (Fig.VII.10), indica que os diques da suite básica devem ter se originado de uma fonte enriquecida comparativamente à "Terra Global". Algumas amostras (e.g. 27 e 22) mostram tendência em se deslocarem para o conjunto dos granulitos e ortognaisses encaixantes $[\varepsilon(\mathrm{Nd})=-5,3$ a $-7,3]$, sugerindo uma possível contaminação crustal. 


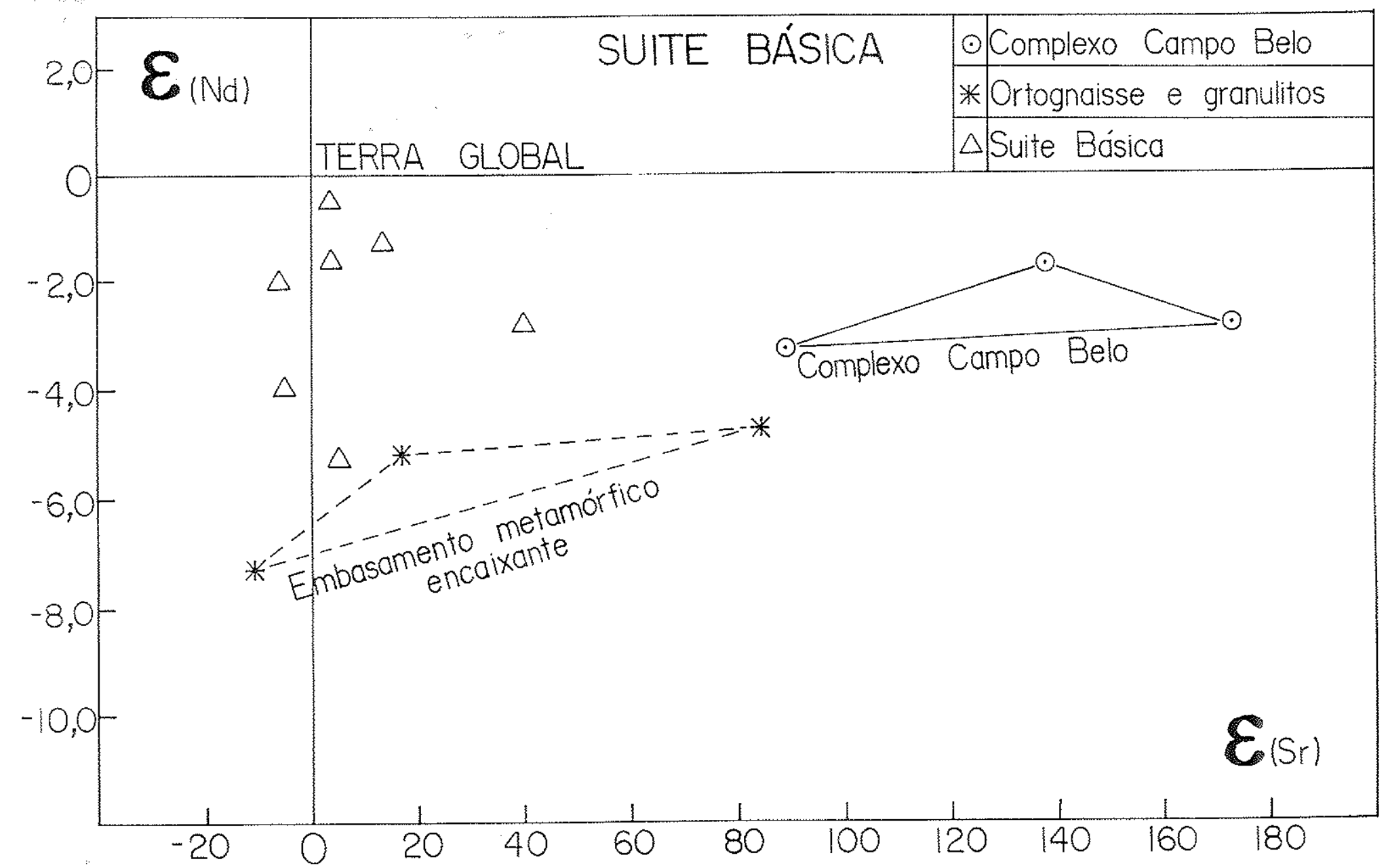

FIGURA VII. 10: Diagrama $\varepsilon(\mathrm{Nd})$ vs $\varepsilon(\mathrm{Sr})$ com valores recalculados para idade de $1,9 \mathrm{Ga}$ representativos dos diques da suite básica de Lavras $(\Delta)$, rochas encaixantes do embasamento metamórfico local e gnaisses adjacentes do Complexo Campo Belo. Valores atuais da "Terra Global". ${ }^{87} \mathrm{Sr} /{ }^{86} \mathrm{Sr}=0,7045 \mathrm{e}{ }^{143} \mathrm{Nd} /{ }^{144} \mathrm{Nd}=0,512638$ (Faure, 1986). Fonte de dados: presente trabalho e Teixeira et al (1996 a e b). 
Todavia, nos diagramas das razões de $\mathrm{Sr}_{i}$ e $\mathrm{Nd}_{i}$ vs $\mathrm{SiO}_{2}, \mathrm{~K}_{2} \mathrm{O}, \mathrm{Ba}, \mathrm{Rb}$ e $\mathrm{Sr}$ (Fig. VII.11), não se verificam indícios contundentes da atuação de processos de assimilação crustal envolvendo diques da suite básica. Em geral, estes diagramas (Fig. VII.11), mostram que a correlação é inexistente no âmbito das razões de $\mathrm{Sr}_{\mathrm{i}}$. No caso das razões de $\mathrm{Nd}_{i}$ observase uma correlação negativa com $\mathrm{Rb}$ e $\mathrm{Ba}$, a qual não se confirma para outros elementos (e.g. $\mathrm{SiO}_{2}, \mathrm{Sr}$ ). Adiciona-se, que os valores de $\mathrm{Rb}$ (18 a 144 ppm) e Ba (442 a 1137 ppm) das rochas do embasamento são muito elevados e extremamente diferentes dos diques. Em sintese, identifica-se apenas um conjunto isotópico na suite básica, o qual não deve ter sido afetado significativamente por processos de assimilação crustal.

Finalizando, como anteriormente salientado, os valores de $\varepsilon(\mathrm{Nd})$ e $\varepsilon(\mathrm{Sr})$ associados a dados químicos, indicam que a maioria dos diques das duas suites investigadas não foi afetada por processos de assimilação crustal. Contudo, os valores de $\varepsilon(\mathrm{Sr})$ maiores ou iguais a 30 e os valores de $\varepsilon(\mathrm{Nd})$ menores ou iguais a 4 , podem sugerir processos de interação crustal com materiais seja enriquecido $[\varepsilon(\mathrm{Sr})]$ como empobrecido $[\varepsilon(\mathrm{Sr})]$ em relação a "Terra Global" (Fig. VII.12). Diante do exposto, para avaliar as características da fonte magmática serão consideradas principalmente as amostras que estão contidas nos campos $\mathrm{A}$ e $\mathrm{B}$ da Figura VII.12.

\section{VII - ASPECTOS PETROGENÉTICOS}

\section{VIII.1 - Cristalização Fracionada}

Como anteriormente evidenciado pelo comportamento geoquímico tanto para elementos maiores quanto para os traços, os diques das suites básica e básico noritica, em geral, são compativeis qualitativamente com magmas em evolução através de um processo de cristalização fracionada a baixa pressão.

Com o objetivo de avaliar quantitativamente este processo de diferenciação, foram realizados cálculos de balanço de massa para elementos maiores, respeitando-se o grau de evolução das amostras (cf. Stormer \& Nicholls, 1978) para definir os possiveis caminhos evolutivos de cada suite envolvida. 


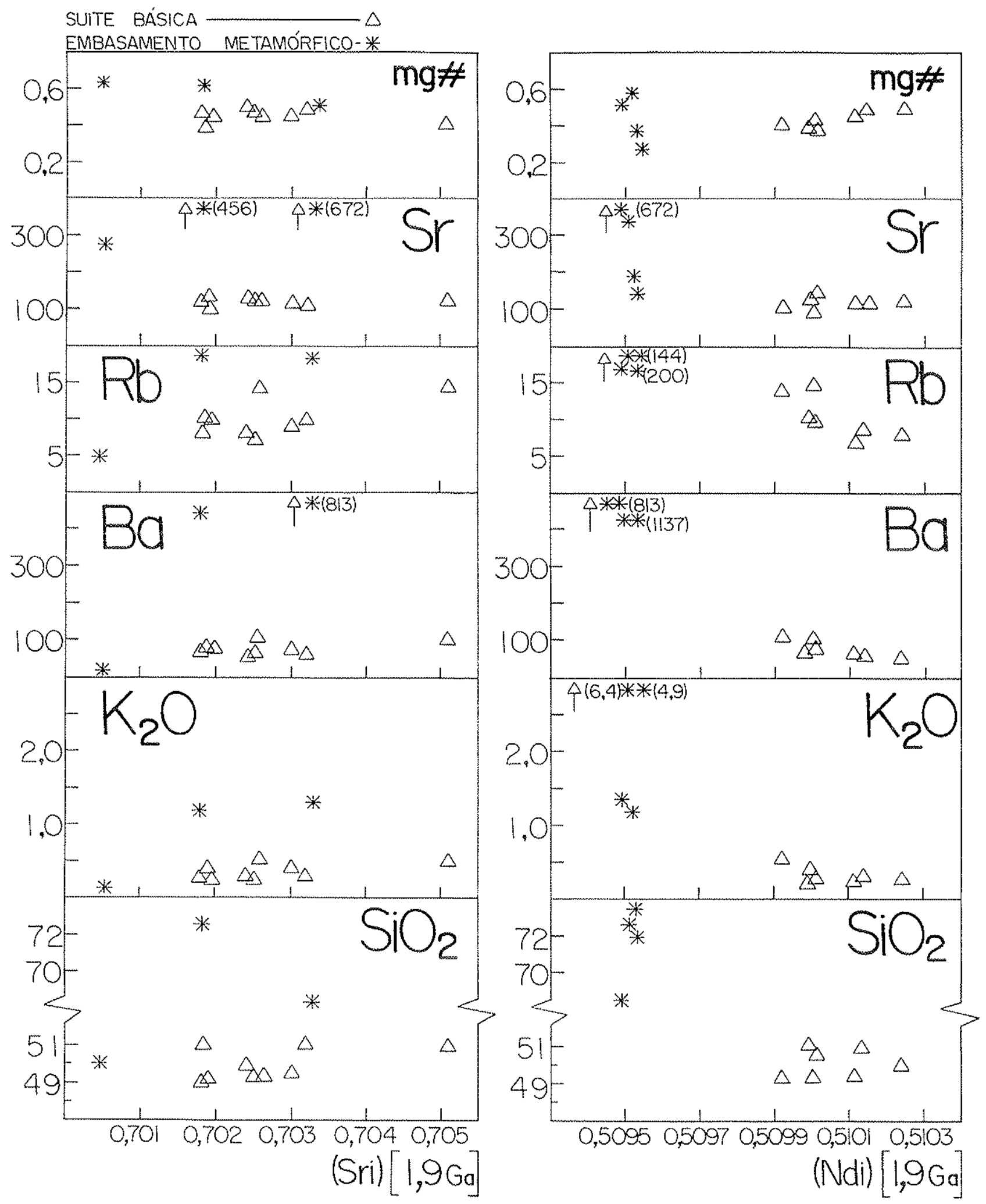

FIGURA VII 11: Razões iniciais ${ }^{87} \mathrm{Sr} /{ }^{86} \mathrm{Sr}$ (Sri) e ${ }^{143} \mathrm{Nd} /{ }^{144} \mathrm{Nd}$ (Ndi) versus $\mathrm{SiO}_{2}, \mathrm{~K}_{2} \mathrm{O}, \mathrm{Ba}, \mathrm{Rb}, \mathrm{Sr}$ e mgł dos diques da suite básica $(\Lambda)$ e do embasamento metamórfico encaixante (*) da região de Lavras. Valores recalculados para $\mathrm{t}_{0}=1,9 \mathrm{Ga}$. 


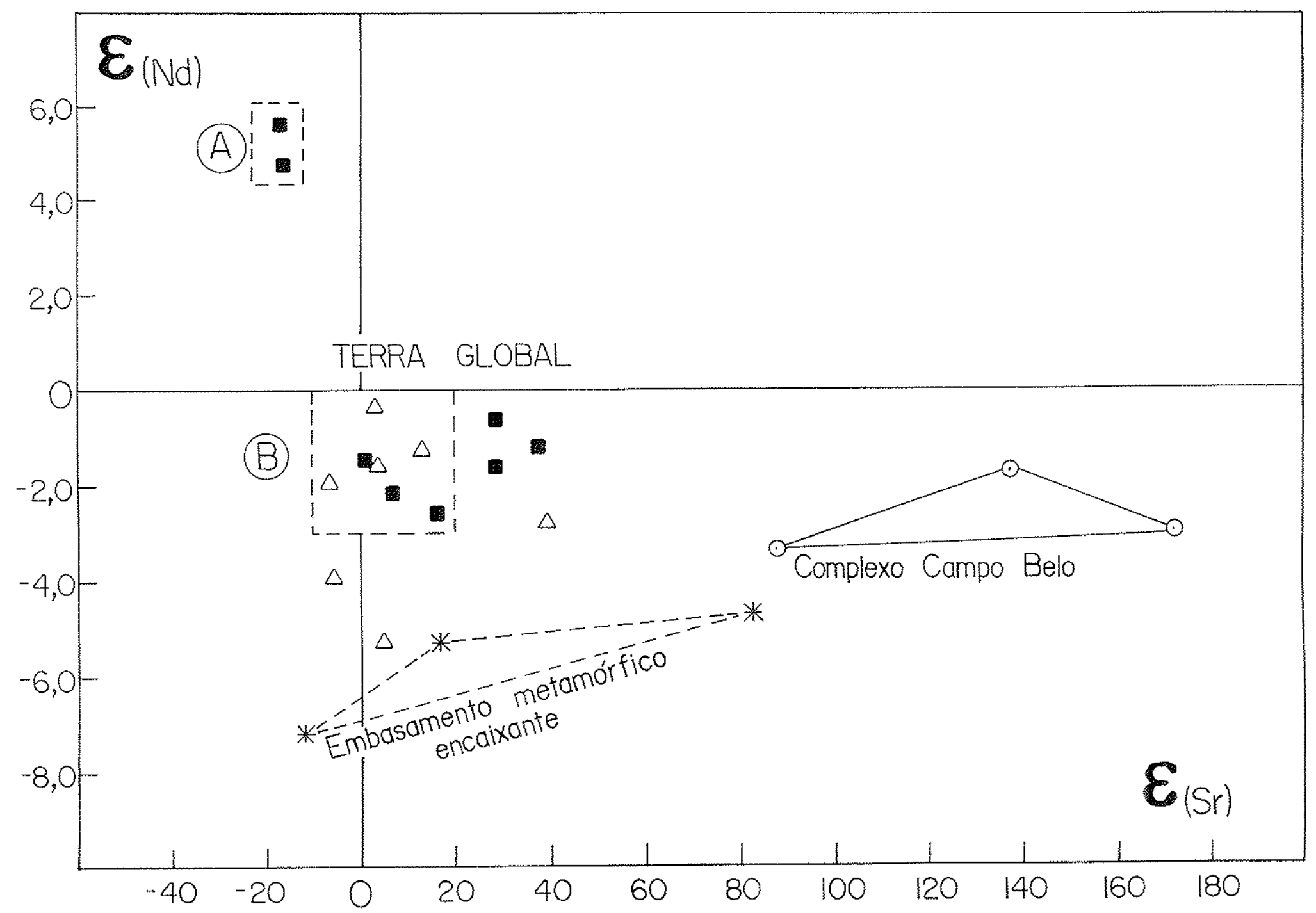

FIGURA VII.12: Diagrama $\varepsilon(\mathrm{Nd})$ vs $\varepsilon(\mathrm{Sr})$ representativo dos diques das suítes básico norítica (需) e básica $(\Delta)$, e das rochas do embasamento metamórfico local e adjacente. Os valores de $\varepsilon$ do embasamento e da suite básico norítica foram recalculados a $2,65 \mathrm{Ga}$, enquanto os valores da suíte básica foram recalculados a $1,9 \mathrm{Ga}$. O quadro $\mathrm{A}$ contém as amostras 70 e 112 da suíte básico norítica. $\mathrm{O}$ quaưro $\mathrm{B}$ contém as amostras 25 , 28 e 55 da suíte básico norítica e $19,45,60$ e 100 da suite básica. "Terra Global" atual: ${ }^{87} \mathrm{Sr} /{ }^{86} \mathrm{Sr}=0.7045$ e ${ }^{143} \mathrm{Nd} /{ }^{144} \mathrm{Nd}=0,512638$ (Faure, 1986). Simbolos e legendas como nas figuras VII.8 e VII. 10. Fonte de dados: presente trabalho e Teixeira et al (1996 a e b). 
As fases minerais utilizadas são aquelas observadas na petrografia, e suas composições quimicas encontram-se nas tabelas concernentes ao item Química Mineral. A composição da olivina $\left(\mathrm{Fo}_{89}\right)$ foi obtida da literatura (Deer et al, 1992). Esta composição (Fo89), foi calculada levando-se em consideração o indice evolutivo da amostra 64 [mg\# $(0,15)=0,724]$ e um coeficente de partição de Fe e Mg entre olivina e líquido igual a 0,30 (Roeder \& Emslie, 1970).

Em geral, o ajuste para os elementos maiores no processo de cristalização fracionada é considerado bom ou ótimo quando na somatória do quadrados dos residuos ( $\Sigma$ res $^{2}$ ) os valores são inferiores a 0,5 e 0,2 respectivamente. Para sustentar o mencionado processo efetuou-se os cálculos para o ajuste dos elementos traços. Para tal, utilizou se a equação prevista pela lei de fracionamento de Rayleigh e os coeficentes de partição sólido/líquido para os diversos elementos, cujos dados encontram-se na Tabela VIII.1. Estes dados, se referem a suítes toleiticas e foram extraídos de Marques (1988) e Antonini (1995). Geralmente, o ajuste é considerado razoável, bom e ótimo quando os percentuais dos erros relativos, que representam os valores das concentrações calculadas divididas pelas concentrações observadas, não ultrapassem 30\%,20\% e 10\%, respectivamente.

\begin{tabular}{|l|l|l|l|l|l|l|}
\hline & Kd (OI) & Kd (Cpx) & Kd (Pig) & Kd (Opx) & Kd (PI) & Kd (Mt) \\
\hline $\mathbf{L a}$ & 0,01 & 0,11 & 0,02 & 0,03 & 0,18 & 0,24 \\
\hline $\mathbf{C c}$ & 0,01 & 0,15 & 0,03 & 0,03 & 0,14 & 0,22 \\
\hline $\mathbf{N d}$ & 0,01 & 0,30 & 0,04 & 0,03 & 0,10 & 0,23 \\
\hline $\mathbf{Y}$ & 0,01 & 0,40 & 0,20 & 0,30 & 0,02 & 0,40 \\
\hline $\mathbf{N b}$ & 0,04 & 0,07 & 0,03 & 0,03 & 0,04 & 0,30 \\
\hline $\mathbf{Z r}$ & 0,04 & 0,20 & 0,08 & 0,08 & 0,07 & 0,30 \\
\hline $\mathbf{B a}$ & 0,01 & 0,05 & 0,03 & 0,01 & 0,40 & 0,20 \\
\hline $\mathbf{R b}$ & 0,05 & 0,02 & 0,02 & 0,01 & 0,10 & 0,09 \\
\hline $\mathbf{S r}$ & 0,01 & 0,20 & 0,03 & 0,02 & 1,80 & 0,08 \\
\hline $\mathbf{C r}$ & 2,40 & 6,00 & 11,0 & 14,9 & 0,06 & 69,0 \\
\hline $\mathbf{N i}$ & 14,0 & 5,00 & 8,00 & 9,33 & 0,06 & 15,0 \\
\hline
\end{tabular}

Tabela VIII. 1: Valores dos coeficentes de partição sólido/líquido para as diferentes fases minerais utilizadas nos ajustes dos elementos traços nas suítes básica e básico noritica. $\mathrm{Kd}=$ coeficente de partição, $\mathrm{Ol}=$ olivina, $\mathrm{Cpx}=$ clinopiroxênio, $\mathrm{Pig}=$ pigeonita, $\mathrm{Opx}=$ ortopiroxênio, $\mathrm{Pl}=$ plagioclásio e $\mathrm{Mt}=$ magnetita. Fonte: Marques (1988) e Antonini (1995).

\section{Suíte Básico Noritica}

Na suite básico noritica que é dominada por fase fêmica (olivina, piroxênios e \pm magnetitas), os resultados relativos aos elementos maiores e traços para os diques com a 
mesma assinatura isotópica, indica que a evolução é compatível com um processo de cristalização fracionada (cf. Tabela VIII.2).

As melhores passagens obtidas para elementos maiores definiram duas possiveis "trajetórias" evolutivas para a suite básico norítica, a saber (Tab. VIII.2): $64 \Rightarrow 41$ $\Rightarrow[25$ ou 38$]$ e $54 \Rightarrow 41 \Rightarrow[25$ ou 38]. Em geral, o ajuste pode ser classificado como ótimo, pois a soma dos quadrados dos resíduos não ultrapassa 0,15 (veja Tabela VIII.2).

Suite Básico Noritica

\begin{tabular}{|c|c|c|c|c|c|c|c|c|}
\hline Passagen & Ol $\%$ & $O_{p x} \%$ & $\mathrm{Cpx} \%$ & Pig \% & $\mathrm{Pl} \%$ & Mt $\%$ & F & $\left(\sum \operatorname{res}^{2}\right)$ \\
\hline $64 \Rightarrow 4 !$ & $16\left(F_{089}\right)$ & $32(64 \mathrm{opx})$ & $13(64 \mathrm{cpx})$ & $\ldots$ & $35(64 \mathrm{pl})$ & $5(55 \mathrm{nt})$ & 0,67 & 0,14 \\
\hline $41 \Rightarrow 25$ & w.m. & $39(28$ opx $)$ & $24(28 \mathrm{cpx})$ & $-\cdots$ & $34(28 \mathrm{pl})$ & $3(55 \mathrm{mt})$ & 0,74 & 0,14 \\
\hline $41 \Rightarrow 38$ & $\ldots$ & $62(250 p x)$ & $11(25 \mathrm{cpx})$ & $\ldots$ & $25(25 \mathrm{pl})$ & $2(55 \mathrm{mt})$ & 0,75 & 0,15 \\
\hline $54 \Rightarrow 41$ & $38\left(l^{\circ}\left(0_{89}\right)\right.$ & $1(540 p x)$ & $11(54 \mathrm{cpx})$ & $\cdots$ & $43(54 \mathrm{pl})$ & $8(55 \mathrm{mit})$ & 0,72 & 0,13 \\
\hline
\end{tabular}

Suíte Básica

\begin{tabular}{|l|l|l|l|l|l|l|l|l|}
\hline $37 \Rightarrow 32$ & -- & $\cdots \cdots$ & $16(60 \mathrm{cpx})$ & $24(45 \mathrm{pig})$ & $54(37 \mathrm{pl})$ & $6(45 \mathrm{ml})$ & 0,61 & 0,50 \\
\hline $32 \Rightarrow 34$ & -- & $-\cdots-$ & $24(45 \mathrm{cpx})$ & $16(45 \mathrm{pig})$ & $55(45 \mathrm{pl})$ & $5(45 \mathrm{ml})$ & 0,62 & 0,22 \\
\hline $90 \Rightarrow 19$ & $\cdots$ & $-\cdots$ & $24(60 \mathrm{cpx})$ & $14(45 \mathrm{pig})$ & $56(37 \mathrm{pl})$ & $6(45 \mathrm{mt})$ & 0,44 & 0,41 \\
\hline $19 \Rightarrow 44$ & --- & $-\cdots$ & $18(19 \mathrm{cpx})$ & $15(45 \mathrm{pig})$ & $62(19 \mathrm{pl})$ & $5(100 \mathrm{mt})$ & 0,67 & 0,31 \\
\hline $90 \Rightarrow 100$ & - & $-\cdots$ & $22(60 \mathrm{cpx})$ & $16(45 \mathrm{pig})$ & $56(37 \mathrm{pl})$ & $6(45 \mathrm{mt})$ & 0,40 & 0,38 \\
\hline $100 \Rightarrow 27$ & $-\cdots$ & $-\cdots$ & $36(19 \mathrm{cpx})$ & $8(27 \mathrm{pig})$ & $52(100 \mathrm{pl})$ & $4(100 \mathrm{mi})$ & 0,85 & 0,06 \\
\hline
\end{tabular}

Tabela VIII.2: Resultados obtidos na aplicação do modelo de cristalização fracionada para os diques das suítes básica e básico norítica. $\mathrm{Ol}=$ olivina, $\mathrm{Opx}=$ ortopiroxênio, $\mathrm{Cpx}=$ clinopiroxênio, $\mathrm{Pig}=$ pigeonita, $\mathrm{Pl}=$ plagioclásio, $\mathrm{Mt}=$ magnetita, $\mathrm{F}=$ fração líquida residual, $(\Sigma$ $\left.\operatorname{res}^{2}\right)=$ somatória dos quadrados dos resíduos relativos a elementos maiores. $(60 \mathrm{cpx}$, pig, etc) $=$ fases minerais utilizadas (amostra 60) cujas composições encontram-se no apêndice 2.

Entretanto, a qualidade dos ajustes para os elementos traços não pode ser considerada como boa, haja visto a significativa dispersão de valores obtidos entre as concentrações calculadas sobre concentrações observadas (Fig. VIII.1). Este fato, é relacionado a valores bem diferentes das razões entre os elementos traços incompativeis. De fato, ao se analisar detalhadamente o comportamento dos elementos traços nos diagramas de variação do $\mathrm{Zr}$ ( Fig. VI.7), verifica-se uma ampla dispersão das amostras da suite básico norítica, dado por valores muito diferentes nas razões destes elementos (e.g. $\mathrm{Zr} / \mathrm{La}=5,3$ a 8,9). Desse modo, nas "trajetórias" evolutivas cujas amostras apresentam a mesma razão Zr vs traços, o ajuste é ótimo e torna-se cada vez pior a medida que a diferença entre estas razões aumentam. Um exemplo na suíte básico noritica, pode ser dado pela "trajetória" $41 \Rightarrow 25$ (Fig. VIII.1), cujos valores nas razões $\mathrm{Zr} / \mathrm{La}(5,4$ vs 5,4$)$ e $\mathrm{Zr} / \mathrm{Ce}(3,3$ vs 3,0) [Fig. VI.7] são próximos e o ajuste tanto para o La quanto para o Ce podem ser considerados ótimos. A 
mesma "trajetória" apresenta razões $\mathrm{Zr} / \mathrm{Y}$ muito diferentes $(2,7$ vs 4,3) propiciando um ajuste péssimo para o elemento $Y$ (conc. calculada/conc. observada $=1,75$ )[Fig. VIII.1].

Cabe notar, que as concentrações calculadas para $\mathrm{Cr}$ e $\mathrm{Ni}$, invariavelmente afastam-se dos valores observados (Fig. VIII.1). Em geral, este comportamento pode estar relacionado ao fracionamento de sulfetos

\section{Suite Básica}

Para os diques da suite básica, onde os plagioclásios devem ter sido mais importantes no processo de cristalizaçăo fracionada, o balanço de massa também indica uma evolução compativel com a separação dos fenocristais presentes nesta suíte (cf. Tabela VIII.2)

Três possiveis "trajetórias" evolutivas foram definidas pelos elementos maiores: a) $37 \Rightarrow 32 \Rightarrow 34$; b) $90 \Rightarrow 19 \Rightarrow 44$ e c) $90 \Rightarrow 100 \Rightarrow 27$. A soma dos quadrados dos residuos situa-se predominantemente entre 0,2 e 0,5 e o ajuste pode ser qualificado como bom (veja Tabela VIII.2).

$\mathrm{Na}$ suite básica, no âmbito dos elementos traços, bons ajustes podem ser observados nas "trajetórias" $32 \Rightarrow 34$ e $100 \Rightarrow 27$ (Fig. VIII.1). Contudo, as demais "trajetórias" mostram-se razoáveis (i.e. $19 \Rightarrow 44$ ) ou péssimas (e.g. $37 \Rightarrow 32$ ). Em geral, um determinado elemento (e.g. Nb) não apresenta os mesmos valores de concentrações calculadas sobre observadas, nas diferentes "trajetórias" evolutivas que possam ser consideradas boas ou razoáveis (Fig. VIII. 1).

Do mesmo modo que a suíte básico noritica, a análise detalhada do comportamento destes elementos nos diagramas Zr vs traços (Fig.VI.7), revela que eles apresentam significativas diferenças em suas razões na passagem evolutiva de uma amostra para outra. Via de regra, tais amostras não se alinham para formar uma reta passando pela origem. $\mathrm{Na}$ "trajetória" da amostra 90 para a amostra 100 (Fig VI.7) o alinhamento é perfeito para o $\mathrm{Y}$ (razões $\mathrm{Zr} / \mathrm{Y}$ similares: 3,6 vs 3,6) e conseqüentemente verifica-se um bom ajuste para este elemento (Fig. VIII.1). Vale salientar que na mesma "trajetória" (90 $\Rightarrow 100)$, não se observa o alinhamento das amostras para o $\mathrm{Nb}$ (razões $\mathrm{Zr} / \mathrm{Nb}$ diferentes: 10,2 vs 15,1) propiciando um ajuste de péssima qualidade (Fig. VIII.1).

Como anteriomente assinalado, $\mathrm{Cr}$ e $\mathrm{Ni}$ sempre apresentam ajustes de péssima qualidade podendo estar associado ao fracionamento de sulfetos. 

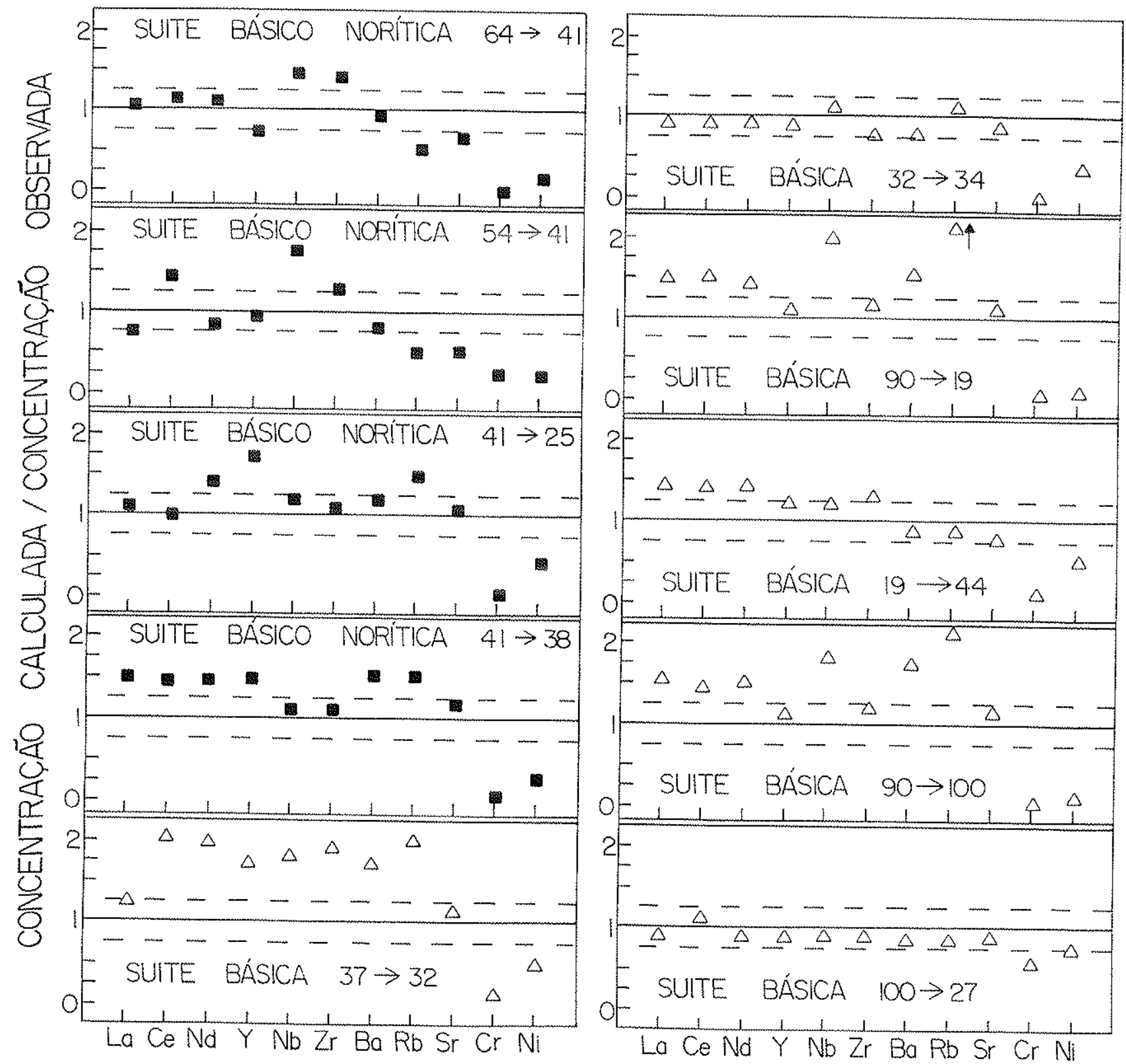

FIGURA VIII. 1: Razões entre as concentrações de elementos traços calculadas e observadas nas passagens selecionadas para os diques das suites básico norítica (1) e básica $(\Delta)$ da região de Lavras (MG). 
Em sintese, a evolução das suites básica e básico noritica estão de acordo com um processo de cristalização fracionada (cf. elementos maiores), a partir de magmas genitores distintos do ponto de vista composicional (i.e. pequena heterogeneidade), no âmbito de cada suíte. Isto é suportado pelas variações nos valores das razões $\mathrm{Zr}$ vs traços, que indicam fontes diferentes tanto para a suite básica como para a básico norítica (i.e. heterogeneidade composicional em maior escala). Vale ressaltar, que os cálculos realizados não apoiam a hipótese de que a evolução da suite básica, teria se dado a partir da suíte básico norítica e vice-versa.

\section{VIII.2 - Inferências sobre a natureza da fonte}

No estudo geoquímico (Cap. VI.3) verificou-se que os diques prém cambrianos da região investigada, são representados pelas suites básica e básico norítica, as quais apresentam entre si significativas diferenças no quimismo. Em geral, aqueles da suite básico noritica mostram-se mais enriquecidos, por exemplo, em $\mathrm{SiO}_{2}, \mathrm{~K}_{2} \mathrm{O}, \mathrm{Rb}, \mathrm{Sr}$ e $\mathrm{Ba}$ relativamente aos da suite básica.

Com o objetivo de obter algumas informações adicionais acerca do quimismo e da natureza das fontes que originaram os diques das suites envolvidas, foram efetuados os padrões de distribuição de elementos menores e traços normalizados ao manto primitivo proposto por Sun \& McDonough (1989). Para tal, utilizaram-se amostras anteriormente caracterizadas como não contaminadas na crosta (Cap. VII.2), a saber: a) suite básico norítica: amostras 25,28 e 55 posicionadas no quadrante $[\varepsilon(\mathrm{Nd})$ vs $\varepsilon(\mathrm{Sr})]$ enriquecido (próximas a "Terra Global") e as amostras 70 e 112 posicionadas no quadrante empobrecido; b) suite básica: amostras 19,45,60 e 100 posicionadas no quadrante enriquecido, próximas a "Terra Global" (Fig VII.12).

\section{Suite Básico Norítica}

Em geral, a suíte básico norítica é caracterizada pelas anomalias negativas de $\mathrm{Nb}, \mathrm{P}, \mathrm{Sm}$ e Ti (Fig. VIII.2). As razões $\mathrm{La}_{\mathrm{N}} / \mathrm{Nb}_{\mathrm{N}}$ apresentam valores entre 1,09 a 1,94, com média de $1,52 \pm 0,32$. 


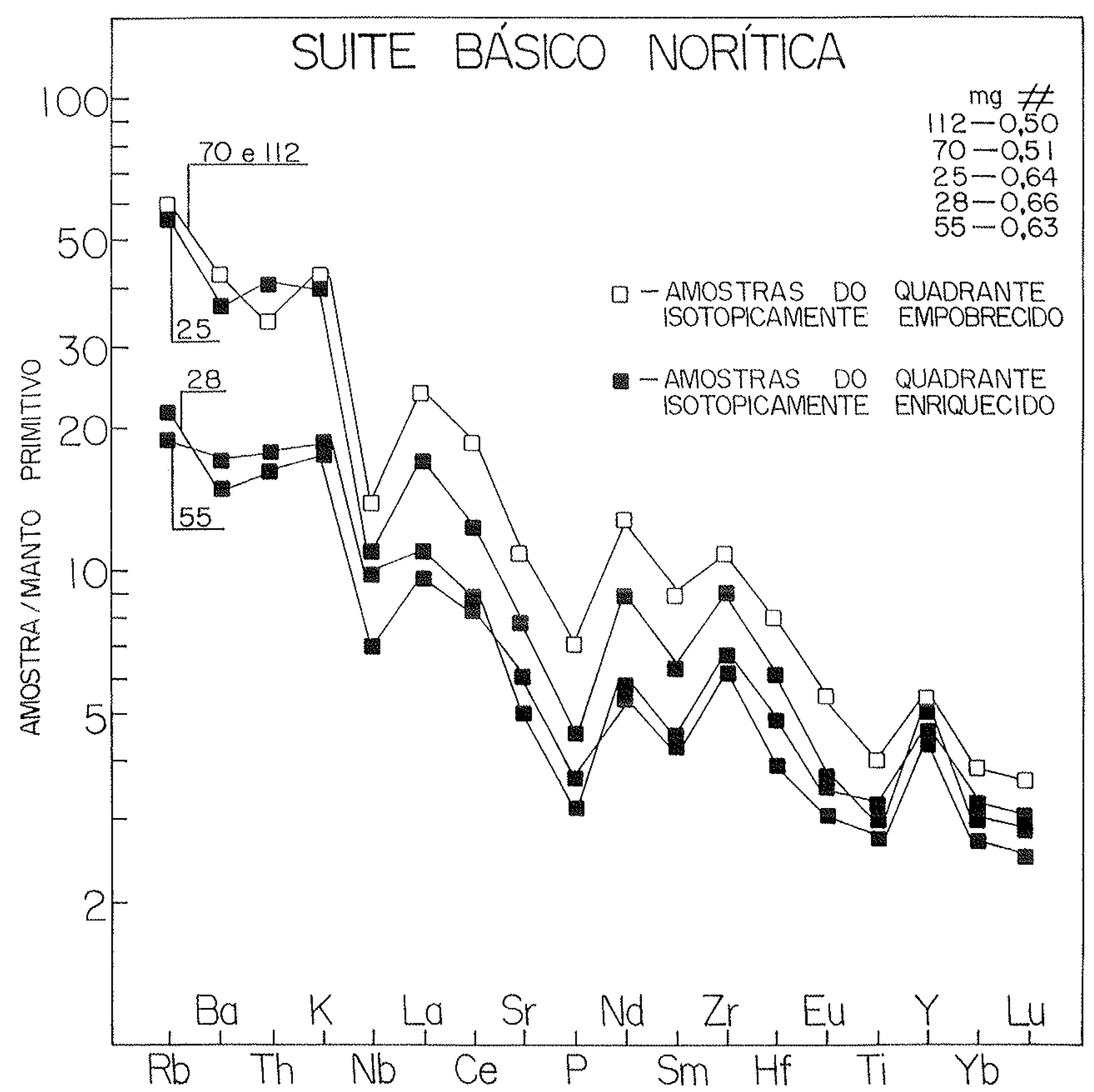

FIGURA VIII.2: Padrões de abundância de elementos menores e traços incompativeis normalizados em relação ao manto primitivo (Sun \& McDonough, 1989) das amostras isotopicamente selecionadas pertencentes aos diques da suíte básico noritica ( $\square$ - quadrante empobrecido e - quadrante enriquecido) da região de Lavras (MG). Os valores de mg\# $\left[\mathrm{Mg}^{+2} / \mathrm{Mg}^{+2}+\mathrm{Fe}^{+2}\left(\mathrm{Fe}_{2} \mathrm{O}_{3} / \mathrm{FeO}=0,15\right)\right]$ para cada amostra estão indicados no canto superior direito da figura. $\mathrm{Ba}, \mathrm{K}, \mathrm{Nb}, \mathrm{P}, \mathrm{Zr}$, Ti e Y obtidos por fluorescência de raios-X (FRX); La, Ce, Eu, Yb, $\mathrm{Lu}$, Th e Hf obtidos por ativação neutrônica (INAA); $\mathrm{Rb}, \mathrm{Sr}, \mathrm{Sm}$ e $\mathrm{Nd}$ obtidos por diluição isotópica (DI). 
$\dot{\mathrm{E}}$ importante destacar, que estas características são observadas seja para as amostras do grupo situadas no quadrante isotopicamente empobrecido (Fig. VIII.2), como para o grupo das amostras situadas no quadrante isotopicamente enriquecido.

Observa-se que a amostra 25 (grupo enriquecido) está situada bem próxima das amostras do grupo empobrecido (70 e 112), mesmo sendo menos evoluida [mg $\#=0,64]$ do que aquelas do grupo empobrecido $[\mathrm{mgH}=0,50$ e 0,51] (Fig. VIII.2).

Como anteriormente evidenciado (veja ETR), este tipo de diagrama revela que houve um processo de enriquecimento em elementos mais incompativeis, o qual deve ter ocorrido subcontemporaneamente ao processo de fusão que gerou os diques do grupo isotopicamente empobrecido, ou de maneira precedente como no processo de fusão responsável pelo grupo isotopicamente enriquecido.

As anomalias negativas de $\mathrm{Nb}$ e os valores relativamente elevados das razões $\mathrm{La}_{N} / \mathrm{Nb}_{\mathrm{N}}$, indicam para a suíte básico noritica uma fonte que em tempos anteriores a fusão pode ter sofrido contaminação por material crustal (e.g. associados a antigos processos de subducção). Alternativamente, pode se pensar em uma fonte com minerais do tipo "titanatos" (e.g. rutilo, ilmenita, esfeno), os quais reteriam no residuo após fusão parte substancial das concentrações de Ta e Nb (e.g. Hellman \& Green, 1979; McCulloch \& Gamble, 1991; Rivalenti et al, 1995).

\section{Suite Básica}

$\mathrm{Na}$ suite básica verificam-se significativas anomalias negativas de $\mathrm{Ba}, \mathrm{K}, \mathrm{Sr}$, Sm e Eu (Fig. VIII.3). As razões $\mathrm{La}_{\mathrm{N}} / \mathrm{Nb}_{\mathrm{N}}$ variam entre 0,93 a 1,08 e a média obtida é de 1,02 $\pm 0,06$. Vale ressaltar, que isotopicamente as amostras da suite básica posicionam-se próximas a "Terra Global" e que evolutivamente são muito similares [mg\# $=0,44$ a 0,49$]$.

No âmbito dos elementos mais incompativeis, observa-se uma anomalia positiva de Th relativamente ao Ba e K (Fig. VIII.3). Observa-se também, as anomalias negativas de Sr e Eu, as quais demonstram a importância do fracionamento do plagioclásio nesta suite.

Para a suíte básica, a anomalia tendencialmente positiva de $\mathrm{Nb}$ e os valores das razões $L a_{N} / N b_{N}$ próximas a 1,0, não favorecem a hipótese de uma fonte que tenha sofrido significativa participação de material crustal. Estes dados não favorecem também, a hipótese de uma fonte cujo resíduo após fusão mostra-se enriquecido em minerais do tipo "titanatos". 


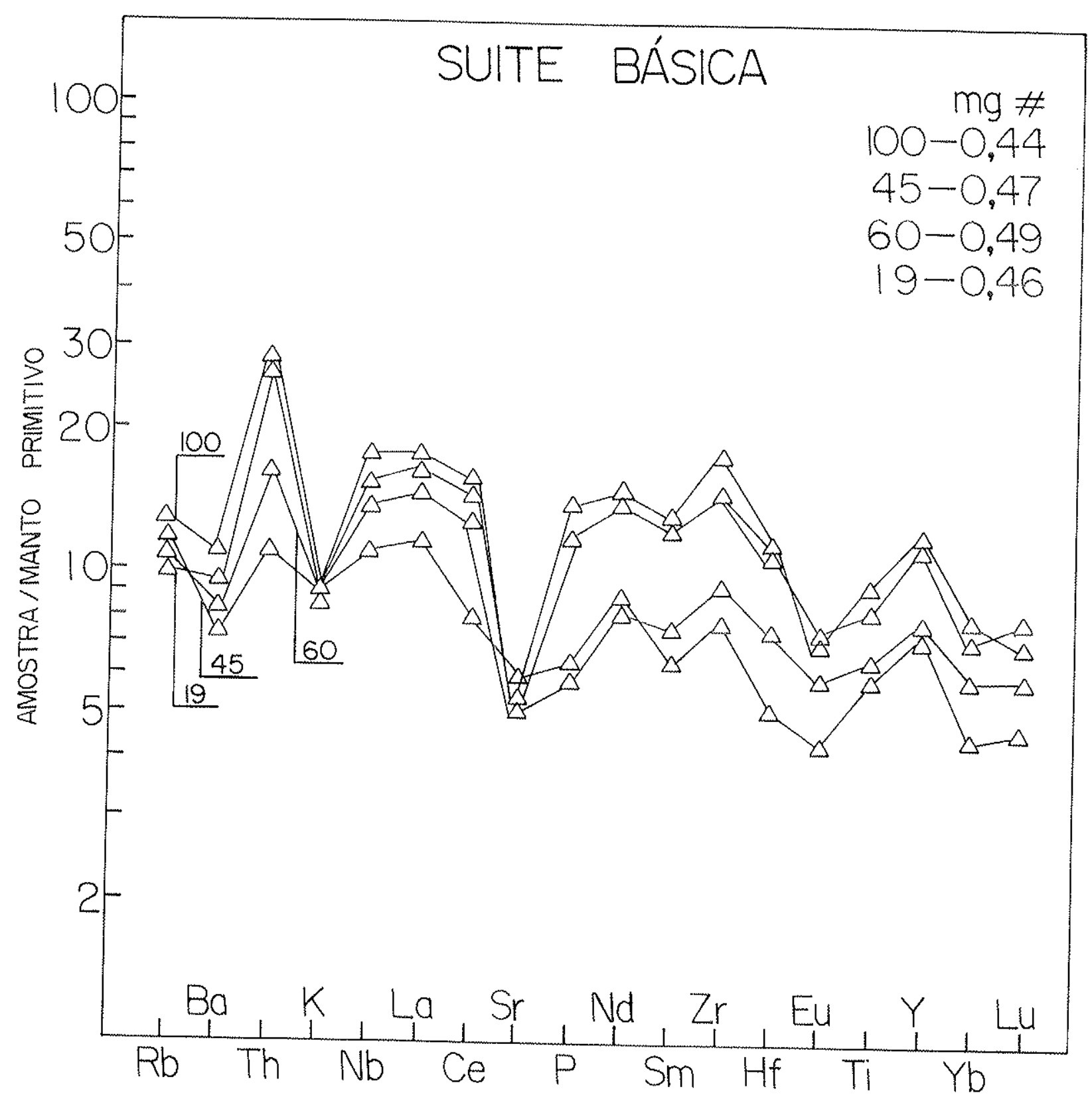

FIGURA VIII.3: Padrões de abundância de elementos menores e traços incompatíveis normalizados em relação ao manto primitivo (Sun \& McDonough, 1989) das amostras isotopicamente selecionadas pertencentes aos diques da suite básica $(\Delta)$ da região de Lavras (MG). Os valores de $\mathrm{mg \#}\left[\mathrm{Mg}^{+2} / \mathrm{Mg}^{+2}+\mathrm{Fe}^{+2}\left(\mathrm{Fe}_{2} \mathrm{O}_{3} / \mathrm{FeO}=0,15\right)\right]$ para cada amostra estão indicados no canto superior direito da figura. $\mathrm{Ba}, \mathrm{K}, \mathrm{Nb}, \mathrm{P}, \mathrm{Zr}$, Ti e $\mathrm{Y}$ obtidos por fluorescência de raios- $\mathrm{X}(\mathrm{FRX})$; $\mathrm{La}, \mathrm{Ce}, \mathrm{Eu}, \mathrm{Yb}, \mathrm{Lu}$, Th e Hf obtidos por ativação neutrônica (INAA); Rb, Sr, Sm e Nd obtidos por diluição isotópica (DI). 
Importantes diferenças são assinaladas entre as suites básica e básico noritica, além da anomalia positiva de Th de ocorrência restrita na suíte básica (Fig.VIII.3). Conforme anteriormente antecipado, a suíte básico norítica é caracterizada por anomalias negativas de $\mathrm{Nb}, P, \mathrm{Sm}$ e Ti, enquanto na suite básica destacam-se as anomalias negativas de $\mathrm{Ba}, \mathrm{K}, \mathrm{Sr}$ e Eu (Figs. VIII.2 e VIII.3).

Em suma, os padrões de distribuição dos elementos traços e outros elementos incompativeis (e.g. K), sugerem uma origem para as suítes básica e básico norítica a partir de fontes distintas. As amostras das duas suítes investigadas que apresentam características isotópicas similares (i.e. plotam-se no quadrante enriquecido, próximas a "Terra Global") são geoquimicamente bem distintas. Por outro lado, a suíte básico norítica demonstra "trends" geoquímicos internos semelhantes, embora apresente uma diferença isotópica muito importante em termos de $\varepsilon(\mathrm{Nd})$ vs $\varepsilon(\mathrm{Sr})$.

As diferenças geoquímicas e isotópicas relatadas são também condizentes com processos magmáticos de idades diferentes conforme aqui demonstrado, a saber: suíte básico norítica situada no Neoarqueano $(2,65 \mathrm{Ga})$ e suíte básica no Paleoproterozóico (1,9 $\mathrm{Ga})$.

\section{IX - COMPARAÇÃO COM OUTROS ENXAMES DE DIQUES MÁFICOS}

Conforme anteriormente demonstrado, os dados K-Ar, $\mathrm{Rb}-\mathrm{Sr}, \mathrm{U}-\mathrm{Pb}$ e Sm$\mathrm{Nd}$, aliados a dados de campo, registram a existência de pelo menos 5 grandes eventos de intrusivas básicas na porção meridional do Cráton do São Francisco. O primeiro $(2,65 \mathrm{Ga})$, representado pela suite básico noritica deve estar relacionado às fases distensivas finais da cratonização do Complexo Campo Belo (Teixeira et al, 1996a). O segundo evento (1,9 Ga), reforçado por dados de campo, possivelmente esteja relacionado às fases finais do Cinturão Mineiro (Teixeira, 1985) e sua colocação é aproximadamente concomitante às intrusões graniticas transamazônicas distribuídas pela região (e.g. Granito Tabuões). O terceiro evento (1,5-1,7 Ga), tentativamente pode estar associado às fases distensivas iniciais que aparecem nas extremidades meridionais do Sistema Espinhaç, tal qual os eventos ígneos (granitos e vulcânicas) descritos por Silva (1992), Dussin (1994) e Silva et al (1996). O quarto evento é representado pelos pulsos pré-cambrianos mais jovens $(1,0-0,9 \mathrm{Ga})$ no âmbito cratônico e 
deve estar relacionado às fases distensivas finais do Sistema Espinhaço. Interessante notar que, tais pulsos foram registrados também através de dados ${ }^{40} \mathrm{Ar} /{ }^{39} \mathrm{Ar}$ nos enxames de diques máficos de Salvador (Renne et al, 1990). O quinto e último evento (Mesozóico), parece se distribuir por todo o segmento meridional e deve se relacionar com a fragmentação do Gondwana e conseqüentemente a evolução do vulcanismo da Bacia do Paraná.

A Tabela IX.1 resume características petrográficas, gequimicas e isotópicas disponiveis, dos principais enxames situados à norte da região de Lavras (MG) e na porção meridional do Cráton do São Francisco.

Nela pode-se observar que os diques do grupo IV descritos por Silva (1992) e Silva et al (1996), com distribuição no Quadrilátero Ferrifero (QF) e idade K-Ar de $120 \mathrm{Ma}$, a julgar pelos dados petrográficos, podem pertencer a mesma família dos diabásios Santa Cruz descritos por Carneiro (1992) no Complexo Bonfim. Em Lavras foram inferidos alguns corpos deste grupo, com base nas características geoquimicas e uma datação K-Ar de $127 \pm 3$ Ma, conforme já antecipado.

O grupo de diques III (Tabela IX.1) também descritos por Silva (1992) no QF e Espinhaço Meridional (EM), apresentam idade $\mathrm{Pb}-\mathrm{Pb}$ igual a $655 \mathrm{Ma}$ e U-Pb (zircão/badeleita - intercepto inferior) igual a $618 \mathrm{Ma}$, as quais recentemente são interpretadas como decorrência de processos metamórficos (Silva et al, 1996). Tais processos, possivelmente favoreceram a mobilização dos elementos químicos a ponto deste grupo apresentar uma razão $\mathrm{La} / \mathrm{S} m_{N}$ muito elevada $(6,9)$, a qual não encontra correspondentes até o presente na porção sul do Cráton do São Francisco. Adicionalmente, Silva et al (1996) sugerem que o grupo de diques III façam parte de um conjunto mais antigo que foi parcialmente afetado por ocasião da evolução do Ciclo Brasiliano.

Os diques não metamórficos ricos em "LILE" (elementos litófilos de íons de grandes tamanhos) de Ribeirão das Neves, MG (Chaves, 1996), podem estar relacionados com os diques alto $\mathrm{K}$ da região de Pará de Minas (Teixeira et al, 1988) como indicam suas idades Rb-Sr e K-Ar. 


\begin{tabular}{|c|c|c|c|c|c|c|c|c|c|c|c|c|}
\hline \multirow{3}{*}{\begin{tabular}{|l|} 
\\
Petrografia \\
\end{tabular}} & \multirow{2}{*}{\multicolumn{2}{|c|}{$\begin{array}{l}\text { DIQUES DE } \\
\text { RIBEIRÄO DAS } \\
\text { NEVES }\end{array}$}} & \multirow{2}{*}{\multicolumn{2}{|c|}{$\begin{array}{l}\text { DIQUES DE PARÁ } \\
\text { DE MINAS }\end{array}$}} & \multicolumn{4}{|c|}{$\begin{array}{c}\text { DIQUES DO QUADRILATERO FERRIEFERO } \\
\text { E ESPINHACO MERIDIONAL }\end{array}$} & \multicolumn{4}{|c|}{$\begin{array}{c}\text { DIQUES DO COMPLEXO METAMÓRFICO } \\
\text { BONFIM }\end{array}$} \\
\hline & & & & & Gr I & Gr II & Gr III & Gr IV & A. Par. & A. Can & Metad. & Diab. \\
\hline & $\begin{array}{l}\text { Textura gra } \\
\text { noblástica a } \\
\text { granonema } \\
\text { toblástica. }\end{array}$ & $\begin{array}{l}\text { Textura } \\
\text { subofitica } \\
\text { a ofitica }\end{array}$ & $\begin{array}{l}\text { textura gra- } \\
\text { noblástica a } \\
\text { porfirítica }\end{array}$ & a mesma & $\begin{array}{l}\text { Textura } \\
\text { granoblásti- } \\
\text { ca a lepido- } \\
\text { blástica } \\
\end{array}$ & $\begin{array}{l}\text { Textura } \\
\text { blasto sub } \\
\text { ofítica }\end{array}$ & $\begin{array}{l}\text { Textura } \\
\text { blasto } \\
\text { intergra- } \\
\text { nular } \\
\end{array}$ & $\begin{array}{l}\text { Textura in } \\
\text { tergranu- } \\
\text { lar }\end{array}$ & $\begin{array}{l}\text { textura gra- } \\
\text { noblástica a } \\
\text { granonema- } \\
\text { toblástica } \\
\end{array}$ & $\begin{array}{l}\text { Textura } \\
\text { granemato } \\
\text {-blástica }\end{array}$ & $\begin{array}{l}\text { Textura } \\
\text { blastoin- } \\
\text { tergranu- } \\
\text { lar } \\
\end{array}$ & $\begin{array}{l}\text { Textura in- } \\
\text { tergranular }\end{array}$ \\
\hline minerais & $\begin{array}{l}\text { pl, anf,aug, } \\
\text { il, granada }\end{array}$ & $\begin{array}{l}\text { pl, aug, il e } \\
\text { ap }\end{array}$ & $\begin{array}{l}\text { pl, anf, aug. } \\
\text { Epidotiza- } \\
\text { dos }\end{array}$ & a mesma & $\begin{array}{l}\text { pl, } \mathrm{cl}, \mathrm{qze} \\
\text { il }\end{array}$ & $\begin{array}{l}\text { pl, anf, ang, } \\
\text { tre, act }\end{array}$ & $\begin{array}{l}\text { pl, aug. } \\
\text { il, and. }\end{array}$ & $\begin{array}{l}\text { pl, aug, } \\
\text { op. }\end{array}$ & $\begin{array}{l}\text { pl, anf, qze } \\
\text { op. }\end{array}$ & $\begin{array}{l}\text { pl, anf, qz } \\
\text { e op. }\end{array}$ & $\begin{array}{l}\text { pl, anf, } \\
\text { biot, } \\
\text { op, gz }\end{array}$ & $\begin{array}{l}\text { pl, aug, op, } \\
\text { anf. }\end{array}$ \\
\hline metamorfis- & $\begin{array}{l}\text { facies } \\
\text { anfibolito }\end{array}$ & ausente & $\begin{array}{l}\text { xistos } \\
\text { verdes a } \\
\text { anfibolítico }\end{array}$ & o mesmo & $\begin{array}{l}\text { fácies } \\
\text { anfibolito }\end{array}$ & $\begin{array}{l}\text { fácies } \\
\text { anfibolito }\end{array}$ & $\begin{array}{l}\text { fácies } \\
\text { anfíbolito }\end{array}$ & ausente & $\begin{array}{l}\text { fácies } \\
\text { anfibolito }\end{array}$ & $\begin{array}{l}\text { fácies } \\
\text { anfibolito }\end{array}$ & $\begin{array}{l}\text { fácies } \\
\text { xistos } \\
\text { verdes }\end{array}$ & ausente \\
\hline geoquímica & $\frac{L a / \operatorname{Sin}}{1.1-1.8}$ & \begin{tabular}{|l}
$\frac{\mathrm{La} / \mathrm{Sm}}{2,2-2,8}$ \\
ricos em \\
LILE
\end{tabular} & $\begin{array}{l}\text { AltoK } 1 \text { a } \\
5 \% / \%\end{array}$ & $\begin{array}{l}\text { Baixo } \\
\mathrm{K}<1 \%\end{array}$ & $\frac{\mathrm{La} / \mathrm{Sm}}{\cong 3.68}$ & $\frac{\mathrm{La} / \mathrm{Sm}}{1,3-1,8}$ & $\frac{\mathrm{La} / \mathrm{Sm}}{\cong 6,9}$ & ver figura & ver figura & ver figura & ver figura & ver figura \\
\hline idade & $\begin{array}{l}\mathrm{K}-\mathrm{Ar} \text { anf } \\
-2,0 \mathrm{Ga}\end{array}$ & $\begin{array}{l}\mathrm{K}-\mathrm{Ar} \mathrm{pl} \\
\sim 0,9 \mathrm{Ga} \\
\mathrm{Rb}-\mathrm{Sr} \\
1,03 \mathrm{Ga}\end{array}$ & $\begin{array}{l}\text { K-Ar rt e pl } \\
0,5-0,7 \text { e } \\
0,9-1,0 \mathrm{Ga}\end{array}$ & $\begin{array}{l}\text { K-Ar anf } \\
1,7-1,5 \mathrm{e} \\
1,9-2,1 \\
\mathrm{Ga}\end{array}$ & $\begin{array}{l}\text { U-Pb badel. } \\
1,71 \mathrm{Ga}\end{array}$ & $\begin{array}{l}\text { U-Pb badel. } \\
0,90 \mathrm{Ga}\end{array}$ & $\begin{array}{l}\mathrm{Pb}-\mathrm{Pb} \\
\text { badel } \\
0,65 \mathrm{Ga} \\
\mathrm{U}-\mathrm{Pb} \\
\text { badel. } \\
0,61 \mathrm{Ga}\end{array}$ & $\begin{array}{l}\text { K-Ar } 0,12 \\
\text { Ga. }\end{array}$ & $\begin{array}{l}\mathrm{K}-\mathrm{Ar} \text { anf } 1,9 \\
\mathrm{a} 2,1 \mathrm{Ga}\end{array}$ & $\begin{array}{l}\text { K-Ar anf } \\
1.7 \mathrm{Ga}\end{array}$ & $\begin{array}{l}\mathrm{K} \text {-Ar anf } \\
1,0 \mathrm{Ga}\end{array}$ & \\
\hline Fonte & 1 & 1 e 2 & 2 & 2 & 3 & 3 e 5 & 3 & 3 & 4 & 4 & 4 & 4 \\
\hline
\end{tabular}

Tabela IX.1: Quadro comparativo dos enxames de diques máficos pertencentes a porção meridional do Cráton do São Francisco e adjacentes ao enxame de Lavras. Anf = anfibolio, $\mathrm{pl}=$ plagioclásio, badel = badeleita, aug = augita, $q \mathrm{z}=$ quartzo, op $=$ opacos, biot $=$ biotita, il $=$ ilmenita, $\mathrm{cl}=$ clorita, tre $=$ tremolita, act $=$ actinolita e ap $=$ apatita. $\underline{L a} S \mathrm{Sm}=\mathrm{La} / \mathrm{Sm} \times \mathrm{Kr}=$ grupo; A.Par $=$ anfibolitos Paraopeba, A. Can $=$ anfibolitos Candeias; Metad = metadiabásio Conceição de Itaguá e Diab = diabásio Santa Cruz. (1) = Chaves, 1996; (2) = Teixeira et al, 1988 e Teixeira et al, $1996 \mathrm{c}$; (3) = Silva et al, 1996 e Silva, 1992; (4) = Carneiro, 1992; (5) = Abreu, 1991. 
O enxame de diques do grupo II (Silva, 1992) das regiões do QF e EM (U$\mathrm{Pb}=906 \pm 2 \mathrm{Ma} ;$ Abreu, 1991), cujos valores nas razões $\mathrm{La}_{\mathrm{N}} / \mathrm{Sm}_{\mathrm{N}}$ são um pouco distintas (1,3-1,8 vs 2,2-2,8) daquelas dos diques não metamórficos de Ribeirão das Neves, também podem pertencer a esta familia. Alternativamente, o grupo II pode se relacionar com os diques metamórficos de Ribeirão das Neves, a julgar pela similaridade no intervalo das razões $\mathrm{La}_{N} / \mathrm{Sm}_{\mathrm{N}}(1,1-1,8)$

A intrusão dos enxames de diques do grupo I no QF e EM apresentam idade U-Pb (badeleita) de $1714 \pm 5 \mathrm{Ma}$ (Silva et al, 1996) e não encontram similares na porção sul do cráton, exceto os diques baixo $\mathrm{K}$ do enxame de Pará de Minas que sugerem através dos anfibólios idades K-Ar no intervalo de 1,7-1,5 Ga.

Os diques anfibolíticos Candeias e Paraopeba do Complexo Bonfim (Carneiro, 1992) e os diques metamórficos de Ribeirão das Neves (Chaves, 1996), ambos com idades $\mathrm{K}$-Ar (anfibólios) entre 1,7 a 2,1 Ga, mostram fortes semelhanças geoquímicas (Fig. IX.1) com os diques da suite básica da região de Lavras. Estas semelhanças sugerem uma única familia cuja idade intrusiva situar-se-ia em 1,9 $\mathrm{Ga}$, como já evidenciado anteriormente para os diques desta suíte. Todavia, a idade de intrusão dos diques anfíbolíticos tipo Paraopeba é inferida como arqueana por Carneiro (1992), uma vez que as idades $\mathrm{K}-\mathrm{Ar}$ (anfibólios) de 1,9 a 2,1 Ga (Tabela IX.1) retratam tão somente os sucessivos eventos metamórficos. Esta inferência aparentemente é corroborada por dados Sm-Nd em um desses exemplares (Teixeira et al 1996a).

Cumpre ressaltar, que do ponto de vista cronológico e geoquímico nenhum dos enxames abordados na porção sul do cráton mostra correlação com os diques da suite básico norítica $(2,65 \mathrm{Ga})$ da região de Lavras (Tabela IX.1; Fig. IX.1).

No âmbito da porção setentrional do Cráton do São Francisco, merece destaque o enxame de diques toleíticos de Uauá (Bahia) [Bastos Leal et al, 1994; Menezes Leal et al, 1995; Bellieni et al, 1995] que são "contemporâneos" a suite básica do enxame de Lavras (MG). Duas isócronas minerais (Bastos Leal et al, 1994) identificaram a existência de duas gerações de diques em Uauá (2384 1114 Ma e $1983 \pm 31$ Ma). Naquela região, um outro grupo de diques de composição norítica é assinalado na área (Oliveira, 1993), todavia os levantamentos geoquímicos e geocronológicos encontram-se atualmente em andamento (Oliveira, 1996, comunicação verbal). 


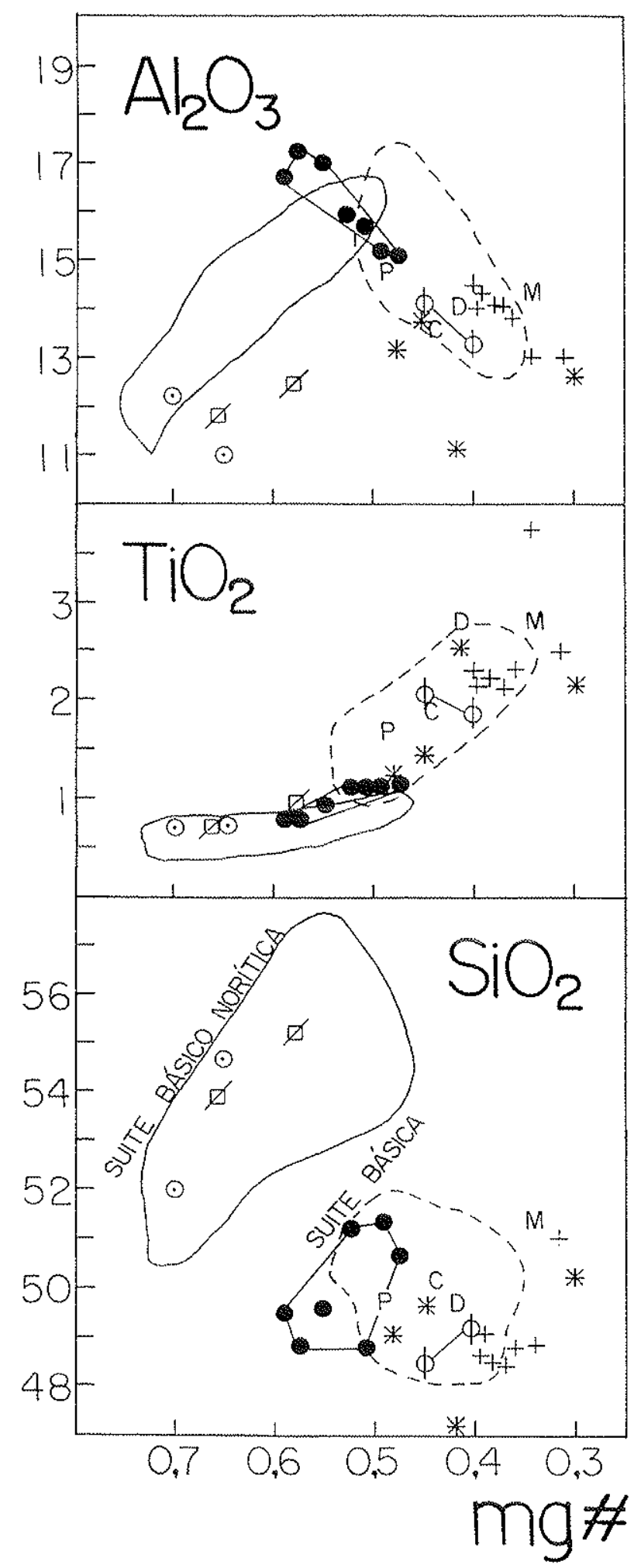

- DIQUES NÁ METAMÓRFICOS-UAUÁ(BA) +-DRQUES NÁO METAMÓFFICOS RIB. NEVES(MG) * DIQUES METAMÓRFICOS RIB. NEVES (MG) ఫ-DIQUES ALTO MgO-ANTÁRTICA $(2,42 \mathrm{Ga}$ ○-DIQUES NORITICOS-FINLÃNDIA (2,45Ga) D-DRUES FERRO TOLEITOS-FINLÄNDIA(1,97Ga).

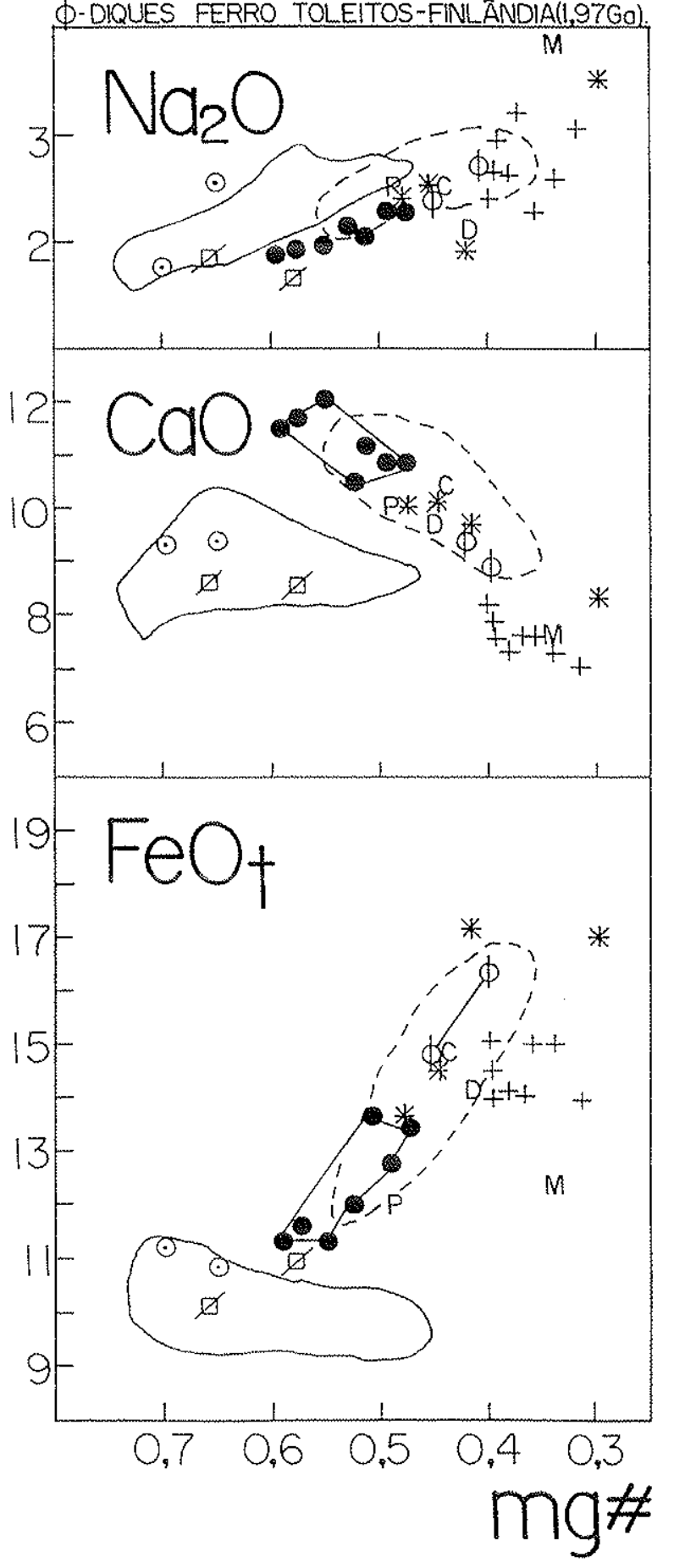

FIGURA IX.1: Diagramas de variação mg\# valores versus elementos maiores (\% em peso) e traços (ppm) dos campos representativos dos diques das suítes básico norítica (campo com linha contínua) e básica (campo com linha tracejada) da região de Lavras, bem como dos grupos de diques representativos das seguintes localidades: 1) Complexo Bonfim: Pananfibolitos Paraopeba; $\mathrm{C}$ manfibolitos Candeias: $\mathrm{M}=$ metadiabásio Conceição do Itaguá: $\mathrm{D}$ =-diabásio Santa Cruz posicionados na porção sul do Cráton do São Francisco (CSF); 2) diques de Ribeirão das Neves (MG) posicionados à oeste de Belo Horizonte e na porção sul do CSF; 3) diques não metamórficos de Uauá, Bahia, posicionados na porção setentrional do CSF; 4) diques dos escudos da Antárctica e Finlândia. Fonte de dados: presente trabalho; Carneiro (1992); Chaves (1996); Bellieni et al (1995); Sheraton et al (1987); Collerson \& Sheraton (1986); Vuollo et al (1995). 


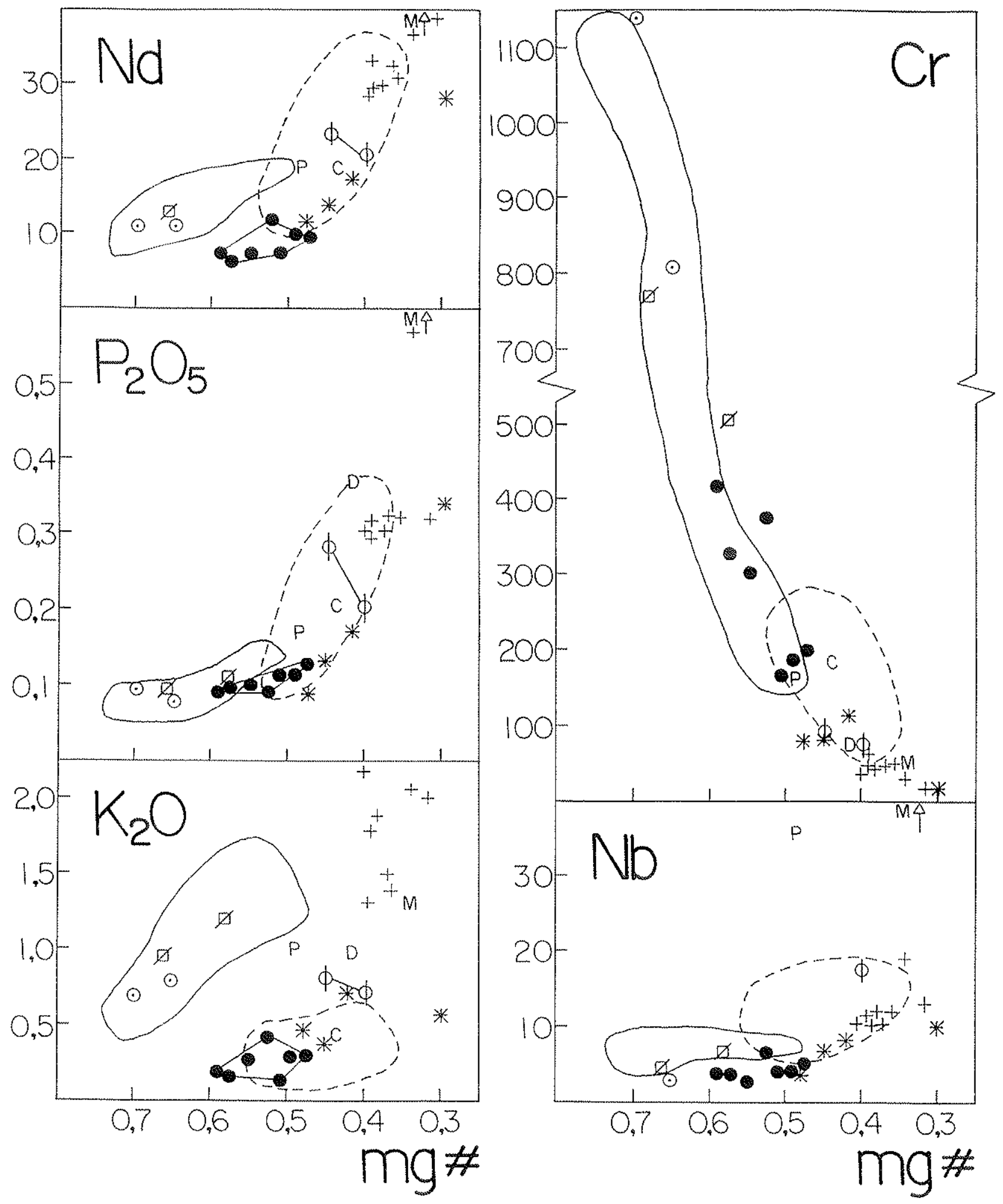

FIGURA IX. 1: continuação. 

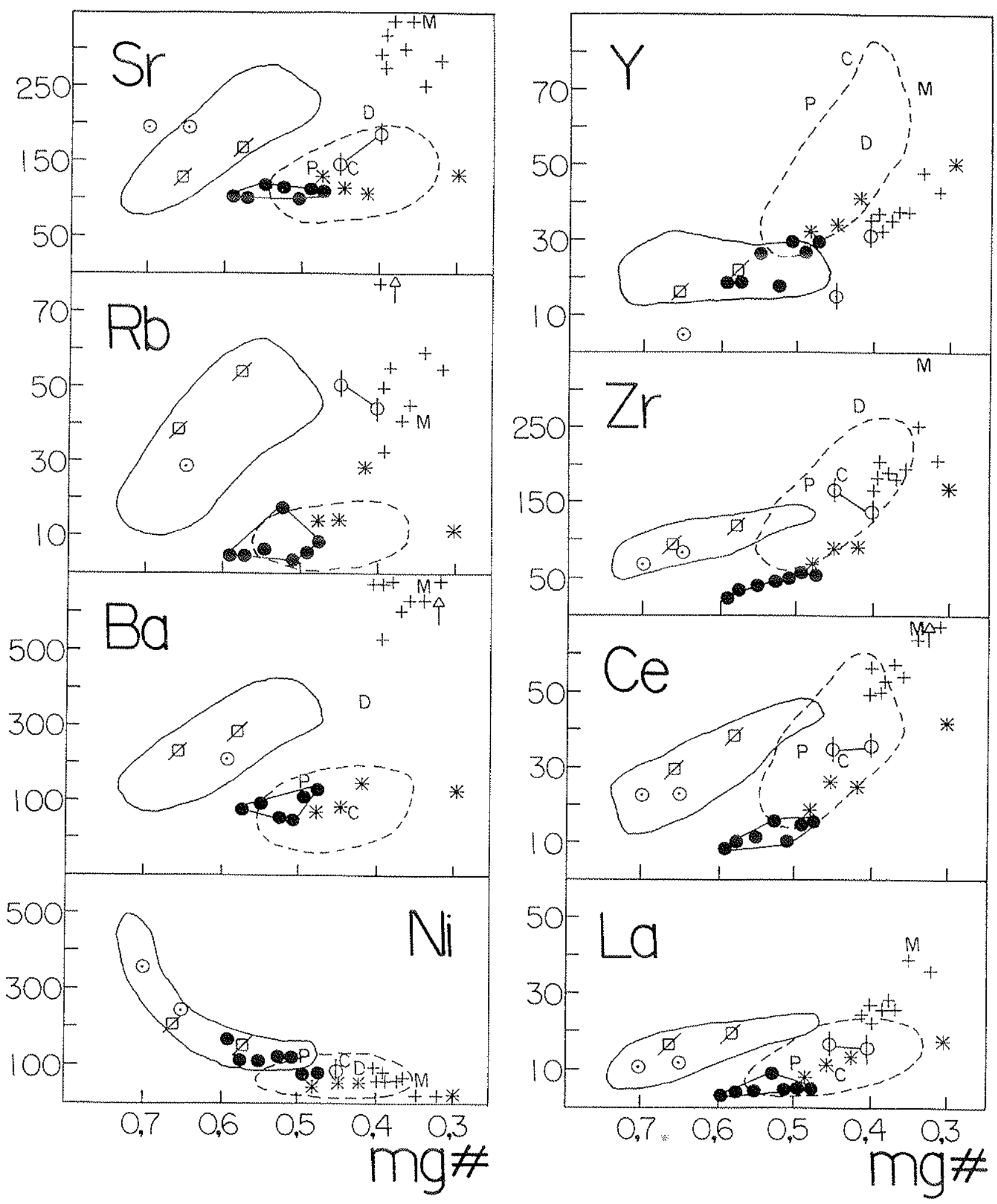

FIGURA IX 1 : continuação. 
A comparação entre os diques da suite básıca de Lavras e os diques não metamórficos (não contaminados) de Uauá (Bellieni et al, 1995), revela que os últimos são similares aos exemplares menos evoluidos da suíte básica. Em particular quando se observa o comportamento do $\mathrm{SiO}_{2}, \mathrm{CaO}, \mathrm{FeOt}, \mathrm{K}_{2} \mathrm{O}, \mathrm{Ba}, \mathrm{Rb}, \mathrm{Sr}, \mathrm{La}, \mathrm{Ce}$ e Zr (Figura IX.1). Os diques de Uauá apresentam assinatura isotópica comparável aos exemplares da suíte básica de Lavras. Apesar de se posicionarem predominantemente no quadrante enriquecido relativamente a "Terra Global" (Figura IX.2) encontram-se um pouco deslocados à esquerda devido aos valores negativos do $\varepsilon(\mathrm{Sr})$, mostrando ainda uma maior variação no intervalo do $\varepsilon$ (Nd) $[-0,8$ a -8]. Adicionalmente, no diagrama da Figura IX.3, verifica-se que os diques não contaminados de Uauá e da suíte básica apresentam o mesmo intervalo de valores nas razões $\mathrm{La} / \mathrm{Nb}$ e $\mathrm{Zr} / \mathrm{Nb}$, reafirmando as similaridades entre as fontes magmáticas envolvidas e, sugerindo conseqüentemente um comportamento mantélico geoquimicamente similar entre as regiões de Lavras e Uauá no Paleoproterozóico.

A comparação com enxames de diques máficos de outros segmentos cratônicos, como na Finlândia (Vuollo et al, 1995) e na Antártica (Collerson \& Sheraton, 1986; Sheraton et al, 1987; Kuehner, 1989) sugere uma evolução similar a da porção extremo sul do Cráton do São Francisco. Como pode se observar nos diagramas de variação da Figura IX.1, os diques da suíte básico norítica $(2,65 \mathrm{Ga})$ revelam semelhanças composicionais com os diques noríticos da Finlândia $(2,45 \mathrm{Ga})$ e os diques de alto $\mathrm{MgO}$ da Antártica $(2,42 \mathrm{Ga})$. Também nas razões $\mathrm{La} / \mathrm{Nb}$ e $\mathrm{Zr} / \mathrm{Nb}$ eles se assemelham, sendo que os últimos apresentam valores mais próximos da suite básico norítica (Figura IX.3).

Os diques da suite básica de Lavras (1,9 Ga), exceto para Rb e Y (Figura IX.1), apresentam nitidas semelhanças composicionais com os diques toleíticos ricos em ferro da Finlândia (1,97 Ga). Estes últimos no diagrama $\mathrm{La} / \mathrm{Nb}$ vs $\mathrm{Zr} / \mathrm{Nb}$ estão posicionados próximos a suite básica (Figura IX.3).

Em suma, a exemplo de alguns outros crátons no mundo, a porção extremo sul do Cráton do São Francisco é caracterizada por importantes feições intrusivas na forma de enxames de diques, representativas de um magmatismo tolético que se desenvolveu em grande parte no Paleoproterozóico $(2,3$ a 1,9 Ga). No Neoarqueano todavia (2,65 Ga), o magmatismo intrusivo se iniciou na porção extremo sul do fragmento arqueano meridional. 


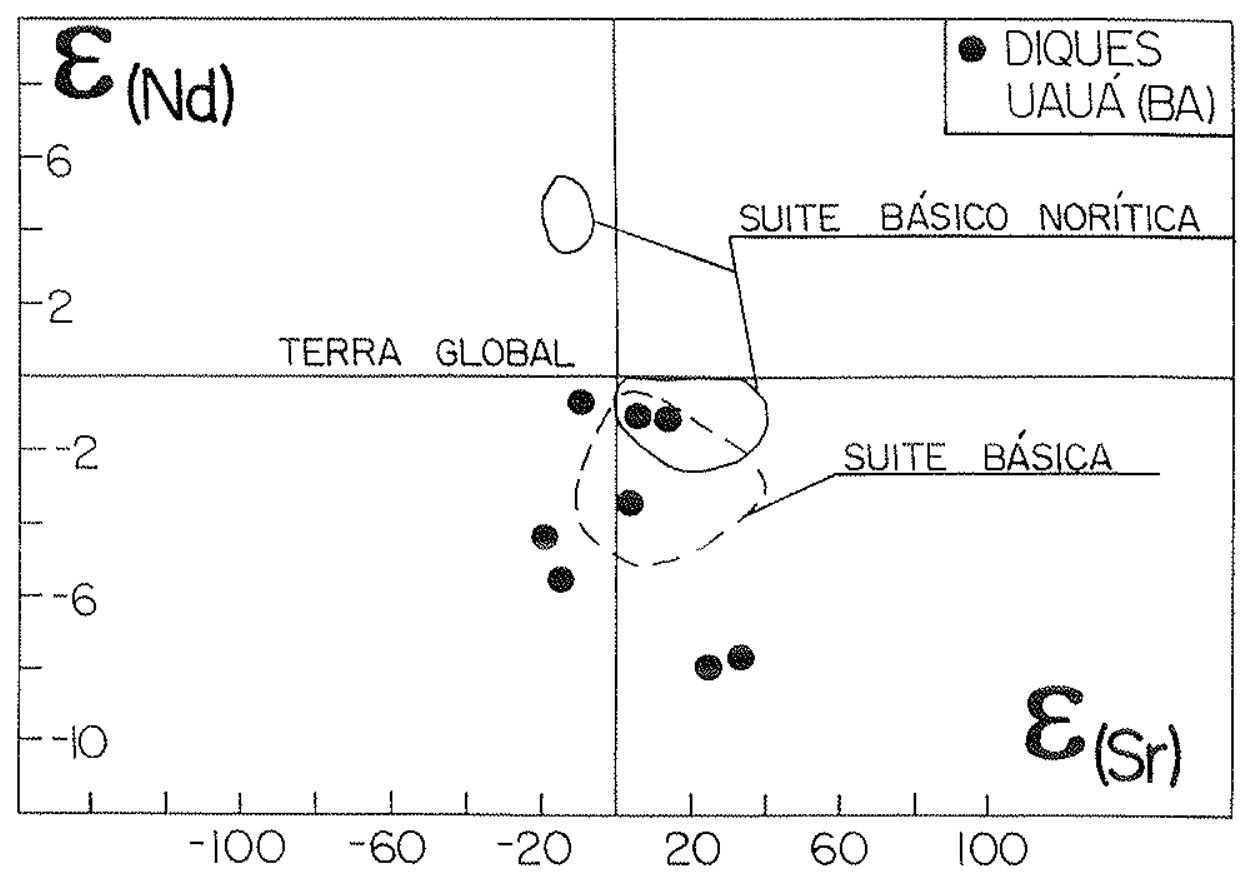

FIGURA IX.2: Diagrama $\varepsilon(\mathrm{Nd})$ vs $\varepsilon(\mathrm{Sr})$ com valores recalculados para 1,9 Ga dos diques não metamórficos e não contaminados de Uauá (Bahia), pertencentes a porção setentrional do Cráton do São Francisco. Suite básica de Lavras $\left(\mathrm{t}_{0}=1,9 \mathrm{Ga}\right.$ ) representada pelo campo com linha tracejada. Linhas contínuas formam os campos das amostras da suite básico norítica de Lavras $\left(\mathrm{t}_{0}=2,65 \mathrm{Ga}\right.$ ). "Terra Global" atual: ${ }^{87} \mathrm{Sr} /{ }^{86} \mathrm{Sr}=0,7045 ;{ }^{143} \mathrm{Nd} /{ }^{144} \mathrm{Nd}=0,512638$ (Faure, 1986). Fonte de dados: presente trabalho; Bellieni et al (1995).

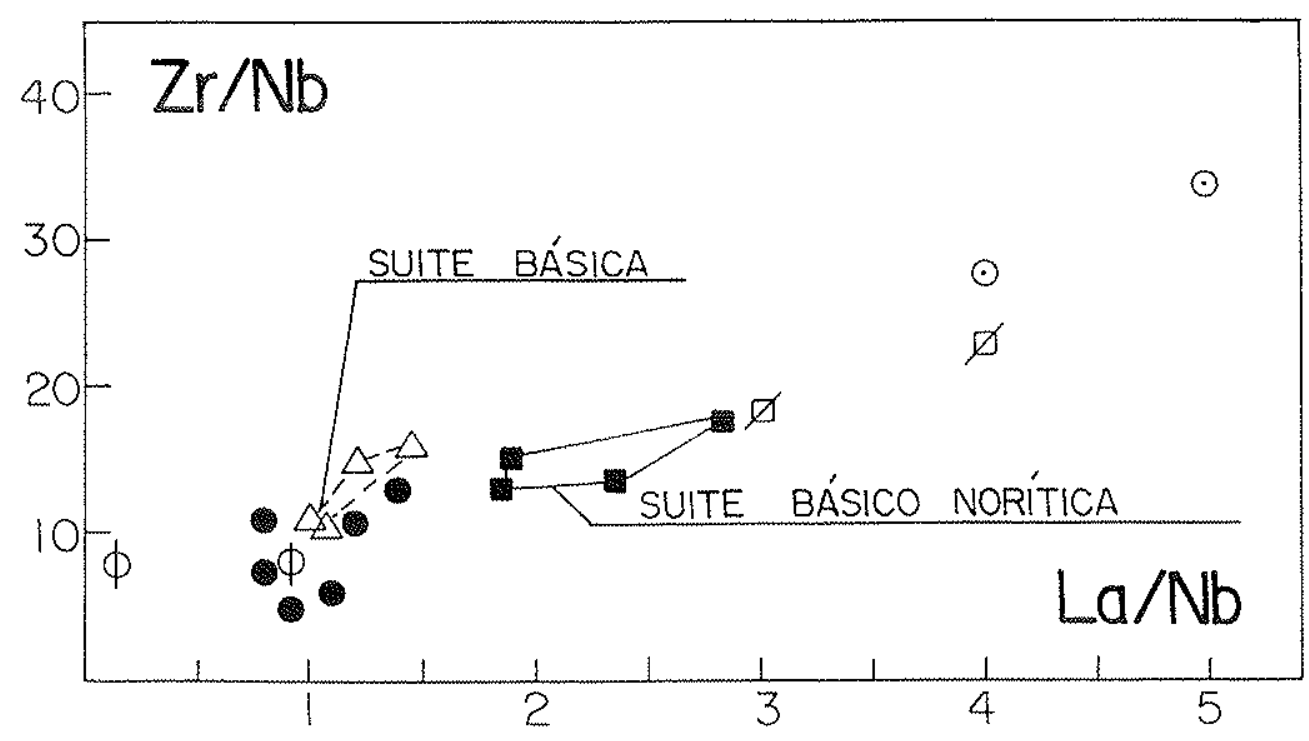

FIGURA IX.3: Diagrama $\mathrm{Zr} / \mathrm{Nb}$ versus $\mathrm{La} / \mathrm{Nb}$ das amostras isotopicamente selecionadas e representativas da suíte básico noritica (1) e suíte básica $(\Delta)$ da região de Lavras $(M G)$, em comparação com aquelas dos diques de Uauá (Bahia) e diques dos escudos da Antárctica e Finlândia. Linha tracejada une amostras da suíte básica e linha contínua une amostras da suite básico noritica. Demais simbolos como na figura IX.1. Fonte de dados: presente trabalho; Bellieni et al (1995); Sheraton et al (1987); Collerson \& Sheraton (1986); Vuollo et al (1995). 
Este magmatismo revela uma fonte mantélica caracterizada por altas concentrações em $\mathrm{SiO}_{2}, \mathrm{MgO}, \mathrm{Cr}, \mathrm{Ni}, \mathrm{K}_{2} \mathrm{O}, \mathrm{Ba}, \mathrm{Rb}$ e $\mathrm{Sr}$, e baixas concentrações em elementos de alta densidade de carga (e.g. Ti, $\mathrm{Nb}$ ). Já no Paleoproterozóico, as características da fonte praticamente inverteram, ou seja, apresenta-se relativamente com baixas concentrações em elementos litófilos com ions de grande tamanho ("LILE") e altas em elementos de alta densidade de carga ("HFSE"). 


\section{X - CONCLUSÕES}

Os estudos efetuados neste trabalho permitem sumarizar as seguintes conclusões e implicações de ordem tectônica:

1) Os diques máficos metamórfícos e não metamórficos investigados se distribuem preferencialmente à oeste da Serra de Bom Sucesso. Em geral, orientam-se predominantemente a $\mathrm{N} 40^{\circ}-60^{\circ} \mathrm{W}, \mathrm{N} 20^{\circ}-40^{\circ} \mathrm{E}$, e subordinadamente a $\mathrm{N}-\mathrm{S}, \mathrm{N} 50^{\circ}-70^{\circ} \mathrm{E}$, $\mathrm{N} 10^{\circ}-30^{\circ} \mathrm{W}$ e E-W. Os diques metamórficos mostram ligeira predominância de direções NE e NS, semelhantes a direção da Serra de Bom Sucesso.

2) Petrograficamente os diques podem ser subdivididos em: a) diques básico noríticos (DBN), b) diques básicos 1 e $2\left(D_{1}\right.$ e $\left.\left.D B_{2}\right), c\right)$ diques metabásicos (DMB) e d) diques anfibolíticos (DA). Os DA mostram nítidas feições de transformação mineral, fruto da atuação de processos metamórficos no grau anfibolito. Nos DMB as feições indicam atuação de processos mais brandos do tipo epídoto-anfibolito. Os processos metamórficos assinalados nos DA e DMB devem estar associados a deformações do tipo cisalhamento longitudinais aos corpos tabulares, ou seja, os esforços se desenvolveram na mesma direção dos diques afetando-os em seu comprimento, portanto com possibilidades de atuação concomitante de fluidos quimicamente ativos. A seqüência de cristalização sugerida na petrografia para os diques da suite básico noritica (olivina-bronzita-augita-plagioclásiomopacos) é diferente daquela para os diques da suite básica (plagioclásio-augita-hiperstênio-pigeonita-opacos).

3) Dados sobre o quimismo das fases minerais, reafirmam, através das temperaturas de cristalização, as sequêencias sugeridas pela petrografia. Revelam adicionalmente, que a evolução dos piroxênios é típica de suítes toleiticas e que diferenças composicionais entre os minerais da suite básico norítica e suíte básica residem preferencialmente nos piroxênios, que são mais magnesianos e menos cálcicos nos primeiros. Por outro lado, os plagioclásios da suite básica são um pouco mais sódicos.

4) As classificações geoquímicas utilizadas mostram que os diques máficos investigados possuem afinidade toleitica. O fraco enriquecimento em FeOt demonstrado pelos diques da suite básico noritica deve estar ligado a um fracionamento de olivinas e piroxênios \pm magnetitas. 
5) Os dados geoquímicos dos elementos maiores e traços revelam que a suite básico norítica é composicionalmente diferente da suíte básica. Quando confrontadas, a suíte básico noritica é destacadamente enriquecida em $\mathrm{SiO}_{2}, \mathrm{~K}_{2} \mathrm{O}, \mathrm{Rb}$, Sr e Ba e empobrecida em FeOt, $\mathrm{CaO}$ e Y. Também é caracterizada pelas baixas concentrações em "HFSE". Adicionalmente, as razões Zr/elementos traços incompativeis acentuam as diferenças assinaladas entre as suites, por exemplo, os valores nas razões $\mathrm{Zr} / \mathrm{La}$ da suíte básica $(8,8$ a 17,7) são sempre maiores do que aquelas da suíte básico norítica $(5,3$ a 8,9$)$. Este comportamento sugere duas familias geoquimicas distintas relacionadas a magmas genitores diferentes. Um pequeno grupo de amostras da suíte básica mostra-se diferente do conjunto, tratando-se possivelmente de diques mesozóicos devido as suas semelhanças composicionais e uma datação $\mathrm{K}$-Ar similar (127 $\pm 3 \mathrm{Ma}$ ) com diques dessa idade datados na extremidade sul do Sistema Espinhaço.

6) Os elementos terras raras (ETRs) reafirmam a existência de 2 famílias geoquímicas de diques máficos, uma representada pela suite básico noritica e outra pela suite básica. A suíte básico norítica mostra razões $\mathrm{La}_{\mathrm{N}} / \mathrm{Yb}_{\mathrm{N}}$ no intervalo de 3,6 a 6,1 e $\mathrm{La}_{\mathrm{N}} / \mathrm{Sm}_{\mathrm{N}}$ entre 2,9 e 3,5, enquanto na suíte básica as razões $L a_{N} / Y b_{N}$ são de 1,6 a 2,3 e $L a_{N} / S m_{N}$ entre 1,4 e 1,8 .

7) Os diques metamórficos são composicionalmente semelhantes aos diques da suite básica, contudo, alguns elementos (e.g. K, Rb, Sr) sofreram mobilização no processo metamórfico devendo, como tal, mascarar em parte a real evolução destas suites.

8) Os dados $\mathrm{Rb}-\mathrm{Sr}, \mathrm{Sm}-\mathrm{Nd}$ e K-Ar indicam a ocorrência de duas gerações pré-cambrianas de magmatismo fissural na região. A primeira representada pelos diques da suíte básico noritica foi datada em $2.658 \mathrm{Ma}$ e a segunda representada pelos diques da suíte básica datada em cerca de $1.875 \mathrm{Ma}$. A Serra de Bom Sucesso constituída por rochas do Super Grupo Minas, cujo metamorfismo se deu entre 2,0 e 2,1 Ga (Noce, 1995; Babinski et al, 1995), é seccionada pelos diques da suíte básica e aqueles metamórficos tipo DMB ou DA.

9) Os valores de $\varepsilon(\mathrm{Nd})$ vs $\varepsilon(\mathrm{Sr})$ indicam que os diques da suíte básica e básico noritica predominantemente derivaram de uma fonte enriquecida em relação a "Terra Global". Duas amostras da suíte básico norítica plotam no quadrante empobrecido do diagrama de correlaçầo, aventando assim a presença de variações internas na fonte isotópica. Nenhuma das suites mostra evidências isotópicas e geoquimicas de terem sido afetadas de 
maneira significativa por processos de interação crustal durante a intrusão. Contudo, a suite básico norítica pode ter sofrido "processos metassomáticos" subcontemporaneamente ao processo de fusão, os quais provocaram enriquecimento de $\mathrm{Rb}$ e $\mathrm{Nd}$ em relação a $\mathrm{Sr}$ e $\mathrm{Sm}$ respectivamente, em parte do conjunto da suite que está no quadrante empobrecido.

10) A evolução das suites básica e básico noritica está quantitativamente de acordo com um processo de cristalização fracionada a partir de magmas que apresentam pequena heterogeneidade química no âmbito de uma mesma suíte. Contudo, os magmas das duas suites apresentam entre si heterogeneidade composicional em grande escala, em decorrência da derivação de duas fontes geoquimicas distintas. Uma propiciou a geração dos diques da suite básico norítica, e é caracterizada pelo destacado enriquecimento em elementos mais incompativeis em relação ao manto primitivo e por anomalias negativas de $\mathrm{Nb}, \mathrm{P}, \mathrm{Sm} \mathrm{e}$ Ti. A outra fonte, propiciou os diques da suíte básica e é caracterizada por um menor enriquecimento dos elementos incompatíveis em relação ao manto primitivo e pelas anomalias negativas de $\mathrm{Ba}, \mathrm{K}$, Sr e Eu e anomalia positiva de Th. Para as duas suites do tipo tolético o grau de fusão deve ter sido ao menos da ordem de $10 \%$.

11) Na suite básico noritica os dois conjuntos isotópicos assinalados indicam uma fonte litosférica caracterizada pela heterogeneidade química e isotópica, conseqüentemente uma fonte onde as correntes convectivas foram praticamente ausentes por centenas de milhões de anos. O manto litosférico no Neoarqueano corroborado pelas idades modelo $\mathrm{T}^{\mathrm{DM}}(\mathrm{Nd})$ das rochas da suíte básico norítica e com base na existência da anomalia negativa de $\mathrm{Nb}$, pode ter sido fertilizado (metassomatizado) através de um processo de subducção envolvendo crosta oceânica e/ou sedimentos terrigenos continentais e crosta continental reciclada. Os fluidos destes componentes crustais e crosta oceânica subductada, propiciaram a formação de magmas enriquecidos em $\mathrm{SiO}_{2}, \mathrm{~K}_{2} \mathrm{O}$, "LILE" e ETRL, por exemplo.

Evolução semelhante tem sido indicada para diferentes tipos de boninitos (e.g. Crawford et al, 1989), bem como para diques noriticos (e.g. Hall \& Hughes, 1990). Os diques da suíte básico noritica possivelmente se encaixaram na crosta continental sob regimes tectônicos extensionais, os quais consentiram a intrusão após o Evento Rio das Velhas ocorrido há $2780-2700 \mathrm{Ma}$.

12) Os diques da suite básica também devem ter se alojado na crosta continental, durante um regime tectônico extensivo que se desenvolveu de maneira 
concomitante e logo após a orogenia transamazônica (Cinturão Mineiro), a julgar, respectivamente pelos diques metamórficos tipo $\mathrm{DA}$ e $\mathrm{DMB}$ que possivelmente foram intrudidos em regime tectônico transicional a aquele extensivo que consentiu a colocação dos diques não metamórficos. As caracteristicas da fonte litosférica ao final do Paleoproterozóico, parecem ter sido diferentes daquelas do Neoarqueano, a julgar pela geração de magmas com concentrações mais elevadas em "HFSE" e mais baixas em "LILE" como este que propiciou os diques da suíte básica.

13) Isótopos de $\mathrm{Nd}$ e $\mathrm{Sr}$ e dados geoquímicos revelam que a suíte básico norítica é diagnosticada, até o momento, exclusivamente na porção extremo sul do Cráton do São Francisco, indicando para a região de Lavras composições distintas do manto litosférico subcontinental em relação as demais áreas cratônicas. Recentes estudos tem destacado a presença de corpos noriticos intrusivos na porção setentrional do cráton a oeste do enxame de diques de Uauá.

A suite básica, por outro lado, composicionalmente pode ser considerada similar ao enxame do Complexo Bonfim bem como aquele posicionado à oeste de Belo Horizonte (Rib. das Neves), ambos na parte sul cratônica. No âmbito do segmento setentrional do cráton, os diques paleoproterozóicos de Uauá (Bahia) são os que apresentam semelhanças químicas e isotópicas com os diques da suite básica de Lavras. Desse modo, pelo menos em termos do Paleoproterozóico (2,3 a 1,9 Ga) é possivel aventar a existência de um manto subcontinental, geoquimicamente similar em varias porções do Cráton do São Francisco. Tal possibilidade, é descartada no contexto da Plataforma Sul Americana, a julgar pelas diferentes características químicas e isotópicas apresentadas entre os diques de Uauá e aqueles do Uruguai (1,9 - 1,7 Ga) situados no Cráton Rio de La Plata (Bellieni et al, 1995). Neste caso, a evolução do manto subcontinental na Plataforma deve ter sido diferenciada, como reflexo do desenvolvimento de processos distintos durante a evolução continental.

14) Outros escudos pré-cambrianos (e.g. Antártica, Finlândia), apresentam diques com idades e composição semelhantes aos da suite básica e básico norítica, sugerindo que estes tipos de magmatismo fissural no Neoarqueano e Paleoproterozóico, tenham tido expressão global e, portanto, que as características e a evolução das fontes mantélicas nestes períodos, eram mais ou menos similares no contexto de algumas áreas cratônicas do Planeta.

15) O posicionamento evolutivo dos diques máficos da região de Lavras, bem como do embasamento metamórfico encaixante, no contexto dos principais eventos 
magmáticos e tectônicos da porção sul do Cráton do São Francisco, pode ser sintetizado com base no acervo geocronológico disponível (e.g. Teixeira et al 1996a; Quéméneur, 1996; Noce, 1995; Babinski et al, 1995) de acordo com o seguinte quadro:

\begin{tabular}{|c|c|}
\hline \multirow{4}{*}{$\begin{array}{l}\text { Crosta } \\
\text { Continental } \\
\text { Arqueana do }\end{array}$} & $\begin{array}{l}3380-3000 \mathrm{Ma}(\mathrm{U}-\mathrm{Pb}) \\
\text { Crosta primitiva composta essencialmente por gnaisses TTG e granulitos }(3204-3068 \mathrm{Ma}) \text {, } \\
\text { anfibolitos }\left[\mathrm{T}^{\mathrm{DM}}(\mathrm{Nd}) 2530-3140 \mathrm{Ma}\right] \text { e ultrabásicas. }\end{array}$ \\
\hline & $\begin{array}{l}3120 \mathrm{Ma}(\mathrm{U}-\mathrm{Pl}) \\
\text { Sill do "greenstone belt" de Piumhí. }\end{array}$ \\
\hline & $\begin{array}{l}\text { 2920-2900 Ma (Rb-Sr) } \\
\text { Plutonismo granitico (2881 Ma) }\end{array}$ \\
\hline & $\begin{array}{l}2839 \text { Ma (U-Pb) } \\
\text { Migmatização de ortognaisses e granitos. }\end{array}$ \\
\hline \multirow{3}{*}{$\begin{array}{l}\text { Complexo } \\
\text { Campo Belo } \\
\text { incluindo a } \\
\text { região de }\end{array}$} & $\begin{array}{l}2787 \mathrm{Ma}(\mathrm{Rb}-\mathrm{Sr}) \\
\text { Granito Bom Sucesso - Evento Rio das Vellias. }\end{array}$ \\
\hline & $\begin{array}{l}\text { 2750-2700 Ma (Rb-Sr) } \\
\text { Complexos gnáissicos e granitóides - Evento Rio das Velhas. Migmatização dos gnaisses } \\
\text { graníticos de Lavras. }[2690-2688 \mathrm{Ma}(\mathrm{Rb}-\mathrm{Sr})]\end{array}$ \\
\hline & $\begin{array}{l}2661 \mathrm{Ma}(\mathrm{Rb}-\mathrm{Sr}) \\
\text { Granulitos de Lavras }\left[\mathrm{T}^{\mathrm{IPM}}(\mathrm{Nd}) 2,9-3,5 \text { Gal }\right.\end{array}$ \\
\hline \multirow[t]{2}{*}{ Lavras } & $\begin{array}{l}2658 \text { Ma }(\mathrm{Sm}-\mathrm{Nd}) \\
\text { Colocação dos diques da suíte básico norítica em regime extensional, indicando estágio de } \\
\text { cratonização arqueana e conseqüente estabilização do Complexo Campo Belo. }\end{array}$ \\
\hline & $\begin{array}{l}2650 \mathrm{Ma}(\mathbf{R b}-\mathrm{Sr} \text { e Pb-Pb em rocha total) } \\
\text { Distúrbios isotópicos em gnaisses e granitóides da porção sul do Cráton do São Francisco. }\end{array}$ \\
\hline
\end{tabular}

\begin{tabular}{|c|c|}
\hline \multirow[b]{3}{*}{ Evolução } & $\begin{array}{l}2575 \mathrm{Ma}(\mathrm{U}-\mathrm{Pb}) \\
\text { Inicio da sedimentação do Supergrupo Minas (Gr. Caraça) e dos metassedimentos da Serra de } \\
\text { Bom Sucesso. }\end{array}$ \\
\hline & $\begin{array}{l}2420 \mathrm{Ma}(\mathbf{P b}-\mathbf{P b}) \\
\text { Deposição dos carbonatos da Formação Gandarcla (Gr. Ltabira). }\end{array}$ \\
\hline & $\begin{array}{l}2124 \text { Ma (U-Pb) } \\
\text { Plutonismo granítico juvenil (Batólito Alto Maranhão) e migmatização dos gnaisses } \\
\text { monzoníticos de Lavras }(\mathrm{Rb}-\mathrm{Sr}=2137 \mathrm{Ma}) \text {. Inicio da deposição do Gr. Sabará. }\end{array}$ \\
\hline \multirow{2}{*}{$\begin{array}{c}\text { Paleoprotero } \\
\text { zóica } \\
\text { do } \\
\text { Cinturão }\end{array}$} & $\begin{array}{l}2050 \mathrm{Ma}(\mathrm{U} \mathrm{Pb}) \\
\text { Metamorfismo do Supergnupo Minas (Gr. Sabará) e dos metassedimentos da Serra de Bom } \\
\text { Sucesso. }\end{array}$ \\
\hline & $\begin{array}{l}\text { 2041-2050 Ma (U-Pb) } \\
\text { Pico dos eventos metamórficos da Orogenia Transamazônica no Cinturão Mineiro. } \\
\text { Ortognaisses de Lavras com idade Rb-Sr igual a } 1982 \mathrm{Ma} \text { e protólito Arqueano }\left[\mathrm{T}^{\mathrm{DM}}(\mathrm{Nd})=\right. \\
3,0 \mathrm{Ga} \text {. }\end{array}$ \\
\hline \multirow[t]{2}{*}{ Mineiro } & $\begin{array}{l}1932 \text { Ma (Rb-Sr) } \\
\text { Manifestaçôes tardias do plutonismo granítico (tipo Tabuôes), com evidências de campo de } \\
\text { intima associação temporal com os diques da suite básica de Lavaras. }\end{array}$ \\
\hline & $\begin{array}{l}1875 \mathrm{Ma}(\mathbf{R b}-\mathrm{Sr}) \\
\text { Intrusăo dos diques máficos da suíte básica em regime extensional, desenvolvido nos } \\
\text { estágios finais da evolução do Cinturão Minciro. }\end{array}$ \\
\hline
\end{tabular}




\section{XI - BIBLIOGRAFIA}

ABREU, F.R. (1991). Estudo das mineralizações auriferas filonianas da região da cidade de Diamantina-MG. Campinas. 103pp. (dissertação de Mestrado - IG-UNICAMP).

ALKMIM, F.F.; BRITO NEVES, B.B.; CASTRO ALVES, J.A. (1993). Arcabouço Tectônico do Cráton do São Francisco - Uma Revisão. In: DOMINGUEZ, J.M.L. \& MISI, A. (eds), O Cráton do São Francisco. Salvador. SBG-SGM-CNPq. p. 45-62.

ALMEIDA, F.F.M. de, (1977). O Cráton do São Francisco. Rev. Bras. de Geoc., 7(4):349-364.

ALMEIDA, F.F.M. de; HASUI, Y.; BRITO NEVES, B.B.; FUCK, R.A. (1977). Províncias estruturais brasileiras. VIII Simp. Geol. Nordeste, Campina Grande, PB. Atas..., 363-391.

ALMEIDA, F.F.M. de; HASUI, Y.; BRITO NEVES, B.B.; FUCK, R.A. (1981). Brazilian structural provinces: An introduction. Earth Science Rev., 17:1-29.

AMARAL, G.; CORDANI, U.G.; KAWASHTA, K.; REYNOLDS, J.H. (1966). Potassium argon dates of basaltic rocks from Southern Brazil. Geoch. Cosm. Acta, 31:117-142.

ANTONINI, P. (1995). Significato del magmatismo Giurassico nel Victoria Land (Antartide): Aspetti Petrogenetici e Geodinamici. Trieste, Itália, 160 pp. (Tese de doutoramento - Universidade de Trieste - Itália).

BABINSKI, M. (1993). Idades isocrônicas $\mathrm{Pb} / \mathrm{Pb}$ e geoquímica isotópica de $\mathrm{Pb}$ das rochas carbonáticas do Grupo Bambuí, na porção sul da Bacia do São Francisco. São Paulo, 133pp. (Tese de doutoramento - IPENUSP).

BABINSKI, M.; CHEMALE Jr, F.; VAN SCHMUS, W.R. (1995). The Pb/Pb age of the Minas Supergroup, carbonate rocks, Quadrilátero Ferrifcro, Brazil. Prec. Research, 72: 235-245.

BASTOS LEAL, L.R., (1992). Geocronologia Rb/Sr e K/Ar, cvolução isotópica e implicações tectônicas dos enxames de diques máficos de Uauá e Vale do Rio Curaçá, Bahia. São Paulo, 118pp. (dissertação de mestrado, IG-USP).

BASTOS LEAL, L.R.; TEIXEIRA, W; PICCIRILLO, E.M.; MENEZES LEAL, A.B.; GIRARDI, V.A.V. (1994). Geocronologia Rb/Sr e K/Ar do enxame de diques máficos de Uauá, Bahia (Brasil). Geochim. Brasil., $(8): 99-114$

BELLIENI, G.; PICCIRILLO, E.M; ZANETTIN, B. (1981). Classification and nomenclature of basalts. IUGS subcomisson on the systematics of Igneous rocks circular 34, contribution 87: 119. Cambridge, UK.

BELLIENI, G.; BROTZU, P.; COMIN-CHIARAMONTI, P.; ERNESTO, M.; MELFI, A.J.; PACCA, I.G.; PICCIRILLO, E.M.; STOLFA, D. (1983). Petrological and Paleomagnetic data on the plateau basalts to rhyolite sequences of the southern Paraná basin (Brazil). An. Acad. Bras. Ciênc., 55: 355-383.

BELlienI, G.; PICCIRILlO, E.M; COMIN-CHIARAMONTI, P.; MELFI, A.J.; DAROIT, P. (1988). Mineral Chemistry of continental stratoid volcanics and Related Intrusives from The Paraná Basin (Brazil). In: The Mesozoic Flood Volcanism of the Paraná Basin: Petrogenetic and geophysical aspects, Piccirillo \& Melfi (Eds). IAG-USP, São Paulo. p. 73-92.

BELlIENI, G.; PETRINI, R.; PICCIRILlo, E.M.; CAVAZZINI, G.; CIVETTA, L.; COMINCHIARAMONTI, P.; MELFI, A.J.; BERTOLO, S.; DE MIN, A. (1991). Proterozoic mafic dyke swarms of the São Francisco Craton (SE - Bahia State, Brazil): petrology and Sr/Nd isotopes. Eur. J. Mineral., 3:429449. 
BELLIENI, G.; PICCIRILLO, E.M.; PETRINI, R.; GIRARDI, V.A.V.; MENEZES LEAL, A.B.; TEIXEIRA, W.; BASTOS LEAL, L.R.; DE MIN, A.; COMIN-CHIARAMONTI, P.; TANNER DE OLIVEIRA, M.A.F. (1995). Petrological and Sr-Nd evidence bearing on Early Proterozoic magmatic events of the subcontinental mantle: São Francisco Craton (Uauá, NE Brazil). Contrib. Mincral. Petrol., 122: 252-261.

BEN OTHMAN, D.; FOURCADE, S.; ALLÉGRE, C.J. (1984). Recycling process in granite-granodiorite complex genesis: The Querigut case studied by Nd-Sr isotope systematics. Earth Planet. Sci. Lett., 69: 290300 .

BESWICK, A.E. \& SOUCIE, G. (1978). A correction procedure for metassomatism in an Archean Greenstone belt. Precambrian Res, 6: 235-248.

BESWICK, A.E. (1982). Some geochemical aspects of alteration and genctic relations in Komatiitic suites. In: Komatiites, Ardnt, N.T. \& Nesbitt, E.G. (eds); London, George Allen and Unwin: 283-308.

BOSSI, J; CAMPAL, N.; CIVETTA, L.; DEMARCHI, G.; GIRARDI, V.A.V.; MAZZUCCHELLI, M.; NEGRINI, L.; RIVALENTI, G.; FRAGOSO CESAR, A.R.S.; SINIGOI, S.; TEIXEIRA, W., PICCIRILLO, E.M.; MOLESINI, M. (1993). Early Proterozoic dyke swarms from western Uruguay: geochenistry, Sr-Nd isotopes and petrogenesis. Chem. Geol. 106:263-277.

BOYNTON, W.V. (1984). Cosmochemistry of rare carth elements: metcorite studies. In: P.Henderson (ed.) Rare Earth element geochemistry. Elsevier Publ. Co., Amsterdam, p.63-114.

BREWER, T.S. \& ATKIN, B.P. (1989). Elemental Mobilities produced by low-grade metamorphic events. A case study from the Proterozoic supracrustals of southern Norway. Precambrian Res., 45: 143-158.

BRITO NEVES, B.B.; KAWASHITA, K.; CORDANI U.G.; DELHAL, J. (1979). A evolução geocronológica da Cordilheira do Espinhaço: dados novos e integração. Rev. Bras. de Geoc. (9): 71-85.

BRITO NEVES, B.B. (1990). Processos orogênicos no pré-Cambriano do Brasil In; Raja Gabaglia, G.P. e Milani, E.J (eds). Origem e Evolução de Bacias Sedimentares. Petrobrás: 99-114.

BRITO NEVES, B.B. \& CORDANI, U.G. (1991). Tectonic evolution of South America during Late Proterozoic. Prec. Res., 53:23-40.

BRITO NEVES, B.B. \& ALKMIM, F.F. (1993). Cráton: Evolução de um conceito. In: DOMINGUEZ, J.M.L. \& MISI, A. (eds), O Cráton do São Francisco. Salvador SBG-SGM-CNPq p. 1-10.

BROWN, G.M. (1957). Pyroxenes from the early and middle stages of fractionation of the Skaergaard intrusion. East Greenland. Mincral. Mag., $31: 511 \cdots 543$.

BROWN, G.M. \& VINCENT, E.A. (1963). Pyroxenes from the late stages of fractionation of Skacrgaard intrusion, east Greenland. J.Petrol., 4: 175-197.

CADMAN, A.; TARNEY, J.; PARK, R.G. (1990). Intrusion and crystallisation features in Proterozoic dyke swarms. In: Mafic Dykes and Emplacement Mechanisms, Parker, Rickwood \& Tucker (eds), Balkema: 13-24.

CANN, J.R. (1970). Rb, Sr, Y, Zr and Nb in some ocean floor basaltic rocks. Earth Planet. Sci. Lett, 10: 7-11.

CARMICHAEL, IS.E. (1967). The iron-Titanium oxides of sialic volcanic rocks and their associated ferromagnesium silicates. Contrib. Mincral. Petrol., 14: 36-64.

CARNEIRO, M.A. (1992). O Complexo Mctamórfico Bonfin Setentrional (Quadrilátero Ferrífero, Minas Gerais): Litoestratigrafia e Evolução Geológica de um segmento de crosta continental do Arqueano. São Paulo, 233pp.(Tese de doutoramento, IG-USP). 
CARNEIRO, M.A.; NOCE, C.M.; TEIXEIRA, W. (1995). Evolução Policíclica do Quadrilátero Ferrifero: Uma análise fundamentada no conhecimento atual da Geocronologia U-Pb e geoquimica Isotópica $\mathrm{Sm}-\mathrm{Nd}$. REM: Rev. Esc. Minas, Ouro Preto, 48(4): 264-273.

CAVALCANTE, J.C.; CUNHA, H.C.S.; CHIEREGATTI; L.A.; KAEFER, L.Q.; ROCHA, J.M.; DAITX, E.C.; COUTINHO, M.G.N.; YAMAMOTO, K.; DRUMOND, J.B.V.; ROSAM, D.B. E RAMALHO, R. (1979). Projeto relatório final de Geologia - Estados de S.Paulo e Minas Gerais. DNPM, Brasilia, série Gcologia no 4 Seção Geologia básica n²: 299pp.

CAWTHORN, R.G. \& DAVIES, G. (1982). Possible Komatitic affinity of the Busheveld Complex, South Africa. In: Komatiites, Arndt, N.T. \& Nisbett, E.G. (Eds). London, George Allen and Unwin: 91 -96.

CHAVES, A.O. (1996). Enxame de Diques Máficos Proterozóicos da porção meridional do Cráton do São Francisco, MG, Brasil. Belo Horizonte, 91 pp. (dissertação de mestrado -UFMG).

CHOUDHURI, A.; SIAL, A.N.; OLIVEIRA, E.P. (1990). Unmetamorphosed Proterozoic tholeiite dykes from the northern Amazon Craton, Guiana, the evolution of basaltic magmatism. In: Mafic dykes and Emplacement Mechanisms. Parker, Rickwood \& Tucker (eds) Balkema: 275-283.

COLLERSON, K.D. \& SHERATON, J.W. (1986). Age and Geochemical characteristics of a Mafic Dyke Swarm in the Archean Vestfold Block, Antarctica: Inferences about Proterozoic Dyke Emplacement in Gondwana, Journal of Petrol. 27(4): 853-886.

CONDIE, K.C.; BOBROW, D.J.; CARD, K.D. (1987). Geochemistry of Precambian Mafic Dykes from the Southen Supcrior Province of the Canadian Shield. M: Mafic dyke Swarms, Halls \& Fahrig (eds). Geological Association of Canadá, special paper 34: 95-108.

CORDANI, U.G.; KAWASHITA, K.; MULLER, G.; QUADE, H.; REIMER, V.; ROESER, H. (I980). Interpretação tectônica e petrológica do embasamento no bordo sudeste do Quadrilátero Ferrífero, MG. An. Acad. Bras. Ciênc., 52(4): 785-799.

CORDANI, U.G. \& BRITO NEVES, B.B. (1982). The geologic evolution of South America during the Archean and Early Proterozoic. Rev. Bras.Geociênc., 12:78..88.

CORDANI, U.G.; TEIXEIRA, W.; TASSINARI, C.C.G.; KAWASHITA, K.; SATO, K. (1988). The growth of the Brazilian shield. Episodes, 11(3): 163-167.

CORREA GOMES, L.C.; TANNER DE OLIVEIRA, M.A.F; CONCEIÇÃO, H; ABRAM, M.B. (1991). Tectonic styles and chemistry of the mafic dykes in the eastern part of São Francisco Craton, Bahia, Brazil. In: INTERN. SYMP. MAFIC DYKES, São Paulo, 1991. Extended Abstracts... São Paulo, p. 66-70.

CRAWFORD, A.J.; FALLOON, T.J.; GREEN, D.H. (1989). Classification, petrogenesis and tectonic setting of boninites. In: Boninites and Related Rocks, Crawford, A.J. (Ed), London, Unwin Hyman: 1 49.

CRAWFORD, A.J. (1989). Boninites and Related Rocks. London, Unwin Hyman. 465pp.

D'AGRELLA-FILHO, M.S.; PACCA, I.G.; RENNE, P.R.; ONSTOTT, T.C; TEIXEIRA, W. (1990). Paleomagnetism of middle-Proterozoic 1.01 to $1.08 \mathrm{Ga}$ mafic dykes in the São Francisco Craton, Brazil. Earth Planet. Sci. Lett. (101): 332-348.

D'AGRELLA.FLHO, M.S. (1992). Paleomagnetismo dos enxames de diques máfícos proterozóicos e rochas do embasamento do Craton do São Francisco. São Paulo, 201 pp. (Tese de Doutoramento, lAG-USP).

DARDENNE, M.A. (1978). Síntese sobre a estratigrafia do Grupo Bambui no Brasil Central. In: 30 Congress. Bras. Geol. Recife, SBG, anais ... vol. 2:597-610. 
DE LA ROCHE, H, LETERRIER, P., GRANDCLAUDE, P.; MARCHAL, M. (1980). A classification of volcanic and plutonic rocks using $R_{1}-R_{2}$ diagram and major-element analyses. Its relationships with current nomenclature. Chem.Geol., 28: 183-210.

DEER, W.A.; HOWIE, R.A.; ZUSSMAN, J. (1992). An introduction to the rock forming minerals. $2^{\text {a }}$ ed, London, Longman, $695 \mathrm{pp}$.

DOOR, J.V.N., (1969). Physiographic, stratigraphic and structural development of Quadrilatero Ferrifero, Minas Gerais, Brazil. Geol. Survey Prof Paper, 64l(4):1-110.

DNPM (1978). Carta Geológica do Brasil ao Milionésio. Folha Rio de Janeiro/Vitória e lguape. Brasília.

DePAOLO, D.J. (1981). Trace element and isotopic effects of combined wallrock assimilation and fractional crystallization. Earth Planet. Sci. Lett., 53:189-202.

DUSSIN, T.M. (1994). Associations Volcano-Plutoniques de L'Espinhaço Meridional (SE-Brésil): Un example d'evolution de la croûte protérozoique. Orléans, França 177pp. (Tese de doutoramento - Universidade de Orléans, França).

EBERT, H. (1984). Aspectos principais da geologia da região de São João del Rei, Estado de Minas Gerais./Os Paraibides entre São João del Rei $(\mathrm{MG})$ e ttapira (SP) e a bifurcação entre Paraibides e Araxaides (in memorian). Publ. n'. 12, SBG-SP, 114p.

EMERMAN, S.H. \& MARRETT, R. (1990). Why dykes? Geology, 18:231-233.

ERNST, R.E.; HEAD, J.W.; PARFITT, E.; GROSFILS, E.; WILSON, L. (1995). Giant radiating dyke swarms on Earth and Venus. Earth Sci. Rev., 39:1-58.

FAHRIG, W.F. (1987). The Tectonic setting of continental mafic dyke swarms: failed arm and early passive margin. In: Mafic Dyke Swarms, Halls \& Fahrig (Eds). Geol. Assoc. Can., spec. pap, 34: 331-348.

FAURE, G. (1986). Principles of Isotope Geology. New York, John Wiley \& Sons (2a ed.) 589 pp.

FÉRAUD, G.; GIANNERINI, G.; CAMPREDON, R. (1987). Dyke swarms as paleostress indicators in areas adjacent to continental collision zones: Examples from European and northwest Arabian Plates. In: Mafic Dyke Swarms, Halls \& Fahrig (Eds). Geol. Assoc. Canada, special paper 34:273-278.

FIELD, D. \& ELLIOT, R.B. (1974). The Chemistry of gabbro/amphibolite transitions in south Norway. Contrib. Mineral. Petrol., 47: 63-76.

FIUMARI, S.L.; PADILHA, A.V.; ARAUjO, M.C. (1985). Complexo Granulítico de Passa Tempo. In: 3 Simp. Geol. Minas Gerais, Belo Horizonte, anais ... p.60-67.

GELINAS, L.; MELLINGER, M.; TRUDEL, P. (1982). Archean mafic metavolcanics from the Royn-Noranda district, Abitibi Greenstone belt. Quebec 1. Mobility of major elements. Can. J. Earth Sci, 19: 2258-2275.

HALL, R.P.; HUGHES, D.J; FRIEND, C.R.L. (1985). Geochemical Evolution and Unsual Pyroxenc Chemistry of the MD Tholeiite Dyke Swarm from the Archean Craton of Southern West Greenland. Journal of Petrology, 26: 253-282.

HALL, R.P. \& HUGHES, D.I. (1987). Noritic dykes of southern West Greenland: carly Proterozoic boninitic magmatism. Contrib. Mineral. Petrol., 97: 169-182.

HALL, R.P. \& HUGHES, D.J. (1990). Noritic magmatism. In: Early Precambrian basic magmatism, Hall \& Hughes (eds), Blackie p.83-110. 
HALLS, H.C. (1982). The importance and Potential of Mafic Dyke Swarms in Studies of Geodynamic Process. Geoscience Canadá, 9(3): 145-154.

HALLS, H.C. (1987). Dyke swarms and continental rifting: some concluding remarks. In: Mafic dyke swarms, Halls, H.C. \& Fahrig, W.F.(eds). Geological Association of Canada, special paper 34: 483-491.

HAWKESWORTH, C.J. \& VAN CALSTEREN, P.W.C. (1984). Radiogenic Isotopes - Some Geological applications. In: Rare Earth Element Geochemistry. Henderson, P. (Ed). Elsevier, Amsterdan: 375-42.1.

HEAMAN, L.M. \& TARNEY, J. (1989). U-Pb baddeleyite ages for the Scouric dyke Swarm, Sconland: Evidence for two distinct intrusion events. Nature, 340:705-708.

HEAMAN, L.M. (1995). U.Pb dating of Mafic Rocks: past, present and future. Abstract, Geol. Assoc. Canada and Mineral. Assoc. Canada, Anmu. Meet., 20: A43.

HELlBRON, M.; LOPES, M.; TEIXEIRA, W.; TROUW, R.; PADILHA, A.V.; KAWASHITA, K. (1989). Geocronologia da região entre Lavras, São João del Rei, Lima Duarte e Caxambu, MG. An. Acad. Bras. Ciênc., 61(2): 177-199.

HEIMANN, A.; EYAL, Y.; EYAL, M.; FOLAND, K.A. (1995). Thermal events and low temperature alteration in the Precambrian Schistose Dykes and their host rocks in the Elat area, southern Israel: ${ }^{40} \mathrm{Ar} /{ }^{39} \mathrm{Ar}$ geochronology. In: Physics and Chemistry of Dykes. Baer \& Heimam (eds) Balkema: 281-292.

HELLMAN, P.L. \& GREEN, T.H. (1979). The role of sphene as an accessory phase in the high pressure partial melting of hydrous mafic compositions. Earth Planet. Sci. Lett., 42:191 201.

HOOPER, P.R. (1988). The Columbia River basalt. In: Continental Flood Basalts. Macdougall, J.D. (Ed) Kluwer, Dordrecht: 1.33 .

IBGE (1979). Cartas topográficas na escala 1:50.000. Folhas de Lavras, Santo Antônio do Amparo, Santana do Jacaré, Nepomuceno, São Tiago, Nazareno, Jacarandira e São Jõao Del Rei. Brasília, 1979.

IGA/CPGeo - Datações geocronológicas da borda sul do craton do São Francisco. inédito.

INDA, H.A.V.; SCHORSCHER, H.D.; DARDENNE, M.A.; SCHOBBENHAUS, C.; HARALYI, N.L.E.; BRANCO, P.C.A.; RAMALHO, R. (1984). O Cráton do São Francisco e a faixa de dobramentos Araçuaí. In: Geologia do Brasil. Schobbenhaus, Campos, Derze \& Asmus (Eds). Brasilia MME/DNPM: 193-248.

IRVINE, T.N. \& BARAGAR, W.R.A. (1971). A guide to the Chemical classification of the common volcanic rocks. Can. J. Earth. Sci., 8:523-548.

ISHII, T. (1975). The relations between temperature and composition of pigeonites in some lavas and their application to geothermometry. Miner. J., 8: 48-57.

KALSBEEK, F.; BRIDGWATER, D.; ZECK, H.P. (1978). A $1950 \pm 60$ Ma Rb-Sr whole rock isochron age from two Kangâmiut dykes and the timing of the Nagssugtogidian (Hudsonian) orogeny in West Greenland. Can. J. Earth Sci., 15: 1122-1128.

KALSBEEK, F. \& TAYLOR, P.N. (1985). Age and origin of early Proterozoic dolerite dykes in South-West Greenland. Contrib. Mineral. Petrol, 89: 307-316.

KALSBEEK, F. \& TAYLOR, P.N. (1986). Chemical and isotopic homogeneily of a $400 \mathrm{Km}$ long basic dyke in central West Greenland. Contrib. Mineral. Petrol, 93:439-448.

KAWASHITA, K. (1996). Carbonatos neoproterozóicos da America do Sul: idades e inferências químicoestratigráficas. São Paulo 126pp. (Tese de Livre Docência - IG-USP). 
KRETZ, R.C. (1982). Transfer and exchange equilibria in a portion of the pyroxene quadrilateral as deduced from natural and experimental data. Geoch. Cosm. Acta, 46: 411 -421.

KUDO, A.M. \& WEILL, D.F. (1970). An igneous plagioclase thermometer. Contrib. Mineral. Petrol., 26: 52 65.

KUEHNER, S.M. (1989). Petrology and gcochemistry of carly Proterozoic high-Mg dykes from the Vestfold Hills, Antarctica. In: Boninites and Related Rocks, Crawford, A.J. (Ed.). London, Unwin Hyman: 208-231.

LANYON, R.; BLACK, L.P.; SEITZ, H.M. (1993). U-Pb zircon dating of mafic dykes and its application to the Proterozoic geological history of the Vestfold Hills, East Antarctica. Contrib. Mineral. Petrol. 115:184-203.

LEAKE, B.E. (1978). Nomenclature of amphiboles. Amer. Miner., 63: 1023-1052.

LE BAS, M.J.; LE MAITRE, R.W.; STRECKEISEN, A; ZANETTIN, B. (1986). A chemical classification of volcanic rocks based on total alkali-silica diagram. J.Petrol, 27: 745-750.

LECHEMINANT, A.N. \& HEAMAN, L.M. (1989). Mackenzic igneous events, Canada: Middle Proterozoic hotspot magmatism associated with ocean opening. Earth Planet. Sci. Lett., 96: 38-48.

LE MAITRE, R.W. (1989). A Classification of Igneous Rocks and glossary of terms: recommendations of The International Union of Geological Sciences Subcommission on The Systematic of Igneous Rocks. Le Maitre, R.W. (ed). Oxford, Blackwell, 193 pp.

MACHADO, N.; SCHRANK, A.; ABREU, F.R.; KNAUER, L.G.; ALMEIDA-ABREU, P.A. (1989). Resultados preliminares da geocronologia U-Pb na Serra do Espinhaço Meridional. In: V Simp. Geologia de Minas Gerais/I Simp. Geol. Brasilia. Belo Horizonte, SBG-MG. Anais ... p. 171-174 (Boletim 10).

MACHADO, N. \& SCHRANK, A. (1989). Geocronologia U.Pb no Maciço de Piumhi - resultados preliminares. In: V Simp. Geol. Minas Gerais, I Simp. Geol. Brasilia, Belo Horizonte, SBG-MG. Anais p. 4549.

MACHADO, N.; NOCE, C.M.; LADEIRA, E.A.; BELO DE OLIVEIRA, O.A. (1992). U.Pb geochronology of Archean magmatism and Proterozoic metamorphism in the Quadrilatero Ferrifero, southern São Francisco Craton, Brazil. Geol. Soc. Am. Bull. 104: 1221-1227.

MACHADO, N.; \& CARNEIRO, M.A. (1992). U-Pb evidence of late Archean tectonothermal activity in the southern São Francisco shield, Brazil. Can. Journal Earth Sci., 29: 2341-2346.

MACHADO, N.; SCHRANK, A.; NOCE, C.M.; GAUTHIER, G. (1996). Ages of detrital zircon from Archean - Paleoproterozoic sequences: Implications for Greenstone Belt setting and evolution of a Transamazonian Foreland basin in Quadrilátero Ferrifero, southeast Brazil. Earth Planet. Sci. Lett., 141: 259-276.

MACHADO FILHO, L.; RIBEIRO, M.W.; GONZALEZ, S.R.; SCHENINI, C.A.; NETO, A.S.; PALMEIRA, R.C. de B.; TEIXEIRA, W.; CASTRO, H.E.F. (1983). Geologia. In: Projeto Radam Brasil, folhas SF 23/24 Rio de Janeiro o Vitória. DNPM/MME/SG p. 27-304. (levantamento de Recursos Naturais, 32).

MARQUES, L.S. (1988). Caracterização gcoquimica das rochas vulcânicas da Bacia do Paraná: implicaçõcs petrogenéticas. São Paulo, 175pp. (Tese de Doutoramento, IAG-USP).

MATHEZ, E.A. (1973). Refinament of Kudo Weill plagioclase thermometer and its application to basaltic rocks. Contrib.Mineral. Petrol., 41: 61-72. 
MAZZUCCHELLI, M.; RIVALENTI, G.; PICCIRILLO, E.M.; GIRARDI, V.A.V.; CIVETTA, L.; PETRINI, R. (1995). Petrology of the Proterozoic mafic dyke swarms of Uruguay and constraints on their mantle source composition. Precambrian Res., 74: 177-194.

MCCULLOCH, M.T. \& GAMBLE, J.A. (1991). Geochemical and geodynamical constraints on subduction zone magmatism. Earth Planet. Sci. Lett. 102:358-374.

MELLINI, M.; CARBONIN, S; DAL NEGRO, A.; PICCIRILLO, E.M. (1988). Tholeitic hypoabyssal dykes: How many clinopyroxenes? Lithos, 22: 127-134.

MENEZES, A.B. (1992). O enxame de diques máficos de Uauá-Bahia: Caracterização petrológica e geoquímica. São Paulo, 126pp. (dissertação de Mestrado, Instituto de Gcociências - USP)

MENEZES LEAL, A.B.; BELLIENI, G.; GIRARDI, V.A.V.; BASTOS LEAL, L.R.; TEIXEIRA, W.; PICCIRILLO, E.M. (1995). Contribuição ao estudo Petrológico e Geoquímico dos enxames de diques máficos de Uauá, Bahia, Brasil. Geochim. Brasil., 9(1): 61-90.

MICHARD, A.; GURRIET, P.; SOUNDANT, M.; ALBAREDE, F. (1985). Nd isotopes in French Phanerozoic shales: extental vs internal aspects of crustal cvolution. Geochim. Cosmochim. Acta, 49: 601-610.

MORAES BRITO, C., (1992). Caracterização geológica, geoquímica e petrológica dos diques máficos Proterozóicos da região de Salvador-BA. São Paulo, 96pp. (Dissertação de Mestrado, IAG-USP).

NOCE, C.M; PINHEIRO, S.O.; LADEIRA, E.A.; FRANCA, C.R.; KATTAH, S. (1992). A sequência vulcano-sedimentar do Grupo Nova Lima na região de Piedade do Paraopeba, oeste do Quadrilátero Ferrifero, Minas Gerais. Rev. Bras. Geociências, 22(2): 175-183.

NOCE, C.M. (1995). Geocronologia dos eventos magmáticos, sedimentares e metamórficos na região do Quadrilátero Ferrifero, Minas Gerais. São Paulo, 127 pp. (Tese de Doutoramento, IG - USP).

NOCE, C.M. \& TEIXEIRA, W. (1996). Estudos isotópicos $\mathrm{cm}$ granitóides do Cinturão Mineiro: margem continental de idade transamazônica. In: 39 Congress. Bras. de Geologia. Salvador, SBG-BA, anais ... vol. 6: $483-488$.

OLIVEIRA, E.P.; TARNEY, J; JOÃO, X.J. (1990). Geochemistry of the Mesozoic Amapa and Jari Dyke Swarms, northern Brazil: Plume-related magmatism during the opening of the central Atlantic. In: Mafic dykes and Emplacement mechanisms. Parker, Rickwood \& Tucker (eds). Balkema: 173-183.

OLIVEIRA, E.P. (1993). Diques toléticos, noriticos e piroxeníticos no enxame de Uauá, Bahia: Evidências geoquímicas de heterogeneidade no manto Proterozóico inferior do Cráton do São Francisco. In: $4^{\circ}$. Congr. Bras. Geoquimica, SBGQ - Boletim de resumos, p.5-7.

OLIVEIRA, E.P. \& TARNEY, J. (1995). Petrogenesis of the Late Proterozoic Curaçá mafic dyke swarm, Brazil: asthenospheric magmatism associated with continental collision. Mincral. and Petrol, 53: 27-48.

PAPIKE, J.J; CAMERON, K.; BALDWIN, K. (1974). Amphyboles and pyroxenes: characterization of the other than quadrilateral components and estimates of ferric iron from microphobe data. Bull. Geol. Soc. Am. 6: $1053-1054$.

PARENTI COUTO, J.G.; TEIXEIRA, W.; CORDANI, U.G., (1983). Considerações sobre as principais épocas de fraturamento do Cráton do São Francisco, com base $\mathrm{cm}$ datações $\mathrm{K}$-Ar $\mathrm{cm}$ rochas básicas. In: An. do II Simp. Geol. de Minas Gerais, Belo Horizonte, MG, Bol, 3:38-49

PEARCE, T.H. (1968). A contribution to the theory of variation diagrams. Contrib. Mineral. Petrol., 19: 142157. 
PEARCE, T.H. (1970). Chemical variations in the Palisades Sill. Journal of Petrology, 11: 15-32.

PEARCE, J.A. \& CANN, J.R. (1973). Tectonic setting of basic volcanic rocks determined using trace element analyses. Earth Planet. Sci. Leti., 19:290-300.

PEDROSA SOARES, A.C.; DARDENNE, M.A.; HASUY, I.; CASTRO, F.D.C.; CARVALHO, M.V.A.; REIS, A.C. (1994). Mapa Gcológico do Estado de Minas Gerais, escala 1:1000.000 (texto explicativo). Belo Horizonte, COMIG, 97pp.

PICCIRILLO, E.M.; COMIN-CHIARAMONTI, P.; MELFI, A.J.; STOLFA, D.; BELLIENI, G.; MARQUES, L.S.; GIARETTA, A.; NARDY, A.J.; PINESE, J.P.P.; RAPOSO, M.I.B.; ROISEMBERG, A. (1988). Petrochemistry of continental nood basalt-rhyolite suites and related intrusives from the Parana basin (Brazil). In: The Mesozoic flood volcanism of the Paraná basin: Petrogenetic and Geopliysical aspects, Piccirillo, E.M. \& Melfi, A.J. (Eds). São Paulo, IAG-USP: 107-156.

PICCIRILLO, E.M.; BELLIENI, G.; CAVAZZINI, G.; COMIN-CHIARAMONTI, P. PETRINI, R.; MELFI, A.J.; PINESE, J.P.P.; ZANTEDESCHI, P.; DE MIN, A. (1990). Lower Cretaceous Tholeitic Dyke Swarms from Ponta Grossa Arch (SE-BRAZIL): petrology, Sr/Nd isotopes and genetic relationships with the Parana flood volcanics. Chemical Geology, 89: 19-48.

PINESE, J.P.P. (1989). Caracterização Petrológica c Geoquimica dos diques do Arco de Ponta Grossa. São Paulo, 196pp. (dissertação de Mestrado-IAG-USP).

PINESE, J.P.P.; TEIXEIRA, W.; PICCIRILLO, E.M.; QUEMENEUR,J.J.G.; BELLIENI,G. (1995). The Precambrian Lavras mafic dykes, southern São Francisco Craton, Brazil: Preliminary geochemical and geochronological results. Physics and Chemistry of Dykes, Bacr \& Heimann (eds), Balkema: 205-218.

POLDERVAART, A. \& HESS, H.H. (1951). Pyroxenes in the crystallization of basaltic magma. J. Geology, 59: 472-489.

PONTE NETO, C.F. (1996). Estudo Paleomagnético de enxames de diques máficos pré-Cambrianos da região de Lavras, Minas Gerais. São Paulo 98pp. (dissertạ̧ão de Mestrado - IAG-USP).

QUÉMÉNEUR, J.J.G. (1987). Esboço estratigráfico, estrutural e metamórfico da Serra de Bom Sucesso, MG. In: 4 Simp. Geol. Minas Gerais, Belo Horizonte. Anais SBG, Boletim 7: 135-148.

QUÉMÉNEUR, J.J.G. (1989).Proterozoic dikes of the Bom Sucesso Region, Minas Gerais, Brazil. In: Workshop on Mafic Dykes Swarm of Brazil, 1989. Bol. IG-USP, Séric Cientifica, 20:31-32.

QUÉMÉNEUR, J.J.G. \& VIDAL, P. (1989). Primeiras datações radiométricas dos granitos da região de São Jõao Del Rey. In: Simp. de Geol. Minas Gerais, 5, Belo Horizonte, 1989. Anais, Belo Horizonte, SBG. p.5054.

QUÉMÉNEUR, J.J.G. (1991). Proterozoic dykes of the Bom Sucesso-Lavras Region (Minas Gerais, Brazil). Excursion Guide. Bol. IG-USP, Publ. Esp., 10:97-103.

QUÉMÉNEUR, J.J.G. \& GARCIA, D. (1993). Os maciços de Tabuões e Ritápolis na região de São Jõao Del Rey, Granitóides Transamazônicos com a associação granito trondjhemito pegmatito. In: Simp. de Geol. de Minas Gerais, 7, 1993. Anais...BH, SBG-MG, p.105-107.

QUÉMÉNEUR, J.J.G.; NOCE, C.M.; GARCIA, D. (1994). Caractcrização das suites granitóides do Arco magmático transamazonico na borda meridional do Cráton do São Francisco, Minas Gerais. In: 38 Congress. Bras. Geologia, Bal. de Camboriu, SBG.SC. Anais ... vol. 1:117-119. 
QUÉMÉNEUR, J.J.G. (1996). Os magmatismos de idade Arqueana e Transamazônica na região de Campos das Vertentes, Minas Gerais (sul do Cráton do São Francisco), com base em Geoquímica e Geocronologia. (Em preparação)

RAPOSO, M.I.B. \& ERNESTO, M. (1995). Anisotropy of magnetic susceptibility in the Ponta Grossa dyke swarm (Brazil) and its relationship with magma flow direction. Phys. Earth Planet Int., 87:183-196.

RENGER, F.E.; NOCE, C.M.; ROMANO, A.W.; MACHADO, N. (1994). Evolução Sedimentar do Supergrupo Minas (500 Ma de registro geológico), Quadrilátero Ferrifero, Minas Gerais, Brasil. Geonomos (2): $1-11$.

RENNE, P.R.; ONSTOTT, T.C.; D'AGRELLA-FILHO, M.S.; PACCA, I.G.; TEIXEIRA, W., (1990). ${ }^{40} \mathrm{Ar} /{ }^{39} \mathrm{Ar}$ dating of 1.0-1.1 Ga magnetizations from the São Francisco and Kaapvaal Cratons: Tecionic implications for Pan-African and Brasiliano Mobile belts. Earth Planet. Sci. Lett., 101: 349-366.

RENNE, P.R.; DECKART, K.; ERNESTO, M.; FÉRAUD, G.; PICCIRILLO, E.M. (1996). Age of the Ponta Grossa dike swarm (Brazil), and implications to Parana flood volcanism. Earth Planet. Sci. Lett. 144: 199. 211.

RIVALENTI, G.; MAZZUCCHELLI, M.; MOLESINI, M.; PETRINI, R.; GIRARDI, V.A.V.; BOSSI, J.; CAMPAL, N. (1995). Petrology of late Proterozoic mafic dikes in the Nico Perez region, central Uruguay. Mineralogy and Petrology, 55: 239-263.

ROEDER, P.L. \& EMSLIE, R.F. (1970). Olivine-liquid equilibrium. Contrib. Mineral. Petrol., 29: 275-289.

ROLLINSON, H.R. \& ROBERTS, C.R. (1986). Ratio correlations and major element mobility in altered basalts and Komatiites. Contrib. Mineral. Petrol., 93: 89-97.

ROLLINSON, H.R. (1993). Using Geochenical Data: Evaluation, Presentation, Interpretation. London, U.K., Longman Group Ltd, 352pp.

RUSSEL, J.K. \& NICHOLLS, J. (1988). Analyses of petrologic hypothesis with Pearce element ratio. Contrib. Mineral. Petrol.; 99: 25 35.

SATO, K.; TASSINARI, C.C.G.; KAWASHITA, K.; PETRONLHO, L. (1995). O Método Geocronológico Sñ-Nd no IG-USP e suas aplicações. An. Acad. Bras. Ciências. 67(3): 313-336.

SCHORSCHER, H.D. (1978). Komatiitos na estrutura "Greenstone belt" Série Rio das Velhas, Quadrilátero Ferrifero, Minas Gerais, Brasil. In: 30 Congress. Bras. de Geologia. Recife; SBG anais ... Bol. resumos: 292. 293.

SCHORSCHER, H.D. (1988). NE Quadrilátero Ferrifero and Adjacent Areas. In: International Conference "Geochemical Evolution of The Continental Crust". Poços de Caldas, Guidebook. 96p.

SCHORSCHER, H.D. (1992). Arcabouço petrográfico e evolução crustal de terrenos pré-cambrianos do nordeste de Minas Gerais: Quadrilátero Ferrífero, Espinhaço Meridional e domínios granito-gnáissicos adjacentes. São Paulo, 394 pp. (Tese de Livre Docência - IG-USP).

SECCO, L.; CARBONIN, S.; DAL NEGRO, A.; MELLINI, M.; PICCIRILLO, E.M. (1988). Crystal chemistry of pyroxenes from basalts and rhyodacites of the Parana basin (Brazil). In: The Mesozoic flood volcanism of the Paraná basin: Petrogenetic and Geophysical aspects. Piccirillo \& Melfi (Eds). São Paulo. IAGuUSP. p. 93. 106.

SIAL, A.N.; OLIVEIRA, E.P.; CHOUDHURI, A. (1987). Mafic dyke swarms of Brazil. In: Mafic dyke swarms, Halls \& Fahrig (Eds) Geological Association of Canada, special paper 34:467 481. 
SHERATON, J.W.; THOMSON, J.W.; COLLERSON, K.D. (1987). Mafic Dyke Swarms of Antarctica. In: Mafic Dyke Swarms. Halls \& Fahrig (Eds) Geol. Assoc. of Canada, spec. pap. 34: 419-432.

SILVA, A.M. (1992). Geologia e petroquímica dos cnxames de diques máficos do Quadrilátero Ferrifero e Espinhaço Meridional, MG. Brasilia, 118pp. (Dissertação de Mestrado, IG-UnB).

SILVA, A.M.; CHEMALE JR, F.; KUYUMJIAN, R.M.; HEAMAN, L. (1996). Mafic dyke swarms of Quadrilátero Ferrifero and Meridional Espinhaço, Minas Gerais State, Brazil. Journal of South American Earth Sci. (submetido).

STEIGER, R.H. \& JÄGER, E. (1977). Subcomission on Geochronology: Convention on the use of decay constants in geochronology and cosmochronology. Earth Planet. Sci. Lett, 36: 359-362.

STERN, R.A.; PERCIVAL, J.A.; MORTENSEN, J.K. (1994). Geochemical evolution of the Minto block: a 2.7 Ga continental magmatic are built on the Superior proto-craton. Precambrian Res., 65:115-153.

STORMER JR, J.C. \& NICHOLLS, J. (1978). XLFRAC: a program for the interactive testing of magmatic differentiation models. Computer \& Geoscience, 4: 143-159.

SUMMERS, M.A.; HALL, R.P.; HUGHES, D.J.; NESBITT, R.W.; SNYDER, G.L. (1995). The Tony Ridge zoned ultramafic dykes, Wyoming, USA: Preliminary geochemical results. In: Physics and Chemistry of Dykes, Baer \& Heimann (eds), Balkema: 193-204.

SUN, S.»s. \& MCDONOUGH, W.F. (1989). Chemical and isotopic systematics of oceanic basalts: implications for mantle composition and process. In: Magmatism in the ocean basins, Sauders, A.D. \& Norry, M.J. (Eds). Blackwell, Geol. Soc. Spec. Publ., 42: 313-345.

TARNEY, J. \& WEAVER, B.L. (1987). Geochemistry and Petrogenesis of Early Proterozoic Dyke Swarms. In: Mafic Dyke Swarms, Halls \& Fahrig (eds). Geol. Assoc. Can., special paper, 34: 81-94.

TARNEY, J. (1992). Geochemistry and significance of Mafic Dyke Swarms in the Proterozoic. In: Proterozoic Crustal Evolution, Condic, K.C. (ed), Elsevier: 151-174.

TEIXEIRA, W. (1982). Geochronology of the southern part of the São Francisco craton. Rev. Bras. Geoc., 12 (1-3):268-277.

TEIXEIRA, W. (1985). A evolução geotectônica da porção Meridional do Craton do São Francisco, con base em interpretações geocronológicas. São Paulo, Brasil, 207 pp. (Tese de Doutoramento).

TEIXEIRA, W.; CORDANI, U.G.; KAWASHITA, K.; TAYLOR, P.N. VAN SCHMUS R. (1987). Archean and Early Proterozoic crustal evolution in the southern part of the São Francisco Craton. In: International Symp. on Granites and associated mineralizations, Salvador, Extended Abstracts: 37.40.

TEIXEIRA, W.; PECCHIO, M.; TAME, N.R.; KAWASHITA, K. (1988). Geocronologia K/Ar do enxame de diques da parte Mcridional do Cráton do São Francisco e implicaçôes no contexto geotectônico In: Congr. Bras. de Geologia, 35, Belém. Anais. Belém SBG. V.G. p. 2870-2878.

TEIXEIRA, W. (1989). Mafic dykes in the southern part of the São Francisco Craton: A tectonic review based on K/Ar geochronology. Bol. IG-USP, Série Científica, 20:25-30.

TEIXEIRA, W. (1990). The Proterozoic mafic dyke swarms and alkaline intrusion in the Amazonian Craton, South Amcrica, and their tectonic evolution based on $\mathrm{Rb}-\mathrm{Sr}, \mathrm{K}$-Ar and ${ }^{20} \mathrm{Ar}-{ }^{39} \mathrm{Ar}$ geochronology. In: Mafic dykes and Emplacement Mechanisms. Parker, Rickwood \& Tucker (eds) Balkema: 285-293.

TEIXEIRA, W.; ONSTOTT, T.C.; MACKENYA, M. (1990). Geochronology and crustal evolution of granitegreenstone terranes in the Southern São Francisco Craton, Brazil. 3rd Intern. Arch. Symp., Perth, 113-114. 
TEIXEIRA, W. \& FIGUEIREDO, M.C.H. (1991). In: An outline of Early Proterozoic crustal evolution in the São Francisco Craton, Brazil: A review. Precambrian Research, 53: 1-22.

TEIXEIRA. W. (1992). Contribuição ao conhecimento geocronológico do Craton do São Francisco: avaliação de dados isotópicos em rochas ígneas e metamórficas - implicações na evolução crustal Pré-Cambriana. São Paulo, 197 pp. (Tese de Livre Docência., IG-USP).

TEIXEIRA, W. \& CANZIAN, F.S. (1994). A evolução tectonotermal Proterozóica do Cráton do São Francisco com base $\mathrm{cm}$ interpretações geocronológicas $\mathrm{K}$-Ar $\mathrm{cm}$ rochas do scu embasamento. Boletim IG-USP, Séric Cientifica, 25: 61-80.

TEIXEIRA, W.; CARNEIRO, M.A.; NOCE, C.M.; MACHADO, N.; SATO, K.; TAYLOR, P.N. (1996a). Pb, $\mathrm{Sr}$ and $\mathrm{Nd}$ isotope constraints on the Archean evolution of gneissic granitoid complexes in the southern São Francisco Craton, Brazil. Precambrian Research, 78: 151-164.

TEXXERA, W.; CORDANI, U.G.; NUTMAN, A.P.; SATO, K. (1996b) Polyphase Archean evolution in the Campo Belo metamorphic complex, southern São Francisco Craton (Brazil): SHRIMP U.Pb zircon evidence. Geology (submetido).

TEIXEIRA, W.; GONZALES, C.; CHAVES, A.O. (1996c). Caracterização Isotópica Rb-Sr e K Ar do enxame de diques de Pará de Minas, MG, inferências tectônicas. In: 39 Congress. Bras. de Geologia. Salvador, SBG. $B A$, anais ... volume 6: 614-616.

TROMPETTE, R. (1994). Gcology of Westen Gondwana (2000-500 Ma) Pan-Africa Brasiliano Aggregation of South America and Africa. Balkema, 350pp.

VILJOEN, M.J.; VILJOEN, R.P.; PEARTON, T.N. (1982). The nature and distribution of Archean Komatiite volcanis in South Africa. In: Komatiites, Annd, N.T. \& Nisbett, E.G. (Eds). London, George Allen and Unwin: $53-79$.

VLACH, S.R.F. (1990). Isojob - Um programa para manipulação de dados e cálculos isotópicos $\mathrm{Rb} / \mathrm{Sr}$, Sm/Nd, $\mathrm{Lu} / \mathrm{Hf}$ em microcomputadores. In: CONGRESSO BRAS. DE GEOL., 36, Natal, 1990. Resumos ... Natal, SBG p. 74 .

VUOLLO, J.I; NYKÄNEN, V.M.; LIIPO, J.P.; PIRAINEN, T.A. (1995). Paleoproterozoic mafic dyke swarms in the Eastern Fennoscandian Shicld. Finland: A review. In: Physies and Chemistry of Dykes, Baer \& Heimann (eds), Balkema: 179-192.

ZANETTIN, B. (1984). Proposed new chemical classification of volcanic rocks. Episodes, 7: 19-20.

ZHANG, B. \& HALLS, H.C. (1995). The origin and age of feldspar clouding in the Matachewan dyke swarm, Canada. In: Physics and Chemistry of Dykes, Baer \& Heimann (eds), Balkema: 171-176.

WAGER, L.R. \& BROWN, G.M. (1968). Layered igneous rocks. Edinburgh and London, Oliver \& Boyd, $588 \mathrm{p}$.

WALKER, G.P.L. (1987). The dike complex of Koolau volcano, Oahu: internal structure of a Hawaiian rift zone. In: Volcanism in Hawaii 2, Decker, Wright \& Stauffer (eds), U.S. Geol. Surv., Prof. Paper 1350, (41): $961 . .993$.

WILLIAMSON, J.H. (1968). Least - square fitting of a straight line. Canadian Joumal of Physics, 46: 18451847.

WILSON, J.F.; JONES, D.L.; KRAMERS, J.D. (1987). Mafic dyke swarms in Zimbabwe. In: Mafic Dyke Swarms, Halls \& Fahrig (Eds). Geol. Assoc. of Canada, spec. pap. 34: 433-444. 
WINCHESTER, J.A. \& FLOYD, P.A. (1976). Geochemical magma type discrimination: application to altered and metamorphosed basic igneous rocks. Earth Planet. Sci. Lett., 28: 459-469.

WINCHESTER, J.A. \& FLOYD, P.A. (1977). Geochemical discrimination of different magma series and their differentiation products using immobile elements. Chem. Geol, 20: 325-343.

WINCHESTER, JA. (1984). The geochemistry of Stratheonon amphibolites, Northern Scotland. Scottish Journal of Geology, 20: 37-51.

WINCHESTER, J.A. \& MAX, M.D. (1984). Geochemistry and origins of the Annagh division of the Precambrian Erris complex, NW County Mayo, Ireland. Precambrian Res, 25: 397-414.

WIRTH, K.R. \& VERVOORT, J.D. (1995). Nd isotopic constraints on mantle and crustal contributions to Early Proterozoic dykes of The southern Superior Province. In: Physics and Chemistry of Dykes, Baer \& Hcimann (cds), Balkema: 237-249. 
APENDICE 1 - Análises químicas em rocha total (elementos maiores e traços)

\begin{tabular}{|c|c|c|c|c|c|c|c|}
\hline Amostra & 15 & 17 & 18 & 19 & 20 & 21 & 22 \\
\hline $\mathrm{SiO}_{2}$ & 51,89 & 48,77 & 49 & 49,42 & 48,48 & 49,53 & 50,89 \\
\hline $\mathrm{TiO}_{2}$ & 3,15 & 2,47 & 1,68 & 1,85 & 2,65 & 1,62 & 1,76 \\
\hline $\mathrm{Al}_{2} \mathrm{O}_{3}$ & 13,92 & 13,14 & 16,07 & 15,45 & 13,45 & 14,32 & 15,25 \\
\hline $\mathrm{Fe}_{2} \mathrm{O}_{3}$ & 2,42 & 0,87 & 0,14 & 0,03 & 1,14 & 0,96 & 0,07 \\
\hline FeO & 12,6 & 16,1 & 13,33 & 13,79 & 15 & 13,17 & 13,8 \\
\hline $\mathrm{MnO}$ & 0,21 & 0,24 & 0,21 & 0,22 & 0,25 & 0,22 & 0,2 \\
\hline $\mathrm{MgO}$ & 3,8 & 5,26 & 5,76 & 5,75 & 5,65 & 6,94 & 4,87 \\
\hline $\mathrm{CaO}$ & 6,81 & 9,87 & 10,7 & 10,29 & 9,75 & 10,23 & 9,6 \\
\hline $\mathrm{Na}_{2} \mathrm{O}$ & 3,03 & 2,67 & 2,56 & 2,67 & 2,57 & 2,46 & 2,82 \\
\hline $\mathrm{K}_{2} \mathrm{O}$ & 1,86 & 0,41 & 0,31 & 0,26 & 0,7 & 0,43 & 0,49 \\
\hline $\mathrm{P}_{2} \mathrm{O}_{5}$ & 0,55 & 0,29 & 0,25 & 0,27 & 0,47 & 0,22 & 0,26 \\
\hline P.I. & 2,53 & 1,46 & 0,94 & 0,91 & 1,67 & 2,07 & 0,9 \\
\hline Soma & 100 & 100 & 100 & 100 & 100 & 100 & 100 \\
\hline \multicolumn{8}{|c|}{ NORMA CIPW } \\
\hline$Q z$ & 3,44 & 0 & 0 & 0 & 0 & 0 & 0 \\
\hline Or & 10,99 & 2,42 & 1,83 & 1,53 & 4,13 & 2,54 & 2,89 \\
\hline $\mathrm{Ab}$ & 25,63 & 22,59 & 21,66 & 22,59 & 21,74 & 20,81 & 23,86 \\
\hline An & 18,88 & 22,65 & 31,44 & 29,4 & 23,09 & 26,76 & 27,5 \\
\hline Wo/Di & 4,72 & 10,19 & 8,35 & 8,3 & 9,27 & 9,41 & 7,69 \\
\hline $\mathrm{En} / \mathrm{Di}$ & 1,76 & 3,57 & 3,33 & 3,25 & 3,59 & 4,21 & 2,73 \\
\hline Fs/Di & 3,04 & 6,88 & 5,1 & 5,15 & 5,8 & 5,15 & 5,13 \\
\hline $\mathrm{En} / \mathrm{Hy}$ & 7,69 & 5,84 & 5,49 & 6,53 & 6,45 & 8,18 & 8,19 \\
\hline Fs/hy & 13,28 & 11,25 & 8,41 & 10,33 & 10,41 & 10 & 15,36 \\
\hline $\mathrm{Fo} / \mathrm{OI}$ & 0 & 2,57 & 3,86 & 3,17 & 2,81 & 3,42 & 0,83 \\
\hline $\mathrm{Fa} / \mathrm{Ol}$ & 0 & 5,46 & 6,52 & 5,53 & 5 & 4,61 & 1,73 \\
\hline $\mathrm{Mt}$ & 3,5 & 1,26 & 0,2 & 0,04 & 1,65 & 1,39 & 0,1 \\
\hline Il & 5,98 & 4,69 & 3,19 & 3,51 & 5,03 & 3,07 & 3,34 \\
\hline $\mathrm{Ap}$ & 1,3 & 0,68 & 0,59 & 0,63 & 1,11 & 0,52 & 0,63 \\
\hline FeOt & 14,78 & 16,88 & 13,46 & 13,82 & 16,03 & 14,03 & 13,86 \\
\hline mg\#(0.15) & 0,342 & 0,387 & 0,464 & 0,457 & 0,416 & 0,500 & 0,415 \\
\hline \multicolumn{8}{|c|}{ ELEMENTOS TRAÇOS } \\
\hline $\mathrm{Nd}$ & 48 & 25 & 23 & 24 & 36 & $2 !$ & 24 \\
\hline $\mathrm{Nb}$ & 29 & 15 & 11 & 11 & 18 & 12 & 12 \\
\hline $\mathrm{Cr}$ & 52 & 156 & 231 & 189 & 181 & 226 & 155 \\
\hline $\mathrm{Ni}$ & 47 & 82 & 105 & 104 & 133 & 112 & 76 \\
\hline $\mathrm{Ba}$ & 1296 & 107 & 68 & 67 & 155 & 67 & 107 \\
\hline $\mathrm{Rb}$ & 54 & 10 & 8 & 7 & 21 & 17 & 15 \\
\hline $\mathrm{Sr}$ & 350 & 122 & 118 & 113 & 133 & 132 & 133 \\
\hline La & 42 & 14 & 12 & 15 & 21 & 14 & 13 \\
\hline $\mathrm{Ce}$ & 81 & 38 & 29 & 34 & 59 & 29 & 32 \\
\hline $\mathrm{Zr}$ & 315 & 194 & 161 & 170 & 293 & 151 & 168 \\
\hline$Y$ & 63 & 60 & 50 & 52 & 81 & 49 & 48 \\
\hline Petrogralia & $\mathrm{DB}_{2}$ & $\mathrm{DB}_{2}$ & $\mathrm{DB}_{2}$ & $\mathrm{DB}_{2}$ & $\mathrm{DB}_{2}$ & $\mathrm{DB}_{2}$ & $\mathrm{DH}_{2}$ \\
\hline Suile & básica & básica & básica & básicá & básica & básica & básica \\
\hline Direção & $\mathrm{N} 55^{\circ} \mathrm{W}$ & & & $\mathrm{N} 40^{\circ} \mathrm{E}$ & $\mathrm{N} 15^{0} \mathrm{~W}$ & $\mathrm{~N} 45^{\circ} \mathrm{E}$ & $\mathrm{N} 25^{6} \mathrm{E}$ \\
\hline Espessura(m) & 0.30 & & & 15 & 8 & 7 & 14 \\
\hline Longitude & $45^{0} 02^{\prime} 05^{\prime \prime}$ & $45^{\circ} 02^{\prime} 05^{\prime \prime}$ & $45^{\circ} 02^{\prime} 41^{\prime \prime}$ & $45^{\circ} 00^{\prime} 39^{\prime \prime}$ & $45^{\circ} 00^{\prime} 56^{\prime \prime}$ & $\left.45^{\circ} 0\right]^{\prime} 00^{\prime \prime}$ & $45^{\circ} 01^{\prime} 56^{\prime \prime}$ \\
\hline Latitude & $21^{\circ} 08^{\prime} 43^{\prime \prime}$ & $21^{0} 08^{\circ} 43^{\prime \prime}$ & $21^{0} 08^{\prime} 35^{\prime \prime}$ & $21^{0} 13^{\prime} 11^{\prime \prime}$ & $21^{0} 12^{\prime} 58^{\prime \prime}$ & $21^{0} 12^{\prime} 54^{\prime \prime}$ & $21^{0} 12^{\prime} 35^{\prime \prime}$ \\
\hline
\end{tabular}

OBS: DBN, DB $1, D B_{2}, D M B$ e DA, confonne capitulo da Petrografa. Elementos maiores e menores (\% em peso) normalizados a $100 \%$ sem a perda ao fogo (P.F.). Elementos traços em ppm. (bás. norítica = básica norítica). 


\begin{tabular}{|c|c|c|c|c|c|c|c|}
\hline Amostra & 23 & 25 & 27 & 28 & 30 & 32 & 34 \\
\hline $\mathrm{SiO}_{2}$ & 50,3 & 55,49 & 49,25 & 52,86 & 49,59 & 50,47 & 51,24 \\
\hline$\overline{\mathrm{TiO}_{2}}$ & 3,01 & 0,67 & 2,28 & 0,61 & 2,07 & 1,42 & 1,61 \\
\hline$\overline{\mathrm{Al}_{2} \mathrm{O}_{3}}$ & 11,75 & 13,28 & 14,91 & 15,08 & 14,21 & 15,15 & 13,96 \\
\hline $\mathrm{F}^{\mathrm{e}} \mathrm{e}_{2} \mathrm{O}_{3}$ & 1,62 & 0,62 & 0,21 & 0,07 & 0,87 & 0,02 & 0,4 \\
\hline Feo & 16,11 & 9,38 & 14,46 & 9,33 & 13,92 & 13,28 & 14,44 \\
\hline $\mathrm{MnO}$ & 0,25 & 0,16 & 0,22 & 0,17 & 0,22 & 0,22 & 0,24 \\
\hline $\mathrm{MgO}$ & 4,54 & 8,72 & 5,36 & 8,95 & 5,84 & 5,85 & 4,97 \\
\hline $\mathrm{CaO}$ & $8,8.3$ & 8,26 & 9,84 & 10,17 & 10,19 & 10,39 & 9,67 \\
\hline $\mathrm{Na}_{2} \mathrm{O}$ & 2,74 & 2,14 & 2,53 & 2,14 & 2,51 & 2,8 & 2,87 \\
\hline $\mathrm{K}_{2} \mathrm{O}$ & 0,49 & 1,24 & 0,55 & 0,55 & 0,37 & 0,27 & 0,38 \\
\hline $\mathrm{P}_{2} \mathrm{O}_{5}$ & 0,52 & 0,1 & 0,41 & 0,08 & 0,3 & 0,13 & 0,26 \\
\hline P.F. & 1,79 & 2,2 & 1,11 & 1,11 & 1,43 & 1,23 & 1,62 \\
\hline Soma & 100 & 100 & 100 & 100 & 100 & 100 & 100 \\
\hline \multicolumn{8}{|c|}{ NORMA CIIPW } \\
\hline $\mathrm{Qz}$ & 2,22 & 4,38 & 0 & 0,26 & 0 & 0 & 0 \\
\hline Or & 2,89 & 7,32 & 3,25 & 3,25 & 2,18 & 1,59 & 2,24 \\
\hline $\mathrm{Ab}$ & 23,18 & 18,1 & 21,4 & 18,1 & 21,23 & 23,69 & 24,28 \\
\hline An & 18,31 & 22,96 & 27,7 & 29,91 & 26,41 & 27,97 & 24,08 \\
\hline Wo/Di & 9,22 & 7,24 & 7,69 & 8,35 & 9,26 & 9,48 & 9,26 \\
\hline En/Di & 3,06 & 4,02 & 2,87 & 4,63 & 3,73 & 3,77 & $3,2.3$ \\
\hline Fs/Di & 6,44 & 2,94 & 4,96 & 3,4 & 5,6 & 5,81 & 6,26 \\
\hline $\mathrm{E}_{1 / \mathrm{H}}$ & 8,23 & 17,69 & 7,58 & 17,65 & 8,81 & 6,51 & 8,55 \\
\hline Fs/hy & 17,29 & 12,95 & 13,08 & 12,97 & 13,23 & 10,03 & 16,57 \\
\hline Fo/Ol & 0 & 0 & 2,01 & 0 & 1,39 & 2,99 & 0,4 \\
\hline $\mathrm{Fa} / \mathrm{Ol}$ & 0 & 0 & 3,83 & 0 & 2,3 & 5,08 & 0,87 \\
\hline $\mathrm{Mt}$ & 2,34 & 0,89 & 0,3 & 0,1 & 1,26 & 0,02 & 0,57 \\
\hline Il & 5,71 & 1,27 & 4,33 & 1,15 & 3,93 & 2,69 & 3,05 \\
\hline$A p$ & 1,23 & 0,23 & 0,97 & 0,18 & 0,71 & 0,3 & 0,61 \\
\hline FeOt & 17,57 & 9,94 & 14,65 & 9,39 & 14,7 & 13,3 & 14,8 \\
\hline mg\#(0.15) & 0,343 & 0,640 & 0,425 & 0,658 & 0,446 & 0,471 & 0,405 \\
\hline \multicolumn{8}{|c|}{ DLEMENTOS TRAÇOS } \\
\hline $\mathrm{Nd}$ & 37 & 15 & 30 & 10 & 28 & 14 & 22 \\
\hline $\mathrm{Nb}$ & 21 & 8 & 16 & 5 & 13 & 9 & 13 \\
\hline $\mathrm{Cr}$ & 33 & 540 & 173 & 766 & 174 & 115 & 102 \\
\hline $\mathrm{Ni}$ & 48 & 158 & 88 & 215 & 69 & 61 & 49 \\
\hline$B a$ & 121 & 258 & 106 & 110 & 72 & 46 & 79 \\
\hline $\mathrm{Rb}$ & 11 & 38 & 14 & 15 & 9 & 7 & 10 \\
\hline $\mathrm{Sr}$ & 131 & 169 & 116 & 131 & 116 & 109 & 123 \\
\hline La & 19 & 19 & 20 & 9 & 15 & 9 & 16 \\
\hline $\mathrm{Ce}$ & 59 & 34 & 46 & 24 & 33 & 22 & 39 \\
\hline $2 \mathrm{r}$ & 310 & 102 & 236 & 70 & 195 & 94 & 176 \\
\hline$Y$ & 94 & 24 & 66 & 20 & 60 & 37 & 60 \\
\hline Petrografia & $\mathrm{DA}$ & $\mathrm{DBN}$ & $\mathrm{DB}_{2}$ & DBN & $\mathrm{DB}_{2}$ & $\mathrm{DB}_{2}$ & $\mathrm{DB}_{2}$ \\
\hline Suite & metamórfica & bás. noritica & básica & bás. noritica & básica & básica & básica \\
\hline Direção & $\mathrm{N} 40^{\circ} \mathrm{E}$ & $\mathrm{N} 45^{\circ} \mathrm{W}$ & $\mathrm{N} 25^{\circ} \mathrm{W}$ & $\mathrm{N} 40^{\circ} \mathrm{W}$ & $\mathrm{N} 10^{6} \mathrm{E}$ & $\mathrm{N} 30^{6} \mathrm{E}$ & \\
\hline Espessura(m) & & & 15 & 20 & & 10 & \\
\hline Longitude & $44^{6} 55^{\prime} 37^{\prime \prime}$ & $44^{6} 55^{\circ} 56^{\prime \prime}$ & $45^{\circ} 00^{\prime} 58^{\prime \prime}$ & $45^{\circ} 00^{\prime} 53^{\prime \prime}$ & $44^{\circ} 59^{\prime} 49^{\prime \prime}$ & $44^{\circ} 58^{\prime} 42^{\prime \prime}$ & $44^{0} 58^{\prime} 42^{\prime \prime}$ \\
\hline Latitude & $21^{\circ} 08^{\circ} 07^{\prime \prime}$ & $21^{\circ} 07^{\prime} 04^{\prime \prime}$ & $21^{6} 08^{\circ} 09^{\circ}$ & $21^{6} 0801^{\circ}$ & $21^{\circ} 077^{\prime} 43^{\prime \prime}$ & $21^{\circ} 07^{\prime} 14^{\prime \prime}$ & $21^{\circ} 07^{\prime} 14^{\prime \prime}$ \\
\hline
\end{tabular}

OBS: DBN, DB, DB, DMB e DA, conforme capítulo da Petrografia. Elementos maiores e menores (\% em peso) normalizados a $100 \%$ sem a perda ao fogo (P.F.). Elementos traços em ppm. (bás. noritica = básica norítica). 


\begin{tabular}{|c|c|c|c|c|c|c|c|}
\hline Amostra & 35 & 37 & 38 & 39 & 41 & 42 & 43 \\
\hline $\mathrm{SiO}_{2}$ & 53,62 & 49,54 & 54,8 & 73,74 & 54,2 & 48,99 & 48,82 \\
\hline $\mathrm{TiO}_{2}$ & 1,15 & 1,45 & 0,74 & 0,11 & 0,64 & 0,8 & 2,32 \\
\hline $\mathrm{Al}_{2} \mathrm{O}_{3}$ & 14,55 & 15,89 & 14,46 & 13,79 & 12,96 & 14,73 & 11,78 \\
\hline $\mathrm{Fe}_{2} \mathrm{O}_{3}$ & 0,9 & 0,08 & 0,69 & 0,08 & 1,02 & 1,38 & 2,09 \\
\hline Feo & 11,26 & 12,91 & 9,54 & 1,08 & 9,23 & 10,96 & 15,78 \\
\hline $\mathrm{MnO}$ & 0,18 & 0,2 & 0,16 & 0,01 & 0,17 & 0,19 & 0,26 \\
\hline $\mathrm{MgO}$ & 5,67 & 6,42 & 6,94 & 0,31 & 10,26 & 9,46 & 6,54 \\
\hline $\mathrm{CaO}$ & 8,95 & 10,58 & 9,33 & 1,03 & 8,55 & 11,34 & 9,96 \\
\hline $\mathrm{Na}_{2} \mathrm{O}$ & 2,56 & 2,46 & 2,15 & 3,48 & 1,78 & 1,94 & 1,99 \\
\hline $\mathrm{K}_{2} \mathrm{O}$ & 1,05 & 0,31 & 1,16 & 6,36 & 1,22 & 0,27 & 0,36 \\
\hline $\mathrm{P}_{2} \mathrm{O}_{5}$ & 0,2 & 0,17 & 0,1 & 0,02 & 0,07 & 0,08 & 0,31 \\
\hline P.F. & 1,95 & 1,38 & 1,98 & 0,54 & 2,05 & 1,94 & 1,88 \\
\hline Soma & 100 & 100 & 100 & 100 & 100 & 100 & 100 \\
\hline \multicolumn{8}{|c|}{ NORMA CIPW } \\
\hline $\mathrm{Qz}$ & 3,16 & 0 & 4,65 & 26,12 & 2,69 & 0 & 0,21 \\
\hline Or & 6,2 & 1,83 & 6,85 & 37,58 & 7,2 & 1,59 & 2,12 \\
\hline $\mathrm{Ab}$ & 21,66 & 20,81 & 18,19 & 29,44 & 15,06 & 16,41 & 16,83 \\
\hline $\mathrm{An}$ & 25,11 & 31,4 & 26,38 & 3,22 & 23,77 & 30,68 & 22,14 \\
\hline Wo/Di & 7,51 & 8,34 & 8,03 & 0,73 & 7,59 & 10,45 & 10,53 \\
\hline $\mathrm{En} / \mathrm{Di}$ & 3,26 & 3,55 & 4,07 & 0,23 & 4,5 & 5,71 & 4,3 \\
\hline $\mathrm{Fs} / \mathrm{Di}$ & 4,24 & 4.8 & 3,77 & 0,52 & 2,7 & 4,37 & 6,31 \\
\hline $\mathrm{Em} / \mathrm{Hy}$ & 10,85 & 7,08 & 13,2 & 0,53 & 21,04 & 8,76 & 11,98 \\
\hline Fs/hy & 14,12 & 9,57 & 12,24 & 1,22 & 12,65 & 6,7 & 17,58 \\
\hline $\mathrm{Fo} / \mathrm{OI}$ & 0 & 3,74 & 0 & 0 & 0 & 6,36 & 0 \\
\hline $\mathrm{Fa} / \mathrm{Ol}$ & 0 & 5,58 & 0 & 0 & 0 & 5,36 & 0 \\
\hline $\mathrm{Mt}$ & 1,3 & 0,11 & 1 & 0,11 & 1,47 & 2 & 3,03 \\
\hline 11 & 2,18 & 2,75 & 1,4 & 0,2 & 1,21 & 1,51 & 4,4 \\
\hline $\mathrm{Ap}$ & 0,47 & 0,4 & 0,23 & 0,04 & 0,16 & 0,18 & 0,73 \\
\hline FeOt & 12,07 & 12,98 & 10,16 & 1,15 & 10,15 & 12,2 & 17,66 \\
\hline mg\#(0.15) & 0,487 & 0,500 & 0,580 & 0,353 & 0,672 & 0,611 & 0,428 \\
\hline \multicolumn{8}{|c|}{ ELEMENTOS TRAÇOS } \\
\hline $\mathrm{Nd}$ & 23 & 17 & 15 & 12 & 16 & 5 & 27 \\
\hline $\mathrm{Nb}$ & 11 & 10 & 8 & 6 & 7 & 5 & 16 \\
\hline $\mathrm{Cr}$ & 253 & 254 & 328 & 2 & 948 & 393 & 223 \\
\hline $\mathrm{Ni}$ & 136 & 102 & 127 & 8 & 216 & 165 & 111 \\
\hline $\mathrm{Ba}$ & 370 & 55 & 196 & 808 & 241 & 32 & 74 \\
\hline $\mathrm{Rb}$ & 27 & 9 & 36 & 193 & 44 & 9 & 10 \\
\hline $\mathrm{Sr}$ & 168 & 118 & 159 & 136 & 168 & 106 & 102 \\
\hline La & 19 & 7 & 14 & 30 & 16 & 4 & 13 \\
\hline $\mathrm{Ce}$ & 36 & 29 & 25 & 50 & 26 & 10 & 34 \\
\hline $2 r$ & 156 & 116 & 101 & 67 & 87 & 48 & 203 \\
\hline$Y$ & 38 & 41 & 27 & 9 & 32 & 26 & 73 \\
\hline Petrografia & $\mathrm{DBB}_{1}$ & $\mathrm{DI}_{3}$ & $\mathrm{DB}_{1}$ & granulito & $\mathrm{DBN}$ & $\mathrm{DM} \mathrm{B}$ & $\mathrm{DA}$ \\
\hline Suite & bás. norifica & básica & bás. noritica & encaixante & bás. noritica & metamórfica & metamórfica \\
\hline Direção & $\mathrm{N} 60^{\circ} \mathrm{W}$ & $\mathrm{N}-\mathrm{S}$ & $\mathrm{NI} 0^{\circ} \mathrm{W}$ & & $\mathrm{N} 40^{\circ} \mathrm{W}$ & $\mathrm{N} 30^{6} \mathrm{~L}$ & $\mathrm{~N} 40^{6} \mathrm{E}$ \\
\hline Espessura(m) & 10 & 7 & & & & 10 & \\
\hline Longitude & $44^{\circ} 57^{\circ} 49^{\prime \prime}$ & $44^{\circ} 56^{\prime} 12^{\prime \prime}$ & $44^{0} 56^{\prime} 09^{\prime \prime}$ & $44^{0} 59^{\prime} 34^{\prime \prime}$ & $44^{\circ} 52^{\circ} 04^{\prime \prime}$ & $44^{\circ} 52^{\circ} 00^{\prime \prime}$ & $44^{0} 5 !^{\prime} 20^{\prime \prime}$ \\
\hline Latitude & $21^{\circ} 07^{\prime} 12^{\prime \prime}$ & $21^{\circ} 07^{\prime} 12^{\prime \prime}$ & $21^{\circ} 07^{\prime} 12^{\prime \prime}$ & $21^{\circ} 10^{\circ} 20^{\prime \prime}$ & $21^{\circ} 06^{\prime} 26^{\prime \prime}$ & $21^{\circ} 06^{\prime} 08^{\prime \prime}$ & $21^{\circ} 05^{\prime} 16^{\prime \prime}$ \\
\hline
\end{tabular}

OBS: DBN, DB, DB, DMB e DA, conforme capitulo da Petrografia. Elenentos maiores e menores (\% em peso) normalizados a $100 \%$ sem a perda ao fogo (P.F.). Elementos traços em ppm. (bás. norítica = básica norítica). 


\begin{tabular}{|c|c|c|c|c|c|c|c|}
\hline Amostra & 44 & 45 & 46 & 47 & 48 & 49 & 50 \\
\hline $\mathrm{SiO}_{2}$ & 50,1 & 50,33 & 50,13 & 49,91 & 50,15 & 50,38 & 49,89 \\
\hline $\mathrm{TiO}_{2}$ & 2,12 & 1,31 & 2,17 & 1,79 & 1,5 & 1,83 & 1,59 \\
\hline $\mathrm{Al}_{2} \mathrm{O}_{3}$ & 13,46 & 17,07 & 12,38 & 13,65 & 14,46 & 13,2 & 13,97 \\
\hline $\mathrm{Fe}_{2} \mathrm{O}_{3}$ & 0,1 & 0,36 & 2,06 & 0,8 & 1,19 & 2,24 & 0,51 \\
\hline $\mathrm{FeO}$ & 15,33 & $\$ 1,74$ & 15,3 & 14,07 & 14,02 & 13,12 & 13,36 \\
\hline $\mathrm{MnO}$ & 0,25 & 0,2 & 0,25 & 0,23 & 0,22 & 0,22 & 0,22 \\
\hline $\mathrm{MgO}$ & 5,72 & 5,35 & 5,28 & 6,68 & 5,95 & 6,75 & 6,95 \\
\hline $\mathrm{CaO}$ & 9,69 & 10,54 & 9,53 & 10,06 & 9,18 & 10,19 & 10,61 \\
\hline $\mathrm{Na}_{2} \mathrm{O}$ & 2,61 & 2,73 & 2,38 & 2,23 & 2,92 & 1,72 & 2,4 \\
\hline $\mathrm{K}_{2} \mathrm{O}$ & 0,35 & 0,27 & 0,46 & 0,39 & 0,28 & 0,31 & 0,33 \\
\hline $\mathrm{P}_{2} \mathrm{O}_{5}$ & 0,28 & 0,14 & 0,27 & 0,27 & 0,25 & 0,26 & 0,22 \\
\hline P.F. & 1,62 & 0,82 & 1,8 & 1,73 & 1,6 & 1,71 & 1,72 \\
\hline Soma & 100 & 100 & 100 & 100 & 100 & 100 & 100 \\
\hline \multicolumn{8}{|c|}{ NORMA CIPW } \\
\hline$Q \%$ & 0 & 0 & 1,52 & 0 & 0 & 3,72 & 0 \\
\hline $\mathrm{Or}$ & 2,06 & 1,59 & 2,71 & 2,3 & 1,65 & 1,83 & 1,95 \\
\hline $\mathrm{Ab}$ & 22,08 & 23,1 & 20,13 & 18,86 & 24,7 & 14,55 & 20,3 \\
\hline An & 23,97 & 33,52 & 21,73 & 26,08 & 25,52 & 27,38 & 26,37 \\
\hline $\mathrm{Wo} / \mathrm{Di}$ & 9,29 & 7,45 & 9,92 & 9,21 & 7,67 & 8,96 & 10,36 \\
\hline $\mathrm{En} / \mathrm{Di}$ & 3,43 & 3,04 & 3,65 & 3,91 & 3,06 & 4,1 & 4,56 \\
\hline $\mathrm{FS} / \mathrm{Di}$ & 6,04 & 4,45 & 6,47 & 5,32 & 4,69 & 4,79 & 5,77 \\
\hline $\mathrm{En} / \mathrm{Ay}$ & 8,64 & 7,48 & 9,49 & 11,31 & 8,5 & 12,7 & 8,62 \\
\hline Fs/liy & 15,18 & 10,94 & 16,8 & 15,4 & 13,02 & 14,83 & 10,91 \\
\hline Fo/Ol & 1,51 & 1,95 & 0 & 0,98 & 2,27 & 0 & 2,88 \\
\hline $\mathrm{Fa} / \mathrm{Ol}$ & 2,93 & 3,14 & 0 & 1,47 & 3,84 & 0 & 4,02 \\
\hline $\mathrm{Mt}$ & 0,14 & 0,52 & 2,98 & 1,15 & 1,72 & 3,24 & 0,73 \\
\hline II & 4,02 & 2,48 & 4,12 & 3,39 & 2,84 & 3,47 & 3,01 \\
\hline $\mathrm{Ap}$ & 0,66 & 0,33 & 0,63 & 0,63 & 0,59 & 0,61 & 0,52 \\
\hline FeOt & 15,42 & 12,06 & 17,15 & 14,79 & 15,09 & 15,14 & 13,82 \\
\hline mg\#(0.15) & 0,429 & 0,473 & 0,384 & 0,477 & 0,444 & 0,474 & 0,504 \\
\hline \multicolumn{8}{|c|}{ ELEMENTOS TRACOS } \\
\hline $\mathrm{Nd}$ & 24 & 12 & 26 & 23 & 18 & 24 & 21 \\
\hline $\mathrm{Nb}$ & 14 & 8 & 15 & 13 & 13 & 14 & 11 \\
\hline $\mathrm{Cr}$ & 209 & 108 & 98 & 172 & 139 & 185 & 228 \\
\hline $\mathrm{Ni}$ & 82 & 72 & 89 & 86 & 101 & 82 & 95 \\
\hline $\mathrm{Ba}$ & 97 & 51 & 80 & 91 & 62 & 80 & 88 \\
\hline $\mathrm{Rb}$ & 11 & 8 & 6 & 11 & 5 & 5 & 8 \\
\hline $\mathrm{Sr}$ & 128 & 127 & 119 & 126 & 179 & 146 & 128 \\
\hline La & 15 & 8 & 15 & 18 & 9 & 16 & 14 \\
\hline $\mathrm{Ce}$ & 35 & 16 & 38 & 34 & 32 & 31 & 30 \\
\hline $2 r$ & 191 & 87 & 194 & 185 & 170 & 192 & 160 \\
\hline$Y$ & 64 & 34 & 71 & 58 & 56 & 58 & 51 \\
\hline Petrografia & $\mathrm{DB}_{2}$ & $\mathrm{DB}_{2}$ & $\mathrm{DA}$ & $\mathrm{DMB}$ & $\mathrm{DA}$ & $\mathrm{DA}$ & $\mathrm{DMB}$ \\
\hline Suite & básica & básica & metamórfica & metamórfica & metamórfica & metamórfica & metamórfica \\
\hline Direção & $\mathrm{N} 20^{\circ} \mathrm{E}$ & $N-S$ & $\mathrm{~N} 25^{\circ} \mathrm{E}$ & $\mathrm{N} 50^{\circ} \mathrm{E}$ & & $\mathrm{N} 10^{\circ} \mathrm{E}$ & $\mathrm{N} 50^{\circ} \mathrm{E}$ \\
\hline Espessura(m) & 8 & 50 & & 5 & & & \\
\hline Longitude & $44^{0} 50^{\prime} 53^{\prime \prime}$ & $44^{\circ} 50^{\prime} 43^{\prime \prime}$ & $44^{\circ} 45^{\prime} 56^{\prime \prime}$ & $44^{0} 46^{\prime} 21^{\prime \prime}$ & $44^{\prime} 46^{\prime} 53^{\prime \prime}$ & $44^{\circ} 48^{\prime} 37^{\prime \prime}$ & $44^{\circ} 48^{\prime} 48^{\prime \prime}$ \\
\hline Latitude & $21^{\prime} 04^{\prime} 44^{\prime \prime}$ & $21^{\circ} 04^{\prime} 11^{\prime \prime}$ & $21^{\circ} 02^{\circ} 06^{\circ}$ & $21^{\circ} 01^{\prime} 57^{\prime \prime}$ & $21^{\circ} 01^{\prime} 59^{\prime \prime}$ & $21^{\circ} 03^{\prime} 16^{\prime \prime}$ & $21^{\circ} 03^{\prime} 16^{\prime \prime}$ \\
\hline
\end{tabular}

OBS: DBN, DB, $\mathrm{DB}_{2}, \mathrm{DMB}$ e DA, conforme capitulo da Petrografia, Elementos máores e menores (\% em peso) normalizados a $100 \%$ sem a perda ao fogo (P.F.). Elenentos traços em ppm. (bás. norítica = básica noritica) 


\begin{tabular}{|c|c|c|c|c|c|c|c|}
\hline Amostra & 51 & 52 & 53 & 54 & 55 & 56 & 57 \\
\hline $\mathrm{SiO}_{2}$ & 50,45 & 49,85 & 69,89 & 50,98 & 52,89 & 48,42 & 50,21 \\
\hline $\mathrm{riO}_{2}$ & 2,01 & 0,98 & 0,55 & 0,67 & 0,67 & 1,8 & 2,74 \\
\hline $\mathrm{Al}_{2} \mathrm{O}_{3}$ & 13,22 & 15,58 & 14,4 & 13,14 & 14,71 & 14,4 & 12,59 \\
\hline $\mathrm{Fe}_{2} \mathrm{O}_{3}$ & 0,62 & 1,64 & 0,23 & 0,19 & 0,34 & 0,34 & 1,48 \\
\hline FeO & 14,5 & 9,47 & 2,64 & 10,84 & 10,11 & 15,37 & 14,81 \\
\hline $\mathrm{MnO}$ & 0,23 & 0,17 & 0,03 & 0,18 & 0,18 & 0,26 & 0,25 \\
\hline $\mathrm{MgO}$ & 6,25 & 8,86 & 0,87 & 13,06 & 8,86 & 6,6 & 5,3 \\
\hline $\mathrm{CaO}$ & 9,68 & 10,7 & 1,94 & 8,31 & 9,62 & 9,47 & 9,13 \\
\hline $\mathrm{Na}_{2} \mathrm{O}$ & 2,48 & 1,92 & 3,71 & 1,89 & 2,04 & 2,83 & 2,56 \\
\hline $\mathrm{K}_{2} \mathrm{O}$ & 0,33 & 0,78 & 5,58 & 0,66 & 0,54 & 0,33 & 0,65 \\
\hline $\mathrm{P}_{2} \mathrm{O}_{5}$ & 0,29 & 0,21 & 0,18 & 0,1 & 0,07 & 0,21 & 0,43 \\
\hline P.F. & 1,67 & 2,55 & 0,9 & 0,99 & 1,19 & 2,13 & 1,98 \\
\hline Soma & 100 & 100 & 100 & 100 & 100 & 100 & 100 \\
\hline \multicolumn{8}{|c|}{ NORMA CIPW } \\
\hline$Q \%$ & 0 & 0 & 20,76 & 0 & 1,22 & 0 & 1,25 \\
\hline $\mathrm{Or}$ & 1,95 & 4,6 & 32,97 & 3,9 & 3,19 & 1,95 & 3,84 \\
\hline $\mathrm{Ab}$ & 20,98 & 16,24 & 31,39 & 15,99 & 17,26 & 23,94 & 21,66 \\
\hline An & 23,96 & 31,59 & 6,15 & 25,42 & 29,38 & 25,61 & 20,94 \\
\hline Wo/Di & 9,25 & 8,4 & 0,95 & 6,32 & 7,46 & 8,34 & 8,99 \\
\hline $\mathrm{En} / \mathrm{Di}$ & 3,74 & 4,81 & 0,35 & 3,78 & 4,02 & 3,31 & 3,43 \\
\hline Fs/Di & 5,58 & 3,21 & 0,62 & 2,2 & 3,19 & 5,12 & 5,7 \\
\hline $\mathrm{En} / \mathrm{Ly}$ & 11,39 & 12,35 & 1,81 & 17,39 & 18,04 & $3,7,3$ & 9,76 \\
\hline Fs/hy & 17 & 8,24 & 3,18 & 10,15 & 14,31 & 5,79 & 16,21 \\
\hline $\mathrm{Fo} / \mathrm{Ol}$ & 0,29 & 3,43 & 0 & 7,94 & 0 & 6,57 & 0 \\
\hline $\mathrm{Fa} / \mathrm{Ol}$ & 0,48 & 2,52 & 0 & 5,11 & 0 & 11,22 & 0 \\
\hline $\mathrm{Mt}$ & 0,89 & 2,37 & 0,33 & 0,27 & 0,49 & 0,49 & 2,14 \\
\hline II & 3,81 & 1,86 & 1,04 & 1,27 & 1,27 & 3,41 & 5,2 \\
\hline Ap & 0,68 & 0,49 & 0,42 & 0,23 & 0,16 & 0,49 & 1,01 \\
\hline FeOt & 15,06 & 10,95 & 2,85 & 11,01 & 10,42 & 15,68 & 16,14 \\
\hline $\mathrm{mg} \#(0.15)$ & 0,456 & 0,621 & 0,382 & 0,706 & 0,632 & 0,460 & 0,399 \\
\hline \multicolumn{8}{|c|}{ ELEMENTOS TRAÇOS } \\
\hline $\mathrm{Nd}$ & 26 & 13 & 78 & 10 & 8 & 17 & 34 \\
\hline $\mathrm{Nb}$ & 15 & 7 & 20 & 9 & 7 & 11 & 20 \\
\hline $\mathrm{Cr}$ & 167 & 368 & 12 & 1898 & 832 & 142 & 97 \\
\hline $\mathrm{Ni}$ & 87 & 175 & 30 & 446 & 164 & 146 & 63 \\
\hline Ba & 92 & $|5|$ & 1099 & 143 & 121 & 8 & 172 \\
\hline $\mathrm{Rb}$ & 10 & 25 & 169 & 19 & 14 & 11 & 12 \\
\hline $\mathrm{Sr}$ & 110 & 137 & 186 & 101 & 110 & 147 & 125 \\
\hline La & 13 & 9 & 122 & 9 & 7 & 9 & 21 \\
\hline $\mathrm{Ce}$ & 36 & 18 & 214 & 27 & 21 & 26 & 57 \\
\hline $\mathrm{Zr}$ & 208 & 101 & 346 & 83 & 75 & 141 & 279 \\
\hline$Y$ & 65 & 30 & 39 & 22 & 21 & 45 & 82 \\
\hline Petrogralia & $\mathrm{DMB}$ & $\mathrm{DA}$ & granito & $\mathrm{DBN}$ & $\mathrm{DBN}$ & $\mathrm{IMMB}$ & DA \\
\hline Suite & metanórfica & metamórifa & encaixante & bás. noritica & bás. noritica & metamórfica & metamórfica \\
\hline Direçâo & $\mathrm{N} 30^{\circ} \mathrm{E}$ & $\mathrm{N} 80^{\circ} \mathrm{W}$ & & $\mathrm{N} 55^{\circ} \mathrm{W}$ & $\mathrm{N} 60^{\circ} \mathrm{W}$ & $\mathrm{N} 30^{\circ} \mathrm{W}$ & $\mathrm{N} 40^{6} \mathrm{E}$ \\
\hline Espessura(m) & 4 & & & & & & \\
\hline Longitude & $44^{\circ} 49^{\circ} 04^{\prime \prime}$ & $44^{\circ} 45^{\circ} 00^{\prime \prime}$ & $44^{\circ} 45^{\circ} 00^{\prime \prime}$ & $44^{0} 50^{\prime} 46^{\prime \prime}$ & $44^{0} 50^{\prime} 25^{\prime \prime}$ & $44^{\prime} 49^{\prime} 41^{\prime \prime}$ & $44^{0} 52^{\prime} 30^{\prime \prime}$ \\
\hline Latitucie & $21^{\circ} 03^{\prime} 21^{\prime \prime}$ & $21^{0} 00^{\prime} 00^{\prime \prime}$ & $21^{0} 00^{\prime} 00^{\prime \prime}$ & $21^{\circ} 01^{\prime} 39^{\prime \prime}$ & $21^{\circ} 01^{\prime} 38^{\prime \prime}$ & $21^{0} 01^{\prime} 13^{\prime \prime}$ & $21^{\circ} 04^{\prime} 03^{\prime \prime}$ \\
\hline
\end{tabular}

OBS: DBN, DB, DB, DMB e DA, conforme capítulo da Petrografia. Elementos maiores e menores (\% em peso) normalizados a $100 \%$ sem a perda ao fogo (P.F.). Elementos traços em pprm. (bás. noritica = básica norítica). 


\begin{tabular}{|c|c|c|c|c|c|c|c|}
\hline Amosira & 58 & 59 & 60 & 61 & 62 & 63 & 64 \\
\hline $\mathrm{SiO}_{2}$ & 54,82 & 55,2 & 51,03 & 53,45 & 51,03 & 51,09 & 52,25 \\
\hline $\mathrm{TiO}_{2}$ & 0,9 & 0,82 & 1,4 & 3,64 & 1,14 & 1,26 & 0,55 \\
\hline $\mathrm{Al}_{2} \mathrm{O}_{3}$ & 15,65 & 16,66 & 14,43 & 14,37 & 13,59 & 15,6 & 12,62 \\
\hline $\mathrm{li}_{2} \mathrm{O}_{3}$ & 0,03 & 0,47 & 0,78 & 2,19 & 2,2 & 2,48 & 1,07 \\
\hline FeO & 10,07 & 9,11 & 12,7 & 10,15 & 11,62 & 10,85 & 9,27 \\
\hline $\mathrm{MnO}$ & 0,15 & 0,14 & 0,23 & 0,2 & 0,23 & 0,21 & 0,18 \\
\hline $\mathrm{MgO}$ & 5,68 & 4,83 & 6,33 & 3,02 & 7,04 & 5,6 & 13,28 \\
\hline $\mathrm{CaO}$ & 8,67 & 8,86 & 10,41 & 7,13 & 11,03 & 9,83 & 8,33 \\
\hline $\mathrm{Na}_{2} \mathrm{O}$ & 2,52 & 2,62 & 2,37 & 3,27 & 1,92 & 2,57 & 1,87 \\
\hline $\mathrm{K}_{2} \mathrm{O}$ & 1,35 & 1,2 & 0,27 & 1,73 & 0,31 & 0,63 & 0,61 \\
\hline $\mathrm{P}_{2} \mathrm{O}_{5}$ & 0,16 & 0,14 & 0,13 & 1,07 & 0,11 & 0,13 & 0,08 \\
\hline P. & 1,73 & 0,98 & 1,14 & 1,31 & 1,9 & 2,26 & 0,83 \\
\hline Soma & 100 & 100 & 100 & 100 & 100 & 100 & 100 \\
\hline \multicolumn{8}{|c|}{ NORMA ClPW } \\
\hline$Q Z$ & 3,68 & 5,41 & 0,3 & 7,88 & 2,34 & 1,36 & 0 \\
\hline $\mathrm{Or}$ & 7,97 & 7,09 & 1,59 & 10,22 & 1,83 & 3,72 & 3,6 \\
\hline $\mathrm{Ab}$ & 21,32 & 22,16 & 20,05 & 27,67 & 16,24 & 21,74 & 15,82 \\
\hline $\mathrm{An}$ & 27,4 & 30,15 & 27,93 & 19,42 & 27,54 & 29,17 & 24,24 \\
\hline Wo/Di & 6,08 & 5,38 & 9,54 & 3,74 & 11,04 & 7,82 & 6,91 \\
\hline $\mathrm{En} / \mathrm{Di}$ & 2,72 & 2,36 & 4,11 & 1,51 & 5,35 & 3,59 & 4,4 \\
\hline Fs/Di & 3,32 & 3 & 5,43 & 2,25 & 5,51 & 4,16 & 2,07 \\
\hline $\mathrm{En} / \mathrm{Hy}$ & 11,41 & 9,66 & 11,64 & 6 & 12,18 & 10,35 & 24,01 \\
\hline Fis/hy & 13,93 & 12,24 & 15,36 & 8,93 & 12,55 & 12,01 & 11,3 \\
\hline $\mathrm{Fo} / \mathrm{Ol}$ & 0 & 0 & 0 & 0 & 0 & 0 & 3,26 \\
\hline $\mathrm{Fa} / \mathrm{Ol}$ & 0 & 0 & 0 & 0 & 0 & 0 & 1,69 \\
\hline $\mathrm{Mi}$ & 0,04 & 0,68 & 1,13 & 3,17 & 3,18 & 3,59 & 1,55 \\
\hline 11 & 1,7 & 1,55 & 2,65 & 6,91 & 2,16 & 2,39 & 1,04 \\
\hline$A p$ & 0,37 & 0,33 & 0,3 & 2,53 & 0,26 & 0,3 & 0,18 \\
\hline FeOt & 10,1 & 9,53 & 13,4 & 12,12 & 13,6 & 13,08 & 10,23 \\
\hline $\mathrm{mg \# (0.15)}$ & 0,532 & 0,506 & 0,489 & 0,335 & 0,511 & 0,464 & 0,724 \\
\hline \multicolumn{8}{|c|}{ ELEMINTOS TRACOOS } \\
\hline $\mathrm{Nd}$ & 19 & 23 & 17 & 51 & 14 & 15 & 12 \\
\hline $\mathrm{Nb}$ & 8 & 8 & 10 & 32 & 9 & 12 & 7 \\
\hline $\mathrm{Cr}$ & 224 & 207 & 189 & 9 & 158 & 120 & 1824 \\
\hline $\mathrm{Ni}$ & 116 & 122 & 75 & 22 & 102 & 60 & 428 \\
\hline $\mathrm{Ba}$ & 316 & 297 & 60 & 537 & 38 & 93 & 152 \\
\hline $\mathrm{Rb}$ & 44 & 43 & 9 & 40 & 7 & 31 & 16 \\
\hline $\mathrm{Sr}$ & 258 & 217 & 110 & 551 & 102 & 146 & 104 \\
\hline $\mathrm{La}$ & 17 & 17 & 10 & 42 & 8 & 13 & 12 \\
\hline $\mathrm{Ce}$ & 40 & 42 & 23 & 105 & 22 & 27 & 21 \\
\hline $7 \mathrm{r}$ & 125 & 119 & 105 & 274 & 101 & 114 & 87 \\
\hline $\mathrm{Y}$ & 26 & 21 & 34 & 48 & 40 & 37 & 16 \\
\hline Petrografia & $\mathrm{DB}_{1}$ & $\mathrm{DB}_{1}$ & $\mathrm{DB}_{2}$ & $\mathrm{DJB}_{3}$ & $\mathrm{DMB}$ & DMB & DBN \\
\hline Suite & bás. noritica & bás. norítica & básica & básica & metamórfica & metamórfica & bás. noriticá \\
\hline Direção & $\mathrm{N} 45^{\circ} \mathrm{W}$ & $\mathrm{N} 40^{\circ} \mathrm{W}$ & $\mathrm{N}-\mathrm{S}$ & & $N-S$ & $\mathrm{~N} 35^{\circ} \mathrm{E}$ & $\mathrm{N} 50^{\circ} \mathrm{W}$ \\
\hline Espessura(m) & & 30 & & & 15 & & \\
\hline Longitude & $44^{0} 52^{\prime} 56^{\prime \prime}$ & $44^{6} 53^{\prime} 22^{\prime \prime}$ & $44^{0} 53^{\prime} 22^{\prime \prime}$ & $44^{6} 40^{\prime} 17^{\prime \prime}$ & $44^{\circ} 43^{\prime} 56^{\prime \prime}$ & $44^{0} 46^{\prime} 18^{\prime \prime}$ & $44^{0} 5128^{\prime \prime}$ \\
\hline Latitude & $21^{0} 04^{\prime} 00^{\prime \prime}$ & $21^{0} 03^{\prime} 34^{\prime \prime}$ & $21^{\circ} 0334^{\prime \prime}$ & $21^{\circ} 00^{\prime} 31^{\prime \prime}$ & $21^{\circ} 01^{\prime} 28^{\prime \prime}$ & $20^{6} 57^{\prime} 56^{\prime \prime}$ & $21^{\circ} 01^{\prime} 18^{\prime \prime}$ \\
\hline
\end{tabular}

OBS: DBN, DBB, DB3,$D \mathrm{DMB}$ e DA, conforme capítulo da Petrografia. Elementos maiores e menores (\% em peso) normalizados a $100 \% \mathrm{sem}$ a perda ao fogo (P.F.). Elementos traços em ppm. (bás. norítica $=$ básica norítica). 


\begin{tabular}{|c|c|c|c|c|c|c|c|}
\hline Amostra & 65 & 66 & 67 & 68 & 70 & 72 & 73 \\
\hline $\mathrm{SiO}_{2}$ & 50,74 & 50,22 & 58,61 & 55,27 & 55,29 & 52,02 & 52,58 \\
\hline $\mathrm{TiO}_{2}$ & 2,1 & 2,26 & 0,58 & 0,85 & 0,87 & 0,46 & 2,36 \\
\hline $\mathrm{Al}_{2} \mathrm{O}_{3}$ & 13,87 & 14,06 & 16,1 & 16,4 & 16,4 & 10,44 & 14,88 \\
\hline $\mathrm{Fe}_{2} \mathrm{O}_{3}$ & 2,99 & 2,37 & 0,59 & 0,06 & 0,62 & 1,7 & 2,28 \\
\hline $\mathrm{FeO}$ & 11,08 & 12,09 & 6,54 & 9,44 & 9,03 & 8,9 & 11,69 \\
\hline $\mathrm{MnO}$ & 0,21 & 0,22 & 0,11 & 0,14 & 0,14 & 0,19 & 0,19 \\
\hline $\mathrm{MgO}$ & 6,11 & 5,76 & 4,9 & 5,05 & 4,87 & 17,49 & 3,61 \\
\hline $\mathrm{CaO}$ & 9,65 & 9,6 & 8,17 & 8,88 & 8,82 & 6,98 & 7,28 \\
\hline $\mathrm{Na}_{2} \mathrm{O}$ & 2,75 & 2,81 & 2,78 & 2,57 & 2,59 & 1,44 & 3,29 \\
\hline $\mathrm{K}_{2} \mathrm{O}$ & 0,54 & 0,59 & 1,59 & 1,2 & 1,28 & 0,49 & 1,64 \\
\hline $\mathrm{P}_{2} \mathrm{O}_{5}$ & 0,26 & 0,26 & 0,09 & 0,15 & 0,15 & 0,06 & 0,43 \\
\hline P.Y. & 2,15 & 2,1 & 1,75 & 1,1 & 1,05 & 1,12 & 1,68 \\
\hline Soma & 100 & 100 & 100 & 100 & 100 & 100 & 100 \\
\hline \multicolumn{8}{|c|}{ NORMA CIPW } \\
\hline$Q z$ & 1,69 & 0,22 & 9,74 & 5,13 & 5,7 & 0 & 2,75 \\
\hline Or & 3,19 & 3,48 & 9,39 & 7,09 & 7,56 & 2,89 & 9,69 \\
\hline $\mathrm{Ab}$ & 23,26 & 23,77 & 23,52 & 21,74 & 21,91 & 12,18 & 27,83 \\
\hline An & 23,9 & 24 & 26,75 & 29,67 & 29,34 & 20,57 & 20,99 \\
\hline Wo/Di & 9,29 & 9,15 & 5,5 & 5,59 & 5,6 & 5,7 & 5,14 \\
\hline $\mathrm{En} / \mathrm{Di}$ & 4,61 & 4,16 & 2,84 & 2,44 & 2,5 & 3,93 & 1,88 \\
\hline $\mathrm{Fs} / \mathrm{Di}$ & 4,49 & 4,91 & 2,51 & 3,14 & 3,07 & 1,31 & 3,36 \\
\hline $\mathrm{En} / \mathrm{Hy}$ & 10,59 & 10,17 & 9,35 & 10,12 & 9,62 & 32,28 & 7,1 \\
\hline Is/hy & 10,3 & 12 & 8,25 & 13 & 11,81 & 10,77 & 12,67 \\
\hline $\mathrm{Fo} / \mathrm{Ol}$ & 0 & 0 & 0 & 0 & 0 & 5,14 & 0 \\
\hline $\mathrm{Fa} / \mathrm{Ol}$ & 0 & 0 & 0 & 0 & 0 & 1,89 & 0 \\
\hline Mt & 4,33 & 3,43 & 0,85 & 0,08 & 0,89 & 2,46 & 3,3 \\
\hline 11 & 3,98 & 4,29 & 1,1 & 1,61 & 1,65 & 0,87 & 4,48 \\
\hline$A p$ & 0,61 & 0,61 & 0,21 & 0,35 & 0,35 & 0,14 & 1,01 \\
\hline FeOt & 13,77 & 14,22 & 7,07 & 9,49 & 9,59 & 10,43 & 13,74 \\
\hline $\mathrm{mg} \#(0.15)$ & 0,473 & 0,450 & 0,584 & 0,518 & 0,507 & 0,772 & 0,347 \\
\hline \multicolumn{8}{|c|}{ ELEMENTOS TRACOS } \\
\hline $\mathrm{Nd}$ & 22 & 22 & 16 & 20 & 20 & 10 & 41 \\
\hline $\mathrm{Nb}$ & 18 & 19 & 7 & 9 & 10 & 6 & 17 \\
\hline $\mathrm{Cr}$ & 118 & 102 & 197 & 211 & 207 & 2519 & 60 \\
\hline $\mathrm{Ni}$ & 69 & 67 & 101 & 113 & 114 & 528 & 50 \\
\hline $\mathrm{Ba}$ & 139 & 136 & 417 & 295 & 305 & 95 & 404 \\
\hline $\mathrm{Rb}$ & 21 & 22 & 43 & 39 & 42 & 15 & 57 \\
\hline $\mathrm{Sr}$ & 249 & 271 & 261 & 219 & 217 & 82 & 167 \\
\hline La & 14 & 14 & 15 & 17 & 18 & 9 & 34 \\
\hline $\mathrm{Ce}$ & 33 & 35 & 28 & 40 & 38 & 15 & 73 \\
\hline $7 \mathrm{r}$ & 172 & 182 & 93 & 121 & 126 & 55 & 261 \\
\hline$Y$ & 40 & 41 & 13 & 23 & 23 & 13 & 55 \\
\hline Petrografia & $\mathrm{DA}$ & DA & $\mathrm{DB}_{1}$ & $\mathrm{DB}_{1}$ & $\mathrm{D}_{3}$ & DBN & $\mathrm{JPB}_{2}$ \\
\hline Suíte & metamórfica & metamorlica & bás. morítica & bás. noríica & bás. noritica & bás. noritica & básica \\
\hline Direção & & $E m W$ & $\mathrm{~N} 40^{0} \mathrm{~W}$ & & $\mathrm{~N} 60^{\circ} \mathrm{W}$ & $\mathrm{N} 40^{\circ} \mathrm{W}$ & $\mathrm{N} 30^{\circ} \mathrm{W}$ \\
\hline Espessura(m) & & 10 & 40 & & 100 & 20 & 40 \\
\hline Longitude & $44^{0} 28^{\prime} 42^{\prime \prime}$ & $44^{\circ} 28^{\prime} 25^{\prime \prime}$ & $45^{0} 12^{\prime} 31^{\prime \prime}$ & $45^{0} 12^{\prime} 31^{\prime \prime}$ & $44^{0} 58^{\circ} 08^{\prime \prime}$ & $44^{6} 56^{\prime} 32^{\prime \prime}$ & $44^{0} 52^{\prime} 30^{\prime \prime}$ \\
\hline Latitude & $20^{\circ} 55^{\circ} 49^{\prime \prime}$ & $20^{6} 56^{\prime} 21^{\prime \prime}$ & $20^{\circ} 51^{\prime} 44^{\prime \prime}$ & $20^{\circ} 51^{\prime} 44^{\prime \prime}$ & $21^{\circ} 00^{\prime} 16^{\prime \prime}$ & $20^{\circ} 58^{\prime} 39^{\prime \prime}$ & $20^{\circ} 55^{\circ} 41^{\prime \prime}$ \\
\hline
\end{tabular}

OBS: DBN, DB, $\mathrm{DB}_{2}, \mathrm{DMB}$ e DA, conforme capitulo da Petrografra. Elementos maiores e menores (\% em peso) nomalizados a $100 \%$ sem a perda ao fogo (P.F.). Elementos traços em ppm. (bás. norítica - básica noritica). 


\begin{tabular}{|c|c|c|c|c|c|c|c|}
\hline Amostra & 74 & 75 & 76 & 77 & 79 & 80 & 81 \\
\hline $\mathrm{SiO}_{2}$ & 50,4 & 49,83 & 49,42 & 50,76 & 48,96 & 51,83 & 50,01 \\
\hline $\mathrm{TiO}_{2}$ & 3,05 & 1,6 & 1,15 & 1,52 & 3,23 & 2,35 & 1,89 \\
\hline $\mathrm{Al}_{2} \mathrm{O}_{3}$ & 14,34 & 13,61 & 13,84 & 13,12 & 14,41 & 14,65 & 13,45 \\
\hline $\mathrm{Fe}_{2} \mathrm{O}_{3}$ & 2,66 & 2,32 & 0,74 & 1,78 & 2,69 & 2,56 & 3,82 \\
\hline FeO & 12,86 & 12,1 & 13,25 & 11,68 & 12,06 & 11,66 & 10,9 \\
\hline $\mathrm{MnO}$ & 0,21 & 0,2 & 0,25 & 0,22 & 0,21 & 0,19 & 0,23 \\
\hline $\mathrm{MgO}$ & 4,34 & 7,49 & 7,67 & 7,74 & 5,56 & 4,11 & 7,13 \\
\hline $\mathrm{CaO}$ & 7,61 & 9,78 & 11,41 & 10,43 & 8,86 & 7,75 & 9,43 \\
\hline $\mathrm{Na}_{2} \mathrm{O}$ & 2,57 & 2,12 & 2,11 & 2,08 & 2,67 & 3,17 & 2,68 \\
\hline $\mathrm{K}_{2} \mathrm{O}$ & 1,78 & 0,98 & 0,15 & 0,73 & 0,87 & 1,58 & 0,61 \\
\hline $\mathrm{P}_{2} \mathrm{O}_{5}$ & 0,45 & 0,2 & 0,08 & 0,12 & 0,75 & 0,41 & 0,23 \\
\hline P.F. & 2,28 & 2,48 & 0,7 & 2,2 & 2,13 & 1,88 & 2,96 \\
\hline Soma & 100 & 100 & 100 & 100 & 100 & 100 & 100 \\
\hline \multicolumn{8}{|c|}{ NORMA CIPW } \\
\hline$Q z$ & 2,18 & 0 & 0 & 0 & 1,2 & 1,75 & 0,28 \\
\hline Or & 10,51 & 5,79 & 0,88 & 4,31 & 5,14 & 9,33 & 3,6 \\
\hline$A b$ & 21,74 & 17,93 & 17,85 & 17,6 & 22,59 & 26,82 & 22,67 \\
\hline An & 22,33 & 24.72 & 27,85 & 24,3 & 24,76 & 21,07 & 22,86 \\
\hline Wo/Di & 5,21 & 9,38 & 11,78 & 11,12 & 5,96 & 6,13 & 9,35 \\
\hline $\mathrm{En} / \mathrm{Di}$ & 2,06 & 4,67 & 5,39 & 5,63 & 2,82 & 2,44 & 5,03 \\
\hline $\mathrm{Fs} / \mathrm{si}$ & 3,2 & 4,52 & 6,29 & 5,22 & 3,06 & 3,76 & 4,01 \\
\hline $\mathrm{En} / \mathrm{Sy}$ & 8,74 & 11,73 & 8,15 & 13,5 & 11,01 & 7,79 & 12,72 \\
\hline Fs/hy & 13,56 & 11,34 & 9,51 & 12,52 & 11,91 & 12 & 10,15 \\
\hline $\mathrm{Fo} / \mathrm{Ol}$ & 0 & 1,57 & 3,89 & 0,09 & 0 & 0 & 0 \\
\hline $\mathrm{Fa} / \mathrm{Ol}$ & 0 & 1,67 & 5 & 0,09 & 0 & 0 & 0 \\
\hline $\mathrm{Mi}$ & 3,85 & 3,36 & 1,07 & 2,58 & 3,9 & 3,71 & 5,53 \\
\hline II & 5,79 & 3,03 & 2,18 & 2,88 & 6,13 & 4,46 & 3,58 \\
\hline$A p$ & 1,06 & 0,47 & 0,18 & 0,28 & 1,77 & 0,97 & 0,54 \\
\hline $\mathrm{FeOt}$ & 15,25 & 14,19 & 13,92 & 13,28 & 14,48 & 13,96 & 14,34 \\
\hline $\mathrm{mg} \#(0.15)$ & 0,365 & 0,516 & 0,527 & 0,541 & 0,437 & 0,373 & 0,501 \\
\hline \multicolumn{8}{|c|}{ BLEMENTOS TRACOS } \\
\hline $\mathrm{Nd}$ & 38 & 20 & 11 & 15 & 37 & 39 & 22 \\
\hline $\mathrm{Nb}$ & 30 & 12 & 6 & 9 & 21 & 17 & 18 \\
\hline $\mathrm{Cr}$ & 47 & 234 & 259 & 297 & 90 & 90 & 108 \\
\hline $\mathrm{Ni}$ & 56 & 102 & 100 & 96 & 71 & 80 & 77 \\
\hline $\mathrm{Ba}$ & 707 & 311 & 32 & 201 & 431 & 377 & 159 \\
\hline $\mathrm{RB}$ & 106 & 32 & 7 & 38 & 43 & 67 & 29 \\
\hline $\mathrm{Sr}$ & 274 & 204 & 89 & 169 & 582 & 178 & 341 \\
\hline La & 37 & 16 & 7 & 11 & 21 & 31 & 16 \\
\hline $\mathrm{Ce}$ & 79 & 34 & 18 & 26 & 52 & 69 & 38 \\
\hline $\mathrm{Zr}$ & 341 & 151 & 64 & 90 & 188 & 247 & 162 \\
\hline Y & 53 & 44 & 26 & 37 & 37 & 55 & 39 \\
\hline Petrografia & $\mathrm{DB}_{2}$ & $\mathrm{DMB}$ & $\mathrm{DB}_{2}$ & $\mathrm{DA}$ & $\mathrm{DH}_{2}$ & $\mathrm{DB}_{2}$ & DA \\
\hline Suite & básica & metamórfica & básica & metamórfica & básica & básica & metamórfica \\
\hline Direção & & $\mathrm{N} 40^{\circ} \mathrm{E}$ & $\mathrm{N}-\mathrm{S}$ & N-S & $\mathrm{N} 60^{\circ} \mathrm{Z}$ & $\mathrm{N} 40^{\circ} \mathrm{W}$ & \\
\hline Espessura(m) & 0.35 & 20 & & 20 & 20 & 20 & \\
\hline Longitude & $44^{0} 52^{\prime} 30^{\prime \prime}$ & $44^{\prime \prime} 52^{\prime} 13^{\prime \prime}$ & $44^{\circ} 51^{\prime} 38^{\prime \prime}$ & $44^{0} 50^{\prime} 38^{\prime \prime}$ & $44^{\circ} 45^{\prime} 26^{\prime \prime}$ & $44^{\prime \prime} 41^{\prime} 58^{\prime \prime}$ & $44^{0} 27^{\prime} 50^{\prime \prime}$ \\
\hline Latitude & $20^{\circ} 55^{\circ} 41^{\prime \prime}$ & $20^{\circ} 55^{\prime} 00^{\prime \prime}$ & $20^{\circ} 5428^{\prime \prime}$ & $20^{\circ} 52^{\prime} 18^{\prime \prime}$ & $20^{\circ} 45^{\prime} 00^{\prime \prime}$ & $20^{\circ} 45^{\prime} 16^{\prime \prime}$ & $20^{\circ} 56^{\circ} 37^{\prime \prime}$ \\
\hline
\end{tabular}

OBS: DBN, DB $, D B_{2}, D M B$ e DA, conforme capitulo da Petrografia. Elementos maiores e menores (\% em peso) normalizados a $100 \%$ sem a perda ao fogo (P.E.). Elementos traços em ppm. (bás. noritica = básica noritica). 


\begin{tabular}{|c|c|c|c|c|c|c|c|}
\hline Amostra & 83 & 84 & 85 & 86 & 87 & 88 & 89 \\
\hline $\mathrm{SiO}_{2}$ & 49,8 & 49,87 & 49,91 & 51,7 & 50,07 & 50,19 & 49,9 \\
\hline $\mathrm{TiO}_{2}$ & 1,93 & 1,62 & 2,3 & 1,53 & 1,42 & 1,67 & 1,24 \\
\hline $\mathrm{Al}_{2} \mathrm{O}_{3}$ & 14,27 & 13,55 & 13,96 & 13,24 & 15,81 & 14,85 & 16,58 \\
\hline $\mathrm{Fe}_{2} \mathrm{O}_{3}$ & 3,66 & 2,11 & 2,99 & 1,37 & 1,17 & 1,54 & 1,68 \\
\hline $\mathrm{FeO}$ & 10 & 12,24 & 13,28 & 13,28 & 11,91 & 12,97 & 10,74 \\
\hline $\mathrm{MnO}$ & 0,21 & 0,21 & 0,22 & 0,23 & 0,21 & 0,23 & 0,2 \\
\hline $\mathrm{MgO}$ & 7,26 & 6,82 & 5 & 6,03 & 5,7 & 5,37 & 6,46 \\
\hline $\mathrm{CaO}$ & 9,84 & 10,33 & 8,98 & 9,44 & 10,89 & 10,29 & 10,62 \\
\hline $\mathrm{Na}_{2} \mathrm{O}$ & 2,4 & 2,68 & 2,78 & 2,59 & 2,59 & 2,54 & 2,38 \\
\hline $\mathrm{K}_{2} \mathrm{O}$ & 0,81 & 0,57 & 0,7 & 0,57 & 0,22 & 0,32 & 0,27 \\
\hline $\mathrm{P}_{2} \mathrm{O}_{5}$ & 0,19 & 0,21 & 0,18 & 0,16 & 0,13 & 0,18 & 0,1 \\
\hline P.F. & 2,68 & 1,77 & 2,06 & 1,99 & 0,98 & 1,09 & 1,1 \\
\hline Soma & 100 & 100 & 100 & 100 & 100 & 100 & 100 \\
\hline \multicolumn{8}{|c|}{ NORMA CIPW } \\
\hline$Q z$ & 0,36 & 0 & 0,71 & 1,01 & 0 & 0,12 & 0 \\
\hline $\mathrm{Or}$ & 4,78 & 3,36 & 4,13 & 3,36 & 1,3 & 1,89 & 1,59 \\
\hline $\mathrm{Ab}$ & 20,3 & 22,67 & 23,52 & 21,91 & 21,91 & 21,49 & 20,13 \\
\hline An & 25,77 & 23,26 & 23,54 & 22,81 & 30,86 & 28,17 & 33,76 \\
\hline Wo/Di & 9,1 & 11,11 & 8,27 & 9,59 & 9,31 & 9,06 & 7,62 \\
\hline $\mathrm{En} / \mathrm{Di}$ & 5,15 & 5,25 & 3,35 & 4 & 3,99 & 3,64 & 3,68 \\
\hline $\mathrm{Fs} / \mathrm{Di}$ & 3,57 & 5,71 & 4,99 & 5,63 & 5,33 & 5,5 & 3,81 \\
\hline $\mathrm{En} / \mathrm{LH}$ & 12,92 & 7,58 & 9,09 & 11,01 & 8,35 & 9,73 & 11,04 \\
\hline Fs/lly & 8,97 & 8,23 & 13,53 & 15,51 & 11,15 & 14,7 & 11,44 \\
\hline $\mathrm{Fo} / \mathrm{Ol}$ & 0 & 2,9 & 0 & 0 & 1,29 & 0 & 0,94 \\
\hline $\mathrm{Fa} / \mathrm{Ol}$ & 0 & 3,47 & 0 & 0 & 1,9 & 0 & 1,07 \\
\hline $\mathrm{Mt}$ & 5,3 & 3,05 & 4,33 & 1,98 & 1,69 & 2,23 & 2,43 \\
\hline II & 3,66 & 3,07 & 4,36 & 2,9 & 2,69 & 3,17 & 2,35 \\
\hline$A p$ & 0,45 & 0,49 & 0,42 & 0,37 & 0,3 & 0,42 & 0,23 \\
\hline $\mathrm{FeOt}$ & 13,29 & 14,14 & 15,97 & 14,51 & 12,96 & 14,36 & 12,25 \\
\hline $\mathrm{mg} \#(0.15)$ & 0,525 & 0,494 & 0,388 & 0,457 & 0,471 & 0,431 & 0,516 \\
\hline \multicolumn{8}{|c|}{ ELJEMENTOS TRACOOS } \\
\hline $\mathrm{Nd}$ & 24 & 22 & 19 & 23 & 19 & 21 & 17 \\
\hline $\mathrm{Nb}$ & 18 & 13 & 13 & 13 & 9 & 10 & 10 \\
\hline $\mathrm{Cr}$ & 185 & 218 & 69 & 91 & 114 & 131 & 206 \\
\hline $\mathrm{Ni}$ & 95 & 114 & 55 & 67 & 70 & 65 & 96 \\
\hline $\mathrm{Ba}$ & 112 & 85 & 176 & 116 & 54 & 64 & 80 \\
\hline $\mathrm{Rb}$ & 53 & 21 & 25 & 24 & 7 & 14 & 9 \\
\hline $\mathrm{Sr}$ & 226 & 125 & 167 & 134 & 124 & 113 & 119 \\
\hline La & 16 & 16 & 15 & 17 & 10 & 12 & 7 \\
\hline $\mathrm{Ce}$ & 33 & 36 & 38 & 34 & 23 & 33 & 30 \\
\hline $\mathrm{Zr}$ & 176 & 165 & 140 & 141 & 90 & 131 & 97 \\
\hline$Y$ & 36 & 48 & 42 & 49 & 29 & 42 & 30 \\
\hline Petrografia & $\mathrm{DA}$ & $\mathrm{DA}$ & $\mathrm{DA}$ & $\mathrm{DA}$ & $\mathrm{DB}_{2}$ & $\mathrm{DB}_{2}$ & $\mathrm{DH}_{2}$ \\
\hline Suite & metamórfica & metamorfica & melamorfica & metámórlica & básica & básica & básica \\
\hline Direção & $\mathrm{N} 60^{\circ} \mathrm{E}$ & $\mathrm{E}-\mathrm{W}$ & $\mathrm{E}-\mathrm{W}$ & & $\mathrm{N} 45^{\circ} \mathrm{W}$ & & $\mathrm{N}-\mathrm{S}$ \\
\hline Espessura(m) & 2 & 6 & 20 & & 40 & & 1 \\
\hline Longitude & $44^{0} 36^{\prime} 29^{\prime \prime}$ & $44^{0} 53.31^{\prime \prime}$ & $44^{\circ} 52^{\prime} 26^{\prime \prime}$ & $44^{\circ} 52^{\prime} 26^{\prime \prime}$ & $44^{\circ} 51^{\circ} 47^{\prime \prime}$ & $44^{\circ} 51^{\prime} 47^{\prime \prime}$ & $44^{0} 50^{\prime} 55^{\prime \prime}$ \\
\hline Latitude & $20^{\circ} 58^{\prime} 15^{\prime \prime}$ & $20^{\circ} 57^{\prime} 26^{\prime \prime}$ & $20^{\circ} 58^{\prime} 06^{\prime \prime}$ & $20^{6} 58^{\circ} 06^{\prime \prime}$ & $20^{\circ} 59^{\prime} 28^{\prime \prime}$ & $20^{\circ} 59^{\prime} 28^{\prime \prime}$ & $20^{0} 59^{\prime} 28^{\prime \prime}$ \\
\hline
\end{tabular}

OBS: DBN, DBB, $\mathrm{DB}_{2}, \mathrm{DMB}$ e DA, conforme capitulo da Petrografia. Elementos maiores e menores (\% em peso) normalizados a $100 \%$ sem a perda ao fogo (P.F.). Elementos traços em ppm. (bás. noritica = básica noritica). 


\begin{tabular}{|c|c|c|c|c|c|c|c|}
\hline Amostra & 90 & 91 & 92 & 93 & 94 & 95 & 96 \\
\hline $\mathrm{SiO}_{2}$ & 48,73 & 72,58 & 49,21 & 70,31 & 69,54 & 49,19 & 50,97 \\
\hline $\mathrm{TiO}_{2}$ & 1,27 & 0,28 & 2,89 & 0,66 & 0,82 & 2,79 & 1,51 \\
\hline $\mathrm{Al}_{2} \mathrm{O}_{3}$ & 16,76 & 14,86 & 11,92 & 14,15 & 13,7 & 11,93 & 12,41 \\
\hline $\mathrm{Fe}_{2} \mathrm{O}_{3}$ & 0,86 & 0,73 & 3,54 & 0,37 & 0,23 & 3,28 & 2,81 \\
\hline $\mathrm{FeO}$ & 11,86 & 1,01 & 14,73 & 2,99 & 4,16 & 14,85 & 12,37 \\
\hline $\mathrm{MnO}$ & 0,2 & 0,02 & 0,23 & 0,04 & 0,05 & 0,21 & 0,25 \\
\hline $\mathrm{MgO}$ & 6,25 & 1,09 & 4,82 & 0,76 & 0,77 & 5,02 & 6,01 \\
\hline $\mathrm{CaO}$ & 11,41 & 2,77 & 9,43 & 1,83 & 2,29 & 9,53 & 10,99 \\
\hline $\mathrm{Na}_{2} \mathrm{O}$ & 2,34 & 5,42 & 2,61 & 3,22 & 3,16 & 2,34 & 2,45 \\
\hline $\mathrm{K}_{2} \mathrm{O}$ & 0,28 & 1,18 & 0,57 & 5,48 & 4,97 & 0,76 & 0,31 \\
\hline $\mathrm{P}_{2} \mathrm{O}_{5}$ & 0,13 & 0,13 & 0,4 & 0,23 & 0,33 & 0,43 & 0,2 \\
\hline P.F. & 0,97 & 0,63 & 1,51 & 0,68 & 0,79 & 1,7 & 1,54 \\
\hline Soma & 100 & 100 & 100 & 100 & 100 & 100 & 100 \\
\hline \multicolumn{8}{|c|}{ NORMA CIPW } \\
\hline$Q z$ & 0 & 29 & 1,98 & 24,3 & 24,34 & 2,04 & 1,97 \\
\hline$O x$ & 1,65 & 6,97 & 3,36 & 32,38 & 29,37 & 4,49 & 1,83 \\
\hline $\mathrm{Ab}$ & 19,8 & 45,86 & 22,08 & 27,24 & 26,73 & 19,8 & 20,73 \\
\hline An & 34,4 & 12.73 & 19,12 & 7,57 & 8,52 & 19,8 & 21,95 \\
\hline Wo/Di & 8,91 & 0,06 & 10,45 & 0 & 0,28 & $10,2,9$ & 13,05 \\
\hline $\mathrm{En} / \mathrm{Di}$ & 3,96 & 0,04 & 4,01 & 0 & 0,07 & 3,97 & 5,83 \\
\hline Fs/Di & 4,92 & 0,01 & 6,6 & 0 & 0,23 & 6,47 & 7,16 \\
\hline $\mathrm{En} / \mathrm{Hy}$ & 5,5 & 2,66 & 7,99 & 1,89 & 1,84 & 8,52 & 9,13 \\
\hline Fs/liy & 6,84 & 0,81 & 13,17 & 4,16 & 5,95 & 13,87 & 11,2 \\
\hline Fo/Ol & 4,27 & 0 & 0 & 0 & 0 & 0 & 0 \\
\hline $\mathrm{Fa} / \mathrm{Ol}$ & 5,85 & 0 & 0 & 0 & 0 & 0 & 0 \\
\hline $\mathrm{Mt}$ & 1,24 & 1,05 & 5,13 & 0,53 & 0,33 & 4,75 & 4,07 \\
\hline Il & 2,41 & 0,53 & 5,48 & 1,25 & 1,55 & 5,29 & 2,86 \\
\hline Ap & 0,3 & 0,3 & 0,94 & 0,54 & 0,78 & $1,0\}$ & 0,47 \\
\hline FeOt & 12,63 & 1,67 & 17,92 & 3,32 & 4,37 & 17,8 & 14,9 \\
\hline $\mathrm{mg} \#(0.15)$ & 0,500 & 0,569 & 0,352 & 0,316 & 0,263 & 0,363 & 0,449 \\
\hline \multicolumn{8}{|c|}{ ELEMENTOS TRACOS } \\
\hline $\mathrm{Nd}$ & 16 & 15 & 29 & 69 & 56 & 28 & 20 \\
\hline $\mathrm{Nb}$ & 10 & 6 & 20 & 26 & 26 & 20 & 13 \\
\hline $\mathrm{Cr}$ & 201 & 4 & 74 & 5 & 7 & 89 & 162 \\
\hline $\mathrm{Ni}$ & 96 & 6 & 59 & 11 & 9 & 50 & 50 \\
\hline $\mathrm{Ba}$ & 57 & 442 & 114 & 1279 & 1246 & 100 & 79 \\
\hline $\mathrm{Rb}$ & 10 & 20 & 8 & 117 & 95 & 17 & 9 \\
\hline $\mathrm{Sr}$ & 127 & 456 & 130 & 152 & 150 & 112 & 113 \\
\hline La & 11 & 30 & 19 & 95 & 67 & 16 & 14 \\
\hline $\mathrm{Ce}$ & 27 & 50 & 45 & 188 & 136 & 46 & 29 \\
\hline $\mathrm{Zr}$ & 102 & 148 & 274 & 560 & 620 & 248 & 153 \\
\hline$Y$ & 28 & 2 & 82 & 42 & 41 & 69 & 49 \\
\hline Petrografia & $\mathrm{DB}_{2}$ & grantlito & $\mathrm{DA}$ & granulito & granulito & $\mathrm{DA}$ & DMB \\
\hline Suíte & básica & encaixante & metamórfica & encaixante & encaixante & metamórfica & metamórfica \\
\hline Direção & $\mathrm{N}-\mathrm{S}$ & & & & & $\mathrm{N} 50^{\circ} \mathrm{E}$ & $\mathrm{N} 30^{\circ} \mathrm{Z}$ \\
\hline Espessura(m) & 5 & & & & & 20 & 10 \\
\hline Longitlde & $44^{0} 50^{\prime} 55^{\prime \prime}$ & $44^{\circ} 50^{\prime} 55^{\prime \prime}$ & $44^{0} 49^{\prime} 04^{\prime \prime}$ & $44^{0} 5 I^{\prime} 28^{\prime \prime}$ & $44^{0} 51^{\prime} 57^{\prime \prime}$ & $44^{0} 48^{\prime} 03^{\prime \prime}$ & $44^{\circ} 51133^{\prime \prime}$ \\
\hline Latitude & $20^{\circ} 59^{\prime} 28^{\prime \prime}$ & $20^{\circ} 59^{\prime} 28^{\prime \prime}$ & $21^{\circ} 00^{\prime} 49^{\prime \prime}$ & $21^{\circ} 01^{\prime} 18^{\prime \prime}$ & $21^{\circ} 01^{\prime} 18^{\prime \prime}$ & $21^{\circ} 01^{\prime} 37^{\prime \prime}$ & $21^{0} 017^{\prime \prime \prime}$ \\
\hline
\end{tabular}

OBS: DBN, DB, DBB,$D M B$ e DA, contorme capitulo da Petrografia. Jilementos maiores e menores (\% em peso) normalizados a $100 \%$ sem a perda ao fogo (P.F.). Elementos traços en ppm. (bás. norítica = básica noritica). 


\begin{tabular}{|c|c|c|c|c|c|c|c|}
\hline Amostra & 97 & 98 & 99 & 100 & 103 & 105 & 106 \\
\hline $\mathrm{SiO}_{2}$ & 51,15 & 51,7 & 51,89 & 49,2 & 50,67 & 50,31 & 50,38 \\
\hline $\mathrm{TiO}_{2}$ & 1,84 & 1,82 & 1,53 & 2,05 & 1,08 & 1,64 & 0,98 \\
\hline $\mathrm{Al}_{2} \mathrm{O}_{3}$ & 12,58 & 12,83 & 13,03 & 15,3 & 12,49 & 13,52 & 13,54 \\
\hline $\mathrm{Fe}_{2} \mathrm{O}_{3}$ & 3,09 & 3,91 & 2,52 & 0,76 & 8,79 & 2,62 & 2,49 \\
\hline $\mathrm{FeO}$ & 13,3 & 12,03 & 11,28 & 13,46 & 5,66 & 11,82 & 10,82 \\
\hline $\mathrm{MnO}$ & 0,25 & 0,23 & 0,22 & 0,22 & 0,2 & 0,22 & 0,22 \\
\hline $\mathrm{MgO}$ & 5,4 & 5,09 & 6,64 & 5,48 & 8,55 & 7,02 & 8,52 \\
\hline $\mathrm{CaO}$ & 9,52 & 9,61 & 10,16 & 10,48 & 11,2 & 10,48 & 10,29 \\
\hline $\mathrm{Na}_{2} \mathrm{O}$ & 2,43 & 2,49 & 2,22 & 2,55 & 1,86 & 2,17 & 1,99 \\
\hline $\mathrm{K}_{2} \mathrm{O}$ & 0,53 & 0,47 & 0,58 & 0,27 & 0,26 & 0,26 & 0,92 \\
\hline $\mathrm{P}_{2} \mathrm{O}_{5}$ & 0,22 & 0,21 & 0,18 & 0,31 & 0,12 & 0,2 & 0,1 \\
\hline P.I. & 1,83 & 1,98 & 1,9 & 0,82 & 1,93 & 1,82 & 2,64 \\
\hline Soma & 100 & 100 & 100 & 100 & 100 & 100 & 100 \\
\hline \multicolumn{8}{|c|}{ NORMA CIPW } \\
\hline Qz & 3,53 & 5,56 & 3,55 & 0 & 8,1 & 1,73 & 0 \\
\hline $\mathrm{Or}$ & 3,13 & 2,77 & 3,42 & 1,59 & 1,53 & 1,53 & 5,43 \\
\hline $\mathrm{Ab}$ & 20,56 & 21,06 & 18,78 & 21,57 & 15,73 & 18,36 & 16,83 \\
\hline An & 21,85 & 22,44 & 23,87 & 29,5 & 24,96 & 26,38 & 25,29 \\
\hline Wo/Di & 9,99 & 9,96 & 10,58 & 8,54 & 12,44 & 10,14 & 10,48 \\
\hline $\mathrm{En} / \mathrm{Di}$ & 4,12 & 4,35 & 5,19 & 3,39 & 10,13 & 5,01 & 5,67 \\
\hline $\mathrm{F}^{\mathrm{S}} \mathrm{s} / \mathrm{Di}$ & 5,92 & 5,59 & 5,19 & 5,24 & 0,81 & 4,94 & 4,44 \\
\hline $\mathrm{En} / \mathrm{Hy}$ & 9,31 & 8,32 & 11,33 & 7,77 & 11,15 & 12,47 & 12,76 \\
\hline Fs/lyy & 13,37 & 10,68 & 11,32 & 12,03 & 0,9 & 12,3 & 9,98 \\
\hline $\mathrm{Fo} / \mathrm{Ol}$ & 0 & 0 & 0 & 1,73 & 0 & 0 & 1,94 \\
\hline $\mathrm{Fa} / \mathrm{Ol}$ & 0 & 0 & 0 & 2,95 & 0 & 0 & 1,67 \\
\hline Mt & 4,48 & 5,66 & 3,65 & 1,1 & 12,74 & 3,79 & 3,61 \\
\hline II & 3,49 & 3,45 & 2,9 & 3,89 & 2,05 & 3,11 & 1,86 \\
\hline Ap & 0,52 & 0,49 & 0,42 & 0,73 & 0,28 & 0,47 & 0,23 \\
\hline FeOt & 16,08 & 15,55 & 13,55 & 14,14 & 13,57 & 14,18 & 13,06 \\
\hline $\mathrm{mg} \#(0.15)$ & 0,404 & 0,398 & 0,498 & 0,439 & 0,560 & 0,500 & 0,569 \\
\hline \multicolumn{8}{|c|}{ ELEMENTOS TRACOS } \\
\hline $\mathrm{Nd}$ & 23 & 70 & 18 & 24 & 15 & 25 & 22 \\
\hline $\mathrm{Nb}$ & 14 & 15 & 12 & 13 & 7 & 14 & 8 \\
\hline $\mathrm{Cr}$ & 90 & 98 & 99 & 220 & 325 & 226 & 282 \\
\hline $\mathrm{Ni}$ & 56 & 46 & 67 & 95 & 113 & 94 & 121 \\
\hline $\mathrm{Ba}$ & 112 & 1221 & 103 & 79 & 42 & 59 & 100 \\
\hline $\mathrm{Rb}$ & 20 & 11 & 25 & 10 & 11 & 8 & 57 \\
\hline $\mathrm{Sr}$ & 116 & 118 & 1.38 & 110 & 162 & 109 & 117 \\
\hline La & 17 & 70 & 13 & 15 & 12 & 17 & 15 \\
\hline $\mathrm{Ce}$ & 35 & 36 & 38 & 44 & 18 & 38 & 2) \\
\hline $\mathrm{Zr}$ & 171 & 169 & 148 & 196 & 93 & 171 & 80 \\
\hline $\mathrm{Y}$ & 56 & 59) & 52 & 54 & 31 & 50 & 29 \\
\hline Petrografia & DMB & DMB & $\mathrm{DB}_{2}$ & $\mathrm{DB}_{2}$ & $\mathrm{DA}$ & $\mathrm{DA}$ & $\mathrm{DA}$ \\
\hline Suíle & metamórfica & metamórfica & básica & básica & metamórfica & metamórica & metamórfica \\
\hline Direção & & $\mathrm{N} 30^{\circ} \mathrm{E}$ & $\mathrm{N} 30^{\circ} \mathrm{W}$ & $\mathrm{N}-\mathrm{S}$ & $\mathrm{E}-\mathrm{W}$ & $\mathrm{N}-\mathrm{S}$ & $\mathrm{N} 20^{\circ} \mathrm{E}$ \\
\hline Espessura(m) & & & 30 & 3 & 30 & 30 & 25 \\
\hline Longitude & $44^{\circ} 51^{\prime} 13^{\prime \prime}$ & $44^{0} 51^{\prime} 13^{\prime \prime}$ & $44^{\circ} 48^{\circ} 47^{\prime \prime}$ & $45^{\circ} 022^{\prime} 7^{\prime \prime}$ & $44^{0} 42^{\prime} 35^{\prime \prime}$ & $44^{\circ} 44^{\prime} 45^{\prime \prime}$ & $44^{0} 45^{\prime} 11^{\prime \prime}$ \\
\hline Latitude & $21^{\circ} 01^{\prime} 37^{\prime \prime}$ & $21^{\circ} 01^{\prime} 37^{\prime \prime}$ & $21^{\circ} 01^{\prime} 13^{\prime \prime}$ & $21^{\circ} 12^{\prime} 20^{\prime \prime}$ & $21^{\circ} 05^{\prime} 16^{\prime \prime}$ & $21^{\circ} 02^{\prime} 02^{\prime \prime}$ & $21^{\circ} 0347^{\prime \prime}$ \\
\hline
\end{tabular}

OBS: DBN, DB, DB, DMB e DA, conforme capitulo da Petrografia. lilementos maiores e menores (\% em peso) normalizados a $100 \%$ sem a perda ao fogo (P.F.). Elementos traços em ppm. (bás. noritica = básica noritica) 


\begin{tabular}{|c|c|c|c|c|c|c|c|}
\hline Amostra & 107 & 110 & 111 & 112 & 113 & 128 & 131 \\
\hline $\mathrm{SiO}_{2}$ & 49,83 & 49,66 & 50,18 & 55,03 & 55,1 & 50,41 & 50,47 \\
\hline $\mathrm{TiO}_{2}$ & 0,81 & 2,28 & 1,56 & 0,89 & 0,8 & 1,02 & 1,88 \\
\hline $\mathrm{Al}_{2} \mathrm{O}_{3}$ & 13,68 & 12,81 & 12,77 & 16,11 & 14,57 & 12,64 & 12,98 \\
\hline $\mathrm{Fe}_{2} \mathrm{O}_{3}$ & 2,21 & 3,7 & 3,1 & 0,79 & 2,51 & 3,78 & 1,38 \\
\hline $\mathrm{FeO}$ & 9,41 & 13,54 & 12,56 & 9,16 & 8,04 & 10,33 & 14,84 \\
\hline $\mathrm{MnO}$ & 0,19 & 0,21 & 0,22 & 0,14 & 0,15 & 0,22 & 0,25 \\
\hline $\mathrm{MgO}$ & 9,06 & 6,59 & 7,17 & 4,89 & 6,28 & 8,79 & 5,45 \\
\hline $\mathrm{CaO}$ & 12,62 & 8,02 & 9,55 & 9,03 & 8,8 & 10,76 & 9,66 \\
\hline $\mathrm{Na}_{2} \mathrm{O}$ & 1,77 & 1,9 & 2,4 & 2,56 & 2,14 & 1,72 & 2,7 \\
\hline $\mathrm{K}_{2} \mathrm{O}$ & 0,57 & 1,29 & 0,56 & 1,32 & 1,72 & 0,62 & 0,34 \\
\hline $\mathrm{P}_{2} \mathrm{O}_{5}$ & 0,07 & 0,37 & 0,24 & 0,16 & 0,14 & 0,09 & 0,19 \\
\hline P.F. & 1,87 & 2,92 & 2,33 & 1,04 & 2,33 & 2,56 & 1,79 \\
\hline Soma & 100 & 100 & 100 & 100 & 100 & 100 & 100 \\
\hline \multicolumn{8}{|c|}{ NORMA CIPW } \\
\hline$Q Z$ & 0 & 2,49 & 0,3 & 5,36 & 6,75 & 1,5 & () \\
\hline Or & 3,36 & 7,62 & 3,3 & 7,8 & 10,16 & 3,66 & 2 \\
\hline $\mathrm{Ab}$ & 14,97 & 16,07 & 20,3 & 21,66 & 18,1 & 14,55 & 22,84 \\
\hline $\mathrm{All}_{\mathrm{l}}$ & 27,7 & 22,61 & 22,41 & 28,56 & 25,07 & 24,93 & 22,29 \\
\hline Wo/Di & 14,38 & 6,16 & 9,76 & 6,34 & 7,37 & 11,63 & 10,18 \\
\hline $\mathrm{En} / \mathrm{Di}$ & 8,35 & 2,87 & 4,73 & 2,83 & 4,07 & 6,67 & 3,8 \\
\hline $\mathrm{F} / \mathrm{s} / \mathrm{Di}$ & 5,35 & 3,22 & 4,86 & 3,47 & 3,03 & 4,44 & 6,57 \\
\hline $\mathrm{En} / \mathrm{Hy}$ & 9,38 & 13,53 & 13,11 & 9,34 & 11,56 & 15,21 & 9,41 \\
\hline Fs/hy & 6,01 & 15,2 & 13,46 & 11,47 & 8,61 & 10,12 & 16,28 \\
\hline Fo/Ol & 3,37 & 0 & 0 & 0 & 0 & 0 & 0,24 \\
\hline $\mathrm{Fa} / \mathrm{Ol}$ & 2,38 & 0 & 0 & 0 & 0 & 0 & 0,47 \\
\hline $\mathrm{Mt}$ & 3,2 & 5,36 & 4,49 & 1,14 & 3,63 & 5,48 & 2 \\
\hline Il & 1,53 & 4,33 & 2,96 & 1,69 & 1,51 & 1,93 & 3,57 \\
\hline Ap & 0,16 & 0,87 & 0,56 & 0,37 & 0,33 & 0,21 & 0,45 \\
\hline FeOt & 11.4 & 16,87 & 15,35 & 9,87 & 10,3 & 13,73 & 16,08 \\
\hline mgłt(0.15) & 0,616 & $0,44 !$ & 0,486 & 0,500 & 0,552 & 0,564 & 0,407 \\
\hline \multicolumn{8}{|c|}{ ELEMENTOS TRAYOS } \\
\hline $\mathrm{Nd}$ & 9 & 34 & 20 & 23 & 23 & 11 & 15 \\
\hline $\mathrm{Nb}$ & 6 & 18 & 14 & 8 & 9 & 9 & 15 \\
\hline $\mathrm{Cr}$ & 874 & 178 & 203 & 200 & 183 & 273 & 130 \\
\hline $\mathrm{Ni}$ & 126 & 76 & 95 & 113 & 105 & 151 & 72 \\
\hline $\mathrm{Ba}$ & 63 & 317 & 126 & 303 & 302 & 35 & 71 \\
\hline $\mathrm{Rb}$ & 22 & 50 & 20 & 46 & 65 & 29 & 10 \\
\hline $\mathrm{Sr}$ & 147 & 158 & 183 & 234 & 277 & 156 & 108 \\
\hline La & 7 & 34 & 17 & 22 & 21 & 6 & 13 \\
\hline $\mathrm{Ce}$ & 22 & 80 & 34 & 43 & 43 & 27 & 36 \\
\hline $\mathrm{Zr}$ & 59 & 332 & 178 & 135 & 142 & 78 & 155 \\
\hline $\mathrm{Y}$ & 23 & 54 & 53 & 24 & 26 & 26 & 49 \\
\hline Petrografia & DA & $\mathrm{DA}$ & DA & $\mathrm{DB}_{1}$ & $\mathrm{DB}_{1}$ & $\mathrm{DA}$ & $\mathrm{DB}_{2}$ \\
\hline Suíte & metamórfica & metamórfica & metamórfica & bás. noritica & bás. norítica & metamórfica & básica \\
\hline Direção & $\mathrm{N} 70^{\circ} \mathrm{E}$ & $\mathrm{N}-\mathrm{S}$ & $\mathrm{N} 40^{\circ} \mathrm{IE}$ & $\mathrm{N} 20^{\circ} \mathrm{W}$ & & & $\mathrm{N} 15^{\circ} \mathrm{E}$ \\
\hline Espessura(m) & 30 & 25 & 15 & 50 & & & 4 \\
\hline Longitude & $44^{\circ} 45^{\prime} 28^{\prime \prime}$ & $44^{\prime} 47^{\prime} 20^{\prime \prime}$ & $44^{\circ} 47^{\prime} 20^{\circ}$ & $44^{\circ} 47^{\prime} 20^{\prime \prime}$ & $44^{\circ} 47^{\prime} 20^{\prime \prime}$ & $44^{\circ} 42^{\prime} 11^{\prime \prime}$ & $45^{\circ} 03^{\prime} 53^{\prime \prime}$ \\
\hline Latitude & $21^{\circ} 07^{\prime} 18^{\prime \prime}$ & $21^{6} 09^{\prime} 28^{\prime \prime}$ & $21^{\circ} 09^{\circ} 52^{\prime \prime}$ & $21^{0} 08^{\prime} 55^{\circ}$ & $21^{\circ} 08^{\circ} 31^{\prime \prime}$ & $20^{\circ} 59^{\prime} 44^{\prime \prime}$ & $21^{\circ} 10^{\circ} 43^{\prime \prime}$ \\
\hline
\end{tabular}

OBS: DBN, DB $, 1, \mathrm{DB}_{2}, \mathrm{DMB}$ e DA, confome capituto da Petrografia. Elementos maiores e menores (\% em peso) normalizados a $100 \%$ sem a perda ao fogo (P.F.). Elementos traços em ppm. (bás. norítica = básica norítica) 


\begin{tabular}{|c|c|c|c|c|c|c|c|}
\hline Amostra & 133 & 142 & 144 & 150 & $451^{*}$ & $621^{*}$ & $659^{*}$ \\
\hline $\mathrm{SiO}_{2}$ & 50,13 & 71,88 & 53,81 & 68,42 & 50,74 & 53,93 & 49,97 \\
\hline $\mathrm{TiO}_{2}$ & 0,61 & 0,42 & 0,67 & 0,51 & 2,9 & 0,6 & 1,72 \\
\hline $\mathrm{Al}_{2} \mathrm{O}_{3}$ & 15,45 & 13,56 & 13,2 & 16,24 & 14,73 & 14,37 & 13,32 \\
\hline $\mathrm{Fe}_{2} \mathrm{O}_{3}$ & 0,68 & 0,37 & 0,84 & 0,18 & 1,38 & 1,28 & 2,64 \\
\hline $\mathrm{FeO}$ & 9,8 & 2,88 & 9,5 & 2,54 & 13,49 & 8,48 & 12,33 \\
\hline $\mathrm{MnO}$ & 0,2 & 0,04 & 0,18 & 0,04 & 0,2 & 0,16 & 0,22 \\
\hline $\mathrm{MgO}$ & 8,32 & 0,55 & 9,95 & 1,27 & 4,41 & 9,59 & 6,81 \\
\hline $\mathrm{CaO}$ & 12,69 & 1,35 & 9,27 & 3,55 & 7,23 & 9,01 & 10,56 \\
\hline $\mathrm{Na}_{2} \mathrm{O}$ & 2,09 & 3,95 & 1,86 & 5,77 & 3,07 & 2,02 & 2,13 \\
\hline $\mathrm{K}_{2} \mathrm{O}$ & 0,04 & 4,9 & 0,72 & 1,28 & 1,67 & 0,62 & 0,34 \\
\hline $\mathrm{P}_{2} \mathrm{O}_{\mathrm{s}}$ & 0,06 & 0,14 & 0,08 & 0,22 & 0,7 & 0,07 & 0,22 \\
\hline P.F. & 0,97 & 0,7 & 1,68 & 0,48 & 1,37 & 1,73 & 1,64 \\
\hline Soma & 100 & 100 & 100 & 100 & 100 & 100 & 100 \\
\hline \multicolumn{8}{|c|}{ NORMA CIPW } \\
\hline$Q z$ & 0 & 25,05 & 2,79 & 19,7 & 0 & 3,54 & 1,34 \\
\hline $\mathrm{Or}$ & 0,23 & 28,95 & 4,25 & 7,56 & 9,86 & 3,66 & 2 \\
\hline $\mathrm{Ab}$ & 17,68 & 33,42 & 15,73 & 48,82 & 25,97 & 17,09 & 18,02 \\
\hline An & 32,65 & 4,79 & 25,54 & 14,63 & 21,48 & 28,31 & 25,78 \\
\hline Wo/Di & 12,48 & 0,41 & 8,31 & 0,64 & 4,09 & 6,65 & $10,5\}$ \\
\hline En/Di & 6,67 & 0,1 & 4,82 & 0,29 & 1,51 & 3,99 & 5,02 \\
\hline F $/ \mathrm{S} / \mathrm{i}$ & 5,41 & 0,33 & 3,11 & 0,34 & 2,65 & 2,3 & 5,33 \\
\hline$E_{n} / \mathrm{Hy}$ & 8,26 & 1,26 & 19,95 & 2,87 & 9,12 & 19,89 & 11,93 \\
\hline Fs/hy & 6,7 & 4,03 & 12,86 & 3,4 & 15,97 & 11,51 & 12,69 \\
\hline $\mathrm{Fo} / \mathrm{Ol}$ & 4,05 & 0 & 0 & 0 & 0,23 & 0 & 0 \\
\hline $\mathrm{Fa} / \mathrm{Ol}$ & 3,61 & 0 & 0 & 0 & 0,45 & 0 & 0 \\
\hline $\mathrm{Mt}$ & 0,98 & 0,53 & 1,21 & 0,26 & 2 & 1,85 & 3,82 \\
\hline I1 & 1,15 & 0,79 & 1,27 & 0,96 & 5,5 & 1,13 & 3,26 \\
\hline$A p$ & 0,14 & 0,33 & 0,18 & 0,52 & 1,65 & 0,16 & 0,52 \\
\hline FeOt & 10,41 & 3,21 & 10,26 & 2,7 & 14,73 & 9,63 & 14,71 \\
\hline $\mathrm{mg} \#(0.15)$ & 0,618 & 0,257 & 0,662 & 0,487 & 0,383 & 0,668 & 0,484 \\
\hline \multicolumn{8}{|c|}{ ELEMENTOS TRAÇOS } \\
\hline $\mathrm{Nd}$ & 8 & 50 & 12 & 24 & 45 & 12 & 21 \\
\hline $\mathrm{Nb}$ & 7 & 20 & 6 & 13 & 27 & 8 & 14 \\
\hline $\mathrm{Cr}$ & 501 & $\bar{l}$ & 659 & 9 & 42 & 941 & 202 \\
\hline $\mathrm{Ni}$ & 176 & 10 & 191 & 5 & 61 & 198 & 100 \\
\hline $\mathrm{Ba}$ & 3 & 3137 & 138 & 813 & 804 & 139 & 63 \\
\hline $\mathrm{Rb}$ & 5 & 144 & 27 & 18 & 42 & 18 & 7 \\
\hline $\mathrm{Sr}$ & 267 & 137 & 111 & 672 & 282 & 116 & 116 \\
\hline La & 2 & 78 & 10 & 38 & 34 & 9 & 15 \\
\hline $\mathrm{Ce}$ & 14 & 143 & 26 & 67 & 85 & 27 & 39 \\
\hline $7 r$ & 21 & 276 & 77 & 132 & 301 & 77 & 176 \\
\hline $\mathrm{Y}$ & 14 & 42 & 17 & 11 & 50 & 17 & 49 \\
\hline Petrografia & granulito & ortognaisse & $\mathrm{DBN}$ & granulito & $\mathrm{DB}_{2}$ & $D B N$ & $\mathrm{DMB}$ \\
\hline Suíle & encaixante & encaixante & bás. noritica & encaixante & básica & bás. noritica & metamórfica \\
\hline Direção & & & $\mathrm{N} 20^{\circ} \mathrm{W}$ & & & & \\
\hline Espessura(m) & & & 20 & & & & \\
\hline Longitude & $\left.45^{\circ}\right) 4^{\prime} 36^{\prime \prime}$ & $45^{\circ} 03^{\prime} 01^{\prime \prime}$ & $45^{\circ} 02^{\prime 35^{\prime \prime}}$ & $44^{0} 58^{\circ} 07^{\prime \prime}$ & & & \\
\hline Latitude & $21^{\circ} 07^{\prime} 28^{\circ \prime}$ & $21^{\circ} 12^{\prime} 29^{\prime \prime}$ & $21^{\circ} 10^{\prime} 39^{\prime \prime}$ & $21^{\circ} 10^{\prime} 30^{\prime \prime}$ & & & \\
\hline
\end{tabular}

$\left({ }^{*}\right)=$ Amostras cedidas pelo Prof. Quéméneur. OBS: DBN, DB, DB, DMB e DA, conforme capitulo da Petrografia.

Elementos maiores e menores (\% em peso) nomalizados a $100 \%$ sem a perda ao fogo (P.F.). Elementos traços em ppm. (bás. noritica $=$ básica noritica). 


\begin{tabular}{|c|c|c|c|c|c|c|c|}
\hline Amostra & $1091^{*}$ & $1206^{*}$ & $1208^{*}$ & $1211^{*}$ & $1212^{*}$ & $1215^{*}$ & $1217^{*}$ \\
\hline $\mathrm{SiO}_{2}$ & 51,05 & 48,73 & 48,4 & 50,95 & 51,35 & 51,68 & 50,34 \\
\hline $\mathrm{TiO}_{2}$ & 1,31 & 1,87 & 1,88 & 0,59 & 0,54 & 0,36 & 1,35 \\
\hline $\mathrm{Al}_{2} \mathrm{O}_{3}$ & 13,36 & 14,67 & 13,99 & 12,89 & 10,53 & 12,08 & 15,12 \\
\hline $\mathrm{Fe}_{2} \mathrm{O}_{3}$ & 4,16 & 2,07 & 2,16 & 1,08 & 3,48 & 0,72 & 0,79 \\
\hline $\mathrm{FeO}$ & 10,2 & 13,65 & 13,93 & 9,83 & 7,93 & 8,89 & 12,26 \\
\hline $\mathrm{MnO}$ & 0,23 & 0,24 & 0,27 & 0,18 & 0,19 & 0,17 & 0,22 \\
\hline $\mathrm{MgO}$ & 6,94 & 6,21 & 6,47 & 13,58 & 16,93 & 16,4 & 6,35 \\
\hline $\mathrm{CaO}$ & 10,49 & 9,59 & 9,92 & 8,58 & 7,34 & 7,81 & 10,9 \\
\hline $\mathrm{Na}_{2} \mathrm{O}$ & 2,16 & 2,7 & 2,7 & 1,81 & 1,47 & 1,59 & 2,38 \\
\hline $\mathrm{K}_{2} \mathrm{O}$ & 0,4 & 0,29 & 0,3 & 0,54 & 0,51 & 0,32 & 0,24 \\
\hline $\mathrm{P}_{2} \mathrm{O}_{5}$ & 0,12 & 0,19 & 0,2 & 0,08 & 0,08 & 0,05 & 0,13 \\
\hline P.F. & 2,12 & 1,91 & 1,63 & 0,71 & 0,83 & 0,77 & 0,89 \\
\hline Soma & 100 & 100 & 100 & 100 & 100 & 100 & 100 \\
\hline \multicolumn{8}{|c|}{ NORMA CIPW } \\
\hline$Q z$ & 3,84 & 0 & 0 & 0 & 0 & 0 & 0 \\
\hline $\mathrm{Or}$ & 2,36 & 1,71 & 1,77 & 3,19 & 3,01 & 1,89 & 1,41 \\
\hline $\mathrm{Ab}$ & 18,27 & 22,84 & 22,84 & 15,31 & 12,43 & 13,45 & 20,13 \\
\hline $\mathrm{An}$ & 25,57 & 27,05 & 25,16 & 25,45 & 20,62 & 24,88 & 29,86 \\
\hline Wo/Di & 10,72 & 8,05 & 9,49 & 6,92 & 6,37 & 5,65 & 9,75 \\
\hline $\mathrm{En} / \mathrm{Di}$ & 5,8 & 3,44 & 4,1 & 4,36 & 4,58 & 3,79 & 4,29 \\
\hline $\mathrm{Fs} / \mathrm{Di}$ & 4,55 & 4,61 & 5,39 & 2,13 & 1,21 & 1,43 & 5,43 \\
\hline $\mathrm{En} / \mathrm{Hy}$ & 11,47 & 7,67 & 6,11 & 19,74 & 32,93 & 26,81 & 9,88 \\
\hline Fs/hy & 9 & 10,27 & 8,04 & 9,64 & 8,7 & 10,14 & 12,53 \\
\hline $\mathrm{Fo} / \mathrm{Ol}$ & 0 & 3,04 & 4,13 & 6,8 & 3,25 & 7,17 & 1,14 \\
\hline $\mathrm{Fa} / \mathrm{O})$ & 0 & 4,49 & 5,99 & 3,66 & 0,94 & 2,98 & 1,59 \\
\hline $\mathrm{Mt}$ & 6,03 & 3 & 3,13 & 1,56 & 5,04 & 1,04 & 1,14 \\
\hline II & 2,48 & 3,55 & 3,57 & 1,12 & 1,02 & 0,68 & 2,56 \\
\hline$A p$ & 0,28 & 0,45 & 0,47 & 0,18 & 0,18 & 0,11 & 0,3 \\
\hline $\mathrm{FeOt}$ & 13,94 & 15,51 & 15,87 & 10,8 & 11,06 & 9,54 & 12,97 \\
\hline $\mathrm{mg} \#(0.15)$ & 0,502 & 0,447 & 0,452 & 0,718 & 0,756 & 0,777 & 0,498 \\
\hline \multicolumn{8}{|c|}{ ELIEMENTOS TR $\triangle C O S$} \\
\hline $\mathrm{Nd}$ & 15 & 20 & 17 & 9 & 11 & 8 & 14 \\
\hline $\mathrm{Nb}$ & 12 & 10 & 12 & 8 & 7 & 6 & 9 \\
\hline $\mathrm{Cr}$ & 179 & 144 & 170 & 1974 & 2590 & 2381 & 192 \\
\hline $\mathrm{Ni}$ & 75 & 120 & 92 & 453 & 547 & 519 & 80 \\
\hline $\mathrm{Ba}$ & 67 & 85 & 94 & 115 & 117 & 72 & 47 \\
\hline $\mathrm{Rb}$ & 12 & 12 & 11 & 17 & 16 & 10 & 8 \\
\hline $\mathrm{Sr}$ & 114 & 156 & 149 & 96 & 78 & 90 & 107 \\
\hline $\mathrm{La}$ & 12 & 9 & 7 & 10 & 11 & 7 & 7 \\
\hline $\mathrm{Ce}$ & 33 & 25 & 27 & 19 & 12 & 14 & 19 \\
\hline $7 r$ & 111 & 130 & 130 & 73 & 69 & 44 & 98 \\
\hline $\mathrm{Y}$ & 36 & 38 & 36 & 18 & 17 & 10 & 30 \\
\hline Petrografia & $\mathrm{DA}$ & $\mathrm{DB}_{2}$ & $\mathrm{DB}_{2}$ & DBN & DBN & DBN & $\mathrm{DB}_{2}$ \\
\hline Suíle & metamórtica & básica & básica & bás. noritica & bás. noritica & bás. noritica & básica \\
\hline \multicolumn{8}{|l|}{ Direção } \\
\hline Espessura(m) & & & & & & & \\
\hline
\end{tabular}

$\left.{ }^{*}\right)=$ Amostras cedidas pelo Prof. Quéméneur. OBS: DBNN, DB, $, \mathrm{DB}_{2}, \mathrm{DMB}$ e DA, conforme capítulo da Petrografia. Elementos maiores e menores (\% em peso) normalizados a $100 \%$ sem a perda ao fogo (P.F.). Elementos traços em ppm. (bás. noritica = básica norítica) 


\begin{tabular}{|c|c|c|c|c|}
\hline Amostra & $1220^{*}$ & $1223^{*}$ & $1230^{*}$ & $1231^{*}$ \\
\hline $\mathrm{SiO}_{2}$ & 49,29 & 55,03 & 50,73 & 50,55 \\
\hline $\mathrm{riO}_{2}$ & 1,93 & 0,82 & 1,08 & 1,31 \\
\hline $\mathrm{Al}_{2} \mathrm{O}_{3}$ & 14,89 & 17,16 & 15,56 & 15,01 \\
\hline $\mathrm{Fe}_{2} \mathrm{O}_{3}$ & 1,56 & 0,38 & 1,31 & 0,92 \\
\hline Feo & 12,47 & 8,88 & 10,52 & 12,19 \\
\hline $\mathrm{MnO}$ & 0,22 & 0,14 & 0,21 & 0,22 \\
\hline $\mathrm{MgO}$ & 5,72 & 4,44 & 6,76 & 6,55 \\
\hline $\mathrm{CaO}$ & 11 & 9,27 & 11,25 & 10,61 \\
\hline $\mathrm{Na}_{2} \mathrm{O}$ & 2,55 & 2,55 & 2,35 & 2,33 \\
\hline $\mathrm{K}_{2} \mathrm{O}$ & 0,25 & 1,22 & 0,25 & 0,28 \\
\hline $\mathrm{P}_{2} \mathrm{O}_{5}$ & 0,28 & 0,15 & 0,11 & 0,12 \\
\hline P.F. & 0,89 & 0,88 & 0,89 & 1,03 \\
\hline Soma & 100 & 100 & 100 & 100 \\
\hline \multicolumn{5}{|c|}{ NORMA CIPW } \\
\hline$Q Z$ & 0 & 5,54 & 0 & () \\
\hline $\mathrm{Or}$ & 1,47 & 7,2 & 1,47 & 1,65 \\
\hline $\mathrm{Ab}$ & 21,57 & 21,57 & 19,88 & 19.71 \\
\hline An & 28,44 & 31,77 & 31,17 & 29,67 \\
\hline Wo/Di & 10,14 & 5,52 & 9,98 & 9,26 \\
\hline $\mathrm{En} / \mathrm{Di}$ & 4,37 & 2,35 & 4,9 & 4,15 \\
\hline $\mathrm{Fs} / \mathrm{Di}$ & 5,77 & 3,17 & 4,9 & 5,06 \\
\hline $\mathrm{En} / \mathrm{Hy}$ & 7,97 & 8,69 & 11,41 & 11,3 \\
\hline Fs/hy & 10,54 & 11,72 & 11,41 & 13,76 \\
\hline $\mathrm{Fo} / \mathrm{Ol}$ & 1,32 & 0 & 0,36 & 0,6 \\
\hline $\mathrm{Fa} / \mathrm{Ol}$ & 1,93 & 0 & 0,4 & 0,8 \\
\hline $\mathrm{Mt}$ & 2,26 & 0,55 & 1,89 & 1,33 \\
\hline II & 3,66 & 1,55 & 2,05 & 2,48 \\
\hline Ap & 0,66 & 0,35 & 0,26 & 0,28 \\
\hline FeOt & 13,87 & 9,22 & 11,7 & 13,02 \\
\hline$m g \#(0.15)$ & 0,455 & 0,493 & 0,539 & 0,504 \\
\hline \multicolumn{5}{|c|}{ ELEMENTOS TRACOS } \\
\hline $\mathrm{Nd}$ & 20 & 24 & 13 & 13 \\
\hline $\mathrm{Nb}$ & 13 & 8 & 8 & 10 \\
\hline $\mathrm{Cr}$ & 183 & 200 & 229 & 248 \\
\hline $\mathrm{Ni}$ & 78 & 115 & 88 & 83 \\
\hline $\mathrm{Ba}$ & 58 & 281 & 51 & 60 \\
\hline $\mathrm{Rb}$ & 9 & 38 & 9 & 11 \\
\hline $\mathrm{Sr}$ & 113 & 220 & 113 & 109 \\
\hline $\mathrm{La}$ & 17 & 21 & 7 & 9 \\
\hline $\mathrm{Ce}$ & 40 & 43 & 20 & 22 \\
\hline $\mathrm{Zr}$ & 170 & 120 & 82 & 98 \\
\hline$Y$ & 49 & 21 & 30 & 33 \\
\hline Petrografia & $\mathrm{DB}_{2}$ & $\mathrm{DB}_{1}$ & $\mathrm{DB}_{2}$ & $\mathrm{DB}_{2}$ \\
\hline Suite & básica & bás. norítica & básica & básica \\
\hline \multicolumn{5}{|l|}{ Direção } \\
\hline Espessura(m) & & & & \\
\hline
\end{tabular}

$\left(^{*}\right)=$ Amostras cedidas pelo Prof. Quéméneur. OBS: DBN, DB, DB 2, DMB e DA, conforme capitulo da Petrografia. Elementos maiores e menores (\% em peso) normalizados a $100 \%$ sem a perda ao fogo (P.F.). Elementos traços em ppm. (bás. noritica = búsica norítica). 


\section{APÊNDICE 2 - Análises químicas das fases minerais}

\begin{tabular}{|c|c|c|c|c|c|c|c|c|c|c|c|c|}
\hline AMOSTRA & \multicolumn{2}{|c|}{$\mathrm{DB}_{2}+19$} & \multicolumn{4}{|c|}{$D 3_{2}-34$} & \multicolumn{3}{|c|}{$\mathrm{DI}_{3}-45$} & \multicolumn{2}{|c|}{$\mathrm{DB}_{2}+60$} & $\mathrm{DDB}_{2}+100$ \\
\hline & $P$ & ' & 1 & 1 & $P$ & II & $P$ & $\mathrm{I}$ & Tpig & p & $\mathrm{T}$ & $\mathrm{p}$ \\
\hline $\mathrm{SiO}_{3}$ & 50,28 & 51,03 & 52,40 & 48,66 & 48.46 & 47.78 & 52,33 & 51.65 & 51.96 & 53,11 & 49,58 & $\$ 2,01$ \\
\hline $\mathrm{TjO}_{2}$ & 0,74 & 0,53 & 0.02 & 0,85 & 0,61 & 0.61 & 0,31 & 0.54 & 0,34 & 0,26 & 0,53 & 0.20 \\
\hline $\mathrm{Al}_{2} \mathrm{O}_{3}$ & 2,89 & 2,58 & 0,20 & 6,15 & 5.84 & 6.17 & 1.77 & 2,68 & 1.20 & 1,95 & 5,66 & 1.27 \\
\hline $\mathrm{FeO}_{4}$ & $1,3,83$ & 14,31 & 13.76 & 22,07 & 23.68 & 25,044 & 10,48 & 11,67 & 22,24 & 10,40 & 19.46 & 10,54 \\
\hline $\mathrm{MnO}$ & 0.34 & 0.36 & 0,36 & 0,27 & 0.30 & 0,39 & 0,22 & 0,22 & 0.57 & 0.21 & 0,27 & 0,21 \\
\hline $\mathrm{MgO}$ & 14,01 & 13,87 & 10.57 & 9.63 & 9,31 & 9.15 & 16.74 & 15,51 & 19,02 & 14,74 & 10,81 & 12,71 \\
\hline $\mathrm{CaO}$ & 17,51 & 16.85 & 22,48 & 11,13 & 10.73 & 9,70 & 17,65 & 17,32 & 4,57 & 18,96 & 12,77 & 22,93 \\
\hline $\mathrm{Na}_{2} \mathrm{O}$ & 0,35 & 0.27 & 0,22 & 1,20 & 1.06 & 1.13 & 0,21 & 0.28 & 0,02 & 0,31 & 0,91 & 0,11 \\
\hline $\mathrm{Cr}_{2} \mathrm{O}_{3}$ & $0,0.5$ & 0,20 & & 0,04 & & 0,03 & 0,29 & 0,14 & 0,08 & 0,06 & & 0,03 \\
\hline SOMA & 100,00 & 100,00 & 100,00 & 100,00 & 100.00 & 100,00 & 10000 & 100,00 & 100,00 & 100,00 & 100,00 & 100,00 \\
\hline $\mathrm{Fe}_{3} \mathrm{O}_{3}{ }^{*}$ & 2.65 & 0,83 & 0,21 & 0.43 & 0.85 & 1,91 & 1.4 & 0,82 & 0,24 & & & 1,01 \\
\hline & & & & & & & & & & & & \\
\hline $\mathrm{Si}$ & 1,889 & 1,923 & 2,001 & 1,874 & 1.876 & 1.855 & 1,936 & 1.922 & 1,960 & 1,972 & 1,893 & 1,955 \\
\hline $\mathrm{Al}^{\mathrm{W}}$ & 0,111 & 0,077 & & 0,126 & 0,124 & 0.145 & 0,064 & 0,078 & 0,040 & 0,028 & 0.107 & 0,045 \\
\hline SOMA & 2,000 & 2,000 & 2,001 & 2,000 & 2,000 & 2,000 & 2,000 & 2,000 & 2,000 & 2,000 & 2,000 & 2,000 \\
\hline $\mathrm{Al}^{\mathrm{VI}}$ & 0,017 & 0,038 & 0,009 & 0,153 & 0.143 & 0.137 & 0,013 & $0,0,40$ & 0,013 & 0,057 & 0,148 & 0,011 \\
\hline $\mathrm{Fe}^{2+2}$ & 0,360 & 0,427 & 0,433 & 0,698 & 0,742 & 0.757 & 0,285 & 0,340 & 0,695 & 0,323 & 0,021 & 0,303 \\
\hline $\mathrm{Fe}^{3+}$ & 0,075 & 0,024 & 0,006 & 0,012 & 0.025 & 0,056 & 0,039 & 0.023 & 0,007 & & & 0,029 \\
\hline $\mathrm{Cr}$ & 0,001 & 0,006 & & 0.001 & & 0,001 & 0.008 & 0,004 & 0,002 & 0,002 & & 0,001 \\
\hline $\mathrm{Mg}$ & 0,784 & 0,779 & 0,601 & 0,553 & 0.537 & 0,529 & 0,923 & 0,860 & 1,069 & 0,816 & 0,615 & 0,712 \\
\hline $\mathrm{Mn}$ & 0,011 & 0,012 & 0,012 & 0,009 & 0,010 & 0,013 & 0,007 & 0,007 & 0,018 & 0,007 & 0,009 & 0,007 \\
\hline $\mathrm{Ti}$ & 0,021 & 0,015 & 0,001 & 0,025 & 0,018 & 0,018 & 0,009 & 0.015 & 0,010 & 0,007 & 0,015 & 0,006 \\
\hline $\mathrm{Ca}$ & 0,705 & 0,680 & 0,920 & 0,459 & 0,445 & 0,403 & 0,700 & 0,691 & 0,185 & 0,754 & 0,523 & 0,924 \\
\hline $\mathrm{Na}$ & 0,025 & 0,020 & 0,016 & 0,090 & 0,080 & 0.085 & 0,015 & 0,020 & 0,001 & 0,023 & 0,067 & 0,008 \\
\hline SOMA & 1,999 & 2,001 & 1,998 & 2,000 & 2,000 & 1,999 & 1,999 & 2,000 & 2,000 & 1,989 & 1,998 & 2,001 \\
\hline $\mathrm{Ca}$ & 36,43 & 35,38 & 46,65 & 26,52 & 25,30 & 22.92 & 35,82 & 35,97 & 9,37 & 39,68 & 29,58 & 46,78 \\
\hline$M g$ & 40,52 & 40,53 & 30,48 & 31,95 & 30,53 & 30,09 & 47,24 & 44,77 & 54,15 & 42,95 & 34,79 & 36,05 \\
\hline $\mathrm{Ir} \mathrm{c}^{*}$ & 23,05 & 24,09 & 22,87 & 41,54 & 44,17 & 46,99 & 16,94 & 19,26 & 36.47 & 17,37 & 35,63 & 17,16 \\
\hline
\end{tabular}

\begin{tabular}{|c|c|c|c|c|c|c|c|c|}
\hline AMOSYRA & \multicolumn{2}{|c|}{$\mathrm{DB}_{2} \cdot 15$} & \multicolumn{2}{|c|}{$\mathrm{DB}_{2}-22$} & \multicolumn{2}{|c|}{$D B_{2}-27$} & \multirow{2}{*}{$\frac{D B_{24}, 37}{T}$} & \multirow{2}{*}{$\frac{D M B-50}{T}$} \\
\hline & $\mathrm{T}$ & Tpig & $T$ & Topx & $T$ & Tpig. & & \\
\hline $\mathrm{SiO}_{2}$ & 48,65 & 52,23 & 52.09 & 49, 22 & 50.76 & 51,14 & 50,96 & $46,1 !$ \\
\hline $\mathrm{TiO}_{2}$ & 2,22 & 0.57 & 0,11 & 0,07 & 0.18 & 0,02 & 0,35 & 0,50 \\
\hline $\mathrm{Al}_{2} \mathrm{O}_{3}$ & 3,83 & 1,55 & 0,49 & 2,12 & 1,92 & 0,46 & 2.57 & 11,19 \\
\hline $\mathrm{YeO}$ & 17,30 & 20,38 & 11,56 & 33.67 & 12.23 & 28,03 & 13,55 & 18.72 \\
\hline $\mathrm{MnO}$ & 0,39 & 0.37 & 0,37 & 0.85 & 0,31 & 0,76 & 0,31 & 0,20 \\
\hline $\mathrm{MgO}$ & 13.37 & 19.98 & 11,44 & 13.80 & 11,89 & $1,3,88$ & 15,30 & 9,50 \\
\hline $\mathrm{CaO}$ & 13,87 & 4.80 & 23,74 & 0,48 & 22,43 & 5,71 & 16,54 & 12,49 \\
\hline $\mathrm{Na}_{2} \mathrm{O}$ & 0.31 & 0,08 & 0.19 & & 0,42 & & 0,15 & 1,25 \\
\hline $\mathrm{Cr}_{2} \mathrm{O}_{3}$ & 0.06 & 0,05 & 0,01 & & 0.06 & & 0,27 & 0,04 \\
\hline SOMA & 100,00 & 100,00 & 100,00 & 100,00 & 100,00 & 100,00 & 100,00 & 100,00 \\
\hline $\mathrm{Fe}_{2} \mathrm{O}_{3}^{*}$ & 0,62 & & 1,03 & 0,51 & 3,57 & & 1,97 & 2,31 \\
\hline & & & & & & & & \\
\hline $\mathrm{Si}$ & 1,852 & 1,953 & 1,975 & 1,941 & 1.916 & 1,992 & 1,907 & 1,748 \\
\hline $\mathrm{Al}^{\mathrm{IV}}$ & 0,148 & 0,047 & 0,022 & 0,059 & 0,084 & 0,008 & 0,093 & 0,252 \\
\hline SOMA & 2,000 & 2,000 & 1,997 & 2,000 & 2,000 & 2,000 & 2,000 & 2,000 \\
\hline $\mathrm{Al}^{\mathrm{V}}$ & 0,024 & 0,021 & & 0,040 & 0,001 & 0,014 & 0,021 & 0,248 \\
\hline $\mathrm{Jec}^{2-1}$ & 0.533 & 0,637 & 0,337 & 1,096 & 0,285 & 0,913 & 0,369 & 0,528 \\
\hline $\mathrm{Fe}^{3+}$ & 0,018 & & 0,029 & 0.015 & 0,101 & & 0,056 & 0.066 \\
\hline $\mathrm{Cr}^{3+}$ & 0,002 & 0,001 & & & 0,002 & & 0,008 & 0,001 \\
\hline $\mathrm{Mg}$ & 0,758 & 1,112 & 0,649 & 0,799 & 0,658 & 0.806 & 0,854 & 0.537 \\
\hline $\mathrm{Mn}$ & 0,013 & 0,012 & 0,012 & 0,028 & 0,010 & 0,025 & 0,010 & 0,006 \\
\hline $\mathrm{Ti}$ & 0,064 & 0,016 & 0.003 & 0,002 & 0,005 & 0,001 & 0,010 & 0,014 \\
\hline $\mathrm{Ca}$ & 0,566 & 0,193 & 0,965 & 0,020 & 0,907 & 0,238 & 0,663 & 0,507 \\
\hline $\mathrm{Na}$ & 0,023 & 0.006 & 0,014 & & $0,0,31$ & & 0,011 & 0,092 \\
\hline SOMA & 2,000 & 1,999 & 2,006 & 2,000 & 2,000 & 1,996 & 2,000 & 1.999 \\
\hline $\mathrm{Ca}$ & 29,08 & 9,88 & 48,44 & 1,02 & 46,25 & 12,01 & 33,97 & 3084 \\
\hline $\mathrm{Mg}$ & 40,15 & 56,01 & 32.58 & 4081 & 33,66 & 40.67 & 43,75 & 32,66 \\
\hline $\mathrm{Fo*}$ & 29.87 & $3,3,21$ & 18.98 & 58.17 & 20,19 & $47,3,3$ & 22.28 & 36,50 \\
\hline
\end{tabular}

Tabela V.1 - Microanálises químicas dos piroxênios ricos e pobres em cálcio presentes nos diques básicos (DB) 1 e 2, metabásicos (DMB) e básicos noríticos (DBN). P = estágio de cristalização precoce; $\mathrm{T}=$ estágio de cristalização tardia; pig $=$ pigeonita, opx $=$ ortopiroxênio. $\mathrm{Fe}_{2} \mathrm{O}_{3}$ * calculado segundo Papike et al, 1974. $\mathrm{Fe}^{*}=\mathrm{Fe}^{+2}+\mathrm{Fe}^{+3}+\mathrm{Mn}$. 


\begin{tabular}{|c|c|c|c|c|c|c|c|c|c|c|c|}
\hline AMOSTRA & \multicolumn{5}{|c|}{$\mathrm{Dl} 3 \mathrm{~N}_{-28}$} & \multicolumn{3}{|c|}{$\mathrm{DB}_{3},-35$} & \multicolumn{3}{|c|}{ DBN-54 } \\
\hline & P & $T$ & Popx & Topx 1 & $\mathrm{Iopx}_{2}$ & $\mathrm{~T}$ & Pp!g & This & $\mathrm{T}$ & $\operatorname{Pon} x$ & Topx \\
\hline $\mathrm{SiO}_{2}$ & 52,17 & 52,01 & 54.57 & 52,29 & 53,93 & 49,56 & 50,75 & 50,13 & 51,62 & 56.21 & 54.46 \\
\hline $\mathrm{TiO}_{2}$ & 0,24 & 0,25 & 0.04 & 0,12 & 0,13 & 0.68 & 0.25 & 0,23 & 0.33 & 0.04 & 0.09 \\
\hline $\mathrm{Al}_{2} \mathrm{O} \mathrm{I}_{3}$ & 2,18 & 2,68 & 2.59 & 2,17 & 1,63 & 2.87 & 1,52 & 1,59 & 3,11 & 1,06 & 1,32 \\
\hline $\mathrm{FeO}_{1}$ & 10,28 & 11,43 & 13,05 & 20,49 & 17,39 & 18.88 & 26,36 & 27,40 & 11,42 & 10,09 & 13,92 \\
\hline $\mathrm{MnO}$ & 0,19 & 0.18 & 0.18 & 0,42 & 0,51 & 0.35 & 0.56 & 0.70 & 0.26 & 0.23 & 0.23 \\
\hline $\mathrm{MgO}$ & 15,26 & 16,59 & 28.25 & 21,96 & $23,7,3$ & 12,01 & 15,74 & 14,44 & 17,20 & 30.29 & 26,98 \\
\hline $\mathrm{CaO}$ & 19,24 & 16,41 & 0,61 & 1.61 & 2,52 & 15.39 & 4.79 & 5.43 & 15,66 & 1.67 & 2.53 \\
\hline $\mathrm{Na}_{2} \mathrm{O}$ & 0.22 & 0,22 & 0.01 & 0.04 & 0,01 & 0.26 & 0,03 & 0,06 & 0,15 & & 0,03 \\
\hline $\mathrm{Cr}_{2} \mathrm{O}_{3}$ & 0,22 & 0,24 & 0.70 & 0.90 & 0,14 & & & 0,02 & 0.26 & 0,41 & 0,44 \\
\hline SOMA & 100,00 & 100,00 & 100,00 & 100,00 & 100,00 & 100,00 & 100,00 & 100,00 & 100,00 & 100,00 & 100,00 \\
\hline $\mathrm{Fe}_{2} \mathrm{O}_{3}{ }^{*}$ & 0,83 & 0,87 & & & & 1,89 & 0,39 & 1,03 & 1,19 & & 045 \\
\hline & & & & & & & & & & & \\
\hline $\mathrm{Si}$ & 1,939 & 1,927 & 1.944 & 1,941 & 1,971 & 1,898 & 1,954 & 1,944 & 1,908 & 1.979 & 1,958 \\
\hline $\mathrm{Al}^{\mathrm{IV}}$ & 0,061 & 0,073 & 0.056 & 0,059 & 0,029 & 0,102 & 0,046 & 0.056 & 0,092 & 0,021 & 0,042 \\
\hline SOMA & 2,000 & 2,000 & 2,000 & 2,000 & 2,000 & 2,000 & 2,000 & 2,000 & 2,000 & 2,000 & 2,000 \\
\hline$A)^{V}$ & 0,034 & 0,044 & 0.053 & 0,036 & 0,041 & 0,028 & 0,023 & 0.017 & 0,044 & 0,023 & 0,014 \\
\hline $\mathrm{Fe}^{24}$ & 0,296 & 0,330 & 0.389 & 0,636 & 0,532 & 0,551 & 0,838 & 0.858 & 0,320 & 0,297 & 0,406 \\
\hline $\mathrm{Fe}^{3+}$ & 0,023 & 0,024 & & & & 0,054 & 0,011 & 0,030 & 0,033 & & 0,012 \\
\hline $\mathrm{Cl}^{3+1}$ & 0,006 & 0,007 & 0.020 & 0,026 & 0,004 & & & 0,001 & 0,008 & 0,011 & 0,013 \\
\hline $\mathrm{Mg}$ & 0.845 & 0,916 & 1,499 & 1,215 & 1,293 & 0,686 & 0,903 & 0,835 & 0,948 & 1,589 & 1,446 \\
\hline $\mathrm{Mn}$ & 0,006 & 0,006 & 0,005 & 0,013 & 0,016 & 0,011 & 0,018 & 0,023 & 0,008 & 0,007 & 0,007 \\
\hline $\mathrm{Ti}$ & 0,007 & 0,007 & 0,001 & 0,003 & 0,004 & 0,020 & 0,007 & 0,007 & 0,009 & 0,001 & 0,002 \\
\hline $\mathrm{Ca}$ & 0,766 & 0.651 & 0,023 & 0,064 & 0,099 & 0,632 & 0,197 & 0,226 & 0,620 & 0,063 & 0.097 \\
\hline $\mathrm{Na}$ & 0,016 & 0,016 & 0,001 & 0,003 & 0,001 & 0,019 & 0,002 & 0,004 & 0,011 & & 0,002 \\
\hline SOMA & 2,000 & 2,000 & 1.991 & 1,996 & 1,989 & 2.000 & 2,000 & 2,000 & 2,000 & 1,992 & 2,000 \\
\hline $\mathrm{Ca}$ & 3067 & $22 \gamma_{8}$ & 720 & & & & & & & & \\
\hline & 39,97 & 33.78 & 1,20 & 3,32 & 5,10 & 32,68 & 10,02 & 11,46 & .32 .14 & 3,22 & 4,93 \\
\hline $\mathrm{Mg}$ & 43,65 & 47,54 & 78,24 & 63,02 & 66,65 & 35,47 & 45,91 & 42,34 & 49,14 & 81,24 & 73,48 \\
\hline$\sqrt{e^{* *}}$ & 16,79 & 18,68 & 20,56 & 33,66 & 28,25 & 31,85 & 44,08 & 46,20 & 18,71 & 15,54 & 21,60 \\
\hline
\end{tabular}

\begin{tabular}{|c|c|c|c|c|c|c|c|c|c|c|c|c|c|}
\hline AMOSTR $\Lambda$ & \multicolumn{4}{|c|}{ DBN-25 } & \multicolumn{5}{|c|}{ DBN-55 } & \multicolumn{4}{|c|}{$\mathrm{DBN}-64$} \\
\hline & Popx & Topx & P & $T$ & $\mathrm{P}$ & $\mathrm{T}$ & Popx & Iopx & Tpig & $\mathrm{P}$ & 1 & Popx & Topx \\
\hline $\mathrm{SiO}_{2}$ & 55,43 & 55,00 & 52,48 & 52,13 & 52,32 & 51,54 & 55,61 & 54,67 & 53,60 & 52,32 & 49,71 & 54,94 & 54,39 \\
\hline $\mathrm{TiO}_{2}$ & 0,15 & 0,04 & 0.17 & 0,22 & 0,18 & 0.17 & 0.09 & 0,15 & 0,12 & 0,54 & 0.44 & 0,11 & 0.10 \\
\hline $\mathrm{Al}_{2} \mathrm{O}_{3}$ & 1,44 & 0,95 & 2.69 & 2,14 & 3,28 & 1,95 & 1,56 & 1,91 & 1,20 & 3,19 & 3,42 & 2,12 & 1,44 \\
\hline $\mathrm{FeO}_{1}$ & 10,59 & 34.26 & 7.48 & 11,28 & 9.84 & 21,02 & 9,05 & 11.65 & 16.42 & 9,87 & 14,38 & 9,42 & 15,13 \\
\hline $\mathrm{MnO}$ & 0,16 & 0.24 & 0.16 & 0,22 & 0.24 & 0,53 & 0,14 & 0,21 & 0,35 & 0,16 & 0,08 & $0,2.1$ & 0,23 \\
\hline $\mathrm{MgO}$ & 29,71 & 27,13 & 17,23 & 16,46 & 20,07 & 13,99 & $3 \mathrm{I}, 02$ & 29,01 & 20,99 & 15,42 & 17,09 & 30,21 & 26,26 \\
\hline $\mathrm{CaO}$ & 1,98 & 2,12 & 19,32 & 17,29 & 13,61 & 10,68 & 1,77 & 1,66 & 7,36 & 18,12 & $1,3,42$ & 2,22 & 1,88 \\
\hline $\mathrm{Na}_{2} \mathrm{O}$ & 0,03 & 0,01 & 0,17 & 0.20 & 0,14 & 0.12 & 0,02 & & 0,06 & 0,30 & 0,26 & 0,04 & \\
\hline $\mathrm{Cr}_{2} \mathrm{O}_{3}$ & 0,50 & 0,26 & 0.31 & 0,07 & 0,33 & & 0,75 & 0,74 & & 0,08 & 1,20 & 0,74 & 0,57 \\
\hline SOMA & 100,00 & 100,00 & 100.00 & 100,00 & 100.00 & 100.00 & 100,00 & 100.00 & 100,00 & 100,00 & 100,00 & 100,00 & 100,00 \\
\hline $\mathrm{Fe}_{2} \mathrm{O}_{3}{ }^{*}$ & & & 1,09 & 1,54 & 1,34 & & 0,26 & 0.21 & & & 3,88 & 0,77 & \\
\hline & & & & & & & & & & & & & \\
\hline $\mathrm{Si}$ & 1,960 & 1,977 & 1.924 & 1,932 & 1.906 & 1,967 & 1,952 & 1,943 & 1,975 & 1,935 & 1,850 & 1,934 & 1,964 \\
\hline$A l^{\mathrm{T}}$ & 0,040 & 0,023 & 0,076 & 0,068 & 0,094 & 0,033 & 0,048 & 0,057 & 0,025 & 0,065 & 0,150 & 0,066 & 0,036 \\
\hline SOMA & 2,000 & 2,000 & 2,000 & 2,000 & 2,000 & 2,000 & 2,000 & 2,000 & 2,000 & 2,000 & 2,000 & 2,000 & 2,000 \\
\hline $\mathrm{Al}^{\mathrm{VI}}$ & 0,020 & 0,017 & 0.040 & 0,025 & 0,047 & 0,055 & 0,016 & 0,023 & 0.027 & 0,074 & 0,000 & 0,022 & 0.025 \\
\hline$F e^{21}$ & 0,313 & 0,429 & 0.199 & 0,306 & 0.26 .3 & 0.671 & 0,259 & 0,341 & 0,507 & 0.305 & 0,339 & 0,257 & 0,457 \\
\hline $\mathrm{Fe}^{3+}$ & & & 0,030 & 0,043 & 0,037 & & 0,007 & 0,005 & & & 0,109 & 0,020 & \\
\hline $\mathrm{Cr}$ & 0,014 & 0,007 & 0.009 & 0,002 & 0,009 & & 0,021 & 0,021 & & 0,002 & 0,035 & 0.021 & 0,016 \\
\hline $\mathrm{Mg}$ & 1,566 & 1,453 & 0,941 & 0,909 & 1,090 & 0.796 & 1,623 & 1,536 & 1,154 & 0,850 & 0,948 & 1,585 & 1,413 \\
\hline Mn & 0,005 & 0,007 & 0.005 & 0,007 & 0,007 & 0,017 & 0,004 & 0,006 & 0.011 & 0,005 & 0,003 & 0,006 & 0,007 \\
\hline Ij & 0,004 & 0,001 & 0,005 & 0,006 & 0,005 & 0,005 & 0,002 & 0,004 & 0,003 & 0,015 & 0,012 & 0,003 & 0.003 \\
\hline $\mathrm{Ca}$ & 0,075 & 0,082 & 0,759 & 0,687 & 0,531 & 0,437 & 0,066 & 0,063 & 0,291 & 0,718 & 0,535 & 0,084 & 0,073 \\
\hline $\mathrm{Na}$ & 0,002 & 0,001 & 0.012 & 0,014 & 0.010 & 0.009 & 0,001 & & 0,004 & 0,022 & 0,019 & 0,003 & \\
\hline SOMA & 1,999 & 1,997 & 2,000 & 1,999 & 1.999 & 1,990 & 1,999 & 1,999 & 1,997 & 1,991 & 2,000 & 2,001 & 1,994 \\
\hline $\mathrm{Ca}$ & 3,83 & 4,16 & 39,25 & 35,19 & 27,54 & 22.75 & 3,37 & 3,23 & 14,82 & 38,23 & 27,66 & 4,30 & 3,74 \\
\hline$\overline{\mathrm{Mg}}$ & 79,94 & 73.72 & 48.66 & 46,57 & $\$ 6,54$ & 41.44 & 82,85 & 78.73 & 58,79 & 45,26 & 49.02 & 81,20 & 72.46 \\
\hline lie* & 16,23 & 22,12 & 12.10 & 18,24 & 15.92 & 35.81 & 13,78 & 18,04 & 26,39 & 16,51 & 23,32 & 14,50 & 23,79 \\
\hline
\end{tabular}

Tabela V.1 - Continuação. 


\begin{tabular}{|c|c|c|c|c|c|c|c|c|c|c|c|c|}
\hline AMOSTRA & \multicolumn{4}{|c|}{$\mathrm{DB}_{1}-112$} & \multicolumn{4}{|c|}{ DBN- 1212} & \multicolumn{4}{|c|}{$\mathrm{DB}_{1}, 70$} \\
\hline & P & $\mathrm{T}$ & Ppig & Tpig & $P$ & $\mathrm{~T}$ & Popx & Topx & $P$ & $T$ & Ppig & $T$ \\
\hline $\mathrm{SiO}_{2}$ & 52,97 & 49,93 & 54,11 & 52,94 & 52,05 & 51.97 & 55,73 & 54,62 & $\$ 2,32$ & 50,03 & 52.72 & 49,51 \\
\hline $\mathrm{TiO}_{2}$ & 0,22 & 0,84 & 0,16 & 0.26 & 0.26 & 0.31 & 0.09 & 0.12 & 0,29 & 0,74 & 0,27 & 0.64 \\
\hline $\mathrm{Al}_{2} \mathrm{O}_{3}$ & 2,10 & 1,77 & 1,17 & 1,25 & 3,56 & 3.35 & 1,95 & 2,45 & 1,89 & 1,51 & 1,06 & 1,34 \\
\hline $\mathrm{FeO}$ & 10,71 & 21,82 & 16,32 & 18.50 & 7,63 & 8.50 & 8,00 & 12,03 & 11,37 & 23,73 & 20,34 & 28,48 \\
\hline $\mathrm{MnO}$ & 0,26 & 0,43 & 0,45 & 0,41 & 0,19 & 0,25 & 0,16 & 0,21 & 0,24 & 0,35 & 0,30 & 0,43 \\
\hline MgO & 17,65 & 10.18 & 22,63 & 19.14 & 18.20 & 17.60 & 31.55 & 28.09 & 16,69 & 10.60 & 18,80 & 10,96 \\
\hline $\mathrm{CaO}$ & 15,73 & 14,85 & 4,99 & 7,31 & 17.58 & 17.52 & 1,45 & 2,29 & 16,73 & 12,92 & 6.41 & 8.48 \\
\hline $\mathrm{Na}_{2} \mathrm{O}$ & 0,15 & 0,17 & 0,07 & 0,06 & 0,18 & 0,24 & 0,07 & & 0,24 & 0.13 & 0,10 & 0,16 \\
\hline $\mathrm{Cr}_{2} \mathrm{O}_{3}$ & 0,20 & 0,01 & 0.11 & 0.13 & 0,36 & 0.28 & 1,00 & 0,20 & 0,23 & & & \\
\hline SOMA & 100,00 & 100,00 & 100,00 & 100,00 & 100,00 & 100,00 & 100,00 & 100,00 & 100,00 & 100,00 & 100,00 & 100,00 \\
\hline $\mathrm{Ie}_{2} \mathrm{O}_{3}{ }^{*}$ & & & & & 1,26 & 1.37 & & & 1,19 & & & 0.31 \\
\hline & & & & & & & & & & & & \\
\hline $\mathrm{Si}$ & 1,953 & 1,944 & 1,982 & 1,974 & 1,900 & 1,905 & 1,947 & 1,945 & 1,939 & 1,952 & 1,977 & 1,951 \\
\hline $\mathrm{Al}^{\mathrm{N}}$ & 0,047 & 0,056 & 0,018 & 0,026 & 0,100 & 0,095 & 0,053 & 0.055 & 0,061 & 0,048 & 0,023 & 0.049 \\
\hline SOMA & 2,000 & 2.000 & 2,000 & 2,000 & 2,000 & 2,000 & 2,000 & 2,000 & 2,000 & 2,000 & 2,000 & 2,000 \\
\hline $\mathrm{Al}^{\mathrm{m}}$ & 0,044 & 0,025 & 0,033 & 0,029 & 0.053 & 0,050 & 0,027 & 0,048 & 0,021 & 0,0122 & 0,024 & 0,013 \\
\hline $\mathrm{Fe}^{+2}$ & 0,330 & 0,710 & 0.500 & 0,577 & 0,198 & 0,223 & 0,234 & 0,358 & 0,319 & 0.774 & 0,638 & 0,929 \\
\hline $\mathrm{Fe}^{3+}$ & & & & & 0,035 & 0,038 & & & 0,033 & & & 0,009 \\
\hline $\mathrm{Cr}$ & 0,006 & & 0,003 & 0,004 & 0,010 & 0,008 & 0,028 & 0,006 & 0,007 & & & \\
\hline $\mathrm{Mg}$ & 0,970 & 0,591 & 1,235 & 1,064 & 0,990 & 0,962 & 1,643 & 1,490 & 0,922 & 0,616 & 1,051 & 0,644 \\
\hline $\mathrm{Mn}$ & 0,008 & 0,014 & 0,014 & 0,013 & 0,006 & 0,008 & 0,005 & 0,006 & 0,007 & 0,012 & 0,009 & 0,014 \\
\hline $\mathrm{Ti}$ & 0,006 & 0,025 & 0,004 & 0,007 & 0,007 & 0,008 & 0,002 & 0,003 & 0,008 & 0.022 & 0,008 & 0,019 \\
\hline $\mathrm{Ca}$ & 0,621 & 0,619 & 0,196 & 0.292 & 0,688 & 0,688 & 0,054 & 0,087 & 0,664 & 0,540 & 0,257 & 0,358 \\
\hline $\mathrm{Na}$ & 0,011 & $0 ; 013$ & 0,005 & 0,004 & 0,013 & 0,017 & 0,004 & & 0,017 & 0,010 & 0,007 & 0,012 \\
\hline SOMA & 1,996 & 1,997 & 1,990 & 1,990 & 2,000 & 2,002 & 1,997 & 1,998 & 1,998 & 1,996 & 1,994 & 1,998 \\
\hline $\mathrm{Ca}$ & 32,19 & $32,0 \mathrm{l}$ & 10,08 & 15,01 & 35,89 & 35,85 & 2,79 & 4,48 & 34,14 & 27,81 & 13,15 & 18,32 \\
\hline $\mathrm{Mg}$ & 50,29 & 30,56 & 63,50 & 54,68 & 51,64 & 50,13 & 84,87 & 76,76 & 47,40 & 31,72 & 53,76 & 32,96 \\
\hline $\mathrm{Fe}^{*}$ & 17,52 & 37,44 & 26,43 & 30,32 & 12,47 & 14,02 & 12,35 & 18,75 & 18,46 & 40,47 & 33,09 & 48,72 \\
\hline
\end{tabular}

Tabela V.1 - Continuação.

\begin{tabular}{|c|c|c|c|c|c|c|c|c|c|c|}
\hline AMOSTRA & \multicolumn{2}{|c|}{$\mathrm{DB}_{2}-19$} & \multicolumn{2}{|c|}{$\mathrm{DB}_{2}-34$} & \multicolumn{2}{|c|}{$\mathrm{DH}_{2}-4 \mathrm{~S}$} & \multicolumn{2}{|c|}{$\mathrm{DB}_{2}-60$} & \multicolumn{2}{|c|}{$\mathrm{DB}_{2}-100$} \\
\hline & $\mathrm{P}$ & $T$ & $\mathrm{P}$ & $\mathrm{T}$ & P & $\mathrm{T}$ & $\mathrm{B}$ & 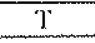 & $\mathrm{P}$ & $T$ \\
\hline $\mathrm{SiO}_{2}$ & 52,03 & 56,97 & 55,69 & 58.17 & 52,61 & 55,85 & 48,52 & 53,91 & 50,72 & 52,96 \\
\hline $\mathrm{TiO}_{2}$ & 0,04 & 0,03 & 0,05 & 0,09 & 0,02 & 0,03 & 0,13 & 0,05 & 0,07 & \\
\hline $\mathrm{Al}_{2} \mathrm{O}_{3}$ & 30,40 & 27,17 & 28,04 & 25,90 & 30,14 & 27,83 & 30,62 & 29,00 & 31,38 & 29.99 \\
\hline $\mathrm{FeO}$ & 0,37 & 0,23 & 0,21 & 0,86 & 0,20 & 0,37 & 3,47 & 0,58 & 0,21 & 0,09 \\
\hline $\mathrm{CaO}$ & 12,94 & 9,12 & 10,14 & 7.80 & 12,59 & 9,92 & 13,94 & 11,34 & 14,05 & 12.39 \\
\hline $\mathrm{Na}_{2} \mathrm{O}$ & 4,13 & 6,39 & 5,80 & 7,06 & 4,38 & 5,85 & 3,01 & 5,04 & 3,52 & 4,50 \\
\hline $\mathrm{K}_{2} \mathrm{O}$ & 0,09 & 0,09 & 0,07 & 0,12 & 0,06 & 0,15 & 0,31 & 0,08 & 0,05 & 0,07 \\
\hline SOMA & 100,00 & 100,00 & 100,00 & 100,00 & 100,00 & 100,00 & 100,00 & 100.00 & 100,00 & 100,00 \\
\hline Or \%peso & 0,52 & 0,53 & 0,41 & 0,69 & 0,34 & 0,89 & 1,89 & 0,47 & 0,30 & 0,42 \\
\hline$\% \mathrm{~m}$ & 0,51 & 0,51 & 0.39 & 0,67 & 0,34 & 0,87 & 1,86 & 0,46 & 0,29 & 0,41 \\
\hline $\mathrm{Ab} \%$ peso & 35,03 & 54,14 & 49,18 & 60,28 & 37,09 & 49,70 & 26,37 & 42,91 & 29.81 & 38,10 \\
\hline$\% \mathrm{~m}$ & 36,38 & 55,60 & 50,66 & 61,68 & 38.49 & 51,17 & 27,53 & 44,37 & 31,07 & 39,50 \\
\hline An \%peso & 64,45 & $\mathbf{4 5 , 3 4}$ & 50,42 & 39,04 & 62,56 & 49,42 & 71,74 & 56,62 & 69.89 & 61,49 \\
\hline$\% \mathrm{~m}$ & 63,10 & 43,89 & 48,95 & 37,65 & 61.18 & 47,96 & 70,61 & 55,18 & 68,64 & 60,09 \\
\hline
\end{tabular}

Tabela V.2 - Microanálise química dos feldspatos presentes nos diques básicos 1 e $2\left(\mathrm{DB}_{1}\right.$ e $\left.\mathrm{DB}_{2}\right)$, metabásicos (DMB) e noríticos (DBN) pertencentes a região de Lavias (MG). $P$ = estágio de cristalização precoce; $\mathrm{T}$ = estágio de cristalização tardia. 


\begin{tabular}{|c|c|c|c|c|c|c|c|c|}
\hline AMOSTRA & \multicolumn{2}{|c|}{$\mathrm{DB}_{2}-37$} & $\mathrm{DB}_{2}-15$ & \multicolumn{2}{|c|}{$\mathrm{DDB}_{2}-22$} & $D B_{2}-27$ & \multicolumn{2}{|c|}{ DMB-50 } \\
\hline & $\mathrm{p}$ & $T$ & $\mathrm{~T}$ & $\mathrm{P}$ & $\mathrm{T}$ & $T$ & $\mathrm{p}$ & $\mathrm{T}$ \\
\hline $\mathrm{SiO}_{2}$ & 51,54 & 56,13 & 59,27 & 51.55 & 52,90 & 56,58 & 50.28 & 58,72 \\
\hline $\mathrm{TiO}_{2}$ & 0,06 & 0,06 & 0,16 & 0.02 & 0,04 & 0,03 & 0,04 & 0,01 \\
\hline $\mathrm{Al}_{2} \mathrm{O}_{3}$ & 30,30 & 27.85 & 23,33 & 30,78 & 30.02 & 27,52 & 31,77 & 26,04 \\
\hline $\mathrm{FeO}_{1}$ & 1,00 & 0.05 & 3,44 & 0,30 & 0,10 & 0,11 & 0,10 & 0,19 \\
\hline $\mathrm{CaO}$ & 12,97 & 9,8 & 5,42 & 13.37 & 12,43 & 9,51 & 14.48 & 7,78 \\
\hline $\mathrm{Na}_{2} \mathrm{O}$ & 4,01 & 5.99 & 7,86 & 3,86 & 4.51 & 6.18 & 3,30 & 7,19 \\
\hline $\mathrm{K}_{2} \mathrm{O}$ & 0.12 & 0.04 & 0,52 & 0.13 & 0.02 & 0,08 & 0,03 & 0,07 \\
\hline SOMA & 100,00 & 100.00 & 100.00 & 100,00 & 100.00 & 100,00 & $100,(30$ & 100,00 \\
\hline Or \%peso & 0,74 & 0,23 & 3,17 & 0,75 & 0,11 & 0,46 & 0,17 & 0,40 \\
\hline$\% \mathrm{ml}$ & 0,72 & 0.22 & 3.04 & 0.74 & 0,11 & 0,45 & 0,17 & 0,39 \\
\hline $\mathrm{Ab} \%$ peso & 34,23 & 50,71 & 68,96 & 32,74 & 38,18 & 5234 & 27,94 & 60,93 \\
\hline$\% \mathrm{~m}$ & 35,58 & 52.19 & 70,22 & 34,05 & 39.59 & 53,81 & 29,14 & 62,32 \\
\hline An \% peso & 65,03 & 49.06 & 27,87 & 66.52 & 61.71 & 47,21 & 71,90 & 38,68 \\
\hline$\% \mathrm{~m}$ & 63,70 & 47,59 & 26,74 & 65,21 & 60.30 & 45,74 & 70,69 & 37,29 \\
\hline
\end{tabular}

\begin{tabular}{|c|c|c|c|c|c|c|c|}
\hline AMOSTRA & \multicolumn{2}{|c|}{$1 \mathrm{DBN}-28$} & \multicolumn{2}{|c|}{$\mathrm{DB}_{1},-35$} & \multicolumn{3}{|c|}{ DBN.54 } \\
\hline & P & $\mathrm{T}$ & $P$ & $\mathrm{r}$ & $\mathrm{p}$ & $\mathrm{T}$ & $\mathrm{T}_{\mathrm{FK}}$ \\
\hline $\mathrm{SiO}_{2}$ & 49.89 & 51,14 & 54,43 & 54,65 & 50,42 & 50,78 & 65,03 \\
\hline $\mathrm{TiO}_{2}$ & 0,03 & 0.07 & 0,05 & 0.07 & 0.03 & 0,04 & \\
\hline $\mathrm{AS}_{2} \mathrm{O}_{3}$ & 31,06 & 31,07 & 28,75 & 28,68 & 31,38 & 31,19 & 18,43 \\
\hline $\mathrm{PeO}_{4}$ & 1,57 & 0,21 & 0,41 & 0,27 & 0,56 & 0,47 & 0,08 \\
\hline $\mathrm{CaO}$ & 13,99 & 13,70 & 11,02 & 10,91 & 14,12 & 13,89 & 0,03 \\
\hline $\mathrm{Na}_{2} \mathrm{O}$ & 3,37 & 3,62 & 5,22 & 5,29 & 3,43 & 3,57 & 1,06 \\
\hline $\mathrm{K}_{2} \mathrm{O}$ & 0,09 & 0.20 & $0,1.3$ & 0,14 & 0,07 & 0,07 & 15,37 \\
\hline SOMA & 100,00 & 100,00 & 100,00 & 100,00 & 100,00 & 100,00 & 100,00 \\
\hline Or \%peso & 0.54 & $\overline{1,16}$ & 0.75 & 0.82 & 0,40 & 0,40 & 9088 \\
\hline$\% \mathrm{~m}$ & 0,54 & 1,13 & 0,73 & 0,80 & 0,39 & 0,39 & 90,38 \\
\hline$A b \%$ peso & 28,95 & 30,71 & 44,34 & 44.90 & 29.14 & 30,37 & 8,98 \\
\hline$\% \mathrm{~m}$ & 30,18 & 31,98 & 45,80 & 46,37 & 30,37 & 31,64 & 9,47 \\
\hline An \%peso & 70,51 & 68,15 & 54,92 & 54,28 & 70,46 & 69,24 & 0,15 \\
\hline$\% \mathrm{~m}$ & 69,28 & 66,89 & 53,47 & 52.83 & 69,23 & 67,97 & 0,15 \\
\hline
\end{tabular}

\begin{tabular}{|c|c|c|c|c|c|c|c|c|c|c|c|c|}
\hline AMOSTRA & \multicolumn{2}{|c|}{ DBN-55 } & \multicolumn{2}{|c|}{$D B N-64$} & \multicolumn{2}{|c|}{$D B_{1}-70$} & \multicolumn{2}{|c|}{$D B_{1}-112$} & \multicolumn{2}{|c|}{$1 \mathrm{DBN}-1212$} & \multicolumn{2}{|c|}{ DBN-25 } \\
\hline & $\mathrm{P}$ & $T$ & $\mathrm{P}$ & $\mathrm{T}$ & $\mathrm{P}$ & $\mathrm{T}$ & P & $T$ & ? & $\mathrm{T}$ & $\mathrm{P}$ & $\mathrm{T}$ \\
\hline $\mathrm{SiO}_{2}$ & 53,37 & 54,14 & 50,61 & 54,48 & 51,36 & 56.31 & 52,32 & 57,55 & 49,51 & 50,39 & 51,05 & 54,87 \\
\hline $\mathrm{TiO}_{2}$ & 0,02 & 0,08 & & 0,02 & 0,02 & 0,08 & 0,41 & 0,05 & 0,03 & $0,0 \mathrm{l}$ & 0,07 & 0,06 \\
\hline $\mathrm{Al}_{2} \mathrm{O}_{3}$ & 29,56 & 28,61 & 31,58 & 28,80 & 30,74 & 27.27 & 29,81 & 26,64 & 31,81 & 31,63 & 29,52 & 28,35 \\
\hline FeO & 0,31 & 0,89 & 0.07 & 0,32 & 0,50 & 0.57 & 0.51 & 0,44 & 0,82 & 0,19 & 2,69 & $0,5.5$ \\
\hline $\mathrm{CaO}$ & 11,93 & 10,97 & 14,25 & 11,05 & 13,38 & 9,36 & 12,38 & 8,54 & 14,69 & 14,34 & 12,44 & 10.58 \\
\hline $\mathrm{Na}_{2} \mathrm{O}$ & 4,76 & 5.20 & 3,38 & 5,26 & 3,73 & 5,90 & 4,21 & 6,71 & 3,06 & 3,29 & 4,13 & 5,45 \\
\hline $\mathrm{K}_{2} \mathrm{O}$ & 0,05 & 0,11 & 0,11 & 0,07 & 0,27 & 0,51 & 0,36 & 0,07 & 0,08 & 0,15 & 0,10 & 0,14 \\
\hline SOMA & 100,00 & 100,00 & 100,00 & 100,00 & 100,00 & 100,00 & 100,00 & 100,00 & 100,00 & 100,00 & 100,00 & 100,00 \\
\hline & & & & & & & & & & & & \\
\hline Or \%peso & 0,29 & 0,65 & 0,64 & 0,42 & 1,58 & 3,03 & 2,12 & 0,40 & 0,46 & 0,90 & 0,60 & 0,83 \\
\hline$\% \mathrm{~m}$ & 0,29 & 0,64 & 0,63 & 0,41 & 1,55 & 2,94 & 2,08 & 0,39 & 0,45 & 0,89 & 0,59 & 0,81 \\
\hline Ab \% peso & 40,35 & 44,44 & 28,63 & 44,61 & 31,73 & 50,24 & 35,89 & 57,04 & 26,06 & 27,85 & 35,95 & 46,35 \\
\hline$\% \mathrm{~m}$ & 41,78 & 45,90 & 29,85 & 46,08 & 33,02 & 51,72 & 37,27 & 58,48 & 27,22 & 29,05 & 37,33 & 47,83 \\
\hline An \% peso & 59,36 & 54,91 & 70,73 & 54,98 & 66.69 & 46.74 & 61,98 & 42,56 & 73,49 & 71,25 & 63,45 & 52,82 \\
\hline$\% m$ & 57,93 & 53,46 & 69.52 & $5,3,52$ & 65,42 & 45,35 & 60.66 & 41,13 & 72,34 & 70,06 & 62,09 & 51,36 \\
\hline
\end{tabular}

Tabela V.2 - Continuação. 


\begin{tabular}{|c|c|c|c|c|c|}
\hline AMOSTRA & $\mathrm{DB}_{2}-45$ & $\mathrm{DB}_{2}=60$ & $1) 13_{2}-100$ & DBN-55 & DBN-1212 \\
\hline $\mathrm{SiO}_{2}$ & 0,24 & 0,11 & 0,03 & 0.24 & 0,02 \\
\hline $\mathrm{TiO}_{2}$ & 0,45 & 0,69 & 0,52 & 0.91 & 0,76 \\
\hline $\mathrm{Al}_{2} \mathrm{O}_{3}$ & 1,11 & 0,09 & 0,11 & 1.43 & 0,24 \\
\hline $\mathrm{FeO}_{1}$ & 90.65 & 92,25 & 92.76 & 90,08 & 91,05 \\
\hline $\mathrm{MnO}$ & 0.01 & 0,01 & 0,06 & 0,01 & \\
\hline $\mathrm{MgO}$ & 1.07 & 0,03 & 0,02 & 0,67 & 0,03 \\
\hline $\mathrm{CaO}$ & 0.07 & 0,02 & 0,11 & 0,16 & \\
\hline $\mathrm{Cr}_{2} \mathrm{O}_{3}$ & & 0,12 & 0,10 & $0,0 !$ & 1,23 \\
\hline SOMA & 93.60 & 93,32 & 93,71 & 93,51 & 93,33 \\
\hline $\mathrm{FeO}^{*}$ & 30,32 & 31,76 & 31,52 & 31,25 & 31,76 \\
\hline $\mathrm{Fe}_{2} \mathrm{O}_{3}$ & 67,03 & 67,19 & 68,04 & 65,36 & 65,87 \\
\hline SOMA & 100,30 & 100,02 & 100,51 & 100,04 & 99,91 \\
\hline
\end{tabular}

\begin{tabular}{|c|c|c|c|c|c|c|}
\hline AMOSTRA & $\mathrm{DB}_{2}-19$ & $\mathrm{DB}_{2}-34$ & $\mathrm{DB}_{2}-60$ & $\mathrm{DB}_{2}-100$ & $\mathrm{DBN}=55$ & $\mathrm{DB}_{1}-112$ \\
\hline $\mathrm{SiO}_{2}$ & 0,01 & 0,04 & 0,16 & 0.02 & 0,03 & 0,02 \\
\hline $\mathrm{TiO}_{2}$ & 52,04 & 52,52 & 48,74 & 51,29 & 51,91 & 52,17 \\
\hline $\mathrm{Al}_{2} \mathrm{O}_{3}$ & 0,02 & & 0.06 & 0,01 & 0,03 & \\
\hline $\mathrm{FeO}_{\mathrm{t}}$ & 46,59 & 45,67 & 48,92 & 47,20 & 45,84 & 46,32 \\
\hline $\mathrm{MnO}$ & $0,7 !$ & 1,45 & 0,97 & 0,63 & 1,33 & 0,79 \\
\hline $\mathrm{MgO}$ & 0.13 & 0,07 & 0,08 & 0,11 & 0,08 & 0,02 \\
\hline $\mathrm{CaO}$ & 0,08 & 0,05 & 0,08 & 0,14 & 0,13 & 0,02 \\
\hline $\mathrm{Cr}_{2} \mathrm{O}_{3}$ & 0,01 & & & & & 0,01 \\
\hline SOMA & 99,59 & 99,80 & 99,01 & 99,40 & 99,15 & 99,35 \\
\hline $\mathrm{FeO}^{*}$ & 45,75 & 45,60 & 42,79 & 45,13 & 45,26 & 46,08 \\
\hline $\mathrm{Fe}_{2} \mathrm{O}_{3}$ & 0,94 & 0,07 & 6,81 & 2,30 & 0,65 & 0,27 \\
\hline SOMA & 99,69 & 99,80 & 99,69 & 99,63 & 99,22 & 99,38 \\
\hline
\end{tabular}

\begin{tabular}{|c|c|c|c|c|c|c|}
\hline AMOSTRA & $\mathrm{DB}_{2}-22$ & $\mathrm{DB}_{2} \cdot 27$ & DIBN-28 & $\mathrm{DB}_{1}, .35$ & $\mathrm{DB}_{2} \cdot 37$ & DBN-54 \\
\hline $\mathrm{SiO}_{2}$ & 0,01 & 0,01 & 0,19 & 0,07 & 0,02 & 0,02 \\
\hline $\mathrm{TiO}_{2}$ & 51,86 & 50,49 & 49,91 & 51,13 & 50,91 & 51,22 \\
\hline $\mathrm{Al}_{2} \mathrm{O}_{3}$ & $\therefore$ & . & - & $\therefore$ & 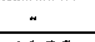 & - \\
\hline $\mathrm{FeO}_{1}$ & 45,31 & 47,01 & 46,56 & 45,40 & 46,25 & 46,73 \\
\hline $\mathrm{MnO}$ & 1.11 & 1.06 & 1,75 & 1,88 & 1,42 & 0,64 \\
\hline $\mathrm{MgO}$ & 0.20 & 0,11 & 0,14 & 0,06 & 0,01 & 0,25 \\
\hline $\mathrm{CaO}$ & 0.01 & 0,07 & 0,10 & 0,13 & 0,23 & 0,01 \\
\hline $\mathrm{Cr}_{2} \mathrm{O}_{3}$ & $\sim$ & ت & - & 0.02 & $=$ & 0,02 \\
\hline SOMA & 98,50 & 98,75 & 98,65 & 98,69 & 98.84 & 98.89 \\
\hline $\mathrm{FeO}^{*}$ & 45,16 & 44,05 & 42,95 & 43,89 & 44,05 & 44,98 \\
\hline $\mathrm{Ie}_{2} \mathrm{O}_{3}$ & 0.17 & 3,29 & 4,00 & 1,69 & 2,44 & 1,94 \\
\hline SOMA & 98.52 & 99,08 & 99,05 & 98,86 & 99,08 & 99,08 \\
\hline
\end{tabular}

Tabela V.3 - Microanálises químicas das magnetitas e ilmenitas presentes nos diques básicos 1 e 2 $\left(\mathrm{DB}_{1}\right.$ e $\left.\mathrm{DB}_{2}\right)$ e básicos noríticos (DBN) do enxame da região de Lavras $(\mathrm{MG})$. $\mathrm{FeO}$ e $\mathrm{Fe}_{2} \mathrm{O}_{3}$ foram calculados segundo Carmichael (1967). 


\begin{tabular}{|l|c|c|}
\hline \multicolumn{2}{|c|}{} & \multicolumn{2}{|c|}{$\mathrm{DBN}-1212$} \\
\hline & $\mathrm{T}$ & $\mathrm{T}$ \\
\hline $\mathrm{SiO}_{2}$ & 38,54 & 39,09 \\
\hline $\mathrm{Al}_{2} \mathrm{O}_{3}$ & 0,02 & \\
\hline $\mathrm{FeO}_{t}$ & 21,74 & 20,28 \\
\hline $\mathrm{MnO}$ & 0,23 & 0,15 \\
\hline $\mathrm{MgO}$ & 39,31 & 40,48 \\
\hline $\mathrm{CaO}$ & 0,15 & \\
\hline $\mathrm{SOMA}$ & 100,00 & 100,00 \\
\hline & & \\
\hline $\mathrm{Si}$ & 0,999 & 1,004 \\
\hline $\mathrm{Al}$ & 0,001 & \\
\hline $\mathrm{SOMA}$ & 1,000 & 1,004 \\
\hline $\mathrm{Fe}$ & 0,472 & 0,436 \\
\hline $\mathrm{Mn}$ & 0,005 & 0,003 \\
\hline $\mathrm{Mg}$ & 1,519 & 1,550 \\
\hline $\mathrm{Ca}$ & 0,004 & \\
\hline $\mathrm{SOMA}$ & 2,000 & 1,989 \\
\hline & & \\
\hline $\mathrm{Fo}$ & 76,12 & 77,93 \\
\hline $\mathrm{Fa}$ & 23,63 & 21,90 \\
\hline
\end{tabular}

Tabela V.4 - Microanálise química da olivina da amostra DBN 1212; dique básico norítico do enxame da região de Lavras (MG).

\begin{tabular}{|c|c|c|c|c|c|}
\hline AMOSIRA & & -22 & & $\mathrm{DB}_{2}-27$ & $\mathrm{DB}_{2}-37$ \\
\hline & $\mathrm{T}_{1}$ & $\mathrm{~T}_{2}$ & $T_{3}$ & $T_{4}$ & $T_{s}$ \\
\hline $\mathrm{SiO}_{2}$ & 40,35 & 41,94 & 46,18 & 43.90 & 43,18 \\
\hline $\mathrm{TiO}_{2}$ & 1,16 & 0,81 & 1,05 & 1,15 & 2,02 \\
\hline $\mathrm{Al}_{2} \mathrm{O}_{3}$ & 11,48 & 10,98 & 7,63 & 9,78 & 8,66 \\
\hline $\mathrm{FeO}_{1}$ & 22,15 & 21,69 & 19,72 & 19,59 & 22,28 \\
\hline $\mathrm{MnO}$ & 0,19 & 0,19 & 0,22 & 0.15 & 0,21 \\
\hline $\mathrm{MgO}$ & 6,61 & 7,67 & 10,15 & 8,81 & 8,12 \\
\hline $\mathrm{CaO}$ & 11.92 & 12,04 & 11,99 & 11,92 & 10,79 \\
\hline $\mathrm{Na}_{2} \mathrm{O}$ & 1,56 & 1,51 & 1,15 & 1.41 & 1,74 \\
\hline $\mathrm{K}_{2} \mathrm{O}$ & 1,61 & 3,21 & 0.72 & 0,75 & 0,42 \\
\hline SOMA & 97,03 & 98,04 & 98,81 & 97,46 & 97,42 \\
\hline $\mathrm{Fe}_{2} \mathrm{O}_{3}{ }^{*}$ & 1,88 & 2,86 & 1,65 & 0,71 & 0,47 \\
\hline $\mathrm{Si}$ & 6,3004 & 6,4111 & 6,8845 & 6,6712 & 6,6511 \\
\hline $\mathrm{Al}^{\mathrm{N}}$ & 1,6996 & 1,5889 & 1,1155 & 1,3288 & 1,3489 \\
\hline SOMA & 8,0000 & 8,0000 & 8,0000 & 8.0000 & 8.0000 \\
\hline $\mathrm{Al}^{\mathrm{NT}}$ & 0,4137 & 0,3899 & 0,2255 & 0.4234 & 0,2236 \\
\hline $\mathrm{Fe}^{2+}$ & 2,6721 & 2,4437 & 2,2734 & 2,4081 & 2,8151 \\
\hline $\mathrm{Fe}^{3+}$ & 0,2205 & 0,3293 & 0,1853 & 0,0817 & 0,0551 \\
\hline $\mathrm{Mg}$ & 1,5382 & 1,7474 & 2,2551 & 1.9953 & 1,8640 \\
\hline $\mathrm{Mn}$ & 0,0251 & 0,0246 & 0.0278 & 0.0193 & 0,0274 \\
\hline $\mathrm{Ti}$ & 0,1362 & 0,0931 & 0,1177 & 0,1314 & 0,2340 \\
\hline SOMA & 5,0058 & 5,0280 & 5,0848 & 5,0591 & 5,2192 \\
\hline $\mathrm{Ca}$ & 1,9943 & 1,9721 & 1,9153 & 1,9410 & 1,7808 \\
\hline $\mathrm{Na}$ & 0,4723 & 0,4476 & 0,3324 & 0,4154 & 0,5197 \\
\hline $\mathrm{K}$ & 0,3207 & 0,2360 & 0,1369 & 0.1454 & 0,0825 \\
\hline SOMA & 2.7873 & 2,6557 & 2,3846 & 2,5018 & 2,3830 \\
\hline $\mathrm{Mg} / \mathrm{le} \mathrm{e}^{2+}+\mathrm{Mg}$ & 0,37 & 0,42 & 0,50 & 0,45 & 0,40 \\
\hline
\end{tabular}

Tabela V.5 - Microanálise química dos anfibólios presentes nos diques básicos 2 do enxame de Lavras (MG). Fórmula estrutural calculada com base em 23 átomos de oxigênio. $\mathrm{Fe}_{2} \mathrm{O}_{3} *$ calculado segundo Papike et al (1974). T = estágio de cristalização tardio.

$T_{1}$ e $T_{2}=$ bordas de piroxênios com Ferro - Pargasita hornblenda; $T_{3}=$ cristal isolado de magnésio hornblenda; $\mathrm{T}_{4}$ e $\mathrm{T}_{5}=$ borda e cristal isolado respectivamente de Ferro edenita hornblenda. (com base em Leake, 1978). 
APENDICE 3 - Descriçós petrográficas simplificadas alas principais amostras estudadas.

\begin{tabular}{|c|c|c|c|c|c|c|c|}
\hline \multicolumn{8}{|c|}{ DIQUES BÁSICOS NORÍTICOS (DBN) } \\
\hline amostra & granulação & textura & macrofeno & feno & microfeno & matriz & acessórios \\
\hline 25 & média & subofítica & pl, aug & \begin{tabular}{|ll} 
pl, aug, \\
bronz.
\end{tabular} & $\begin{array}{ll}p l, & \text { aug, } \\
\text { bronz. op }\end{array}$ & $\begin{array}{l}\text { pl, aug, op, } \\
\text { microp. }\end{array}$ & $\begin{array}{l}\text { pig, ap, anf, } \\
\text { cl, biot, ep. }\end{array}$ \\
\hline 28 & média & subofitica & aug, bronz & \begin{tabular}{|ll} 
pl, & aug, \\
bronz.
\end{tabular} & \begin{tabular}{|l|} 
pl, aug, \\
bronz.
\end{tabular} & pl, aug. op. & $\begin{array}{l}\text { microp, ap, } \\
\text { anf, cl, biol. }\end{array}$ \\
\hline 41 & fina & $\begin{array}{l}\text { intergranu- } \\
\text { lar }\end{array}$ & & \begin{tabular}{|ll}
$\mathrm{pl}$, & aug, \\
bronz.
\end{tabular} & $\begin{array}{ll}\text { pl, } & \text { aug, } \\
\text { bronz. }\end{array}$ & pl, aug, op. & $\begin{array}{l}\text { microp, ap, } \\
\text { anf, biol. }\end{array}$ \\
\hline 54 & média & subofitica & \begin{tabular}{|ll}
$\mathrm{pl}$ & aug, \\
bronz. & \\
\end{tabular} & $\begin{array}{l}\mathrm{pl}, \\
\text { bronz. }\end{array}$ & $\begin{array}{l}\mathrm{pl}, \quad \text { aug, } \\
\text { bronz, ol. }\end{array}$ & ol, op. & $\begin{array}{l}\text { microp, ap, } \\
\text { biot, cl. }\end{array}$ \\
\hline 55 & fina & $\begin{array}{l}\text { iniergranu- } \\
\text { lar }\end{array}$ & & 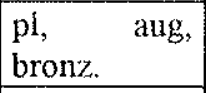 & \begin{tabular}{|ll} 
pl, aug, \\
bronz.
\end{tabular} & $\begin{array}{l}\text { pl, aug, op, } \\
\text { biot. }\end{array}$ & $\begin{array}{l}\text { pig, microp, } \\
\text { ap, scr. }\end{array}$ \\
\hline 64 & fina & $\begin{array}{l}\text { intergranu- } \\
\text { lar }\end{array}$ & $\mathrm{pl}$ & \begin{tabular}{|ll} 
pl, & aug, \\
bronz.
\end{tabular} & $\begin{array}{ll}\mathrm{pl} & \text { aug, } \\
\text { bronz, op, ol }\end{array}$ & $\mathrm{pl}$, aug, op. & $\begin{array}{l}\text { ol (alterada), } \\
\text { biot. ap. }\end{array}$ \\
\hline 72 & média & cumulática & $\mathrm{pl}$ & aug, bronz. & aug, bronz. & aug, op & ol, anf, biot \\
\hline 144 & fina & $\begin{array}{l}\text { intergranu- } \\
\text { lar }\end{array}$ & & 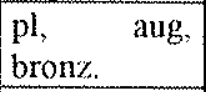 & $\begin{array}{l}\text { pl, aug, } \\
\text { bronz, op. }\end{array}$ & pl, aug, op. & $\begin{array}{l}\text { microp, anf, } \\
\text { biot, ap, cal. }\end{array}$ \\
\hline 621 & fina & $\begin{array}{l}\text { intergranu- } \\
\text { lar }\end{array}$ & & \begin{tabular}{|ll}
$\mathrm{pl}$, & aug \\
bronz. & \\
\end{tabular} & $\begin{array}{l}\mathrm{pl} \text { aug, } \\
\text { bronz. }\end{array}$ & pl, aug, op. & $\begin{array}{l}\text { microp, anf, } \\
\text { biot, ap. }\end{array}$ \\
\hline 1211 & média & subofitica & $\begin{array}{l}\mathrm{pl}, \quad \text { aug, } \\
\text { bronz. }\end{array}$ & $\begin{array}{ll}\text { pl, } & \text { aug, } \\
\text { bronz. }\end{array}$ & $\begin{array}{l}\mathrm{pl}, \quad \text { aug, } \\
\text { bronz, op, ol }\end{array}$ & ol, op. & $\begin{array}{l}\text { microp, ap, } \\
\text { biot. }\end{array}$ \\
\hline 1212 & média & cumulática & $\mathrm{pl}$ & aug, bronz. & aug, bronz. & ol. & op, biot \\
\hline 1215 & média & cumulática & $\mathrm{pl}$ & aug, bronz. & $\begin{array}{l}\text { aug, bronz, } \\
\text { ol. }\end{array}$ & ol. & op, biot, anf. \\
\hline
\end{tabular}

\begin{tabular}{|c|c|c|c|c|c|c|c|}
\hline \multicolumn{8}{|c|}{ DIQUES BÁSICOS $1\left(\mathrm{DB}_{1}\right)$} \\
\hline amostra & granulação & textura & macrofeno & feno & microfeno & matriz & acessórios \\
\hline 35 & média & subofitica & & $\begin{array}{l}\text { pl, aug, } \\
\text { bronz. }\end{array}$ & $\begin{array}{l}\text { pl, aug, pig, } \\
\text { bronz, op }\end{array}$ & pl, microp. & $\begin{array}{l}\text { op, microp, } \\
\text { biot, ap, cp. }\end{array}$ \\
\hline 38 & fina & subofitica & & pl, aug, pig & $\begin{array}{l}\text { pl, aug, pig, } \\
\text { bronz. }\end{array}$ & pl, pig, op & $\begin{array}{l}\text { microp, biot, } \\
\text { ap, cl. cal. }\end{array}$ \\
\hline 58 & média & $\begin{array}{l}\text { intergranu- } \\
\text { lar }\end{array}$ & pl. & $\begin{array}{ll}\text { pl, aug, } \\
\text { bronz. }\end{array}$ & $\begin{array}{l}\text { pl, pig, aug, } \\
\text { bronz, op. }\end{array}$ & $\begin{array}{l}\text { pl, pig, } \\
\text { microp, op. }\end{array}$ & $\begin{array}{l}\text { microp, ap, } \\
\text { biot, cl, ser. }\end{array}$ \\
\hline 59 & fina & $\begin{array}{l}\text { intergranu- } \\
\text { lar }\end{array}$ & & $\mathrm{pl}$, aug & $\begin{array}{l}\text { pl, aug, pig, } \\
\text { op. }\end{array}$ & $\begin{array}{ll}\text { pl, bronz, } \\
\text { op. }\end{array}$ & $\begin{array}{l}\text { microp, ap, } \\
\text { biot. }\end{array}$ \\
\hline 67 & fina & $\begin{array}{l}\text { intergranu- } \\
\text { lar }\end{array}$ & & $\begin{array}{l}\text { pl, aug, } \\
\text { bronz. }\end{array}$ & $\begin{array}{l}\text { pl, aug, pig, } \\
\text { op }\end{array}$ & $\begin{array}{l}\text { pl, microp, } \\
\text { aug. }\end{array}$ & $\begin{array}{l}\text { microp, ap, } \\
\text { anf, biot, op. }\end{array}$ \\
\hline 68 & fina & $\begin{array}{l}\text { intergranu- } \\
\text { lar }\end{array}$ & & pl, aug, pig. & $\begin{array}{l}\mathrm{pl} \text {, aug, pig, } \\
\text { bronz, op }\end{array}$ & $\begin{array}{l}\text { pl, aug, pig, } \\
\text { bronz, op. }\end{array}$ & $\begin{array}{l}\text { microp, ap, } \\
\text { biot, cl. }\end{array}$ \\
\hline 70 & fina & subofítica & & pl, aug. & pl, aug, pig & $\begin{array}{l}\text { pl,pig,bronz, } \\
\text { microp, op. }\end{array}$ & $\begin{array}{l}\text { ap, biol, anf, } \\
\text { cl. }\end{array}$ \\
\hline 112 & fina & subofítica & & pl, aug. & $\begin{array}{l}\text { pl aug, pig, } \\
\text { op. }\end{array}$ & $\begin{array}{l}\text { pl, aug, pig, } \\
\text { bronz, op. }\end{array}$ & $\begin{array}{l}\text { microp, ap, } \\
\text { biot, cl. }\end{array}$ \\
\hline 113 & média & $\begin{array}{l}\text { intergranu- } \\
\text { lar }\end{array}$ & pl. & pl, aug. & pl, aug, pig. & $\begin{array}{l}\mathrm{pl}, \quad \text { aug, } \\
\text { bronz. }\end{array}$ & $\begin{array}{l}\text { microp, ap, } \\
\text { cl, biot. }\end{array}$ \\
\hline 1223 & média & $\begin{array}{l}\text { intergranu- } \\
\text { lar }\end{array}$ & pl. & $\begin{array}{l}\text { pl, aug, } \\
\text { bronz. }\end{array}$ & $\begin{array}{l}\text { pl, aug, pig, } \\
\text { bronz. }\end{array}$ & $\begin{array}{l}\text { pl, aug, } \\
\text { microp. }\end{array}$ & $\begin{array}{l}\text { microp, ap, } \\
\text { biot.cl. }\end{array}$ \\
\hline
\end{tabular}

OBS: $\mathrm{pl}=$ plagioclásio; aug $=$ augita; bronz $=$ bronzita; op $=$ opacos; microp = micropegmatito; pig = pigeonita; ap $=$ apatita; anf = anfibólio; $\mathrm{cl}=$ clorita; biot $=$ biotita; ol = olivina; $\mathrm{ep}=$ epídoto; hiper $=$ hiperstênio; ser = sericita; cal $=$ calcita; $\mathrm{qz}=$ quartzo; $\mathrm{esc}=$ escapolita; $\mathrm{t}=$ titanita. Macrofeno $=$ macrofenocristal; feno $=$ fenocristal; microfeno $=$ microfenocristal. Textura cumulática $=$ heteradcumulática. 


\begin{tabular}{|c|c|c|c|c|c|c|c|}
\hline \multicolumn{8}{|c|}{ DIQUES BÁSICOS $2\left(\mathrm{DB}_{2}\right)$} \\
\hline amostra & granulação & textura & macrofeno & feno & microfeno & matriz & acessórios \\
\hline 15 & muito fina & porfiritica & & pl, aug. & pl, aug, pig. & vítrea & - \\
\hline 17 & fina & subofitica & & pl, aug. & pl, aug, op & pl, aug, pig & $\mathrm{cl}$, anf \\
\hline 18 & média & subofitica & & pl, aug. & pl, aug, op. & pl, aug, anf. & $\begin{array}{l}\text { op, cl, biot, } \\
\text { hiper. }\end{array}$ \\
\hline 19 & média & subofitica & & $\mathrm{pl}$, aug. & pl, ang. & pl, op, pig & cl, ap, anf. \\
\hline 20 & fina & $\begin{array}{l}\text { intergranu- } \\
\text { lar }\end{array}$ & & $\mathrm{pl}$, aug. & $\mathrm{pl}$, aug, op & op, anf. & $\begin{array}{l}\text { cl, ap, biot, } \\
\text { hiper. }\end{array}$ \\
\hline 21 & média & subofitica & & $\mathrm{pl}$, aug. & pl, aug, pig. & pl, aug, op & anf.cl. \\
\hline 22 & média & subofitica & & pl, aug. & pl,aug. & $\begin{array}{l}\text { pl, aug, pig, } \\
\text { op. }\end{array}$ & $\begin{array}{l}\text { cl, biot, anf, } \\
\text { liper. }\end{array}$ \\
\hline 24 & fina & porfirítica & & pl. & pl, aug. & $\begin{array}{l}\mathrm{pl} \text {, aug, anf, } \\
\text { op. }\end{array}$ & $\begin{array}{l}\mathrm{ep}, \mathrm{cl} \text {, anf, } \\
\text { ser, cal. }\end{array}$ \\
\hline 26 & média & subofitica & $\mathrm{pl}$ & pl, aug. & $\mathrm{pl}$, aug. & pl, op, anf. & $\begin{array}{l}\text { ep, cl, anf, } \\
\text { ser, cal. }\end{array}$ \\
\hline 27 & fina & subofitica & & pl, aug. & pl, aug, pig & pl, aug, pig & $\begin{array}{l}\text { anf, cl, ap, } \\
\text { op. }\end{array}$ \\
\hline 30 & fina & $\begin{array}{l}\text { intergranu- } \\
\text { lar }\end{array}$ & & pl. & $\mathrm{pl}$, aug. & $\mathrm{pl}$, aug, op & anf, cl, ap. \\
\hline 31 & fina & subofitica & & pl, aug. & pl, aug. & anf, op & $\begin{array}{ll}\mathrm{ep}, \mathrm{cl}, & \text { ser, } \\
\text { cal, } \mathrm{g} z . & \\
\end{array}$ \\
\hline 32 & média & subofitica & & pl, aug. & pl, aug. & pl, aug, op. & anf, cl, hiper \\
\hline 33 & fina & $\begin{array}{l}\text { intergranum } \\
\text { lar }\end{array}$ & & pl, aug. & pl, aug. & anf, op & $\begin{array}{ll}\mathrm{ep}, \mathrm{cl}, \mathrm{ser} \\
\mathrm{cal}\end{array}$ \\
\hline 34 & média & subofitica & pl. & pl, aug. & pl, aug. op & pl, aug, pig. & anf, ap. \\
\hline 37 & média & porfirítica & pl. & pl, aug. & pl, aug. & anf, op. & ap, cl, ser. \\
\hline 44 & média & subofítica & & pl, aug. & $\mathrm{pl}$, aug, op & pl, aug, op & anf, $\mathrm{cl}, \mathrm{ap}$. \\
\hline 45 & média & subofitica & & pl, aug. & pl, aug. & $\begin{array}{l}\text { pl, aug, pig, } \\
\text { op. }\end{array}$ & $\begin{array}{l}\text { anf, biot, } \\
\text { hiper. }\end{array}$ \\
\hline 60 & média & subofitica & & pl, aug. & $\mathrm{pl}$, aug, op & $\mathrm{pl}$, aug, op. & anf, biot, ap. \\
\hline 61 & fina & $\begin{array}{l}\text { intergranu- } \\
\text { lar }\end{array}$ & & pl, aug. & pl, aug. & $\mathrm{pl}$, aug, op. & anf, cl, ap. \\
\hline 73 & média & subofitica & & pl, aug. & pl, aug. & $\mathrm{pl}$, aug, op. & anf, cl, ser. \\
\hline 74 & fina & porfirítica & & pl, aug. & pl, aug, pig & vilrea & 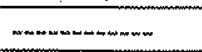 \\
\hline 76 & média & subofitica & & $\mathrm{pl}$, aug. & $\mathrm{pl}$, aug & pl, aug, op & cl, anf. \\
\hline 79 & fina & porfiritica & & pl. & pl, aug. & $\begin{array}{l}\text { pl, aug, pig, } \\
\text { op. }\end{array}$ & anf, cl. \\
\hline 80 & média & subofítica & & $\mathrm{pl}$, aug. & $\mathrm{pl}$, aug; op & pl, aug, op & anf. cl. \\
\hline 87 & média & subofitica & & $\mathrm{pl}$, aug. & pl, aug. & pl, aug, op. & pig, anf, cl \\
\hline 88 & fina & $\begin{array}{l}\text { intergranu- } \\
\text { lar }\end{array}$ & & pl. & pl, aug. & pl, aug, op. & $\begin{array}{l}\text { anf, cl, biot, } \\
\text { hiper. }\end{array}$ \\
\hline 89 & média & subofítica & & pl, aug. & $\mathrm{pl}$, aug, op & pl, aug, pig. & anf, $\mathrm{cl}$ \\
\hline 90 & fina & subofítica & & $\mathrm{pl}$ & pl, aug. & $\mathrm{pl}$, aug, op. & anf, cl, ser. \\
\hline 99 & média & Subofitica & & pl, aug. & $\mathrm{pl}$, aug, op. & $\mathrm{pl}$, aug, op. & hiper, anf, cl \\
\hline 100 & fina & $\begin{array}{l}\text { intergranu- } \\
\text { lar }\end{array}$ & & & pl, aug. & $\mathrm{pl}$, aug, op. & anf, cl, ap. \\
\hline 101 & fina & subofitica & & & pl, aug. & $\mathrm{pl}$, aug, op. & $\mathrm{ep}, \mathrm{ser} \mathrm{cal}, \mathrm{cl}$ \\
\hline 104 & média & subofitica & & pl, aug. & $\mathrm{pl}$, aug. & anf, op. & ep, ser, cal. \\
\hline 131 & média & subofitica & & pl, aug & $\mathrm{pl}$, aug. & anf, op. & ep, ser, cal. \\
\hline 451 & média & subofitica & & pl, aug & pl, aug. & $\mathrm{pl}$, aug, op. & anf, cl. \\
\hline 1206 & média & subofitica & & $\mathrm{pl}$, ang & pl, aug. & $\mathrm{pl}$, aug, pig. & op, anf cl. \\
\hline 1208 & média & subofitica & & $\mathrm{pl}$, aug & $\mathrm{pl}$, aug, op & pl, aug, op. & anf, $\mathrm{cl}$, ap. \\
\hline 1230 & média & subofitica & & pl, aug. & $\mathrm{pl}$, aug. & pl, aug.op. & anf. ap. \\
\hline 1231 & média & subofitica & & pl, aug. & pl, aug. & pl, aug, op. & $\mathrm{cl}$, anf, ser. \\
\hline
\end{tabular}




\begin{tabular}{|c|c|c|c|c|c|c|c|}
\hline amostra & $\begin{array}{l}\text { TABASICO: } \\
\text { granulação }\end{array}$ & textura & macrofeno & feno & microfeno & matriz & acessórios \\
\hline 42 & fina & $\begin{array}{l}\text { blastosubofi- } \\
\text { lica }\end{array}$ & & pl, anf, op. & pl, anf. & pl, aug. & $\begin{array}{l}\text { op, } \quad \text { q }, \quad \text { ap, } \\
\text { cl. }\end{array}$ \\
\hline 47 & fina & $\begin{array}{l}\text { blastosubofi- } \\
\text { tica. }\end{array}$ & & pl, anf. & pl, anf, aug. & $\mathrm{pl}$, anf, op. & ap, cl, qz. \\
\hline 50 & fina & $\begin{array}{l}\text { blastosubofi- } \\
\text { tica }\end{array}$ & & pl. & \begin{tabular}{|l|}
$\mathrm{pl}$, anf, op, \\
aug.
\end{tabular} & pl, anf, op. & $\begin{array}{l}\mathrm{cl}, \quad \text { ap, } \\
\text { esc. }\end{array}$ \\
\hline 51 & fina & $\begin{array}{l}\begin{array}{l}\text { blastosubofi- } \\
\text { tica }\end{array} \\
\end{array}$ & & pl. & pl, anf, op. & pl, anf, op. & $\mathrm{cl}, \mathrm{ap}, \mathrm{qz}$. \\
\hline 56 & média & $\begin{array}{l}\text { blastosubofi- } \\
\text { tica }\end{array}$ & & $\mathrm{pl}$, anf. & pl, anf, aug. & $\begin{array}{l}\text { pl, anf, op, } \\
\text { aug. }\end{array}$ & ap, biot, qz. \\
\hline 62 & média & $\begin{array}{l}\text { blastoporfirí } \\
\text { tica }\end{array}$ & pl. & pl, anf. & pl, anf. & $\begin{array}{l}\mathrm{pl}, \text { anf, } \mathrm{qz}, \\
\text { op. }\end{array}$ & ti, cl, ep. \\
\hline 63 & média & \begin{tabular}{|l|}
$\begin{array}{l}\text { blastoporfiri } \\
\text { tica. }\end{array}$ \\
\end{tabular} & $\mathrm{pl}$ & pl, anf. & pl, anf, op. & $\begin{array}{l}\text { pl, anf, op, } \\
\text { qz. }\end{array}$ & ti, cl, ep. \\
\hline 75 & fina & $\begin{array}{l}\text { blastosubofi- } \\
\text { tica. }\end{array}$ & & & $\mathrm{pl}$, anf. & pl, anf, op. & $\begin{array}{l}\text { qz, ep, ser, } \\
\text { cal, cl. }\end{array}$ \\
\hline 96 & fina & $\begin{array}{l}\text { blastosubofi- } \\
\text { tica }\end{array}$ & & pl, anf, op. & $\begin{array}{l}\text { pl, anf, aug, } \\
\text { op. }\end{array}$ & pl, anf, op. & $\mathrm{qz}, \mathrm{cl}$ \\
\hline 97 & fina & $\begin{array}{l}\text { blastosubofí- } \\
\text { tica }\end{array}$ & & pl. & pl, anf, aug. & pl, anf, op. & $\begin{array}{ll}\text { ap, cl, biot } \\
\text { az. }\end{array}$ \\
\hline 98 & fina & $\begin{array}{l}\begin{array}{l}\text { blastointer- } \\
\text { granular }\end{array} \\
\end{array}$ & & pl. & pl, anf. & $\begin{array}{l}\mathrm{pl} \text {, anf, aug, } \\
\mathrm{qz} \text {, op }\end{array}$ & $\mathrm{cl}, \mathrm{ap}$ \\
\hline 659 & fina & $\begin{array}{l}\text { blastointer- } \\
\text { granular }\end{array}$ & & pl, op. & pl, anf. & $\begin{array}{lll}\mathrm{pl}, & \text { anf, op, } \\
\mathrm{qz}\end{array}$ & $\mathrm{cl}, \mathrm{ap}$. \\
\hline
\end{tabular}

\begin{tabular}{|c|c|c|c|c|}
\hline \multicolumn{5}{|c|}{ DIQUES ANFIBOLITTICOS (DA) } \\
\hline amostra & granulação & textura & minerais essenciais & minerais acessórios \\
\hline 23 & fina & granonematoblástica & pl, anf, op. & $\mathrm{qz}, \mathrm{ti}$. \\
\hline 43 & fina & granoblástica & $\mathrm{pl}$, anf, op. & $\mathrm{qz}, \mathrm{ii}$ \\
\hline 46 & fina & granonematoblástica & pl, anf, op. & $\mathrm{qz}, \mathrm{ti}, \mathrm{ep}$ \\
\hline 48 & fina & granoblástica & $\mathrm{pl}$, anf, op. & $\mathrm{gz}$ \\
\hline 49 & fina & granoblástica & $\mathrm{pl}$, anf, op. & $\mathrm{qz}, \mathrm{ti}$ \\
\hline 52 & fina & granonematoblástica & pl, anf, op. & $\mathrm{ep}, \mathrm{ti}$ \\
\hline $57,65,66$ & fina & granoblástica & pl, anf, op. & ti, ap, qz. \\
\hline 77,81 & média & granoblástica & pl, anf, op. & ii, ep. \\
\hline $83,84,85,86$ & fina & granoblástica & pl, anf, op. & ti, gz. \\
\hline 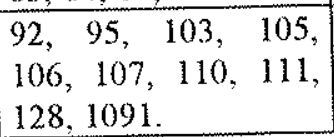 & fina & granoblástica & pl, anf, op. & ep,qz, cl, ser, cal. \\
\hline
\end{tabular}

OBS: $\mathrm{pl}=$ plagioclásio; aug $=$ augita; bronz $=$ bronzita; $\mathrm{op}=$ opacos; microp $=$ micropegmatito; pig = pigeonita; ap = apatita; anf = anfibolio; $\mathrm{cl}=$ clorita; biot = biotita; ol = olivina; $\mathrm{ep}=$ epídoto; hiper = hiperstênio; ser = sericita; $\mathrm{cal}=$ calcita; $\mathrm{q} z=$ quartzo; esc $=$ escapolita; $\mathrm{ti}=$ titanita. Macrofeno $=$ macrofenocristal; feno $=$ fenocristal; microfeno $=$ microfenocristal. Textura cumulática $=$ heteradcumulática 